\title{
The campaign for the disestablishment of the Welsh Anglican Church: a study in political intrigue and popular frustration.
}

David William Jones

\begin{abstract}
A dissertation submitted to Swansea University in fulfilment of the requirements for the degree of Doctor of Philosophy.
\end{abstract}

College of Arts and Humanities, Swansea University, 


\section{Summary.}

The significance of the campaign to seek the disestablishment of the Anglican Church in Wales, and the outcome of that struggle has, in the context of modern Welsh history, either been forgotten or has been regularly misrepresented. Consideration of the campaign to disestablish the four Welsh dioceses of the Church of England could be dismissed as seemingly irrelevant, particular in an increasingly secular world. Two factors should militate against such treatment: its significance as a key political issue and the fact that, despite popular and constant demand within Wales, as expressed through the electoral process, the campaign was to last for at least half a century. The longevity of the struggle has inordinate significance, in terms of what it says about the development of democracy in Wales. The objective is to re-examine the campaign for the disestablishment of the Church of England in Wales in its widest context, attempting to understand how the campaign impacted upon aspects of Welsh politics and identity.

The thesis will also examine whether the form of disestablishment which was eventually delivered in 1920, as a result of the Welsh Church Act 1914, and subsequent amending legislation, bore any resemblance to what had been fought for or whether, in reality, the Welsh Anglican Church was disestablished, de jure, but not de facto. It is argued that if any party can be lauded as a victor of that prolonged campaign, then that accolade should be awarded to the efforts of the Church defenders who were successful in ensuring that the event described as disestablishment was delayed and attenuated to such an extent that it was of no substantive consequence. This was in the context of the actions of those secular politicians who, although they ostensibly supported disestablishment, exhibited an ineffectiveness which almost caused disestablishment to be lost. 


\section{DECLARATION}

This work has not previously been accepted in substance for any degree and is not being concurrently submitted in candidature for any degree.

Signed ............................................................... (candidate)

Date

\section{STATEMENT 1}

This thesis is the result of my own investigations, except where otherwise stated.

Other sources are acknowledged by footnotes giving explicit references. A bibliography is appended.

Signed (candidate)

Date

\section{STATEMENT 2}

I hereby give consent for my thesis, if accepted, to be available for photocopying and for inter-library loan, and for the title and summary to be made available to outside organisations.

Signed (candidate)

Date 


\section{Contents}

Page

Introduction 1

$\begin{array}{ll}\text { Critical questions } & 1\end{array}$

'A controversy which has embittered Welsh life for generations'

$\begin{array}{ll}\text { Perceptions } & 6\end{array}$

$\begin{array}{ll}\text { Secular and ecclesiastical politics } & 7\end{array}$

An 'alien’ Church? $\quad 9$

Disestablishment etc. $\quad 10$

$\begin{array}{ll}\text { Originality } & 11\end{array}$

$\begin{array}{ll}\text { Sources } & 12\end{array}$

Significance $\quad 15$

An examination of the literature $\quad 15$

$\begin{array}{ll}\text { Outline } & 24\end{array}$

\section{Chapter 1:}

$\begin{array}{ll}\text { Inauspicious beginnings } & 28\end{array}$

$\begin{array}{ll}\text { The other 'Alien’ Church } & 29\end{array}$

'In Welsh politics Rhyl seems to be synonymous with Disunity’ 33

The 'New Liberalism’ 37

The reaction to the Rhyl Resolution $\quad 40$

$\begin{array}{ll}\text { Gladstone’s successor } & 49\end{array}$

'The Liberal Welsh members are a sort of political tadpole - all head' 56

A precursor to the campaign $\quad 59$

'A curious repetition of the history of 11 years ago' 63

'Of the nineteen men who constituted the Cabinet, nineteen were in favour of 66

Disestablishment' 


\section{Chapter 2:}

\section{'Welsh disestablishment has gone into the background'}

A Royal Commission $\quad 72$

$\begin{array}{ll}\text { 'It should be leisurely, not dilatory’ } & 76\end{array}$

'A Renewed attack on the position and endowments of the Church' 82

Reaction to the Welsh Church Commission 83

The Nonconformist Convention, $1907 \quad 92$

$\begin{array}{lr}\text { The spectre of socialism } & 97\end{array}$

'For forty years have we patiently tramped the wilderness' 101

'On the eve of the introduction of a Welsh Disestablishment Bill' 105

$\begin{array}{ll}\text { Like Haley's Comet } & 107\end{array}$

$\begin{array}{ll}\text { Coalition } & 108\end{array}$

$\begin{array}{ll}\text { Waning interest? } & 109\end{array}$

$\begin{array}{ll}\text { Looking to } 1911 & 110\end{array}$

$\begin{array}{ll}\text { The Imperial imprimatur } & 113\end{array}$

'The drum ecclesiastic was beating to arms and militant Bishops had taken to the 118

Field'

Introduction of the Established Church (Wales) Bill 1912

\section{Chapter 3:}

\section{The final imbroglio}

Immediate responses to the Established Church (Wales) Bill

1912

'Must keep their armour bright'

‘The journey to justice has been long, but it is nearly over’ 136

The Select Committee of the House of Lords on Matters 138

affecting the Church in Wales

18 May 1914: 'a unique occasion in the history of Parliament' 142

$\begin{array}{ll}\text { The endgame } & 143\end{array}$

'It has been a long fight; many have been sacrificed on the way, 145 
but the loyalty of Welsh Liberalism to the great principles

involved was won'

Political and personal differences: 'Friends through it all'

148

'But they seized their other prisoner at once, blindfolded him

and said War or no war, we will, at any rate, do for you.'

The Welsh Church (Postponement) Bill 1915: evidence of

continuing tension

1917: 'the hope of redress'

155

Dismemberment

Ecclesiastical armistice?

Disendowment

\section{Chapter 4:}

\section{Dramatis personce}

The Archbishop of Canterbury's first visit to Wales for seven

hundred years

Bringing bees back to the hive?

The Rhyl Church Congress of 1891

'Our chief danger is panic among Welsh and apathy among

\section{English Churchmen'}

The Church defenders: 'More Anglican than the English'

'The Wheaten Bread Bishop.'

'Half an Englishman'

Dean H. T. Edwards

'One of the most powerful exponents of the Progressive cause,

The 'undeniable' revival of the Church in Wales 


\section{Chapter 5:}

The Legacy

'The National Church'

225

How disestablishment was described by the Church

Symbolism

238

A celebration of 'defeat'?

The Church in Wales

Anniversaries

'The shadow of the Church of England'

The Church and the State

Established Church redux

258

An appraisal of the disestablished Church

262

Conclusion 


\section{Acknowledgements.}

I am especially grateful to Professor R. Gwynedd Parry, who has supervised this thesis and who encouraged, guided and supported my efforts with such care, professionalism, insightfulness, knowledge, understanding and, vitally, with bonhomie.

Professor Parry's belief in the project was crucial. Our sessions together were a great pleasure but, however enjoyable, they always ensured that I left the meeting feeling confident about the next step.

Diolch o galon. 


\section{Introduction.}

In the context of modern Welsh history, any consideration of the campaign to disestablish the four Welsh dioceses of the Church of England could be dismissed as recondite; a subject which could be confined to the arcane, internal machinations of religious bodies. The seeming insignificance of disestablishment highlighted by the fact that it coincided with an identifiable adverse change in Welsh religious life ${ }^{1}$ and, more prosaically, by its propinquity with the Great War; with the enactment of the Welsh Church Act just six weeks after Britain declared war upon Germany, and its implementation two months after the terms of the Treaty of Versailles took effect. ${ }^{2}$ Whereas it was, during the nineteenth and early twentieth centuries, the sole example of a popular movement which sought, through political means, to arrogate something which repeatedly reflected the will of the majority of the Welsh electorate. Writing in 1891, Osborne Morgan $^{3}$ described the 'overwhelming preponderance of Welsh votes in favour', which he observed was 'a preponderance without parallel in Parliamentary history'. ${ }^{4}$

\section{Critical questions.}

One of the questions which requires consideration is why at least half a century was spent in seeking disestablishment, as it is apparent that one of the remarkable characteristics of the campaign to seek Welsh disestablishment was its duration. ${ }^{5}$, The longevity of the struggle has inordinate significance, in terms of what it says about the development of democracy in Wales, and yet, as will be seen, this facet is often ignored, or the period of turmoil is attenuated, so that

\footnotetext{
${ }^{1}$ R. Tudur Jones, Faith and the Crisis of a Nation, Wales 1890-1914, ed. R. Pope, (Cardiff: UWP, 2004) and D. Densil Morgan, The Span of the Cross. Christian Religion and Society in Wales 1914-2000 (Cardiff: UWP, 2011).

${ }^{2}$ The Treaty of Versailles was signed by the Allied powers and Germany on 28 June 1919, but entered into force on 20 January 1920: M. Macmillan, Peacemakers. The Paris Conference of 1919 and Its Attempt to End War (London, 2002).

${ }^{3}$ George Osborne Morgan, (1826-1897), lawyer and politician. He was Liberal M.P. for Denbighshire from 1868 to 1885 and for Denbighshire East from 1885 to his death. He 'took a prominent part in Welsh affairs': D.W.B.

${ }^{4}$ G. Osborne Morgan, 'The Progress of Welsh Disestablishment', The Nineteenth Century (April 1891), vol.29, issue 170, p.602. Osborne Morgan added that it was a 'cardinal axiom' of the Liberal Party that 'such questions ought to be mainly determined by the views and wishes of the people immediately affected by them, as reflected in the votes of their constitutional representatives' and: 'To ignore this axiom is, indeed, to run counter to the first principle of modern Liberalism'.

${ }^{5}$ David Lloyd George applauded the Nonconformist minister, and leading disestablisher, Reverend Evan Jones, when he wrote that: 'You have fought a brilliant and tenacious fight for religious equality in Wales for half a century', although he could not resist reference to his own prolonged efforts: 'I have done my best in the same direction on the platform, in the House of Commons, and inside the Government, in all for over a quarter of a century': 'Mr. Lloyd George and the Welsh Church Act', The North Wales Chronicle and Advertiser, 26 March 1915, p.5.
} 
observers are not obliged to address it. To many, however, disestablishment simply became a constant feature of Welsh political and religious life, with W. Llewelyn Williams M.P. ${ }^{6}$ able to write in 1911 that: 'Ever since I can remember the Welsh people have been agitating for Disestablishment'. ${ }^{7}$ At the enthronement of the first Archbishop of Wales in 1920, David Lloyd George described disestablishment as ‘one of the dramatic episodes of history' and that: 'It is the end of an old feud - a controversy which has embittered Welsh life for generations and absorbed some of the best energies of mind and soul for 50 years'. ${ }^{8}$ Archbishop Edwards also recognised that: 'The first time the Welsh Church question came before the electors was in $1868^{9}$, and the last time at the general election in 1918'. ${ }^{10}$ He was to pointedly remind the House of Lords, in 1919, that, by dint of his knowledge and longevity, he was in an advantageous position to comment upon disestablishment:

'It is fifty years ago almost to the month when this question of Welsh Disestablishment was first started in another place by Sir Watkin Williams, afterwards Mr. Justice Watkin Williams, and during those fifty years some of us have taken a constant part in Church defence in this controversy'. ${ }^{11}$

The prolonged nature of the campaign also impacted upon the eventual outcome in that the inevitable shifts in political exigencies would influence what was being sought, and by whom. Aside from David Lloyd George, few secular politicians were to serve for periods anywhere near that claimed by Bishop Edwards above or, indeed, John Owen, Bishop of St. David’s.

\footnotetext{
${ }^{6}$ William Llewelyn Williams, (1867-1922): journalist, barrister and member of Parliament for Carmarthen boroughs from 1906 to 1918. He became editor of the South Wales Star and then the South Wales Post in Swansea. According to his entry in the ODNB, 'he was disillusioned with slow progress of nationalism in the South Wales seaports and he complained of the 'howling wilderness of Swansea Philistinism', with Barry 'intent on nothing but moneymaking, while Cardiff 'was lost to the Welsh'. He was called to the bar in 1897. He was elected member of Parliament for Carmarthen boroughs from 1906 to 1918. His entry in the Dictionary of Welsh Biography states that: 'it was on nationalistic grounds rather than on the ground of religious liberationism that he supported the disestablishment and disendowment of the Established Church in Wales'. He was, post-war, a fierce opponent of Lloyd George.

${ }^{7}$ W. Llewelyn Williams, 'The Welsh Claim for Disestablishment', Wales (May 1911), p.9.

8 'Welsh Archbishop Enthroned. A Notable Ceremony. The New Order in Wales', The Times, 2 June 1920, p.13.

9 'Our Letter Box': a letter to the editor, Monmouthshire Merlin, 22 August 1868, p.8: In 1868, a 'Lay Churchman' recognised the threat from Irish Church disestablishment, particularly in the 'Principality', and the fact that the legislature had changed 'according to modern Liberal notions', with 'Roman Catholics, Presbyterians, Dissenters and men of no religion' having ‘equal voices with Churchmen'. He urged 'every Churchman to put his shoulder to the wheel, as if the Church were now attacked in England. And I need not say that his best opportunity will be the coming election. Which is of most consequence, Church or Party?'

${ }^{10}$ A. G. Edwards, The Archbishop of Wales, Memories (London, 1927), p.285.

${ }^{11}$ Welsh Church (Temporalities) Bill, HL Deb., 14 August 1919, vol. 36, cc 919.
} 
Despite this seemingly unobtainable objective, the public support for disestablishment demonstrated a remarkable stamina, irrespective of the litany of delaying tactics and unfulfilled promises which formed a recurring feature of the political response. Writing in 1912, David Caird, the Secretary of the Liberation Society, highlighted the fact that the campaign for disestablishment was a 'national demand', as explicitly demonstrated by its parliamentary history:

'A practical consideration of the demand for Disestablishment in Wales must begin with recognition of the fact that it has been made by the Welsh people through their representatives in Parliament for more than thirty years. The national character of the demand throughout that comparatively long period has been as remarkable as its persistence'. ${ }^{12}$

Another ineluctable question is whether the relatively benign, 'soft' disestablishment ${ }^{13}$ that was to emerge in 1920, with the Church in Wales still viewed as 'having many of the characteristics of establishment', merited the bitter, protracted, monumental struggle that was to characterise the disestablishment campaign. ${ }^{14}$ The result should also be considered against the impact upon Wales's political and spiritual life and whether the expenditure of such extensive political capital caused other Welsh causes to be starved of attention. It has been suggested that: 'Religion also laid the foundation of the political campaign that formed the expression of Welsh national feeling in the second half of the century' ${ }^{15}$ But whereas it may have 'laid the foundation', the fact that disestablishment was perpetually the cynosure ensured that there was a dearth of the requisite political time and coordination required to build upon any manifestations of that national feeling.

The centenary of the creation of the Church in Wales or, more accurately the termination of the 'establishment of the Church of England in Wales and Monmouthshire'16, on 31 March 2020,

\footnotetext{
${ }^{12}$ David Caird, Church and State in Wales. A Plain Statement of the Case for Disestablishment (London, 1912), p.11.

${ }^{13}$ The writer has adopted terminology utilised by the media in describing the potential outcome of the negotiations between the British government and the European Union concerning Brexit, with 'soft' denoting an agreement which has been described as 'gentler': 'a kind of semi-detached separation, in which the country gains a degree of independence while at the same time maintaining some of the EU features it currently has'. This appears to accurately describe the relationship, post-1920, between the Welsh Church and the Church of England.

${ }^{14}$ F. Cranmer, J. Lucas B. Morris, Church and State. A mapping exercise (Constitution Unit, U.C.L., April 2006), p.9.

${ }^{15}$ D. W. Bebbington, 'Religion and National Feelings in Nineteenth-Century Wales and Scotland', in Religion and National Identity (Oxford, 1982), ed. by S.P. Mews, p.495.

${ }^{16}$ The preamble to the Welsh Church Act, 1914 [4 \& 5 Geo.5.].
} 
makes it an opportune time to consider this question and the nature, contents and impact of the prolonged, convoluted, belligerent campaign that sought the disestablishment of the Anglican Church in Wales. Professor Glanmor Williams suggested that the obedience and subjection of the Welsh Church to Canterbury had instigated a change which was 'comparable in scope and magnitude with those later brought about by the reformation or the Methodist Revival' ${ }^{17}$ This work will consider whether the unravelling of the Anglican Church, as a state institution within Wales, was to create anything comparable, or whether it passed without any substantive consequence; with an Established, endowed Church of England in Wales morphing into a reestablished, re-endowed Church in Wales. The symbolism of that transition which was to be graphically portrayed during the ceremony surrounding the enthronement of the first Archbishop of Wales, at St. Asaph Cathedral, in June 1920.

It should be recognised that those who sought Welsh disestablishment were attempting to bring about something quite extraordinary and, by any objective analysis, seemingly impossible. It amounted to an unprecedented constitutional and political change, by threatening to dismember one of the pillars of the English state and thereby severing a Church/state relationship which, to many, was immutable. Opponents considered that any modification to be unthinkable, sacrilegious and unnecessary, with unforeseeable, but potentially profound consequences for England, as well as Wales. As Lord Rosebery, the Prime Minister, ${ }^{18}$ had warned a Cardiff audience in 1895, there were seemingly insurmountable hurdles and, however much aspirations for disestablishment represented the desire of the majority of Welsh people, it faced a harsh democratic reality, in that: 'it is hard for the representatives of the other 37 millions of population which are comprised in the United Kingdom to give first and the foremost place to a measure which affects only a million and a half' ${ }^{19}$ But there was: ‘another and more permanent barrier which opposes itself to your wishes in respect to Welsh Disestablishment, ${ }^{20}$, being the

\footnotetext{
17 Ibid.

18 'Archibald Philip Primrose, fifth earl of Rosebery and first earl of Midlothian (1847-1929)', Oxford Dictionary of National Biography, Oxford University Press, 2004.

${ }^{19}$ A Speech Delivered by the Rt. Hon. the Earl of Rosebery at Cardiff, on January $18^{\text {th }}, 1895$ (The Liberal Publication Department, London, 1895), p.13.

${ }^{20}$ Ibid., p.15.
} 
intransigence of the House of Lords, whose ultimate veto, albeit under increasing scrutiny, must have appeared unassailable. ${ }^{21}$

\section{'A controversy which has embittered Welsh life for generations'.}

The campaign evoked a prodigious level of emotive and irreconcilable feeling and, as will be apparent throughout the thesis, opposing parties were wont to resort to bellicose language and imagery in order to elucidate their grievances. ${ }^{22}$ Both sides were driven to bitter frustration by the fact that they considered that their supporting arguments were unassailable and that any reasonable party should concur with their cause; with Welsh disestablishers resentful of the obstruction to their demand for religious equality and Church defenders outraged by this attempt to 'lop off the four Welsh dioceses from the organic life of the Church of England', as 'it would leave the whole organisation, the discipline, and the standards of the Church in Wales in a state of chaos'. ${ }^{23}$ But behind the political posturing, postulations and public pronouncements, lay the fact that the subject went to 'very hearth and home of the community', and for Cardiganshire, it was possible to substitute Wales, when it was noted that:

'Considering that there are both Nonconformists and Churchmen in nearly every family in Cardiganshire in the ministry and in orders, this matter goes to the very hearth and home of the community, and should be considered kindly and calmly where strife must be so disastrous, for both live under the same roof, and are brothers and sisters and husband and wife'.24

\section{Perceptions.}

The genesis of Welsh disestablishment could clearly be detected in Welsh affairs as far back as $1830^{25}$ and Glyn E. German has even suggested that the achievement of disestablishment, in 1920, ended a 'conflict that began in 597 when Augustine was appointed first Archbishop of

\footnotetext{
${ }^{21}$ The Earl of Shaftesbury demonstrated an awareness of the onset of the 'great democratic wave', in 1867, when he stated that: 'The people must govern, and not a set of hereditary peers, never chosen by the people', Hansard, Parliamentary Debates, vol.188, cols. 1925-6, 23 July 1867.

22 'Church News. The Attack on the Church in Wales. The Protest of Bristol', The Bristol Times and Mirror, 22 March 1895, p.6, N.L.W, Bishop John Owen papers, 4/2. Addressing a 'magnificent meeting' at Bristol, the future Bishop of St. David's, John Owen, said that the Church: 'must be like the Spanish soldier, the hand on the hilt of the sword and a readiness to fight' and: 'If they wished for peace let them prepare for war'.

${ }^{23}$ A. G. Edwards, Bishop of St. Asaph, Landmarks in the History of the Welsh Church (London, 1913), p.261.

24 'Disestablishment', letter to the Editor, The Aberystwyth Observer, 17 May 1894, p.8.

${ }^{25}$ R. Tudur Jones, 'The Origins of the Nonconformist Disestablishment Campaign 1830-1840', Historical Society of the Church in Wales, vol.25 (1970), pp.39-75. Professor Tudur Jones has suggested, at page 39, that the formative period was from 1830 to 1840 , 'which saw the alignment of the interested parties into two hostile groups'.
} 
Canterbury'. ${ }^{26}$ It could be assumed that the end of the struggle is relatively easy to identify, with the provisions of the Welsh Church Act 1914 taking effect on 31 March 1920 ${ }^{27}$, although this needs to be considered in the context of the recommendation 'that the Church in Wales should be fully disestablished', which was included in a report of the National Assembly's Constitution and Legislative Affairs Committee, almost a century later, in $2013 .{ }^{28}$ The fervid, confused and prolonged nature of the campaign, and the inchoate outcome, has often caused observers to misconstrue Welsh disestablishment, in terms of how it came about and the nature of what was delivered, and if, today, it evades nescience, it will usually evoke befuddlement or antipathy. However, any attempt to understand Welsh history, without a full appreciation of this subject, will be, at best, incomplete or, at worse, fallacious. The significance of Welsh disestablishment is, today, difficult to appreciate but, writing in 1918, J. Vyrnwy Morgan ${ }^{29}$ advised his readers that:

'We are participants in, or spectators of, two dramas of the great world war, and of the disestablishment of the Church of England in Wales. Many years must elapse before the full effect of the former can be measured, and the Church as yet stands only on the edge of the consequences of the latter'. ${ }^{30}$

Many readers of the above might today flinch at any correlation between the 'drama' of the Great War of 1914/1918 and the campaign to achieve Welsh disestablishment, particularly as the guns on the Western Front had only just been silenced, but the statement provides an insight into how the topic of disestablishment was perceived by a contemporary, experienced commentator. Speaking during a debate on the Welsh Church (Burial Grounds) Bill in 1945, Robert Richards ${ }^{31}$ stated, during that the campaign for disestablishment had: 'caused more bitterness and acrimony that any political controversy in which the Welsh nation has ever been engaged'. ${ }^{32}$ Mr. Richards went on to suggest that 'during the last 100 years nothing has so touched the Welsh nation as the

\footnotetext{
${ }^{26}$ Glyn E. German, Welsh History. A Chronological Outline (Talybont: Y Lolfa, 2015), p.244.

27 Section 2, Welsh Church (Temporalities) Act 1919,

${ }^{28}$ Constitutional and Legislative Affairs Committee, National Assembly for Wales, Report on the Inquiry into Lawmaking and the Church in Wales, (June 2013).

${ }^{29}$ Rev. J. Vyrnwy Morgan, (1860-1925), minister of religion and writer.

${ }^{30}$ Rev. J. Vyrnwy Morgan, The Church in Wales in the Light of History. A Historical and Philosophical Study (London, 1918), p.1.

${ }^{31}$ Robert Richards, (1884-1954), historian and Labour Member of Parliament for Wrexham from 1922 to 1924, 1929 to 1931 and 1935 to his death: D.W.B.

${ }^{32}$ Welsh Churches (Burial Grounds) Bill, HC Deb. 16 March 1945, vo.409. col.523. The Welsh Church (Burial Grounds) Act 1945, Chapter 27, 8 \& 9, Geo.6. It was passed unanimously to allow for the transfer of churchyards and burial grounds from the Welsh Church Commissioners back to the Church in Wales which, in effect, reversed the disendowment of those churchyards.
} 
struggle for Disestablishment and to-day we are witnessing the coping stone being put on that structure by the Home Secretary'. ${ }^{33}$ It would be tempting to draw a humorous, if somewhat pertinent, analogy from a suggestion that legislation concerning graveyards should form the coping stone of Welsh disestablishment, particularly as the proposed legislation marked a further retreat from the original Act. Although, as Clement Davies ${ }^{34}$ advised his fellow M.P.s, there was a certain historical symmetry, as: 'The rancour began over churchyards ${ }^{35}$ and it closes over churchyards'.36

\section{Secular and ecclesiastical politics.}

The basis for the pursuit of disestablishment was that the Anglican Church had practically no hold upon the Welsh speaking population of Wales, as: 'the Church is largely dependent upon English settlers and Anglicised Welshmen for its numerical strength' ${ }^{37}$ But it was essentially a clash between those well-established, influential bodies that represented the defence of the establishment status quo and a neophyte movement that was obliged, through the dearth of alternatives, to trust its radical aspirations to a Westminster-based political party which would, by definition, have other demands upon its attention. That party recognised disestablishment as a potential vote-winner in Welsh constituencies, but it would often appear fail to reciprocate Welsh support with any demonstration of the sustained commitment which would have been required to undermine such an entrenched position. Understanding the role of politicians, both secular and religious, and their failures and successes, forms an integral part of this thesis, together with a comparison of their motivation, actions, pronouncements, commitment and, ultimately, their achievements. It was apparent to the then Bishop of St. Asaph, writing in 1913, that:

'Strictly and actually, the case for Disestablishment has been reduced now to one argument; and that is called the political argument, or the argument deduced from the character of the political representation of Wales'. ${ }^{38}$

\footnotetext{
${ }^{33}$ House of Commons Official Record 1945, vol.409, col.527.

${ }^{34}$ Clement Edward Davies, (1884-1962), King's Counsel in 1926, elected Liberal M.P. for Montgomeryshire in 1929 and he held the seat until his death. Leader of the Liberal Party from 1945 to 1956.

${ }^{35}$ Catrin Stevens, 'The 'Burial Question': Controversy and Conflict', Welsh History Review, vol.21, no.2 (December 2002), p.331, where it is suggested that the 'Burial Question', as demonstrated by the press coverage between 1860 and the Burial Act of 1880, 'was another vital and highly emotive expression of nonconformist frustration and Anglican intransigence'.

${ }^{36}$ Welsh Church (Burial Grounds) Bill, HC Deb 16 March 1945 vol 409, col.523.

${ }^{37}$ Owen Owen, Welsh Disestablishment. Some Phases of the Numerical Argument (Wrexham, 1895), p.46.

${ }^{38}$ Bishop of St. Asaph, Landmarks in the History of the Welsh Church, pp.258-259. The Bishop was obliged to denigrate the Welsh claim to nationality, in order to undermine the claim for disestablishment, although Anglicans were increasingly forced to focus on Welsh specifics and this was the position he was obliged to adopt when he
} 
It has been suggested that every major figure in Welsh radical politics 'established his reputation upon the scarred battlement of disestablishment' and, whereas it is apparent that most were influenced or effected by the campaign, a crucial point to be considered is to what extent the campaign was influenced by the vagaries exhibited by politicians. ${ }^{39}$ Whereas the 'commitment' of the Liberal Party to disestablishment was erratic and, upon occasions, duplicitous, the ruthless and unremitting efficacy of the Church defenders, particularly the Bishops of St. Asaph and St. David's, will be explored in chapter four, including their political adeptness, ubiquity and the daedal manner in which they constructed and adapted their defence of the Established Anglican Church. It will be demonstrated that their actions, combined with the extended length of the campaign to achieve disestablishment, ensured that what was eventually delivered was almost a parody of what had been envisaged in the 1890s, allowing the disestablished Church to morph into a re-established Church. A dearth of the necessary militancy and political guile was something which could be levelled at both Welsh Liberal politicians and those Nonconformists who sought disestablishment and it is possible that a desire to exhibit 'respectability' was something which still clung to the Welsh middle-class psyche, after the trauma of the 1847 Reports of the Commissioners of Inquiry into the State of Education in Wales, the 'Blue Books', and that this outbid any temptation to exhibit the necessary belligerence to effect change. There had been an intimation of what that militancy could have achieved, by dint of the Tithe Wars ${ }^{40}$, but this did not ignite the tinder ${ }^{41}$ or cause commentators to be obliged to seriously equate Wales with Ireland ${ }^{42}$ Due to the adversarial nature of the campaign for Welsh disestablishment, it would be tempting to draw the conclusion that everything appeared to be essentially binary; that is Church versus Chapel, Conservative versus Liberal, unionist versus nationalist and, in so

\footnotetext{
became head of the new Province in 1920. Writing in 1927, the Archbishop was to claim that the creation of 'Wales a Province' was to unite the Welsh people and was to 'thrill' them with the thought of Wales "a nation": Edwards, A.G., Memories, p.321.

${ }^{39}$ Kenneth O. Morgan, Freedom or Sacrilege? (Penarth: Church in Wales Publications, 1965), p.3.

${ }^{40}$ The description of a sale of stock under distress, for tithes, on 26 August 1886, was described by The Times, with local farmers extolling the hope that 'the agitation would be conducted in an orderly manner, but still in a manly and resolute spirit': 'The Collection of Tithes in Wales', The Times, 27 August 1886, p.6.

41 'The present attitude of Wales in respect to tithes is one of silent stubbornness': 'Wales and Tithes', The Cambrian News, 24 June 1887, p.4.

42 'Is Wales to become a second Ireland', South Wales Daily News, 20 September 1886, p.2: an editorial did 'not wish to excite feelings or passions', but warned that Welsh M.P.s 'were not troubling the House of Commons very much with their presence, but it must not be inferred from that circumstance that there is perfect peace and contentment throughout the Principality'.
} 
doing, to generalize about motives, arguments and aims, when such labelling actually masks many of the subtleties which require exploration.

\section{An 'alien' Church?}

An understanding of the constitutional ramifications of Welsh disestablishment will be attempted and the realisation that, viewed from the other side of Offa's Dyke, or even by many people within Wales, Welsh disestablishment was a misnomer, as demonstrated by Gladstone, when he had opined that 'there really is no Church in Wales', that it was simply a question of it being 'four diocese within the Church of England'. ${ }^{43}$ This premise was taken a step further by some who argued that there was no separate entity called Wales. ${ }^{44}$ Such thinking would have confirmed the anguish and despair felt by a Welsh Churchman such as Dean H.T. Edwards and offered further confirmation, if required, that the 'Alien Church' was indeed 'Yr Eglwys Wladol', 'a State Church using religion as an instrument for fulfilling the purposes of a shortsighted statecraft'. ${ }^{45}$ The Church establishment was to be rigorously and the vehemence of those politicians who sought to defeat disestablishment was 'precisely because it was one bulwark defending the rest of the power edifice' and there was uncertainty about the resilience of that constitution if one element should be dislodged or revised. ${ }^{46}$ An indication of the importance attached to this state of affairs was given by Lord Parmoor ${ }^{47}$, in 1917, when he said, without any intended hyperbole, that the 1914 Welsh Church Act, which provided for Welsh disestablishment, 'was probably the greatest interference on the part of the State in the affairs of the Church which our history has seen in other than times of open revolution' ${ }^{48}$ The timing of the 1914 Welsh Church Act ensured that any claim to a 'victory' could be interpreted as

\footnotetext{
${ }^{43}$ W. E. Gladstone, The Church in Wales: A speech by the Right Hon. W. E. Gladstone, M.P., in the House of Commons on the Resolution of Mr. (now Mr. Justice) Watkin Williams (London, 1870).

${ }^{44}$ The Venerable Bevan described the country's topography and: 'hence there is no trunk-road between North Wales and South Wales; hence also Wales has never had a capital - a sign that it was not a single State, nor yet a single Church': The Ven. W.L. Bevan, Notes on the Church in Wales (London, 1905), p.32.

${ }^{45}$ H. T. Edwards, 'Wales and the Welsh Church', in H. T. Edwards and David Jones, Wales and the Welsh Church (London, 1889), p.267. 'Wales and the Welsh Church' was written in the spring of 1884.

${ }^{46}$ K. Manton, 'Edwardian Conservatism and the Constitution: The Thought of Lord Hugh Cecil', Parliamentary History, vol.34, pt3 (2015), p.371.

${ }^{47}$ Charles Alfred Cripps, $1^{\text {st }}$ Baron Parmoor, (1852-1941). He criticized what he considered to be Archbishop Davidson's temporizing attitude towards the government's proposals for Welsh church disestablishment. It was due to his dissatisfaction with parliament's interference in church matters that led him, in July 1913, to successfully move a resolution in the Representative Church Council calling for measures to secure the church's 'spiritual independence'. This led to the Archbishop's Committee on Church and State, which met from 1913 to 1916, and which recommended the establishment of the Church Assembly; O.D.N.B.

${ }^{48}$ The Archbishops' Committee on Church and State (London: SPCK, 1917), p.241.
} 
inappropriate, in the context of the minatory events across the English Channel. This timing is just one of the factors which have engendered a seemingly bizarre transformation of roles, as Nonconformists had morphed from being the victims of religious inequality to the current perception, where they are often portrayed as vengeful persecutors, who made unwarranted attacks upon the Anglican Church.

\section{Disestablishment etc.}

One of the contributing factors to the confusion which has surrounded disestablishment is that it is used as a term which also included disendowment and dismemberment. Disendowment is that aspect of disestablishment which still generates adverse comments from Church people, historians and commentators, with attempts to portray it as the main objective of disestablishment. This echoes the comments of many Church and lay politicians during the campaign itself when, for example F. E. Smith ${ }^{49}$ said of the Chancellor of Exchequer, David Lloyd George, during a debate in House of Commons in 1912 that it could all be summed up in one sentence: 'You want the money'. ${ }^{50}$ Little consideration has been given to the actual financial arrangements or the fact that the endowments were eventually put to secular eleemosynary objectives. The least discussed element of the trinity, dismemberment, was, ironically, a consequence which probably caused the first Archbishop of Wales, A. G. Edwards, greatest consternation, when he wrote that: 'The exclusion from Convocation is an irreparable loss to the clergy and bishops of Wales', and that: 'The dismemberment of the Church of England has for the Church in Wales severed the arteries through which the life of the Church pulsed'. ${ }^{51}$ The Archbishop's anxiety would have been heightened by the fact that, as will be described, the Bishop of St. Asaph, as he was at the time, had written to the Archbishop of Canterbury, Randall Davidson, in 1919, seeking guidance on the point, including the possibility that the disestablished Welsh Church would attempt to 'retain our place in the Convocations of Canterbury. ${ }^{52}$ It was the Archbishop of Canterbury who cast the Welsh Church adrift; albeit that

\footnotetext{
49 Frederick Edwin Smith, $1^{\text {st }}$ Earl of Birkenhead (1872-1930), Conservative member for Walton, 1906-1918, member for West Derby, 1918-1919, Solicitor General, June-November 1915, Attorney General, 1915-1919, Lord Chancellor, 1919-1922, Secretary of State for India, 1924-1928. It is ironic that this vocal opponent of Welsh disestablishment should have been serving as Lord Chancellor, in 1920, when disestablishment took place.

${ }^{50}$ Established Church (Wales) Bill, HC Deb. 13 May 1912, vol.38, c810.

51 The Archbishop of Wales, Memories, London, 1927, pp.328-329.

${ }^{52}$ G.K.A. Bell, Davidson, Randall, Archbishop of Canterbury, Volume 1 (Oxford, 1935), p.987.
} 
he reported that the majority of bishops believed that it would allow for the 'happy and orderly working of the whole Church in England and Wales'. ${ }^{53}$

\section{Originality.}

This thesis provides for a contextualized examination of both the campaign seeking Welsh disestablishment and the outcome of that struggle, although it disputes the generally accepted viewpoint that the Anglican Church in Wales was disestablished in 1920; that is by any measure of what would have been anticipated by a true separation of Church and State. The paradox is that the pre-eminent Church defenders, the Bishops of St. Asaph and St. David’s, were successful in their efforts to nullify what were considered to be the most feared elements of disestablishment and disendowment. Whereas dismemberment, that is a separation from the Convocation of Canterbury, could not be avoided, it is necessary to recognize that this was the position preferred by the Archbishop of Canterbury, almost as if there needed to be a separation from potential contagion, at a time when the Church of England was exercised by an examination of its own relationship with the State. It is important to not only consider the nature of the disestablished Church in Wales but, also, to fully appreciate the Church of England's own concerns about disestablishment. In 1913, when, ironically, there were last ditch attempts to defer, or at least modify, Welsh disestablishment, the Church of England's Representative Church Council passed a resolution requesting the Archbishops of Canterbury and York to establish a committee to report on the relationship between Church and State, to secure 'a fuller expression of the spiritual independence of the Church as well as of the national recognition of

religion'. ${ }^{54}$ The significance of what was happening in respect of England and the impact, if any upon Wales, has rarely, if ever, been examined. This work will indicate that, despite the best efforts of the Welsh Church defenders to harness the Church of England to its efforts to defeat disestablishment, it will be demonstrated that the four Welsh dioceses rapidly became a 'side show' and, post 1914, inconsequential and insignificant.

The originality of this work derives from its examination of the received position, as far as disestablishment and disendowment are concerned, in addition to a re-evaluation of the role of

\footnotetext{
${ }^{53}$ Ibid., p.988.

${ }^{54}$ The Archbishops' Committee on Church \& State (London, 1917), p.2.
} 
the Liberal Party in Wales and the opinion that it represented the view of Nonconformists. It also considers the Church in Wales, post-1920, and how far the characteristics of that Church suggest a disestablished Church. In terms of the Liberal Party, it will be shown that the majority of commentators have assumed that the general position of Welsh Liberals in particular was supportive, but this work will attempt a more nuanced analysis and it will attempt to answer the crucial question which is usually avoided, or is attributed with cursory attention, that is why the Welsh Liberals, consisting of some the best talent within the Liberal Party generally, repeatedly failed to deliver and why, despite the fact that the Welsh Nonconformists were often portrayed in contemporary cartoons, as being the unwitting dupes of the Liberal Party, they continued to support the Party, with any faint attempt at rebellion rapidly quelled by promises or, as will be shown, the labyrinthine machinations of their political heroes. A number of exemplars will be noted, but the one which exhibited all of the worst attributes of mendacious political manoeuvring was the formation of the Royal Commission on the Church of England and other Religious Bodies in Wales and Monmouthshire, a cynical object in procrastination, with its instigators eventually disowning the body and the protracted proceedings. When the Report was finally published in 1910, The Times made a whimsical suggestion that in relation to the profusion of reports and memoranda, both official and unofficial, that there was perhaps no alternative but for the Prime Minister to 'now ask for another Royal Commission to examine the methods and test the statistics'. ${ }^{55}$

\section{Sources.}

The sources used have included newspaper accounts and archival sources, albeit primarily English medium, official reports and commentaries and references to speeches by political and ecclesiastical actors, in addition to the accounts of the committees, Royal Commissions and other bodies which have considered aspects of disestablishment or related topics. Contemporaneous visual representations of political discourse, including cartoons and photographs, have been introduced, as these often provided a stark portrayal of the issues in question. Staniforth's cartoons, in particular, provided a uniformly anti-disestablishment perspective, with imaginative and skilfully drawn images which often illustrated the figure whom he came to use to portray Nonconformity, as either a guileless dupe of the Liberal Party or a violent, irreligious footpad,

55 ‘The Welsh Church Commission’, The Times, 3 December 1910, p.13. 
preying upon some innocent Churchman. The following cartoon, drawn at a time of particular Anglican anxiety about disendowment, depicts a brutal robbery committed on Christmas Eve.

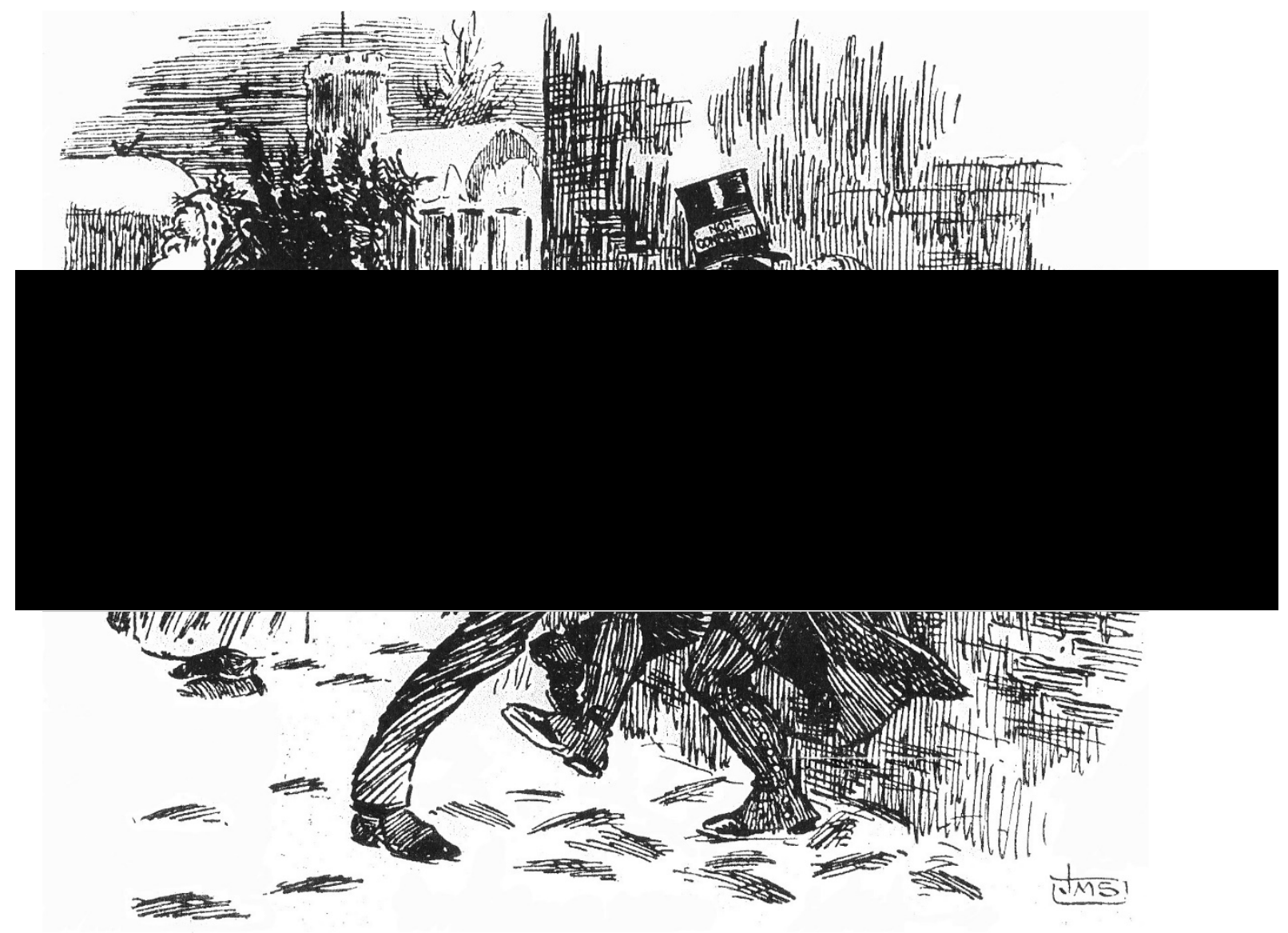

'A Christian Land', Western Mail, 24 December 1912.

Father Christmas: 'How peaceful is this dear old Christian land of ours! Listen to the sweet bells of the House of God ringing joyously, "Peace on earth: goodwill towards men!””

As the funds that were to be released by disendowment were to be utilised for secular charitable objectives, perhaps Staniforth ${ }^{56}$ should have portrayed the footpad as a Welsh Robin Hood (perhaps Twm Siôn Cati). The gaiters would suggest that the Churchman is a prelate and the cartoon would appear to inadvertently suggest that the 'Welsh Church' is living well off those Church endowments.

\footnotetext{
56 Joseph Morewood Staniforth, (1863-1921), cartoonist at the Western Mail from 1893 to his death. As Chris Williams has identified, Staniforth's cartoons were 'reliant on the active participation of his readers', due to the visual clues, as well as the literary and popular cultural references': Chris Williams, 'Cartooning the rise of Labour, 1900-21', in The art of the possible: Politics and Governance in modern British history, 1885-1997: Essays in memory of Duncan Tanner, ed. By Chris Williams and Andrew Edwards (Manchester: University Press, 2015), pp.70-72.
} 
A critical examination of the historiography was required, as the Welsh disestablishment campaign has often been omitted from accounts of the period concerned. This is partly attributable to the Anglo-centric nature of certain accounts, or by a failure to believe that the campaign was a pertinent topic for inclusion within an English/British context or had any importance. The extended period of the campaign is a feature which often appears to elude those who have commented, probably because the length of the period confounds them, which is understandable, and it is therefore tempting to restrict their observations to one of the many phases. It is also discernible that the subject has been regularly subjected to vagaries, in terms of the attention of the Welsh 'schools' of history with, in recent times, a bias against disestablishment and the motives that lay behind the campaign, with a tendency to portray the Anglican Church as the unfairly injured party.

Although written contemporary accounts have been considered, there has been no attempt to interview those who might have a view upon what disestablishment means to them individually, or the institutions they represent. Through the writer's social interaction with Churchmen and lay people, it has been apparent that there is often confusion about the topic, with a surprising lack of knowledge about the outcome of disestablishment and disendowment and the characteristics that should define a disestablished Church often being considered of less import and, in cases, a failure to distinguish the Church in Wales from the Church of England. This last point is particularly fascinating as the centenary of the Church in Wales draws near and it raises the question of how the Church would commemorate the event.

Material has been utilized to both garner an understanding of the Welsh disestablishment campaign, as it proceeded, and then to set it in the context of Welsh politics generally, but also to understand how such an all-pervasive subject could, as far as the majority of people were concerned, abruptly fall away from popular consciousness, albeit that the outbreak of the Great War was a factor. It could be claimed that it was essentially a religious issue, during increasingly secular times, so its fortunes became increasingly less relevant. It is submitted that the approach taken and the sources utilized have allowed the objectives of this research to be met. 


\section{Significance.}

The above approach will provide for a re-examination of an event whose centenary will take place on 31 March 2020. It is therefore apposite to attempt to better understand both the protracted campaign to achieve Welsh disestablishment and what actually transpired as a result of the creation of the disestablished Church in Wales. It would be understandable if many of those who marked the centenary will restrict their observations to the Church itself, with no reason to analyse the period of gestation and the impact upon Wales more generally, particularly its national aspirations. It will be evident that Welsh disestablishment was the primary political issue for much of the nineteenth-century, and the period leading to the Great War, but for reasons which need to be understood, it almost proved impossible to achieve and, even when legislation managed to stagger onto the statute book in 1914, there were many who were certain that it would be repealed, or at least amended. The thesis contains numerous statements which provide for a different interpretation to Welsh disestablishment and its aftermath, as suggested by the above. These assertions will be supported by the requisite evidence and the writer's interpretation of that evidence, and the basis of the suppositions, will be made apparent.

\section{An examination of the literature.}

It has often been the case that commentary upon disestablishment can, perhaps unwittingly, create a perception that the Established Church was a victim of some process which, in itself was alien and imposed, rather than the fact that it could be argued that it was the Church of England in Wales which was 'alien’, and that disestablishment was a popular objective:

'The cause célèbre of the Liberal Nonconformist majority in Wales was undoubtedly the disestablishment of the Church of England within the Welsh counties. Having closed the taverns on Sundays, they sought to extinguish the privileges of the parish churches’. ${ }^{57}$

Such a pithy, and not wholly inaccurate, observation does not address the source of those 'privileges', or indeed whether they were warranted, particularly in light of the Anglican Church's position in Wales at the time. This will be considered, in addition to those other reflections which tend to stress that disestablishment was little more than a necessary means of capturing the Church's endowment, albeit that it is often ignored that the funds would be utilized for eleemosynary objectives:

\footnotetext{
${ }^{57}$ Thomas Glyn Watkin, The Legal History of Wales, second edition (Cardiff: University of Wales Press, 2012), p.
} 180 
'By the time of Welsh disestablishment, the political disabilities on dissenters had already been removed. Disestablishment of the Welsh Church was, therefore, primarily an economic measure as far as Welsh society was concerned'. ${ }^{58}$

Much of the literature, post disestablishment, appears to replicate the themes apparent in the leaflets and speeches which attempted to undermine disestablishment, with the Church portrayed as a helpless victim, whereas it formed part of the 'establishment', and inopportune issues are regularly ignored. For example, Welsh disestablishment has rarely been considered in the context of the tensions and misunderstandings within the Church/state relationship which were already inherent in the Church of England, as would eventually be highlighted by the 'Prayer Book Crisis' of $1927 .{ }^{59}$ This would provide an unwelcome and extremely uncomfortable reminder that the essence of 'Establishment signified, above all, Parliament's statutory power over the Church. ${ }^{60}$ As early as 1897, the Bishop of Durham had recognized that 'Parliament is not able to deal effectively in debate with questions of Church reform. It no longer represents Church feeling.' ${ }^{61}$ The fact that this has led to 'a process of creeping disestablishment', where the Church has gained an increasing level of self-government ${ }^{62}$, is viewed as relatively benign, whereas contemporary commentators are more censorious about Welsh disestablishment, which was:

'forced upon unwilling Anglicans in Wales by a Parliament in which the vast majority of Welsh members represented the liberal, Nonconformist element which accounted for the greater part of the population. Disestablishment in Wales was forced upon the Church by dissenters'.63

The other regular omission is any consideration of the freedoms which disestablishment inaugurated. The relative ease with which the Church in Wales was able to form two new Sees, shortly after disestablishment, without recourse to parliamentary approval, should have provided sufficient evidence of the benefits. It will be demonstrated that a continuing confusion about the

\footnotetext{
${ }^{58}$ C. Harris and R. Startup, The Church in Wales. The Sociology of a Traditional Institution (Cardiff, 1999), p.5.

${ }^{59}$ J. P. Parry and S. Taylor, 'Introduction: Parliament and the Church of England from the Reformation to the Twentieth Century', Parliamentary History, vol.19, issue 1 (February 2000), p.11.

${ }^{60}$ Robert Currie, 'Power and Principle: The Anglican Prayer Book Controversy, 1927-1930', Church History, vol.33, no.2 (June 1964), p.193.

${ }^{61}$ G. T Machin, Politics and the Churches in Great Britain, 1869 to 1921 (Oxford: Clarendon Press, 1987), p.232.

${ }^{62}$ K. Medhurst, 'The Church of England: A Progress Report', Parliamentary Affairs, vol.52, issue 2 (April 1999), pp.278-279.

${ }^{63}$ Thomas Glyn Watkin, 'Disestablishment, Self-determination and the Constitutional Development of the Church in Wales', in Essays in Canon Law. A Study of the Law of the Church in Wales, ed. by Norman Doe (Cardiff: UWP, 1992), p.31.
} 
effects of disendowment has supplied a casus belli for those who seek reasons to denigrate disestablishment and the position has been exacerbated by the fact that the Church, postdisestablishment, drew a veil over its financial position in order to obfuscate matters.

An examination of the campaign to disestablish the Church of England in Wales, particularly during its later stages, will regularly encounter what Kenneth Morgan described as 'the use and abuse of history and law', as each side endeavoured to enhance its case and to mobilise support. ${ }^{64}$ The 'histories' which emerged were therefore essentially propaganda tools. Bishop Edwards of St. Asaph swiftly grasped the potency of Anglican historiography ${ }^{65}$ and its importance, in terms of both combatting those who sought disestablishment and, as will be considered in chapter four, the Bishop’s awareness that the interest of English Church people was likely to wane. In the introduction to his 1894 book, A Handbook on Welsh Church Defence, the Bishop quoted from an exchange with the 'Vicar of a great English town' who, in response to the Bishop’s enquiry about what he should say about the Welsh Church at a forthcoming Church defence meeting, received the reply that: 'The people here know as much about India and Hindustani as they do about Wales and Welsh', from which the Bishop concluded that 'information about Wales, and the Church in Wales, is needed at the present time'. ${ }^{66}$

In the foreword to his 'brief essay' on the campaign for Welsh disestablishment, Lord Kenneth Morgan expressed the hope that his 1966 'monograph' would encourage future historians to address the history of Welsh disestablishment in 'its entirety'. ${ }^{67}$ Although published in 1966, Lord Morgan’s 'brief essay' on the campaign for disestablishment is still quoted as one of the main sources on the subject and, in it, he claimed that 'to look back on the history of disestablishment is no mere antiquarian exercise. It is a theme that illuminates the innermost substance of the Welsh nation and its culture, in all its unity and in all its diversity. It helps to make intelligible the Wales of today' ${ }^{68}$ Freedom or Sacrilege? has rightly been accorded a reputation as a leading work on Welsh disestablishment, but it did not escape some critical

\footnotetext{
${ }^{64}$ Kenneth O. Morgan, 'Wales in British Politics: Forty Years On’, Llafur, vol.9, no.1 (2004), p.22.

${ }^{65}$ A. G. Edwards, Bishop of St. Asaph, The Truth about the Church in Wales (London, 1889), which commences with: 'The present position of the Church in Wales cannot justly or adequately be explained without some reference to its past history'.

${ }^{66}$ A. G. Edwards, Bishop of St. Asaph, A Handbook on Welsh Church Defence (Denbigh, April 1894).

${ }^{67}$ Morgan, Freedom or Sacrifice? p.1.

${ }^{68}$ Morgan., Freedom or Sacrilege? p.3.
} 
comments which merit examination, as perhaps they suggest that, in 1966, the question of Welsh nationality was re-emerging, marked by the election of Gwynfor Evans, as the first Plaid Cymru member of Parliament, in July of that year. ${ }^{69}$

The critic concerned was T. I. Ellis ${ }^{70}$, son of Tom Ellis, and he pointed out, at the beginning of his review, that Kenneth Morgan's book dealt, more accurately, with the disestablishment of 'the Church (of England) in Wales', the words in brackets being his own. ${ }^{71}$ This was a subtle, but important emphasis and a point which has often eluded commentators, but it was a precursor to his concern that the title of the work might have been misleading, in that: 'The campaign for the disestablishment of the Church of England in Wales was up to the end of the nineteenth century at least a part of the struggle for the recognition of Welsh nationality'. ${ }^{72}$ Kenneth Morgan was scrupulous in declaring that he was committed to 'neither the Anglican nor the Nonconformist point of view' and hoped that he had 'done serious injustice to neither'. ${ }^{73}$ It is possible, however, that in the context of the political changes at the time, combined with his desire to be unbiased, Kenneth Morgan did not attribute sufficient weight to the question of Welsh nationality. A noted Welsh historian, A. H. Dodd ${ }^{74}$, appeared to demonstrate how historians, writing at that time, may have been influenced by their personal discomfort with contemporaneous political events when, writing in 1970, he proffered an interpretation which charted what he appeared to view as the regressive nature of Welsh nationalism, when he claimed that it found: 'its expression first in Gladstonian Liberalism, then in the Cymru Fydd movement and Plaid Cymru, and now in more violent manifestations on which I need not enlarge'. ${ }^{75}$

\footnotetext{
${ }^{69}$ Rhys Evans, Gwynfor Evans. Portrait of a Patriot (Talybont: Y Lolfa, 2008), p.264.

${ }^{70}$ Thomas Iorwerth Ellis, (1899-1970), educationalist and author.

${ }^{71}$ T. I. Ellis, 'The Disestablishment Campaign', Journal of the Historical Society of the Church in Wales, vol. XVII (1967), p.62.

72 T.I. Ellis made this point in his review of K.O. Morgan's Freedom or Sacrilege?, where he believed that the title did not do justice to the nature of the campaign: Ellis, T.I, 'The Disestablishment Campaign', Journal of the Historical Society of the Church in Wales, vol. XVII (1967), p.62.

${ }^{73}$ Morgan, Freedom or Sacrilege? p.1.

${ }^{74}$ Professor Arthur Herbert Dodd, (1891-1975).

${ }^{75}$ A. H. Dodd, 'Nationalism in Wales', Transactions of the Honourable Society of Cymmrodorion, 1970, Part 1, p.47.
} 
The relationship between Welsh nationalism and disestablishment is certainly symbiotic and this was recognised by A.W. Wade-Evans ${ }^{76}$, when he posited that: 'Underlying the question of Disestablishment in Wales is the broader, deeper, and more vital one of Welsh Nationality ${ }^{\text {, }}{ }^{\text {. It }}$ is difficult, however, to accept John S. Ellis's analysis, when he wrote of Wales at the turn on the twentieth-century that 'Welsh political nationalism had worked splendidly' and that all that remained of their programme was 'its much sought after capstone: Welsh disestablishment', which had become 'a symbolic fetish of nationalist victory, the crowning achievement that would signify the realization of Welsh nationhood' ${ }^{78}$ This thesis will attempt to outline the far more subtle relationship between disestablishment and nationalism.

It is the contention of this thesis that the significance of disestablishment has rarely been fully considered 'in its entirety’, an exception being P.M.H. Bell’s 1969 book on disestablishment in Ireland and Wales, of which two-thirds concerns Ireland alone. ${ }^{79}$ A reviewer of that book admirably demonstrated a characteristic which is still propounded, that is an anti-Nonconformist bias, when he suggested that the reason why only a third of the book dealt with Welsh disestablishment was that 'the campaign for disestablishment was accordingly more bitter and the Nonconformists more vindictive. This distasteful aspect of the Welsh episode no doubt explains Mr. Bell’s economy’, which was described as ‘a charitable abbreviation'. ${ }^{80}$ The reviewer's standpoint was made apparent when he wrote that: 'In Ireland the arguments were constitutional and political: the pressures for change expressed a well-defined polemicism. In Wales the attack on the establishment is attributed merely to 'nationalism' ${ }^{81}$ The reviewer might have done Mr. Bell some disservice, because although the book takes up the story from 1880, there is a call for 'some comment and qualification', to the 'explanations for the loss of contact between Church and people'. ${ }^{82}$ However, it was evident that P. M. H. Bell was to echo a feature which has, either consciously or unconsciously, bedevilled modern commentary on Welsh disestablishment, when he suggested that: 'Enemies are of prime importance to any nationalist

\footnotetext{
${ }^{76}$ Arthur Wade Wade-Evans, (1875-1964), clergyman and historian. 'He became vicar of France Lynch (1909-26). During this period he led a campaign for the disestablishment of the Church in Wales': D.W.B.

77 A. W. Wade-Evans, Papers for Thinking Welshmen (London: T. Fisher Unwin,1909).

${ }^{78}$ John S. Ellis, Investiture. Royal Ceremony and National Identity in Wales, 1911-1969 (Cardiff: UWP, 2008), p.33.

${ }^{79}$ P.M.H. Bell, Disestablishment in Ireland and Wales (London: SPCK, 1969).

${ }^{80}$ E. R. Norman, 'Other Reviews', The Historical Journal, vol.13, issue.3 (September 1970), p.559.

${ }^{81}$ Ibid., p.559.

${ }^{82}$ Bell, Disestablishment in Ireland and Wales, p.237.
} 
movement, and once an enemy has been defined and given a prominent place in propaganda and ritual of nationalism, it is very hard for the impression so created to be changed'. ${ }^{3} \mathrm{Mr}$. Bell had identified the 'natural enemies' of 'Welsh nationalism' and 'Welsh Nonconformity' as 'the landlords and the established Church'. ${ }^{84}$ The Church has therefore been targeted simply as the victim of a dastardly plot to deliver Welsh nationalism. In a sense, such utterances have a patina of plausibility in that Welsh disestablishment was utilised as a 'stalking horse', and, in a letter in Young Wales, D.A. Thomas ${ }^{85}$ stated that, 'I am in favour of Home Rule all round, but I see no prospect of securing this and I regard Welsh Disestablishment as the more practical measure at the present time'. ${ }^{86}$ However, where this argument disintegrates is that it ignores how the role of the Church of England in Wales, and as Stuart Rendel ${ }^{87}$ confessed, his desire was to see disestablishment be used as a protest against the 'all Anglicising influence in Wales'. ${ }^{88}$

Mr. Bell's understanding of the position in Wales should be brought further into question by his observation that the appointment of A. G. Edwards, as bishop of St. Asaph, and that of John Owen to St. David's, 'showed that it was possible to find men whose Welshness was beyond cavil and who were also generally well qualified to become bishops. ${ }^{89}$ Chapter four will consider their 'Welshness', but A. G. Edwards's position can be garnered from his attitude towards the publication of the Blue Books, the 1847 report on education in Wales. He claimed that the

83 Ibid., p.229.

${ }^{84}$ Ibid., p. 229.

${ }^{85}$ David Alfred Thomas, (1856-1918), first Viscount Rhondda, Liberal member of Parliament for Merthyr Tydfil from 1888 to January 1910 and then M.P for Cardiff until December 1910 general election, when he left politics. After his failure to obtain office under Campbell-Bannerman's government of 1906, he focused on the Cambrian collieries, later to become the successful Cambrian Combine: D.W.B

86 'Our Round Table Conference: Home Rule All Round’, Young Wales, October 1895, p.238.

${ }^{87}$ Stuart Rendel, $1^{\text {st }}$ Baron Rendel, (1834-1913), was an industrialist and politician. He was born in Plymouth, went to Eton, and graduated from Oriel College, Oxford, in 1856. Despite being called to the Bar, he eventually became the manager of the Sir William Armstrong \& Co. gunnery company, being vice-chairman of the company by the time of his death. The links he formed with foreign governments in this capacity became useful when he was involved in peace negotiations between China and France in 1885. In 1880 he was elected the Liberal Member of Parliament for Montgomeryshire, becoming the chairman of the 'Welsh Parliamentary Party', 1888-1894. He was president of University College of Wales, Aberystwyth from 1895 to 1913, contributing $£ 1000$ a year to the College. He also donated land in Aberystwyth to serve as the site for the National Library of Wales, in 1897. Rendel was a close friend of W. E. Gladstone and, as will be shown, a greater friend to Wales. He was an Englishman who, much to the Bishop of St. Asaph's chagrin, was an Anglican who was also a Welsh patriot. 'The services Lord Rendel has rendered to Wales in many directions have been great and, in some ways, so permanent that they have become part of the history of the country. For instance, he taught the Liberals of Wales by his successful attack upon

Conservatism in Montgomeryshire that there was really nothing politically impossible to them': 'Lord Rendel', The Cambrian News, 27 November 1908, p.5.

${ }^{88}$ F. E. Hamer, The Personal Papers of Lord Rendel (London: Ernest Benn, 1931), p.306.

${ }^{89}$ Ibid., p.238. 
'Report of this sincere and well-intentioned Commission had angered and almost maddened the people whom it had come to benefit and bless'. ${ }^{90}$ Such a benign interpretation should be contrasted with the immediate response of a leading Anglican, Sir Thomas Phillips ${ }^{91}$, who, despite being an 'establishment figure', produced a detailed riposte to the contents of the 'Blue Books'.92

A number of 'schools' can be identified in terms of recent commentators. Firstly, there are those books which purport to present an unbiased account, although phraseology tends to suggest otherwise. A History of the Church in Wales is regularly cited as one of the few works to examine disestablishment, but the opening of Canon David Walker’s chapter, entitled 'Disestablishment and Independence', would suggest that the writer's interpretation of events, over half a century after disestablishment took effect, was less than objective, when he interpreted disestablishment and disendowment as 'the twin methods of attacking the Church., 93 It will be seen that similar accusations formed a core element of Church defence and that the arguments for disestablishment, even when compromise was being sought, were ignored and even today, the Church still pursues a narrative that it has 'survived'. This apparent failure, by Churchmen, for reconciliation can often be drawn from the language used after 1920 and, in 1937, Archbishop C.A.H. Green wrote, in his authoritative guide to the constitution of the Church in Wales, that disestablishment had 'torn out' the four Welsh dioceses from the Province of Canterbury. ${ }^{94}$

Another 'school' is that taken from an Anglo-centric standpoint, with scant knowledge of the nature of the campaign or an accurate understanding of the secular and ecclesiastical politicians involved. A somewhat Anglo-centric approach to disestablishment is demonstrated by William

\footnotetext{
90 The Archbishop of Wales, Memories, p.114.

${ }^{91}$ Sir Thomas Phillips, barrister and author, (1801-1867). He was mayor of Newport in 1839, at the time of the Chartist march upon the town, and his part in the defence of the Westgate Hotel, in which he was wounded, led him to be knighted and to be widely acclaimed as a hero.

92 Sir Thomas Phillips, Wales, The Language, Social Conditions, Moral Character and Religious Opinions of the People (London: John W. Parker, 1849).

${ }^{93}$ Canon David Walker, ed., A History of the Church in Wales (Penarth: Church in Wales Publications, 1976), p.164.

94 The Most Reverend C.A.H. Green, The Setting of the Constitution of the Church in Wales (London, 1937$)$, p.12. He was Archbishop from 1934 until his death in 1944. He was described as the 'ecclesiastical administrative genius that the Church in Wales needed' to cope with the 'upheavals of disestablishment, Frederic Hood, 'Charles Alfred Howell Green (1864-1944)’, rev. Marc Brodie, (ODNB, 2004).
} 
H. Mackintosh in his Disestablishment and Liberation, which has little to say about the Welsh aspect of the campaign. ${ }^{95}$ But, as will mentioned throughout the thesis, the surprising characteristic is that Welsh disestablishment has often been simply ignored, even when the Church of England has endured the paroxysms associated with its own examination of the nature of the relationship with the state. ${ }^{96}$

The third 'school' is what could be described as the revisionist approach, with an assertion that the history of the Welsh Anglican Church had been misrepresented and that recent research 'is beginning to show that its poor reputation is far from justified' ${ }^{97}$ This has also raised questions about the results of the Census of Religious Worship in $1851^{98}$ and its aftermath. ${ }^{99}$ Professor Yates wrote that:

'The established church was labelled by its critics, and even regarded by some of its adherents as, the 'Church of England in Wales'. Whether the allegation was justified or not is a matter of debate, but its effect was to strengthen the nationalistic concept of Welsh Christianity' ${ }^{100}$

Professor Yates wrote this when he launched a new journal to study Welsh church history, with a specific stated objective, which was to challenge the 'nationalistic approach to Welsh ecclesiastical history' and the 'incalculable' damage which it had caused. ${ }^{101}$ This tendency to view disestablishment through the prism of Welsh nationalism is in contrast with the criticism that Kenneth Morgan had omitted to place the subject in that political context. A book, published in 2007 was explicitly described as 'the first major revisionist study of the established church in Wales between the early seventeenth and early twentieth centuries'. ${ }^{102}$ Nigel Yates

\footnotetext{
${ }^{95}$ William H. Mackintosh, Disestablishment and Liberation. The Movement for the Separation of the Anglican Church from State Control (London: Epworth Press, 1972).

${ }^{96}$ The Church of England has regularly considered the Church/State relationship, with the Selborne Report in 1916, the Cecil Committee in 1930, the Moberly Commission of 1949 and the Chadwick Committee in 1967.

${ }^{97}$ Nigel Yates, 'Wind, Rain and the Holy Spirit: Welsh Evangelism in a Pan-Celtic Context 1750-1850', in Bishop Burgess and his World (Cardiff, 2007), ed. By N. Yates, p.104.

${ }^{98}$ Ieuan Gwynedd Jones and David Williams, (eds.), The Religious Census of 1851. A Calendar of the Returns Relating to Wales, Volume 1, South Wales (Cardiff, 1976).

${ }^{99}$ F. Knight, 'The 1851 Religious Census and its Aftermath', in The Welsh Church from Reformation to Disestablishment 1603-1920 (Cardiff: UWP, 2007), ed. by Sir Glanmor Williams, William Jacob, Nigel Yates, and Frances Knight, pp.310-315.

${ }^{100}$ Nigel Yates, 'The Welsh Church and Celtic Nationalism', Journal of Welsh Ecclesiastical History, vol.1 (1984), p.3.

${ }^{101}$ Ibid., p.9.

${ }^{102}$ Williams, Jacob, Yates and Knight, eds., The Welsh Church from Reformation to Disestablishment 1603-1920, description on the inside cover of the dust jacket.
} 
acknowledged that 'between 1727 and 1870 no Welshman held an episcopal see in Wales' and although he felt that this had 'encouraged the image of the Welsh Church as both an Anglicized and an Anglicizing institution', it was a 'fiction'. ${ }^{103}$ Writing in 2010, Martin Johnes appeared to subscribe to this anti-nationalistic interpretation of the pre-disestablished Church, when he suggested that: 'The Anglican Church was always both more popular and less Anglicized than is often imagined'. ${ }^{104}$ Putting to one side those Anglicans who, from 1832 to the 1912, wrote about the 'alien' nature of the Anglican Church in Wales and its effect, this thesis will demonstrate that the ‘alien’ characteristics associated with the pre-1920 Church are relatively easy to substantiate. This view does require careful examination in the context of criticism of the Welsh Anglican church by those who were themselves Anglicans. This group would include Dean H.T. Edwards, Dean David Howell and the clergy who were active within the Association of Welsh Clergy in the West Riding of Yorkshire ${ }^{105}$, in addition to leading Anglican laymen such as A.J. Johnes ${ }^{106}$, Sir Thomas Phillips ${ }^{107}$ and Sir Benjamin Hall of Llanover. ${ }^{108}$

\footnotetext{
${ }^{103}$ Nigel Yates, ‘A Reforming Episcopate’, in Williams, Jacob, Yates, Knight, Frances, (eds.), The Welsh Church from Reformation to Disestablishment 1603-1920, p.223.

${ }^{104}$ Martin Johnes, 'For Class and Nation: Dominant Trends in the Historiography of Twentieth-Century Wales', History Compass, 8/11 (2010), p,1260.

105 The Association, which started, in 1821, as a dining club of ex-patriate Welsh clergy based in Yorkshire became an effective lobbying group, which was able, due to their geographical distance from Wales, to be highly critical of the operation of the Anglican Church in Wales and as their Report of 1852 expounded: 'Our clerical brethren in the Principality, in North Wales especially, being completely in the power of their bishops, whose patronage in the church is exceedingly large, dare not raise a voice, however faint, against a system productive of so much injustice towards themselves': Report of the Proceedings of the Association of Welsh Clergy in the West Riding of the County of York (1855), p.6.

${ }^{106}$ Arthur James Johnes, (1809-1871), was appointed a county court judge in 1847. He wrote numerous pamphlets on legal reform and published an English translation of the poems of Dafydd ap Gwilym: O.D.N.B. He wrote On the Causes which have produced Dissent from the Established Church in the Principality of Wales in 1832.In describing the 'anglicising policy' of the Established Church in Wales, the Reverend David Jones wrote that Dean H.T. Edwards had opined that it was 'the book on the subject': David Jones, The Welsh Church and Welsh Nationality' (Bangor, 1906), p. ix.

${ }^{107}$ Sir Thomas Phillips, Wales: The Language, Social Condition, Moral Character and Religious Character of the People Considered in their Relation to Education (London, 1849).

${ }^{108}$ Benjamin Hall, (1802-1867), later Lord Llanover. He served as MP for Monmouth until 1837, when he transferred to Marylebone. The Dictionary of Welsh Biography records that 'his importance in the history of Wales is entirely overshadowed by that of his wife', Lady Llanover. Benjamin Hall is perhaps known for the suggestion that the great bell in the clock tower of Westminster is known, eponymously, as 'Big Ben', as it was erected during his time in office as commissioner for works but, in terms of Wales and it is suggested, by Marion Löffler, in the 2016 revision of the DNB entry that perhaps, more than his wife, he was especially concerned with 'the provision of Welsh-speaking Anglican clergy. This is the background to his controversy with bishop Connop Thirlwall on the state of the church in the diocese of St. David's'.
} 


\section{Outline.}

Chapter one, entitled 'Inauspicious beginnings', attempts to portray the parliamentary and political chronicle which opened with a seemingly surprising motion by Watkin Williams M.P., in May 1870, and which witnessed Welsh disestablishment warp and weft its way as the key political objective, although appearing unattainable following spasmodic attempts to legislate for it. Albeit that its pursuit was characterised by a lack of clarity about how the ultimate barrier, being the legislative power of the House of Lord could possibly be overcome. The chapter ends in 1906, with a landslide victory by a Liberal government and, ostensibly, the way to disestablishment was within sight. Professor Densil Morgan's observed that; 'What had been in the 1860s a crusade for righteousness had degenerated into a mean-spirited and unedifying political imbroglio' and this chapter will start the process of examining parliamentary proceedings and extra-parliamentary activity in order to understand why this should have been the case. ${ }^{109}$ The chapter considers the role of the Liberal Party in the Welsh disestablishment campaign and, in so doing, it evaluates the vacillating fortunes of the party itself and the leading personalities, with an attempt to understand the cause of the vagaries and whether those Welsh politicians who espoused the cause demonstrated the commitment and tenacity which characterized the efforts of the Church defenders.

Chapter two, 'A battle royal', and, as the title implies, it demonstrates that 1906, rather than being designated as the year in which Welsh demands would be met, was only the commencement of a battle which would become increasingly bitter, particularly as those who defended the Established Church sought to ensure that the 'radical' government did not at last meet its electoral promises. It was largely a question of playing for time, by both Church defenders and, as will be shown, by the government, with David Lloyd George continuing to demonstrate his adeptness. This chapter will describe how the decisive electoral victory in 1906 rewarded those who supported the Liberal party in Wales with a Royal Commission, an 'orphan' body for which nobody would eventually assume responsibility.

${ }^{109}$ D. Densil Morgan, The Span of the Cross. Christian Religion \& Society in Wales 1914-2000 (Cardiff: UWP, 2011), p.33. 
Chapter three, 'The final imbroglio', will consider the legislative tribulations in the years leading to the Welsh Church Act 1914 and the subsequent amendments, threats of repeal and repositioning of the Church before it was disestablished in 1920. Even though Welsh disestablishment was often portrayed as a Gordian knot, which required patience and deliberation, it is apparent that other subjects, with similar levels of complexity, were capable of resolution and well within half a century. Therefore, other causes for the delay and discombobulation are considered. This analysis will provide an understanding of the amount of political effort invested in the campaign for disestablishment and how this focus impacted upon the development of other Welsh causes, including Welsh nationhood and the politics of Welsh Home Rule. In particular, the relationship between disestablishment and democracy requires careful evaluation, in order to understand to what extent a 'democratic deficit' was apparent. Disestablishment was to continue to be of vital importance to the Church defenders after the 1914 legislation, as they endeavoured to work towards its repeal, or at least to mitigate the terms of the Welsh Church Act, in the latter of which they were successful. In addition to establishing the date of disestablishment on 31 March 1920, section 3(2) of the Welsh Church (Temporalities) Act 1919 provided for a sum of one million pounds to be paid to the Welsh Commissioners which, as will be described, was a form of re-endowment. In addition, section 23 of the 1914 Welsh Church Act, which had been intended to bring the Established Church in line with other denominations as far as law relating to marriage was concerned, was repealed by section 6 of the 1919 legislation, before it took effect. This will be shown to be an important element of the disestablished Church's ability to retain the 'vestiges of establishment'. 110

The revamped financial arrangements that were granted to the newly disestablished Church and its new-found independence of action, which compared favourably with the anguish that was to be a continuing feature of the Church of England as it endured the constraints of its ongoing Established state, are usually ignored. It would appear that the Welsh Church had achieved, despite its best efforts, an ultimately enviable state, as it was released from potential interference by the legislature but, as most commentators would acknowledge, it had 'retained the mission of an established church’ and, more subtly, the characteristics of such a Church. ${ }^{111}$ It has been

\footnotetext{
${ }^{110}$ Thomas Glyn Watkin, 'Vestiges of Establishment. The Ecclesiastical and Canon Law of the Church in Wales', Ecclesiastical Law Journal, 1990, pp.110-115.

${ }^{111}$ Harris and Startup, The Church in Wales. The Sociology of a Traditional Institution, p.ix.
} 
suggested that this legerdemain, in that it has continued to maintain its 'establishment outlook', has allowed it to 'accommodate itself' better than the Free Churches, to the decline in worship and attendance. ${ }^{112}$ An area which will be explored will be the Church's relationship with the Welsh language, which was, as will be shown, was a factor in perceptions of the established Church. The position, post-1920, has often been uncomfortable and to read of Welshmen 'who claimed that the national spirit is being crushed by an anglicized squirearchy' would have been a common complaint during the disestablishment campaign, but to read it in 1958 might surprise some ${ }^{113}$, although a warning that the 'Church in Wales is becoming more English because of the leadership in our churches' was expressed in 2012. ${ }^{114}$

Chapter four considers the ecclesiastical dramatis personae. Although the secular and ecclesiastical worlds were, by necessity, interwoven during the disestablishment campaign, it is necessary to acknowledge the relative success of the two leading Church defenders, the Bishops of St. Asaph and St. David's, who were natural ecclesiastical politicians. In terms of those who sought to defeat Welsh disestablishment, they could not have been better led. It will be demonstrated that, in terms of consistent and effective performance, over a long duration, they exhibited a tireless, tenacious and terrifyingly thorough commitment, combined with an astute political acumen, which should merit the admiration of any exponent of the dark art of politics, then and now. There was also an impression the Bishop St. Asaph, and his brother-in-law the Bishop of Chester, aspired to control the entire Welsh Church, in which they were successful. This meant that there was only one approach, in terms of how the Church addressed the threat of disestablishment, and that would be 'the St. Asaph policy'. ${ }^{115}$

However, the chapter will also examine the nature of the Church they were defending and whether it was a uniform institution. In so doing, it considers the remarkable fact that two antithetical versions of that Welsh Church existed, propounded by two extraordinary clerics, who happened to be brothers.

${ }^{112}$ D. P. Davies, Against the Tide. Christianity in Wales on the threshold of a New Millennium (Llandysul: Gomer, 1995), p.34.

113 'Archbishop of Wales Without the Language', The Times, Monday, 18 November 1958, p.6.

114 'Church seeks Welsh-speakers to fill language gap', Church Times, 27 April 2012, p.6.

${ }^{115}$ Described by the Bishop's biographer as the new policy of Church defence, 'to which he had resolved that all his clergy must adhere under pain of being charged with disloyalty’: George Lerry, Archbishop George Edwards. Archbishop of Wales (Oswestry: Caxton Press), 1940), p.37. 
The legacy of Welsh disestablishment is considered in chapter five. Some fifteen years after disestablishment, Frank Morgan, the long-serving and influential secretary of the Welsh Church's governing and representative bodies, provided a clear indication of how far the hierarchy of the Welsh Church had shied away from their new found freedom, when he admitted to representatives from the Church of England that although the Welsh Church was 'free to determine its rule of worship and would probably be able to obtain conformity thereto' the situation had not arisen ${ }^{116}$ It could be argued that disestablishment 'never took place' and a statement made in the House of Commons by a government minister, in 2012, tended to support this view. ${ }^{117}$ Archbishop Edwards gave an indication of his own grasp of relative significance, when he wrote that: 'The dismemberment of the Church of England has for the Church in Wales severed the arteries through which the life of that Church passed' ${ }^{\prime 18}$ and he described how: 'from the very beginning I dreaded loss of unity more than loss of endowments'. ${ }^{119}$ The surviving 'vestiges of establishment' will be appraised and, as discussed by a committee of the National Assembly of Wales in 2013, they were an indication of how the 'ambiguous' nature of that Church/state relationship still pertains and still has a relevance. ${ }^{120}$ It will be seen that 'the Church in Wales is often viewed as having many of the characteristics of establishment' and therefore it would be germane to identify how far the Church was disestablished or whether the Welsh Anglican Church, which emerged in 1920, was merely 'established' in a modified form. ${ }^{121}$

\footnotetext{
${ }^{116}$ Church \& State. Report of the Archbishops' Commission on the Relations between Church and State, volume 1, London, 1935, volume 2, Evidence of Witnesses, p.1., p.139.

${ }^{117}$ Maria Miller, the Minister for Women and Equalities, made the following statement: 'Finally, because the Churches of England and Wales have explicitly stated that they do not wish to conduct same-sex marriage, the legislation will explicitly state that it would be illegal for the Churches of England and Wales to marry same-sex couples. That provision recognises and protects the unique and established nature of those Churches'. HC Debates, 11 December 2012, vol.555, col.155.

118 The Archbishop of Wales, Memories, p.329.

119 Ibid., p.330. The Archbishop's comments are particularly worthy of examination, when measured against his efforts, and success, in respect of disendowment.

120 Thomas Glyn Watkin, 'Vestiges of Establishment. The Ecclesiastical and Canon Law of the Church in Wales', Ecclesiastical Law Journal, (1990), pp.110-115 and p.124.

${ }^{121}$ Cranmer, Lucas and Morris, Church and State. A mapping exercise, p.9.
} 


\section{Chapter one: Inauspicious beginnings.}

Watkin Williams ${ }^{1}$ might have appeared an atypical instigator of radical reform, yet his actions on 24 May 1870 marked the genesis of the extraordinary parliamentary saga that would eventually deliver a disestablished Welsh Anglican Church on 31 March 1920. In relation to 'the state of the Established Church in the Principality of Wales, ${ }^{2}$, he moved resolutions for its union with the State to be ended and for its endowments to be appropriated for secular education in Wales. ${ }^{3}$ His bold action motivated one of his constituents to comment that his 'sitting in parliament for Denbigh has perverted a mild and inoffensive Liberal into a wild and bigoted Radical'. Although Williams, in response, was at pains to 'to say that Denbigh found, and has not made, as incorrigible a Radical' as he was and that his purpose in raising the issue of disestablishment was based upon long-standing principles:

'With respect to the Church and State question, I had been convinced years before I was invited to stand for Denbigh, by the writings of De Tocqueville and Baptist $\mathrm{Noel}^{4}$, not to mention others, that state religions, if they have sometimes been necessary to governments, have uniformly being injurious to the interests of true religion'. ${ }^{5}$

In addition to some of his constituents ${ }^{6}$, Watkin Williams was to take his own parliamentary colleagues by surprise, due to a failure to consult with them, but he also evoked a large

\footnotetext{
${ }^{1}$ Charles James Watkin Williams, (1828-1884), who was a 'zealous member of the Established Church', was the eldest son of Reverend Peter Williams, rector of Llansannan. He originally trained as a doctor, but was admitted to the Bar in 1854, specialising in commercial cases. He was elected Liberal Member of Parliament for Denbigh Boroughs in 1868 and, in 1880, as M.P. for Caernarvonshire, but resigned after a few months, upon his appointment as a puisne judge; a vacancy created upon the promotion of his father-in-law, Sir Robert Lush, to a lord-justiceship: 'Death of Mr. Justice Williams', The Times, 19 July 1884, p.6.

${ }^{2}$ Although the motion was to receive criticism in terms of its timing and a failure to consult with his colleagues in advance, Watkin Williams's speech was to receive praise from a very unlikely source, the then Archbishop A. G. Edwards, who described the speech as one that: 'stands alone in all the recorded speeches of the Welsh Liberationists in Parliament. The speech was truthful, straightforward and without a note of bitterness', Memories, London, 1927, p.120.

${ }^{3}$ In order to fully appreciate the context of the 1870 resolutions, it is important to note that the English Member of Parliament for Bradford, and founder of the Liberation Society, Edward Miall, presented a resolution to Parliament a year later, on 9 May 1871, in which he argued: 'that it was expedient, at the earliest practicable period, to apply the policy initiated by the disestablishment of the Irish Church by the Act of 1869 to the other Churches established by law in the United Kingdom'.

${ }^{4}$ Baptist Wriothesley Noel, (1799-1873), Church of England clergyman and Baptist minister: church/state tensions led to Noel leaving the established church and in 1848 he published his Essay on the Union of Church and State: an attack on the Church of England and its civil connection.

5 'Mr. Watkin Williams and the Standard', Wrexham and Denbighshire Advertiser, 15 January 1870, p.5.

${ }^{6}$ Williams's comments during a public meeting to consider whether he was a 'fit and proper person to represent the boroughs in parliament' would have alerted the large and enthusiastic gathering to his views on disestablishment,
} 
measure of good-natured amazement from The Times. ${ }^{7}$ Williams did attempt to utilise the disestablishment of the Church of Ireland, in order to mobilise support for the disestablishment of the Welsh Church ${ }^{8}$, but any serious consideration of the question could be summed up by Gladstone's contribution to the 1870 debate, when he opined 'there really is no Church in Wales' and that it was simply a question of it being four diocese within the Church of England'. 9 However, as Henry Richard was to highlight, in an article in January 1871, that Gladstone 'made no attempt to defend the Welsh Church'. ${ }^{10}$ Watkin Williams was the subject of criticism due to the fact his motion for Welsh disestablishment, on the heels of Irish disestablishment was emphatically defeated, by 211 votes to forty-seven, due to the fact that his actions were 'taken quite independently without consulting even his closest colleagues'. ${ }^{11}$ Williams had given the House notice of his intentions, in August 1869, so it could be argued that it was his colleagues who failed to either support him or to persuade him to defer until a more propitious time:

'Mr Watkin Williams gave notice that early next session he should call attention to the religious state of the Principality of Wales, and moved resolutions to the effect that in the opinion of the House the time has arrived when it is expedient that the same religious equality granted to Ireland should be extended to Wales'. ${ }^{12}$

\section{The other 'alien' Church. ${ }^{13}$}

The expeditious manner in which Irish disestablishment had been achieved might have led Welsh observers to conclude that due to the 'great speed at which events are moving', the time left to the State Church in Wales would be limited and a meeting was to be held at the Temperance Hall, Merthyr, in April, 1871, to remind people of the possibilities. ${ }^{14}$ The newspaper

both Irish and Welsh: 'Representation of the Denbigh Boroughs', Carnarvon and Denbigh Herald, 1 August 1868, p.6.

${ }^{7}$ The Times, Wednesday, 25 May 1870, p.9, where the newspaper's correspondent admitted that he had believed that he was 'just like any other lawyer', but that 'he has been silently building up a Church policy'. The newspaper considered that it was 'delightful' for those who had to deal with "actualities”, such as the Irish Land Question, 'to fall back upon speculations of pure theory'. The actions of Mr. Williams were happily dismissed.

${ }^{8}$ HC Deb. 24 May 1870, vol.201, cc.1274-304.

${ }^{9}$ W. E. Gladstone, 'The Church in Wales: A speech by the Right Hon. W. E. Gladstone, M.P., in the House of Commons on the Resolution of Mr. (now Mr. Justice) Watkin Williams' (London, 1870).

${ }^{10}$ Henry Richard, 'The Established Church in Wales', British Quarterly Review, January 1871, reprinted in Richard, Henry, Letters and Essays on Wales (London: James Clarke \& Co., 1884), p.130.

${ }^{11}$ Kenneth O. Morgan, Wales in British Politics 1868-1922 (Cardiff: UWP, 1991, p.30.

12 'Proposed Disestablishment of the Welsh Church', The Aberystwyth Times, 7 August 1869, p.2.

${ }^{13}$ Bell, Disestablishment in Ireland and Wales, p.47. Disraeli had first used the phrase, in relation to the Irish Anglican Church, in 1844, when he defined the 'Irish Question' as a 'starving population, an absentee aristocracy, and an alien Church, and in addition the weakest executive in the world'.

14 'Church Disestablishment', The Merthyr Telegraph, 28 April 1871, p.2. 
reported that: 'during the Irish Church controversy the grievances of Wales stood out more prominently than ever, because the analogy between it and Ireland was one which could not possibly be overlooked'. ${ }^{15}$ It is possible, from the newspaper report, to sense the anticipation that followed Irish disestablishment, with a belief that 'the nibbling at Church Establishments came to an end. What is just in Ireland must be just in England, Wales, and Scotland'. ${ }^{16}$ The Times acknowledged that, in relation to the Church of England: 'It is scarcely possible to doubt that the century will see the consummation Mr. Miall so devoutly wishes'. ${ }^{17}$ The tenacity identified by Mr. Gladstone enabled the Church to forestall predictions about the demise of its own establishment by the fin de siècle, but perhaps it was the fact that it was this potential weakness which caused any objective consideration of the arguments in favour of Welsh disestablishment to be impossible. The disestablishment of the Irish Church could be compartmentalised but, even so, it had exposed a weakness which the Church of the England could not tolerate in its four dioceses that happened to lie in Wales.

A comparison of the disestablishment of the Anglican Churches in Ireland and Wales is almost de rigueur, although there were a range of graphic differences, not least of which was the inescapable fact that Welsh disestablishment necessitated the dismemberment of the Church of England. ${ }^{18}$ Another factor, which is certainly not unrelated, is the relatively brief, almost indecently short, period which preceded the enactment of the Irish Church Act on 26 July 1869, compared to the protracted and convoluted span of time which led to the Welsh Church Act of 1914. It was on 28 March 1865 that Gladstone spoke on the issue of the Irish Church, in response to a resolution by Lewis Dillwyn ${ }^{19}$ : 'That, in the opinion of this House, the present position of the Irish Church Establishment is unsatisfactory, and calls for the early attention of Her Majesty's

\footnotetext{
15 Ibid.

16 Ibid.

${ }^{17}$ Edward Miall, (1809-1881), politician, journalist, and Congregational minister. Miall was a key figure in the creation, in 1844, of the Anti-State Church Association, known, from 1853, as the Society for the Liberation of Religion from State Patronage and Control, or Liberation Society. Miall was instrumental in organizing a major registration drive, in 1867, in South Wales which paved the way for the Liberal party's electoral gains in 1868 : D. A. Hamer, The Politics of Electoral Pressure (Sussex: Harvester Press, 1977, p.116.

${ }^{18}$ Bell, Disestablishment in Ireland and Wales, London, 1969. A review of the book suggested the 'distasteful' nature of the campaign for Welsh disestablishment, being 'more bitter and the Nonconformists more vindictive', explained why Bell allocated only one-third of the book in addressing the situation in Wales and that this was 'a charitable abbreviation': The Historical Journal, vol.13, issue3 (September 1970, p.559.

${ }^{19}$ Lewis Llewelyn Dillwyn, (1814-1892), was M.P. for Swansea from 1855 to 1885 and for the newly formed Swansea Town division from 1885 to 1892. From 1883, he was responsible for almost annual resolutions calling for Welsh disestablishment: D.W.B.
} 
Government'. ${ }^{20}$ Although he had opposed the resolution, Gladstone was not unsympathetic and believed that it was: 'not so much a question for present as for future consideration' ${ }^{21}$

Gladstone's words were to be used against him, by Lord Salisbury, when Gladstone used a similar expression in respect of the Church of England and Salisbury cautioned that the last occasion the last time upon which the 'Grand Old Man' had assured people that the question of disestablishment was unripe, the Irish Church Act had been enacted within two and a half years. ${ }^{22}$ Gladstone’s support for Welsh disestablishment was a very different matter and he did not commit himself until 1891. ${ }^{23}$ He had, in the grounds of Singleton Abbey, Swansea, on 4 June 1887, not felt it opportune to go beyond an affirmation: 'that Welsh nationality is as great a reality as English nationality', although he did tease the assembled masses with a statement that, on disestablishment, he was: 'going to be very stinted and jejune', leaving the crowds to draw their own conclusions from his indirect reference to Irish disestablishment and his support of the 'Hartingtonian principle' of determination by the people concerned. ${ }^{24}$ It will be evident Gladstone was to demonstrate that, with regard to Welsh disestablishment, he was supremely adept at maintaining this ambiguity, although he still retained almost universal admiration among Welsh Liberals. ${ }^{25}$ R. T. Jenkins posited the question why 'Welsh Nonconformist Radicalism' came to expect anything from Gladstone and that it was 'hard to see what Gladstone ever actually did for Wales'. ${ }^{26}$

Many of those in the crowds who met Gladstone's train, as it progressed from Hawarden to Swansea, may have implicitly agreed with Professor David Shannon’s suggestion that the tour 'signalled as no other event did, or could, the inauguration of a modern Wales' but not every stop

20 'Resolution', HC Deb. 28 March 1865, vol. 178, cc.384.

${ }^{21}$ Ibid., 422.

${ }^{22}$ The Times, 13 November 1885, p.4.

23 'Church in Wales', HC Deb. 20 February 1891, vol. 350, cc1241-318.

${ }^{24}$ A. W. Hutton and H. J. Cohen, (eds.), The Speeches of the Right Hon. W. E. Gladstone, 1886-1888, London, 1902, pp.228-230. Lord Hartington, when asked whether the Church in Scotland should remain established, was of the view that it ought to be according to the 'views of the Scotch'.

25 'The Singleton Speeches', South Wales Daily News, 6 June, 1887, p.4: although the newspaper expressed the fact that: 'On Welsh questions Mr. Gladstone may not have been so explicit as many of his hearers would have liked, and we betray no secret when we state that they would have been better pleased if he had pronounced more emphatically on the question of Disestablishment in Wales', it took comfort from the fact that Gladstone had intimated that that: 'the question of Disestablishment should be dealt with according to the views of the Welsh people'.

${ }^{26}$ R. T. Jenkins, 'The Development of Nationalism in Wales', The Sociological Review, vol.27, issue2 (April 1935), p.171. The fact that Gladstone married into a Welsh family, the Glynnes, and that he made the Glynne family home, Hawarden Castle, his own, might, prosaically, have assisted him. 
along the way was an opportunity for hero-worship. ${ }^{27}$ Professor Shannon describes the 'vigorous harangue' that Gladstone received from the Liberal Association members in Wrexham, on both the subject of disestablishment and that even though the nation was loyal, Welsh home rule aspirations were not met. This was clearly a rather pointed allusion to the position of the Irish who were being rewarded for reasons concerned with the maintenance of law and order.

In terms of understanding how disestablishment was viewed, in a wider context, the response to Queen Victoria’s visit to Wales in 1889, the first such visit in 'more than a generation', provided a graphic example of Welsh self-perception. ${ }^{28}$ It was a visit which was generally met with popular acclaim and yet it was a time of anti-tithe activity and a strident disestablishment movement. Perhaps the most indicative feature of the visit was the 'loyal address of welcome to her Majesty, which has now been signed by the great majority of Non-conformist ministers of Denbighshire, Merionethshire, and Flintshire' ${ }^{29}$, to the horror of Thomas Gee ${ }^{30}$, who exclaimed 'Cywilydd! Cywilydd! (Shame! Shame!). ${ }^{31}$ The Times was gloating in its report and described Gee as the ‘professor of extreme Home Rule, anti-Church and anti-English opinions', who had 'the mortification of seeing his effort to make Welsh Nonconformists boycott the Queen a complete and ignominious failure'. 32 The report continued with the verdict that the Welsh 'may vote all one way at election times', but they understood the commercial value of 'belonging to this United Kingdom'. The correspondent did however stress that, save in one area, the Welsh had no cause to complain: 'except in the one doubtful point of the Church establishment, there is no specially English institution that has been impressed upon them: they are allowed to work out their own lives in their own way'. 33 The report concluded that a Welsh welcome: 'hearty and enthusiastic, may be taken as implying that, in spite of a few political grievances, real or imaginary, they are satisfied with their national lot, and proud of being subjects of the British

\footnotetext{
${ }^{27}$ Professor David Shannon, Inaugural Lecture, 18 November 1980. Professor Shannon alludes to the real purpose of the tour being 'the greater glory of the G.O.M., to the greater glory of Swansea, of Welsh Liberals in general, of the Vivians of Singleton and, somewhat, of home rule in Ireland'. It was apparent that Welsh support for Irish home rule was the vital factor from Gladstone's perspective.

28 'To-day the Queen begins her long-promised', The Times, 23 August 1889, p.7.

29 'Welsh Nonconformists and the Queen', South Wales Daily News, 17 August 1889, p.3.

30 Thomas Gee, (1815-1898), Calvinistic Methodist minister, journalist and politician. When the elected as the first chairman of Denbighshire County Council in 1888. He was also president of the Anti-tithe league.

31 'Y Frenhines, A Chymru', Baner ac Amserau Cymru, 17 Mis Awst/August 1889, p.4.

32 'To-day the Queen begins her long-promised visit to Wales', The Times, 23 August 1889, p.7.

33 Ibid.
} 
Crown'. The Times's dismissive summation of Welsh aspirations could be taken as confirmation of Professor Prys Morgan’s view that the: 'predominant spirit of the 1850s and 1860s in Wales was progressive, positivist, utilitarian, middle-class Anglophones setting the pace, dragging the Welsh into Victorian respectability, nervously glancing at the English for praise and approval'.34 He goes on to write that the 'fury and hostility' which arose as a result of the 'Blue Books' segued into 'a sense of national shame and, from shame, a kind of national anxiety as Wales adjusted to the norms of bourgeois Victorian Britain'. ${ }^{35}$ Henry Richard ${ }^{36}$ was to explain to an English readership that: 'For the last hundred or hundred and fifty years there is probably no part of the United Kingdom that has given the authorities so little trouble or anxiety'. ${ }^{37}$ Professor David Williams believed that Queen Victoria 'was always disdainful where the principality was concerned' 38 and this ambivalence was probably supported by John Davies's calculation that she spent seven nights in Wales, during her 64-year reign, compared with seven years in Scotland and seven weeks in Ireland. 39

\section{'In Welsh politics Rhyl seems to be synonymous with Disunity'40.}

The 'salubrious and delightful watering place' of Rhyl was to become the scene of notable events associated with disestablishment, as evidenced by the influential 1891 Church Congress, which is described in chapter four. ${ }^{41}$ But it was also to witness secular gatherings of significance. Although The Times was later to report that the 'lively controversy' which arose during the Conservative conference held at Rhyl, in November 1889, had 'proved to be more apparent than real' 42 , it had been manifest that the majority of Conservatives who had attended 'the recent great Unionist gathering' were serious in their criticism of the clergy of the Church in Wales. ${ }^{43}$

\footnotetext{
34 Prys Morgan, 'Early Victorian Wales and its Crisis of Identity', in Union of Multiple Identities: The British Isles c. 1750-c.1850 (Manchester, 1997), ed. by L. Brockliss and David Eastwood, p.102.

35 Ibid., p.102.

${ }^{36}$ Henry Ricard, (1812-1888), Member of Parliament for Merthyr Tydfil from 1868 to 1888.

${ }^{37}$ Richard, Henry, Letters and Essays on Wales, pp.81-82. Richard was obliged to explain that the 'Chartist outbreak in Newport' had been 'entirely of English inspiration and that the Rebecca Riots had 'no political significance whatever' but was the result of 'a grievance that had become intolerable'.

${ }^{38}$ David Williams, The Rebecca Riots: A Study in Agrarian Discontent (Cardiff: UWP, 1955), p.265.

39 John Davies, 'Victoria and Victorian Wales', in Politics and Society in Wales, 1840-1922 (Cardiff, 1988), ed. by Geraint H. Jenkins and J. Beverley Smith, p.7.

40 'Gladstonianism in Wales', The Times, 27 May 1890, p.10.

${ }^{41}$ William Davies, Handbook for the Vale of Clwyd (Ruthin: Isaac Clarke, 1856), p.26.

42 'Gladstonianism in Wales', The Times, 27 May 1890, p.10.

43 'The Church in Wales', The Times, 3 December 1889, p.13.
} 
This became manifest in their belief that a Clergy Discipline Bill ${ }^{44}$ was urgently required, more so than a demand for legislation concerning tithes, and a resolution was passed to that effect:

'The burden of all the speeches delivered at the Tory demonstration at Rhyl on Monday was that the Church in Wales has been an ignominious failure. There seemed to be a concurrence of opinion that the Welsh clergy as a body are anything but what they ought to be'. ${ }^{45}$

It was, however, acknowledged that it was too late 'to attempt to thwart the national crusade against the Establishment by the mere passing of a Church Discipline Bill’. But the conference was highly critical of bishops who admitted that they were unable to 'purge out of the Church those clergy who are a disgrace to the Establishment'. It begged the question why these 'unworthy clergy' were ever permitted to enter the Church. The conference went on to acknowledge that:

'The Welsh nation has made up its mind that it will no longer carry the Church on its back, and Churchmen would do well to teach the old mother to walk before she is thrown on her own resources. As we have already said, the proposal to reform the Church in the hope that the Welsh nation will tolerate it as an established institution will be of no avail'. 46

It was argued that the 'very fact that the Church itself was quite satisfied with its own mode of discipline until it found that its coffers were being affected showed how unreal the cry about reform is'. It was intimated that reform would not save the Establishment, but that if Churchmen were serious in their desire for reform, then it would be a 'consolation to them to know that the time is not far distant when they will be able to bring it about', as 'Disestablishment will be accomplished in a very short time, and Churchmen will then be at liberty to carry out reforms to their hearts' content'. The Times noted that the 'landlords in conference have carried a resolution that the particular requirement of Wales is a Church Discipline Bill' and that the chairman, Sir Richard Bulkeley ‘opened with a vigorous assault on the Church’ and that despite the discomfort of many present, who felt that it was only just fell 'short of a vote of censure on the Welsh clergy', a resolution to the effect that a Church Discipline Bill was required was carried unanimously. ${ }^{47}$

\footnotetext{
${ }^{44}$ The Clergy Discipline Act 1892, 55-56 Vic., c.32, dealt with the moral conduct of the clergy.

45 'The Church in Wales', The North Wales Express, 22 November 1889, p.4.

${ }^{46}$ Ibid.

47 'The Church in Wales', The Times, 3 December 1889, p.13.
} 
The Times observed that neither the Bishop of Bangor nor the Bishop of St. Asaph were there to defend the Church, but it is possible to imagine their great discomfort, and it was left to the clergy themselves to counter the allegations. One clergyman was reported as saying: 'at the Rhyl Tory Conference not one person present could say a single word for the clergy' and, clearly in a state of shock, he added that: 'The Liberationists will learn that they have unexpected allies in their attack upon the Church' and, of course, those who refused to pay tithes 'will learn to proceed in their nefarious work' ${ }^{48}$ Although the controversy was concerned with the fact that landlords were resistant to the proposed tithe legislation, which was intended to transfer responsibility to them, the incident did demonstrate that the Church was not as 'sacrosanct' as perhaps some clergy might assume.

Rhyl was to be the venue for another revolt, although on this occasion the 'Rhyl Resolution' of 1890 would materialize from a meeting of frustrated Liberals and it would precipitate a more significant 'rumpus', in the context of a changing attitude towards the performance of the Liberal Party in Wales. This was partly in response to a change in the background and demeanour of the Welsh members of Parliament elected in 1885, but also, as the circumstances surrounding the Resolution would suggest a new-found confidence displayed by rank and file members, whose expectations were now heightened, and who sought and anticipated substantive Welsh measures to follow in the wake of their support for the Liberal Party. A meeting of the Welsh National Council of the Liberal Party, held at Llandrindod Wells in September 1889, provided an illustration of the latent tension, which was developing between party members and elected politicians, concerning progress on disestablishment. In his President's address, Stuart Rendel had emphasized what had been done for Wales in Parliament and, perhaps in attempt to preempt any criticism, he added that the change in the 'general attitude towards Welsh affairs was simply astonishing'. His case was weakened by the fact that he was obliged to admit that Gladstone's attitude towards Welsh disestablishment 'was not of an active character', although he was sympathetic. ${ }^{49}$ The members' disappointment with Gladstone's position would not have been helped by the fact that, in his frequent series of well-publicised anti-disestablishment speeches, the Bishop of St. Asaph had taken care to include multiple quotations from the leader of the

\footnotetext{
${ }^{48}$ Ibid.

49 'Disestablishment', The North Wales Express, 6 September 1889, p.5.
} 
Liberal Party, in order to assist him in accentuating the inequity of the case against the Welsh Church. Shortly after the meeting of the Welsh National Council, in November 1889, the Bishop, whilst delivering a lecture in Truro, was careful to utilise statements which Gladstone had made, and which later came to embarrass him, about the Welsh Sees being no different from the English Sees and that it was 'practically impossible to separate the case of Wales from that of England'. ${ }^{50}$ This lack of confidence and faith in the elected members was amply demonstrated by the contents of a resolution moved by T. J. Hughes (Adfyfyr), which was subsequently carried. ${ }^{51}$ The resolution required the Council to: 're-direct the attention of the National Liberal Federation and by its means the Liberal leaders, to the preeminent claims of Wales in the matter of Welsh State Church disestablishment and disendowment'.

The resolution went on to hope that although Welsh members would give support to the question of English and Scottish disestablishment, they reminded the National Federation that the Welsh case should be the first item dealt with by the Liberal party next to Irish Home Rule. The resolution ended with a clear warning that if the Liberal party did not comply, then it would 'seriously and actively imperil Welsh loyalty to the political party with which Wales is associated'. 1890 could be viewed as a potentially pivotal time, in terms of how the Liberal party was to function in Wales. Henry Richard, who had served as chairman of the Welsh members of Parliament, had died in August 1888 and, as described by Stuart Rendel, who assumed the role of chairman; 'He was Welsh, but he was old Wales. Old Wales aimed at respectability above all things, and was very “middle class"” 52 , and a division developed between his followers and those who came to be identified as 'Young Wales', combined with the crucial decision, by Rendel, that Welsh members should pursue disestablishment by means of their own political organization rather than the Liberation Society, with which Richard had been intimately involved. Rendel had recognized that 'to consolidate the Welsh members into a Welsh party was the obvious preliminary step ${ }^{53}$, in order to ensure that Wales and Welsh issues were recognised. Even

\footnotetext{
50 The Bishop of St. Asaph, The Truth about the Church in Wales. A lecture delivered at Truro on November 7,1889 (London, 1889), pp.3-4.

51 Thomas John Hughes, Adfyfyr, (1853-1927), journalist. He was the first editor of Cymru Fydd. The National Liberal Pamphlet number 8, 'Neglected Wales', London, 1887, contained Adfyfyr's letters to The Daily News on a range of topics, including land reform and 'The State Church'.

52 Hamer, The Personal Papers of Lord Rendel, p.305.

${ }^{53}$ Hamer, The Personal Papers of Lord Rendel, p.293.
} 
Bishop Edwards acknowledged that it was Stuart Rendel whose 'war-cry rallied the Radical party, hitherto stumbling under inferior leadership'. ${ }^{54}$

\section{The ‘New Liberalism'.}

An editorial in The North Wales Express drew on the event of the recent death of David Davies Llandinam ${ }^{55}$, in 1890, to eulogize about the 'New Liberalism', which was 'becoming more and more national in its character', whereas it had been the case that 'the highest ambition of the orthodox Welsh Liberal member used to be to merge and bury himself in the great English Liberal party'. ${ }^{56}$ It went on to proclaim how these new members of Parliament, who now lobbied for Welsh demands, did not attempt to disguise their Welshness and they were 'making their mark on English platforms’, mentioning Thomas Ellis and David Lloyd George in particular. In what must have appeared to be the dawning of a new era, with exciting possibilities, it was also possible to glimpse the beginning of this growing frustration reflected in newspaper reports, with accusations that Welsh members of Parliament had: 'agreed practically to shelve the question of Welsh disestablishment this session. This is a most extraordinary and unaccountable decision, especially when read in the light of the outcry from Wales day by day for disestablishment’ ${ }^{57}$

It was apparent that Welsh Liberal members had 'gone up to Parliament every session for years with a mandate from their constituents making the movement of the disestablishment resolution imperative upon them' ${ }^{58}$ It was considered that the objective was to ensure that the subject was brought to the attention of the House of Commons, irrespective of the chance of success. The bruhaha caused by the Rhyl Radical Resolution arose from a routine quarterly meeting of the North Wales Liberal Federation, held on 30 April 1890, at the Rhyl Working Men's Club, but a succinct report in the Rhyl Journal stated that after a meeting behind closed doors, something extraordinary was to emerge, when:

'a resolution was passed expressing deep dissatisfaction at the inattention of successive Liberal Governments to the demands of Wales for the disestablishment and disendowment of the English Church and expressing the opinion that, a pledge should be

\footnotetext{
54 The Archbishop of Wales, A.G. Edwards, Memories, p.129.

55 David Davies, (1818 - 20 July 1890), industrialist, railway magnate, colliery owner and the builder of Barry Docks. He was elected Liberal member of Parliament for Cardigan Boroughs from 1874 to 1885 and, then member for Cardiganshire from 1885 to 1886.

56 'The Old and the New Liberalism', The North Wales Express, 25 July 1890, pp.4-5.

57 'The Members for Wales in Council', South Wales Daily News, 24 February 1890, p.4.

58 Ibid.
} 
obtained from every candidate for a Welsh constituency at the next general election that he would decline to support any Government except on the condition that a bill for Welsh disestablishment and disendowment should be brought together concurrently with or immediately after the passing of a measure of Home-rule for Ireland'. ${ }^{59}$

It was reported, in June 1890, that: 'The rumpus created by what is now known as the "Rhyl Resolution" has not yet subsided; on the contrary, the question has assumed an importance which was scarcely contemplated by the framers of the resolution when they met some few weeks ago at the salubrious Welsh watering-place ${ }^{60}$ It had been recognised that 'the Alpha and Omega of the Rhyl resolution' was intended to pressurise Gladstone and the leaders of the Liberal Party to undertake to introduce the question of the Disestablishment of the Welsh Church, 'simultaneous with or immediately subsequent to the disposal of the Irish question'. Gladstone's response was to take the Welsh Liberals to task and to warn them that their impatience was unwise and that it failed to appreciate the complexity of the issue. Clearly the party establishment were frustrated by this uncharacteristic challenge, particularly from Wales. Neville Masterman's biography of Tom Ellis suggests that it was Lloyd George who had prevailed upon delegates to the North Wales Liberal Federation to pursue this course of action, although newspaper reports do not substantiate this claim and he was not present at the Rhyl meeting. ${ }^{61}$ The evidence is that Lloyd George had resisted the Reverend Evan Jones's ${ }^{62}$ attempt to 'catechise' him, during the byeelection in April 1890, which saw him first elected to Caernarfon Boroughs, albeit by eighteen votes: 'as to his willingness to give a pledge that he would not support Irish Home Rule unless Mr. Gladstone undertook to bring in a measure of Welsh disestablishment, either concurrently with it or immediately afterwards and before the dissolution of Parliament'. ${ }^{63}$

The correspondent reported that Lloyd George had managed to avoid any commitment, by reference to the 'futility of encumbering himself with such a pledge at a bye-election'.

\footnotetext{
59 North Wales Liberal Federation', Rhyl Journal, 3 May 1890, p.2.

60 'The Radical Resolution at Rhyl', The North Wales Chronicle, 14 June 1890, p.5.

${ }^{61}$ Neville Masterman, The Forerunner. The Dilemmas of Tom Ellis 1859-1899 (Llandybie: Christopher Davies, 1972), p.164.

${ }^{62}$ Evan Jones, (1836-1915), Calvinistic Methodist minister. He was President of the National Free Church Council in 1909. According to the D.W.B, 'he was usually thought of as a controversialist and an ecclesiastical statesman', but he was also 'a great preacher, a very great preacher'.

63 'Gladstonianism in Wales. From a Welsh Correspondent', The Times, 27 May 1890, p.10.
} 
After his failure to persuade Lloyd George, the Reverend Jones would take the proposal to Rhyl, to the National Liberal Federation, to 'get the Federation to give the proposed "shibboleth" its endorsement'. Lloyd George was to become adroit at working behind the scenes, in a similar manner to John Owen, who would become Bishop of St. David's, but the Rhyl Resolution was too early in his career as an elected politician for him to staunch the initiatives of those who sought action with which he was uncomfortable. However, his name was shortly to be associated with the 1895 'Bangor Scheme', a moderate plan for Welsh disestablishment, although the plan was drafted by that Welsh nationalist and Anglo-Catholic, J. Arthur Price ${ }^{64}$, albeit with Lloyd George's support. It is therefore possible that he encouraged those Liberal members, who met at Rhyl, to take the initiative. It has been suggested that it is 'possible to overrate the general force of the Rhyl resolution', on the basis that it lacked legal importance and that the Reverend Evan Jones, one of the main instigators, 'was by no means a universally beloved figure'. ${ }^{65}$ The comment about Evan Jones is, it is suggested, a misunderstanding, based upon an interpretation of the robust stance adopted by the Reverend. The evidence to support the statement about the Reverend Jones is an article in the North Wales Express which, although the newspaper acknowledged Evan Jones’s tendency to challenge, it is hardly disrespectful and in fact the article continues with an exposé of exactly the type of frustration which generated the support for the Rhyl Resolution and which Evan Jones espoused, with the same direct language for which he was known:

'Most people are sick of hearing Disestablishment spoken of and written of ad nauseam, and without anything drastic and substantial being done to bring it a day nearer. This is a reform for which our fathers fought and suffered, and yet we their children seem to be but a little nearer to its consummation than they were'.

'Yet what action have the Welsh members taken on Disestablishment? Nothing beyond voting and speaking on Mr Dillwyn's resolution; and people may go on moving resolutions in the House of Commons until doomsday without anybody being the wiser or the better. The Welsh members have yet to learn that political action is something different from moving resolutions, and that public reforms require sterner methods of advocacy and advancement than vapouring talk in the House of Commons'. ${ }^{6}$

\footnotetext{
${ }^{64}$ Frances Knight, 'Welsh Nationalism and Anglo-Catholicism: The Politics and Religion of J. Arthur Price’, in Religion and National Identity. Wales and Scotland, c.1700-2000 (Cardiff: UWP, 2001), ed. by Robert Pope, pp.114-115.

${ }^{65}$ B. B. Gilbert, David Lloyd George, a political life. The Architect of Change 1863-1912 (London: Batsford Ltd., 1987), p.79.

66 'The Welsh Members and Disestablishment', The North Wales Express, 25 April 1890, p.4.
} 
The significance of the meeting at Rhyl was noted by The Times, as indeed was the importance of Evan Jones's influence, with his 'insubordination' being that: 'He has the effrontery to think that the special grievance of Wales should be more to Welshmen than obedience to the mot d'ordre from Avondale ${ }^{67}$ and Hawarden' ${ }^{68}$

\section{The reaction to the Rhyl Resolution.}

Stuart Rendel was opposed to the so-called Rhyl Resolution, because it felt that he felt that it would jeopardise English sympathy for Welsh causes, which provides a graphic illustration of how Welsh politicians believed that Welsh issues were tolerated within the wider party, but he was also concerned lest it created a 'vulgar scramble on the part of the more powerful Radical sections to secure priority over the Principality'. ${ }^{69}$ No doubt his reasons were reasonable, based upon the significance attributed to the pursuit of Welsh issues within the Liberal Party. It was also made abundantly clear, by the Rhyl Resolution, that the 'feeling of Wales is decidedly in favour of their refusing to support the Liberal Party' unless the stated conditions were met. Furthermore, it was also agreed that the Federation should seek to form a deputation, together with the South Wales Federation. By July 1890, Welsh Liberals were expressing great satisfaction, due to the success of the 'now famous Rhyl Resolution'. ${ }^{70}$ Whilst it was acknowledged that not all Liberals approved, newspapers were reporting that: 'Beyond any doubt whatsoever the cause of Welsh Disestablishment has been advanced within the last three months from a position of comparative despair to one of reassured hopefulness' and that the resolution had: 'Set the whole of Wales ablaze'. ${ }^{71}$ Although it already appeared that the media and professional politicians were uneasy with the prospect of the opinion of rank and file members holding sway and Bryn Roberts, the member of Parliament for Eifion, was vocal in his opposition, as might one expect from somebody whose parliamentary career was based upon a 'rigid adherence to orthodox Gladstonian Liberalism'. His biographer described Roberts as somebody who 'pursued loyalty to Gladstone - even to the point of hero-worship'. ${ }^{72}$

\footnotetext{
${ }^{67}$ Avondale, County Wicklow was the birthplace and home of Charles Stewart Parnell: Bew, P., (2004) Parnell, Charles Stewart (1846-1891), politician and landowner. Oxford Dictionary of National Biography.

68 'The Welsh Gladstonians', The Times, 29 May 1890, p.9.

${ }^{69}$ Michael Barker, Gladstone and Radicalism. The Reconstruction of Liberal Policy in Britain 1885-1894 (Brighton: Harvester Press, 1975), p.125.

70 'Grand Success of the Rhyl Resolution', The North Wales Express, 25 July 1890, p.4.

${ }^{71}$ Ibid.

72 Jack Eaton, Judge John Bryn Roberts. A Biography (Cardiff, 1989), p.17.
} 
Despite the best efforts of that doyen of political organisers, Francis Schnadhorst ${ }^{73}$, the secretary of the National Liberal Federation ${ }^{74}$, he was obliged to declare, on behalf of the Federation, that Welsh disestablishment would 'be a political battle-cry throughout the kingdom at the next general election' and that it would rank only second to Irish home rule. It was apparent that the efforts of those attending the meeting at the Rhyl Working Men's Club had succeeded and it was acknowledged that: 'It would be useless to close our eyes to the fact, and unfair to deny that Mr. Schnadhorst's letter is the direct fruit of the historical Rhyl resolution' ${ }^{75}$ The political manoeuvrings by the National Liberal Federation were summed up by its dealings with the Welsh Liberal Federation, when the result of a meeting of Welsh Liberals with the Federation's general purposes committee evoked a comment that: 'To-day has undoubted marked a fresh epoch in the Welsh Disestablishment campaign', as the committee had 'actively ranged itself on the side of the Welsh agitation. ${ }^{76}$ However, it was apparent that those who sought 'a faithful record' of what transpired were to be disappointed, as a high level of secrecy was attached to the proceedings. Although it was apparent that Welsh Liberals wished to interpret and communicate the successful outcome, the strict measures to minimize what could be recorded and reported may have given the impression that the Federation was simply attempting to placate those in the constituencies who 'waited with feverish anxiety for a faithful record of what took place', but not with a desire not to publicise the fact. In a report of the response from the Welsh press, it was apparent that the newspapers found it difficult to provide adequate reports of the negotiations between the Welsh and English Federations due to the secrecy which had been imposed, with the Tarian emphatically declaring that:

'the Disestablishment of the Church is not a theoretical principle desirable of attainment, but a matter of life and death to the Welsh nation, a conviction arising from the very depths of its being, and that consequently it is no wonder that the nation should be stirred by the slowness of the movement. The time for playing with this question is passed the day of battle has dawned and every Welsh member who is not prepared to stand fire and to fight in this battle with every nerve strained, must move aside to make room for those who will do so'. ${ }^{77}$

\footnotetext{
${ }^{73}$ Francis H. Herrick, 'The Origins of the National Liberal Federation', Journal of Modern History, vol.17, no.2 (June 1945), p.124, where Schnadhorst was described as 'one of the significant, though now forgotten, figures of British politics'.

${ }^{74}$ Ibid., p.117: 'The National Liberal Federation or "the caucus,” as it was popularly known, is regarded by students of British politics as the source of modern popular party organisation'.

75 'Disestablishment', The Cardiff Times, 16 August 1890, p.6.

76 'Welsh Disestablishment. The Conference with the National Federation', South Wales Echo, 18 July 1890 , p.4.

77 'Disestablishment. The Welsh Press on the Question', South Wales Daily News, 30 July 1890, p.5.
} 
The 'famous' Rhyl Resolution was still recognised as a decisive event when the Welsh National Council met two years later, again in Rhyl, when it was recorded 'with pleasure the definite pledges which Wales has received from the leaders of the Liberal party', that the disestablishment and the disendowment of the Church of England in Wales would be 'regarded as second only to the Irish question'. A speaker expressed satisfaction at the 'strides' being made concerning the Church in Wales and: 'It was most appropriate that this satisfaction should be expressed at Rhyl, for was it not there that the famous Rhyl resolution was passed a little over two years ago? He ventured to that that resolution had done more than thing else to secure for them the pledges to which the present resolution referred'. ${ }^{78}$

Yet it was still the case that many Welsh Liberal party activists sought further means by which they could ensure that Welsh members of Parliament did not allow the momentum to stall. At a conference of the South Wales Liberal Federation, held at Builth Wells in August 1890, delegates were delighted with the fact that efforts by 'Liberals and Nonconformists of the Principality on the great advance in connection the cause of disestablishment'. ${ }^{79}$ The Reverend Emlyn Jones moved that Welsh constituencies should 'concentrate their undivided energies on this subject previous to and at the next general election' ${ }^{80}$ Osborne Morgan M.P., whilst supporting the resolution, 'defended the Welsh members from the charge of apathy' ${ }^{81} \mathrm{He}$ and other M.P.s in attendance would have been relieved at the withdrawal of a rider which, if passed, would have required M.P.s to oppose every government that would not grant disestablishment at once. They had argued that it would have been contrary to party unity.

The speaker referred to the fact that their 'opponents' merely said that these were 'sham pledges’. However, even those who favoured disestablishment displayed a certain scepticism and a letter, to the editor, which appeared in the South Wales Daily News in March 1892, was particularly prescient when the writer posited that if the Liberal party placed Irish Home rule as its main priority, and Welsh disestablishment second, then: 'Is it not placing Disestablishment on

\footnotetext{
78 'Welsh National Council. Annual Meeting at Rhyl. Disestablishment and Disendowment', Carnarvon and Denbigh Herald, 11 November 1892, p.8.

79 'South Wales Liberal Federation', The Times, 14 August 1890, p.4.

80 Ibid.

81 Ibid.
} 
a peg for 30 years?' The writer, a Mr. D. Jones of Llanon, may have considered the 30-year period as mere hyperbole, but it was to prove very close to reality. Mr. Jones construed politics from a very practical standpoint, as perhaps should others, and he envisaged that Irish home rule would see sixty potential votes in favour of Welsh disestablishment lost, as the Irish representatives moved to a new Irish parliament. On this he was also prognostic, as the Welsh Church Bill would require the support of Irish votes, albeit twenty years later. He was adamant that: 'Such a deep-rooted fabric as the Church of England requires all the strength available in the United Kingdom to break it apart from the State'. ${ }^{82}$ His letter was to evoke a response from a correspondent who probably summed up the frustration felt by many Welsh people that they had already heard sufficient about Irish Home Rule and he believed that:

'The British Parliament spends more than half of its time already on measures pertaining to Ireland. Are we now on the same footing as Ireland in regard to land laws? I venture to say no but for all that 'Gallant little Wales' will have to wait patiently for an indefinite period before the vital question of Disestablishment is taken in hand, as the Home Rule question blocks the way' ${ }^{83}$

Wales Drops the Pilots was a rather doleful account of the missed opportunities associated with the activities of Tom Ellis and Lloyd George in the 1890s, but the author, writing in the 1930s, was only too aware that: 'Welsh Disestablishment seems to mean very little to Wales to-day. But it must be remembered that it was to the Wales of the 'eighties and 'nineties what Home Rule was to Ireland. It was "the Welsh Nationalist movement in religious dress" ${ }^{84}$ As mentioned in the Introduction, the perceived relationship between Welsh nationalism and disestablishment was symbiotic, but it is tempting to subsume them. However, David Lloyd George was to exhibit an early ambivalence about the effort to achieve disestablishment, as evidenced by an interview he gave in 1894, when he described it as 'the first, and by no means the greatest, of our national questions that are awaiting solution'. ${ }^{85}$ He even appeared to express a level of impatience, when he was reported as saying that: 'the Local Veto, Land Reform, Welsh Home Rule, the completion of a national system of education, these and many others are only waiting for the Disestablishment of the Church in order to secure our attention’.

\footnotetext{
82 'Disestablishment', South Wales Daily News, 8 March 1892, p.7.

83 'Disestablishment', South Wales Daily News, 15 March 1892, p.6.

${ }^{84}$ W. Hughes Jones, Wales Drops the Pilots (London: Foyle's Welsh Co., 1937), p.59.

85 'Mr Lloyd George Interviewed', South Wales Daily News, 16 July 1894, p.5.
} 
Lloyd George viewed it as 'only as important as it is because it is the first political fight we have ever had on national grounds. The other questions are greater and more far-reaching, and, besides, much bigger interests are affected by them' ${ }^{86}$ However, to utilise the bellicose imagery which was commonly used during the campaign, it proved not to be a blitzkrieg ${ }^{87}$, but resembled a war of attrition, with its longevity and complexity causing a debilitating impact upon other Welsh aspirations, including home rule: 'From the outset the prospects of success were bleak, for by 1888 the possibility of securing disestablishment through legislative action at Westminster had captured the Nonconformist imagination, thereby reducing what limited support had previously existed for Welsh home rule' ${ }^{88}$

In its partisan report on the Welsh results of the 1895 general election, The Times attributed the fact that 'Wales shows the highest percentage of Unionist gains in this election' to the Nonconformist minsters who have never shown greater activity in Wales, but they carried the spirit of intolerance to an extent which repelled some of their own people'. With something which read more like a desired outcome, than the reality, the newspaper posited that: 'The power of the Nonconformist minister in Wales is declining'. Whilst the newspaper regretted the 'intolerance' which had brought this about, their criticism was tempered with a hope 'that Churchmen will show a conciliatory spirit to their Nonconformist brethren' ${ }^{89}$ It is likely that the newspaper had the Bishop of St. Asaph in mind and, in May 1894, he had expressed a belief that the defeat of anything that supports disestablishment must be so 'decisive' that it 'will render its repetition impossible'. ${ }^{90} \mathrm{He}$ was therefore unlikely to mollify Nonconformist ministers, lest it encouraged them in their disestablishment endeavours, when he sought total victory and unconditional surrender. At the Annual Meeting of the Church Defence Institution, held on 16 August 1895, at which the Bishop of St. Asaph was the only prelate present, the institution considered that it had become 'associated with party politics - not from choice, but from necessity', that 'necessity being a response to the 'attack upon the Church' by the liberationists.

\footnotetext{
${ }^{86}$ Ibid.

${ }^{87}$ German: 'lightning war'.

${ }^{88}$ Emyr W. Williams, 'Liberalism in Wales and the Politics of Welsh Home Rule 1886-1910', Bulletin of the Board of Celtic Studies, vol.37 (1970), p.197.

89 'The Elections in Wales', from a Welsh Correspondent, The Times, 12 August 1895, p.13.

${ }^{90}$ A.G. Asaph, 'The Welsh Disestablishment Bill', The Times, 19 May 1894, p.10.
} 
It was considered that the work of Churchmen was 'not yet at an end' and, as they lived in 'very democratic time, it might arise again!'91

The body of Welsh Liberal Members of Parliament seemed to be relatively easily swayed from exploiting political advantage, as and when the opportunity arose, and although the Bishop of St. Asaph was to believe, presumably with relief, that the 'Welsh party missed their opportunity', he did hold a high opinion of at least one Welsh Liberal politician: 'Mr. Lloyd George seemed almost alone in the gift of insight and courage'. ${ }^{92}$ Kenneth Morgan noted that, in relation to events in 1893: 'At the critical moment, as on so many occasions before and since, brave threats of independent action, by Welsh Liberal members of Parliament, dissolved when brought up against the realities of political power' ${ }^{93}$ The consequences of the failure of the Welsh Liberal party to perform had a dramatic effect upon two areas; firstly, in terms of the timing, the manner and the terms of the disestablishment that was eventually delivered and, secondly, crucially, in the realisation that the political capital expended on this campaign caused other 'Welsh issues' to be deferred sine die. This prospect was recognised by Alfred Thomas, the M.P. for East Glamorgan, when he drafted his National Institutions (Wales) Bill, albeit that Thomas was acting, to a large degree, at the behest of Tom Ellis ${ }^{94}$ :

'there has been a tendency to look upon Disestablishment as the Alpha and the Omega of our political aspirations. It has, in short, been a sort of Aaron's rod, swallowing up its less pretentious, but equally useful fellows. We require something more to satisfy the aspirations of our countrymen'. ${ }^{95}$

Herbert Lewis ${ }^{96}$, 'the most consistent nationalist and devolutionist of them all' ${ }^{97}$, was advised by T.E. Ellis, in a letter dated 31 October 1891, concerning a forthcoming election address, that: 'Nationality and Labour are the two main principles are they not? How are they to be preserved

\footnotetext{
91 'The Church Defence Institution', The Times, 17 August 1895, p.8.

92 The Archbishop of Wales, A.G. Edwards, Memories, p.175.

${ }_{93}$ Morgan, Wales in British Politics 1868-1922, p.140.

${ }^{94}$ Masterman, The Forerunner, The Dilemmas of Tom Ellis, 1859-1899, pp.137-138. Masterman describes correspondence which suggests that Thomas was being motivated to act, but Ellis writes of him in a somewhat patronizing manner. Masterman does confirm that it is unclear why Ellis subsequently demonstrated a lack of interest in the measure. Another example of where an initiative was allowed to wither, which was a recurring theme in Welsh Liberal politics.

95 ‘Alfred Thomas, ‘A Welsh Programme’, Welsh Review, vol.1, no.3 (January 1892), p.231.

${ }^{96}$ Rowland Williams, 'Lewis, Sir (John) Herbert (1858-1933), lawyer and politician, ODNB, Oxford, 2004.

${ }^{97}$ Kenneth O. Morgan, 'Liberalism’s Flintshire Loyalist: The Political Achievement of John Herbert Lewis', Flintshire Historical Society Journal, vol.36 (2003), p.118.
} 
and interwoven in a constituency like yours? I think we ought to make it clear that when disestablishment is settled, Wales will throw herself heart and soul into the Labour movement' ${ }^{98}$ It would be interesting to surmise whether Tom Ellis's advice would have been different if he had anticipated that disestablishment would not be 'settled' for almost a quarter of a century. It is reasonable to observe that of the 'two main principles', 'Nationality' was to be a casualty of the extended temporising that became a feature of disestablishment. Herbert Lewis joined Lloyd George, D.A. Thomas and Frank Edwards in the 'Welsh Revolt' of 1894, when they refused the Liberal whip over the question of Welsh disestablishment. ${ }^{99}$ Lewis was perhaps the more realistic, at least in terms of Welsh disestablishment, when he justified his action with the comment that:

'My recent talks with Ministers and Members have convinced me that Wales is simply being led on from step to step without any definite goal in view, and that we have nothing to gain by subservience to the Liberal Party, and that we shall never get the English to do us justice until we show our independence of them'. ${ }^{100}$

It was of note that an article in The Spectator, in 1893, was swift to associate Welsh disestablishment with national identity, when it warned of the dangers inherent in the government's apparent decision to include a Welsh Disestablishment Bill for the Session in 1894. It had no illusions about what was being proposed and although its logic may have brought a quiet nod of approval from many, it was in fact highlighting yet another reason why Welsh disestablishment would be resisted, however compelling the specific arguments might appear;

'A Bill to disestablish the Church of England in Wales has no meaning, except in connection with Home-Rule for Wales. If Wales has a right to be treated ecclesiastically distinct from England, she has an equal right to be treated politically distinct from England. The two claims stand or fall together.' ${ }^{101}$

Just in case Unionists were insufficiently alarmed by this suggestion, the article went on to allude to the prospect of an improbable 'Celtic' domino-effect, when the magazine stated that: 'we have heard on good authority that the Cornish Dissenters are only waiting......to begin agitation for the Disestablishment of the Church of England in Cornwall. The cases are very much alike.' 102

\footnotetext{
${ }^{98}$ Masterman, The Forerunner. The Dilemmas of Tom Ellis, 1859-1899, pp.170-171.

99 D.A. Hamer, Liberal Politics in the Age of Gladstone and Rosebery (Oxford: Clarendon Press, 1972), pp.185-186. Morgan, Wales in British Politics, p.144.

100 Morgan, ibid., p.144.

101 The Spectator, ‘Mr. Gladstone’s Decision on Welsh Disestablishment', 23 September 1893, p.9.

102 Ibid.
} 
In addition, there were those like Alfred Thomas, the member of Parliament for Glamorgan East, who would posit, from a diametrically opposite standpoint, that the prominence attributed to the campaign for disestablishment was smothering proper and urgent consideration of 'other desirable and necessary reforms’:

'Now, in the forefront of Welsh political problems stands the Disestablishment and Disendowment of the Church. On the wisdom of keeping that question, whose settlement will bring about complete religious equality among our people, in the foremost place we are all agreed. But it seems to me that it is unwise to concentrate attention on Disestablishment to the exclusion of other desirable and necessary reforms. I speak with all submission, but it certainly seems to me that there has been a tendency to look upon Disestablishment as the Alpha and the Omega of our political aspirations'. ${ }^{103}$

The Western Mail was scathing in its summary of Gladstone’s 1891 speech at Newcastle ${ }^{104}$, with an exposé of how he appeared to keep the interests of all factions satisfied with very little and with disestablishment being just one further 'concession’: ‘By the lavish distribution of promises never destined to be redeemed, and by suggesting, more or less vaguely, concessions never likely to be made, the "Old Parliamentary Hand" hopes to attract to the Separatist flag every restless, fluctuating element in the community' 105 This scepticism was to prove to be fully justified ${ }^{106}$ and it was necessary for Stuart Rendel, on behalf of the Welsh Parliamentary Party ${ }^{107}$ to, engage in some deeply respectful, but ostensibly candid, correspondence with Gladstone during the summer of 1893, in an attempt to confirm the nature of what had been the net result of the Newcastle declarations, which had appeared obvious to the Welsh M.P.s at the time. ${ }^{108}$ It was evident that the rank and file members considered that the contents of the Newcastle Programme were binding, although the Liberal leadership was not to be controlled by the National Liberal Federation. The correspondence began on 26 June 1893, when Rendel wrote that:

'It will be recollected that the Newcastle programme conceded to the Welsh demand a second place in that schedule of grievances calling for treatment at the hands of the

\footnotetext{
103 Alfred Thomas, ‘A Welsh Programme’, The Welsh Review, vol.1, no.3 (January 1892), pp.230-231.

${ }^{104}$ Peter Stansky, Ambitions and Strategies. The struggle for the leadership of the Liberal Party in the 1890s (Oxford: Clarendon Press, 1964), p.xii: 'In October 1891, at Newcastle, the National Liberal Federation voted in favour of a Programme for the party which was to prove a continual burden to the leadership’.

105 'The Old Man Mysterious at Newcastle', The Western Mail, 3 October 1891, p.4.

${ }^{106}$ H.H. Asquith was to suggest that Gladstone was 'indifferent to, not to say critical of' a number of the policies which he had apparently endorsed at Newcastle: Asquith, H.H., Fifty Years of Parliament, vol.1 (1926), p.193.

${ }^{107}$ Grahame V. Nelmes, 'Stuart Rendel and the Welsh Liberal political organisation in the late-nineteenth century', Welsh History Review, vol.9, no.4 (December 1979), p.479. Rendel became chairman of the Welsh Parliamentary Party in 1888, upon the death of Henry Richard, under whose chairmanship it had proved to be a looser association, with infrequent meetings.

108 'The Welsh Demand', South Wales Daily News, 16 August 1893, p.4.
} 
Liberal party on its expected access to power. This programme was considered to be the official charter of Liberal policy at the last election, and Liberal candidates in Wales appealed for support on the specific ground of the pledge thus given by the party to settle the Welsh question immediately after Home Rule. They considered that they were fully justified in placing this interpretation upon the Newcastle programme and the method of its acceptance'.

Gladstone's response was that no order of business had been agreed at Newcastle, which must have driven the Welsh M.P.s to utter distraction and, despite their innate respect for Gladstone, Rendel's letter of 28 July 1893 was obliged to conclude with an apparent threat:

'The loyalty of Wales to the Liberal party has hitherto been unswerving, and we earnestly trust that you, as leader of the Liberal party, can see your way to avert any misunderstanding which would have the effect of imperilling that devotion, by placing in the forefront of your programme for next Session, not a preliminary but a final and complete measure for the Disestablishment and Disendowment of the Church in Wales'.

Gladstone, however, either knew the limits of the mettle of the Welsh M.P.s too well or perhaps he had 'insider information' about how far they had decided to take matters, bearing in mind his intimate friendship with Rendel ${ }^{109}$. He felt able to fend them off with a letter of 8 August 1893 which, in a patronising manner, congratulated the Welsh M.P.s on how far they had advanced the question of Welsh disestablishment. As would be anticipated, the Western Mail considered that an electoral programme which the Conservative party had published could 'hardly fail to win the respect and favour of all classes, for it is the most comprehensive and practical policy that could well be conceived', whereas:

'The Radicals are pledged to their pet measures - Home Rule, Welsh and Scotch disestablishment and the other fads they have promised some of their supporters by way of concessions and bribes'. ${ }^{110}$

\footnotetext{
109 The social news indicated how close they were and although it would be assumed that having Gladstone's ear was beneficial to Welsh interests, the flow of information was two-way:

'Mr and Mrs Gladstone', South Wales Echo, 29 April 1893, p.3: Mr and Mrs Gladstone arrived at Autchlands, the Surrey residence of Mr Stuart Rendel, this morning, and will remain there until Monday next.

'The Premier Dines with Mr Rendel', South Wales Daily News, 6 November 1893, p.5: Mr Gladstone dined with Mr Stuart Rendel at Carlton-gardens on Saturday evening 'Christmas at Cannes', Evening Express, 4 December 1893, p.3: 'Mr Stuart Rendel getting Things Ready for the Premier. A Dalziel's telegram from Cannes says: Mr. Stuart Rendel M.P. arrived on Saturday night, in order to inspect the progress of the work now being carried out at the villa which he recently purchased from the Duchess of Montrose. Mr Rendel has invited Mr. Gladstone to spend Christmas with him, and special attention is being paid to the rooms which the great statesman will occupy during his visit'.

110 'Editorial Comment', The Western Mail, 26 July 1894, p.4.
} 
It is however the use of the term 'fads' which is pertinent, because it is clear that many senior Liberal politicians would have shared this designation of disestablishment and, as described by Professor Hamer, this pejorative expression would appear to associate the supporter of Welsh disestablishment, with the 'distinguishing characteristic of a faddist', being their enthusiasm, to the exclusion of all else, which was something which was never going to allow for a comfortable state of affairs within a Liberal party that craved for internal discipline and order. ${ }^{111}$ However, the Welsh members of Parliament were not genuine faddists, as their commitment could easily be depleted, and their actions enervated. If there was one politician in Wales who did understand the nature of fads, it was Stuart Rendel who, according to Hamer, was 'the Liberal who most thoroughly, consistently, and clear-sightedly put into practice an understanding of an organic relationship between Liberal sections and Liberal Party'. ${ }^{112}$ Hamer goes on to observe that;

'the two great purposes of Rendel's career were the integration of sectional politics into general Liberal politics and the achievement within this basic condition of integration of a particular sectional aim, in his case Welsh disestablishment'. ${ }^{113}$

\section{Gladstone's successor.}

With the resignation of Gladstone in 1894, the Welsh members of parliament were particularly concerned about how Lord Rosebery’s succession would impact upon disestablishment. Although Lloyd George was reported as 'strongly in favour of the Earl of Rosebery, and thinks the Imperialist views attributed to his lordship should be welcomed as an additional source of strength to the Liberal party', Major Rowland Jones was concerned that Lord Rosebery was not well enough acquainted with the Welsh people to realise the earnestness of their expectation that the question of Welsh Disestablishment will be dealt with in the new Session'. In May 1894 the Western Mail included a cartoon which depicted H. H. Asquith, the Home Secretary, astride a donkey, which represents the 'Welsh Party', and Asquith is holding a rod with carrots dangling from the tip, entitled 'promise' and 'Disestablishment'. ${ }^{114}$

\footnotetext{
${ }^{111}$ Hamer, The Politics of Electoral Pressure, p.1.

112 Hamer, D.A., Liberal Politics in the Age of Gladstone and Rosebery. A Study in Leadership and Policy, p.29. 113 Ibid., pp.29-30.

114 Western Mail cartoon, 14 July 1894, p.5: 'Gulling the Donkey’, drawn by cartoonist V Mc. The text is: 'Heehaw! Hee-haw! My gallant steed. Thou jogg'st along to - deuce knows where'.
} 
Whatever their viewpoint, it was recognised that 'it would be unwise of the Radicals, by either active hostility or withholding support, to defeat or weaken Lord Rosebery' s administration before it has a fair chance of showing what it is prepared to do'. ${ }^{115}$ It was a further indication of how the progression of a supposedly agreed Welsh policy was subject to the buffeting from factors over which the Welsh party had no control and where passivity was recognised as the best option. However, the change in prime minister led to the announcement of the ministerial programme and the disappointing contents were sufficient to drive some Welsh members to 'revolt', if temporarily. The ministerial programme placed Welsh disestablishment well down the list of proposed measures and this caused four M.P.s, David Lloyd George, Frank Edwards, D. A. Thomas, and Herbert Lewis to resign the Liberal Party whip. They appeared at a meeting held at Bangor in May 1894, 'in explanation and defence of the independent attitude they have assumed in the House of Commons towards the Government'. ${ }^{116}$

Frank Edwards was the first of the M.P.s to speak and he commenced with the subject upon which all those present were agreed: 'that the one all-important question in Wales at the present time was the disestablishment and disendowment of the Church of England in Wales. It was absolutely necessary that a Bill with that object should be carried through the House of Commons and sent to the House of Lords this session'. Those present were not to know that this was precisely the approach which the Bishop of St. Asaph was to believe would have forced the issue, with the House of Lords, he believed eventually, succumbing to Welsh disestablishment, as the lesser of other Welsh aspirations, such as home rule. Frank Edwards was adamant that: 'all Welshmen were agreed on two points, viz. - that the all-important question of Wales was disestablishment and that the Disestablishment Bill should pass through the House of Commons'. ${ }^{117}$ Edwards went on to ask whether the Irish members would 'have been satisfied with a mere second reading?' and therefore, 'why should Wales be satisfied with less?'118 Herbert Lewis expounded that 'it was now abundantly clear that nothing was to be gained by a patient acquiescence on the part of the Welsh representatives in the neglect of their own country' and he emphasized the democratic argument that 'Wales had been won at four successive general

\footnotetext{
115 'Gladstone’s Resignation Confirmed. The Welsh Members’, South Wales Daily News, 5 March 1894, p.5.

116 'The Welsh Revolters. On Their Defence at a Bangor Meeting', Evening Express, 17 May 1894, p.4.

117 'The Welsh Members and Disestablishment', The Times, 17 May 1894, p.10.

118 Ibid.
} 
elections on the question of disestablishment and won by over- whelming majorities'. D.A. Thomas took the opportunity, as was often the case ${ }^{119}$, to denigrate the leader of the Welsh Parliamentary Party, Alfred Thomas ${ }^{120}$ and highlighted his move from tacit support to opposition. In what was clearly intended to suggest that the 'Revolters' appeared less than determined, it was reported that: 'Mr. Frank Edwards. Mr. Herbert Lewis and Mr. Lloyd-George leave town on Friday for a fortnight's tour in Switzerland. Each member has paired in favour of the Government. The late revolters do not regard their doing so as being in any way inconsistent with' the attitude they recently adopted'. ${ }^{121}$

It was apparent that Lloyd George was the speaker that the audience was keen to hear and, when he rose to speak, he was met with 'enthusiastic cheers and by the singing of 'He's a jolly good fellow'. He stressed that he believed that all would agree that: 'that there was absolutely no limit to party allegiance or that under no conceivable set of circumstances were men justified in deserting their party' and to support that opinion, he pointed out that:

'the Welsh Disestablishment Bill, instead of being second on the Government programme, was now actually tenth on the list, and they had not received from the Government any absolute, distinct, conclusive pledge that the Government would carry that Bill, not only this session, but possibly not even in the course of the present Parliament. No circumstances of urgency and no unforeseen circumstances had arisen to justify the Government in dis- placing the Welsh Disestablishment Bill from the Ministerial programme'. ${ }^{122}$

Lloyd George was adamant that 'if they had a resolute, strong, independent Welsh national party years ago in the House of Commons the Government would not have dared to insult them with such a Disestablishment Bill as had been introduced'. He mentioned some comment about the 'dog-like fidelity of the Welsh members', but that loyalty had worked to their detriment and:

'When a Liberal Ministry whistled for them the Welsh members scampered away in the Liberal service until they were almost out of breath, and if they occasionally barked for

\footnotetext{
119 D.A. Thomas, senior M.P. for the Merthyr Boroughs had been a harsh critic of Alfred Thomas's National Institutions (Wales) Bill in 1891. Although Alfred Thomas had suggested that jealousy was the cause, this is unlikely in view of D.A. Thomas's beliefs and was more likely concerned with valid concerns about certain clauses in the Bill: Gerard Charmley, 'Alfred Thomas and Wales in Parliament, 1885-1910', Cymmrodorion, Vol.16 (2010), p.45.

${ }^{120}$ Alfred Thomas, baron Pontypridd, (1840-1927), represented East Cardiff, in Parliament, from 1885 until 1910. He was elected chairman of the Welsh Parliamentary Liberal Party in 1898: D.W.B.

121 'Welsh Disestablishment. The Four Revolters are Once More in Line Again, Evening Express, 26 July 1894 , p.1. 122 Ibid.
} 
want of a bone, their masters had simply to appear on the scene, and they skulked back to their kennels like whipped curs'. ${ }^{123}$

Although the 'Welsh Revolt', which had often been threatened, had at last taken place, it was a damp squib, with extremely limited support and fractious relations between the Welsh members. It was clearly a telling event in terms of the ultimate effectiveness of the Welsh representatives and to the extent that the Welsh aspiration, disestablishment, could be entrusted to them. Fortunately, the Welsh were lifted off the horns of their predicament by the introduction of the first Welsh Disestablishment Bill, by H.H. Asquith, on 26 April 1894, with a second reading on 21 March, $1895^{124}$. Asquith provided an insight into his lack of fervour for the subject, which he described as 'my thankless task' ${ }^{125}$, when he recorded that in addition to:

'piloting my Factories and Workshops Bill among the shallows of a Grand Committee, and for the rest of the day and part of the night in heaving through, inch by inch and almost word by word, the earlier clauses of the Bill for the Disestablishment of the Welsh Church. The short interludes, when other Bills were on, were generally taken up in interchanging amenities with deputations from Welsh members, who did not always speak with the same tongue'. ${ }^{126}$

Although Asquith was later to claim that it was not altogether a case of 'ploughing the sands', 'as the disestablished Welsh Church, the much-compassionated victim of "sacrilege" and “spoilation”, is pursuing with growing efficiency its independent life’. ${ }^{127}$

\footnotetext{
123 Ibid.

${ }^{124}$ A Speech Delivered by The Right Hon. H.H. Asquith Q.C., M.P. on March 21, 1895, in the House of Commons, on the Second Reading of the Established Church (Wales) Bill (London: Liberal Publication Department, 1895).

125 Roy Jenkins, Asquith (London: Pan Macmillan, 1964, p.85: 'After twelve nights in committee and remarkably little progress, "it was with a sigh of relief", Asquith wrote, "that, when the Government was defeated on another issue, I laid down my thankless task'.

126 The Earl of Oxford and Asquith, Memories and Reflections, Vol.1 (London, 1928), p.137.

127 Ibid., p.138.
} 

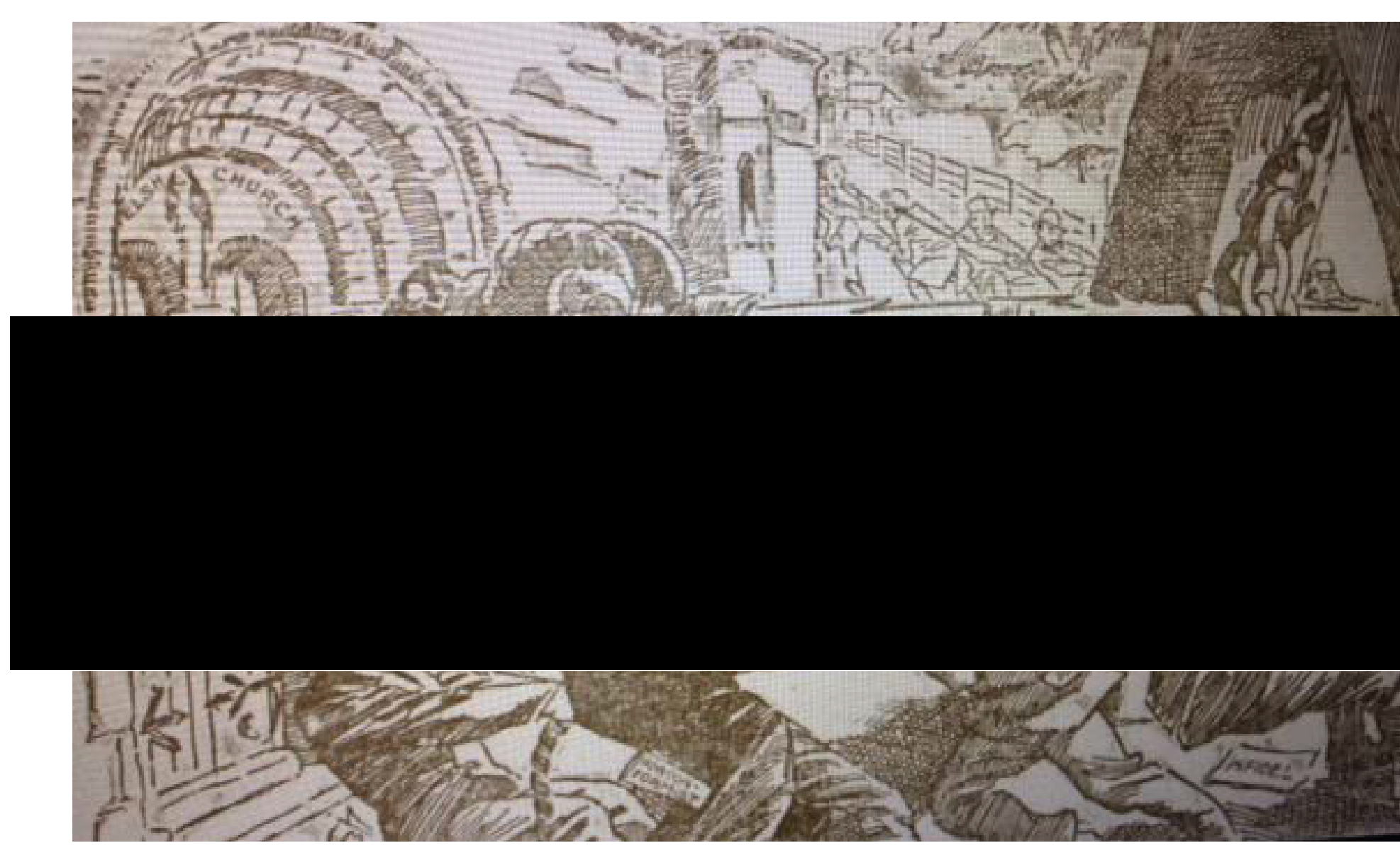

'The Commencement of the Siege', Evening Express, 27 April 1894, p.4.

In this cartoon, David Lloyd George, assisted in his efforts by a Nonconformist, an atheist and, as a dropped card indicates, an 'infidel', appears to be taking aim at the West Door of Llandaff Cathedral. The Conservative-leaning Evening Express characterised the objective of the Bill as "Robbery and jobbery". Whereas the robbery could be readily understood by their horror of the prospect of disendowment, ‘jobbery' provides a fascinating insight into Conservative and Unionist thinking, as it envisaged the proceeds of disendowment being wasted on 'wholesale bribery. The offer of the Church's funds for parochial distribution is a heavy and a direct bribe to Wales, and it is also a covert offer to England of a similar bribe'. ${ }^{128}$

In his speech to the National Liberal Federation, held at Cardiff on 18 January 1895, Lord Rosebery, prime minister and leader of the Liberal Party, mindful of the growing restlessness

128 'Welsh Church. The Disestablishment Bill', Evening Express, 27 April 1894, p.4. 
concerning the progress of Welsh issues, particularly disestablishment, was careful, when describing the 'Government's Welsh Record', to appease doubters with a reminder to the Welsh members of his audience that: 'You have not done so badly under a Liberal Government' ${ }^{129}$ His endeavour, to ensure that Welsh Liberal party remained within the fold was supported by many, including some self-proclaimed 'nationalists', who interpreted the apparent sympathy as sufficient:

'When the Liberal party ceases to sympathise with Wales, and refuses to lend its aid to redress Welsh grievances, and to realise Welsh aspirations, then and only then can it be said that the experiment of influencing the Liberal party from within has failed - then and then only will the attempt to coerce it from without be justified'. ${ }^{130}$

When he addressed the closing session of the Seventeenth Annual Meeting of the National Liberal Federation, held in Cardiff on 18 January 1895, the Prime Minister, the Earl of Rosebery ${ }^{131}$ described the barriers to Welsh Disestablishment, including the absence of devolution, and he admitted that if the thirty four Welsh members of parliament 'were left alone to settle the question', they would 'make short work of the Church Establishment' ${ }^{132}$ However, Lord Rosebery also identified, for the 10,000 people present, the immediate cause or excuse for a failure to achieve Welsh disestablishment:

'But there is another and more permanent barrier which opposes itself to your wishes in respect to Welsh Disestablishment. I need not mention to this assembly the attitude of the House of Lords. You know how it treats Welsh matters; how it treats those Welsh popular schemes of education which have been sent to it during the past two Sessions'. ${ }^{133}$

In fact, Lord Rosebery had made it clear at a meeting held at St. George’s Hall, Bradford, in October 1894, that the next general election would not be fought upon Disestablishment, Home Rule or the liquor question but the 'motive power at the next election' would be the 'one which includes and represents them all - I mean the House of Lords'. ${ }^{134}$ Once the Rosebery government fell in June 1895, it was difficult to envisage any meaningful means by which Welsh disestablishment could be progressed. The Welsh Liberals were themselves seemingly passive,

\footnotetext{
${ }^{129}$ A Speech Delivered by the Rt. Hon. the Earl of Rosebery, p.13.

130 Professor W. Jenkyn Thomas, ‘An Independent Welsh National Party’, Young Wales, vol.1, no.3 (March 1895), p.57.

131 John Davies, 'Primrose, Archibald Philip, fifth earl of Rosebery and first earl of Midlothian (1847-1929)', O.D.N.B.

${ }^{132}$ A Speech Delivered by the Rt. Hon. the Earl of Rosebery, at Cardiff on January 18 ${ }^{\text {th }}$, 1895, p.13.

133 Ibid., p.15.

134 'Lord Rosebery on the House of Lords', The Times, 29 October 1894, p.7.
} 
with occasional forays by members, representing Welsh seats, who were pursuing their own course of action, such as when the champion of 'social purity', Samuel Smith ${ }^{135}$, the M.P. for Flintshire, presented a motion on the question of English and Welsh disestablishment, which was decisively defeated, with 86 members voting for the motion, but 204 against it and, tellingly, it was reported that the front bench of the Liberal opposition abstained. Mr. Smith was concerned with that 'it was expedient to disestablish and disendow the Church of England both in England and Wales' and this action would do nothing to aid Welsh disestablishment. ${ }^{136}$

A pertinent postscript to the fall of the Liberal administration, and a precursor of what was to come, was contained in a description of the proceedings of the Church Defence Institution in August 1895, when Sir John T. D. Llewelyn acknowledged that they should work with their 'Nonconformist friends, who were doing 'admirable work', but the Bishop of St. Asaph assumed, characteristically, a more belligerent stance, with reference to the fact that the electoral results demonstrated that 'it could no longer be maintained that disestablishment and disendowment in Wales were a consuming fire' and if they ever did, the fire was going out. J. G. Talbot seconded a motion that called upon Churchmen to maintain and extend the instruction in the facts of Church history and its work: 'He did not believe the Liberationists would be satisfied with one defeat. The battle has been won in a very sudden manner, but the war was not over and Churchmen must not overlook the fact'. ${ }^{137}$

Although the Church defenders were warned to be vigilant, it was apparent that there was a general understanding that there was no cause to compromise and therefore the 1895 Scheme was certain to fail. The 'Bangor scheme' proposed a fairer distribution of endowments, the abolition of lay patronage, an increase in the role of the laity in church management and the creation of Wales as a separate province, with its own archbishop. As Frances Knight has written: 'Much of the Bangor scheme was put into effect when disestablishment was finally achieved, 138 , a quarter of a century later. It was an attempt, by a number of Anglicans, in the

\footnotetext{
135 'Mr Samuel Smith on Immoral Plays’, Rhyl Record and Advertiser, 19 May 1900, p.7.

136 'Disestablishment. For England and Wales. Mr. S. Smith’s Motion in the Commons', Weekly Mail, 13 February 1897, p.4.

137 'The Church Defence Institution', The Times, 17 August 1895, p.8.

138 Knight, 'Welsh Nationalism and Anglo-Catholicism: The Politics and Religion of J. Arthur Price (1861-1942)', p.115.
} 
context of a burgeoning atmosphere of nationalistic sentiment, to offer a alternative to the disestablishment and the disendowment of the Welsh Anglican church. It has been suggested that 'it is reasonably clear that Lloyd George’s hand was in it somewhere’. ${ }^{139}$ The Scheme emerged in the context of the creation of Cymru Fydd and, according to Neville Masterman's biography of T.E. Ellis, it was Lloyd George who approached one of those involved in the Scheme, J. Arthur Price, a High Church barrister who was a nationalist. ${ }^{140}$ It is interesting that Arthur Price elected to remove his name from a direct association with the 1895 scheme, which he described in an article in 1917, when he attributes the scheme to Reverend Edwin Jones and the Reverend R. Edmunds Jones, although he emphasizes that:

'It was a genuine expression of nationalism, and if the Welsh Liberals had been willing to co-operate with its authors, the Welsh Church question might have been settled by reasonable compromise. Had such a compromise been effected, Wales would have escaped twenty years of an unedifying sectarian wrangle, and a genuine Welsh Nationalist party might have been formed, which would have solved for Wales her still unsettled questions of land, education, and self-government. It was not to be'. ${ }^{141}$

\section{'The Liberal Welsh members are a sort of political tadpole - all head'. ${ }^{142}$}

As the nineteenth-century drew to a close, The Cambrian News reported upon a meeting of Welsh Parliamentary party which had been convened to supposedly consider 'an important question of policy', although the newspaper added that ten of the Welsh Liberals were absent, which they interpreted as a 'fact sufficiently significant of the interest which the party as a whole takes in Welsh business'. ${ }^{143}$ The question to be considered was the future relationship between the Welsh Liberal members and the main party and it was apparent that there was no possibility of a consensus, with Lloyd George suggesting that the Welsh Liberals could not be 'an independent party in the same sense as the Irish members, but a party on the lines of the Liberal Unionists who form the part of, but are not incorporated in, the Conservative party', but with Bryn Roberts hostile to any such proposal and the meeting was adjourned without any decision. ${ }^{144}$ The Cambrian News was driven to reflect upon the state of the Welsh members

\footnotetext{
${ }^{139}$ Roger L. Brown, 'Traitors and compromisers: the shadow side of the Church's fight against Disestablishment', Journal of Welsh religious history, vol.3, (1995), p.42.

140 Masterman, The Forerunner. The Dilemmas of Tom Ellis, 1859-1899, p.210.

141 J. Arthur Price, 'The awakening in the Welsh church', Welsh Outlook, vol.4, no.10 (Oct. 1917), p.362.

142 'Wales and Her Members', The Cambrian News, 26 May 1899, p.5.

143 'Meeting of Welsh Members', The Cambrian News, 26 May 1899, p.2.

144 Ibid.
} 
generally and it no doubt summed up the exasperation of many disestablishers when it reported that:

'We care nothing about the jealousies and bickerings and rivalries of the Welsh Liberal members, but we care a great deal about the position Welsh Disestablishment is to take in the programme of the next Liberal Government. We know as well as anybody for how long a time it is possible to talk round and round a subject without coming to the point, but we also know that sooner or later the subject has to be faced. It does not seem to us that the Welsh Liberal members are in earnest. They have been influenced by the unreal, insincere spirit which at present pervades the House of Commons. It is from the constituencies that a new spirit of earnestness must come, and that spirit can only come out of the brave utterance backed by the brave deed. We refuse to believe that Wales is in favour of the political shuffler, who beats his breast and shouts patriotism at the top of his voice and then runs away and hides himself'. ${ }^{145}$

The newspaper also took exception to 'Welsh members taking up positions in Governments and at the same time posing as patriots. The two functions, patriotism and political officialism, are incompatible' and it suggested that Irish Reformers had realised this fact many years before, with the unequivocal opinion that 'any member of the Home Rule party who sought or accepted Government place would be looked upon as a traitor to the nation'. ${ }^{146}$ It would have been difficult to disagree with the suggestion that: 'The year 1899 cannot be said to have been an exciting one, as regards Welsh politics. There has been no stirring campaign, no rising of the people, no great enthusiasm'. ${ }^{147}$ It is moot point whether the fin de siècle could have marked a very different outcome, if the Welsh parliamentary party had acted as though they were in 'earnest', to quote The Cambrian Times. Instead, The Times’s Welsh correspondent reported that: 'Comparatively little has been heard of Welsh politics in Parliament', and that: 'In ecclesiastical matters the year has been uneventful'. ${ }^{148}$ With its added report that 'the land question has gone into the background', it did appear that any attention to Welsh affairs had withered and that the prospect of disestablishment had, at the turn of the century, simply vanished, and as if to underline the fact; the word 'disestablishment' was not included in the article, although the absence of the 'Church Defence party' was identified as one of the reasons why the Unionists had fared poorly in the recent general election. ${ }^{149}$

\footnotetext{
145 'Wales and Her Members', The Cambrian News, 26 May 1899, p.5.

146 Ibid.

147 'Wales in 1899', The North Wales Times, 6 January 1900, p.4.

148 'Wales in 1900', from a Welsh correspondent, The Times, 7 January 1901, p.12.

149 Ibid.
} 
There was, however, a different, more constructive and hopeful interpretation of the state of Welsh politics, and its people, provided by Lord Rendel, in a letter dated 1 April 1899 which he sent to Sir Alfred Thomas, in order to decline an invitation. He initially described the lack of confidence that plagued the Welsh Liberal party, with a desire that: 'we could nourish more faith in ourselves and in our good men at large in the Party', but a warning that there was: 'no greater mistake thus to think that we have not ample staff for leadership in our ranks, so that we need feel "hung up" for want of this or that individual'. ${ }^{150}$ He was, however, encouraged that 'Welsh politics, like the Welsh people' was steadily moving from 'the Elementary stage, through the Intermediate into the Higher Education'. ${ }^{151}$ As Rendel had played such a critical role in the development of Welsh intermediate education ${ }^{152}$, this was a pertinent observation and, as he had demonstrated when he moved the Second Reading of the Intermediate Education (Wales) Bill in May 1889, he placed the measure firmly within the context of a burgeoning recognition of Welsh nationality, making the point that:

'for two centuries previously nothing Welsh received the slightest encouragement at the hands of Parliament. That neglect and indifference we now hope has passed away for ever, and we confidently anticipate that Parliament is favourably disposed to consider the wants of Wales in the direction which the Welsh people desire'. ${ }^{153}$

Rendel's concern about how that 'desire' could be suborned was to make him aware of those who might attempt to subvert that national feeling for their own parochial purposes and he was suspicious of the efforts made to associate the Welsh National Museum and Library movement ${ }^{154}$ solely with Cardiff, as: 'I know no place where there is more likelihood of true and pure Welsh national feeling and of all the sentiments that should characterise a Welsh University being popularly drowned than at Cardiff'. ${ }^{155}$

\footnotetext{
${ }^{150}$ GRO/PP/IIa, Stuart Rendel to Alfred Thomas, 1 April 1899.

151 Ibid.

152 T. I. Ellis, The Development of Higher Education in Wales (Wrexham, 1935), p.71.

153 'Intermediate Education (Wales) Bill (No. 4)', HC Deb. 15 May 1889 vol. 336, cc121.

154 'The Welsh National Library. Privy Council’s Report', The Cambrian News, 16 June 1905 p.3: Cardiff's ambition to have both the National Library and the National Museum located in the city was to be dashed, much to their chagrin, when a committee of the Privy Council decided, on 8 June 1905, that the National Library of Wales should be located at Aberystwyth and the National Museum at Cardiff.

${ }^{155}$ Hamer, The Papers of Lord Rendel, p.298.
} 


\section{A precursor to the campaign.}

In his analysis of 'Wales in 1901', The Times's Welsh correspondent maintained the opinion which he had expressed the previous year, with his assessment that 'Welsh politics are still in a spiritless condition', highlighting the fact that the question of Welsh disestablishment had been totally neglected at the Liberal Party's meeting of the Welsh National Council, and that the subject was 'scarcely mentioned' 156 The correspondent then described how: 'nothing is more remarkable than the suddenness with which Welsh disestablishment has gone into the background. Bishop Edwards may well claim a triumph’. ${ }^{157}$ Welsh Liberal member of Parliament, D. A. Thomas, would have concurred with The Times's conclusion, as he considered that Welsh politics were: 'at a low ebb’ and that: 'in their collective capacity the Welsh members hardly counted as a pawn on the political board, and he could well understand that dissatisfaction had grown up in the minds of thoughtful Welshmen'. He considered that this was particularly reprehensible as: 'Wales had ever been more ably represented in the House of Commons', but he claimed that the 'so-called Welsh Parliamentary Party was a mere pretence', with 'no suggestion of discipline'. He could, in terms of 'their collective capacity during the past half-dozen years', only identify their success in persuading the kitchen committee to place Caerphilly cheese upon the menu of the House of Commons dinner-table, although this concession was short-lived. ${ }^{158}$ The Times's assertion had swiftly evoked a letter to the editor of The Times, from John Matthews, who had represented the Liberation Society in South Wales, although his assertion that the subject was still being actively pursued by Liberals in Wales appeared unconvincing and was subject to the telling observation that, 'for the moment, the war is more urgent and absorbing' 159

William Jones ${ }^{160}$, the Liberal member of Parliament for Arfon, was to shatter the perceived armistice, when he moved a resolution, declaring: 'That, in the best interests of the Welsh nation

\footnotetext{
156 'Wales in 1901', The Times, 1 January 1902: p.13.

157 Ibid.

158 'Welsh Radicalism', Evening Express, 25 November 1901, p.3.

159 'Wales and Disestablishment', letter to the Editor of The Times, 8 January 1902, p.6. The Second Boer War was fought by Britain and its Empire against the Boers, comprising of the combined forces of the South African Republic and the Republic of the Orange Free State. The Boer Republics declared war on 11th October 1899 and the conflict ended on 31st May 1902, a duration of 2 years and 8 months.

${ }^{160}$ William Jones, (1859-1915), entered the House of Commons, as Liberal MP for Arfon, in the 1895 general election. He was appointed as a government whip in 1911. He died in office in May 1915. His entry in the Dictionary of Welsh Biography describes him as 'one of the most effective speakers in the Commons'. He was
} 
and of the Church, the State establishment of the Church of England in Wales should cease to exist'. ${ }^{161}$ The resolution was rejected, on a division, by 218 votes against 177, although it was pointed out by The Times that the smallness' of the Government's majority was due to administrative confusion, whereby Unionist MPs were under the impression that the division would be held later than it was. ${ }^{162}$ An editorial in The Times declared that: 'There was nothing new in the debate on Mr. Jones’s motion. Mr. Jones himself, a typical Welshman, displayed an earnestness and an eloquence which the House was glad to welcome'. ${ }^{163}$ The somewhat condescending description, albeit diluted with a note of approbation in terms of the contents of his speech, was swiftly followed by criticism levelled at H. H. Asquith ${ }^{164}$ and Sir William Harcourt ${ }^{165}$, who had supported the motion. Their speeches were 'just the same as those that were made before the collapse of 1895' and that was followed by a clear indication that their 'ingenuous and insidious arguments', attacking the Church in Wales was intended as 'attempt to destroy the outworks in order to be able to strike at the citadel' and that if a member of parliament votes for disestablishment in Wales, 'he is establishing a precedent which will be brought into operation elsewhere'. In its review of 'Wales in 1902', The Times believed that William Jones's actions were an attempt to counter the impression given in the newspaper's review of Welsh affairs for the preceding year. ${ }^{166}$ It opined that Jones's 'pretty phrases and graceful manners' did not mask the 'old and commonplace character of the material' and, after an analysis of various indicators. The same report was strangely prescient in one of its prognostications, when it identified one Welshman who had succeeded in making a reputation in the House of Commons, but it anticipated that David Lloyd George’s ambitions were to cause him 'to become another Henry Richard ${ }^{167}$ rather than a second Tom Ellis', when it identified him as a spokesman, 'not of Welsh causes, but of militant English Nonconformity'. 168

appointed as one of the Junior Lords of the Treasury, as a 'Whip' to 'look after the interests of Wales and the attendance of the Liberal Welsh members'.

${ }^{161}$ HC Deb. 4 February 1902, vol.102, cc379-419.

162 'Political Notes', The Times, Wednesday, 5 February 1902, p.10.

163 The Times, Wednesday, 5 February 1902, p.9.

${ }^{164}$ Herbert Henry Asquith, (1852-1928), first earl of Oxford and Asquith.

165 Hamer, Liberal Politics in the Age of Gladstone and Rosebery, pp.331-331: Sir William Harcourt was MP for West Monmouth from 1895 to 1904.

166 'Wales in 1902', The Times, 31 December 1902, p.13.

${ }^{167}$ Hamer, Personal Papers of Lord Rendel, p.304: Rendel had described Richard as 'the doyen of Welsh members', but that he was the leader of a section of the House of Commons 'which was exceedingly English'.

${ }^{168}$ Ibid. The report also identified his 'instinctive sense of opportunities'. 
Mr. Jones's efforts were received more generously by the Speaker, which affirmed that he rested his argument on the 'indisputable truth that the Church in Wales is an alien Church, alien in its history, its doctrines and its spirit' and that 'the protest against Establishment is the assertion of Welsh nationalism, a nationalism which is a perpetual challenge to a foreign land system and a foreign ecclesiastical system’. ${ }^{169}$ Mr. Jones’s speech had adopted a conciliatory and irenic tone and content, expressing the democratic credentials for his Motion, but avoiding an outright attack upon the Church and this approach was clearly more agreeable to English commentators: 'In moving the Resolution I have no animus or spirit of hostility whatsoever towards the Church as a Church; and however imperfectly I may deal with this important matter, I deal with it in the full confidence that I have the majority of the Welsh nation at my back.' ${ }^{170}$ Jones attempted to appease some in the House, or least attenuate the possibility of the ritual knee-jerk response from Church defenders. Mr. Jones was also careful in that, when he referred to the Church as 'alien', he was to cite, as his reference, a speech made in Swansea, by 'one of the most distinguished of modern Churchmen', Dean H.T. Edwards ${ }^{171}$, of Bangor, the late, much-revered brother of the Bishop of St. Asaph. In seconding the motion, Mr. Alfred Thomas ${ }^{172}$ ensured that he attributed Churchmen with praise, in respect 'their zeal, their devotion to duty, and the sacrifices they make in carrying out of their office’ and he was at pains to describe the fact that Bishop of Llandaff ${ }^{173}$ had never 'appointed an English-speaking incumbent in a Celtic-speaking district'. ${ }^{174} \mathrm{He}$ believed that disestablishment would be good for the Church: 'But the State Church arrogates to itself a status which is insulting to Nonconformists, and we are determined that that inequality shall be removed as soon as possible'. It was apparent that the attempt at emollience had severe

\footnotetext{
169 'Welsh Disestablishment', The Speaker: the liberal review, February 8, 1902: 5, 123, p.522.

${ }^{170}$ Established Church (Wales), HC Deb 04 February 1902 vol. 102 cc379-419, Mr. William Jones, (Carnarvon, Arfon).

${ }^{171}$ Henry Thomas Edwards, (1837-1884), Dean of Bangor from 1876. His address to the Church Congress, Swansea, on 9 October 1879, was entitled The Past and Present Position of the Church in Wales and its second sentence was, 'Till the twelfth century, the Church was the Church of Wales'. Lest anybody should be confused about his views, he had preached at St. David's Church, Liverpool, on 25 May 1879, on the topic of Why are the Welsh People Alienated from the Church? Both are included within Wales and the Welsh Church, London, 1889. 172 Alfred Thomas, Baron Pontypridd, (1840-1927), Liberal member of Parliament for East Glamorgan, 1885 to 1910. He was elected chairman of the Welsh Liberal MPs, a post he held until his retirement from the Commons in 1910.

173 Richard Lewis, (1821-1905), Bishop of Llandaff, 1883 to 1905. The Bishop had been nominated as rector of Llanbedr Felfre in 1851, but Bishop Thirlwall was not convinced that his Welsh was of the required standard and he was examined under the terms of the Ecclesiastical Church Act, 1836. He failed the examination by three Churchmen, but he was to successfully appeal to the Archbishop of Canterbury.

174 John Viriamu Jones, (1856-1901), appointed as the first Principal of University College, Cardiff, in 1883 and as first vice-chancellor of the University of Wales in 1895.
} 
limitations, whilst members of Parliament would habitually allude to two substantive objections, namely the threat of disendowment and, as Mr. Gibbs declared, the habitual hurdle that: 'the Church in England and the Church in Wales are one and indivisible, and the two must necessarily and logically stand or fall together'. ${ }^{175}$ Presumably on the grounds of simply advising electors of the dangers ahead, the Conservative-supporting Aberystwyth Observer, in 1905, listed the eleven members of the new Cabinet who had voted in favour of the 1902 Motion. ${ }^{176}$ But then, in the following year, the same newspaper identified what it understood to be a fundamental shift in how Welsh Churchmen viewed the prospect of disestablishment:

'The feeling amongst Churchmen in favour of the Disestablishment of the Church in Wales is growing with great rapidity. Twenty years ago it would have been difficult to find a Conservative Churchman who would even listen to a proposal for Disestablishment. Now, at least in this part of the country, it would be difficult to find an intelligent Church man who is not in favour of Disestablishment, although all are prepared to fight for the endowments' ${ }^{177}$

There were, however, pragmatic reasons behind the newspaper's recommendation that those who were afraid of disestablishment should study the subject, because it also believed that: 'With this question out of the way many Nonconformists would vote in accordance with their Conservative instincts, and Wales would then for the first time be fairly represented in the House of Commons'. ${ }^{178}$ The newspaper was adamant that the failure of the Conservative party's efforts in Wales was attributable to its opposition to disestablishment, allowing the 'Radicals' to regularly win more parliamentary seats. It was therefore imperative, apart from disendowment, for the political agenda to change, in order to give the Conservative cause a fillip. In case the reader might experience any qualms about this political pragmatism, the article did assert that 'the clergy also are paralysed by the ecclesiastical system’ and it countered any suggestion by the Bishop of St. David's 'that the Church people in England will not permit the Government to Disestablish the Church in Wales', with the riposte that the English Church had acknowledged the possibility of Church reform in 1894. It foresaw that an unstoppable 'snowball' had been set in motion, following the public support from a Churchman, who was a Welsh member of Parliament, Colonel Pryce-Jones. ${ }^{179}$

\footnotetext{
${ }^{175}$ Vicary Gibbs, (1853-1932), member of Parliament for St. Albans, 1892 to 1904.

176 'Disestablishment', The Aberystwyth Observer, 28 December 1905, page 3.

${ }^{177}$ Disestablishment', The Aberystwyth Observer, 22 February 1906, page 3.

178 Ibid.

${ }^{179}$ Colonel Edward Pryce-Jones, MP for Montgomery, 1895-1906.
} 


\section{'A curious repetition of the history of 11 years ago'.}

In 1905, the determination of Sir Alfred Thomas to revive the claims of Welsh disestablishment was to give rise to a clash with David Lloyd George and The Times could not resist reminding its readers that that it was 'a curious repetition of the history of 11 years ago', when Tom Ellis had been the only Welshman serving in the government and it had been Lloyd George who had sought to revolt, in order to ensure that Welsh disestablishment was given some priority. ${ }^{180}$ An interview which Alfred Thomas gave to Beriah Evans ${ }^{181}$, in August 1905, was to cause consternation. It was evident that Beriah Evans was acting as a publicist for Sir Alfred and in a letter dated 31 August 1905, he was keen to confirm to Sir Alfred why the interview had taken place and the dual objective was that: 'your official position as Chairman of the Welsh Party, and the importance of the Disestablishment position should get their due recognition'. ${ }^{182}$ He believed that this had been achieved, by reference to various editorial comment in a range of newspapers which gave 'prominence to the interview', including The Times. ${ }^{183}$ Evans wrote that he was 'delighted to have been the means of reminding the public that the Welsh Party has a Chairman who and will assent himself when the need arises'. ${ }^{184}$ In a follow-up note sent the same day, Evans made further reference to the pleasing newspaper coverage but, more tellingly, he ended with: 'I may add privately that George much annoyed at the publication of your views'. 185

It was manifest that neither man was disappointed to learn of Lloyd George’s displeasure. The consideration of political strategy and the necessary means of evoking publicity was the subject matter of a letter dated 15 September 1905, in which Evans anticipates receipt of Sir Alfred's latest speech which he was 'sure will be Deserving of public attention' ${ }^{186}$ There was to be significant press interest in Lloyd George’s contradiction of Sir Alfred Thomas's speech, when he attempted to suggest that Sir Alfred's views had been misreported, which caused Beriah Evans to confirm that the contents for the interview, save for 'a slight

\footnotetext{
180 'Wales in 1905', The Times, 1 January 1906, p.14.

${ }^{181}$ Beriah Gwynfe Evans, (1848-1927), journalist and dramatist.

182 GRO/PP/IV.4, letter from letter from Beriah Evans to Alfred Thomas dated 31 August 1905.

183 'Wales and the Liberal Party', The Times, 30 August 1905, p.9. The report in The Times commenced with the statement that Sir Alfred 'has just made an important pronouncement on the political situation' and quoted him widely.

${ }^{184}$ Ibid.

185 GRO/PP/IV.4, Beriah Evans to Alfred Thomas dated 31 August 1905.

${ }^{186}$ GRO/PP/IV.3, Beriah Evans to Alfred Thomas 15 September 1905.
} 
modification’ were accurate. ${ }^{187}$

Although Alfred Thomas has often been portrayed as a Welsh politician who failed to display the guile and ability of others of his cohort, it was evident in 1905 that he was able to be as calculating as any of his colleagues and that he adopted a public relations stratagem which would be admired by contemporary politicians. ${ }^{188}$ It appeared that Alfred Thomas had utilised the very willing services of Beriah Evans to ensure that a copy of a letter he had received from Lord Rendel, was circulated to a variety of newspapers, including The Times. ${ }^{189}$ Lord Rendel's letter of 27 September $1905^{190}$ had been critical of a speech delivered by Lord Stanley of Alderley ${ }^{191}$, who had hosted a gathering of Liberals at his home at Penrhos, Anglesey where, in anticipation of a Liberal Government which would:

'be strong enough to drive through Parliament a measure for the disestablishment of the Church in Wales would be strong enough to pass a similar act embracing the whole country and giving disestablishment and disendowment all round' ${ }^{192}$

Such a proposition had caused Lord Rendel to state: 'how rudely Lord Stanley shakes the policy which I took part in initiating and which you so firmly hold'. Rendel felt able to admit that he had 'first essayed to place Welsh Disestablishment upon strictly National grounds and in exclusively National charge', he did so because the Liberation Society had been 'too Anglican in its objective' and had 'scarcely been fair' to the situation in Wales. ${ }^{193}$ Understandably, at a juncture where Welsh disestablishment was imminent, he was askance at Lord Stanley’s belief that the Welsh should subordinate their aspirations and 'cast in their lot with English Liberationism'. In his letter of 12 October 1905, Beriah Evans had returned Sir Alfred's copy of Rendel's letter and advised that he had circulated it to '30 leading papers at a cost of several pounds in telegraphing, as owing to the letter being a fortnight old'. ${ }^{194}$ At the close of the letter

\footnotetext{
187 'Welsh Party’s Programme. The Cambrian, 15 September 1905, p.8.

${ }^{188}$ Kenneth O. Morgan, (ed.), Lloyd George Family Letters 1885-1936 (Cardiff: UWP, 1973), p.118, where he is described as 'poor Alfred', in the context of his abilities.

189 'Lord Rendel and Welsh Disestablishment', The Times, 11 October 1905, p.9.

190 GRO/PP/IX.6. Lord Rendel to Alfred Thomas, 27 September 1905.

191 Edward Lyulph Stanley, 4th Baron Sheffield, 4th Baron Stanley of Alderley and 3rd Baron Eddisbury, (18391925).

192 'Liberals at Penrhos’, Carnarvon and Denbigh Herald, 22 September 1905, p.7.

193 GRO/PP/IX.6. Lord Rendel to Alfred Thomas, 27 September 1905.

194 GRO/PP/IV. ii, Beriah Evans to Alfred Thomas, 12 October 1905.
} 
he felt able to confirm that 'public opinion is setting strongly in your direction' and that Sir Alfred could 'make the running', if he so decided. 195

But, in addition to Lloyd George's censure, Sir Alfred Thomas's course of action was to evoke a letter of admonition from an unusual source, being an English prelate. The Bishop of Hereford ${ }^{196}$ wanted to express his regret at Thomas's threat to 'withdraw the support of Welsh support from the Liberal Party unless a Welsh Disestablishment Bill is introduced in the first session in which we have a Liberal Government'. ${ }^{197}$ The Bishop believed that the fact that legislation had been introduced in 1894 should have been sufficient cause to have faith in a new Liberal Government and that the threat might lead to a 'grim piece of irony', where potential Liberal voters were deterred by such talk and the Conservatives would be returned. Although the Bishop stated that he was simply concerned about the 'pressing national need for a strong Liberal Government', he did give his permission for the letter to be shared with Lloyd George and it is a moot point whether the letter had been sent with Lloyd George's foreknowledge and, even, at his suggestion, as another means of applying pressure on Alfred Thomas to desist. Sir Alfred was clearly intent on winning over those who could assist him, and he had sent a copy of his speech of 20 September 1905 to J. A. Spender ${ }^{198}$, the influential editor of the Westminster Gazette. Spender was to respond that although he did: 'not object at all to the most zealous advocacy of Welsh disestablishment', he believed that the position of a new Liberal government would 'rapidly become very difficult', if different groups threatened to withdraw their support unless a: 'certain order is preserved in legislation'. 199

\footnotetext{
195 GRO/PP/IV. ii, Beriah Evans to Alfred Thomas, 12 October 1905.

196 John Percival, (1834-1918), bishop of Hereford from 1895 to 1917. Queen Victoria had objected to his elevation because of his views on disestablishment. The Bishop's efforts in support of Welsh disestablishment were, in 1912, to lead him into conflict with both Liberal Churchmen and Conservative Churchmen. Liberal Churchmen such as the Dean of Lincoln had formed a protest group in March 1912 ('Liberal Churchmen and Disestablishment', The Times, 20 March 1912, p.6) and the Bishop was critical of their protest to the Prime Minister and this evoked critical letters from the Dean of Lincoln, on behalf of Liberal Churchmen, (The Times, 11 April 1912, p.12), and the Bishop of St. Asaph (The Times, 12 April 1912, p.6) who clearly delighted in such a public spat where 'The Bishop of Hereford is angry with his Liberal brethren because they are more Liberal than his is himself'.

${ }^{197}$ GRO/PP/IX.2. Bishop of Hereford to Alfred Thomas, 1 September 1905.

198 John Alfred Spender, (1862-1942), journal editor and writer.

199 GRO/PP/IX: J. A. Spender to Alfred Thomas, 27 September 1905.
} 
The Carnarvon and Denbigh Herald's coverage of the issue would have heartened Sir Alfred and Beriah Evans, with an assertion that every day the Liberals' intended approach to the subject 'becomes more and more urgent'. It reported that Sir Alfred aired his views:

'to a well-known publicist at Llandrindod. They were bold and uncompromising. He said that the Welsh members expected the next Liberal Ministry "to recognise the paramount claims of Wales to special recognition, and particularly to the introduction of a Disestablishment Bill, as a Government measure, in the first session of the new Parliament."' 200

The newspaper added that David Lloyd George opposed Sir Alfred and he had 'strongly (but erroneously) doubted the accuracy of the report', with reference to the fact that although he had 'first leapt into political notoriety by engineering a Disestablishment revolt against the Rosebery Government, he thought that it was "preposterous" to expect the next Liberal Government to proceed, without a minute's delay, with a Disestablishment Bill’.

\section{'Of the nineteen men who constituted the Cabinet, nineteen were in favour of}

\section{Disestablishment'.}

A meeting of the 'Carnarvon Boroughs Liberal Association', on 21 December 1905, was the occasion of Lloyd George’s first speech, in Wales, as a 'Minister of the Crown', having been appointed as President of the Board of Trade. He was to cause his audience to cheer, when he claimed that: 'Of the nineteen men who constituted the Cabinet, nineteen were in favour of Disestablishment'. ${ }^{201}$ The audience's expectations had been high, but the reference to disestablishment, although brief, was notable because: 'When the subject of Disestablishment was mentioned, the audience rose and cheered vociferously, so that for some time the speaker could not continue'. ${ }^{202}$ The Times, more soberly, was to describe Lloyd George's reference to his nineteen colleagues as verbiage, the 'sort of statement which may serve platform purposes and yet mean absolutely nothing, ${ }^{203}$ and it suggested that the Liberal Government would defer any attack on 'Church interests' until after the general election. ${ }^{204}$ The question was what Lloyd

\footnotetext{
200 'Disestablishment Tactics’, Carnarvon and Denbigh Herald, 22 September 1905, p.4.

201 'The Right Honourable D. Lloyd-George. Great Reception at Carnarvon', Carnarvon and Denbigh Herald, 22 December 1905, p.8.

202 'The Policy of the Liberal Party. Great Speeches by the Prime Minister and Mr. Lloyd-George'. The Weekly News, 29 December 1905, p.8.

203 'Wales in 1905', The Times, 1 January 1906, p.14.

204 Ibid.
} 
George would say at the National Convention, 'representing all the Progressive forces in Wales', which was held on 2 January 1906, at Caernarvon, with over a thousand delegates. It was noteworthy that, after a resolution congratulating the Liberals on the 'downfall' of the Conservative government, and of course particular mention of Lloyd George's entry into the Cabinet, the second resolution emphasized the 'Welsh demand for Disestablishment as an essential part of the legislative programme early in the new Parliament'. This clear manifestation of expectations required Lloyd George, when he addressed the Convention, to adopt a delicate strategy which would commit to as little as possible and to lessen expectations, when he commenced with a warning that: 'the battle was already half-won, but many a battle after being half-won had been turned into disastrous defeat by carelessness in its later stages'. ${ }^{205}$ In order to maintain the possibility of plausible deniability at some future event, he advised the delegates that he spoke as a Welshman, 'which he was first, last and all the time', and not a member of the Cabinet. He went on to expound what he believed was a changing situation within the Established Church where, he claimed, there was evidence of less of the ferocity which characterized the Bishop of St. Asaph’s approach. Such a comment might have reflected his friendship with the Bishop, as chapter four will demonstrate that the Bishop was unremitting in his fanaticism.

On the basis that Lloyd George understood the real difficulty of achieving disestablishment, he was cynically manipulating his audiences. His reminder that disestablishment had been a key part of the Liberal programme since 1888, together with Sir Henry Campbell-Bannerman’s 206 assurance that it remained there, would have struck many as cold comfort, even with the excitement and goodwill associated with a new Liberal government. Lloyd George suggested that disestablishment would be addressed in the coming parliament, but the timing and opportunity must be decided by the Liberal leaders, in the context of the minatory influence of the House of Lords, 'an irresponsible Chamber, never elected by the people' but which was prepared to thwart the will of the people.

The Liberal Party was returned to power, in January 1906, with a 'sensational' majority, to quote the biographer of Randall Davidson, the Archbishop of Canterbury, and, in addition, the largest

\footnotetext{
205 'Welsh Liberal Convention. Formulation of the Party Demands', Weekly Mail, 6 January 1906, p.7.

${ }^{206}$ Sir Henry Campbell-Bannerman, (1836-1908), served as Prime Minister from 1905 to 1908.
} 
number of Nonconformist Members of Parliament 'since the time of Oliver Cromwell'. ${ }^{207}$ A 'souvenir' of the election, which included biographical details of the newly elected Welsh members of parliament, anticipated great things: “"Gallant Little Wales” has led the van. For the first time in its history it has returned a full phalanx of progressives, - not a single Conservative having been returned for the Principality'. ${ }^{208}$ At the first sessional meeting of the Welsh Liberal Parliamentary party held, at the House of Commons, on 16 February 1906, the government's equivocal attitude towards disestablishment was apparent. At the well-attended meeting, members jostled for precedence in respect of proposed bills that session, with measures such as The Mines Eight Hours Bill, proposed by S. T. Evans and seconded by D. A. Thomas, and the Land Bill for Wales, proposed by Ellis Griffiths but, after a prolonged discussion about Welsh disestablishment, nothing substantive could be reported, other than the platitude that would become familiar to disestablishers, that the meeting desired: "to express its gratification at the communication made by the Prime Minister before the general election to the Chairman of the Welsh Parliamentary party that Welsh disestablishment remains an integral part of the legislative programme of the Liberal party'. ${ }^{209}$ Although the previous, unsatisfactory history of the Liberal party and Welsh disestablishment would have been recalled, it did appear to be an extraordinary position, particularly as the 'great Convention in Carnarvon' had only just appeared to offer a measure certainty, where delegates had accepted Sir Alfred Thomas's assurances that he was 'fully satisfied', with the assurances given him in the presence of Lloyd George upon the matter but, it appeared that, in reality, there was nothing more substantive than 'Welsh Disestablishment remains an essential part of the legislative programme of the Liberal party'. It was apparent that Welsh Liberal supporters searched in vain for exact confirmation of what had been pledged by the Prime Minister about disestablishment, but it was also evident that Lloyd George had also proved to be as vague. Many disestablishers would have agreed with the Reverend Griffith Thomas ${ }^{210}$, who, whilst jotting down his brief notes for a lecture to be delivered at Mountain Ash in 1906, included two sentences which merit consideration in relation to his interpretation of the

\footnotetext{
${ }^{207}$ G.K.A. Bell, Bishop of Chichester, Randall Davidson, Archbishop of Canterbury (Oxford, 1935), p.504. Liberals 377, Labour 53, Nationalists 83; total 513. Opposition, Conservatives and Unionists, 157.

208 'General Election 1906, Wales and Monmouthshire', A Souvenir (1906).

209 'Welsh Business in Parliament. Balloting for Bills', The Welsh Coast Pioneer, 16 February 1906, p.7.

${ }^{210}$ The Reverend Griffith Thomas was a former vicar of Llangyfelach-cum-Morriston. He worked for the Church Committee for Church Defence and was Church Defence Lecturer for the dioceses of Llandaff and St. David's from 1903-1912. Griffith Thomas was heavily involved with the disestablishment of the church in Wales and with religious education.
} 
state of disestablishment at that time and to the byzantine nature of Welsh Liberal politics, as demonstrated by the sequence of events in 1906:

'Dis was “at the door" 30 years ago, 20 years ago and 10 years ago and it is there today'. 'There are only two solutions either the door cannot be opened or else they cannot succeed in finding the latch'. ${ }^{211}$

Reverend Thomas, in his role as a nominated Church Defence lecturer, would have intended to confirm that the very passage of time would have lent weight to the spurious nature of the arguments of those who sought disestablishment. The fact the Reverend underlined the word 'cannot', in the second sentence, indicated that he preferred to relay to his audience the rationale that the 'door' to disestablishment would remain permanently sealed, rather than the possibility that those who actively sought disestablishment were still blundering around, but that that it was possible to that they might alight upon the 'latch'. The note was to assist him in his preparations for another of his relentless round of lectures which, as demonstrated by a press report from November 1906, would have usually involved 'preaching to the converted', where the 'Squire of the Parish' took the chair and Reverend Griffith Thomas gave a most eloquent and forcible address, putting up like nine pins the usual objections to the Established Church, and knocking them down with similar ease'. ${ }^{212}$ This would tend to suggest an attempt to instil confidence at a time when, any glance at the newspapers, would confirm that the challenge facing the Anglican Church involved more than a few 'political agitators'. By 1910, the Reverend Thomas had become more fatalistic about the likely outcome of events, when he told a 'large and enthusiastic meeting' in Haverfordwest that: 'if the present Government were returned with a large or working majority it would enable them to get rid of the House of Lords, and Disestablishment was bound to come sooner or later'. ${ }^{213}$

It was apparent that, as a new year dawned, one in which a Liberal government was returned with its biggest majority, that many Welsh Liberal supporters were uneasy about political prospects, at a time when they should have viewed those goals with confidence. There was a growing suspicion that Lloyd George would not be as sedulous in pursuing disestablishment, in

\footnotetext{
${ }^{211}$ Richard Burton Archives, Swansea University, GB217 LAC/108/4: notes for proposed address at Mountain Ash on the Indebtedness of the Nation to the Church by the Revd. Griffith Thomas, 3 January 1906, p.3.

212 'Camrose', The Pembrokeshire Herald and General Advertiser, 30 November 1906, p.3.

213 'Denounced by the Rev. Griffith Thomas', The Pembroke County Guardian and Cardigan Reporter, 7 January 1910, p.3.
} 
the future, as it was assumed that he had been in the past, when an interesting proposition was made: 'Wanted: Another Lloyd George'. ${ }^{214}$ Although there was little doubt that the following praise was genuine, it was evident that exasperation underwrote the paean: 'The one she has got has done so much for her that she wants more of it. Wales is far from being either indifferent to or unappreciative of what the member for the Carnarvon Boroughs has done for her and it is really a compliment to the skill and courage he has shown in the past that she should now be inclined to look about for another like him’.

214 'Wanted: Another Lloyd George’, Carnarvon and Denbigh Herald, 12 January 1906, p.8. 


\section{Chapter two: 'Welsh disestablishment has gone into the background'.}

In October 1906, a prescient prediction of what was about to occur was provided to its readers, when The Weekly News interpreted a speech by the Bishop of St. Asaph as the opening gambit in a 'war to the knife', describing the 'trenchant speech' as 'cutting and stinging':

'It enables us to realise, almost for the first time, the bitterness, of the controversy into which Wales, is about to be plunged. The third and greatest struggle for Welsh Disestablishment is about to begin. It is going to be a battle royal, and we see from his latest speech that the Bishop of St. Asaph is to be the commander-in-chief of the Church forces. ${ }^{1}$

The newspaper did acknowledge that it was: 'curious to find ourselves employing metaphors derived from the world of warfare' in referring to the subject, although there was no doubt that the Bishop Edwards would have been delighted that his leadership, strategy and tactics, as the 'commander-in-chief', were recognized and it would be abundantly clear that the Bishop, as ever, was intent on unconditional victory. An example of the animus generated by the apparent re-emergence of support for Welsh disestablishment, in 1906, is evident from the reportage in a Pembroke newspaper, albeit one which was Conservative leaning and a strong supporter of the Church. It included mockery: 'For two years they have been put off with promises that a Disestablishment and Disendowment Bill would be introduced by-and-by.... The feelings of Welsh Dissenters are deeply lacerated by this inconsiderate trifling with their dearest hopes'.

This was combined with a crude interpretation of the reasons for disestablishment, albeit reasons that were likely to cause Church supporters to take note: 'For them the Parliament 1906 was elected for one purpose only - to destroy the Church as the National representative of religion in this Realm, and to plunge predaceous and desecrating hands into her treasury to steal the funds accumulated through the ages of time by the generosity of pious founders'. ${ }^{2}$ This was followed by an editorial note, which exhibited another example of 'Project Fear' and equated Nonconformity with extremely diabolical and unsavoury beliefs, when it stated that:

‘"Divide and Devour" has been quaintly described by an old world authority as "the Devil's watchword." Disestablish and Disendowment is the euphonious and modern interpretation our Non-conformist and Secular friends in unholy alliance have adopted as

\footnotetext{
1 'War to the knife', The Weekly News and Visitors' Chronicle: 9 October 1906, p.7.

2 ‘Against the Church', The Pembrokeshire Herald and General Advertiser, 4 October 1907, p.2.
} 
their battle cry. We do not suggest that the phrase in the mouths of those who seek to demolish and destroy the National Church is of Satanic origin'. ${ }^{3}$

The Bishop of St. David's had, after the 1906 General Election, advised fellow clergymen of his fears about impending Welsh Disestablishment, but had taken comfort from the constitutional position, when he wrote, on 25 January 1906, that; 'Welsh Disestablishment is likely to be on next year but I think we will beat it off by the help of the Lords'. ${ }^{4}$

Ellis J. Griffith was reported as, perhaps, identifying 'the one weak spot in the declarations on the great question of Disestablishment', in that he understood Lloyd George's claim that the choice of time and opportunity for introducing disestablishment must be largely left to the discretion of the Liberal Cabinet, which was indisputable, but he was adamant that, when it proceeded, it should do so with a reasonable prospect of success. Ellis Jones Griffith was conscious that the question of disestablishment must be 'put plainly before the electorates at the forthcoming General Election as an essential part of the Government's legislative programme’; if not, then it would meet defeat in the Lords, and 'the Liberal leaders ought most decidedly to deprive them of any legitimate or constitutional reason for doing so'. ${ }^{5}$ In fact Ellis Jones Griffith had made his position abundantly clear the previous December, when he was reported as saying that:

'The question of the hour as far as Wales is concerned is the position of Disestablishment. It might have been anticipated that as Irish Home Rule had receded from its foremost place Welsh Disestablishment would now become the first plank in the Liberal platform, but as one reads the speeches of the Liberal leaders their omission or any reference to this question is ominous of an intention to place it at the back rather than in the front of the legislative proposals to be laid before the next Parliament' ${ }^{6}$

\section{A Royal Commission.}

Ellis Griffith’s mordant appraisal appeared to be justified when it became known the Liberal government would establish a Royal Commission, rather than present a Disestablishment Bill.

\footnotetext{
3 Ibid.

${ }^{4}$ Eluned E. Owen, The Later Life of Bishop Owen (Llandyssul: Gomerian Press, 1961), p.80.

5 'The Carnarvon Convention', Carnarvon and Denbigh Herald, 5 January 1906, p.4.

6 'Disestablishment. Wales and the Liberal Leaders', The Chester Courant and Advertiser for North Wales, 13 December 1905, p.7.
} 
In announcing that Royal Assent had been 'accorded to the Commission which is to prepare the way for that measure of Disestablishment and Disendowment’, Nonconformist Wales had claimed 'for a full half century and more, with one insistent voice', the Carnarvon and Denbigh Herald described the terms of reference as 'short and explicit':

'to enquire into the origin, nature, amount, application of the temporalities, endowments, and other properties of the Church of England in Wales and Monmouthshire; and into the provision made, and the work done, by the Churches of all denominations for the spiritual welfare of the people, and the extent to which the people avail themselves of such provision and to report thereon'.?

The genesis of the Royal Commission was confusing, as indeed were the reasons for its creation, although the evidence would suggest that it was never more than a delaying tactic. However, from a reply to a Parliamentary question, it would have been possible to draw the conclusion that it formed part of a considered and targeted approach by government. D. A. Thomas, one of the two members of Parliament for Merthyr Tydfil, was, however, aware of its dubious background and questionable basis and he asked the Prime Minister why the Royal Commission was deemed necessary now:

'I beg to ask the Prime Minister whether any State inquiry by commission or otherwise was made into the condition and temporalities of the Established Church in Wales, or into the position of the free churches, prior to the introduction of the Welsh Disestablishment Bills of 1894 and 1895'. ${ }^{8}$

To counter this implied criticism about the creation of the Royal Commission, and to formulate a constructive rationale, the Prime Minister countered with the suggestion that earlier, abortive attempts at disestablishment, in 1894 and 1895, had been, in part, due to a dearth of contemporaneous statistics and, as reported in The Weekly Mail, the Prime Minister had considered that:

'The omission was, in his opinion, a very unfortunate one, as, in the absence of official information, the Government of the day was exposed to a good deal of embarrassment in the preparation and conduct of the measure. As he had more than once intimated, the Government hoped to legislate on this subject, and they were anxious to obtain a report from the Commission at an early date, as it would be of material assistance'. ${ }^{9}$

\footnotetext{
7 'Welsh Church Commission. Special Announcement', Carnarvon and Denbigh Herald, 22 June 1906, p.2.

${ }^{8}$ HC Deb., 11 July 1906 vol. 160, cc 895-6.

9 'Welsh Disestablishment. Government waiting for Report of the Commission', The Weekly Mail, 14 July 1906 , p.7.
} 
This implausible explanation was in contrast with David Lloyd George's later comment that, in relation to disestablishment: 'The real issue has been obscured by a cloud of irrelevant and inaccurate statistics, beaten up by one or two imaginative ecclesiastics' ${ }^{10}$ The Royal Commission came into existence, almost by sleight of hand and, eventually, was to become an orphan with nobody readily taking responsibility for its inception. Lloyd George had first raised the possibility of a Royal Commission with the Archbishop of Canterbury and Bishop Edwards when he met them in the Robing Room at the House of Lords, on 22 February $1906 .{ }^{11}$ Although Lloyd George confirmed that he had discussed the proposal with the Prime Minister, who had approved of the proposition, it was apparent who had instigated the matter. If it had become public knowledge that the proposal of a Royal Commission related to Lloyd George's conversation with the Bishop Edwards about the possibility of introducing 'a very mild and kindly Welsh Disestablishment Bill', if the Church would 'modify its opposition', then it is almost certain that Lloyd George's Welsh political support and admiration would have been seriously undermined, just as he had entered the Cabinet and his talents were being recognised more widely. ${ }^{12}$ The confidentiality surrounding the question of the Welsh Church Commission must have placed Randall Davidson, the Archbishop of Canterbury, in a difficult position and it might explain why, at the meeting of the Church Committee for Church Defence and Church Instruction, on 22 June 1906, it was reported, with some implied criticism, that the Archbishop 'said nothing about the terms of reference, nor even the personnel, of the Welsh Church Commission'. ${ }^{13}$ But the position became awkward when the report went on to surmise that 'it is evident that he realizes the hostility to the Established Church which is involved in the appointment of such a Commission at all', when in fact he knew that the Commission's progenitor envisaged that it would assist in the delivery of that that 'very mild and kindly' bill.

Bishop John Owen's daughter provided a slightly different emphasis to the Commission's formation, with pressure from D. A. Thomas M.P. being the catalyst. Thomas was of the opinion that 'the sooner a Disestablishment Bill was brought, the better' and that if it was presented during the first session, then the House of Lords 'would have too much regard for its own safety

\footnotetext{
${ }^{10}$ P. W. Wilson, Welsh Disestablishment (London, 1912), p.vii.

${ }^{11}$ Bell, Randall Davidson, Archbishop of Canterbury, vol.1, p.505.

12 Ibid., pp.504-505.

13 'The shadow of a danger which was vaguely felt', The Times, 23 June 1906, p.13.
} 
to throw it out' ${ }^{14}$ According to this version, the Cabinet met on 23 March 1906 and the proposal to form the Commission was raised at that meeting, as part of the response to the pressure from D. A. Thomas. In his reminiscences, published in 1927, the Archbishop of Wales, presumably because he still wanted to avoid any suggestion of collusion, simply stated that: 'The Prime Minister, in June 1906, appointed a Royal Commission', without any reference to the discussions with the Archbishop or David Lloyd George, which was contrary to his usual habit of describing his influence and familiarity with Establishment figures. ${ }^{15}$ Eluned Owen posits the question about whether her father was approached about this matter, stressing that her father was 'deeply distrustful of Mr. Lloyd George’s actions and quite obviously he was a little anxious about the influence he might have on Bishop Edwards', but she states that there was nothing in his papers to suggest that he was consulted. ${ }^{16}$ This is surprising in the context of the importance of such discussions, although Bishop Edwards might have deliberately excluded his fellow Prelate due to his aversion to Lloyd George.

Whereas the Bishop of St. Asaph was careful not to personally be supportive of the creation of the Royal Commission, the Bishop of St. David's viewed it as a potential threat, due to its association with David Lloyd George: 'This Commission has worried me beyond words, for we deal with a most tricky person in Lloyd George and he really controls the majority on the Commission and so we cannot be too wary.....It is impossible to exaggerate the wiliness and the deadly enmity to the Church of our unscrupulous opponent'. ${ }^{17}$ Bishop Owen's was exercised by his egregious opinion of David Lloyd George and it clearly troubled his episcopal conscience:

'My temptation is unalterable disdain of George, and all his words and deeds. He is a very little man, in my opinion, with all his cleverness and audacity, very little in the heart and soul of him, but I must try to fight against this strong temptation to contempt' ${ }^{18}$

It would not be until March 1915 that Owen was to revise his opinion of Lloyd George when, as will be seen in the next chapter, he advised Lord Hugh Cecil that he 'had heard that the War had changed him a good deal for the better', although he caveated his observation with a conclusion

\footnotetext{
${ }^{14}$ Owen, The Later Life of Bishop Owen, p.81.

15 The Archbishop of Wales, Memories, p.222.

${ }^{16}$ Owen, The Later Life of Bishop Owen. A Son of Wales, pp.132-133.

${ }^{17}$ Ibid., p. 89.

${ }^{18}$ Owen, The Later Life of Bishop Owen. A Son of Wales, p.68.
} 
that he would not trust him, when the War ended, to put 'justice to the Church above party interests'. 19

The government's confusion about the role of the Royal Commission and its relationship with the introduction of legislation was made apparent in an exchange between D.A. Thomas and the Prime Minister, in the House of Commons, in which Mr. Thomas could not resist the opportunity to cause David Lloyd George, President of the Board of Trade, some embarrassment. Relations between D.A. Thomas and Lloyd George, who had been allies in the 'Welsh Revolt' of 1894, had become bitter because of Thomas's role in the break-up of Cymru Fydd in 1896 and he was to ask the Prime Minister:

'whether the promise that the Government would introduce a measure to emancipate the Church in Wales from State control in the course of the third session of this Parliament was conditional on the report of the Royal Commission being received in time, and, if so, could he represent to the Chairman of the Commission the desirability of issuing the report before the close of next year'. ${ }^{20}$

\section{'It should be leisurely, not dilatory'.}

Confirmation of how Lloyd George viewed the Royal Commission, and its intended purpose to delay the consideration of Welsh disestablishment, is provided by a short, undated, pencilwritten note, under the coat of arms of the First Lord of the Treasury, in Lloyd George's handwriting and signed with the letter ' $\mathrm{L}$ ', which stated that:

'I told him there was no hurry, he seemed to think that it would last only 3 or 4 months. I said that we were quite content it should be leisurely, not dilatory and might well last two years.' 21

There is no indication of the identity of the person whom Lloyd George described, and the only associated note is a handwritten note in pencil note undated, with 'Names of Commissioners. Welsh Disestablishment' written on one side and, on the reverse, a list of scribbled names of candidates to serve on the Commission. Lloyd George has added a note to the effect that: 'Seems

\footnotetext{
${ }^{19}$ Owen to Cecil, 22 March 1915, N.L.W. Bishop John Owen papers, 10/4.

20 'Welsh Disestablishment', Weekly Mail, 28 July 1906, p. 3.

${ }^{21}$ Parliamentary Archives, B/1/10/2.
} 
very good, both Cawdor ${ }^{22}$ and Lyddelton ${ }^{23}$ are good'. It was notable for the fact that neither agreed to participate, although their identities had become known, when it was reported that:

'Several eminent men were approached with a view to their serving on the Commission but declined. They are stated to have included Earl Cawdor, Mr. Alfred Lvttelton and Mr. Cripps, K.C. ${ }^{24}$

The Weekly Mail had reported that there had been some difficulty in forming the Commission, and that 'several eminent men whose services would have been of great value have declined, for various reasons, ${ }^{25}$, although C. A. Cripps ${ }^{26}$ had been explicit about his reasons, saying that when politicians wanted ‘to shelve a difficult question a Royal Commission was often appointed' and 'he looked upon it as a Commission constituted on political lines for political purposes'. ${ }^{27}$

Lord Hugh Cecil, Reverend A. G. Fairbairn, principal of Mansfield College, Oxford and Professor Henry Jones, Professor of Moral Philosophy, Glasgow University would be added to the list of names on Lloyd George's penciled note, which included Lord Justice Vaughan Williams, as Chairman, Sir John Williams, S. T. Evans, K.C., M.P., Frank Edwards, M.P., The Venerable Archdeacon Owen Evans and J. E. Greaves (Lord-Lieutenant of Carnarvonshire). ${ }^{28}$ The Times, when it reported upon the death of Sir Roland Vaughan Williams, was obliged to admit he was: 'a somewhat autocratic and irritable chairman, and some degree of friction arose between the several Commissioners'. ${ }^{29}$ The newspaper reported that: ‘As an Appeal Judge he was somewhat trying both to his colleagues and the Bar. Restless in his seat and displaying an

\footnotetext{
${ }^{22}$ Frederick Archibald Vaughan Campbell, 3rd Earl Cawdor, (1847-1911), styled Viscount Emlyn from 1860 to 1898, was a Conservative politician. He sat in parliament as Conservative MP for Carmarthenshire from 1874 to 1885. In parliament he was active on Welsh topics, most notably as a member of the Aberdare committee (188081), set up by Gladstone to examine the state of intermediate and higher education in Wales. He served briefly as First Lord of the Admiralty between March and December 1905. Despite not serving on the Commission, Cawdor was evidently interested in progress, as he was to seek confirmation from the Lord Chancellor that the chairman, Lord Justice Vaughan Williams, would be 'able shortly to resume his place', as his duties on the Court of Appeal had drawn him away: 'The Welsh Church Commission', HL Deb 25 June 1907 vol. 176 cc.1015-6.

${ }^{23}$ Alfred Lyttelton, (1857-1913). He was Liberal Unionist MP for Warwick and Leamington from 1895 to 1906.

24 'Welsh Church Commission. Forecast of its Probable Composition. Vain overtures to Earl Cawdor ', The Cambrian, 1 June 1906, p.7.

25 'The Welsh Royal Commission', Weekly Mail, 2 June 1906, p.3.

${ }^{26}$ Charles Alfred Cripps, 1st Baron Parmoor, (1852-1941), crossed the floor from the Conservative to the Labour Party and was a strong supporter of the League of Nations and of Church of England causes. He lost his Stretford seat in 1906.

27 'Refused to serve' Mr C. A. Cripps K.C. and the Welsh Commission', South Wales Daily News, 17 October 1907, p.7.

28 'Welsh Church Commission', The North Wales Express, 29 June 1906, p.5.

29 'Death of Sir R. Vaughan Williams. A Distinguished Judge', The Times, 11 December 1916, p.11.
} 
unusual amount of facial expression' ${ }^{30}$ In the context of his tenure as Commission chairman it is difficult to appreciate that some suggested that he would be 'partisan' and unacceptable to the 'Church party', as it was suggested that the Judge had expressed views in favour of Welsh disestablishment. ${ }^{31}$

An early indication of how the Commission conducted itself was given by one of the esteemed original members, who rapidly came to appreciate what it involved. Although Sir Henry Jones ${ }^{32}$ was reported as beginning his work, as a member of the Commission, with 'zeal and interest', he concluded that it was an 'unprofitable undertaking' and, 'after a sharp difference of opinion with the Chairman of the Commission, he resigned his membership’. His experience clearly left him despondent and he was quoted as concluding that: 'I learned then for the first time how much illfeeling religious men can entertain towards one another. Such an atmosphere of distrust, suspicion and pious malice I never breathed before or since'. ${ }^{33}$ What became apparent was that the workings of the Commission were to be subject to close scrutiny, with 'leaks' about proceedings becoming a constant feature and the influential editor of the Western Mail, William Davies $^{34}$, made his newspaper's position quite apparent, when he complained to Bishop Owen that he: 'felt that the "Mail" has not been receiving from its friends on the Commission anything like the help accorded to the SWD News (South Wales Daily News) by the Radical members'. ${ }^{35}$ Bishop Owen was in regular contact with those on the Commission who opposed disestablishment, including Owen Evans ${ }^{36}$ and Hugh Cecil ${ }^{37}$, about the minutiae of its

\footnotetext{
30 Ibid.

31 'Welsh Church Inquiry. Will Judge Vaughan Williams be a Partisan? The Cambrian, 4 May 1906, p.2.

32 Sir Henry Jones, (30 November 1852 - 4 February 1922) was a Welsh philosopher and academic. He was instrumental in the passing of the Intermediate Education Act of 1889, and worked for the establishment of the University of Wales and the introduction of a penny rate for education. He held the chair of moral philosophy, at Glasgow University, from 1894 to his death. He was knighted in 1912 and appointed a Companion of Honour in 1922, shortly before his death.

${ }^{33}$ H.J.W. Hetherington, The Life and Letters of Sir Henry Jones (London, 1924), p.94-95.

${ }^{34}$ William Davies, (1863-1935), journalist and editor. He was appointed acting editor of the Western Mail in 1894 and was given sole control of all its publications in 1901: 'Death of Sir William Davies', The Times, 18 March 1935 , p.14.

${ }^{35}$ William Davies to John Owen, 3 March 1907, N.L.W., Bishop John Owen papers, 4/7.

36 'Very private letter' from Owen Evans to Owen, 28 February 1907, N.L.W. Bishop John Owen papers:

'When we met this afternoon Prof Jones brought forward his proposal that he should ask permission to resign because the Chairman's interpretation of the terms of reference was too narrow as to 1 . Work done 2. Spiritual and 3. His claim to the exclusive right to decide the T(erms) of R(erence)'.

${ }^{37}$ Hugh Cecil to Owen, 13 Dec 1906: 'I certainly shall not take part with Prof Henry Jones or indeed in any action that could possibly lead to the resignation ....'I should be glad however to make the business of the Commission be a little better conducted than it is at present'.
} 
deliberations. It was also apparent, from a response he received from the Commission's chairman, that he sought to influence the content of the Church's evidence, when Vaughan Williams responded that he wanted documents relating to 'the ordinary course of church work rather than the evidence of documents prepared and coming into existence for the purpose of being laid before the Commission'. ${ }^{38}$ Owen was also in regular correspondence with the Archbishop of Canterbury ${ }^{39}$, to whom he also sent copies of the returns submitted to the Commission. ${ }^{40}$ In return, the Archbishop advised the Bishop about the manoeuvrings which attempted to resolve the differences between some commissioners and the chairman, even when it appeared to be a breach of confidence. ${ }^{41}$ The extent of Bishop Owen's influence, in terms of the Church's strategy was exemplified in his exchange with Lord Cecil about measures that could be considered in order to modify the chairman's 'modus vivendi' ${ }^{42}$

On 11 April 1907, the Evening Express reported that: 'A crisis has been reached in the proceedings of the Royal Commission’, with the resignation of the three Nonconformist members, Dr. Fairbairn, Professor Henry Jones, and Mr. S. T. Evans, but noted that it was 'not altogether a surprise. For some time, there have been differences as to the interpretation of the terms of reference'. ${ }^{43}$ In particular it was felt that the Chairman's narrow interpretation of the terms of reference served to exclude evidence which the Nonconformist members had considered vital.

\footnotetext{
${ }^{38}$ Vaughan Williams to Owen, 28 November 1907, N.L.W., Bishop John Owen papers, 7/2.

${ }^{39}$ Archbishop of Canterbury to Owen, 20 February 1907, N.L.W., Bishop John Owen papers, 4/7: 'I am certain that the wise course for the Church to follow is to keep quiet, to furnish well-authenticated evidence, and to abstain entirely from unnecessary intervention in the dispute between the Chairman and he anti-Church members of the Commission. I always believed that such a Commission if wisely conducted would do us nothing but good'.

${ }^{40}$ Archbishop of Canterbury to Owen, 11 February 1907: The Archbishop was grateful for copies of the Church's 'wonderful Statistical Returns', but they caused the Archbishop to comment that 'the sumptuousness of its "get-up" is solemnising: I wonder at whose cost?'.

${ }^{41}$ Archbishop to Owen, 2 March 1907: 'Lord Chancellor told me privately last night that he is going to see the Commissioners and their Chairman next week to aim for a modus vivendi'.

${ }^{42}$ Cecil to Owen, 18 February 1907: 'not wise to make a public protest might annoy the Chairman but 'no harm' in you or AGE (Bishop Edwards) writing to him 'privately'.

43 'The Welsh Commission. Three Members Resign', Evening Express, 11 April 1907, p.3.
} 


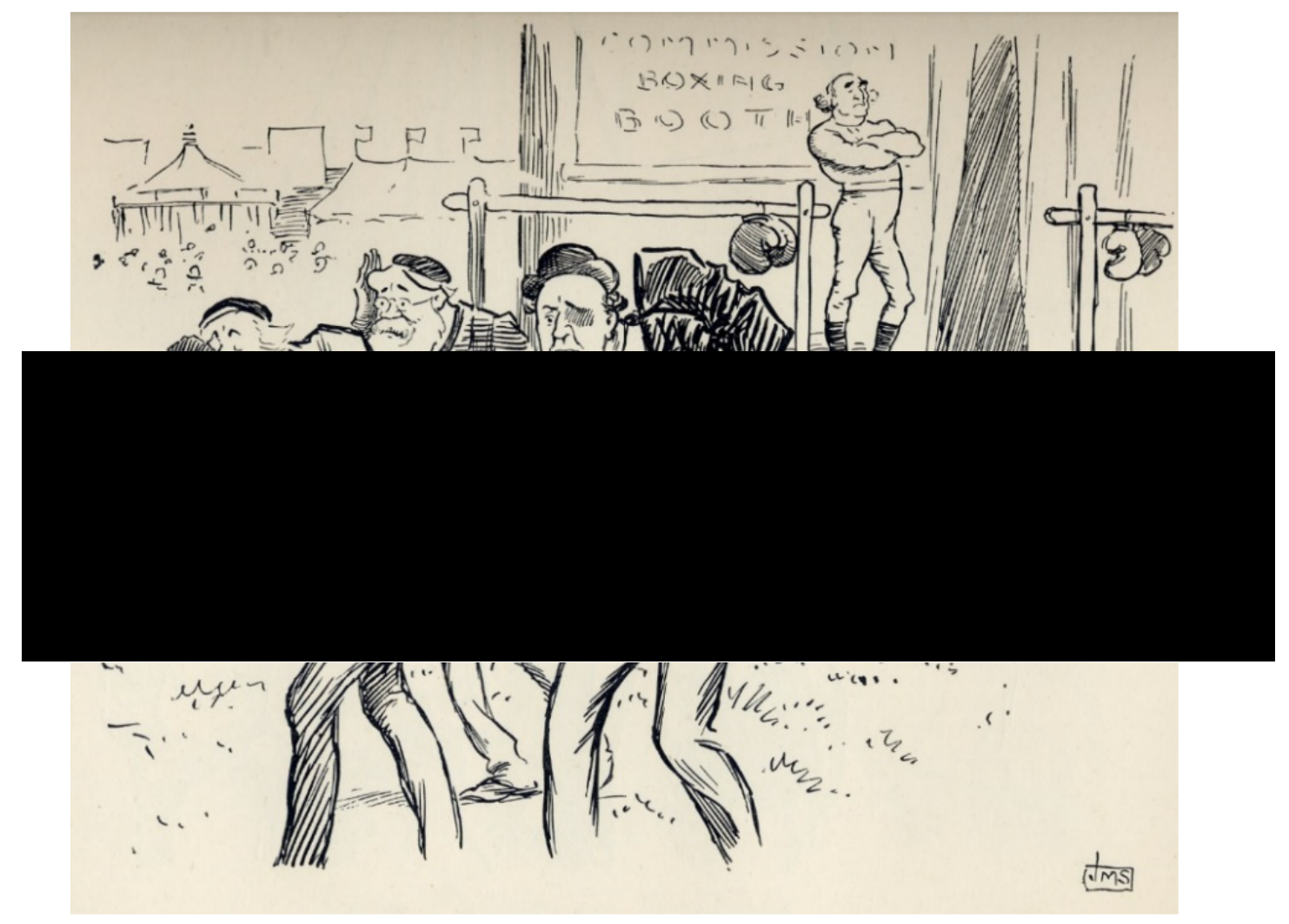

'Retiring from the Contest', Western Mail, 15 April 1907.

Samuel T. Evans MP on the right, Professor Henry Jones on the left, and Principal Andrew Fairbairn in the centre.

In this cartoon, Staniforth depicted the resignations of Sir Henry, Samuel T. Evans ${ }^{44}$, member of Parliament for Mid-Glamorgan, and Principal Andrew Fairbairn ${ }^{45}$, as they stagger bent, battered and bruised from a boxing booth ${ }^{46}$, with the Chairman of the Welsh Church Commission, Lord Justice Vaughan Williams ${ }^{47}$, left standing, undefeated and arms akimbo, at the entrance. After expounding upon the background of the three men who had resigned, P. W. Wilson emphasized

\footnotetext{
${ }^{44}$ Sir Samuel Thomas Evans, (1859-1918), politician and judge. Elected as M.P. for Mid-Glamorgan in 1890, which he then represented until 1910. According to the Dictionary of Welsh Biography he took silk in 1901, being the last Q.C. created by Queen Victoria.

${ }^{45}$ Andrew Martin Fairbairn, (1838-1912), was a Scottish theological scholar. He was Principal of Mansfield College, Oxford, from 1886 to 1909.

${ }^{46}$ Below the cartoon is a caption which shows 'Sam' (Samuel T. Evans) stating: 'Blow me tight! If I'd a-knowed he were such a sticker an' so clever with his fives, I'd a-seen him in Jericho afore I'd a-took him on!'

${ }^{47}$ Sir Roland Lomax Bowdler Vaughan Williams, (1838-1916), judge in the Queen’s Bench and the Court of Appeal. According to his entry in the ODNB, 'he handled the commission effectively and with a complete freedom from political bias' and then, strangely, 'the quick solution of the difficulties attending Welsh disestablishment and disendowment were largely attributed to him'. This is in contrast with the fact that there was continual strife during the Commission and that three of the commissioners, in their published memoranda, complained of his conduct.
} 
that: 'It was men of this scholarly and judicial type who found it impossible to sit at the table of the Commission owing to the manner in which the Welsh evidence was received' ${ }^{48}$ Staniforth went on to draw, with equal delight, a cartoon which suggested that the three replacement appointees to the Commission had been selected for their 'tractable natures'. The names of Sir David Brynmor Jones, K.C., M.P. ${ }^{49}$, Reverend J. Morgan Gibbon ${ }^{50}$ and John Herbert Davies ${ }^{51}$, registrar of the University College, Aberystwyth, had been submitted to the King for approval as members of the Commission. ${ }^{52}$

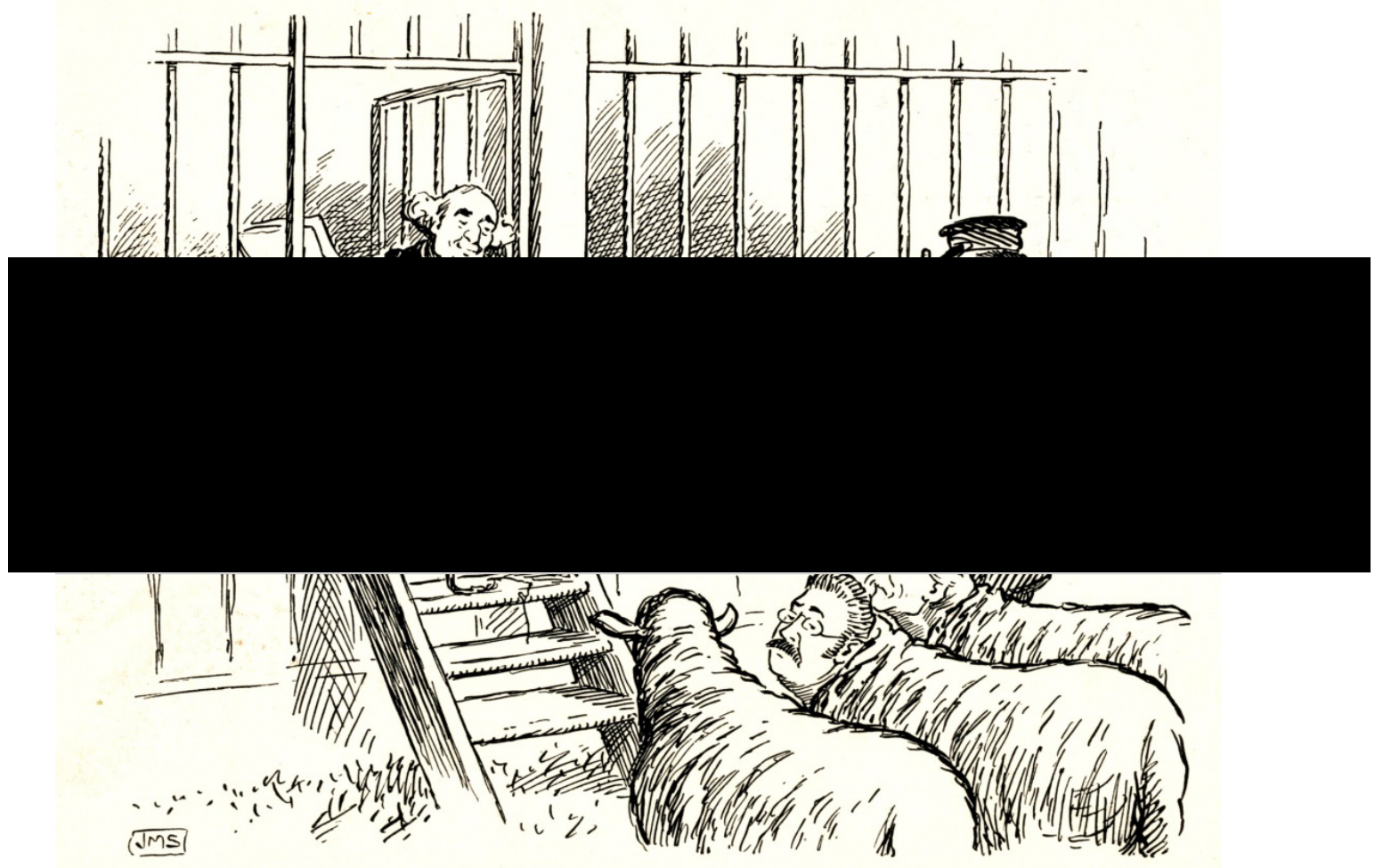

'Not Quite so Savage’, Western Mail, 26 April 1907: 'If you please, sir, I’ve brought substitutes to take the place of the lions just gone'.

\footnotetext{
${ }^{48}$ Wilson, Welsh Disestablishment, p.17.

49 'Sir David Brynmor-Jones, (1852-1921), lawyer and historian. Member of Parliament for Stroud and, in 1895, for Swansea District; resigning the seat in 1914, when he was appointed a Master in Lunacy. According to The Cambrian: 'He has, been closely associated with Welsh higher education, and is generally credited with having been largely responsible for the charter of the Welsh University, and those of the Welsh Museum and Library. He is a very able and accomplished man, a Liberal in politics and a Disestablisher. He is said to be a Churchman of broad views. His knowledge of the inner life of Wales and of Welsh movements must be limited. Some time ago he was knighted in recognition of his services to the cause of Welsh education'.

${ }^{50}$ James Morgan Gibbon, (1855-1932), Independent minister. Despite the assumption that he would be 'tractable', he refused to sign the Commission's report and he published a book, Weighed in the Balance: The Case for Welsh Disestablishment, with a foreword by Lloyd George, in 1910, to describe his standpoint.

${ }^{51}$ According to The Cambrian, Mr. Davies was 'a staunch Nonconformist, but of moderate views both in religion and politics. His views on Disestablishment are not exactly known'.

52 'The Welsh Commission. Three new members', The Cambrian, 26 April 1907, p.5.
} 


\section{'A Renewed attack on the position and endowments of the Church'.}

An indication that the Church defenders and their supporters were again to buckle on their armour was provided by J. M. Staniforth, who had previously had little cause to include disestablishment as the subject-matter of his cartoons. However, a cartoon, which appeared in the Western Mail on 6 July 1906, entitled 'Something Else to do', illustrated a point which would have been difficult to counter, that those Welsh Liberal politicians who were impatient with the government concerning disestablishment, could be distracted by being given 'something else to do’. Staniforth was thus able to suggest that the Welsh politicians were hypocritical, thereby demoralising disestablishers who would have only too aware of the Western Mail's political bias, but who would also have appreciated that Staniforth's comment was valid and that it might provide a further reason why disestablishment was delayed, or at least be attributed with a lesser Priority.

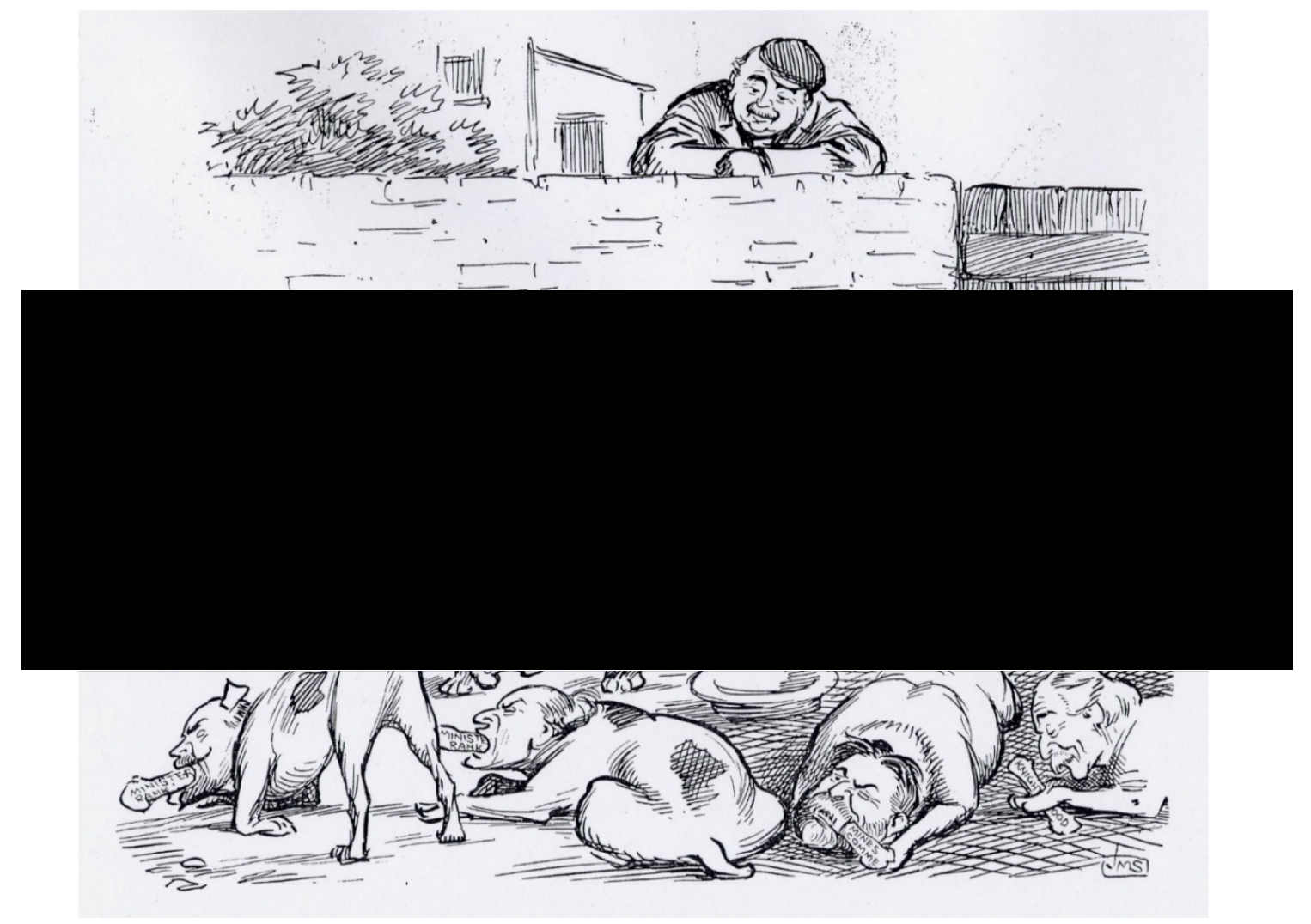

‘Something Else to do’: Western Mail, 6 July 1906.

'Sir Henry: Welsh fighting brigade, eh! I've soon found a way to take the fight out of 'em', thereby belittling their proud reputation as fearless battlers. ${ }^{53}$

\footnotetext{
${ }^{53}$ Ten days after the 'Something else to do' cartoon, on 16 July 1906, Staniforth clearly speculated that it was opportune to give prominence to what he portrayed as Lloyd George's 'waning influence' in the 'councils of South Wales Radicalism', with a cartoon entitled 'Waning Power', with Lloyd George portrayed as a 'mesmerist' on stage,
} 
The cartoon pictured a relaxed looking Sir Henry Campbell-Bannerman, the Liberal Prime Minister, leaning contently on a stone wall, as he observes the pack of dogs, each intent on chewing a bone etched with the 'official favour' which had come their way, with his Cabinet bone firmly clamed in the jaws of David Lloyd George. This theme, of Welsh Liberal politicians who appeared eager to benefit from the 'establishment', whilst ostensibly favouring disestablishment of the Welsh Anglican Church, permitted anti-disestablishers to compare their personal material attainments with the parochial activities of Anglican clergy:

'There is a growing feeling, too, in Wales that the ministers of the Church are doing more good in their generation for the poor in Wales than the handful of loud-mouther politicians whose advocacy of Disestablishment in the past has always been associated with the attainment of knighthoods, baronetcies, recorderships, county-court judgeships, and the like'. ${ }^{54}$

\section{Reaction to the Welsh Church Commission.}

It has been suggested that the formation of the Welsh Church Commission was 'indicative of a fundamental change of mood occurring at the time, ${ }^{55}$, which was that disestablishment had become of 'secondary importance at best'. ${ }^{56}$ However, the duplicitous and mendacious manner in which the Liberal government created the body, and the fact that politicians still publicly attributed their support to the subject, would suggest that it resembled political opportunism, rather than a reflection of a carefully considered strategy. One newspaper adopted a strangely uninquisitive stance in how the Commission came about, but accurately predicted the outcome:

'We neither know nor care who is responsible for the formation of a Royal Commission to enquire into the position of the Welsh Church in view of proposals in Parliament for its disestablishment and disendowment. We can easily imagine that both sides were favourable to a Royal Commission, and if Mr. Lloyd George had opposed its appointment he would have been severely censured. We have no doubt that on both sides all sorts of statistics will be given and all sorts of opinions will be expressed which have no bearing whatever on the demand of Wales for disestablishment'. ${ }^{57}$

\footnotetext{
on his tiptoes, frantically attempting to place the figure that Staniforth drew to represent Nonconformity, under the ''fluence'. Unfortunately, the figure is seated, arms akimbo, with a wide awake, grim expression, whilst members of the audience look on in bemusement at Lloyd George's exasperation.

${ }^{54}$ The Hon. W.G.A. Ormsby Gore, Welsh Disestablishment and Disendowment (London, 1912), p.16. Although not directly pertinent, it should be noted that members of Parliament were not to receive remuneration until 1911, when even then their annual salary was set at $£ 400$, equivalent of that of a junior clerk in the civil service.

${ }^{55}$ Morgan, The Span of the Cross, p.31.

${ }^{56}$ Ibid.

57 'The Welsh Church Commission’, The Cambrian News, 16 November 1906, p. 4.
} 
The newspaper then adopted a balanced and moderate standpoint, acknowledging that 'the Church of England fills a considerable and definite place in the religious life of the Principality' and that 'disestablishment will not be a cure for all the religious ills of Wales', but that whatever else it conceded;

'The feeling in Wales is so strong and general in favour of disestablishment that mere argument is entirely out of the question, and no facts or figures could alter the feeling. Why should clergymen of the Church of England have legislative position and power in Parliament that are not possessed by ministers of any other denomination in the United Kingdom? There is no reason, except that the Church of England is the Church of the State and is established by law' and

'The position of the Bishops in the House of Lords is an insult to every other denomination in the land, and the way they use that position is an outrage on that freedom and equality which the people of these nations are said to enjoy under what is supposed to be a system of representative government'.

There is a supreme irony in that one of the most influential pamphlets written, in 1912, in favour of Welsh disestablishment, ${ }^{58}$ should include a preface by the then Chancellor of Exchequer, David Lloyd George, in which he suggested, as mentioned above, that with regard to Welsh disestablishment: 'The real issue has been obscured by a cloud of irrelevant and inaccurate statistics, beaten up by one or two imaginative ecclesiastics'. ${ }^{59}$ The fact that Lloyd George was instrumental in the creation of the 1906 Royal Commission, which ensured that the pool of contested statistics became even greater, did not dissuade him. It was also oddly dissonant that the author of the publication, which Lloyd George described as 'an admirable statement', should appear to be critical of the then government, of which Lloyd George was a leading member, when he wrote that:

'In 1906 Wales and Monmouthshire returned a unanimous representation in favour of Disestablishment and Disendowment. No one can accuse the Government of the day of acting precipitately in the matter. On June $21^{\text {st }}$, 1906, a Royal Commission was appointed, and with that questionable blessing Wales had to rest content until November 1910 - that is, for more than four years' ${ }^{60}$

Mr. Ellis Davies stated that Welsh people had good reason to complain, when six out of the nine members of the Commission were members of the Church of England, whereas the great

\footnotetext{
${ }^{58}$ Wilson, Welsh Disestablishment.

${ }^{59}$ Wilson, Welsh Disestablishment, p. vii.

${ }^{60}$ Wilson, Welsh Disestablishment, p.15.
} 
majority of the people themselves were Nonconformist, but he offered the opinion that 'the objection of the Welsh people was to the appointment of a Commission at all'. ${ }^{61}$ In an attempt to placate simmering dissent, Sir Alfred Thomas, as so often seemed his role, attempted to assuage his colleagues who were 'apprehensive that the Commission was appointed in order to shelve the dis-establishment of the Welsh Church', whereas he did not believe that was the case. Sir Henry Campbell-Bannerman, the prime minister, attempted to further reassure by confirming that it was not an inquiry into the question of disestablishment, as 'that matter we regard as settled as far as the Welsh people were concerned, and, of course, the Government would not have appointed a judge to sit on a Commission of inquiry into a political controversy’ and it was merely a Commission 'to inquire into certain facts connected with the controversy'. ${ }^{62}$

The following newspaper report from March 1907 clearly demonstrated the confusion about the terms of reference of the Commission and the fractious way members had responded to the Chairman's attempts to adhere to what many perceived as a rigid interpretation of the work of the Commission and the nature of the evidence which he considered admissible: 'The Welsh Church Commission has fallen upon such troublous days that its dissolution appears to be brought within range of breakdown', with the Chairman rigidly adhering to his view of the Commission as a purely judicial tribunal'. ${ }^{63}$

On 20 February 1907, Staniforth's cartoon in the Western Mail, entitled 'The Anaesthetic', would have caused any Nonconformist reader considerable anxiety, as it was again intended to demonstrate the ease with which Nonconformists could be duped by those politicians who, ostensibly, were committed to seeking disestablishment.

\footnotetext{
61 'The Welsh Church Commission. Growls in Parliament. Mr. Lloyd George Explains’, Carnarvon and Denbigh Herald, 15 March 1907, p.8.

62 Ibid.

63 'Welsh Church Commission. Very Stormy Session on Friday’, The Cambrian, 8 March 1907, p.3.
} 


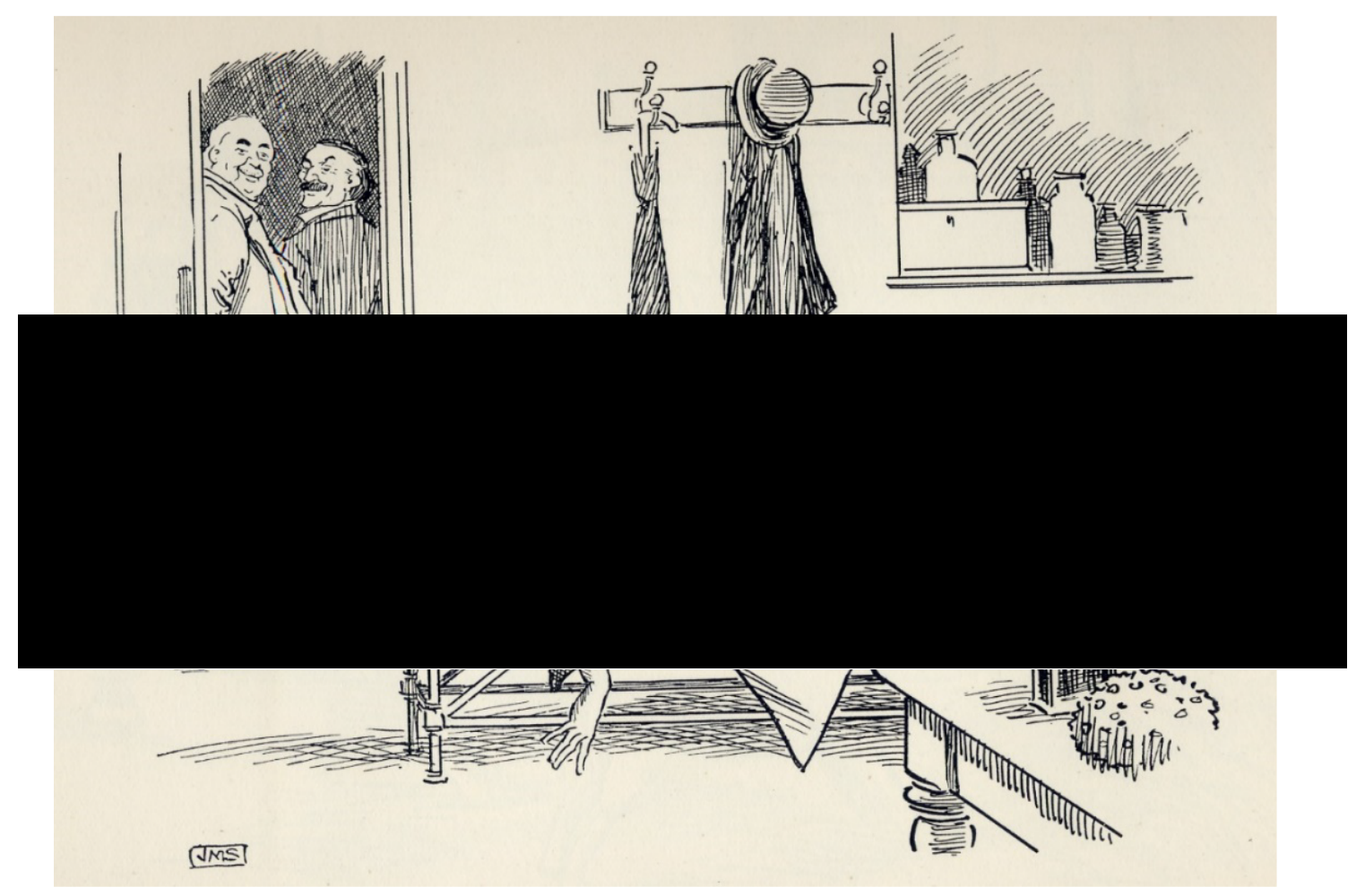

'The Anaesthetic’: Western Mail, 20 February 1907.

In this cartoon, Staniforth depicts the man whom he traditionally drew to represent

Nonconformity, lying comatose, on a hospital trolley, having been treated with the contents of a bottle of 'Church Commission Anaesthetic'. The patient in the cartoon had been diagnosed with 'Disestablishment mania' and Prime Minister Campbell-Bannerman and Lloyd George are vacating the treatment room, with satisfied smiles on their faces, and a caption reads: 'Dr Campbell-Bannerman: Any way, he will be quiet for a time, and we can go on with other cases. (But the patient is coming around sooner than was expected)'. The hearing of evidence to the Royal Commission would continue until 15 June 1908 and the last of the meetings to consider the vast amount of evidence was held on 6 October 1910, therefore it was apparent that the 'patient' was to be kept in a stupor for much longer than anybody could have anticipated and there was no doubt that the patient would suffer as a result. ${ }^{64}$

Contemporary defenders of the pre-1920 Established Church have interpreted the much-delayed results of the 1906 Royal Commission, in 1910, as evidence that the Anglican Church was the

\footnotetext{
${ }^{64}$ Report of the Royal Commission on the Church of England and other Religious Bodies in Wales and Monmouthshire, Vol.1, Part1, HMSO, 1910, p.239.
} 
largest religious body in Wales, but appears to have provided comfort to both Anglicans and Nonconformist, with residual questions about its purpose, its conduct and the validity of the evidence:

'At last the official report of the Welsh Church Commission has been issued. The most interesting part of the report for Free Churchmen is that prepared by the Liberationist members on the Commission. The preparation of this special portion of the report was entrusted to Sir John Williams. His report deals with the origin and early history of Nonconformity in Wales and other important facts, all of which were ruled out by the chairman of the Commission when the witnesses tendered their evidence. Mr. J. H. Davies has discovered the most glaring discrepancies in the figures put forth by the Established Church'. ${ }^{65}$

The final Report of the Royal Commission was not to be signed by members until 1 November 1910. ${ }^{66}$ It was immediately subjected to differing interpretations, but as reported in The Times, 'the delay has produced a natural forgetfulness in certain minds', which included the Cabinet, which decided to introduce legislation before the report was published, and it also identified the common misconceptions about the Commission's terms of reference, as exemplified by the fact that many had called it the 'Welsh Disestablishment Commission'. The newspaper's report's evaluation of the evidence recorded by the Commission was best summed up by its whimsical suggestion that in relation to the profusion of reports and memoranda, both official and unofficial, that there was perhaps no alternative but for the Prime Minister to 'now ask for another Royal Commission to examine the methods and test the statistics' ${ }^{67}$ Only two of the nine members of the Commission were to sign the final report without qualification, which indicates the nature of the outcome. Sir David Brynmor-Jones endeavoured to clarify the position regarding the Commission's timetable, and the manifestation of a confusing array of memoranda, in a letter to The Times on 5 August 1911, but he was at pains to describe the method by which a memorandum, written by Archdeacon Evans, had been inserted into the final Report, but without the knowledge of other members of the Commission. ${ }^{68}$ Such shenanigans, administrative heavyhandedness and selective use of the torrent of statistics added to the belief that the Royal Commission had done little more than obfuscate and provide an excuse for procrastination. Although it could be assumed that Bishop Edwards would have welcomed the delay that had

\footnotetext{
65 'The Welsh Church Commission', The Montgomeryshire Express and Radnor Times, 13 December 1910 , p.3.

66 ‘The Welsh Church Commission', The Times, 2 November 1910, p.6.

67 'The Welsh Church Commission', The Times, 3 December 1910, p.13.

68 'The Report of the Welsh Church Commission', The Times, 5 August 1911, p.11.
} 
accompanied the Royal Commission's proceedings, he wrote that: 'It is enough to say that the Report of the Commission and its proceedings had no influence upon the political controversy. It would have been better if the Commission had died in May 1907.'69

Rather than relish the opportunity to impress the members of the proposed Royal Commission with the statistical arguments which peppered his frequent speeches around the country, and a style of presentation for which he was renowned, the Bishop of St. David's advised the Archbishop of Canterbury that it 'will do more harm than good' ${ }^{70}$ It transpired that his prime concern was that 'all sorts of scandals might be raked up', thereby acknowledging that such improprieties existed, as had been noted by the notional allies of the Church during the 1889 Rhyl Conservative Conference. ${ }^{71}$ However, he believed that Churchmen would retaliate with disclosures of their own, and, due to the precise geographical location of such accusations, the rancor which had, to date, been 'confined to the platform and the press', would engender local bitter disputes. The Bishop’s prime concern was the good reputation of the Church, or at least an avoidance of grounds for criticism which might cause scrutiny, and his approach differed from the Bishop of St. Asaph who viewed the Commission 'as a great deliverance', as he interpreted it as an effective, public method of addressing the 'constant irritation' of the inaccuracies that he believed were published to support disestablishment. ${ }^{72}$ Writing to The Times, with apparent satisfaction, the Bishop of St. David’s indicated, in 1911, that the Prime Minister had never read the Royal Commission's report and its exhaustive findings were not consulted. ${ }^{73}$

The Welsh National Convention met in Cardiff on 11 October 1906, with 'about thousand delegates from all parts of Wales', under the presidency of David Lloyd George, in order to consider 'the present political outlook'. Lloyd George elucidated the purely fact-finding nature of the Welsh Church Commission, which he described as an 'necessity', whose purpose was to: 'ascertain the facts officially as regards number of adherents and as to ancient endowments'. ${ }^{74}$ In an attempt to meet potential criticism or confusion Sir Alfred Thomas, also moved a resolution

\footnotetext{
${ }^{69}$ Edwards, Memories, p.235.

${ }^{70}$ Owen, The Later Life of Bishop Owen, p.82.

${ }^{71}$ Ibid.

72 Edwards, Memories, pp.223-224.

73 'The Church in Wales', The Times, 2 May 1911, p.7.

74 'Welsh National Convention', Carnarvon and Denbigh Herald, 12 October 1906, p.8.
} 
welcoming the appointment of the Welsh Church Commission, and to seek those present to advance the Commission's inquiry. Again, as some measure of reassurance, he averred that 'the convictions of the great majority of the people of Wales were unalterable'. ${ }^{75} \mathrm{He}$ emphasized the point that the Nonconformists of Wales were seeking the Church's good and maintained that those who sought Disestablishment 'were the Church's best friends'.

Reverend W. A. Edwards ${ }^{76}$ of Llangan was welcomed to the Convention and was introduced by Lloyd George as 'one who desired to see the Church of England emancipated from State shackles' and the vicar received an extremely warm reception when he rose to support the resolution. As will be explored in chapter four, the Reverend was a nephew of the Bishop of St. Asaph and this familial link may have contributed towards the rapturous welcome, although he had garnered a reputation as leading proponent of disestablishment. He declared that he was convinced that 'the only tolerable and workable condition in our modern world in relation to religious question of this kind is the idea of Free Church in a Free State', the applause was described as very vigorous, as was the case when he pronounced that: 'I am prepared to defend the Church of which I am a clerical member with my life if it be necessary, but not the Establishment' ${ }^{77}$ William Jones, M.P., paid a tribute to 'the speech of the Vicar of Llangan, and urged that it was in the interest of the spiritual life of Wales that Nonconformists sought to bring about Disestablishment'. As will be explored in chapter four, Reverend Edwards was an ambitious and astute politician, sharing such characteristics with his uncle. At a meeting of the Welsh Liberal Executive, held in Shrewsbury in June 1907, Lloyd George was requested to make a statement in order to clarify the current status of the disestablishment question. He adhered to the government's line that the obstacle was the House of Lords and that the 'the supreme question of the moment was whether the representative or the unrepresentative Chamber was to rule' and therefore he urged that all efforts should be:

'concentrated upon an endeavour to remove the great constitutional hindrance to reform for they must recognise that in questions affecting the land, the Church of England, the liquor traffic, and some other matters of grave moment the whole policy and purpose of

\footnotetext{
75 'Welsh Convention', The Cardiff Times, 13 October 1906, p.7.

${ }^{76}$ The Reverend W.A. Edwards, Rector of Llangan, was the nephew of Bishop A.G. Edwards and the grandfather of Nicholas Edwards, Baron Crickhowell, (1934 - 2018), Secretary of State for Wales, 1979 to 1987.

77 'Welsh Convention', The Cardiff Times, 13 October 1906, p.7.
} 
the Lords was anti- national, anti-Liberal, designed only to serve class interests and to uphold privilege and power'. ${ }^{78}$

It would become apparent that being 'in favour' could be characterized by passivity, rather than a desire to deliver disestablishment, and this was despite any popular demonstration or pressure on Liberal politicians. The events following the 1906 general election would verify if such confirmation was necessary, that there was a continuing disparity between the expectations of Welsh Nonconformist voters and the Liberal party leaders, with Welsh Liberal politicians often adopting a role of appeasement and pacification.

Lloyd George would use the opportunity of an event which was held in Caernarfon, on 17 January 1907, to celebrate his forty-fourth birthday, to reduce expectations about Welsh disestablishment, knowing that it would not feature in the King's Speech the following month. It was therefore necessary to ensure that to denounce the House of Lords, which 'generally aimed at something that is thought could not hit back' and 'Wales was small and only commanded onetwentieth of the voting power of the country' so this craven body treated its petitions with discourteous arrogance' ${ }^{79}$ It was also necessary for Lloyd George to pre-empt any critical response, by suggesting that it was disloyal and this led him to warn his 'fellow-countrymen' that: 'if they found the Government manoeuvring their artillery into position for leading an attack on the Lords, the Welshmen who worried them into attending to anything else until the citadel had been stormed ought to be put in the guard-room'. ${ }^{80}$ Although the exhortation was met with 'laughter and cheers', sober reflection, and a glance at the inevitable Staniforth cartoon might have caused people to ponder on who was being disloyal. ${ }^{81}$

\footnotetext{
78 'Disestablishment Crisis. Statement by Mr. Lloyd George’, Carnarvon and Denbigh Herald, 21 June 1907, p.8.

79 'Mr. Lloyd George at Carnarvon', The Times, 18 January 1907, p.3.

80 Ibid.

${ }^{81}$ Staniforth’s cartoon, entitled, 'On to Battle’, appeared in the Western Mail on 26 January 1907.
} 


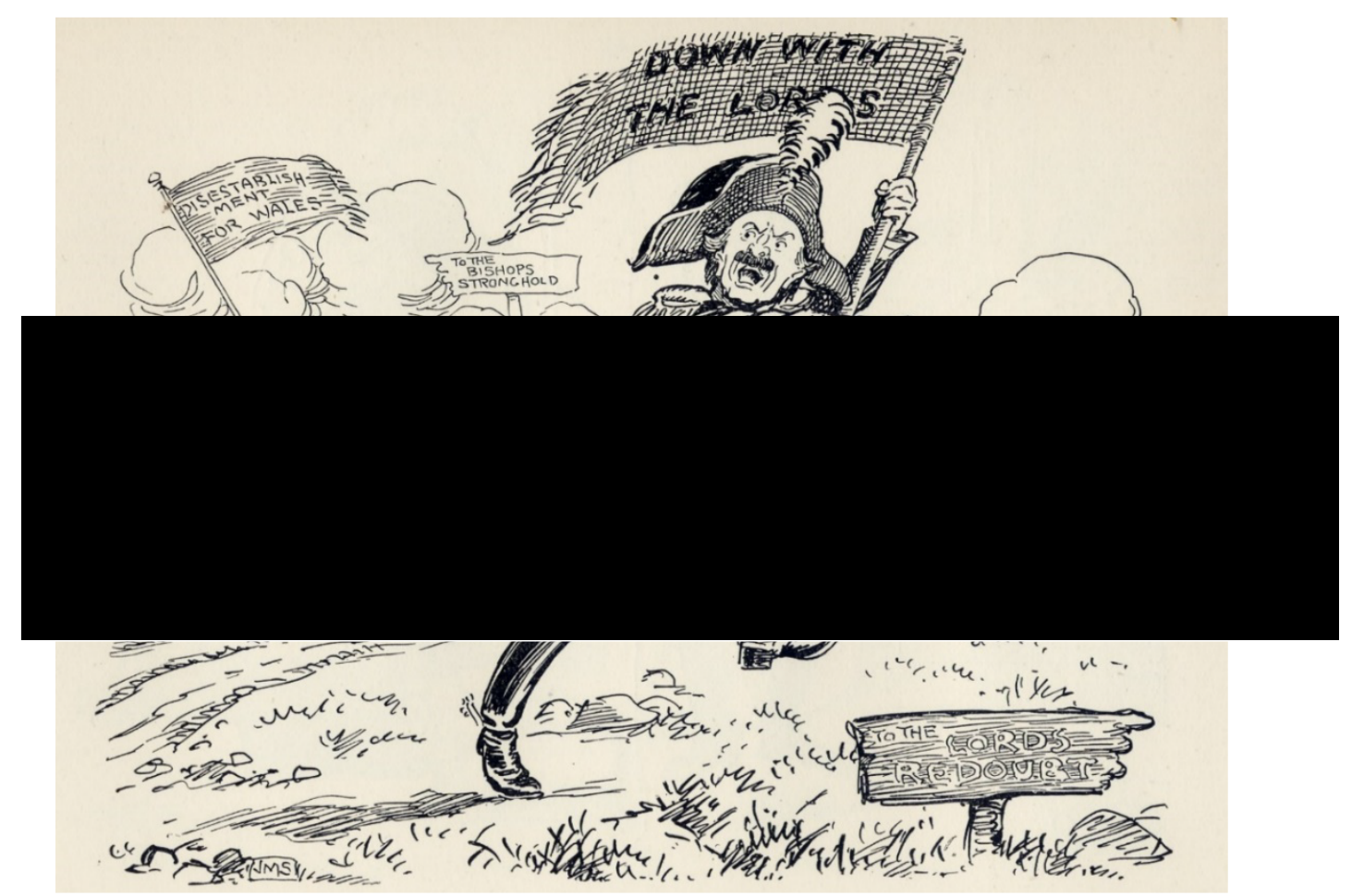

'On to Battle’: Western Mail, 26 January 1907. 'General Lloyd George: Now, my valiant men, I will send to the guard-room the man who disobeys - Cha-r-r-ge!',

Lloyd George, with sabre drawn, attempting to lead his army to assault the Lords’ Redoubt. The accompanying text suggests that: 'Welsh Nonconformists showed little inclination to fall in with Mr. Lloyd George's advice to attack the House of Lords as a preliminary step to the introduction of a Welsh Disestablishment Bill'. Although it was unlikely that Staniforth was aware, but Lloyd George had quoted Napoleon, in 1891, when he had advised a meeting of the Welsh National Council that 'Napoleon used to say that the best policy was to be on the offensive'. ${ }^{82}$ He had continued his motivational homily with the exhortation that: 'Democracy was with them, and that the lessons of the bye-elections told them that they were going to carry their cause to victory'. ${ }^{83}$ Unfortunately, sixteen years had passed and that victory still appeared outside their grasp, irrespective of democracy. At least one newspaper attempted to explain any criticism of David Lloyd George’s changing attitude to disestablishment, with an opinion that: 'a public man so quick as he always is to respond to "atmosphere" never could be chained down to a wooden, mechanical consistency'. ${ }^{84}$ It went on to suggest that Lloyd George had 'something of the same

\footnotetext{
82 'Welsh National Council’, The Times, 11 September 1891, p.5.

83 Ibid.

84 ‘Disestablishment. Mr Lloyd George’s Position’, The Welsh Coast Pioneer, 20 June 1907, p.8.
} 
quality of rapid growth and adaptation’ as Gladstone and this explained his success in handling ‘delicate Government measures’. However, in case this should have led readers to question matters more closely, it also reported that:

'The Chancellor of the Exchequer said there was no question within the sphere of political - reform that had appealed to him more strongly throughout his political life and now than Welsh Disestablishment ${ }^{\text {, }}{ }^{\text {. }}$

Further apparent evidence of Lloyd George's endeavour to defend himself from criticism was to be conveniently provided by his response ${ }^{86}$ to a letter from Elvet Lewis ${ }^{87}$, with one newspaper suggesting that it represented: 'A communication of the utmost importance on the disestablishment and disendowment of the Church in Wales ${ }^{88}$. The letter was read to a meeting of the Welsh Congregational Union at Neath, on 25 June 1907 and it appeared to be written in a manner which suggested that Lloyd George anticipated that the contents would be published. He emphacised that his assurances that the government would pursue legislation was given in the context of the Prime Minister's 'attitude towards the great question of religious equality in Wales', but he was careful to stress that it would be subject to the actions of the House of Lords. The letter was written in English, but it ends with a sentence in Welsh: 'Undeb yn awr ar fin y frwydr fawr yn erbyn gelyn mawr Ryddid, Ymneilluaeth a Chymru, sef Ty yr Arglwyddi’. 89

\section{The Nonconformist Convention, 1907.}

Matters had reached such a pitch, that the failure to progress disestablishment prompted an invitation to all Nonconformist organisations, by means of a letter to the editors of newspapers, to attend a representative convention, on 10 October 1907, at the Wood Street Chapel, Cardiff. ${ }^{90}$ The Nonconformists who signed the letter believed that:

'If Wales now speaks with a united and clear voice, her claims can no longer be ignored, and the danger which threatens her will be averted. It is in the confident hope that every Free Churchman in Wales will realize the responsibility which now rests upon his

\footnotetext{
85 Ibid.

${ }^{86}$ Parliamentary Archives: B/1/8/2, dated 24 June 1907.

${ }^{87}$ Howell Elvet Lewis, ('Elfed': 1860-1953), Independent minister, hymn-writer poet and Archdruid: D.W.B. His name was included in the list of those replacement members of the Welsh Church Commission considered by a meeting of the Cabinet Council: 'Church Commission Vacancies. Names submitted to the King', Evening Express, 23 April 1907, p.3.

88 'Welsh Church. Lloyd George and Government’s Attitude', Evening Express, 25 June 1907, p.3.

89 'Unity now, on the eve of the great battle against the great foe of Liberty, Nonconformity, and Wales - the House of Lords'.

90 'Welsh National Convention and Disestablishment', The Carmarthen Weekly Reporter, 4 October 1907, p.1.
} 
shoulders, and that Nonconformist Wales will seize this opportunity of effectively voicing the National demand'.

The Nonconformists had realized that unless they acted, independent of their members of Parliament, the 'present Parliament would be allowed to pass without any serious attempt at legislation upon this matter so near the heart and the conscience of the Welsh people'. They interpreted the call to defer their claim until the constitutional struggle with the Lords had been settled, as unacceptable filibustering, although they were aware that, of the thirty-four Liberal Welsh members, only four had placed disestablishment foremost in their election addresses.

The outcome of the 'great Nonconformist Convention' was 'an overwhelming victory ${ }^{\text {, }}$ for Lloyd George, which he appeared to achieve by meeting some of the delegates in advance and by an extraordinary, lachrymose speech which he ended with the form of patriotic sentiment which would have made it impossible for those present to doubt his true intentions, at least at that moment. ${ }^{92}$ The Conservative supporting Evening Express was clearly suspicious of some of the manoeuvrings, in advance of the convention, at which there were over two thousand representatives. Resolutions, critical of the government, had been published in advance of the meeting, but these were amended by the Convention Executive, on the eve of the meeting, causing great surprise, particularly when it was realized that they had been amended 'after a private conference' with Lloyd George and other Welsh M.P.s, 'who were not members of the executive, but had been appointed as delegates'. ${ }^{93}$ In addition to the mollifying of the executive, the neutralizing of the resolutions and the ardent speech-making, there was also helpful press coverage:

'Wales is very fortunate in having one of her representatives in the Cabinet, and in future we hope that the shabbier sort of penny-a-liners will be more careful how they manufacture lies which injure their country and endanger themselves, instead of doing harm to Mr. Lloyd George, who stands higher in the estimation of his countrymen than he stood before the Convention was held'. ${ }^{94}$

\footnotetext{
91 John Grigg, Lloyd George. The People’s Champion 1902-1911 (London: Methuen, 1991), p.151.

92 'Am I going to sell the land I love? Duw a wyr mor anwyl yw Cymru lan i mi!'

93 'National Convention. Nonconformist Day at Cardiff', Evening Express, 10 October 1907, p.3.

94 'The Cardiff Convention Collapse', The Cambrian News, 18 October 1907, p.4.
} 
The newspaper noted that the Convention did not 'condemn the Liberal Government, or reprove the Premier, or repudiate Mr. Lloyd George’ and although it attempted to avoid sounding triumphant, it went on to report that:

'We are not going to say that Mr. Lloyd George won a victory, or that the naggers, represented by Mr. Ellis Jones-Griffiths, suffered defeat, but the Government, the Premier, and Mr. Lloyd George were amply and splendidly vindicated, and the naggers were shown that they had no case, not a shadow of a case in asking that the great issue between the House of Lords and the four nations of the United Kingdom should be in the slightest degree endangered or delayed in order that something utterly futile and unnecessary should be done in the House of Commons about Welsh Disestablishment'.

Staniforth adopted a more cynical view of Lloyd George’s ability to subdue the Convention and portrayed as a Native American with his belt adorned with the 'scalps' of those who had already tried to challenge him, and then with him returning cock-a-hoop, to the government tepee, with another challenge averted and a further scalp for his collection.

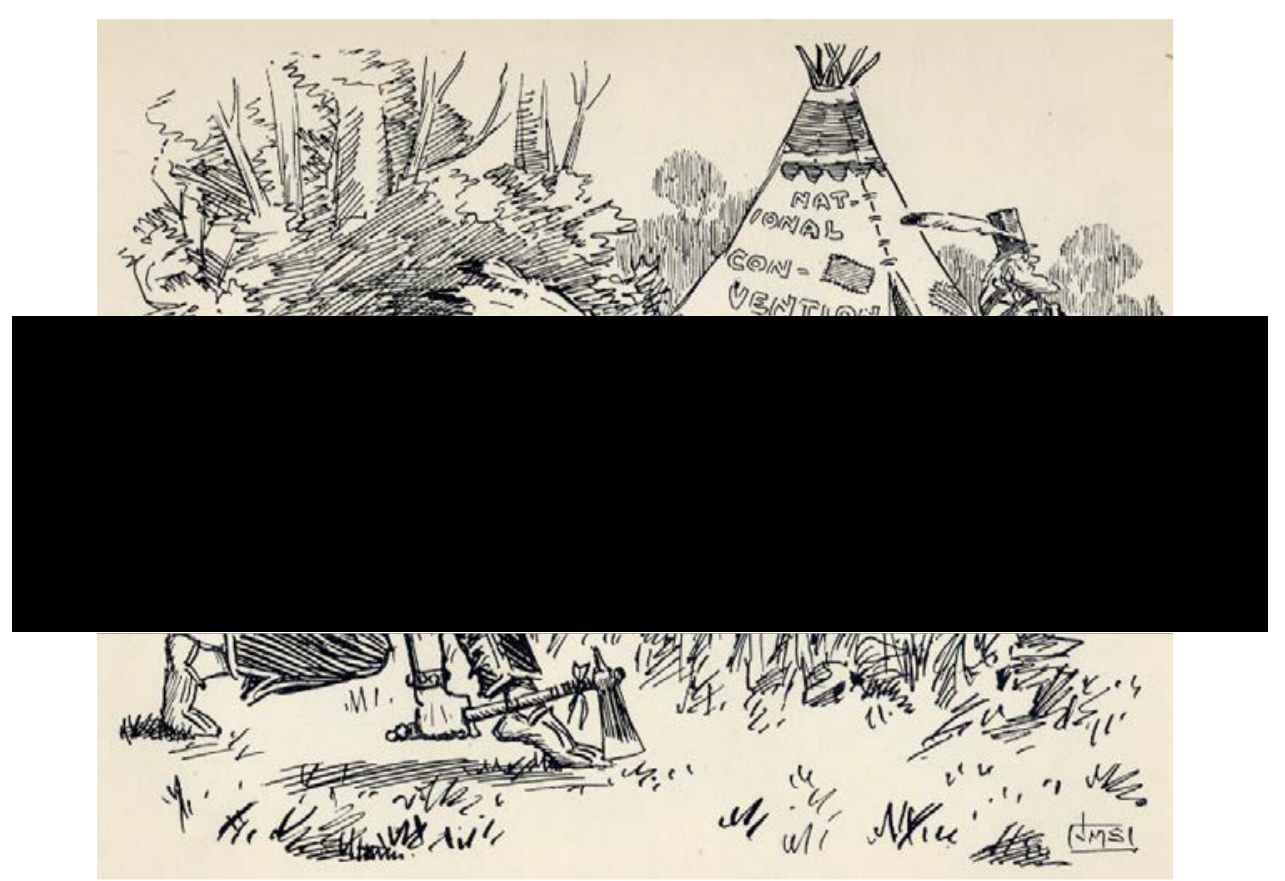

'Will He Get It?', Western Mail, 10 October 1907. 


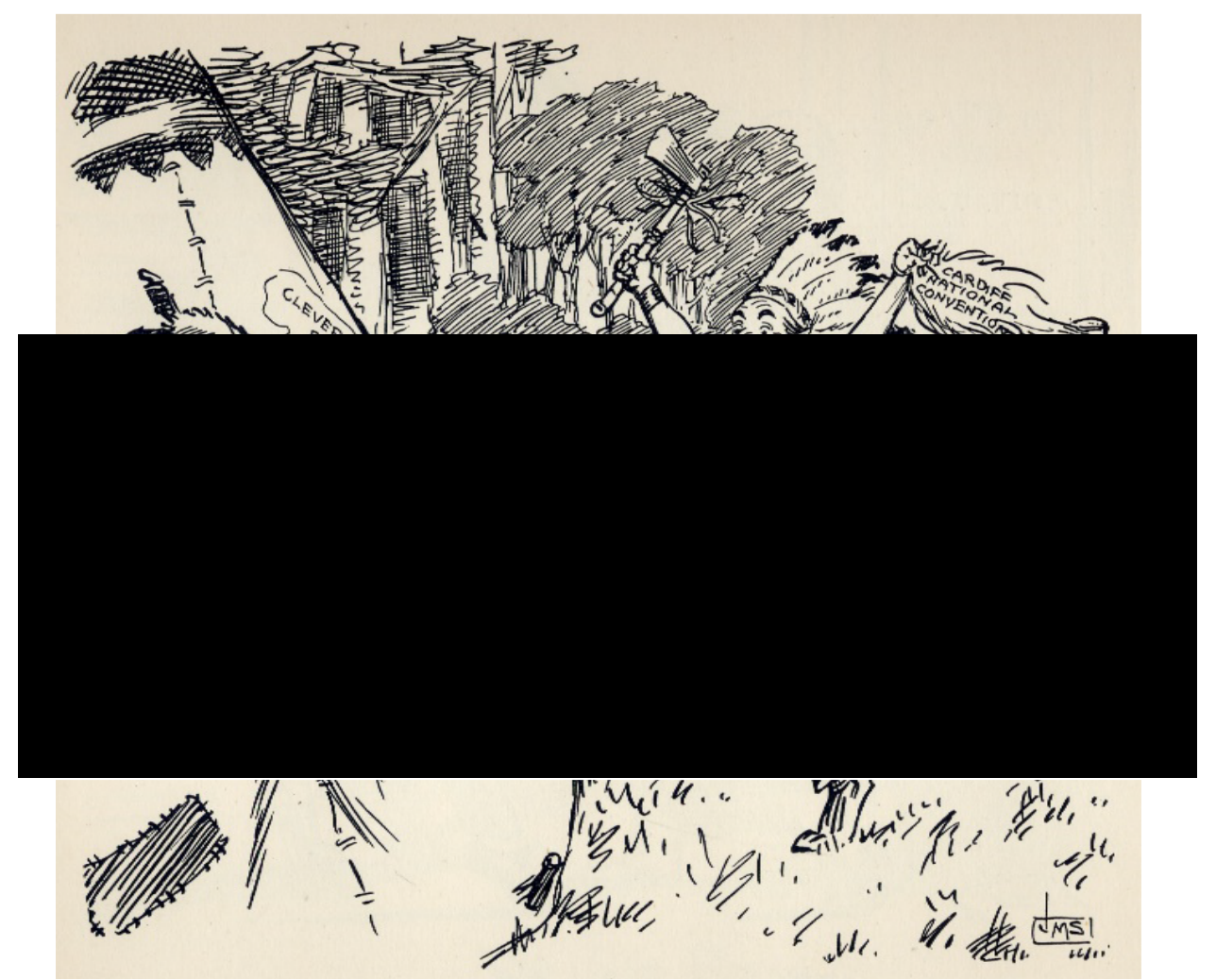

'See, The Conquering Hero Comes!', Western Mail, 12 October 1907.

It is impossible not to feel a level of sympathy for those Nonconformist leaders who promoted the Convention, in that they entered, with sound intentions, but naively, the political fray and were left battered and bruised, or without their scalp as Staniforth portrayed it, and very unlikely to desire a repeat of the event. Indeed, as well as a reference to 'naggers', the Cambrian News also reported that: 'The people of Wales are splendidly true to their principles, but there always have been and always will be traitors and self-seekers who will do their best to see that every great cause has its martyrs' ${ }^{95}$ It went on to provide a hagiographic account of Lloyd George, whom it felt had been woefully wronged and he was described as:

'a fighter, with fine courage and keen insight, and quite able to defend himself, but on behalf of men who have not his skill in conflict or his fiery courage. He is not the first leader in Wales who has been attacked from behind. Others also have been wrongly accused and some of them retired and bore their wrongs in silence. Mr. Lloyd George, as he said, went to Cardiff to face the music, and the tune was certainly not what those who promoted the concert expected, but they had to join in the chorus'.

${ }^{95}$ Ibid. 
Between the political unworldliness of the Convention promoters, which left them being defined as 'traitors and self-seekers', and the credulous veneration of the Cambrian News, it was impossible to envisage a situation where any effective pressure could be brought upon Wales's leading politician in respect of disestablishment. In effect, the decision to call the Convention had spectacularly miscarried. Lloyd George had been sufficiently perturbed by what he might face, to call upon Campbell-Bannerman, the prime minister, for a 'clear declaration', which he could then dangle in front of those present, with a suggestion that action to achieve disestablishment would be taken before parliament dissolved. Campbell-Bannerman was unmoved and reverted to the usual response that the matter would be addressed when the 'crisis between the two Houses’ was resolved. ${ }^{96}$ Perhaps this provided Lloyd George with a valuable political lesson, as he was able to vanquish the threat to the government, and his reputation, with his eloquence and passion.

The situation was made manifest, as cartoonist J.M. Staniforth regularly portrayed Nonconformity being duped, particularly by Lloyd George and an example is given below. ${ }^{97}$ Whilst it may have amused readers of the Conservative-leaning Western Mail, such cartoons did not, in any substantive manner, cause a 'revolt' from those members of the public who were seeking disestablishment. By any analysis, the Liberal Party’s involvement in the delivery of Welsh disestablishment should be acknowledged as a protracted and unmistakeable lesson in political prevarication, equivocation, vacillation and, ultimately, failure, or at least an inability to deliver what had been intended, and without any degree of alacrity.

\footnotetext{
${ }^{96}$ Gilbert, David Lloyd George. The Architect of Change 1863-1912, pp.310-311.

${ }^{97}$ Other examples included: 5 September 1907: 'The Happy Day - of Disestablishment', 5 October 1907: 'The Irony of Fate', 18 October 1907, 'The Gift Horse', where D. A. Thomas examines a horse hurriedly made of wood, string and paper, representing Lloyd George's 'qualified' promise of a Disestablishment Bill, and D. A. Thomas declares that 'I don't think it is of much value'. Punch also regularly poked fun at Nonconformist gullibility, with Mam Cymru usually depicted in a waiting area, 15 February 1911: 'The More Favoured Nation', which depicted the character representing Ireland wearing a wide smile, 7 August 1912: 'Temporary Stopping', where characters representing electoral reform, home rule and Welsh disestablishment are left forlornly in Mr. Asquith’s waiting room.
} 


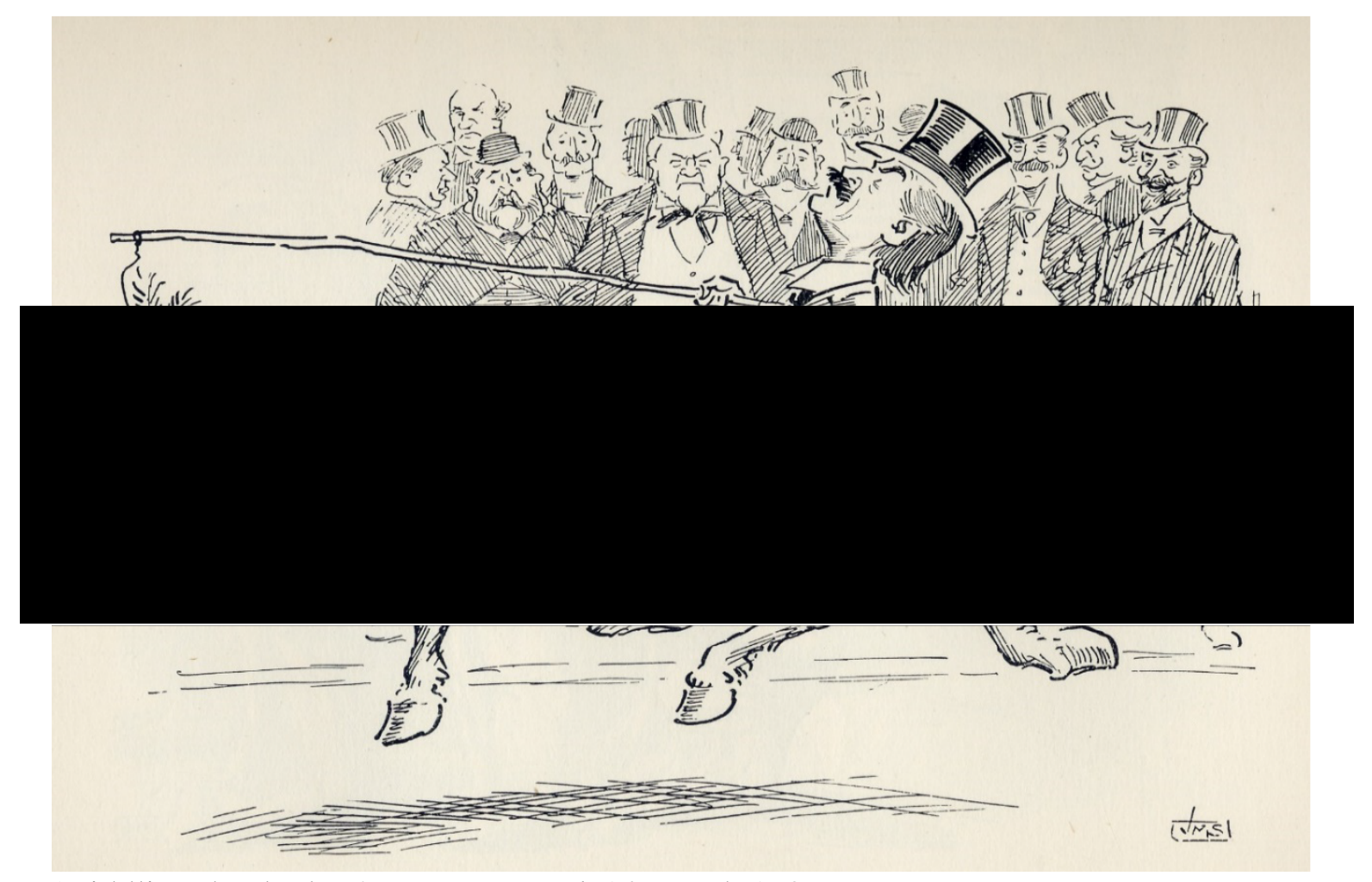

'Diddling the donkey': Western Mail, 14 March 1907.

David Lloyd George’s ability to distract and prevaricate, whilst appearing to offer a way forward, allowed the traditional reader of the Western Mail to both revel in both his artifice and the apparent dupability of the Nonconformists.

\section{The spectre of socialism.}

The Liberal Party was also becoming increasingly aware of a challenge from another source, being an increasing unease about the growth of the Independent Labour Party. J. Keir Hardie ${ }^{98}$ was adamant that the Liberals, themselves, were responsible for the phenomenon, as they had displayed an arrogance in their conviction that they alone represented: 'the common people, their wants and wishes'. In his 1895 exposition of the reason why the Independent Labour Party was growing, Hardie was highly critical of what the Liberal Party had achieved, but also its failure to fully accept that democratic demands had altered. In particular Hardie highlighted the reorganisation of industry, which was the 'crying need of this generation, and will be even more so of the next'. ${ }^{99}$ Hardie believed that Lord Rosebery, the then Prime Minister, considered that the ‘fate of the nation' depended upon 'electoral reform and disestablishment', but the position

\footnotetext{
98 James Keir Hardie, (1856-1915), member of Parliament for Merthyr Tydfil from 1900 until his death.

99 J. Kier Hardie, The Case for an Independent Labour Party (London: LSE Selected Pamphlets, 1895), p.721.
} 
was exacerbated by the Liberal Party’s apparent impotence in successfully completing even these objectives. This caused Hardie to make reference to the fact that: 'The young Welsh Party frankly say they do not believe the Government intends to deal with Disestablishment', and the Irish were of a similar mind in relation to Home Rule. ${ }^{100}$ He was dismissive of any argument that the Liberals were foiled by the Tory-controlled House of Lords as, perhaps somewhat ingenuously, he argued that the House of Lords 'would not dare to block the way', if the Liberal Party 'was engaged in carrying out the will of the nation'. ${ }^{101}$ The Liberal Party was, in Hardie’s opinion, not only 'endeavouring to live and flourish on what were the big reforms of twenty-five years ago', but it was even failing to deliver them, so why, based upon the experience of the experience of those who sought Welsh disestablishment, should the I.L.P. remain within the Liberal Party. ${ }^{102}$ It was evident that Hardie was writing with an acute awareness that the actions of the I.L.P. were viewed as a 'threat to stop the wheels of progress', but his illustration of the frustration of those working within the Liberal Party for disestablishment was significant. ${ }^{103}$ Whilst canvassing, prior to the January 1910 general election, Hardie was clearly under some pressure not to alienate one side or the other, although he wanted to ensure that there was 'no misunderstanding concerning his own position on political issues’:

'There were certain questions upon which the people of Wales held very strong convictions, and rightly so. There was, first of all, the question of the Disestablishment of the English Church in Wales. It was a question upon which practically every Welshman was agreed. It was felt to be both unfair and unjust that one section of the Christian Church should be singled out for special favour at the hands of the State. For himself, born and reared a Dissenter he wanted no State Church'. ${ }^{104}$

Speaking the following day, at Aberdare, following a speech by George Bernard Shaw, Hardie, referred to his position again, when he stated that:

'he had been advised that it would be a wise policy on his part to say as little as possible about Disestablishment. Wise or otherwise, he would tell them be was for Disestablishment (loud applause). He would not object to concurrent endowment, but it should be all sects or none. He did not believe that announcement would lose him any Churchmen's votes'. ${ }^{105}$

\footnotetext{
100 Ibid.

101 Ibid., p.722.

102 Ibid., p.723.

103 Ibid.

104 'Mr Keir Hardie’s Campaign. Meeting at Troedyrhiw. Disestablishment, Education and Temperance', The Merthyr Express, 8 January 1910, p.11.

105 'Meeting at Aberdare. Mr. Hardie and Disestablishment', The Merthyr Express, 8 January 1910, p.11.
} 
He did continue with an assertion that 'the great questions of the moment were the House of Lords and the Budget' and, some four years later, Hardie came to equate the Established Church with the House of Lords:

'In the first place, we support this Disestablishment because it makes for democracy. At the present moment the Established Church is a privileged institution in the regions of religion, and no doubt she occupies much the same position in regard to Church life as the House of Lords did, and still does, in the eyes of the average Radical. We believe that religion, above all things, should be based upon equality of treatment and equality of opportunity. Endowments and privileges still remain to the Church; it is recognised by law, and it has a right to representation in the House of Lords-privileges which give it a position of superiority, social and legal, which in the very nature of things is bound to be offensive to Nonconformist members of the community. Most of us in the Labour party, so far as our religious convictions are concerned, belong to the Nonconformists'. ${ }^{106}$

The Liberal Party was increasingly aware of the challenge presented by the Labour Party and those Liberals aware of his early reputation might have been mildly surprised by David Lloyd George's speech to an 'assemblage of party agents', who were meeting at the time of a Welsh Liberal Convention meeting on 1 October 1908. He was keen to 'revaccinate' many young Liberals against the 'germs and microbes' emanating from Socialism, and reminded his audience that the 'steadier, slower methods of Liberalism were in the long run the surer'. ${ }^{107}$ In a meeting at the Albert Hall, Swansea, later that day, he made reference to the 'hosts of unreasonable people irritated and impatient and threatening to remove their custom to some other store' and although it was the Suffragettes present who constantly interrupted him with cries of 'shame', they could have easily been joined by those in the audience who were 'irritated and impatient' about disestablishment.

Even when the electorate had made their feelings evident, the Liberal government's ambivalence towards disestablishment was only momentarily jolted, as demonstrated in a letter which David Lloyd George wrote to his brother, which recorded that the nature of Walter Roch's ${ }^{108}$

\footnotetext{
106 'Established Church (Wales) Bill', HC Deb. 20 April 1914. Vol. 61 cc. 658.

107 'Mr. Lloyd George at Swansea', The Times, 2 October 1908, p.10.

${ }^{108}$ Walter Francis Roch (1880-1965), politician and landowner, Liberal M.P. representing Pembrokeshire from 1908 to 1918. According to D.W.B, his political career ended when he 'chose to support Asquith rather than Lloyd George’.
} 
Pembrokeshire by-election victory, on 16 July 1908, had 'quite choked' Asquith. ${ }^{109}$ Lloyd George wrote that: 'The result has exhilarated $\&$ heartened the Liberals here $\&$ to a corresponding degree depressed the Tories' and that he had cajoled the Prime Minister with: 'Now you must give them Disestablishment', with Asquith obliged to admit that: 'Yes, they deserve it'. The successful Liberal candidate, Roch, had made it abundantly clear to the press about the reason for his triumph: 'The battle was fought on our side on the whole of the Liberal programme, but the decisive message of Pembrokeshire is a demand for religious equality. Welsh Dis-establishment was the main plank in my platform. It figured in every speech I made’. 110

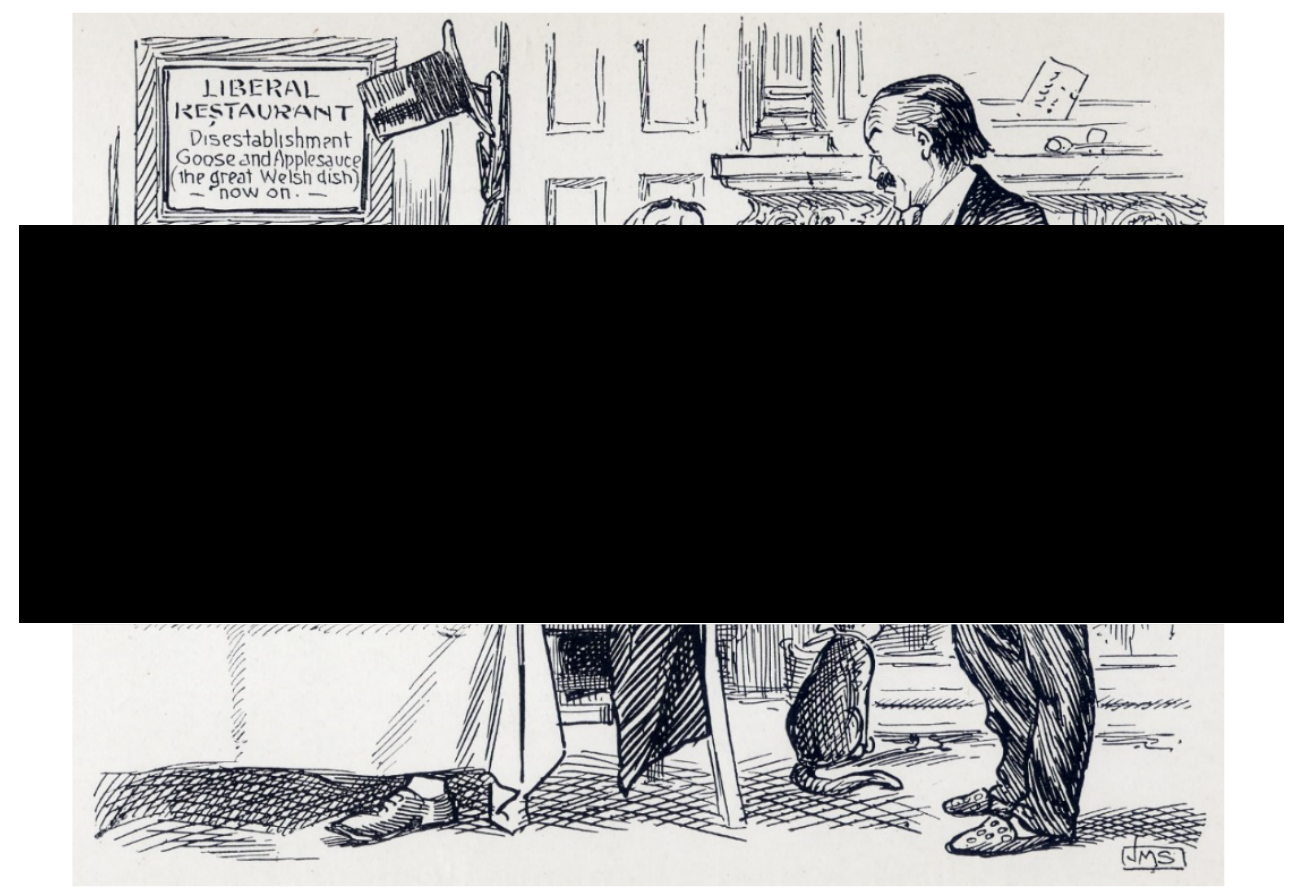

‘A Doubtful Dish’, Western Mail, 19 December 1908.

Waiter: 'Disestablishment and apple sauce, sir, is - er - well, not altogether off, I assure you, sir, but it's not altogether on. (Sotto voce): I haven't the heart to tell the dear old gent that it's hopeless.'

Despite the exchange between Lloyd George and Asquith, Staniforth's cartoon from October 1908, accurately captured the continuing duplicity.

\footnotetext{
${ }^{109}$ N.L.W., William George Papers: Lloyd George, David to William George. Letter 2089, [manuscript], 17 July 1908. The letter also provided an example of how Lloyd George's attention was being drawn to matters which might have appeared less parochial, when he added that he had: 'Met Count Metternich, the German ambassador, over lunch at Sir Edward Grey's house on Wednesday. Grey has assured him that Metternich will report his every word to the Kaiser'.

110 'Pembrokeshire Again Won', The Carmarthen Weekly Reporter, 24 July 1908, p.1. The result was reported as: Roch (Liberal) 5,465, Lort Williams (Conservative) 3,293, Liberal majority 2,172.
} 


\section{'For forty years have we patiently tramped the wilderness'.}

In the context of the Biblical illusion, the Carnarvon and Denbigh Herald maintained a hope that: 'In spite of the attempts of the English newspapers to shunt Welsh Disestablishment from the main line of legislation into an out-of-the-way siding', the newspaper was 'not yet convinced that the Government will break faith with us'. ${ }^{111}$ It did however forewarn that it feared for 'the future of Liberalism in Wales if this strong Government makes no effort to fulfil its promise., helping others while denying ourselves' and contrary to the view expressed by the Rhyl Record in 1905, it did not accept that 'social questions should be given precedence - that Disestablishment can wait', as it believed that 'Disestablishment lies at the root of all our social questions - Disestablishment and land reform' and that: 'Turn where we will, we are for ever face to face with the disadvantages of State-aided religion, and we shall never be free to deal with any other question until we settle once and for all this vital question of religious equality'. 112

Later in the year, although the same newspaper again recognized that: 'Uneasiness, disappointment undoubtedly exists at the failure of the Government to carry a Disestablishment Bill', it still found it difficult to be critical of David Lloyd George and it considered that 'people remember with gratitude that Mr. Lloyd George has not been recreant to his democratic principles', continuing with an encomium of the fact that he had given them an old age pension and that he was: 'engaged in life and death struggle with the landed interests' and the movement to establish an independent party was interpreted 'to weaken his position in the confidence and affection of his fellow-countrymen'. ${ }^{113}$ It was apparent that Lloyd George's past credentials caused people to read, with pride, of his life as a government minister, from which many would have been proud that it was a Welshman. Later in August 1910, it was reported that Lloyd George was required to return early from a holiday abroad, owing to a command from the King to be Minister in attendance, at the royal residence at Balmoral. The newspaper report linked the impending Investiture of the Prince of Wales with this command, but it was also indicative of the nature of personal relationships, in the battle for disestablishment, when it was reported that the

\footnotetext{
111 ‘The Outlook in Wales’, Carnarvon and Denbigh Herald, 5 February 1909, p.4.

112 Ibid.

113 ‘Another Welsh Party’, Carnarvon and Denbigh Herald, 25 June 1909, p.4.
} 
Chancellor of the Exchequer would leave Balmoral for the National Eisteddfod, when he was to be the guest of the Bishop of St. Asaph. ${ }^{114}$ Reverend J. Vyrnwy Morgan, whilst recognising Lloyd George’s talents, considered that he was 'subordinating Welsh Nationalism to a larger statesmanship' and that 'undoubtedly Mr. Lloyd George does love his country dearly, but he loves ambition more’. ${ }^{115}$

However, efforts were being made to demonstrate that the Liberal party was still 'radical'. At a public meeting organised by the Tonypandy Branch of the National League of Young Liberals, an audience of over one thousand people heard Professor T. A. Levi ${ }^{116}$ describe 'The New Liberal Programme'. ${ }^{117}$ His speech was of note in that it attempted to stymie any headway being made by the Labour party, by stressing how David Lloyd George 'went further than the Socialists' and that support for Welsh members, like the Prime Minister, would, in effect, make socialism, under the guise of the Labour party, as redundant. It is significant that the Liberal Party would also be judged on the basis of its reaction to trade disputes. ${ }^{118}$ Its 'relative inactivity' in relation to the Penrhyn strike, in contrast to the Labour movement, was interpreted as an indication: 'that the middle class, Welsh, nonconformist and radical as it might be, was not to be trusted'. ${ }^{119}$ Professor Levi attached particular significance to the forthcoming Parliament Act, which he interpreted as a battering ram which would allow the aspirations of the working classes to be met. It could be argued that, in the context of concerns about the development of the Labour party, it was understandable if the Liberals felt that it was appropriate to emphasise what they had achieved, in the face of vested interests, such as the House of Lords. These claims about the future uses of the legislation are, of course, in contrast to the limited use that was subsequently made of the 1911 Parliament Act, although some might have argued that its

\footnotetext{
${ }^{114}$ Mr. Lloyd George. Receives a Command from the King’, The South Wales Daily Post, 23 August 1910 , p.2. ${ }^{115}$ Morgan, J. Vyrnwy, Welsh Political and Educational Leaders in the Victorian Era, London, 1908, pp.79-80.

116 Thomas Arthur Levi, (1874-1954), professor of law. According to the Dictionary of Welsh Biography: 'When the Law Faculty was opened at the University College of Wales, Aberystwyth, in 1901, he applied for the Chair of Law, despite the advice of the Vinerian Professor of English Law at Oxford, A. V. Dicey, that he should not throw away his brilliant gifts in such a remote and insignificant place (Levi had succeeded F. E. Smith (later Lord Birkenhead) as one of Dicey's star students). Nevertheless, Dicey supported him and he was appointed Professor of English Law at Aberystwyth.

${ }^{117}$ Liberalism and the Future', The Rhondda Leader, 28 October 1911, p.2.

${ }^{118}$ In his talk to Gresham College, on 30 January 2018, on the subject of 'The Labour Party', Professor Vernon Bogdanor suggested that: 'The Labour Party was formed as much for defensive reasons as for radical ones. It may well be that, had it not been for the judicial attack on the trade unions, there would not have been a Labour Party at all. The formation of the Labour Party seems to me a contingent matter and no way inevitable'.

${ }^{119}$ R. Merfyn Jones, The North Wales Quarrymen 1874-1922 (Cardiff: UWP, 1982), pp.278-279.
} 
influence upon the future role of the House of Lords justified such expectations: 'The passing of the Parliament Bill had opened out unlimited possibilities for the people. All around one saw the people arising out of the torpor of ages'. ${ }^{120}$ Professor Levi's expectations about the outcome were shared, albeit from a diametrically different standpoint, by those who had opposed the proposed legislation. Although the 1911 legislation might now, in hindsight, be viewed, as no more than another episode of Whig historiography, in terms of the development of British parliamentary history, it was viewed by many as being of 'revolutionary character' ${ }^{121}$, as something which would provide the means by which its enablers would achieve the policies they cherished, irrespective of the wishes of the establishment;

'The prospect of imposing upon the country Home Rule, Welsh Disestablishment, and Manhood Suffrage proved more attractive to the various ministerial groups than any oldfashioned doctrines about freedom of debate or the integrity of the House of Commons'. ${ }^{122}$

In an example of how opponents of the 1911 Parliament Act could come to then utilise it to undermine the 'Welsh Disestablishment Bill' was supplied by The Saturday Review, in June 1913.The journal recalled H. H. Asquith’s assurances, when first introducing the Parliament Bill, in 1911, that the proposed suspensory veto of the House of Lords:

'precludes the possibility - and I say this with utmost assurance - of covertly or arbitrarily smuggling into law measures which are condemned by public opinion, and it will at the same time ensure an ample opportunity for the reconsideration and revision of hasty and slovenly legislation'. ${ }^{123}$

The writer proceeds with his reproof by stating that there has: 'always has been an atmosphere of Liberal political thought associated with Welsh Nonconformity and though not now often openly advocated inside the Chapel precincts' and that 'the whole ritual of Nonconformity, and Welsh parliamentary leaders, especially the Premier, are virtually Sacrosanct', although he claimed that 'Liberal propaganda' in the chapels was now being challenged by the growth of socialism.

The suggestion that Lloyd George was 'virtually sacrosanct' might be usefully contrasted with a report, in October 1919, that: 'Speculation is rife as to whether Mr. Lloyd George may, with

\footnotetext{
120 'Liberalism and the Future', The Rhondda Leader, 28 October 1911, p.2.

${ }^{121}$ Lord Robert Cecil, ‘The Great Usurpation’, The Saturday Review, 13 January 1912, p.42.

122 Ibid.

123 'Smuggling Through Welsh Disestablishment', The Saturday Review, 21 June 1913, p.766.
} 
propriety, be styled a Tory; and if so, whether Wales will follow his leadership in the future' ${ }^{124}$ This proposition appears to jar with the 'accepted' version of Welsh history, where popular support for the Liberal party segues into general support for the Labour party. Neville Masterman, in his biography of Tom Ellis, provided an illustration of how party alliances in Wales could have been very different, when he described David Lloyd George offering Churchmen, whom he acknowledged as 'the strong element of the conservative party in Wales', the possibility of 'an alliance with Cymru Fydd and much better terms for disestablishment' and a significant role in Wales, after home rule had been secured. ${ }^{125}$ Staniforth took great delight in his caricature of Lloyd George's speech delivered at a reception which formed part of the Welsh National Liberal Convention held at Swansea in October 1908. Depicting both Lloyd George and Asquith as schoolboys, who were about to reward 'the faithful doggie', being Nonconformity portrayed as a Welsh terrier standing on its hind legs, with eyes closed and mouth open. Lloyd George's speech had been clearly intended to confirm that the Welsh Liberals' long-suffering patience and loyalty would be rewarded:

'The time has come to reward the loyalty of Wales. You don't stand for principles for anything you get from it, but for your faith in them, but all the same it is time that Liberalism, which you have done so much for and stood so valiantly by and given such a good example of, should remember the gallant little country that has always stood by it'. 126

However, the preamble to this statement should perhaps have perhaps given pause for reflection upon whether or not the supine role had served disestablishers well, as Lloyd George provided a succinct history of what Welsh Liberals had endured:

'We were Liberals in 1868 when Liberalism was victorious, and when everyone shouted for it and for religions equality. We were Liberals in 1874, when the other more fickle nationalities failed us. In 1880, when the rest came back, they found Wales still holding aloft the banner; and in 1886, when others ran away, the Welch Fusiliers held the fort. In 1900 there were only a few of us, but they were of good quality - the survival of the fittest - purified as if by fire. In 1906 it we were not like the waves of the sea, but (said Mr. Lloyd-George in Welsh) like the rocks of the mountains, and as we were in 1906 we

\footnotetext{
${ }^{124}$ W. Watkin Davies, 'New Lamps for Old', Welsh Outlook, vol.6, no.10 (October 1919), p.252. The author, William Watkin Davies (1895-1973), was a barrister, lecturer and author. He served as the history master at Friends School, Saffron Walden, 1915-17, and at Barmouth County School, 1917-19. Subsequently he lectured at Bristol University, 1919-1921, and for the League of Nations Union. He spent much of his later career lecturing in International Politics at the University of Birmingham. Davies wrote Lloyd George, 1863-1914 (London, 1939). He served as the editor of The Welsh Outlook from 1925 until 1927.

125 Masterman, The Forerunner. The Dilemmas of Tom Ellis 1859-1899, p.210.

126 'Lord Glantawe Gives a Reception', The Cambrian, 2 October 1908, p.5.
} 
shall be in 1912 (which evoked loud applause.) As it was in the beginning is now and ever shall be. Wales stands by her principles, and I congratulate her on the happy and prosperous appearance of her Liberalism'.

\section{'On the eve of the introduction of a Welsh Disestablishment Bill'.}

The Church Defence Committee met at Church House, Westminster, in March 1909, to consider its executive committee's annual report, which had concluded, gloomily, that the last twelve months 'had proved a harassing and anxious period to the Church both in England and Wales'. ${ }^{127}$ But the report delivered a strangely confused and uneasy response to the inclusion of the a Welsh Disestablishment Bill in the King's Speech ${ }^{128}$, as it believed that 'there seemed little prospect of the Bill's reaching the House of Lords', but it warned that 'it would be a serious error for Churchmen to refrain from making the fullest use of the period' before the next general election to make their case to the public. ${ }^{129}$ The Archbishop of Canterbury reiterated the need to act, and he identified that 'the line taken' by those who supported Welsh disestablishment was 'a little different', by which he meant that such opponents now treated the Church with respect, but they maintained that 'the present position and status of the Church in Wales was out of touch with Welsh thought and sentiment'. ${ }^{130}$ He opined that whether or not this was correct would be demonstrated by the report of the Royal Commission formed in 1906, whose creation he had supported as he believed that there ‘should be inquiry’. The Archbishop’s measured response was in marked contrast with the Bishop of St. David's, who both queried the number of those who belonged to the Welsh Free Churches and declared that: 'If the Welsh Church were to be disestablished it would damage the spiritual welfare of Wales as a whole'. ${ }^{131}$

In describing the prospects for Welsh disestablishment, it was evident to Mr. Ellis Jones Griffith ${ }^{132}$ that: 'In our advance towards the promised land of religious equality, we have

\footnotetext{
127 'The Primate on the Church in Wales. Church Defence Committee', The Times, 25 March 1909, p.14.

128 'The King’s Speech', HL Deb.,16 February 1909, vol. 1, cc4: ‘A Bill will be laid before you for the Disestablishment and Disendowment of the Church in Wales'.

129 The Primate on the Church in Wales. Church Defence Committee', The Times, 25 March 1909, p.14.

130 Ibid.

${ }^{131}$ Ibid.

132 Ellis Jones Griffith (later Sir Ellis Jones Ellis-Griffith), (1860 - 1926), barrister and M.P. Elected as the Liberal member for Anglesey in 1895, a seat which he held until 1918. In 1912, he was elected chairman of the Welsh Parliamentary Party and appointed as parliamentary secretary to the Home Office and took a prominent part in steering the Welsh Disestablishment Bill through the House of Commons: D.W.B.
} 
certainly passed through the rich pastures of the land of promises' ${ }^{133}$ During the course of an interview he compared the aggressive position adopted by the Irish members of Parliament, who threatened to unleash 'the dogs of war' in Ireland, if Irish aspirations were not respected and, as Mr. Jones Griffith stated: 'in politics much greater attention is paid to the dogs of war than to the puppies of peace', which suggested the reason why: 'the history of the last four years proves that Wales cannot command the attention of Parliament'.

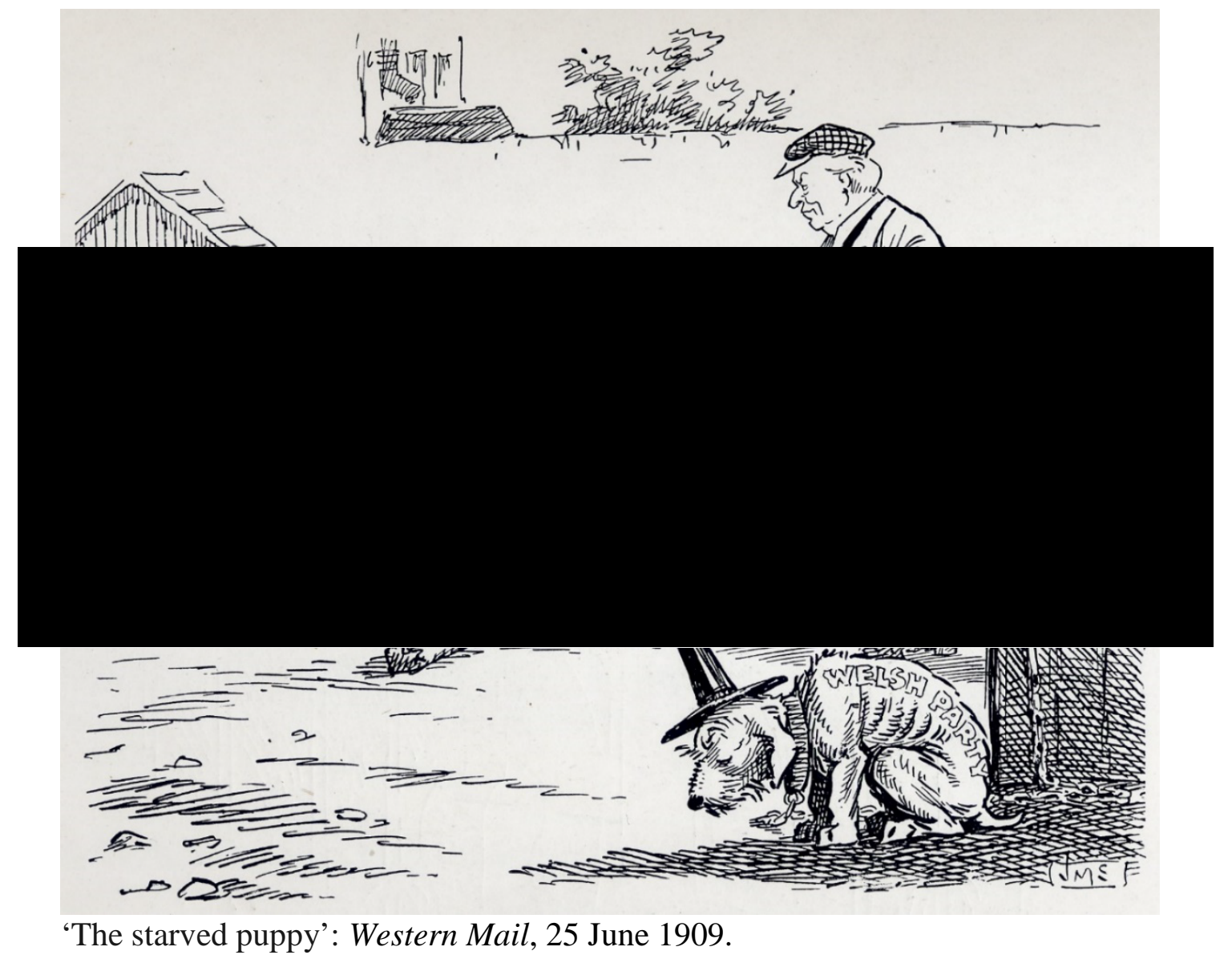

Mr. Ellis Griffith’s colourful figure of speech provided Staniforth with scope for a cartoon which admirably picked up the canine theme, with a 'starved puppy' (the Welsh Party)

133 “'Dogs of War” and “Puppies of Peace”. The Bitterness of Mr. E.J. Griffith, M.P.', Weekly Mail, 26 June 1909, p.7. 
crouched, cringing and undernourished, whilst Asquith throws bones from a tray entitled 'Irish Measures' to a large, aggressive looking well-fed hound (the Irish Party), surrounded by the remains of previous generous meals. ${ }^{134}$

\section{Like Halley's Comet. ${ }^{135}$}

It was reported in 1910 that it was 'the prevailing opinion that with the appearance of Halley's comet in May, the Welsh Church question, would again be raised in Parliament, but 'more for academic discussion rather than with the hope of becoming the law of the realm'. ${ }^{136}$ The newspaper article went on to suggest that: 'Even among Church people there are hazy notions as to the effect of Disestablishment and Disendowment' and it continued with a summary of the 'salient points'. In case there was any possibility that Churchmen within his diocese might be 'lulled into a false sense of security by so many postponements of the measure for disestablishing and disendowing the Church', and therefore not attend one of his many meetings, the Bishop of St. Asaph wrote to Churchmen in his diocese in order to stress 'the grave responsibility laid' upon them and he went on to state that disestablishment would involve the 'violently rendering asunder' of Church and State and the legislation 'would strip the Church bare and wreck her for years'. ${ }^{137}$ For some, there were sinister forces that would benefit from disestablishment and the 'divorce between State and Christianity', with the creation of 'a purely materialist and economic State' which would lead to rejoicing by 'agnostics, atheists and persons indifferent to religion of any kind'. ${ }^{138}$ During his electioneering for the parliamentary seat of Denbigh Boroughs in 1910, the same Conservative, Ormsby Gore had stated that 'one of the greatest forces for Christianity and agencies for good would be swept away' with disestablishment. ${ }^{139}$ However, Ormsby Gore had recognized that it was the issue of church

\footnotetext{
134 'The Starved Puppy’, Western Mail, 25 June 1909. The strap line reads: 'Mr. Asquith: I fear this chap, so I have to feed him well. In politics much greater attention is paid to the dogs of war than to puppies of peace'. 135 'Halley's Comet Seen at Cardiff and Barry', Evening Express, 24 May 1910, p.2. It was reported that: 'On Monday evening for the first time the inhabitants of Cardiff were fortunate enough to obtain a clear view of Halley's Comet'.

136 'St. Asaph, Disestablishment and Disendowment', Denbighshire Free Press, 19 February 1910, p.3.

${ }^{137}$ Bishop of St. Asaph’s Manifesto', The Pembroke County Guardian and Cardigan Reporter, 7 January 1910, p.3.

${ }^{138}$ Ormsby Gore, Welsh Disestablishment and Disendowment, pp.65-66.

${ }^{139}$ Denbighshire Free Press, 15 January 1910, p.5.
} 
disestablishment and disendowment that gave the Conservatives the impetus they needed in the campaign, so it was necessary to attribute it with the necessary condemnation. ${ }^{140}$

\section{Coalition.}

Whilst the Baner ac Amserau Cymru enthusiastically reported upon the holiday perambulations of the Chancellor of the Exchequer ${ }^{141}$, it would have been interesting to speculate upon the newspaper's reaction if it had been aware of his attempt to form a coalition with the Conservative Party, with the detailed memorandum of 17 August 1910, in which he listed those areas of policy which would benefit from the 'active cooperation of both the great Parties in the State’. ${ }^{142}$ This has been described as ‘the extraordinary episode of Lloyd George’s breathtaking proposal to take not only the House of Lords, but Ireland, education, national insurance, unemployment, agriculture and defence out of politics and treat them on a non-party basis of practical consensus' and F.E. Smith 'was enthusiastic and willingly set about converting his leaders to Lloyd George’s bold initiative’. ${ }^{143}$ Although Lloyd George’s memorandum identified a list of subjects stretching from housing to Imperial and Foreign Policy, it was solely concerned with Britain and Empire, and there was certainly no reference to Welsh disestablishment.

Although it was noted from correspondence that Lloyd George had assumed, 'as a condition precedent' to any coalition agreement, that an agreement on education and the issue of the Welsh Church was a 'necessary preliminary'. ${ }^{144}$ The fact that the subject was not specifically listed in his memorandum for discussion could imply that it was omitted because Lloyd George was aware that its inclusion might have forestalled any possibility of serious consideration by the Conservatives.

Whatever the case, it did not bode well and it would not be unreasonable to assume that disestablishment might have been abandoned altogether, if it was, at some stage, perceived to be a deal-breaker, or that at least would have involved a compromise, with the omission of disendowment and, perhaps, dismemberment. John Grigg described the failed attempt at a

\footnotetext{
140 Tom Williams, 'The Re-birth of Conservatism in North-East Wales: the Denbigh Boroughs in the General Elections of 1910', Denbighshire Historical Society, vol.54 (2006/2006), p.110.

${ }^{141}$ Mr. Lloyd George a Mr. Haldane yn Criccieth', Baner ac Amserau Cymru, 10 August 1910, p.3.

142 Sir Charles Petrie, Life and Letters of Austen Chamberlain, Vol.II, (London, 1940), pp.381-388.

143 John Campbell, F.E. Smith. First Earl of Birkenhead (London, 1991), p.222.

144 David Lloyd George to Lord Crewe, 20 October 1910, Crewe Papers, C/31, quoted in Toye, Richard, Lloyd George \& Churchill. Rivals for Power (London: Macmillan, 2007), p.62.
} 
coalition as 'one of the most important incidents' in Lloyd George's life, 'revealing what he really felt about the British political system. He was a good patriot, but not a good party man'. ${ }^{145}$ There was clearly, in Grigg's mind, no confusion about the nature of that patriotism. It should be added that Lloyd Georg's innovative proposal was welcomed by many politicians from the Conservative Party, as well as F. E. Smith, but Lloyd George was to attribute its eventual failure to the 'Conservative die-hards' attachment to Ulster', that topic which so often appeared to be in competition with Welsh disestablishment, as will be discussed below. ${ }^{146}$ The question of the proposed coalition could be viewed as representing an attempt to move beyond a manifestation of purely partisan posturing, as far as British politics were concerned, which in light of the crisis concerning the role of the House of Lords, would have been of appeal to many. But it did provide a further example of the manner in which the Liberal Party, in which the majority of Welshmen had placed their trust, failed to reciprocate.

\section{Waning interest?}

In his attempt to describe the development of the demand for Welsh disestablishment, and to comprehend its changing characteristics, Llewelyn Williams M.P. endeavoured to identify specific phases in that process and he believed that the 'quarter of a century between the election of 1868 and the introduction of the Suspensory Bill were years of enthusiasm, of militant and aggressive propaganda'. The introduction of the Disestablishment Bill of 1895 had 'the same effect on the fortunes of the Welsh question as the passing of the Home Rule Bill by the House of Commons has had on the fate of the Irish measure', with his conjecture that: 'The Welsh people, knowing that a great English party is committed to Disestablishment - and committed irretrievably - have somewhat slackened in their missionary zeal'. ${ }^{147}$ He went to question whether the fact that, during the 1906 general election, disestablishment was not mentioned meant that Welshmen were 'losing interest?' ${ }^{148}$ However, circumstances that followed the 1906 general election would suggest a significant separation between supporters of Welsh disestablishment and their political representatives whereas, at the same juncture, there was a significantly more sustained and formulated effort exhibited by the Church defenders. If there

\footnotetext{
145 Grigg, Lloyd George. The People’s Champion, p.272.

${ }^{146}$ Kenneth O. Morgan, The Age of Lloyd George (London: George Allen, 1971), p.48.

${ }^{147}$ W. Llewelyn Williams, M.P., 'The Welsh Claim for Disestablishment', Wales, no.1 (May 1911), p.9.

${ }^{148}$ Ibid., p.10.
} 
was a waning of interest by the Welsh in disestablishment, then it could be understandable, as the regular examples of procrastination would have dented enthusiasm and, as events were to prove, with no obvious alternative course of action in the absence of a Welsh national party. Modern observers have adopted the mantra that disestablishment had become an irrelevance and Machin, for example, held a viewpoint which has now become the accepted interpretation, as far as the historiography is concerned, that:

'The long arguments over it seemed tired, but the question was kept alive by the persistently large numerical lead of Nonconformity: after many years of impressive advance the Church in Wales could still claim only twenty-six per cent of church membership in 1905'. ${ }^{149}$

Machin's second point, about why 'the question was kept alive', appears to be strangely otiose, as surely this was the raison d'être of the whole campaign and it provided it with a continuing validity and credibility. But the oft-quoted point about the seemingly tired arguments was also reiterated in 1994: 'By the time legislation was finally passed, the disputants were repeating stale arguments'. ${ }^{150}$ It is possible that it is the historian who has become weary of the arguments, and not the contemporary protagonists and, in fact, the people who either sought disestablishment, or to frustrate it, displayed a rugged endurance and continuing passion, even in the face of blatant manipulation and prevarication by those politicians, both lay and ecclesiastical, who utilized every available means to be heard and read, but were often engaged in self-publicity or personal ego and status. The arguments, in their various guises, were, by necessity to be oft repeated, but this was a feature of the long duration of the campaign. Some politicians did tire of the topic, but this could be attributed to their failure to make substantive progress, which would have caused personal embarrassment, in addition to possibly unsettling electoral standing, or by the fact that they had developed other ambitions, such as the notable case of David Lloyd George.

\section{Looking to 1911.}

For constitutional reasons, unconcerned with Wales, the prospects for Welsh disestablishment were about to transmogrify and disestablishment became the inadvertent beneficiary of a radical change to the English legislature, allowing the campaign for disestablishment to enter a final

\footnotetext{
${ }^{149}$ Machin., Politics and the Churches in Great Britain 1869-1921, p.298.

150 “ “Disestablishment in Wales”. Report of the Welsh Religious History Society Day Conference at St. Asaph, 15 October 1994', Journal of Welsh Religious History, vol.3 (1995), p.86.
} 
phase. Unfortunately, the elimination of parliamentary veto by the Parliament Act 1911 was to occur in a climate where to many, including Liberal politicians, disestablishment represented the aspiration of an earlier era. The Church defenders were, however, ever alert to changes in the political climate. As 1910 drew to a close, Bishop A. G. Edwards attempted to cajole 'every Churchman, whether clergy or layman, to take his share in 'the work of defence' and to ensure that English Anglicans were put on notice about the work of the Church in Wales and to properly appreciate:

'the stupendous blow which Disestablishment and Disendowment would mean to that Church, and of accurately appreciating the far-reaching consequence to England, as well as to Wales, which would be involved in such a measure'. ${ }^{151}$

The Bishop now realised that the Welsh Church was about to encounter a challenge which he considered insidious, when he forecast that the: 'Constitutional question would seem to be of sufficient magnitude to overshadow all other considerations, and to demand for the time the postponement of other measures until this supreme question had been decided and clearly defined’ ${ }^{152}$ But his concern about the impending crisis was predicated upon a fear that any decision might subsume matters that were 'hardly less momentous than the Constitutional question itself', being the disestablishment and disendowment of the Church in Wales. Although he implausibly suggested that it was not for him to comment upon the future of the House of Lords, he was required to warn Churchmen of the dangers:

'Wales was, after all, not large enough to command the keen attention of the whole electorate, and wise men had repeatedly warned them that owing to this comparative insignificance a measure for the Disestablishing and Disendowing of the Church in Wales might be rushed or smuggled through Parliament without a just realisation of its true character and importance'. 153

In addition to the insecurity generated by English ennui about Welsh disestablishment, Bishop Edwards was exercised about the prospect of disestablishment occurring almost by accident, obscured by the brouhaha that would accompany the possibility of tectonic changes in the constitution. Lord Hugh Cecil had also shared a similar concern and he had spoken of the ‘unusually grave crisis' facing Church people due to the prospect of a change of the Constitution

\footnotetext{
151 'The Disestablishment Question. The Duty of Churchmen', The Welsh Coast Pioneer and Review for North Cambria, 17 November 1910, p.2.

152 Ibid.

153 Ibid.
} 
which would: 'diminish the safeguards upon which they and many other people had been accustomed to rely in the past against measures of which they disapproved'. ${ }^{154}$

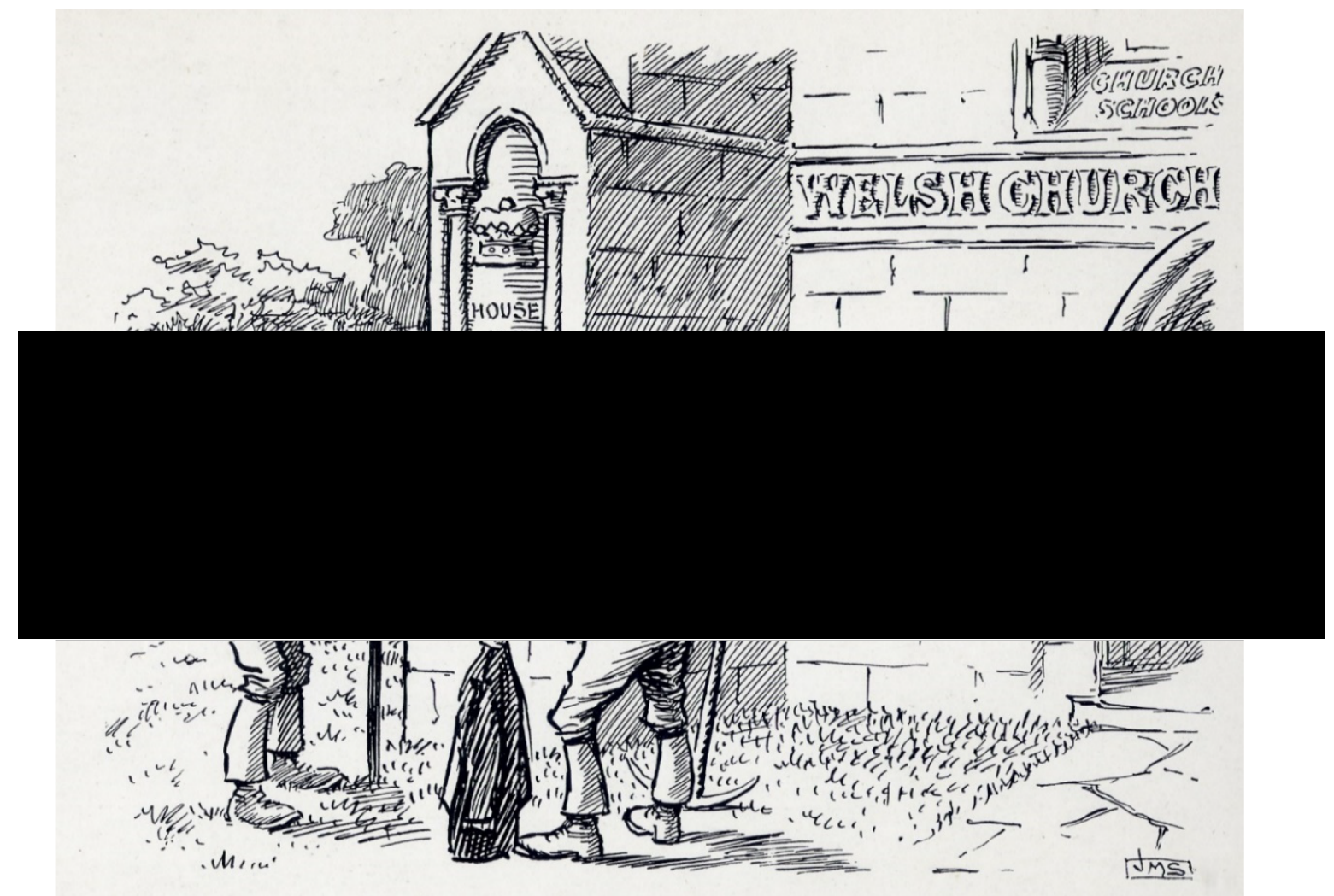

'A Main Support', The Western Mail, 5 January 1910: 'Dai (the Church wrecker): 'What we’ve got to do first, mate, is to get this 'ere buttress down, and the rest'll come down with a run.'

Lord Cecil urged his audience: 'to be up and doing, lest a fatal blow be struck against the Church in Wales and Church schools - a blow which they would never have an opportunity of undoing the mischief of. They would have no second innings' ${ }^{155}$ For both the Bishop and Lord Cecil, it did not appear incongruous that they should have placed their faith in an unelected body in order to protect the Established Church. Staniforth’s cartoon of 5 January 1910, 'A Main Support' reinforced the argument proffered by Lord Cecil, with David Lloyd George, 'the Church wrecker’, ably assisted by his fellow labourer, Prime Minister H. H. Asquith. Those who have adopted scaremongering as a tactic to obfuscate and deter change in recent times could have benefitted from a study of how Church defenders predicted the most extreme possible outcome following disestablishment, but of disendowment and dismemberment. This often aimed at any

154 'Lord Hugh Cecil. Reception by Cardiff Churchmen’, The Cardiff Times, 8 January 1910, p.5. 155 Ibid. 
liberal Churchmen who might have been swayed to support compromise and the Bishop of St.

Asaph made a ‘solemn appeal to Churchmen to stand by their Church', because:

'If the proposals of this Government became law the Church would be stripped bare; her spoliation would be as complete as the ingenuity of man would make it; her whole administration would be thrown out of gear, and her reorganisation made as difficult as possible. Short of sweeping the Church absolutely out of the land, it was difficult to imagine any proposals more confiscatory, more destructive, and more tainted with a malignant desire to cripple and grievously wound'. ${ }^{156}$

\section{The Imperial imprimatur.}

The 1911 Investiture of the Prince of Wales merits examination, in the context of the campaign for Welsh disestablishment, as it has been described as 'a manifestation of the growing conservatism of Welsh nationalism in the Edwardian period'. ${ }^{157}$ There was a concerted effort by those who recognised the potency of Welsh national sentiment to enervate it as a political force and to endeavour to redefine its parameters firmly within an English Establishment and Empire. That 'ecclesiastical politician ${ }^{158}$, Lord Hugh Cecil, who had served as a member of the 1906 Welsh Church Commission, was to state in the House of Commons, in 1911, that: 'the great task of our time is to unite the whole British Empire more closely as a single British unit' and that: 'These local patriotisms in favour of Ireland, Scotland, Wales, and England are all on the same footing. They belong to a bygone stage of civilisation. Home Rule is a sort of atavism' ${ }^{159}$

This attempt to curtail any threat to the existing establishment was admirably demonstrated by the Bishop of St. David’s, in 1912, when he firstly emphasised that Welsh nationalism as being 'literary' rather than political, but then added that it would 'make us all the better subjects of the realm because we are enthusiastic Welshmen’. ${ }^{160}$ The 1911 Investiture was an Imperial ceremony which, for all its contrived Welsh associations, was a celebration of an event which was viewed as the apotheosis of the Edwardian conquest of the thirteenth-century, held within

\footnotetext{
156 'Welsh Churchmen’s Duty. Bishop of St. Asaph on Disestablishment', Denbighshire Free Press, 8 January 1910, p.6.

157 John S. Ellis, 'The Prince and the Dragon: Welsh National Identity and the 1911 Investiture of the Prince of Wales’, Welsh History Review, vol.18, no.2 (December 1996), p.273.

158 Adrian Hastings, A History of English Christianity, 1920-1985 (London: SCM Press, 1986), p.58. The campaign to impede Welsh disestablishment attracted the constant support of Conservative illuminati such as brothers, Hugh and Robert Cecil, and Lord Selbourne, their brother-in-law, and it has been suggested that they 'more or less doubled in ecclesiastical politics'.

159 'Home Rule', HC Deb. 15 February 1911, vol. 21 cc1094.

160 The Right Rev. John Owen, Bishop of St. David’s, 'Welsh Nationalism’, Wales (June 1912), p.343.
} 
one of the castles which had been purposefully designed as a powerful manifestation of that defeat. The 'identity of the first person who thought of reviving the investiture ceremony is debatable', with two of the leading dramatis personce involved in disestablishment identified as possible candidates; David Lloyd George and Bishop Edwards, together with soldier and patriot, Owen Rhoscomyl ${ }^{161}$. John S. Ellis has written that the idea 'to locate the investiture in Wales' first came to Rhoscomyl in the late 1880s, when he was convalescing in North Wales and visited Caernarfon Castle. ${ }^{162}$ In Bishop Edwards’s account, the germ of the idea can be traced to 1893. The Bishop had written to John Owen, who was then Principal of Lampeter College, on 25 February $1893^{163}$, clearly in some excitement, and after requesting: 'Please do not let this go beyond yourself and Mrs. Owen', he wrote that he had been advised by the Dean of Windsor that the Queen commanded the Bishop to preach at the private chapel at Windsor Castle on 19 March 1893. Bishop Edwards added, with great satisfaction that: 'She is with us'. ${ }^{164}$ He went on to advise Owen that he had written to The Times, confirming that: 'We are in the fight' and, with uncharacteristic humility, that 'I shall try to follow your example'. ${ }^{165}$ When he later described a sycophantic conversation with Queen Victoria, a reference was made to the Prince of Wales's motto, and a suggestion that it was eich dyn, rather than Ich Dien, caused the Queen to exclaim that: 'The most dramatic incident in the history of the Welsh people was the presentation to the people of the first Prince of Wales. Why is not more made of the ceremony of the Investiture of the Prince of Wales?'166

\footnotetext{
161 Arthur Owen Vaughan, (1863?-1919), adventurer, soldier and author. Hywel Teifi Edwards has after Vaughan’s disappointment with the outcome of the Cardiff-based National Pageant of Wales, in 1909, 'Rhoscomyl was soon to find his Holy Grail’ in the 1911 Investiture, Hywel Teifi Edwards, The National Pageant of Wales (Gomer, 2009), p.175.

162 John S. Ellis, Investiture. Royal Ceremony and National Identity in Wales, 1911-1969, (Cardiff: UWP, 2008), p.58.

${ }^{163}$ Edwards to Owen, 25 February 1893, N.L.W., Bishop John Owen Papers, box 10/3.

164 This could not have been a surprise. After reading the parliamentary report of the debate in the House of Commons on 23 February 1893, Queen Victoria had written, critically, to Mr. Gladstone, in 25 February 1893 , to complain about his failure to be explicit about the purpose of the Suspensory Bill, and that it was, as Mr. Asquith had admitted: 'the first step towards the disestablishment \& disendowment of the Church of England!! There is no “Church of Wales” \& therefore this measure is in reality directed against the whole Church!': P. Guedalla, The Queen and Mr. Gladstone, 1880-1898 (London, 1933), p.465.

${ }^{165}$ A. G. Asaph, letter: 'The Church in Wales’, The Times, 27 March 1893, p.7. The Bishop’s letter was highly combative, criticising the Prime Minister, who had declared that in the Bishop's own diocese, 'the Church is rather a rich than a poor Church'. The Bishop also took great exception to the Prime Minister's statement of Stuart Rendel that: 'no man better knows the circumstances of Wales'. In addition to pointing out that he was 'not a Welshman by descent, birth or residence, language or property', he went on to compare extracts from speeches by both Gladstone and Rendel in order to point out inconsistencies in their interpretation of the history of the Welsh Church. 166 The Archbishop of Wales, Memories, pp.242-243,
} 
The monarch’s arrant Anglo-centric pronouncement reflected a wider English perception, as confirmed by The Spectator, during its coverage of the debates surrounding the 1894 disestablishment bill, when it demonstrated, without a scintilla of doubt, that 'history' had long settled the matter, including the fate of the Welsh language:

'But the most remarkable illustration of the spasmodic wrath with which the Welsh agitators treat the Church question, is the curious brush between Mr. Lloyd. George and Mr. Balfour on the subject of that perfectly mythical Act of Union which Welsh passion has imagined for itself in order to show that the separate nationality of Wales was recognised by Henry VIII and suppressed, and that the Established Church has been steadily employed in denationalising her. No wilder dream ever entered into ignorant historical heads. Everybody knows how Edward II was presented to Wales as a native Prince born in the Principality; and that since that stroke of Edward I's policy, there has never been any recognition of a distinct Welsh nationality’. ${ }^{167}$

The Bishop devoted a chapter of his Memories to the ceremony and it was clearly of great personal significance to him, but it is strange that he should end his account of the event with the words; 'the night of bitterness was ending and the dawn of a better day at hand', ${ }^{168}$ as the Investiture was held on 13 July 1911, in the midst of general alarm about the Parliament Bill and 1911 was identified as 'the first year of the Church Defence'. ${ }^{169}$ The Investiture had witnessed the 'establishment' on display and, rather than Welsh nationalistic feeling being to the fore, it was more akin to festivals held elsewhere within the British Empire, such as the Delhi Durbars of 1903 and 1911, being Imperial mass-assemblies convened to mark a royal occasion, with suitable recognition of the subservient, indigenous culture, but essentially an opportunity for the leaders and representatives of the vassal state to demonstrate their loyalty and feasance to the British monarchical, Imperial power and it is likely that this would have been utterly compatible with the view of many 'nationalists' like Owen Rhoscomyl whose objective was to ensure that Wales was not neglected within the Empire. ${ }^{170}$

Ellis Jones Griffith was probably under no illusions about what was about to transpire, when he wrote, in January 1912, that: 'Although there are indications that our opponents are renewing

\footnotetext{
167 'The Wrath of Wales', The Spectator, 5 May 1894, p.6.

168 Ibid., p.265.

169 Owen, The Later Life of Bishop Owen, p.145.

170 Owen Rhoscomyl, 'The Place of Wales in the Empire', Wales, July 1912, pp.369-371.
} 
their stores of epithets from the 1869 and 1895 periods, there is really no reason why this controversy as to the Church in Wales should not be conducted in a reasonable spirit on both sides'. ${ }^{171}$ According to The Times, even the Chancellor of the Exchequer's wife, Mrs. Margaret Lloyd George ${ }^{172}$, was drawn into the fray, when she warned why such a 'reasonable spirit' would be absent, by stating that Church people talked: 'of brotherly love, while with the same breath they described Nonconformists as thieves and spoilators'. ${ }^{173} 1912$ was to witness a crescendo in the campaign to achieve disestablishment, with both sides anticipating legislation and tensions heightened even further in the context of the recent, traumatic transformation in the parliamentary legislature; the terms of which were still both raw and controversial, but as J. Fovargue Bradley wrote: 'Now that a time limit has been set to the protective power of the Upper House the Church must be prepared to fight her own battles'. ${ }^{174}$ There had been a failed attempt to introduce an amendment which would have excluded disestablishment from the provisions of the proposed Parliament Bill, which would have sealed the fate of disestablishment, but the Church defenders were now aware that their ultimate tool for maintaining the status quo had been blunted to the extent that it could only provide them with time, although they were to utilize that time effectively, if not to repeal legislation, then to attenuate its impact ${ }^{175}$ They still had to adjust to a seismic shift in the powers of the legislature and the leading constitutional lawyer, A.V. Dicey, explained the true significance of the Parliament Act 1911, in that the existing 'coalition can, without the least breach of law, carry through, within little more than two years, a fundamental revolution in the oldest and most important of our institutions'. ${ }^{176}$ Lord Robert Cecil ${ }^{177}$ also added to the gloomy prognostications

\footnotetext{
${ }^{171}$ Ellis Jones Griffith, 'Welsh Disestablishment. A Review of the Present Position', Wales (January 1912), p.18.

172 Dame Margaret Lloyd George, (1864-1941), was married to David Lloyd George from 1888 to her death.

173 'Mrs. Lloyd George and Disestablishment', The Times, 12 January 1912, p.8. Mrs. Lloyd George was presiding at a meeting of the 'Carnarvon Women's Liberal Association'. She had referred to the number of anonymous, threatening letters her husband had received, but that for each such letter, he received a 'dozen others wishing him a long life'.

${ }^{174}$ A Nonconformist Minister (J. Fovargue Bradley), The Case Against Welsh Disestablishment, London, 1911, p.2: quoted from The Guardian, 18 August 1911.

${ }^{175}$ HC Deb 24 April 1911 vol 24 cc1519.

176 'Thoughts on the Parliament Act. Conclusions', letter to the Editor from A.V. Dicey, The Times, 5 February 1912, p.7. Albert Venn Dicey, (1882-1922), he held the Vinerian professorship of English law at Oxford University from 1882 to 1909 and: His Introduction to the Study of the Law of the Constitution (1885), updated by a lengthy introduction to the eighth edition (1915), established his reputation as a major commentator on the British constitution. Focus on three fundamental principles, parliamentary sovereignty, the rule of law, and constitutional conventions, enabled Dicey to provide for the general public an understanding of constitutional law': O.D.N.B.

${ }^{177}$ Robert Cecil, (later Viscount Cecil of Chelwood), (1864-1958), the sixth child of the Marquess of Salisbury. 'He was promoted to the rank of assistant secretary of state for foreign affairs in June 1918, thereby becoming deputy to his cousin A. J. Balfour, but formally resigned from the government on 21 November 1918 because as a loyal
} 
about the constitutional position in January 1912: 'We have now had five months' experience of the Constitution under the Parliament Act, and even the most prejudiced admirers of the present Government must be beginning to realise its revolutionary character. The gloomiest prophesises by opponents of that measure have been surpassed by actual results'. ${ }^{178}$

Austen Chamberlain ${ }^{179}$ raised an additional cause for English exasperation when, in an attempt to rouse the people of Lancashire in the fight against Irish Home Rule, he alleged that not only had the Liberal Party 'destroyed the Constitution as the first step towards the passage of Home Rule', but he anticipated the prospect of a dastardly conspiracy being perpetrated against the English by the politicians from the Celtic fringes, when he disclosed that:

'Welshmen are to vote for Home Rule in order that they may have the Church in Wales disestablished, and Nationalists are to vote for Disestablishment in order that they may have Welsh votes for Home Rule, and the people of England are paying the price for this bargain'. ${ }^{180}$

Reporting in December 1911, The Saturday Review added to the sense of disaster and despair. After dismissing the arguments for disestablishment, with a reminder that: 'The four British dioceses, after all, are only the western portion of the Ecclesia Anglicana', and, with a prediction which appeared to echo the findings of the 1847 'Blue Books', it anticipated that: 'Disestablish and despoil her, and the poorest districts of Wales will lapse into Paganism'. ${ }^{181}$ As matters were to transpire, the years from 1912 to 1914 were to witness a belligerence in religious affairs, and one which, despite Ellis Jones Griffith’s hopes, would be waged pugnaciously, and without mercy, from pulpits, during meeting halls and demonstrations, within newspapers and in leaflets, in Parliament, across family dining tables and in the street. ${ }^{182}$ However, the strategy that now dictated the campaigning by the Church defenders would require an added sophistication, as the

Anglican — who indeed had co-authored a book entitled Our National Church in 1913-he opposed the disestablishment of the Welsh church, which was due to be implemented once the war was over': O.D.N.B.

178 'The Great Usurpation', Lord Robert Cecil M.P., The Saturday Review, 13 January 1912, p.42.

${ }^{179}$ Austen Chamberlain, (1863-1937), a leading Liberal Unionist. The Liberal Unionists were to merge with the Conservatives in May 1912.

180 'The Campaign Against Home Rule’, The Times, 23 January 1912, p.9.

181 'A False Lead for Wales’, The Saturday Review, 2 December 1911, pp.694-695.

182 'Lively Times at St. Asaph and Rhuddlan', Flintshire Observer Mining Journal, 23 January 1913, p.7: the newspaper reported upon a Liberal speaker who held an open-air meeting in St. Asaph, on disestablishment, but he unfortunately selected 'as his rostrum' the drinking fountain presented by the late wife of Bishop Thomas Vowler Short, (1790-1872), (who was bishop of St. Asaph from 1846 to 1870, and who gave half of his income to the diocese). This led to allegations of desecration and threats to throw the speaker into the river, which caused him to quit the city. 
House of Lords could no longer serve as the Church's ultimate protector, combined with a realisation that the Church of England's concern with matters in Wales was finite.

\section{'The drum ecclesiastic was beating to arms and militant Bishops had taken to the field'.}

The government was very aware that it would encounter sustained opposition to its intended legislation and an 'extra-Parliamentary campaign' was launched by the Home Secretary, Reginald McKenna ${ }^{183}$, on 25 January 1912. ${ }^{184}$ The Home Secretary stated that he would soon introduce a bill and he knew that the measure 'would give rise to much controversy', although the fact that he had to persevere with his speech, in the face of numerous interruptions by those protesting at the exclusion of women from the franchise, would have brought it home to him that the government was already enmeshed in significant 'controversy' and that, in addition to the Suffragette movement, there was an impending national coal strike, a naval arms race with Germany and of course Irish Home Rule. ${ }^{185}$ In between the interruptions, the Home Secretary managed to declare that: 'already the drum ecclesiastic was beating to arms and militant Bishops had taken to the field'. ${ }^{186}$ He sought to explain that if the Churchmen 'came in peace they would meet them in peace; if they came in war they must fight'. ${ }^{187}$ The Times responded by claiming that the 'extra-Parliamentary campaign' was simply a defensive measure and was, in reality: 'a tribute to the thoroughness and the success of the Church Defence campaign of the last few months' and that there was: 'hardly a considerable town in the country in which either the Bishop of St. Asaph or the Bishop of St. David's has not put, or will not put shortly, the case of the Welsh dioceses before the electorate'. ${ }^{188}$ The newspaper went on to report the Bishop of St. David's confession that he had 'attended meetings in twenty-four English dioceses'. ${ }^{189}$ The Bishop had made reference to his ubiquitousness during the course of a meeting at Middleton,

\footnotetext{
${ }^{183}$ Reginald McKenna, (1863-1943), M.P. for North Monmouthshire from 1895 to 1918 and Home Secretary from 1911 to 1915, when he became Chancellor of the Exchequer.

184 'Ministers and Welsh Disestablishment. Mr. McKenna on the Plans of the Government', The Times, 26 January 1912, p.7.

${ }^{185}$ George Dangerfield, The Strange Death of Liberal England (New York: Harrison Smith, 1935). Despite the fact that Welsh disestablishment was an existential threat to one of the pillars of the English Establishment, Dangerfield did not include it as one of the four 'rebellions' which he argued had effectively undermined the Liberal Party in government, prior to the outbreak of the Great War; being the Conservative party's resistance to the 1911 Parliament Act, the threat of civil war in Ireland, the Suffragette movement and the increasingly powerful trades unions.

${ }^{186}$ Ministers and Welsh Disestablishment. Mr. McKenna on the Plans of the Government', The Times, 26 January 1912, p.7.

187 Ibid.

188 'The Disestablishment Campaign’, The Times, 29 January 1912, p.9.

189 Ibid.
} 
near Manchester, and he added that the meetings had convinced him that: 'the Government would have to overcome the whole strength of the Church of England before it could pass into law its Welsh Disestablishment Bill'. ${ }^{190}$ Despite such declarations, the Bishops of St. David's and St. Asaph were never secure in the continued attention and support from England and, therefore, it was imperative to continue to bring the question directly to English Churchmen, wherever an opportunity could be manufactured. Ellis Jones Griffith made a pointed reference to the time that the Bishop appeared to be able to expend upon his perambulations when, in a letter to The Times, in response to the Bishop of St. David's criticism of the time Griffith had taken to reply to an earlier letter, he suggested that: 'my answer would have been published earlier had I been relieved of my other work as the Bishop seems to have been relieved of his spiritual care'. ${ }^{191}$ The Dean of St. David's ${ }^{192}$ was swift to defend his Bishop and, although he suggested that how far the Bishop had 'laid aside his spiritual care may well be left to the judgement of the laymen of his diocese', he also opined that if it was spiritual work to raise money for spiritual purposes, as Nonconformists were doing, then he asked if it was not 'spiritual work to try and protect that money when it has been raised?', which appeared to confirm accusations of Anglican ecclesiastical concern with Mammon alone. ${ }^{193}$

\section{Introduction of the Established Church (Wales) Bill 1912.}

Herbert Asquith, the Prime Minister, asked leave, on 21 April 1912, to introduce a Bill: 'to terminate the Establishment of the Church of England in Wales and Monmouthshire and to make provision in respect of the Temporalities thereof, and for other purposes in connection with the matters aforesaid'. ${ }^{194}$ He proceeded to remind the members that it was:

'almost exactly fourteen years since I asked the Members of the House of Commons of that day to read a second time a Bill designed for the same purpose and framed substantially on the same lines as the Bill which I desire to ask leave to introduce this afternoon'. ${ }^{195}$

The fact that he had to admit that the case rested: 'in all its essential particulars on the same foundations now as it did then', must have caused some to wonder at the resilience of those who

\footnotetext{
190 'Welsh Bishops and Mr. Mckenna', The Times, 27 January 1912, p.6.

191 'The Question of Number', a letter to the Editor, The Times, 19 February 1912, p.4.

192 Dean James Allan Smith, (1841-1918), originally from West Sussex, he served as Dean from 1904 to his death.

193 'Welsh Disestablishment and Spiritual Care', The Times, 26 February 1912, p.7.

${ }^{194}$ HC Deb. 21 April 1909, vol. 3. cc1525.

195 Ibid., cc1526.
} 
sought Welsh disestablishment. However, others had already decided to ensure that the historical background to Welsh disestablishment should receive due consideration, albeit from a very different standpoint and a series of three linked articles on 'The Welsh Church and Disestablishment' were published in The Times, in order to coincide with the Bill. Written by 'a Welsh Correspondent', they included a historical 'retrospective, ${ }^{196}$, the question of the number of worshippers ${ }^{197}$ and buildings and language. ${ }^{198}$ The final article concluded with the assertion that the 'Church is usually treated with a degree of respect very different from what was accorded her twenty years ago' and that there was a 'change in public opinion' and that 'the real driving-force behind the policy of disestablishment has ceased to exist'. ${ }^{199}$ This reflected a theme which the Church defenders would attempt to demonstrate by mass demonstrations, by petitions and by helpful newspaper articles; that public support recognized the manner in which the Church had reformed. The Times's concerted effort to diminish the significance of the proposed legislation, by a reasoned and reasonable exposition, was in contrast with one of its editorials, on 23 April 1912, which adopted the customary partisan approach, with references to the shameful requirement for the legislative support of Irish members of Parliament and the 'humiliating position' in which the government found itself. ${ }^{200}$ The editorial was located between articles on increased German expenditure on rearmament and the Titanic Inquiry, so it would be interesting to gauge the average English reader's response, and whether they simply skimmed over the article, as their attention segued from concern about international tensions to a morbid fascination with the infamous maritime disaster. It is likely that The Times was accurate in a later editorial, when it opined that: 'It would be an exaggeration to describe the attitude of the country towards the Welsh Church Bill as one of interest, or even of concern'. ${ }^{201}$ It would have also added to the Bishop of St. Asaph’s perturbation about continuing English interest and support, a concern which had persisted since the Rhyl Church Congress of 1891, as considered in chapter four. The Bishop's disquiet might have, in part, been assuaged by The Spectator's consideration of the subject. The periodical anticipated being 'vigorously taken to task' when it identified the 'real' title which it believed should accompany the Welsh Disestablishment Bill:

\footnotetext{
196 'The Welsh Church and Disestablishment. I. A Retrospective of Two Centuries’, The Times, 20 April 1912 , p.6.

197 'The Welsh Church and Disestablishment. II. The Argument from Numbers', The Times, 22 April 1912, p.6.

198 'The Welsh Church and Disestablishment. III. Buildings and Language', The Times, 23 April 1912, p.7.

199 Ibid.

200 'The Welsh Church Bill', editorial, The Times, 23 April 1912, p.9.

201 'Echoes of the Welsh Church Debate', editorial, The Times, 30 April 1912, p.9.
} 
'A Bill to disestablish and disendow four dioceses of the Anglican Church in order that the Anglican Church in Wales should not have any apparent advantage either of status or revenue in competing with other religious denominations within the Principality'. ${ }^{202}$

Whereas anybody in favour of disestablishment would have been unfazed by such a description, as it appeared to encapsulate their aims, The Spectator considered that this harsh reality would rouse English ire, from its supposed ennui, and the journal committed itself 'to fight as long as we are able against what is to us the hideous policy of secularizing the State'. The article illustrated the chasm which divided those arguing in favour and against disestablishment and, as the next chapter will portray, the debates in Parliament, the newspaper reportage and the public demonstrations were to provide graphic evidence of the extent of that discord.

The following cartoon, with a chilling portent of what would transpire two years later on the Western Front, depicted how it appeared that the Welsh Church defenders viewed the state of play, with the Bishops of Bangor, St. Asaph, Llandaff and St. David's dug in, ready to repel their goat-like foe, with their crosiers at the high port.

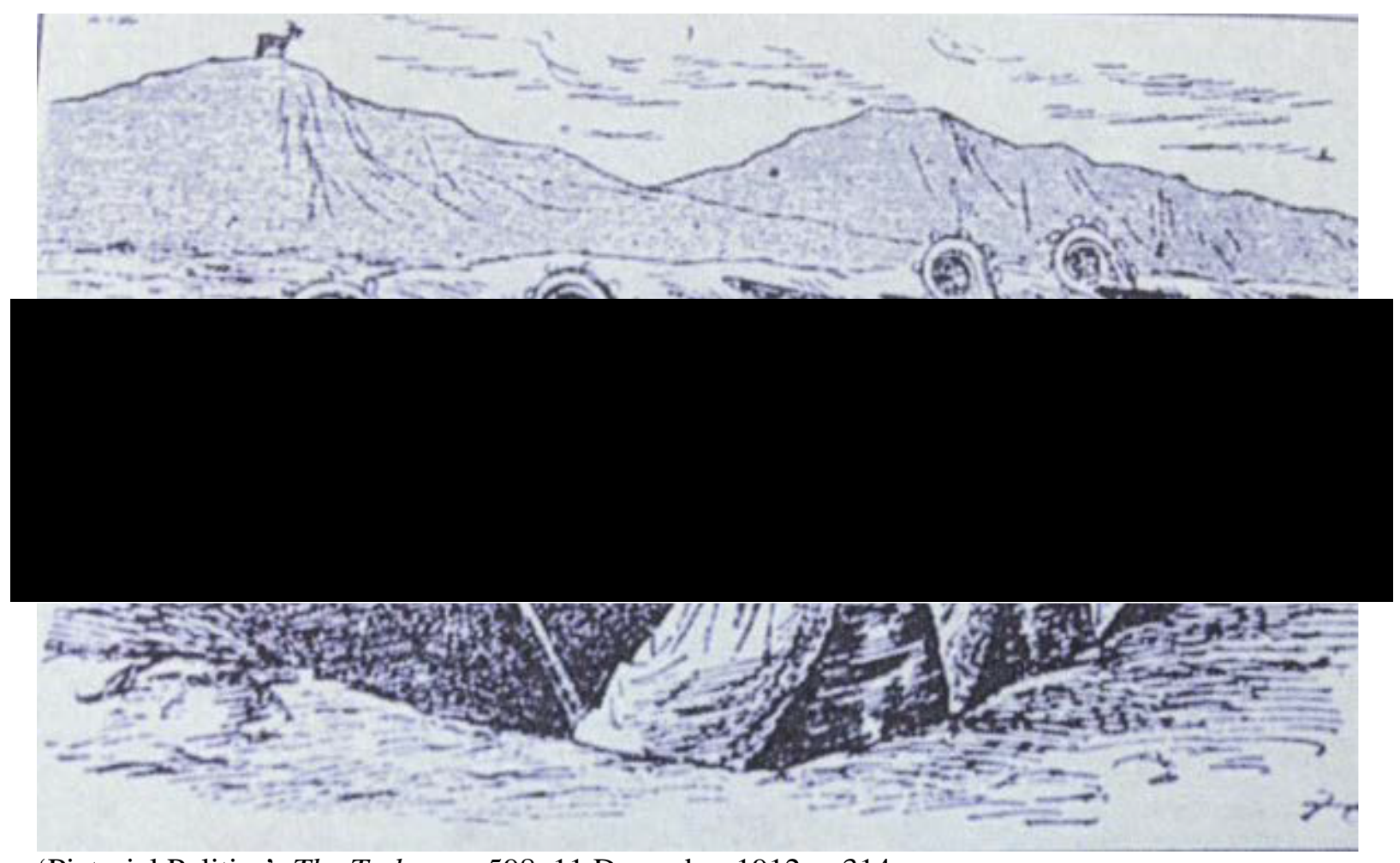

‘Pictorial Politics', The Tatler, no.598, 11 December 1912, p.314.

202 'Topics of the Day. Welsh Disestablishment', The Spectator, 27 April 1912, p.20. 


\section{Chapter three: the final imbroglio.}

Immediate responses to the Established Church (Wales) Bill 1912.

It was a sign of the times that even a draft bill which conceded 'better terms than its predecessors', particularly in relation to funding, was not to receive a positive response, and financial concessions were simply viewed as: 'tantamount to an admission that disendowment does injure and cripple the Church, and completely disposes of the hypothetical argument that it would have an invigorating effect'. ${ }^{1}$ The Bishop of St. Asaph, speaking at Peterborough, on 26 April, stated that he had been present, in the House, on 23 April. His speech was intended to respond to comments made by Sir John Simon, the Solicitor General, about Welsh nationality. The Bishop challenged Sir John's assertions that the 'Welsh people were entitled to be treated as a separate and distinct nationality’ and he again gave voice to his personal view of Welsh nationality, when he said that it was: 'difficult to prove where the Welsh nation ends and the English nation begins'. ${ }^{2}$

The Archbishop of York was also to embark upon this line of argument at a meeting in Colwyn Bay, on 13 November 1912, when he dismissed the 'national demand' for disestablishment, on the basis that: 'Until Wales was a nationality in government it could not be said that the nation of Wales had spoken on the question', although the Bishop of St. Asaph’ presence at the same meeting might suggest that the Archbishop had some assistance in the preparation of his argument, which provided a prominent headline for an article in The Times. ${ }^{3}$ If accepted, this created an impossible dilemma for Wales, as the home rule movement was to be perennially obstructed by disestablishment, with the suggestion that the 'inevitable concomitant' of the introduction of the 1912 Bill meant that the prospects for home rule 'began to appear increasingly dim’. ${ }^{4}$ It has also been mooted that E. T. John’s Government of Wales Bill 1914

\footnotetext{
1 'The Welsh Disestablishment Bill', The Times, 24 April 1912, p.9.

2 'Welsh Disestablishment. The Bishop of St. Asaph. Reply to the Solicitor-General', The Times, 26 April 1912 , p.6. The Bishop of St. Asaph also claimed that a 'Referendum would show that the majority of the Welsh people are opposed to Disendowment, whatever their views may be on the abstract question of Disestablishment'.

3 'The Archbishop of York on Nationality', The Times, 14 November 1912, p.13.

${ }^{4}$ J. Graham Jones, 'E.T. John and Welsh home rule, 1910-1914', Welsh History Review, vol.12, no.4 (December 1987), p.463.
} 
was not fully supported by Welsh M.P.s and that: 'in part this was because they did not want to jeopardise the disestablishment legislation which was proceeding through Parliament' ${ }^{5}$

It would have been difficult to imagine the Bishop of St. Asaph delivering a similar speech, describing the dearth of Welsh sovereignty, at a venue in Wales, and this was the opinion of the Cambrian Daily Leader, when it was reporting upon another attempt by the Archbishop of York, this time speaking in Cardiff, to deny Wales any standing on the issue, because it was not an 'autonomous nation'. The newspaper reported that: 'The argument is old. In Wales it is ineffective. It is the argument the Bishops take in their bags into England when they talk of the dismemberment of the Church of England. They are not so ready to use it in Wales, where the Church of England becomes the old Welsh Church - yr hen fam' ${ }^{6}$ It transpired that as matters became increasingly fraught, the Bishop of St. Asaph was prepared to resort to the argument about sovereignty, at a Welsh venue, when, in 1914, during a speech in Bangor, he maintained: 'the main argument urged for the Welsh Church Bill was that of nationality; but England and Wales were one to-day, and the Church, older than the Throne or Parliament, must only be dismembered by the will of the majority of the people of England and Wales'?

The Bishop had resorted to a similar line of argument, in his reply to the Bishop of Hereford, John Percival, who was in favour of Welsh disestablishment, when the Bishop of St. Asaph had posed the question: 'why should Wales claim the right to pull the Church of England to pieces' and, if so, why should not the 'Province of York, or Cornwall' have the same right. ${ }^{8}$ The Bishop of Hereford, as he advised a meeting of his Diocesan conference, had accepted the fact that he had been subjected to 'a considerable amount of obloquy and abuse and some misrepresentation' from politicians and newspapers, due to his pro-disestablishment viewpoint, but he was distressed that it was a speech he made in the House of Lords which 'brought down on my head a special torrent of vituperation', when he had ventured to say that:

'my episcopal brethren instead of encouraging and promoting, at this last stage, provincial demonstrations which could no longer have any possible influence on the fate

\footnotetext{
${ }^{5}$ Wil Griffith, 'Devolutionist tendencies in Wales, 1885-1914', in Debating nationhood and governance in Britain, 1885-1945 (Manchester, 2006), ed. By D. Tanner, C. Williams, Wil Griffith and Andrew Edwards, p.111.

6 'An Archbishop on Wales', The Cambria Daily Leader, 18 October 1913, p.4.

7 'Disestablishment Sky Overcast. A Profound Change in Welsh Thought. Bishop of St. Asaph’s Striking Speech', Flintshire Observer Mining Journal, 26 February 1914, p.6.

8 'Liberal Churchmen and Welsh Disestablishment', The Times, 12 April 1912, p.6.
} 
of the Bill, had simply made their protest and then, as the battle was practically over, laboured to allay ill-feeling and bitterness, they would have done a higher service to the Church'.9

A Welsh clergyman , the vicar of Clydach Vale, the Rev. W. Meredith Morris, had expressed similar views about the orchestrated efforts by the organisers of Church defence, when he referred to a 'great meeting at Mountain Ash' to demonstrate against the Bill, but he then contemplated: 'What a glorious thing it would be if we were only half as enthusiastic about the salvation of souls as we are about the saving of the cash!' 10 The question of demonstrations and, crucially, estimates of those in attendance, would be increasingly used as a gauge of public support for one side or the other, and the Conservative and Unionist supporting Brecon County Times was at pains to record the processions that 'comprised about 20,850', during the 'Magnificent Rally for the Church', held at Swansea in June 1913, with the crowd swelling to 50,000 by the time it met in the park which, the newspaper smugly exclaimed, included no children in the processions and it was not a holiday ${ }^{11}$.

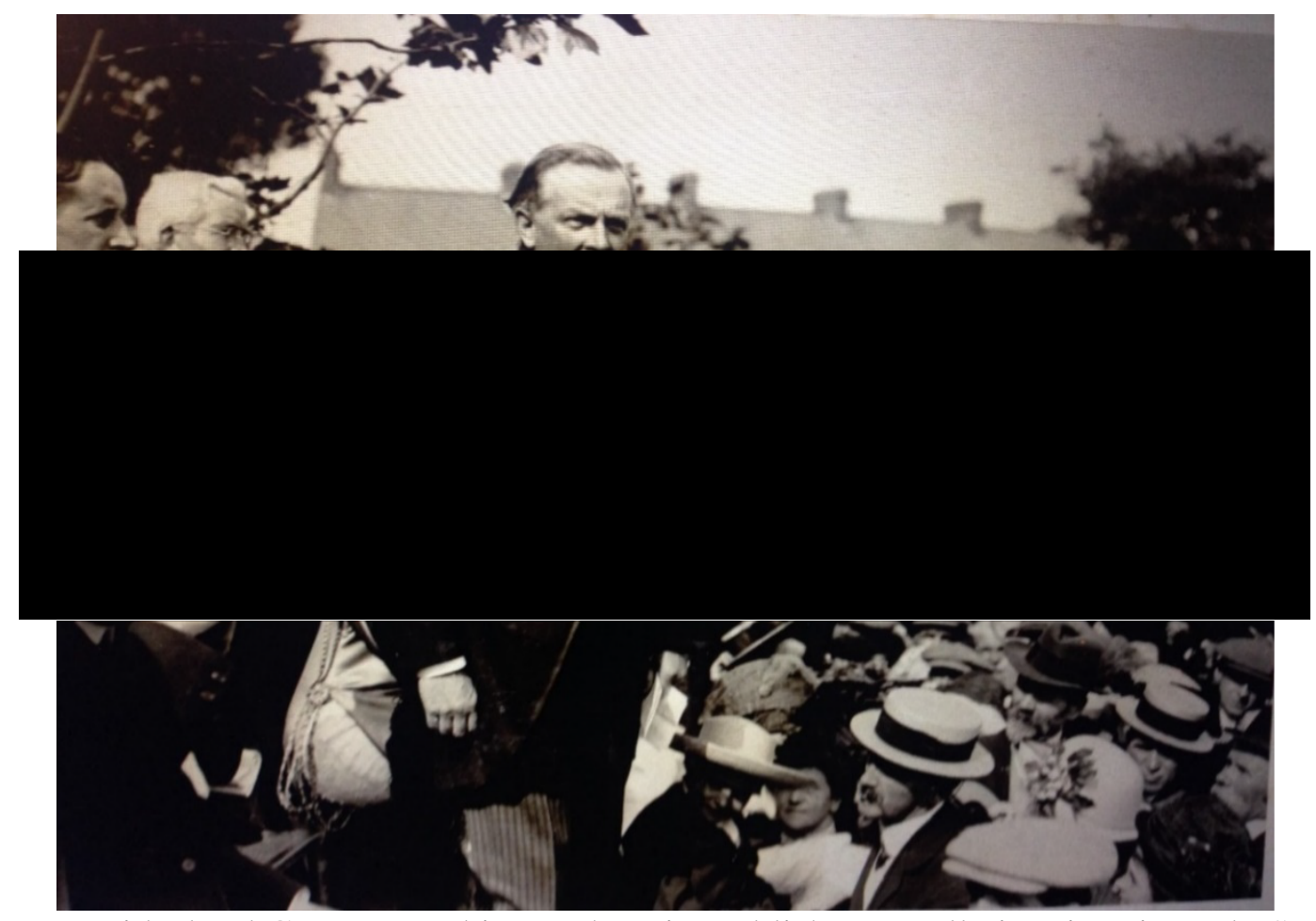

David Lloyd George speaking at the Disestablishment rally in Victoria Park, Swansea, 28 May 1912.

\footnotetext{
9 'Liberal Bishop on Disestablishment', The Carmarthen Weekly Reporter, 7 November 1913, p.3.

10 'Disestablishment and Disendowment', The Rhondda Leader, 28 December 1912, p.2.

11 ‘The Swansea Demonstration', The Brecon County Times, 3 July 1913, p.3.
} 
The newspaper therefore felt comfortable to compare their estimate of attendees with the 17,000, including children, who had marched to hear David Lloyd George speak, at the same venue, in May $1912^{12}$, although the newspaper neglected to mention that the crowd which assembled in the park was estimated at between 30,000 and $40,000 .^{13}$

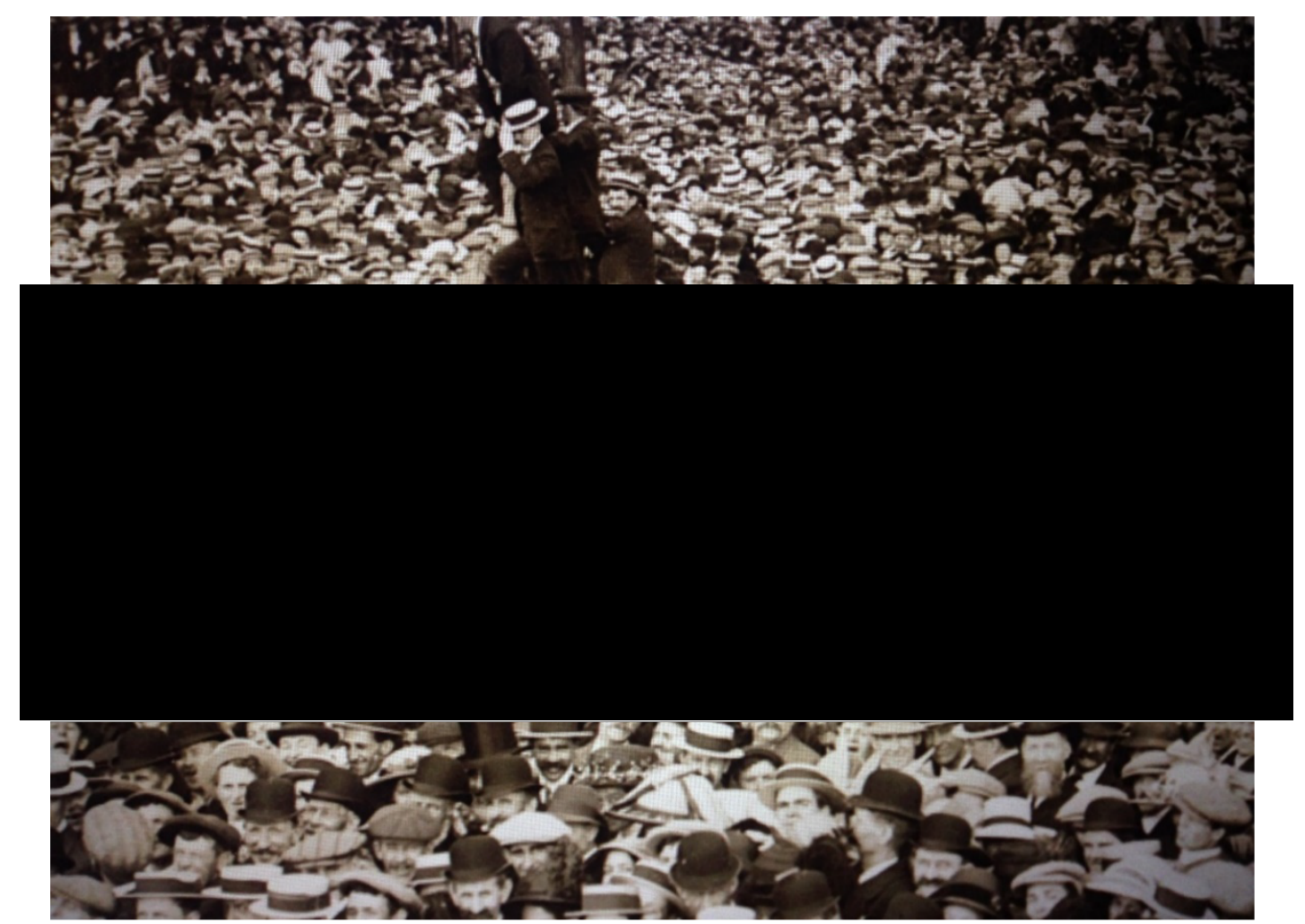

The crowd outside the Victoria Park gates on the National Disestablishment Demonstration, Swansea, 28 May 1912.

The Times was to continue with its challenge of finding superlatives to describe attendance, such as the 'impressive demonstrations against the Welsh Disestablishment Bill' which took place in London on 12 June 1912, when '13,000 Welsh Churchpeople came to London', with processions prior to a 'great gathering at the Albert Hall'. ${ }^{14}$ However, it was to admit that: 'Great meetings have become so constant a feature of modern political controversy that they have ceased to enjoy the importance formerly attached to them', citing improved communication and the efforts of organisers. ${ }^{15}$ Those who wished to march, in order to demonstrate in favour of Church defence,

\footnotetext{
12 'Disestablishment Demonstration. Mr. Lloyd George’s Pledge to Wales’, The Times, 29 May 1912, p.6.

${ }^{13}$ Carmarthen Weekly Reporter, 31 May 1912.

14 'The Welsh Bill. Demonstrations in London. Mr. Bonar Law at the Albert Hall', The Times, 13 June 1912 , p.9.

15 'The Welsh Church demonstration', The Times, 13 June 1912, p.9.
} 
had other opportunities and, page seven of the pro-Conservative and pro-Church Carmarthen Journal published on 13 June 1913 was, aside from advertisements, dedicated to descriptions of the 'Monster Demonstration at Lampeter' ${ }^{16}$ and the 'Huge Demonstration at Carmarthen'17, buttressed by a short description of the Bishop of St. David's talk, to a gathering at Cross Hands, about the 'Moral Right of the Church to its endowments' ${ }^{18}$

Initially at least, opposition appeared to be determined and the Upper House of the Convocation of Canterbury responded to the provisions of the disestablishment Bill with a resolution, which called upon: 'Churchmen and Churchwomen and other Christian people to offer the most strenuous opposition to the Government' ${ }^{19}$ The Bishop of London ${ }^{20}$, who brought forward the resolution, suggested that: 'The Bill was one which in its effect would cripple the work of God in Wales' and he 'wanted to know whether it was quite certain that Welsh opinion demanded Disestablishment'. ${ }^{21}$ The Bishop of Exeter ${ }^{22}$ seconded the resolution, with a comment that 'he could not regard Disestablishment as a purely provincial question’ and that it was their duty to 'protest and to resist', against a 'measure which was intended, without any reference to the nation or to the desire of the Church'.

Reporting upon a Conservative demonstration at Henley, in May 1912, The Times quoted F.E. Smith, M.P. as stating that, with regard to Welsh Disestablishment, 'the Bill which was before Parliament was one of the meanest Bills in the whole course of the political history of this country'. ${ }^{23}$ The future Lord Chancellor's passion as an opponent of Welsh Disestablishment also led him to make a statement, during the Second Reading of the Welsh Church Bill, that it 'shocked the conscience of every Christian community in Europe', which moved G.K. Chesterton to challenge this assertion in an ode entitled Anti-Christ, or The Reunion of

\footnotetext{
16 'Mean Little Bill. Church Defence in Mid-Cardiganshire. Monster Demonstration at Lampeter', The Carmarthen Journal, 13 June 1913, p.7.

17 'Huge Demonstration at Carmarthen', The Carmarthen Journal, 13 June 1913, p.7.

18 'The Moral Right of the Church to its Endowments', The Carmarthen Journal, 13 June 1913, p.7.

19 'The Bishops and the Welsh Bill', The Times, 1 May 1912, p.6.

${ }^{20}$ Arthur Foley Winnington-Ingram, (26 January 1858 - 26 May 1946, was Bishop of London from 1901 to 1939.

21 The Bishops and the Welsh Bill', The Times, 1 May 1912, p.6.

${ }^{22}$ Archibald Robertson, (29 June 1853 - 29 January 1931) was the seventh Principal of King's College London who later served as Bishop of Exeter.

23 'Mr. F.E. Smith at Henley', The Times, 28 May 1912, p.5.
} 
Christendom, which ended with the adjuration to "Chuck it Smith!” ${ }^{24}$ According to his biographer, F. E. Smith 'was not a religious man' ${ }^{25}$ therefore he founded his antagonism towards disestablishment upon secular reasons, interpreting disendowment as an affront to property rights and, as he claimed during a debate in the House of Commons on 21 April 1909, he could not distinguish disendowment 'from any other act of common peculation'. The Times attempted to make a case for the unpopularity of the 1912 Bill, even within the Liberal party, by reporting that: 'By desperate efforts on the part of the Whips, and by pressure of every kind upon their supporters, the Government have succeeded in obtaining a majority of 81 for the second reading of the Welsh Disestablishment Bill’. ${ }^{26}$

The Second Reading of the Bill lasted for four days, from 13 to 16 May and it was to witness several notable contributions, in addition to F. E. Smith's melodramatic statement, as stated above, including Keir Hardie’s declaration of support for the government. Hardie believed that: 'to allow the State to interfere with the religion of citizens, is an unwarrantable and dangerous encroachment which all the experience of the past has proved to be a danger to the liberty of the subject and harmful to the life of the nation'. ${ }^{27}$ The Times was keen to report upon the other ground which he quoted, as it would confirm the ultimate intentions of those supporting such radical causes, when Hardie admitted that: 'It would supply a good precedent for the abolition of the private ownership of land'. ${ }^{28}$ Although described as a devout Anglican who had considered entering the Church, J. Tudor Rees ${ }^{29}$ wrote one of the many pamphlets that appeared in 1912, in which he attempted to answer 'objections' that had been raised against disestablishment. ${ }^{30} \mathrm{He}$ attempted to rebut the claim by Church defenders that 'disestablishment is rank Socialism' by, firstly acknowledging that there are myriad definitions of socialism, but that 'Socialism's aims are not so difficult of ascertainment', in that those aims are to 'nationalise everything' ${ }^{31}$ In the case of the Anglican Church, this was impossible, as it was already effectively nationalised, with every aspect of its operation and every 'comma of its services' subject to State sanction and

\footnotetext{
${ }^{24}$ Established Church (Wales) Bill, HC Deb, 13 May 1912, vol.38, 820.

${ }^{25}$ Campbell, F.E. Smith, First Earl of Birkenhead, p.320.

26 'The Disestablishment Division', The Times, 17 May 1912, p.9.

${ }^{27}$ HC Deb 13 May 1912, vol. 38 cc840.

28 'Welsh Church Bill. Second Reading Debate Opened', The Times, 14 May 1912, p.8.

29 John Thomas Tudor Rees, (1880-1959), lawyer, judge and Liberal politician.

30 J. Tudor Rees, Disestablishment Points. Objections Answered (London, 1912).

31 Ibid., p.13.
} 
'every measure directly or indirectly affecting the welfare of the Church has to obtain the sanction of the Church'. ${ }^{32}$ He went on, with 'the dissolution of the ties that unites State and Church', there should be no 'nationalised' Church and 'this is the direct antithesis of the Socialist's aspirations'.

It was another one of Keir Hardie’s statements which merits closer scrutiny, as it both provides a partial explanation for the oft-quoted accusation that disestablishment had lost popular support and it touched upon one of the arguments of this thesis; that the political capital expended upon disestablishment did not allow other, arguably more pertinent, Welsh issues to be adequately considered and that this served the interests of those who sought to divert focus on other subjects:

'Disestablishment in Wales does not now arouse the fierce antagonism on either side which it did at the time of my first election. The reason is not that the desire for Disestablishment is dead, but because the Welsh people regard it as a settled question. It would undoubtedly suit the book of the opponents of progress to keep that question always open, dividing the Welsh people and preventing them going forward to the consideration of other topics'. ${ }^{33}$

According to The Times, the 'outstanding feature' of the fourth day of debate was David Lloyd George's 'fierce attack upon the Duke of Devonshire', in response the Duke's accusation that the government were charged with the robbery of God. ${ }^{34}$ Such allegations, in respect of disendowment, had proved to be highly charged in the past, when Herbert Asquith, then serving as Home Secretary, had been obliged to address the issue during the debate concerning the Established Church (Wales) Bill of $1895^{35}$ and the charge could be traced back to the debates prior to the disestablishment of the Irish Church in 1869, when it was rejected by the then Bishop of St. David's, Connop Thirlwall. ${ }^{36}$ In 1912, Lloyd George had countered the Duke of Devonshire accusation with a retort that: 'the very foundations of his fortune are laid deep in

\footnotetext{
${ }^{32}$ Ibid., pp.13-14.

${ }^{33}$ HC Deb 13 May 1912, vol. 38 cc840.

34 'The Welsh Church Bill. Second Reading Carried by a Reduced Majority’, The Times, 17 May 1912, p.8.

${ }^{35}$ HC Deb 21 March 1895, vol. 31, cc1574-663.

${ }^{36}$ HL Deb 15 June 1869, vol.196, cc1822, where the Bishop argued that: "such expressions as "sacrilege" and "robbery of God" applied to this subject are as irrelevant and misapplied as they are irritating and offensive’. Connop Thirlwall, (1797-1875), Bishop of St. David's from 1840 to 1874. 'On controversial issues he often took the opposite side to the Anglican episcopate': O.D.N.B.
} 
sacrilege, fortunes built out of desecrated shrines and pillaged altars ${ }^{37}$ and, in order to push the point home, he invited Members to:

'Look at the whole story of the pillage of the Reformation. They robbed the Catholic Church, they robbed the monasteries, they robbed the altars, they robbed the almshouses, they robbed the poor, and they robbed the dead. Then they come here when we are trying to seek, at any rate to recover some part of this pillaged property for the poor for whom it was originally given, and they venture, with hands dripping with the fat of sacrilege, to accuse us of robbery of God'. ${ }^{38}$

Lord Hugh Cecil was stung into high dudgeon, when Lloyd George countered accusations of 'sacrilege' and 'robbery from God', with questions of how the Cecil family had benefited from the Reformation. ${ }^{39}$ It was impossible for the Cecil family to escape its history, as a review of a contemporary book about the 'House of Cecil' demonstrated, with reference to the:

'great Lord Burghley's ${ }^{40}$ disendowment tactics. He did not leave the church even a farthing in the pound, founding the family fortunes upon rich church properties. It was left for his descendants, enjoying the proceeds of his ability as a grabber, to show the family characteristics by sticking to their possessions and hurling abuse at a nation engaged in the task of regaining national property'. ${ }^{41}$

By the time the Committee stage of the Bill began on 29 November 1912, there was evidence concerning an avenue that was being increasingly pursued in an attempt to undermine the supposed democratic legitimacy of the legislation, being the submission of petitions to demonstrate the public antipathy to the Bill. The Select Committee on Public Petitions reported that 5,655 petitions, consisting of 1,442,880 signatories, had been submitted between 1 July and 22 November 1912, coming 'mainly from Wales', although the Committee's report specifically made mention of those who were evidently visiting 'seaside or pleasure resorts' and the heads of families signing on behalf of all family members. ${ }^{42}$ As will be described below, such petitions would continue to be utilised, irrespective of suspicions about the validity of signatories or whether genuine signatories were au fait with what they were signing.

\footnotetext{
${ }^{37}$ HC Deb 16 May 1912, vol. 38, cc1325.

38 Ibid., cc1326-1327.

${ }^{39}$ Professor A.F. Pollard, Professor of Constitutional History, University College, London, was to embark upon correspondence to The Times, with a rejoinder, in a letter dated 26 April, 1912, 'But it is too late for members of an aristocracy raised on the ruins of Church property in the $16^{\text {th }}$ century to talk of sacrilege when it is proposed to divert ecclesiastical endowments to the purposes of public education and not to the foundation of noble families'.

${ }^{40}$ William Cecil, $1^{\text {st }}$ Baron Burghley, (1520-1598), chief advisor to Queen Elizabeth 1 for most of her reign.

41 'The House of Cecil', The Cambria Daily Leader, 4 March 1914, p.4.

42 'The Welsh Church Bill. Statistics of the Petitions', The Times, 7 December 1912, p.10.
} 
In addition to petitions, the Bishop of St. David's recognised the potential of using the moral panic associated with secularisation as a further ground for resisting disestablishment, particularly when more confrontational arguments had become stale and outdated. The Bishop of St. David's had developed this theme during the Flint Boroughs by-election in January 1913. It has been suggested that, by the time of the Flint Boroughs by-election, the Liberals would have preferred not to address Welsh disestablishment as the main issue, as it was already appearing to be out-dated and perceived to be losing popular support, but it was the Unionists who forced them to concentrate upon the topic. ${ }^{43}$ The Bishop was content to display his political sympathies with the Conservative Party, which were evident during the course of two meetings held in Flint and Mold in the week prior to the by-election. In addition to his usual arguments condemning disestablishment, the Bishop identified a fundamental reason why both Anglicans and wavering Nonconformists should indicate their disapproval by voting for the Unionist candidate. The Bishop attempted to arouse the fears of any God-fearing voter, when he said that: 'disestablishment in the first place was an attempt to reconstitute Welsh national life on a secular basis. Hitherto throughout all the changes of the many centuries of Welsh history, religion had been the foundation of Welsh national life'. ${ }^{4}$

\footnotetext{
${ }^{43}$ T. P. Erasmus, 'The Flint Boroughs By-Election of January 1913', Flintshire Historical Society journal, vol.31 (1983/84), p.195.

44 'In Defence of the Church. Great Demonstrations at Flint and Mold. Bishop of St. David's Eloquent Appeal', Flintshire Observer Mining Journal, 16 January 1913, p.8.
} 


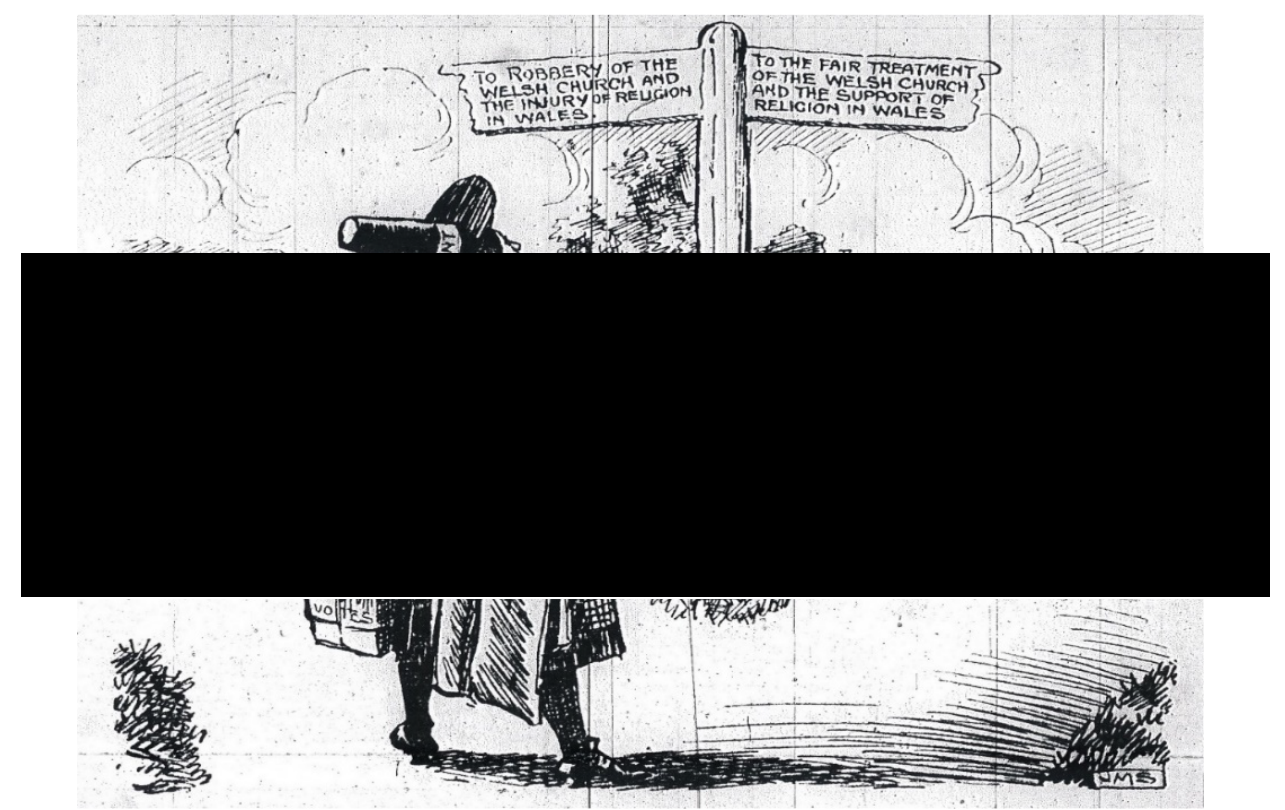

'Miss Flint: 'Which way shall I go? Prejudice says to the left; conscience says to the right', Western Mail, 21 January 1913. Staniforth's cartoon provided electors with an apparently clear choice, although a young woman appeared to represent a strange choice as the bearer of votes, at the height of the suffragette campaign.

The electoral result, which witnessed a reduction in the Liberal candidate's majority, was proclaimed as a 'moral victory', with at least one newspaper claiming that it demonstrated Welsh repugnance at the terms of the 'Spoliation Bill': 'The electors of the Flint Boroughs have made their voice heard plainly, and they have shown the Government that their proposals for the Disestablishment and Disendowment of the Church in Wales are absolutely repugnant to the Welsh people' ${ }^{45}$ The Flintshire Observer extolled the 'religious fervour' as the main characteristic of a 'great and impressive demonstration against the Bill, which was held in Wrexham, with 'about 40,000 Churchmen and Churchwomen, who came from all parts of North Wales, united in protest against a measure which seeks to cripple the Mother Church of Wales'. ${ }^{46}$

\footnotetext{
45 'A Moral Victory', Flintshire Observer Mining Journal, 23 January 1913, p.4. The Liberal majority of T.H. Parry was 211, compared with the previous 1910 majority of 509.

46 'The Voice of North Wales. Great Demonstration at Wrexham Against the Meanest Bill: Protest of 40,000. Lord Robert Cecil's Stirring Call: "Strike One Final Blow and the Victory Will be Ours.”' Flintshire Observer, 14 August 1913, p.6.
} 


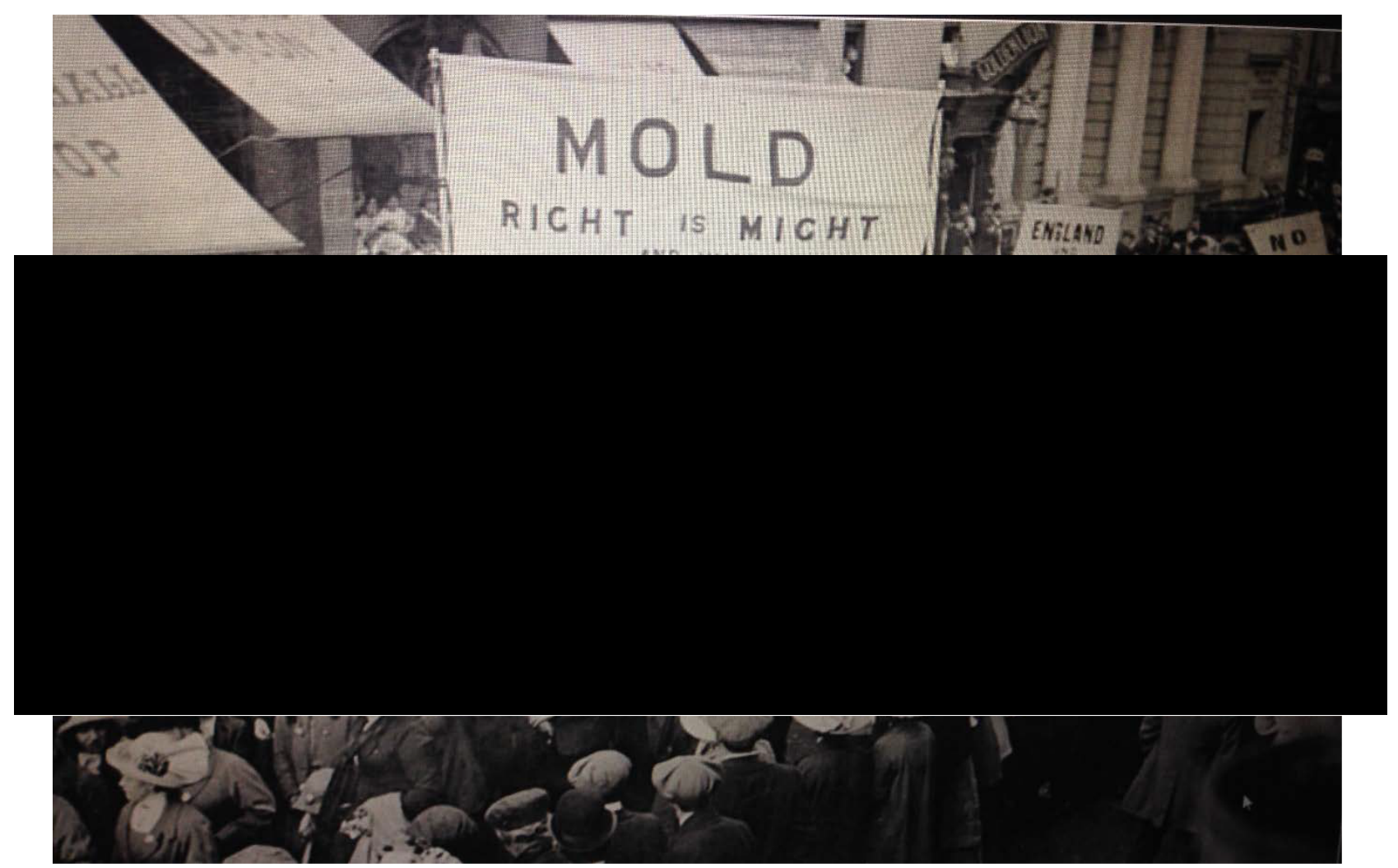

Anti-Disestablishment Demonstration at Wrexham, 9 August 1913.

The smaller banners encapsulate both a key argument by those desperately seeking to defeat disestablishment at this stage, being: 'England and Wales. One Nation. One Church', and the intransigence of their position: 'No Compromise'.

By 1913, the opponents of Welsh disestablishment were increasingly desperate about how to defeat the legislation, with The Saturday Review ending an article with an exhortation to Churchmen that the Welsh Church bill:

'must never come into operation' and this could be: 'by defeat of the Government, the withdrawal of the Bill, the suspension of the Royal Assent, or the repeal of the Act, the country must be rescued from a grievous injury to its Christian life'. ${ }^{47}$

The Hon. W. Ormsby-Gore, M.P. addressed the assembled masses and he warned that it was the intention to 'fritter away' the Church's endowments on secular purposes, and 'take it away from the highest objects of all'. The monies were to be spent it 'on a library at Aberystwyth for which many of them would not be a penny the better'. ${ }^{48}$ It was apparent that secularisation encompassed both the proposal that the Church's endowments, after disestablishment, would be

\footnotetext{
${ }^{47}$ Ibid., p.767.

${ }^{48}$ Ibid.
} 
used for secular objectives and, in addition, that this fissure between Church and State would accelerate tendencies which had already been identified in religious worship generally; a concern expressed by Anglicans and Nonconformists that the Sabbath was no longer sacred. In terms of the Church Defenders, both approaches would prove useful sources of debating points and particularly late in the campaign to defeat disestablishment, when great efforts were being made to demonstrate that an increasing number of Nonconformists were uncomfortable with the concept of disendowment.

The contention that Wales's religious life would be adversely affected, thereby expediting the secularisation of society, was to provide an argument which could be utilised to attempt to sway Nonconformists and one which lifted the debate away from the familiar, opt-repeated, but now enervated, arguments. In the years leading to 1914 it has been suggested that: 'the most pressing problem which Nonconformity, still Wales's principal religious tradition, had to face was that of responding to the secularizing process which accompanied modernity'. ${ }^{49}$ The trepidation resulting from this perceived moral panic, as recognised by both Church and Chapel, was recognized by The Spectator:

'we do not believe that the mass of lay Nonconformists desire to secularize the State, to take up the position that religion and things spiritual are matters in which the State should have no interest, and that its business is to concern itself solely with the material things of national existence, with drains and roads, guns and drums, sheep and oxen, ships and cargoes'. ${ }^{50}$

In case any Nonconformists were disinclined to be swayed by the apprehension of secularization alone, the Bishop of St. David's, during the course of a series of lectures on 'Welsh Nationality and the Welsh Church Bill', alerted 'reasonable Nonconformists' to their 'duty', with an implied threat that any hopes of future cooperation and ecumenism would be inhibited by the Bill:

'He must, therefore, press the question home on the consciences of reasonable Nonconformists, whether it was a reasonable thing to expect the growth of cordial understanding between Christian people in Wales to be helped by a bill, which in its disestablishment clauses overthrew the whole existing legal organisation of the Church, without redressing a single Nonconformist grievance, and in its disendowment clauses secularised all the ancient religious endowments of the Church, without doing the slightest good to the cause of religion in any nonconformist chapel in Wales'. ${ }^{51}$

\footnotetext{
${ }^{49}$ Morgan, The Span of the Cross, p.38.

50 'Secularized State', The Spectator, 25 November 1911, p.7.

51 'A Duty of Nonconformists', The Brecon County Times, 29 January 1914, p.5.
} 
One of the most surprising commentaries on Welsh disestablishment, at this late stage, emanated from Lord Rendel, just five months before his death. He had written to The Times, ostensibly concerned with the demonstration of a 'conciliatory attitude on the question of commutation under the present Bill', as his obituary described it but which actually contained something far more fundamental, being a considered and sober exegesis of Welsh disestablishment, which was a rare event, due the fervid nature of contemporary political and public debate. ${ }^{52}$ In his letter, Lord Rendel, who had retired from politics in 1894, when he was made a peer, reminded readers of his credentials, in that he had been 'closely connected with the question of Welsh Disestablishment' for twenty years. ${ }^{53}$ He was concerned that opponents of the proposed legislation 'wantonly averred that in this Bill Wales seeks revenge'. His Lordship attempted to counter the 'grievous and too common error in England' that supposed that 'the Nonconformist is the enemy of the Church in Wales', whereas he explained that the Nonconformist 'knows and acknowledges what Christianity in Wales owes to the Church and would never seek to cripple the Church as a Christian influence'. ${ }^{54}$ However, in case a partisan reader might have sought to interpret some weakening in his resolve, Lord Rendel concluded by affirming that the Nonconformist: 'stands immovable against State preference of the Church, any claim or practice of ascendency by the Church' and that:

'the whole fervour of Welsh nationality concentrates itself upon this demand for Welsh spiritual freedom on which alone can be based that religious reconciliation which is the first object of Wales as a nation'. ${ }^{5}$

\section{'Must keep their armour bright'.}

Sir David Brynmor Jones made mention of the majority of 107, by which the Bill obtained its third reading and he addressed the accusation that the bill would not have proceeded without the support of the Irish Nationalist vote. ${ }^{56}$ He disputed both the numbers concerned but, more importantly, argued a point which Unionists appeared to ignore, the right of the Irish to vote on Welsh, ‘Scotch’ or English matters, whilst the Union between Great Britain and Ireland remained 'unchanged'. He went out of his way to thank the 'Irish Nationalists for their help' and

\footnotetext{
52 'Death of Lord Rendel', The Times, 5 June 1913, p.10.

53 ‘The Welsh Bill. The Case for Commutation', The Times, 9 January 1913, p.10.

${ }^{54}$ Ibid.

${ }^{55}$ Ibid.

${ }^{56}$ HC Deb. 05 February 1913 vol. 47, cc.2231-337.
} 
to highlight the pride which Welsh Liberal members felt in 'that they and the Irish, who had suffered so long, were at last to triumph together' ${ }^{57}$ Sir David was keen to raise the Bishop of St. Asaph’s ‘curiously comic construction’ of the Parliament Act, when the Bishop had reportedly said that: 'The House of Lords in rejecting this Bill discharged the duty definitely imposed upon it by the Parliament Act'. ${ }^{58}$

But Sir David dismissed the claim of those who had said that the 'measure as it stood today was hardly worth having', as the financial arrangements were too liberal. He asked: 'Is it the Bill for which Thomas Gee, Henry Richard, and others fought?’ and suggested that they would not scorned the ‘boon of religious equality in Wales’ offered by a Liberal Government and a Liberal House of Commons simply because the financial arrangements were too generous. ${ }^{59}$ He did attribute any blame to the government and sought to defend the Welsh Liberal members, whose hands were forced, as they were only 21 out of 670 members. Although the report in Hansard does not record the event, The Times reported that: 'There was great satisfaction among the Government's supporters at the size of the majority, and after the division, when the lobby was crowded, the Welshmen formed a ring and sang "Land of my fathers” in Welsh' ${ }^{60}$ It also noted that the 'song was quelled by shouts of "Order"'. However, as chairman of the Welsh Parliamentary Party, Sir David was pleased:

'to have the opportunity, while the cheers that greeted our splendid majority of 107 are still ringing in my ears, of expressing mv own gratitude and that of the Welsh Liberal members to Mr. McKenna for his masterful and tactful conduct of our Welsh Church Bill at every stage. To do justice in really proper language to Mr. McKenna, "as a general in action”, 61

However, the bill was promptly rejected by the House of Lords and the Welsh Church Bill was to endure the parliamentary ping-pong, resulting from the House of Lords’ power to delay, until the summer of 1914. There were, however, warning signs that it could all be undone:

'The Welshmen who have been in the van of the fight for religious equality must keep their armour bright. The Welsh Bill is very near the Statute Book, but when it becomes

\footnotetext{
57 'Welsh Church Bill. Closing Scenes in the Commons. Mr. Lloyd George's Defence. Government Majority of 107’, The Times, 6 February 1913, p.6.

58 Sir David Brynmor Jones, 'The Position of the Welsh Church Bill’, Wales (July 1913), p.124.

${ }^{59}$ Ibid., p.126.

60 'Welsh Church Bill. Closing scenes in the Commons', The Times, 6 February 1913, p.6.

61 'A General in Action. Mr. Mckenna’s Conduct of the Welsh Church Bill', The Cambria Daily Leader, 7 February 1913, p.1.
} 
the law of the land the struggle will not be over. It was Lord Robert Cecil who reminded us, last night at Newport, that "if the Bill is passed into law under the Parliament Act it will be the first duty of the Unionist Government to restore to the Church the property that has been taken away"'. ${ }^{2}$

\section{'The journey to justice has been long, but it is nearly over'. ${ }^{63}$}

Hugh Edwards ${ }^{64}$ envisaged that: 'The forthcoming Session will undoubtedly be most momentous and epoch-making Session in the history of Parliament and that the: 'first fruits of the Parliament Act will be garnered and a new epoch in British politics will be begun'. He believed that Welsh Liberals should be proud that the 'very first measure that will pass into law under the Parliament Act will be the Welsh Disestablishment Bill'. ${ }^{65}$ Although it was apparent that, as an experienced commentator, he was felt obliged to introduce a smidgen of realpolitik, with advice for his fellow Welsh members of parliament that nothing should be: 'left to chance or to the caprice of circumstances. Wales will do well to emulate the example of Ireland in the matter of both policy and tactics. The Irish members never allow any sudden gust of popular clamour to deflect them from their course'. ${ }^{66}$

The King's Speech to the new Parliamentary session on 10 February 1914 included words which would have heartened those who had witnessed the delay created by the House of Lords: 'The measures in regard to which there were differences last Session between the two Houses will be again submitted to your consideration'. The monarch's measured, impassive words were in direct contrast to at least one newspaper's breathless anticipation:

'The session of Parliament which opens to-day is the most important that Wales has ever faced. The hope of a nation is bound up with its success. Year after year we had been content to look forward to Disestablishment and Disendowment as something with which we would, at some time or other, be blessed. Year after year we buoyed ourselves up with expectation; and, presently, bore the inevitable blow as best we could.' ${ }^{67}$

\footnotetext{
62 'After Disestablishment', The Cambria Daily Leader, 10 October 1913, p.4.

63 'The King’s Speech and Wales', The Cambria Daily Leader, 11 February1914, p.4.

${ }^{64}$ John Hugh Edwards, (1869 -1945), politician and writer. Liberal Member of Parliament for Mid-Glamorgan from 1910 to 1922 : D.W.B.

65 'Mr. Hugh Edwards, M.P. On the Duties of Welsh Members', The Carmarthen Weekly Reporter, 16 January 1914, p.4.

66 Ibid.

${ }^{67}$ The Cambria Daily Leader, 10 February 1914, p.4.
} 
The beginning of 1914 was, however, viewed very differently by the Bishop of St. Asaph, who wrote to The Times in April with a ‘suggestion' which confirmed his continuing trepidation about the attention span of English Church people, and his frustration with the Church of England, when he made an appeal just before a meeting of Convocation. ${ }^{68}$ This was based upon the oft-repeated attempt at 'project fear' ${ }^{69}$, when the Bishop prophesised that the Welsh Church Bill was 'the first step in the attack upon the Church of England' and therefore it was 'a supreme duty for those in authority to bring this fact vividly before the whole laity and clergy of the Church of England'. The Bishop suggested that a day be dedicated by the Church to disestablishment, combining a 'Special Form of Service' with a meeting at which the provisions of the bill would be explained in detail.

In March 1914 a 'Nonconformist deputation from the Diocese of St. Asaph visited London and waited upon the Prime Minister in support of the protest against the Welsh Church Disendowment proposals'. The fact that the Bishop of St. Asaph was a member of the deputation of sixteen persons caused the Prime Minister to comment, particularly as none of the twenty-nine Nonconformist ministers or 158 deacons, who had supposedly signed the petition, had considered it worthwhile to accompany the delegation. The tenor of the meeting could not have been assisted by the Asquith's criticism of the manner in which the petition had been presented to him, rather than to Parliament, and by the lacklustre responses to his questions of the delegation, who appeared to support disestablishment, but opposed disendowment for illdescribed reasons. ${ }^{70}$ The incident was to cause much merriment at a meeting of a branch of the Women's Liberal Association, with reference to the absence of the Nonconformist office-holders and the identity of petition signatories. ${ }^{71}$ The request to meet with the Prime Minister had been conducted, very publicly, through the letter pages of The Times, by the chairman of the 'Nonconformist Committee’ which was instrumental in creating the petition, John Williams, a

\footnotetext{
68 'The Welsh Church Bill. A Suggestion', a letter to the Editor, The Times, 28 April 1914, p.9.

69 “"Project Fear” started as a silly private joke during another referendum, but now it won’t go away', The Guardian, 11 March 2016.Ian Jack argued that the expression first emerged, in modern times, during the Scottish independence referendum, in 2014, as a 'handy name', as it could be used, by those seeking independence, to describe “"Better Together”s alleged Unionist scaremongering'. It entered common parlance during the 2016 European Union membership referendum campaign, to describe the attempts to influence the public by outlining the consequences of Brexit, that is leaving the European Union. There is an analogy with the dire warnings of the Church defenders and the subsequent position that developed after 1920.

70 'The Nonconformist Protest', The Carmarthen Weekly Reporter, 6 March 1914, p.3.

71 'Mrs. Lloyd George at Carnarvon. The St. Asaph Protest', Llangollen Advertiser, 13 March 1914, p.7.
} 
self-confessed Conservative, who had alleged, implausibly, that 'politics have had nothing to do with the protest' ${ }^{72}$

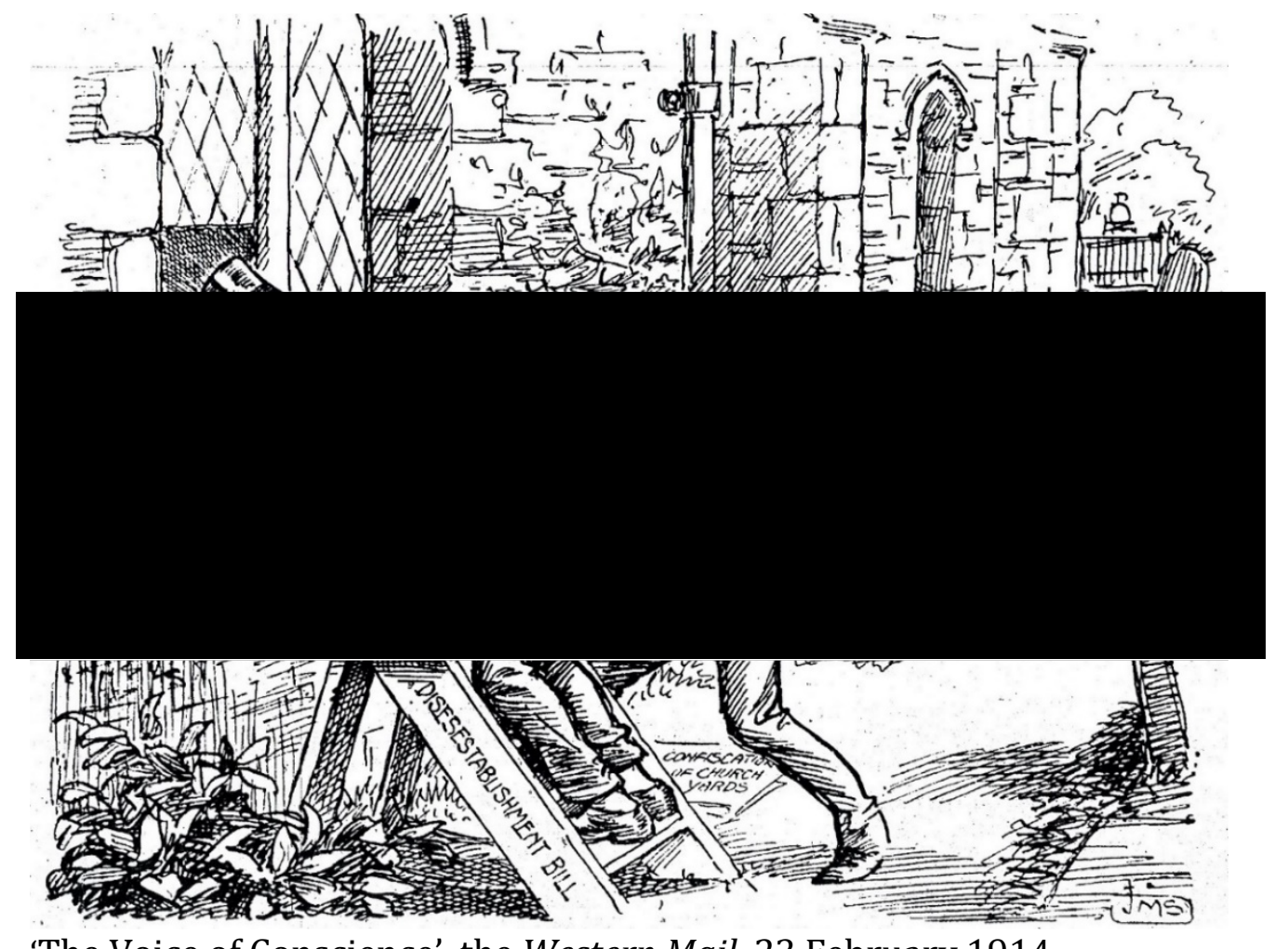

'The Voice of Conscience', the Western Mail, 23 February 1914.

The recurring depiction of Nonconformists as robbers or burglars was again utilized by Staniforth, but on this occasion, crucially, the man who attempts to prevent the theft of 'Church funds' carries a 'Petition against Disendowment' in his pocket, which appears to provide him with increased authority.

\section{The Select Committee of the House of Lords on Matters affecting the Church in Wales.}

Petitions had been intended as a belated, but important, mechanism to undermine the question of disendowment, by demonstrating that large numbers of Nonconformists disapproved of the use of the Church's funds for secular purposes. These petitions were to be a significant ploy and, as such, they formed one of the two issues to be addressed by the Select Committee of the House of Lords on Matters affecting the Church in Wales. ${ }^{73}$ The creation of the Committee was an

\footnotetext{
72 'Nonconformists and the Welsh Church', letter to the Editor, The Times, 18 February 1914, p.9.

${ }^{73}$ First Report from the Select Committee of the House of Lords on Matters affecting the Church in Wales (London, 1914), order of reference, p. ii: 'Whether the memorials alleged to have been signed by Nonconformists in Wales against the disendowment of the Church represents a real and increasing objection on the part of Welsh Nonconformists to disendowment'.
} 
important initiative, which has received little consideration due to the fact that its existence was curtailed due to the outbreak of war. Its importance was recognized by The Times ${ }^{74}$, particularly in the context of the other issue it had been tasked to examine: 'whether the constitution of Convocation of the English Church has ever been altered by Act of Parliament without the assent and against the protest of Convocation'. ${ }^{75}$ The Select Committee was therefore attempting to subvert two of the elements that would follow disestablishment, being disendowment and dismemberment which, at that juncture were causing the Church defenders more concern than disestablishment. ${ }^{76}$ The short-lived Committee met between 7 July and 4 August 1914, just a matter of weeks before the Welsh Church Act was passed, but it provided a useful means of understanding the thinking of Bishops and leading Churchmen at the threshold of Welsh disestablishment taking statutory effect. ${ }^{77}$ The genesis of this Committee could be traced to an adroit ruse by the Bishop of St. David's, again characterizing him as an astute politician, when he wrote to Lord Lansdowne ${ }^{78}$, in the context of the Bill's Second Reading by the House of Lords. The Bishop's subterfuge involved the Select Committee: 'directing the attention of the country in an effective manner, before the next General Election, to the unprincipled character of the Welsh Bill' ${ }^{79}$ The Bishop’s initiative led to the Viscount St. Aldwyn's ${ }^{80}$ successful 'motion of historical inquiry', in which his lordship could resist attacking the government for its failure to consult with Convocation, or even the Welsh Bishops, but he stressed the 'true reason for their actions, when he said that:

'the real promoters of the Bill were men like Mr. Lloyd George, Mr. McKenna, and Mr. Llewelyn Williams, whose every word and action on this subject showed their hatred to the teaching and doctrines and to the very existence of the Church in Wales. They were separatists not only in politics but in religion. It was nothing short of an act of secular tyranny'.

\footnotetext{
74 'The New Erastianism', The Times, 26 June 1914, p.9.

${ }^{75}$ First Report from the Select Committee of the House of Lords on Matters affecting the Church in Wales, London, 1914 , order of reference, p. ii.

76 'Welsh Church Bill. Nonconformist and Liberal Opposition', The Times, 22 July 1914, p.6. The evidence taken witnesses advised that a 'change had become marked since the people learned that under the Welsh Church Bill the endowments of the Church would pass into the hands of the county councils, and that freedom from the payment of tithes would not be gained'.

77 The Committee recorded that: 'In the event of a prorogation of Parliament they recommend that the Committee should be reappointed during the next session': First Report, p. iii.

78 The $5^{\text {th }}$ Marquess of Lansdowne, (1845-1927), became leader of Unionist (Conservative and Liberal Unionist peers0 in the House of Lords in 1903 and he was therefore instrumental in efforts to obstruct Liberal policies through the Unionist majority in the House of Lords.

${ }^{79}$ Owen, The Later Life of Bishop Owen, p.227.

${ }^{80}$ Michael Hicks Beach, (1837-1916), Conservative politician who was raised to the peerage, as Viscount St. Alwyn, in 1906 and as Earl St. Aldwyn in 1915.
} 
Perhaps because he knew the evolution of the motion, the Bishop of St. Asaph appeared less than effusive about matters: 'The Bishop of St. Asaph said Welsh Churchmen welcomed the appointment of this Committee, being convinced their case could be made good at the bar of history and justice. If the Bill ever got to the Statute Book it would be by a chapter of accidents; not as a child of merit, but as a child of chance'. ${ }^{81}$

In the context of the enfolding international situation, the Committee's report of the evidence it had received might have appeared inconsequential and arcane, although its influence would have been significant had war not been declared, as it would, as intended, have been an effective means of instilling a renewed, reinvigorated public interest in Welsh disestablishment, in advance of an anticipated general election. The Committee's report of evidence is emblematic of the Establishment's contemporary thinking on the two matters under consideration and, in the event of a general election, the way would have been prepared for both dismemberment and disendowment to be vanquished, with disestablishment to be deferred, until it eventually disappeared from political consideration. In 1919, the Archbishop of Canterbury made it abundantly manifest, during a debate in the House of Lords concerning the Welsh Church (Temporalities) Bill, that constitutionally the House of Commons had exceeded its authority in 1914, when it had legislated for dismemberment and he referred specifically to the 1914 House of Lords Select Committee, when he stressed that: 'had that Committee been able to make a Report it must have stated quite specifically that there was no precedent whatever for the action which Parliament had at that moment provisionally taken'. ${ }^{82}$ The Archbishop was simply reflecting the Establishment's view, but the Select Committee’s proceedings did cause Professor A. F. Pollard to conclude his summary of relevant Tudor legislation, with a statement that: 'The legal establishment of the Church of England depends absolutely upon the competence of Parliament to define - with or without the concurrence of Convocation - the constitutional position of the Church'. ${ }^{83}$ The Professor went on to compare the 'constitutional arguments used against the Welsh Bill’ with the arguments used, in vain, by Roman Catholics against the

\footnotetext{
81 'The Lords and Welsh Disestablishment. Motion for a Select Committee. Government Accept It', The Amman Valley Chronicle and East Carmarthen News, 2 July 1914, p.7.

${ }^{82}$ HL Deb., 15 August 1919, vol. 36, cc 966.

83 'Parliament and Convocation. Professor Pollard’s Appeal to History', letter to the editor, The Times, 18 July 1914 , p.4.
} 
Elizabethan Settlement. Unfortunately, Professor Pollard's constitutional justification for Parliament's actions concerning dismemberment was also lost in the lead-up to the outbreak of war and Churchmen were left with a 'keen sense of wrong' concerning the basis of that dismemberment. ${ }^{84}$ This thesis will argue that a similar sense of wrong has also permeated disendowment, due to a similar failure to appreciate what transpired.

Whereas Staniforth's cartoons had studiously ignored the inconvenient fact that disendowment would not directly benefit Nonconformists, the following cartoon, perhaps reflecting the political reality now appeared to adopt a revised critique, with Mam Cymru palpably vexed by the effort required to achieve the toppling of the 'Welsh Church Establishment', but also by the reason given. ${ }^{85}$ However, the cartoon also plays to the probable prejudice of the reader, whose animosity would have been reinforced by the suggestion that disestablishment was pursued out of 'love for religion'.

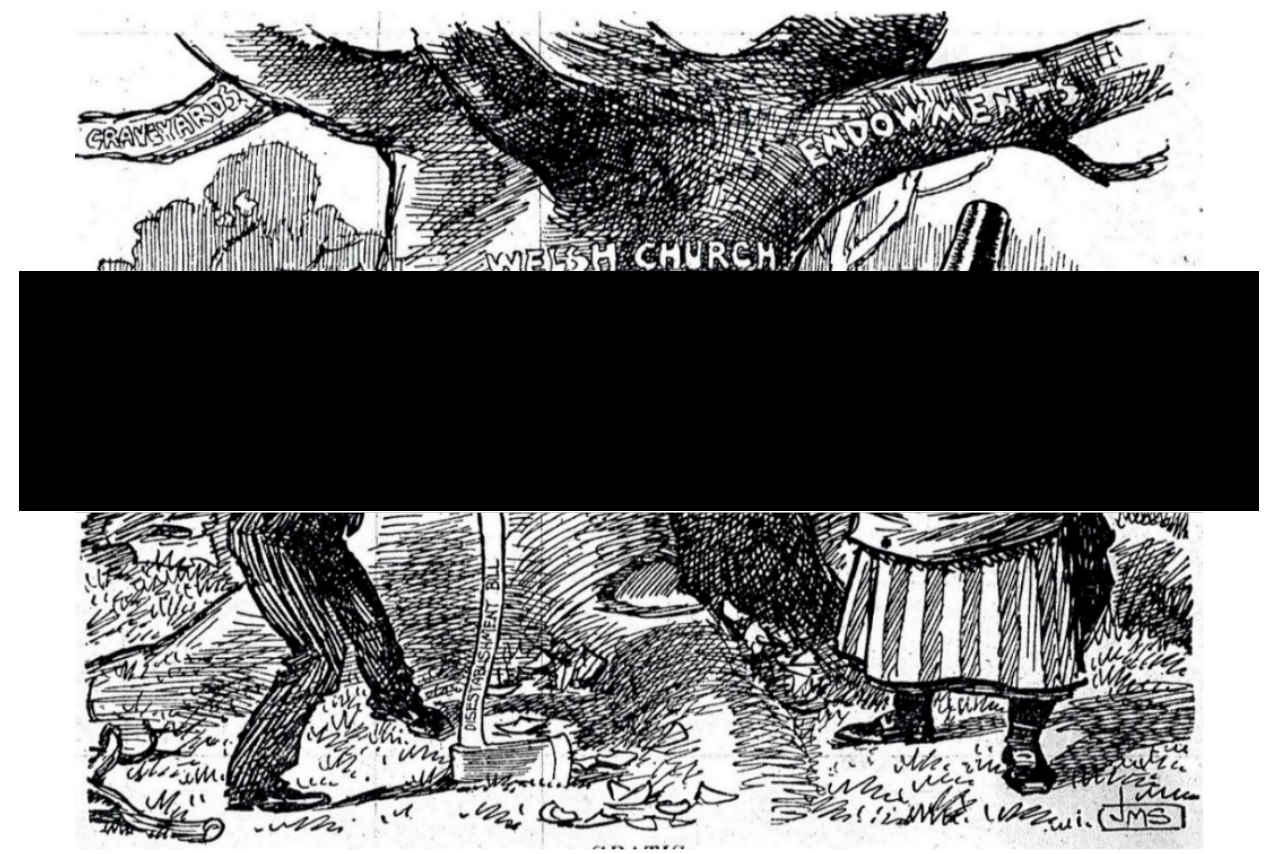

'Gratis’: Western Mail, 18 April 1914.

Political Nonconformist: 'No, mum, I get nothing for this. I do it purely out of want of love for religion'.

\footnotetext{
84 'Parliament and Convocation', editorial, The Times, 15 July 1914, p.9.

${ }^{85}$ Staniforth was proud of the fact that he could lay claim to having invented the cartoon character Mam Cymru and he explained to an interviewer that the idea had originated from the thought that 'John Bull ought to have a fit companion when he visited Wales in cartoon': 'The Welsh Cartoonist', Weekly Mail, 29 December 1906, p.10.
} 


\section{May 1914: 'a unique occasion in the history of Parliament'.}

It was noted that the third reading of the Bill was: 'a unique occasion in the history of

Parliament', because it is the first time this had taken place under the Parliament Act and it led to 'feelings of considerable depression and irritation' among those who opposed it. ${ }^{86}$ Although he had been writing to The Times about the proposed Irish Home Rule legislation, Lord Hugh Cecil would have considered that the 1914 Welsh Disestablishment legislation did not have the 'moral authority of a true law ${ }^{87}$, because it relied upon the terms of the Parliament Act, an Act which he believed had reached the statute books by 'treason' and 'Bills carried under its provisions must bear the same taint'. ${ }^{88}$ The only high point was 'a remarkable oration' ${ }^{89}$ by William Jones ${ }^{90}$, when he attempted to assuage objectors with his assertion that:

'I have in the course of my life spoken hundreds of times on Welsh Disestablishment, but I have never said a word about the religion of the Church in Wales. God forbid I should do so! Our quarrel is not with religion or with the Church. Our quarrel is with the Establishment'. ${ }^{91}$

He also understood concerns that: 'throughout the world to-day Christianity is working against infidelity, atheism, and materialism, with a united front', but he astutely reminded Members of Parliament that: 'in all our Colonies-Crown Colonies as well-and in the whole of the United States of America, it is working without an establishment'. He also addressed a more mundane issue, being the number of petitions against the Bill, by stating that: 'I have letters innumerable which show that in some cases ministers of the Gospel whose names are on the petitions never saw the petitions'. ${ }^{92}$ He dismissed claims that the legislation would lead to bitterness or conflict, but foresaw that: 'Hundreds of young clergymen who are nationalists to the core will then come out and make the Church more national than Anglican, more spiritual than Erastian, and more Christian than all'.93

\footnotetext{
${ }^{86}$ HC Deb 18 May 1914 vol 62 cc1633.

87 'The Resistance of Ulster. Lord Hugh Cecil on Mr. Churchill', The Times, 19 August 1912, p.5.

88 'The Resistance of Ulster. Lord Hugh Cecil on Mr. Churchill', The Times, 19 August 1912, p.5.

${ }^{89}$ Morgan, Wales in British Politics 1868-1922, p.270.

90 William Jones, (1857-1915), M.P. for Arfon from 1895 to 1915. Appointed a Junior Lord of the Treasury, as a 'Whip', in 1911.

${ }^{91}$ HC Deb 18 May 1914 vol 62 cc1627-90.

${ }^{92}$ HC Deb 18 May 1914 vol 62 cc1655.

93 Ibid., cc1666.
} 


\section{The endgame.}

Welsh disestablishment was to be finally achieved, after a period of at least fifty years, by an essentially English power struggle, one which reached crisis point due to the funding of old age pensions and the construction of 'dreadnought' class battleships, being the crucial element of the Anglo-German naval arms race. ${ }^{94}$ Welsh disestablishment would not, in the end, be achieved by the force or the validity of its arguments, however persuasive, or by dint of its democratic credentials, but on the coat-tails of the apparently inadvertent consequences of the remarkable, almost unimaginable, constitutional remodelling, resulting from the Parliament Act, 1911. The Bishop of St. Asaph would have reflected the opinion of many Church people, when he said that the 1914 Act was: 'unjust and its injustice as aggravated by the time and circumstances under which it was passed'. ${ }^{95}$ He was concerned with the constitutional position and, as he regularly voiced, his opinion that 'without the votes of the Irish members', who went on to represent the Irish Free State, 'there would not to-day be a Welsh Church Act on the statute book' ${ }^{96}$ Without any reservations as to stereotyping or over-simplification, he went on to identify those who had voted for disestablishment: 'strange bedfellows - few, perhaps stranger than that of the Welsh Calvinist and the Irish Papist', with 'one burning to sever the Church, the other his country from England' 97 . This was a widely held view and it provided the Spectator with the opportunity to deftly meld Welsh disestablishment with that other Celtic bête noire, Irish Home Rule;

'We all know that it is to be passed into law by Irish votes - that is, by the votes of men who, according to their own policy, ought not to have any right to interfere with the domestic affairs of this island.' 98

The Spectator reflected the view of many, including the Bishop of St. Asaph, when it opined that 'to take advantage of the presence of the Irish members to cut away four dioceses from the English Church is Political brigandage pure and simple'. 99

However, William Jones addressed the suggestion that the votes of Irish Members of Parliament had been crucial and, anyway, even if they had been, that was the constitutional position:

\footnotetext{
${ }^{94}$ Roy Jenkins, Mr. Balfour's Poodle. Peers v. People (London: Collins, 1954).

95 Official Report of the Proceedings of the Convention of the Church in Wales, held at Cardiff, October 2-5, 1917, Cardiff, 1917, p.7.

96 The Archbishop of Wales, Memories, p.285.

${ }^{97}$ Ibid., p.286.

98 The Spectator, 27 April 1912, p.20.

${ }^{99}$ Ibid.
} 
'Reference had been made to the votes of Irish members. As a Government Whip he was familiar with the figures, and if they left out of account the votes of all Irish members, Unionist as well as Nationalist, they would find that in all the important divisions the majorities for the Bill had. ranged from twenty-seven to forty-two, a clear British majority' ${ }^{100}$

The grave situation in Ireland often appeared to impact on the question of Welsh disestablishment, but P.W. Wilson provided a positive slant on any comparison between the two countries. He analysed the voting figures in general elections from 1892 to 1910, where he attempted to allocate those who were in favour of disestablishment and those who were against by reference to those who voted Liberal and Labour, on the one side, and the Conservatives on the other. The interesting extrapolation drawn by Wilson is that: 'there is no suggestion of what one may call an Ulster' in Wales. ${ }^{101}$ He helpfully defined this as there being: 'no oasis or pale where the minority holds a fortress against the prevailing opinion as a whole' and, with obvious relief: 'There is no Sir Edward Carson threatening civil war' ${ }^{102}$. Six months after war had been declared, Bishop Edwards addressed a congregation, at St. Thomas’s Church, Rhyl, on the issue of reconciling 'the profession of the soldier with that of the Christian' and he made a comment which suggested that he would have welcomed a more robust Ulster-type response to Welsh disestablishment: 'Even in civil life we had to bring in force to ward off those who would rob or outrage our homes, and in the same way, when everything else failed, the last appeal for a nation was to force where justice and freedom were at stake'. ${ }^{103}$

There was to be a crucial difference between disestablishment and the other major issues that appeared to engulf England prior to the outbreak of war. Whereas a 'truce' was, initially to be observed by both Irish Nationalists and by Ulster Unionists, who had come close to civil war ${ }^{104}$, as well as those advocating or opposing women suffrage, the 'Church party' reverted to the 'bitter controversies' over disestablishment, despite the general support for a united front in order to address the 'gravest crisis' of war:

\footnotetext{
100 'Welsh Disestablishment Bill', Abergavenny Chronicle, 22 May 1914, p.2.

${ }^{101}$ Wilson, Welsh Disestablishment, pp.7-8.

102 Ibid., p.9.

103 'Bishop of St. Asaph at Rhyl. A simple answer to the doubtful', The North Wales Chronicle and Advertiser for the Principality, 19 February 1915, p.5.

104 O’ Day, Alan, 'Irish Home Rule and Liberalism', in O’ Day, Alan, (ed.), The Edwardian Age: conflict and stability 1900-1914, London, 1979, p.113.
} 
'In addition to the disturbances caused in our country by the War, we are now, unluckily, also disturbed by a distinct breach in the political truce agreed to by both parties to postpone political disputes of a domestic character until after the termination of hostilities' ${ }^{105}$

\section{'It has been a long fight; many have been sacrificed on the way, but the loyalty of Welsh}

\section{Liberalism to the great principles involved was won' ${ }^{106}$}

It was apparent, at least to The Times, that whilst the House of Commons was occupied with Welsh disestablishment on 18 May 1914, the 'real attention of Parliament and of the country' was concentrated upon the situation in Ireland, and particularly 'Ulster'. The newspaper believed that 'under more favourable conditions the fate of the Church in Wales would excite profound anxiety'. ${ }^{107}$ The article confirmed that 'the final stages of the Bill are being watched with painful apprehension', but it was, the newspaper suggested, 'a characteristic of British politics that the bulk of the electorate is unwilling to think of two things at once', with the Ulster crisis overshadowing all else. It was probably in this context that Bishop Owen, who was always adept at reinterpreting his anti-disestablishment rhetoric to reflect events or the contemporary mood, pursued his last-ditch attempt to prevent the Welsh Church Bill becoming law, a week after the start of the Great War. This demonstrated a flagrant attempt to harness something akin to moral blackmail when, in the context of a country now at war, he was to forecast that the:

'inevitable consequence of passing the Welsh Church Bill now would be to deal a staggering blow to the work of the Church in Wales when that work is specially needed to strengthen the people to endure all that they will have to endure'. ${ }^{108}$

In the event that this dire warning was insufficient, he continued by an extraordinary statement that: 'a needless confiscation of religious endowments would seem to multitudes of people an act of dangerous presumption which would weaken their hope of the blessing of Almighty God upon the forces of our country now engaged in war'. Asquith was to be left in no doubt that the British war effort in this major conflict would be jeopardised by the prospect of Welsh disestablishment and disendowment. Although there no evidence that this perturbed the Prime Minister, others

\footnotetext{
105 'The Welsh Church Act', The Cambrian News and Merionethshire Standard, 2 April 1915, p.4.

106 'Sir Alfred Mond and the Welsh Church Bill', The Amman Valley Chronicle, 28 May 1914, p.1.

107 'The Work of the Covenanters', The Times, 19 May 1914, p.9.

108 Owen to the Prime Minister, Mr. Asquith, 10 August 1914, (N.L.W., Bishop John Owen papers: box 10/4).
} 
were less insouciant and it was reported that a 'Church of England writer' had, in April 1916, argued that:

'since the Disestablishment Bill was passed by the British Parliament at the instigation of Welsh Nonconformists, Irish Catholics, and English Atheists, no success has crowned our arms in the great war. Is this the curse of God?'109

On 18 September 1914, the Welsh Disestablishment Bill, and the Suspensory Bill were passed and received Royal Assent, ${ }^{110}$ indicating that disestablishment was on the statute book, albeit that there was uncertainty about implementation.

'Welsh and Irish Bills Passed on Friday in the House of Lords, the King through a Royal Commission, gave his assent to the Irish Home Rule Bill and the Welsh Church (Disestablishment and Disendowment) Bill. Parliament was prorogued until October 27th. This closes a memorable struggle waged for generation after generation by Wales and Ireland. The two acts are suspended for a period owing to the War'. ${ }^{111}$

There could be no starker, nor poignant, way of emphasising changing circumstances, but to note that during the following day, David Lloyd George delivered a speech which was focused on another great struggle that was to be waged, which would lead to the death of 35,000 Welshmen. Lloyd George, who was then Chancellor of the Exchequer, spoke to London Welshman about the 'little 5-foot-5 nations', and the requirement to address the German spirit of militarism. ${ }^{112}$ His exhortation being in marked contrast to his belief, fourteen years earlier, in relation to the Boer War, when he appealed, to Wales, 'herself a small nation, which had fought for centuries for her rights, not to assist in the work of extinguishing two small nations in South Africa' ${ }^{113}$ The early champion of disestablishment was now suggesting that a 'new patriotism' should be recognised by Welshmen and the leaflet containing his 'call to arms' ends with the chilling words; 'There was a big rush of Recruits to the Recruiting Room after the Meeting'. ${ }^{114}$

Perhaps in keeping with the times, or simply by dint of past experience, The Cambrian News adopted a particularly sombre analysis of the 'new conditions which the Church

\footnotetext{
109 'The Curse of God', Cambria Daily Leader, 4 April 1916, p.4.

${ }^{110}$ Morgan, Wales in British Politics', 1868-1922, p.271.

111 'Welsh and Irish Bills Passed', Haverfordwest and Milford Haven Telegraph, 23 September 1914, p.2.

112 David Lloyd George, Through Terror to Triumph! An Appeal to the Nation by the Chancellor of the Exchequer. A Speech delivered at the Queen's Hall, London on September 19 ${ }^{\text {th }}, 1914$ (London, 1914), p.10.

113 Manchester Guardian, 25 April 1900.

${ }^{114}$ Lloyd George, Through Terror to Triumph! An Appeal to the Nation by the Chancellor of the Exchequer, p.15.
} 
Disestablishment Act has brought into existence’, with further: 'agitation, conflicts, and bitterness' anticipated, together with attempts to repeal the legislation, although it did not believe that they would be successful or at least, if they were: 'then there will be revolutions which will have far more serious effects’ than disestablishment itself. ${ }^{115}$ It associated any success in overturning the Act with 'brute force' and Church adherents thereby facilitating 'the rule of wildcat Socialists'. ${ }^{116}$ Such scare-mongering would suggest that the newspaper was more concerned about repeal than it revealed in its reports. In a follow-up article, the newspaper suggested that the: 'power of the adherents of the Conformists of Wales to govern in future their own church affairs will bring about great and startling results of many kinds', presumably hoping to persuade Churchmen of the future benefits. ${ }^{117}$ Whether this strategy was strengthened by a reference to 'the position that women will occupy in future in the churches, Conformist and Nonconformist', was moot, but it described the 'humiliating position that is enforced upon women by all religious denominations' and posited that:

'If a woman is fit to be the queen of this country, surely a woman is fit to be a curate, or a deacon, or an archbishop ${ }^{118}$. The Church of England will not long be able to treat women as the religious inferiors of men. Women are taking a prominent place in the war which is now going on'. 119

Although the path to Welsh disestablishment was facilitated by the Parliament Act 1911, it was a collateral beneficiary, Irish Home Rule demanding the focus. Prior to the Parliament Act 1949, only two pieces of legislation had been enacted through the provisions of the Parliament Act 1911, being the Welsh Church Act 1914 and the Government of Ireland Act 1914 (also known as the Home Rule Act). ${ }^{120}$ The Welsh Church Act is often attributed with secondary importance, if mentioned at all and this is ironic, because although the implementation of the Government of Ireland Act was, like the Welsh Church Act, postponed, due to the outbreak of war, it never took effect, being superseded by the Government of Ireland Act, 1920, which led to the partitioning of

\footnotetext{
115 'Welsh Church Establishment', The Cambrian News, 16 October 1914, p.4.

116 Ibid., p.5.

117 'Welsh Church Disestablishment', The Cambrian News, 23 October 1914, p.4.

118 It would be 1992 before the Church of England's General Synod voted to permit women to enter the priesthood and 1994 until the first group were ordained. The Church in Wales would permit women priests in 1997. 119 Ibid.

${ }^{120}$ R. Kelly and L. Maer, 'The Parliament Acts', Briefing Paper no.00675 (House of Commons Library, 25 February 2016), p.4. Only four acts have been passed since 1949.
} 
Ireland. ${ }^{121}$ During its consideration of Jackson \& others v the Attorney General, in 2005, the House of Lords was asked to consider the validity of the Parliament Act 1949, and therefore the controversial Hunting Act 2004, which had become law under the provisions of the 1949 Act. Their Lordships considered the parliamentary debates preceding the Parliament Act 1911, and their observations were an explicit confirmation of the way in which the two acts were usually considered, with the Welsh Church Act mentioned in a final, throw-away afterthought:

'The known object of the Parliament Bill, strongly resisted by the Conservative party and the source of the bitterness and intransigence which characterized the struggle over the Bill, was to secure the grant of Home Rule to Ireland. This was, by any standards, a fundamental constitutional change. So was the disestablishment of the Anglican Church in Wales'. ${ }^{122}$

The status of the Welsh Anglican Church, and the associated constitutional implications, were made abundantly clear by the then Home Secretary, Winston Churchill, during the debates preceding the 1911 Act:

'What measures, says the right hon. Gentleman, are the House of Lords blocking? Let us be quite frank. We wish to make a national settlement with Ireland. We wish to free Wales from its alien church. We wish to deal with the grievance of Nonconformists' ${ }^{123}$

\section{Political and personal differences: 'Friends through it all'.}

The Archbishop of Canterbury’s Chaplain sent Bishop Owen a revised draft of the report of the Archbishops' Committee on Church and State. ${ }^{124}$, but with an express condition that it could only be read by the Bishop 'and other Welsh bishops if you desire'. ${ }^{125}$ The fact that Owen had been the recipient, and that he had discretion about circulation, might suggest that he was expropriating the role of the leading Welsh bishop, which had been held by Bishop Edwards since his elevation in 1889. There had been a suggestion of this, in addition to an indication of

\footnotetext{
${ }^{121}$ Philip Norton, 'Parliament Act 1911 in its Historical Context', in Feldman, D., (ed.), Law in Politics, Politics in Law, Oregon, 2013, pp.155-173.

122 Jackson \& others v the Attorney General, [2005] UKHL, paras 29 and 31.

${ }^{123}$ House of Commons Debate: 12 April 1910, vol.16, col.1140.

124 The Archbishops' Committee on Church \& State, London, 1917. The Committee met in 1914 and 1915. Some in the Committee believed that disestablishment 'would prove to be the only way of securing spiritual independence', whilst others believed that the 'advantages' would not 'provide adequate compensation for the severance of the historic connection between Church and State' p.39.

Although it was reporting before Welsh disestablishment took place, the Committee was remarkably reticent about the situation in Wales, with only a single paragraph, which simply declared that it 'is probably the greatest interference on the part of the State in the affairs of the Church', condemning the 'invasion' of Church and Crown rights in terms of the proposed dismemberment: p.241.

125 Archbishop’s Chaplain to Owen, 7 August 1915, N.L.W., Bishop John Owen papers, 8/8.
} 
Owen's close collaboration with Frank Morgan, when Bishop Owen confided to Morgan details of a private meeting of the Welsh bishops, in which the bishops agreed that they wanted to commence ‘public action’. Owen also added, perhaps pointedly, as it would have been assumed in earlier years, that it was agreed that 'St. Asaph should stand on our behalf'. ${ }^{126}$ Whereas Bishop Owen had, in the perception of many, garnered a critical role for himself, as demonstrated by the extended influence exercised at the time of the Royal Commission, including communication with politicians such as Lord Hugh Cecil, there was one secular politician with whom he was unable to collaborate, being David Lloyd George.

It was perhaps this failure, particularly when Lloyd George became Prime Minister in December 1916, which militated against him assuming Bishop Edwards’s lead mitre, as the friendly relationship between Lloyd George and the Bishop Edwards was significant and influential, particular with regard to how disendowment would be softened. Indeed, the relationship between Lloyd George and Edwards had been held out as an exemplar of how warring Churchmen and Nonconformists should hold their animosity in check and: 'Just pause and think a little bit about Lloyd George and Bishop Edwards’. ${ }^{127}$ Lloyd George stayed at the Bishop’s palace, when he visited the Rhyl Eisteddfod in 1904. ${ }^{128}$ David Lloyd George’s brother described the 'development of a close friendship' between the two men, which dated from $1903 .{ }^{129} \mathrm{Sir}$ Marchant Williams ${ }^{130}$ had 'laughingly suggested that if Mr. Lloyd George and Bishop Edwards, his "friend and foe", exchanged clothes - nobody would distinguish them by their Eisteddfodion speeches'. ${ }^{131}$ This was to cause great merriment because, at the time he delivered his speech, Lloyd George, the ‘inveterate golfer’ had borrowed an episcopal suit, as he had forgotten his

\footnotetext{
${ }^{126}$ Owen to Frank Morgan, 3 October 1914, N.L.W., Bishop John Owen papers, letters from Frank Morgan, $12 / 7$.

127 'Friends Through It All', The Aberystwyth Observer, 15 September 1904, p.3.

${ }^{128}$ Lloyd George entered the Eisteddfod pavilion with Bishop Edwards and he later delivered a speech in which he stated that: 'Wales possessed every essential element of national success genius, aspiration, patriotism, readiness of sacrifice for principal-yes, the nation possessed a country worth making an effort to save'. He added that: 'They might not see her at her best at all times at Rhyl but let them leave the seaside places of resort and go further inland, into her rich vales, picturesque mountains': 'National Eisteddfod', The Aberystwyth Observer, 15 September 1904, p.3.

${ }^{129}$ W. George, My Brother and I (London, 1958), p.168.

130 Sir Thomas Marchant Williams, (1845-1914), barrister and writer. In 1900 he was appointed stipendiary magistrate at Merthyr Tydfil, a position which he held till his death. While living in London he took an active part in the revival of the Cymmrodorion Society. 'He will be best remembered as the founder and editor, in 1907, of The Nationalist, a monthly magazine in which he gave his critical and controversial abilities full play’: D.W.B.

131 'Mr Lloyd George in the Bishop’s Clothes', The Welsh Coast Pioneer and Review for North Cambria, 16 September 1904, p.10.
} 
golfing garb and it was reported that 'the Radical member won the game'. ${ }^{132}$ Four years later, whilst visiting the National Eisteddfod in Llangollen, Lloyd George again stayed at the episcopal palace in St. Asaph, but on this occasion the President of the Board of Trade, Winston Churchill, also stayed with the Bishop and the Chancellor of the Exchequer ${ }^{133}$ and Lloyd George and Churchill visited the Eisteddfod together and delivered brief speeches. ${ }^{134}$ Lloyd George gave a clear indication of how he believed politics should be conducted:

'Men of all parties are the better for knowing one another. One reason why I admire the Eisteddfod platform is that we as a nation meet there as a nation. On this platform there is neither sect nor party, neither bond nor free, but perfect equality and unanimity, and no other nation can boast of anything comparable with it. Having slain each other all the year round, those of us who are alive at the end come here to shake hands'. ${ }^{135}$

For a self-confessed 'controversialist', Lloyd George did attempt to maintain good relations with all parties, including his 'adversaries', and when asked to explain this attitude to his opponents, he explained to a meeting of the Cardiff Cymmrodorion Society that he recollected a reminiscence of an American soldier who admitted that when he aimed his rifle, he did not identify a particular enemy, whom he hated, but he simply fired at the 'line of battle' and that, admitted Lloyd George, was his approach. ${ }^{136}$ Bishop Edwards’s memoirs described his gratitude to Lloyd George, together with a fulsome compliment, albeit containing a barbed reference to the other Liberal politicians: 'Entirely free from the acerbity and narrowness of the Welsh Calvinist, Mr. Lloyd George was distinguished from his Welsh colleagues not only by his commanding ability but by a certain chivalry and generosity’ ${ }^{137}$ During the enthronement of the first Archbishop of Wales in 1920, Lloyd George was to confirm that A. G. Edwards was 'a redoubtable foe and a true friend' and although the new Archbishop did not reciprocate with a personal description of his relationship with the Prime Minister, he was unstinting in his praise for what he considered to be David Lloyd George’s crowning achievement, placing him in a pantheon as a saviour of civilisation, as:

\footnotetext{
132 Ibid.

133 'Mr. Lloyd George in Wales', Evening Express, 31 August 1908, p.2.

${ }^{134}$ Speeches by Statesmen. Eisteddfod Enshrined in the Hearts of the People', Weekly Mail, 5 September 1908, p.2.

135 'Cabinet Ministers at the Eisteddfod', The North Wales Express, 4 September 1908, p.5.

${ }^{136}$ Grigg, Lloyd George. The People’s Champion, 1902-1911, p.155

137 The Archbishop of Wales, Memories, London, 1927, p.317.
} 
'The Empire owed its life to a Welshman, and he who saved the Empire saved Europe, and he who saved Europe saved civilization. It was a great deed, and it was a Welshman who did it'. ${ }^{138}$

Perhaps just as remarkable was that the fact that he appeared to assume pride from Lloyd George as a Welshman although, as will be discussed in the final chapter, this reference probably reflected the new Archbishop's growing annoyance with an English insouciance with the Welsh Church and its proceedings.

The following report of Winston Churchill's pre-nuptial dinner demonstrated Lloyd George’s belief that: 'Men of all parties are the better for knowing one another', with a group whose loyalties and interests would, at first instance, appear to be incompatible:

'Mr. Winston Churchill on Friday night entertained at dinner Mr. Lloyd George (Chancellor of the Exchequer), the Bishop of St. Asaph, Lord Hugh Cecil, and another friend, this being his farewell dinner before abandoning his state of single blessedness'.139

Newspaper coverage went on to proudly proclaim that: 'Englishmen never allow political disagreement to interfere with their social relations'. ${ }^{140}$ Bishop Edwards was to officiate at Churchill’s ‘society’ wedding on 12 September 1908, and it was an unusual choice, as Churchill's pedigree and reputation would have been sufficient to attract most English prelates to what was: 'unquestionably one of the most interesting society functions of the year'. Winston Churchill's son, Randolph, wrote that he had 'no clue as to why the leading divine in the Church of Wales' performed the solemnization, ignoring the possibility of a link with Lloyd George and probably unaware of the stay at the episcopal place in 1908. Instead, he suggested a highly improbable proposition that the Bishop was invited on account of the assistance he gave to Lord Randolph Churchill in 1893, when Lord Randolph made his 'last successful speech in the House of Commons on the Welsh Suspensory Bill'. ${ }^{141}$ However unlikely the premise, it did offer another example of the Bishop lobbying and guiding senior anti-disestablishment politicians.

\footnotetext{
${ }^{138}$ Welsh Archbishop Enthroned. A Notable Ceremony. The New Order in Wales', The Times, 2 June 1920, p.13.

139 'Mr. Winston Churchill. Last Bachelor Dinner to His Friends', Evening Express, 12 September 1908, p.3.

140 Ibid.

${ }^{141}$ Randolph S. Churchill, Winston S. Churchill, Vol. II, Young Statesman 1901-1914 (London, 1967), pp.273-274.
} 


\section{'But they seized their other prisoner at once, blindfolded him and said War or no war, we will, at any rate, do for you.'}

The shocking suggestion that the start of the Great War provided respite to a beleaguered government was borne out by a letter Prime Minister H.H. Asquith sent to Venetia Stanley in May 1915, when he wrote that 'the sudden outburst of the Great War' had been the 'greatest stroke of luck in his political career'. ${ }^{142}$ Whereas Asquith was callously registering his relief upon how Irish Home Rule, and the impending crisis in Ulster, had been side-stepped, the postponement of Welsh disestablishment was not so effective at deferring this rancorous and troublesome process. Although the initial uncertainty about the exact date upon which the Welsh Church Act 1914 would take effect was to continue to vex the stalwart defenders of the status quo ante, the postponement did offer opportunities, which would be exploited, to continue to lobby in order to ameliorate the terms, or even allow hope for repeal.

It did appear that the wording of the Suspensory Bill, which was intended to delay the operation of both the Irish Home Rule and Welsh Disestablishment Acts, had become muddled and the Bill had inadvertently differentiated between the two Acts. Whereas the operation of the Home Rule Bill was postponed, only the date of disestablishment was postponed. ${ }^{143}$ The Bishop of St. Asaph perceived a sleight of hand by the Asquith government and The Cambrian News reported upon a conference of Welsh Church people who had convened at Shrewsbury, in December 1914, shortly after the Welsh Church Act was enacted. Although the conference had been convened for 'the transaction of inevitable business', in preparation for eventual disestablishment, the tone of the meeting was described as a 'determined protest against the passage of the Welsh Church Act ${ }^{144}$. The Bishop, who presided, was unable to refrain from regaling his audience with a fulmination about unfair treatment with imagery which might have appeared inappropriate, as the casualty lists increased ${ }^{145}$ : 'The Government dealt very treacherously with the Church in Wales. The Prime Minister, on July 30th, gave his promise at a solemn moment that no controversial legislation was to be introduced' but he posited that: 'The war put Ireland and the

\footnotetext{
${ }^{142}$ Michael Brock, eds., H.H. Asquith. Letters to Venetia Stanley (Oxford, 1982), pp.111 and 471.

${ }^{143}$ Bell, Disestablishment in Ireland \& Wales, pp.297-298.

144 'Shamelessly Violated. Attitude of Churchmen to the Spoliation Act', The Brecon County Times, 17 December 1914, p.5.

145 'The Price We Must Pay. Estimate of the Casualties to the Allied Armies in Flanders', The Cambria Daily Leader, 2 December 1914, p.6.
} 
Welsh Church at the mercy of the Government. They condemned both their prisoners, "but to Ireland they said we won't touch you till the war is over, and we will give you a new trial or an amending act." But they seized their other prisoner at once, blindfolded him and said War or no war, we will, at any rate, do for you. ${ }^{146}$

It appeared that not even the War could adequately daunt the Bishops in pursuing their mission and the Bishop of St. David's, when calling for the first Sunday in 1915 to be regarded as a 'day of humble prayer', had acknowledged that: 'the beginning of the New Year, to which we look forward will be darkened by a war of unparalleled magnitude in the history of mankind', but he could not resist a reference to prospect of disestablishment, when he added that: 'the New Year cannot but also be a year of special anxiety to Welsh Church people. We know not yet what the future position of the Church in Wales will be'. ${ }^{147}$ This was certainly the case, but if anybody was placed to anticipate what lay ahead, it was the Bishop of St. David's, as his daughter described that he, together with Frank Morgan, who would be the first secretary of the governing and representative bodies, 'studied all the problems as a whole' and 'made absolutely certain that the leading men knew exactly what those problems were'. ${ }^{148}$ Pardoning any paternal bias, it appeared that John Owen, Bishop of St. David's, thrived in the bureaucratic and administrative detail associated with the creation of the Welsh Church's new structure. ${ }^{149}$

\section{The Welsh Church (Postponement) Bill 1915: evidence of continuing tension.}

An example of how the issue of disestablishment was to remain active, despite the phenomena of all-out World War, was the attempt to postpone an element of the Welsh Church Act and on 9 March 1915, the government introduced into the House of Lords the Welsh Church (Postponement) Bill to determine that the date of disestablishment to six months after the end of hostilities and to allow the government to allow appointments made during the interim period to carry with them a life interest. This was the outcome of discussions between the government and opposition, but with no consultation with Welsh Liberal M.P.s. Lord Selborne, President of the Board of Agriculture, pledged:

\footnotetext{
146 'Welsh Church Conference', The Cambrian News and Merionethshire Standard, 18 December 1914, p.2.

147 'Bishop of St. David's and a Day of Prayer', The Brecon County Times Neath Gazette and General Advertiser, 31 December 1914, p.3.

148 Owen, The Later Life of Bishop Owen, p.263.

${ }^{149}$ Ibid., pp.264-267.
} 
'we on the Front Benches-so far as we can influence those who agree with us, that until six months after the end of the war, until in fact the new date of Disestablishment, we will not be parties to any effort in Parliament to amend or repeal the Act; but after that period we regain our full liberty, and, if we saw right to do so, we should be able to do all in our power to obtain either the repeal or the amendment of the Act'. ${ }^{150}$

The bill was passed by the House of Lords in one day and sent to the Commons, where it was considered on 15 March, but a severe, unanticipated upset would derail it. ${ }^{151}$ Lord Robert Cecil attempted to address any suspicions that the six month postponement was simply a ruse to facilitate efforts to repeal, when he dismissed the suggestion of 'some underhand advantage in this question', and that: 'Six months is not a very long time for an institution that has existed for seven hundred years and possibly for fourteen hundred years'. ${ }^{152}$ Sir Herbert Roberts ${ }^{153}$ addressed the House in his role as chairman of the Welsh Parliamentary Party and he attempted to explain the feeling among Welsh Members by, firstly, reiterating that: 'This is a time of political truce', but, secondly, he added reassuringly that:

'I think I can say there is no portion of the United Kingdom in which there has been a more full and more loyal response to the call of duty by the nation than is the case in Wales. Churchmen and Nonconformists stand to-day shoulder to shoulder in defence of our shores and for the success of our arms'. ${ }^{154}$

This was presumably to prepare the House for the nub of his argument, with a submission that he did not know if the House appreciated: 'the place that this Act, the Welsh Church Act fills in the minds of the Welsh Nonconformists' and that: 'It is for the Welsh Nonconformists a thing very much greater than a mere political triumph—it is a victory which has been won by a small people against overwhelming odds after years of struggle'. He added that any attempt to 'free our minds’ from suspicion was not assisted by 'disturbing events' over recent months, with 'statements made by prominent Churchmen, in Parliament and out, in regard to their intention to repeal the Act'.

\footnotetext{
${ }^{150}$ HL Deb. 9 March 1915, vol. 18, cc.634.

151 Ibid., cc.635.

152 HC Deb. 15 March 1915, vol. 70, cc.1787

153 John Herbert Roberts, $1^{\text {st }}$ Baron Clwyd, (1863-1955), elected as M.P. for Denbighshire West in 1892, which he held until 1918. He was chairman and secretary of the Welsh Liberal Party from 1912 to 1918. He was elevated Baron Clwyd of Abergele in 1919: D.W.B.

${ }^{154}$ HC Deb. 15 March 1915, vol. 70, cc.1800.
} 
Bishop Owen alerted Lord Hugh Cecil to the fact that: 'The Free Church Council wirepullers in Wales are calling Conventions in North and South Wales and are sure to insist on some amendment of the Postponement Bill' 155 and five hundred delegates from Welsh Liberal Associations and Welsh Nonconformist churches attended a meeting, at Rhyl, to consider the situation created by the introduction of the legislation, with Reverend John Williams, of Brynsiencyn, was elected to preside. ${ }^{156}$ The chairman reflected a feeling of duplicity by Asquith's government, at a time 'when the question of the disestablishment and disendowment of the British Empire was being threshed out on the field of battle', and Mr. Asquith had given his pledge that while the question was being settled no subject of domestic controversy should be introduced into parliament. This sense of betrayal was heightened by a belief that that the response to the passing of the 1914 Welsh Church Act had been restrained, due to the war, with the 'only discordant note during those months came from the Bishop of St. Asaph who deliberately dipped his pen in gall when everybody else was praying for peace'. ${ }^{157}$ The bill was put off for further consultation and withdrawn by the Home Secretary on 26 July 1915, providing a graphic illustration of the level of suspicion which existed and which caused generally loyal Welsh Liberals to revolt, even if the government included David Lloyd George as a senior member. ${ }^{158}$

\section{7: 'the hope of redress'.}

The Convention of the Church in Wales, held in Cardiff in 1917, illustrated, within its detailed official report, the curious bureaucratic origins of the Welsh Church. With legislation enacted in 1914, but with postponement and uncertainty, due the onset of the Great War, many Church defenders anticipated repeal and the resumption of the status quo ante. This feeling of a 'phoney war', as far as disestablishment was concerned, would have contrasted markedly with what was happening across the English Channel, with the scale of losses incurred during the Battle of Polygon Wood, the latest phase of the Third Battle of Ypres, which drew to a weary close on the second day of the Convention. ${ }^{159}$ After an initial discussion about whether the press or public

\footnotetext{
155 Owen to Cecil, 27 March 1915, N.L.W., Bishop John Owen Papers. 10/4.

156 John William, (1854-1921), Calvinistic Methodist minister.

157 'Welsh Church Bill', The Cambrian News, 2 April 1915, p.6.

158 HC Deb. 26 July 1915, vol. 73, cc1988.

159 Nick Lloyd, Passchendaele. A New History (London, 2017), pp.191-207.
} 
should be admitted, the introductory sentence from the Bishop of St. Asaph, who by virtue of his seniority officiated as President of the Convention, did sound incongruous in relation to the third year of war, when he said that: 'In the long history of the Church in Wales nothing quite parallel to and certainly nothing more momentous than this Convention has occurred'. ${ }^{160}$

Bishop Edwards had already known the horror of war, when his youngest son was killed in May 1915. ${ }^{161}$ The Bishop wrote that he had been 'summoned to an-important committee meeting' concerned with disestablishment, when he received the news, and that remarkably, in the face of such a personal loss, he 'struggled painfully through it'. ${ }^{162}$ He was use this incident to illustrate how Churchmen were obliged to dedicate themselves to the business of preparing for disestablishment, particularly with the work in preparation for the new Representative Body, despite the fact the 'task in those stricken days proved a strain not easy to bear', as the Churchmen: 'summoned from Wales were toiling at the dark problem of building up an organisation to take the place of one which represented the harvested wisdom and experience of fifteen centuries'. ${ }^{163}$

The Bishop then went on to suggest that the government 'were earmarking for spoliation the property of the Church' and that the work of the Commissioners was attributed a priority over and above the war-effort, and 'no disaster by sea or land checked or postponed their operations'. ${ }^{164}$ Not one to understate the apparently spiteful actions of the government, he contrasted this meanness of spirit with the Church's response to war, with the vainglorious statement that the Church's sons 'were thronging to the war, and more than 70 per cent of the men from Wales who joined the colours before conscription, were Churchmen'. ${ }^{165}$ In a bizarre coupling, the Bishop suggested that the Church was both continuing to battle the consequences

\footnotetext{
${ }^{160}$ The Official Report of the Proceedings of the Convention of the Church in Wales, held at Cardiff, October 2-5, 1917, Cardiff, 1917, p.7. The question of the history of the Welsh Church will be considered elsewhere, as its interpretation provided justification for those in favour and against disestablishment.

161 'Bishop of St. Asaph bereaved', Flintshire Observer Mining Journal and General Advertiser, 27 May 1915, p.2. Thirty-year-old Lieutenant Henry Laidley Garland Edwards, $1^{\text {st }}$ Battalion, the Royal Welch Fusiliers, was killed on 16 May 1915, at the Battle of Festubert,

162 The Archbishop of Wales, Memories, p.270.

163 Ibid., pp.270-271.

${ }^{164}$ Ibid., p.271.

165 Ibid., p.272.
} 
of the Welsh Church Act, as well as 'the cruel and relentless horde' ${ }^{166}$ on the Western Front. The fact that the Bishop included a reference to the '70\%' in his Memories, some nine years after the end of the war, demonstrated that he was obdurate in his use of this statistic, which, 'once it had entered the public discourse', it was 'difficult to eradicate'. ${ }^{167}$ As early as 1915 , the Bishop was being criticized for seeing:

'fit to make a division of sheep and goats in the "Welsh Army. There can be nothing more mischievous than such an effort to tabulate Welsh recruits according to the order of their churchmanship, with a big or little c as the case may be; nothing more warranted to revive old prejudices and; animosities. The figures quoted by the Bishop are incorrect'. ${ }^{168}$

Reverend David Jones referred to an 'official' census made by the Chaplain of the troops who were stationed at Aberystwyth on 16 January 1915 and, of the 7,754 soldiers present, it was intimated that 5,560 were Church of England and 308 were Roman Catholic, with the remainder belonging to a range of Nonconformist denominations. Reverend Jones found the figures to be 'startling', as the men originated from North Wales, Monmouthshire and Cheshire, and he asked whether figures from other military centres should be publicised: 'now to open to open the eyes of the Prime Minister to the enormity of the crime of robbing the Church', when it was the Anglicans who were 'bearing the brunt of the battle' and added that it was 'quite evident that he has been hoodwinked by Welsh Radical members'. He ended with a sarcastic query about 'what has become of the Nation of Nonconformists? Evidently it is not in the fighting Line!' 169

In 1917, the Earl of Crawford ${ }^{170}$, speaking for the government during a debate about the postponement of the operation of disestablishment, was suspicious of the motives behind the request for a delay of twelve months and, although he averred from attributing to the Bishop of St. Asaph any attempt to use such a postponement to re-open the question of disestablishment, he had suggested that:

'if the Bishop of St. Asaph is anxious for sympathy in Wales, let him refrain from repetition of foolish and disproved assertions'.........

\footnotetext{
${ }^{166}$ Morgan, The Span of the Cross, pp.42-43: used by Bishop Joshua Hughes, of Llandaff, in his support to honour the treaty obligations to Belgium.

167 Gethin Matthews, “"For Freedom and Justice”: The Responses of Chapels in the Swansea Area to the First World War’, Welsh History Review, vol.28, issue 4 (December 2017), p.694.

168 'The Hon. Ormsby Gore', The Cambria Daily Leader, 17 March 1915, p.4.

${ }^{169}$ Reverend David Jones, Llanbadarn Fawr Vicarage, to Bishop Owen, 12 February 1915, N.L.W., Bishop John Owen Papers. Box 8/8, 1915.

${ }^{170}$ David Lindsay, $27^{\text {th }}$ Earl of Crawford, (1871-1940), Conservative politician who served as Lord Privy Seal in Lloyd George’s government, from 1916 to 1919.
} 
'That the great majority of those who volunteered for foreign service from Wales were Churchmen, and this was true today of those serving in Welsh regiments. It is hateful to find this church v. chapel spirit being played upon in such times as these; it is repugnant to have to dabble in such a controversy. Of course the Bishop's statement was not true of the volunteers, nor is it true with regard to those serving to-day. Dissent has been as loyal as the Establishment'. ${ }^{171}$

Despite the crucial bureaucratic objectives of the 1917 Church Convention, being to agree the constitutions of the governing body and the representative body, the Bishop seized the opportunity to confirm his hard-won reputation as the 'battling bishop', with the type of address with which his audience would have been familiar, from his many speeches and newspaper reports:

'The Act proclaims that on the day the War ends it will smash our machinery and rob the safe. Our answer is clear. We shall do our best to prevent you doing your worst. Ready for either issue, "we will have our tackle prepared," and we are not going to wait and see. When the time comes, Churchmen will mobilise their forces to appeal for redress, and that appeal will go forth to a nation chastened and enlightened by a great fellowship of sacrifice and achievement'. ${ }^{172}$

After regaling the assembled Church people with 'a modest recital of essential facts', in which he referred to the many who regarded the Welsh Church Act 1914 as 'unjust and its injustice as aggravated by the time and circumstances under which it was passed ${ }^{\text {, }}{ }^{173}$, and that many were tempted to ignore it. However, he acknowledged, judiciously, that:

'We could ignore the law, but the law would not ignore us, and resistance where it concerns only the person resisting is different to resistance where it involves the responsibilities of Trusteeship'. ${ }^{174}$

But in case his comments could be portrayed as, uncharacteristically, akin to acceptance, he followed this with the rhetorical question: 'if we could not ignore, how far could we safely recognize the requirements of the Act without forfeiting the hope of redress' ${ }^{175}$

\footnotetext{
171 'The Welsh Act', Cambria Daily Leader, 17 May 1917, p.2.

172 Ibid., p.8.

${ }^{173}$ The Official Report of the Proceedings of the Convention of the Church in Wales, held at Cardiff, October 2-5, 1917, Cardiff, 1917, p.7.

${ }^{174}$ Ibid., p.8.

175 Ibid., p.8.
} 
The possibility of repeal, or at least an amendment to the disendowment provisions, would also create a quandary for the Welsh Church, as it was required to ask itself whether it should utilise the apparently limited time available to establish the organization of the new Church, or would such action be perceived as an acceptance that disestablishment was a fait accompli. Contrary to those for whom disestablishment: 'seemed a disaster for the Church in Wales' ${ }^{176}$, it was perceived as an opportunity by J. Arthur Price ${ }^{177}$ and he described the 1917 Convention, as being 'of historic interest to Wales', not simply to the Church. ${ }^{178}$ A reading of the Official Report of the 1917 Convention provides a strange mix of bureaucratic planning, with an occasional snippet of aspirational positioning, although it was a layman, Lord Justice Bankes ${ }^{179}$ who, together with Lord Sankey ${ }^{180}$, had drafted the Church’s new constitution, who appeared to grasp the potential and to envisage where the Church should be heading, when he stated that:

'I see in my mind's eye a truly national Church, a Church that will adapt itself to the needs and requirements of all classes and to the ever-changing conditions under which her work must be done, a Church whose sympathy, whose tolerance, whose enthusiasm will draw all men to her and enshrine herself permanently in the affections of the inhabitants of Wales'. ${ }^{181}$

However, to appreciate the differing schools of thought within the assembled mass, and particularly the opinion of those laymen who were in influential positions within the Welsh Church, the comment of Lord Justice Bankes demonstrated the fact that there were positive possibilities and a reference to the challenges that faced the English Established Church:

'If we look over the border into England, we see the Church of England at this moment struggling to free herself from the hindrances and disadvantages arising from working under a system which came into existence under conditions very different from what they

\footnotetext{
176 Thomas Glyn, Watkin, 'Disestablishment, Self-determination and Constitutional Development of the Church in Wales', p.27.

177 John Arthur Price, (1861 - 1942), barrister and journalist. At Oxford he became acquainted with several other young Welshmen , including the historian John Edward Lloyd,_and became a convinced Welsh nationalist until the end of his life. A devout churchman and Anglo-Catholic, he pleaded for disestablishment because he believed that it would be better for the church itself: D.W.B.

178 J. Arthur Price, 'The awakening in the Welsh church’, Welsh Outlook, vol.4, no.10 (October 1917), p.361.

179 Sir John Eldon Bankes, (1854-1946): He was unsuccessful as Unionist candidate for Flint in 1906 , but in 1910 he was appointed a puisne judge and knighted. In 1915 he was promoted to the Court of Appeal and became a privy councillor. He served as chancellor of St Asaph diocese (1908-10) and was a co-author of the constitution of the disestablished Church in Wales. He was chairman of the representative body of the Church in Wales (1928-43): D.W.B.

180 John Sankey, (1866-1948), Baron Sankey, 1929: Viscount Sankey of Moreton, 1932, appointed a judge of the High Court in 1914, and a Lord of Appeal in 1928. He became Lord Chancellor in 1929, in the second Labour Government. He is attributed with being mainly responsible for framing the constitutional documents of the disestablished Church: D.W.B.

${ }^{181}$ Official Report of the Proceedings of the Convention of the Church in Wales, held at Cardiff, October 2-5, 1917, Cardiff, 1917, p.26.
} 
are today. Here in Wales the Church has been compulsory set free. To some this may seem to be an unmitigated evil, to others it may seem to be a blessing in disguise'. ${ }^{182}$

In terms of the Church and the manner in which Churchmen viewed the lessons to be drawn from the war, a speech given the Bishop of St. David's, in anticipation of the Convention, provides a fascinating insight into the manner in which the Bishop measured the impact, from a concern about reduced opportunities for fundraising after the war, to a grandiloquent discourse on an enhanced morality, a 'sovereignty of righteousness', which would, he believed, attach itself to the cause of Church defence, as a result of the war aims:

'Even before the war the secularization of religious endowments and the forcible eviction of Welsh bishops and clergy from the ancient synod of their province did not commend themselves as righteous to the conscience of the country, and it would be faithless on our part to think that public opinion will not have learnt a new lesson on the sovereignty of righteousness from the greatest discipline in all our history'. ${ }^{183}$

The Bishop’s speech is juxtaposed with newspaper columns providing casualty lists from the war, including biographies of some of those who had died. It provided, if advertently, a discordant note to the Bishop’s concerns about endowments and righteous indignation. Any abiding anxieties that the 1917 Convention exhibited signs of the Church seeking redress were dismissed by W. Llewelyn Williams, who opined that despite the verbiage: 'With the meeting of the Church Convention at Cardiff this month, the question of the Disestablishment of the Church of England in Wales may be regarded as finally settled' and 'it would be too cynical a farce to hold the Convention, to set up the Representative Body, and to frame a Constitution for the emancipated Church, if Churchmen still refuse to accept as an accomplished fact the severance of Church and State'. ${ }^{184}$

J. Arthur Price believed that 'the most interesting fact about the Welsh Church to-day is that the Disestablishment Act has left little bad blood behind it' and he went on to write that 'no financial or economic change can seriously divide the citizens of the same country although this did appear to contradict the recent evidence of Welsh emotions evoked by disendowment. Perhaps

\footnotetext{
182 Official Report of the Proceedings of the Convention of the Church in Wales, held at Cardiff, 2-5 October 1917, p.26.

183 'Welsh Church Convention. Reconsideration of the Act. How the War has altered the situation', The North Wales Chronicle and Advertiser for the Principality, 28 September 1917, p.7.

${ }^{184}$ Williams, W. Llewelyn, 'Disendowment: The present position', Welsh Outlook, vol.4, no.10 (Oct. 1917$)$, p.358.
} 
Price's irenic opinion may have been influenced by the fact that he was writing in the middle of the First World War and that he was ever hopeful about the role of Welsh Nationalists within the disestablished Church. In his review of the rumours circulating prior to the meeting of the Convention of the Church in Wales, in October 1917, Price could discern the seeds of a nationalist revival in the Welsh Church, as a result of disestablishment, with the view that 'the ablest minds among her clergy and laity are already turning from the dead past of Erastianism to the living future of Nationalism' ${ }^{185}$ He was, by dint of his experience with the Welsh Church, a realist and although he anticipated a 'demand for a national Welsh Church', he feared that 'the timidity and the Anglicising prejudices of high dignitaries will prevent immediate action'. ${ }^{186} \mathrm{He}$ questioned the actions of the Bishops of St. Asaph and St. David's and was puzzled about the creation of a Welsh Archbishopric:

'For twenty years these two prelates have been preaching and proclaiming the absolute identity of their Church in England and Wales and extolling the Canterbury connection. For either of them to adopt the role of Giraldus Cambrensis would come as a startling surprise. All the same I think that the Disestablished Church is slowly drifting to a reconciliation with Welsh Nationalism, and it is possible that even its leaders may be affected by the feeling of the hour' ${ }^{187}$

Such conclusions were to prove to be premature and although hopes of repeal might recede, the campaign to defend the Church's interests was simply gearing up ready to enter a new phase.

\section{Dismemberment}

Charles Green, the second Archbishop of Wales, attributed an act of wise beneficence to the Archbishop of Canterbury, in resolving the consequences of section 3(5) of the 1914 legislation, whereby: 'As from the date of disestablishment the bishops and clergy of the Church in Wales shall cease to be members of or be represented in the Houses of Convocation of the Province of Canterbury'. It had been recognised that the fact that the Dioceses of Wales would no longer be represented in the Convocation of Canterbury, created a 'situation of extreme delicacy', as the Church of England repudiated the right of the State to do this without the consent of the Church. The difficulty was resolved by the act of the Archbishop of Canterbury, 'proclaiming in full Synod of the Province of Canterbury that he had released the Welsh Bishops from their

\footnotetext{
185 Price, J. Arthur, 'The awakening in the Welsh church', Welsh Outlook, vol.4, no.10 (Oct. 1917), p.361.

186 Ibid, p.363.

187 Ibid., p.362.
} 
allegiance to the See of Canterbury, and that he counselled them to form a separate Province for Wales'. ${ }^{188}$

There would be a provision in legislation which preceded the date of disestablishment ${ }^{189}$ which could have provided for English and Welsh bishops and clergy to meet in voluntary assemblies, but Randall Davidson, the Archbishop, recognised that it would be too complicated. In his evidence to the House of Lords Select Committee, described above, the Bishop of St. Asaph disputed the suggestion proffered by Mr. McKenna that the Welsh Church had been independent and declared that it was 'without historical foundation'. ${ }^{190}$ He gave evidence that he could not recall a single instance where Anglicans, in his diocese, had expressed support for Wales to be a separate Province. ${ }^{191}$ The Bishop also stated 'without hesitation', that all Anglicans in his diocese, be they clergy or laity, were 'unanimous against this dismemberment'. ${ }^{192}$ The Archbishop Edwards, as he was later to become, was to acknowledge that, following disestablishment, the Welsh Church was 'as independent as she was before Augustine came, or before the Norman Conqueror extorted from her reluctant submissions'. ${ }^{193}$ Presumably such sentiments then became more acceptable, as the Archbishop was reconciled with the political outcome and he endeavoured to reinvent the disestablished Church in Wales as the means by which 'the nation arose and thronging voices of approval came from far and wide', and his enthronement 'was an event without precedent in Wales'. ${ }^{194}$ It might have surprised many readers when the Bishop attempted to estimate 'the gains and losses' of disestablishment in the final chapter of his reminiscences, he admitted 'that disendowment, although naturally attracting public attention, was not the heaviest blow that befell the Church'. ${ }^{195}$ This statement might have been viewed with some irony by those who would recall the Bishop's efforts to raise financial concerns throughout the campaign. Archbishop Edwards recognised that exclusion from the House of Lords, as stipulated by section 2(2) of the 1914 Welsh Church Act, was the 'most

\footnotetext{
188 Archbishop C.A.H. Green, The setting of the Constitution of the Church in Wales, London, 1937, p.210.

189 Church of England Assembly (Powers) Act 1919, Chapter 76 (9 and 10 Geo 5).

190 The First Report from the Select Committee of the House of Lords on Matters Affecting the Church in Wales, August 1914, p.7.

191 Ibid, para, 1977.

192 Ibid., para. 1980.

193 Edwards, Memories, p.320.

${ }^{194}$ Edwards, Memories, p.321.

195 Edwards, Memories, p.327.
} 
conspicuous' change, the 'most inevitable' and the 'least important' ${ }^{196}$ Archbishop Glyn Simon ${ }^{197}$, when describing the first fifty years of disestablishment and disendowment, reported that 'the bishops were excluded from the House of Lords, but Archbishop Edwards could still be seen from time to time, sitting on the steps of the Lord Chancellor's seat'. ${ }^{198}$

The fate, or the financial interests, of the Welsh Church held little interest for the English Church and that acidulous observer, the Reverend Hartwell Jones, recalled an incident when he was asked by an English Archdeacon, 'what was the real truth about this Welsh Church?’ He suggested that the Archdeacon had seemed neither to understand, 'or was even interested'. 199 Writing to the Marquess of Salisbury, in August 1919, Randall Davidson, the Archbishop of Canterbury, wrote that he was 'most thankful' that the 'episode is closed' and, whilst stating that he held 'no special brief for the Welsh bishops', it is clear that he now felt able to observe the outcome of 'the change in Wales', with 'no small anxiety', but more in terms of a mild curiosity in terms of the outcome of somebody else's experiment. ${ }^{200}$ The Archbishop of Canterbury's desire to extricate the Church of England from what appeared to be a the prolonged controversy, was further confirmed by the fact that he had, within 24 hours, responded, in the negative, to the Bishop of St. Asaph's request for guidance upon whether it was possible for the Welsh Church to be included in the Convocation of Canterbury. ${ }^{201}$ It is apparent that the Archbishop was concerned about the possibility of confusion, or even chaos, if consideration had been given to Bishop Edwards's request. The Archbishop of Canterbury had been obliged to shield the status of the Church of England, at a particularly challenging time, which witnessed an increase in radical politics during the so-called 'Edwardian Crisis', ${ }^{202}$ and he would have been relieved to stem any potential 'mischievous exacerbation of Welsh opinion with consequent damage to the cause of religion both in England and Wales'. ${ }^{203}$

\footnotetext{
${ }^{196}$ Edwards, Memories, p.328.

197 Archbishop Glyn Simon, (1903-1972), served as Bishop of Swansea and Brecon from 1953 to 1957, when he was translated to Llandaff . He served as Archbishop of Wales from 1968 to 1971.

198 Owain W. Jones, Glyn Simon. His Life and Opinions (Gomer Press, 1981), p.129.

199 The Reverend G. Hartwell Jones, A Celt Looks at the World (Cardiff: William Lewis, 1946), ed. By Wyn Griffiths, p.56.

200 Bell, Randall Davidson, Archbishop of Canterbury, volume 1, p.987.

201 Ibid., p.987-989.

${ }^{202}$ M. Hughes, 'Archbishop Davidson, the "Edwardian Crisis,” and the Defence of the National Church', Journal of Church and State, vol.57, no.2 (October 2013), pp.218-220.

203 Bell, Randall Davidson, Archbishop of Canterbury, volume 1, p.985.
} 


\section{Ecclesiastical armistice?}

It was apparent that, when hostilities ended on 11 November 1918, Church Defenders were still engaged in continuing combat, albeit now primarily associated with the terms of disendowment. Even before the Armistice, in October 1918, the Bishop of St. Asaph recorded that he called upon the Prime Minister and Mr. Bonar Law ${ }^{204}$, with a clear objective of using the uncertainties of a pending general election and the tensions of a coalition government to barter with the politicians. The Bishop admitted that 'reconsideration' of disestablishment, and particularly that of disendowment, had taken the place of 'postponement'. Five days before the Armistice, on 6 November 1918, the Bishop's adept manoeuvrings proved successful and, at a meeting with Bonar Law, accompanied by the Bishop of St. David's, the terms of a declaration to be made by the Prime Minister were agreed. This would acknowledge that the Welsh Church Act was on the statute book and that there was no desire, even on behalf of the Welsh Church, to repeal the legislation, but the quid pro quo for the Church's acknowledgement that it would not lobby for repeal, was that the Prime Minister recognised: 'that the long continuance of the war has created financial problems which must be taken into account'. ${ }^{205}$ The Bishop suggested that the Bishop of St. David's 'and others had doubts about abandoning repeal' and the publication of the declaration on 19 November led to the resignation of Lord Robert Cecil. ${ }^{206}$ The Bishop of St. Asaph asserted that during the general election on 14 December 1918 'Liberal candidates treated the Welsh Church Act with such delicate reserve that they had evidently discovered its unpopularity among the voters' ${ }^{207}$ Whereas this might have been understandable, in the immediate post-war period, the Bishop had clearly demonstrated that he had no reservations and that he had pressed his case irrespective of the demands of the government on the satisfactory ending of the war.

It is noteworthy that the version of events described by Eluned Owen, in the biography of her father, the Bishop of St. David's, provided a different and more complex picture of these crucial

\footnotetext{
${ }^{204}$ Andrew Bonar Law, (1858-1923), Conservative politician, was leader of the party from 1911 to 1921. He served as Secretary of State for Colonies in Asquith's Coalition Government from 1915 to 1916 and then a Chancellor of Exchequer in Lloyd George's government until 1921.

${ }^{205}$ Edwards, Memories, pp.282-283.

${ }^{206}$ Ibid., p.284.

${ }^{207}$ Ibid., p.284.
} 
discussions, with the Bishop of St. Asaph appearing less sanguine about events, whereas the Bishop of St. David's 'pursued his own course'. ${ }^{208}$ It is apparent that the Bishop of St. David’s actions were, in part at least, predicated on his deep, almost obsessive, distrust of, and antipathy towards, David Lloyd George, as described in chapter four. Eluned Owen quoted her father as writing that;

'Our only hope of justice is that the Unionist party should convince George that they insist on justice to the Welsh Church - I do not mean Repeal - as a condition of supporting him. Once he sees they mean business he'll say “yes”. To him the Welsh Church is simply one aspect of high politics, big or small, in precise proportion to its bearing on Unionist support'. ${ }^{209}$

It was apparent that the future of the Welsh Church, as discussed in 1918 and 1919, was the subject matter of a debate which was unconnected with the merits or demerits of the Church/State relationship, but viewed the Church as a political counter, which was to be utilised by competing British political parties. The horse-trading was dealt with succinctly by one of Bonar Law's biographers, when he described that the agreed letter concerning the Unionists and Liberals indicated acceptance of the 1914 Act, but 'embraced the plea of the Welsh bishops that the impending penury of their Church deserved amelioration', while 'the majority of Unionists agreed with Bonar Law that, while Welsh priests must not be driven out into the road to beg, the Church (like the three remaining Welsh Unionist MPs) would simply have to adjust'. ${ }^{210}$ Clearly, not everybody could adjust, and it was reported that the Hon. Alice Douglas Pennant ${ }^{211}$ had resigned her membership of the Representative Body of the Church in Wales, as a protest and the 'folly of not waiting until the result of the general election was known before thinking of any compromise'. ${ }^{212}$ The Prime Minister was presumably unperturbed by the dramatic posturing of a scion of Penrhyn Castle, with recent memories of the Penrhyn Lockouts. ${ }^{213}$ Lord Penrhyn, the owner of the Bethesda slate quarries, was, 'a Conservative, a peer and landowner, thereby

\footnotetext{
208 Owen, The Later Life of Bishop Owen, p.377.

${ }^{209}$ Ibid., p.374.

210 R.J.Q. Adams, Bonar Law (London: John Murray, 1999), p.279.

${ }^{211}$ Lady Alice Douglas Pennant, (1862-1939), second daughter of George Sholto Douglas, $2^{\text {nd }}$ Baron Penrhyn; her gravestone, at Capel Curig, records that: 'She faithfully defended the ancient church in Wales'.

212 'Welsh Representative Body’, The North Wales Chronicle and Advertiser, 2 May 1919, p.4.

213 Pope, Robert, 'Pilgrims Through a Barren Land. Nonconformists and Socialists in Wales 1906-1914', Transactions of the Honourable Society of Cymmrodorion, New Series, Vol.7 (2001), p.151. In the dispute over union recognition and wage agreements 2,800 men were locked-out from 19 November 1900 to 14 November 1903, five days short of three years.
} 
comprising, in his person a trinity as unholy as any which way imaginable to the Liberal mind'. ${ }^{214}$

It has been suggested that the Welsh Church (Temporalities) Act 1919 and the 'change of heart on marriage and burial all indicate that by the time disestablishment occurred much of the venom that had fuelled the debate in earlier decades had already disappeared', the implication being that the 'venom' emanated from those in favour of disestablishment. ${ }^{215}$ However, the fact the Bishop of St. David's felt that it was necessary to go to such great lengths to elucidate the reason for the acceptance of the terms of the 1919 Act, with the production of a sixty-two page pamphlet, would suggest that it was otherwise, and that he realized that there was a high level of disquiet and potential criticism. ${ }^{216}$ In a letter to Y Llan, the Reverend Canon Edwards provided a carefully argued financial analysis of disendowment, in the context of the Church's 'infamous treatment', in which he did emphasise that he had:

'no desire to find fault with any of our leaders for accepting the Government terms, and allowing the Act to pass, as I believe they had at length reluctantly come to the conclusion that our opponents would by no means afford the Church any better treatment'.217

The Bishop of St. David's would have been particularly displeased by the suggestion that the Church had suffered, as he prided himself upon the Welsh Church (Temporalities) Act 1919, in respect of which he had written: 'for the Bill is a huge hanky-panky job after George's best style and much, much better than it looks' ${ }^{218}$ Section 3 (2) of the 1919 legislation confirmed that one million pounds would be 'provided by Parliament to the Welsh Commissioners', that the date of disestablishment would be 31 March 1920 and it also repealed, at section 6, the section within the Welsh Church Act, 1914, in respect of the law relating to marriage. When he had moved that the Bill be read for second time, on 6 August 1919, the Home Secretary, Mr. Edward Shortt ${ }^{219}$, began by stating that the:

\footnotetext{
${ }^{214}$ David Powell, 'The New Liberalism and the Rise of Labour, 1886-1906', The Historical Journal, vol.29, no.2 (1986), p.378.

215 Thomas Glyn Watkin, The Legal History of Wales (Cardiff: UWP, 2012), p.182,

216 The Bishop of St. David's, 'The Welsh Church (Temporalities) Act. Why it was accepted', Y Llan, 21 November 1919, p.15.

217 'The Disendowment of the Church in Wales', Y Llan, 31 October 1919, p.2.

218 Owen, The Later Life of Bishop Owen, p.420.

${ }^{219}$ Edward Shortt, (1862-1935), lawyer and politician. He was Home Secretary from 1919 to 1922.
} 
'title of this Bill may, perhaps, recall to Members the old and somewhat belated controversies of the past, but I hope that the Bill will remove once and for all those old struggles and differences, and enable the various Christian denominations in Wales to work together in the smoothest and most friendly manner'.220

It was difficult to gauge from the Home Secretary's comments that the 'old struggles and differences' had vexed the House of Commons only five years earlier, but of course much had transpired since that time.

\section{Disendowment.}

Regarding the proposed secular uses to which the endowed funds would be put after disestablishment ${ }^{221}$, it was evident that this could create opportunities for political posturing, despite the generally accepted eleemosynary advantages to the nation:

'In response to an invitation from Lord Kenyon ${ }^{222}$ and Lord Penrhyn ${ }^{223}$, as Governors, 170 members of the Courts of Governors of the University of Wales and of its constituent colleges of Bangor, Cardiff, and Aberystwyth have signed a protest "against the transference of any part of the Old Church Endowments to the support of these institutions upon the grounds that, it would injuriously affect them, by alienating the sympathy and support of all those who conscientiously object to the secularization of religious endowments"'.224

The two peers who instigated the 'protest' did so with clear political intent, but it was of note that the much-vaunted utilisation of disendowment funds for secular purposes should cause many to prefer to appear to be somewhat less rapacious than might be alleged by Churchmen.

Cartoons would often depict those in favour of disestablishment as footpads or burglars.

\footnotetext{
${ }^{220}$ Welsh Church (Temporalities) Bill, HC Deb. 6 August 1919, vol.119, cc 459.

${ }^{221}$ Section 19(a) and (b), Welsh Church Act 1914 specified the distribution, by the Welsh Commissioners to the County Council, 'to any charitable or eleemosynary purpose of local or general utility, including the aiding of poor scholars', the University of Wales and specified colleges, and the National Library.

${ }^{222}$ Lloyd Tyrell-Kenyon, 4th Baron Kenyon, (1864-1927), was a Conservative politician. He took his seat in the House of Lords on his 21st birthday in 1885. In December 1900 he was appointed a Lord-in-Waiting (government whip in the House of Lords) in the Conservative government of Lord Salisbury, a post he retained until 1905, the last three years under the leadership of Arthur Balfour. He served the same post again, in the coalition Government of David Lloyd-George, from 1916 to 1918. He was Pro-Chancellor of the University of Wales from 1910 and President of the North Wales University College, as well as President of the National Museum of Wales from 1923. ${ }^{223}$ Edward Sholto Douglas-Pennant, 3rd Baron Penrhyn, (1864 - 1927), was a British Conservative politician. Penrhyn was the son of George Douglas-Pennant, 2nd Baron Penrhyn. He entered Parliament for Northamptonshire South in the 1895 general election, a seat he held until 1900.

224 'University Governors and Church Endowments. Prime Minister Declines to Receive Deputation', The North Wales Chronicle and Advertiser, 3 July1914, p.5.
} 
Writing in October 1917, W. Llewelyn Williams believed that: 'the Welsh people have behaved with singular magnanimity in not demanding that the financial provisions of the Welsh Church Act should be re-considered' and that the 'fighting bishops' were taking advantage of those 'generous instincts'. ${ }^{225}$ He also believed that the Church's financial position had been enhanced by the 'accident of War' and he made the mordant comment that: 'Whoever has suffered by the War, it is surely not the Church of England in Wales, ${ }^{226}$, with a later comment that, in light of the Church's continuing protestations about the financial settlement, that perhaps the whole matter should be reopened, so that 'the Church should not make a profit out of the War'. ${ }^{227}$ As would have been anticipated, in the atmosphere of 'tit for tat', Llewelyn Williams's pronouncements were certain to galvanize a response from a ‘fighting bishop’ and, unsurprisingly, it was the Bishop of St. David's who had taken up the challenge. Prior to his article in Welsh Outlook, Llewelyn Williams had written a letter to the editor of The Times, on 26 March, 1917, in which he had attempted to raise an awareness of the Church's financial state, and this had been in direct response to a letter to the editor, dated 22 March 1917, under the signatures of Lords Salisbury, Plymouth, Selborne, Penrhyn and other prominent laymen, although it would not be unreasonable to discern the hand of the Bishop of St. David's in the letter's drafting. ${ }^{228}$ Whatever the case, the signatories to the letter expressed the 'desire to draw the attention of the public to the present position of the Church in Wales' but they were seeking sympathetic public support and not a forensic analysis of the Church finances. According to Llewelyn Williams, 'the signatories had taken great care not to explain to the public how enormously the Church has benefitted by the war'. ${ }^{229}$ In fact the letter had been concerned with a particularly vital, pressing issue for the Church, in that the Suspensory Act had postponed the implementation of the 1914 Act until a date not later than the conclusion of the war. Their case was that the preoccupation with the war and, in the absence of many Churchmen at the Western Front, they could not make adequate preparations for this contingent date. The Salisbury letter had attempted to garner support by being astute enough to quote David Lloyd George, who had, in 1915, suggested a date of six months after the cessation of hostilities. Their only reference to

\footnotetext{
${ }^{225}$ W. Llewelyn Williams, 'Disendowment: The present position’, Welsh Outlook, vol.4, no.10 (October 1917), p.358.

${ }^{226}$ Williams, 'Disendowment: The present position', p.359.

${ }^{227}$ Williams, 'Disendowment: The present position', p.360.

228 'The Church in Wales', 22 March 1917, p.10.

229 'The Church in Wales', The Times, 26 March 1917, p.6.
} 
finances was in relation to the fact that increased taxation, due to the war, predicated against the collection of funds 'to replace the endowments of the Church' and it was this point which galvanized Llewelyn Williams.

However, it was apparent that many were suspicious of the Church's intentions in seeking this respite, once hostilities had ceased, and such uneasiness would have certainly been exacerbated by a sentence to be found in the midst of the Salisbury letter where, after claiming that: 'the case for allowing the Church time to make arrangements for disestablishment after peace has been proclaimed grow daily stronger', the letter claims that: 'The country, too, requires time for reconsideration'. By any measure, this could lead a reasonable person to draw the conclusion that the attempt to extend the period, until disestablishment took effect, was not solely to ensure for adequate organization, but to permit the question of disestablishment, in toto, to be reopened, in the context of a war-weary public who would certainly be less interested in the subject. In his response to the Salisbury letter, Llewelyn Williams, after making his case that the Church had 'enormously' benefitted by the war, ended his letter with a paragraph with a direct accusation as to precisely the motives of Salisbury et al., in that the stratagem:

'is to revive the old controversy in a time of party truce, to wipe off the Statute-book the Disestablishment and Disendowment Act, or, if they fail in that, to postpone Disendowment till the value of the tithes is still further enhance, and so obtain for the Church a still further endowment out of Welsh national resources’.

This evoked a letter to The Times, from the Bishop of St. David's, in which he attempted to rebut the financial propositions advanced by Llewelyn Williams ${ }^{230}$ but he also felt that a reconsideration of the legislation was also required. He cleverly placed this 'reconsideration', in a context which evoked the 'new spirit' which had been advanced by the Prime Minister as necessary to ‘solve the vast problem of national reconstruction’ after the Great War. As with the 'Salisbury letter', the Bishop displayed a sure political acumen in his invocation of Lloyd George’s aspirations for a post-war society. The Bishop went on to subtly threaten that if postponement was not forthcoming, then such a refusal would: 'strengthen the case for equitable reconsideration of the Welsh Church Act at the end of the war in order to consolidate national unity for the great work of national reconstruction'. It would appear that, in addition to Llewelyn

230 ‘The Church in Wales. Effect of the Way’, The Times, 10 April 1917, p.8. 
Williams’s concerns about profiting financially from the war, the Church was also prepared to harness the anticipated patriotic 'spirit' in order to win the day and the Bishop of St. David's had no compunction in associating the maintenance of the Church's status with 'the future of national welfare', which must surely trump the quest for disestablishment, which he dismissed as 'prewar party prepossessions’.

Whereas W. Llewelyn Williams was highly critical of the bishops, who were clearly manipulating the position, he was to reserve his real ire for his former political ally and friend when, in an article, in 1919, he lambasted David Lloyd George in respect of the fact that, through his machinations and his 'trickiness' he had used to leave the Church 'richer than ever', confirming that 'The Church has won in the last lap of the race'. ${ }^{231}$ Llewelyn Williams had been more prescient than he would have wanted, when he wrote in 1896 that: 'If the Liberalism of England is incompatible with the Nationalism of Wales then we shall become Nonconformists in our politics as well as in our religion', but Welsh 'radical' politicians had remained as conformists within the Liberal party. ${ }^{232}$ It was apparent that Lloyd George was astute enough not to jeopardise the support of his traditional supporters, when it was reported that:

'Representatives of all the Welsh Nonconformist denominations lunched with the Premier, on Thursday, to discuss the position of the Welsh Church under the Disestablishment Act. Mr. Lloyd George laid it down as a, starting point that the Welsh Act is to remain intact, but that the question was how much should be conceded to the Welsh County Councils to cover their losses and to the Welsh Church to cover theirs, if any. The Welsh delegates were not disposed to be ungenerous to the Church, provided a final settlement was effected, and the matter was adjourned for an actuarial report, which will be used as the basis of a final settlement'. ${ }^{233}$

The fact that a grant of one million pounds was to be reported shortly after the Prime Minister's lunch would suggest that reference to 'the actuarial report' was to forestall any suggestion that the payment was a form of 're-endowment' and a political device to maintain political power, so far removed from the original intentions:

'In connection with the Welsh Church (Temporalities) Bill which is down for second reading in the House of Commons on Wednesday, a grant of $£ 1,000,000$ is proposed. A White Paper, issued on Tuesday night, explains that the object of this grant is to enable

\footnotetext{
${ }^{231}$ W. Llewelyn Williams, 'The Great Betrayal', Welsh Outlook, vol.6, no.9 (Sept. 1919), p.227.

${ }^{232}$ W. Llewelyn Williams, 'Through Welsh Spectacles', Young Wales, vol.2, no.14 (February 1896), p.31.

233 'The Premier and the Welsh Church', Llangollen Advertiser Denbighshire Merionethshire and North Wales Journal, 25 July 1919, p.8.
} 
the Welsh Commissioners to meet their obligations in respect of the Commutation of its existing life interests'.234

Frank Morgan’s letter to Bishop Owen provided crucial evidence of how the senior secular official of the Welsh Church was to advise a senior prelate of how that Church would work to ensure that the 'grievance' of disendowment could be tainted by the truth:

'it was urgently important not to let Welsh Nonconformists get the idea that the Church had not suffered by Disendowment. I am absolutely clear that we want $£ 1,000,000$ new money but do not care much on what ground we put the claim. ${ }^{235}$

It is instructive to understand how Welsh Church (Temporalities) Act was viewed by the Church, at a more local level, when, at a mooting of the Wrexham Deanery Association, Archdeacon Fletcher appeared unmoved by the current state of affairs, albeit with an almost Pavlovian response that 'the alienation of the Welsh Church's ancient endowments was nothing else than sacrilege', but at least they 'knew the worst'. He was more vexed by his prediction:

'that there could be no doubt that at the next general election we should see the Labour party come in and that one of the first measures they would bring forward would be the disestablishment and disendowment of the Church in England and a measure of a very drastic character, too'. ${ }^{236}$

Although one of the laymen in attendance was keen to dispel any suggestion that the Act: 'embodied a bargain between Mr Lloyd George and Mr Bonar Law, and that the Church secured better terms because of the support given to the Coalition Government'. He preferred to attribute the 'advantages' to the lapse of time, which was certainly accurate, and 'certain economic effects'. Canon Davies, the vicar of Wrexham, appeared more gracious and said that he was thankful for many things in the Act and, for instance, to be able to have marriages 'conducted in the same old way in their churches', which arguably for many clerics would have been one of those crucial 'establishment' characteristics which were perceived as vital if the disestablished Anglican Church was to continue as before.

\footnotetext{
234 ' $£ 1,000,000$ for the Welsh Church', The Cambria Daily Leader, 6 August 1919, p.1.

${ }^{235}$ Frank Morgan to Bishop Owen, 23 September 1919, N.L.W., Bishop John Owen papers, 12/6.

236 'Welsh Church Endowments. Archdeacon Fletcher's Forecast', The North Wales Chronicle, 28 November 1919, p.5.
} 
It would not have been necessary to have a particularly keen power of recall, in order to recollect 'Mr. Lloyd George’s Pledge to Wales', as The Times captioned its reportage of the major demonstration held in Swansea in May 1912. ${ }^{237}$ It had only been held seven years before the decision to award the one million pounds grant, but much had transpired and few would recall Lloyd George's riposte to suggestions of exhibiting generosity to the Church, with a rebuttal:

'If the property belongs to the nation, or if it was given for the benefit of the Welsh people, it is theirs, and we cannot give away the property of a nation in order to obtain a meretricious credit for generosity'. ${ }^{238}$

In his peroration to the gathered thousands, Lloyd George declared: 'For Heaven’s sake let us apply our principles fearlessly’. It was apparent that British party politics would have eroded those principles by 1919. The Welsh Outlook proclaimed that it had no intention of pronouncing upon the 'merits of the financial solution' that was announced, although it pointedly stressed that at least some viewed it as 'an utter betrayal of Wales'. ${ }^{239}$ However, what the periodical wanted to stress was the ignorance displayed by the 'vast majority' of the Liberal party. The essence of their argument being that Wales was ill-served by the Liberal members of Parliament, whereas 'the Church party had mastered every detail of the controversy' and that 'the sacrifice of every national issue through neglect and ignorance cannot go on'. ${ }^{240}$

It would appear that the 1914 Act, and all that eventually led to it, was being ushered out of the door, like an embarrassing distant relative, despite the fact that the subject matter had been very much a lively, contemporary issue only five years earlier. It is understandable if the traumatic events of 1914/1918 had cast Welsh disestablishment into another era, despite its proximity in time. At least the Home Secretary did attempt to 'satisfy the House' that, in 'the judgement of most people who examined the figures', the Church was not fiscally disadvantaged, as many assumed and he went on to explain the reasons why. It has been demonstrated elsewhere that:

'The passage of two laws reduced the amount paid to the Welsh Beneficiaries and increased the financial security of the Welsh Church after disestablishment. First, in 1918, an increase in the price of grain made it necessary to cap tithe, and that cap limited the income from tithe but not the amount paid to the Welsh Church. Second, in 1919 the

\footnotetext{
237 'Disestablishment Demonstration. Mr. Lloyd George’s Pledge to Wales’, The Times, Wednesday, 29 May 1912, p.6.

238 Ibid.

239 'Welsh M.P.s - Promises and Performances', Welsh Outlook, vol.6, no.9 (September 1919), p.224.

240 Ibid., p.225.
} 
entire disendowment scheme was at risk of collapsing because of the 1918 legislation, and in addition to a subsidy of $£ 1,000,000$ from the government, the Welsh Church also gained other financial concessions that were detrimental to the Welsh Beneficiaries'. ${ }^{241}$

In a markedly different interpretation from that still proffered by the Welsh Church, it is suggested that various Archbishops of Wales have 'successfully diverted attention from the fact that the Church was almost certainly better off financially after disestablishment than it had been before' and very tellingly, it was the intended secular beneficiaries of the endowment who subsidised this state of affairs. ${ }^{242}$ On that basis, and in light of how the Church retained many characteristics of its established status, then Welsh disestablishment was an event whose identifying characteristics had been so attenuated to such an event that it bore no resemblance to what had been originally envisaged fifty years earlier and those early campaigners would not have recognized the resulting disestablishment or disendowment. Not only were the basic tenets of disestablishment not reached, but the Church did not become the 'Welsh' church that had been identified by those Anglicans, such as Dean H.T. Edwards, as described in chapter four.

\footnotetext{
${ }^{241}$ S. Peterson and I. McLean, 'Of Wheat, The Church in Wales and the West Lothian Question', Welsh History Review, vol.23, no.3 (June 2007), p.153.

242 Ibid., p.173.
} 


\section{Chapter four: Dramatis personce.}

It would be reasonable to assume, from the contents of contemporary speeches, newspaper coverage and pamphlets that the established Anglican Church in Wales was an entity with shared values and outlook, combined with an accepted response to the calls for disestablishment, and that substantive and manifest differences lay solely between the Church and Nonconformity. This binary approach masks a battle for the soul of the Welsh Church and this struggle was exemplified, bizarrely, by two brothers, Henry Thomas Edwards ${ }^{1}$ and Alfred George Edwards ${ }^{2}$, whose actions were to generate contrasting reputations. The outcome of their antithetical approaches to the Welsh Church was, in part, to be influenced by the early death of H. T. Edwards, in 1884, although the Reverend David Jones endeavoured to ensure that his views continued to be available, as well as promulgating his own corresponding views. Both brothers sought to defend the Church against disestablishment, but they were defending very different versions of that church.

The writings of the two Edwards brothers highlighted an elementary difference in terms of their perception of the nature of the relationship of the Anglican Church and Wales. H. T. Edwards believed that it was necessary to understand the realities of the 'alien' nature of the Welsh Church and what should be done to address it, whereas A. G. Edwards would casually omit or reinterpret those aspects of the Church's history that might create reason to criticise. It was, essentially, the difference between the Church of England in Wales and a Welsh Anglican Church. Nomenclature had always been problematic, and subject to interpretation, and whereas the 'Welsh Church' or the 'Church in Wales' fell into common usage over time, it was often simply short-hand terminology based upon geography and not nationality. ${ }^{3}$ Although, the Church

\footnotetext{
${ }^{1}$ Henry Thomas Edwards, (1837-1884), Dean of Bangor from 1876 to his death. He was curate, at Llangollen, to his invalid father from 1861 and was appointed vicar of Aberdare in 1866, becoming vicar of Caernarfon in 1869.

${ }^{2}$ Alfred George Edwards, (1848-1937), archbishop of Wales from 1920 to 1934. Appointed headmaster of Llandovery College in 1875 and in 1885, he was appointed chaplain and secretary to Basil Jones, Bishop of St. David's and became vicar of Carmarthen. He was chosen as bishop of St. Asaph in 1889. His entry in the O.D.N.B. contains a tendentious comment that, as Prime Minister, Lloyd George had attended the archiepiscopal enthronement in 1920 'to give his blessing to the church which he had helped to despoil'.

3 'Church in Wales', HC Deb. 20 February 1891, vol. 350, cc.1258: during his pivotal declaration in support of Welsh disestablishment, Gladstone referred to the history of the Established Church in Wales and that: 'as far as I know that history, we might really speak with as much justice of the Church of Wales in England as of the Church of England in Wales'.
} 
was to become aware of the importance of 'branding', particularly as it attempted to maintain an uneasy dual approach; stressing its position as part of the Church of England but, as external factors demanded, to demonstrate an attribution to its own definition of a heavily circumscribed Welsh nationality. The innate contradiction in how the Church defenders, including the Bishop of St. David’s, John Owen, presented the ‘Welsh Church’ was to be emphasised by the bishop’s cousin, Owen Owen ${ }^{4}$, who pointed out that:

'One day we hear that the Established Church in Wales is the ancient British Church, with claims to antiquity far superior to those of the Church of England; another day we are told that it forms so indissoluble a part of the Church of England that its severance would endanger the very life of the great body to which it belongs'. ${ }^{5}$

Before attempting an examination of the two brothers, two significant Church-related events, which occurred shortly after the Dean's death, will be considered. It is argued that they provided indicators of how the Church would meet the 'threat' of disestablishment and whether it would elect to actively pursue a policy of reform and comprehensive revival, as identified by Dean Edwards as the only alternative to disestablishment, or whether it would simply rely upon its privileged position, knowing that, ultimately, it could rely upon the House of Lords to stymie any legislative challenge.

\section{The Archbishop of Canterbury's first visit to Wales for seven hundred years.}

There were some who were increasingly troubled by the Church's apparent complacency and, in 1879, Dean Bonnor ${ }^{6}$ of St. Asaph expressed alarm at the progress of the Liberation movement and he warned that the Church must not ignore:

'the fact that if the public mind was permitted to be poisoned, year after year, by means of lectures, public addresses, pamphlets, and tracts full of misstatements respecting the Church, its history, and endowments, without any explanation or reply, the time would not be far distant when a Parliament would be elected pledged to the disestablishment and disendowment of the National Church'?

\footnotetext{
${ }^{4}$ Owen Owen, (1850-1920), first chief inspector of the Central Welsh Board for Intermediate Education in Wales, a post he held from 1897 to 1915, when he resigned for serious health reasons: D.W.B.

${ }^{5}$ Owen Owen, Welsh Disestablishment. Some Phases of the Numerical Argument, Wrexham, 1895, p.45.

${ }^{6}$ Dean Richard Bonnor Maurice Bonnor, (1804-1889), Dean of St. Asaph from 1859 to 1886: 'Death of Dean

Bonnor', The North Wales Chronicle and Advertiser, 30 March 1889, p.7.

7 'Disestablishment', The Rhyl Advertiser, 15 March 1879, p.3.
} 
In 1880, the Dean of Llandaff ${ }^{8}$ had echoed a similar concern, at a meeting of the Llandaff Diocesan Church Extension Society, when he had warned that: 'we lived in times of very considerable anxiety for the state of the Church. The word Disestablishment was trembling on every tongue'. ${ }^{9}$ His warnings were met with some incredulity and The Cardiff Times was perturbed by the tone and believed that he 'must surely have overstepped the limits of quiet, deliberate judgment'. ${ }^{10}$ It became evident that the Church would only respond if it perceived that political exigencies could form an existential threat. The first significant intimation that the Church of England in Wales would mobilise itself in order to meet the threat of disestablishment can be traced to an ecclesiastical extravaganza which was held in Lampeter in October 1885. The Archbishop of Canterbury, Edward White Benson, laid the foundation stone for the Canterbury Building at St. David's College, where: 'the town was decorated for the occasion, the neighbourhood of the college and the station being specially enlivened with ornamental arches, mottoes, banners, \&c'. ${ }^{11}$

The event was much more than a prosaic, Anglican ceremony to mark an event of limited interest outside the College and the diocese and, in effect, it bore all the characteristics of a 'Trooping of the Colour' ceremony, with Lampeter as a cantonment, and the gathered Anglican masses to be inspected and inspired by a morale-boosting acclamation delivered by Archbishop Benson. ${ }^{12}$ This was in recognition of the fact that: 'The whole country has been resounding from end to end with the conflict about Disestablishment ${ }^{13}$ Archbishop Benson had expounded upon the problems facing the Church of England during a Canterbury Diocesan Conference a few months earlier, in July 1885, when he advised that 'the Church did not desire to enter into the political arena; but circumstances might arise to compel her to do so, and then suddenly she would find herself the most powerful political party' ${ }^{14}$ It was a warning to the Liberal Party that

\footnotetext{
${ }^{8}$ Charles John Vaughan, (1816 - 1897), Dean of Llandaff from 1879 to his death.

9 'Llandaff Diocesan Church Extension Society', Monmouthshire Merlin, 23 April 1880, p.8.

10 'The Church Really in Danger', The Cardiff Times, 24 April 1880, p.5.

11 'The Archbishop of Canterbury at Lampeter, South Wales Daily News, 16 October 1885, p.4.

${ }^{12}$ On the battlefield, a regiment's colours or flags, were used as rallying points. Consequently, regiments would have their junior officers slowly march with their colours between the ranks to enable soldiers to recognise their regiments' colours.

13 'Many minds will be exercised for a long time in interpreting the meaning of the general election', The Times, 2 December 1885, p.9.

14 'Canterbury Diocesan Conference’, The Times, 1 July 1885, p.8.
} 
the Church would have no other option if they should they should formally adopt disestablishment as one of their policies.

The general election of 1885 was described as: 'the nearest point ever attained to the accomplishment of disestablishment in England'15 and it was now recognized that: 'The Welsh Church was the key of the position for the English Church as a whole, and Lampeter in a way was the key of the Welsh position'. ${ }^{16}$ If English Anglicans were anxious about the future of the establishment, then the Anglicans in Wales would have had reason to be extremely perturbed and they would be desperate to seek reassurance and comfort. Lampeter served as Anglicanism’s bastion and garrison town, within a sea of nonconformity, and they would have been aware of how their bastion was perceived: 'Lampeter is merely a Church of England College, tutored by a staff of professors, with one exception, purely English' and that 'The Church of England, it must be said, is flourishing in Lampeter, but what could one otherwise anticipate within arm's length of such a well-endowed proselytising machine'. ${ }^{17}$ A few years later, in 1895, the then Prime Minister, Lord Rosebery, in an endeavour to explain his government's policy on Welsh disestablishment to a hostile Queen Victoria, stated, in a less than graphic manner, that; 'Wales is different. There the Church of England has lost hold on the mass of the people.... It is ... very much what Gibraltar is to Spain, a foreign fortress place on the territory of a jealous, proud and susceptible nation'. ${ }^{18}$

Speaking during that same month as the Archbishop's visit, Henry Chaplin, the Chancellor of the Duchy of Lancaster, believed that: 'the Church never was in greater danger than it was at present' and that 'Liberal lovers of the Church' should seek a 'clear and definite statement' from Gladstone before they cast their vote. ${ }^{19}$ The Archbishop's visit to Lampeter took place the month before the general election and the importance of his presence in Wales, which was the first visit by an Archbishop of Canterbury in seven hundred years, accentuated the significance. There were interesting comparisons with Archbishop Baldwin's tour in 1188, but whereas Baldwin had been intent on consolidating the allegiance of the Welsh Church, Archbishop Benson's

\footnotetext{
${ }^{15}$ Morgan, Wales in British Politics 1868-1922, p.64.

16 'Death of Bishop Jayne', The Times, 25 August 1921, p.11.

17 'Lord Selborne at Lampeter', The Cambrian News, 11 November 1887, p.5.

18 John Davies, 'Victoria and Victorian Wales', in Politics and Society in Wales, 1840-1922 (Cardiff, 1998), ed. by Geraint H. Jenkins and Ieuan Gwynedd Jones, p.13.

19 'Mr. Chaplin at Crieff', The Times, 14 October 1885, p.10.
} 
appearance brought an opportunity to offer comfort and reassurance to a Welsh Church that considered itself under attack. Although it did appear that at least some of the senior Churchmen present that attempts to draw the Welsh Church ever closer to England was the sole means to resist disestablishment, rather than from the Church's efforts within Wales, as suggested by the words of the Dean of Llandaff, Charles John Vaughan:

'Might the barrier between England and Wales become weaker and slighter every day. He was convinced that it was in the solidarity of the churches of England and Wales that the one safety of the Church in Wales at last would be found to consist. He could not find a greater proof of the vitality of the Church in Wales than at Lampeter' ${ }^{20}$

The Archbishop was clearly alert to what the assembled Anglicans wanted to hear and he graphically illustrated the relationship between the Welsh and English Churches:

'When one was travelling over glaciers he took good care to be well roped, if possible, to people stronger than himself, and if there were people weaker than himself, was very glad to have the rope passed on to them, so that if one went down a crevasse five or six would be strong enough to keep him from going to the bottom. He thought that the Churches in England and Wales were well roped together and he hoped and trusted there was nobody on either side the border who would slip a penknife out of his pocket and divide the strand of rope'. ${ }^{21}$

It would be another thirty years before a future Archbishop of Canterbury would 'slip a penknife' out of his archiepiscopal pocket and allow the Welsh Church to fall, rather than permit that 'brotherly embrace' to draw the English Church, in the context of its own unsettled and ambivalent relationship with the state, over the same uncertain precipice. Archbishop Benson was to dismiss Geraldus Cambrensis as a 'harmless agitator', who had simply sought personal advancement, and whom the Archbishop portrayed as a proto-disestablisher who would 'have made Wales and the Church entirely independent of the people of England'. Any accurate depiction of Geraldus Cambrensis ${ }^{22}$ would provide the Church with difficulties, particularly as he was the 'most vigorous of all the champions' of the right of St. David's to be considered the metropolitan see of Wales. ${ }^{23}$ As stated in his entry in the Dictionary of Welsh Biography, it was 'his very qualifications for being bishop of St. David’s - his Welshness, his learning and his

\footnotetext{
20 The Archbishop of Canterbury at Lampeter. Extension of St. David's College', The Cambrian News, 23 October 1885, p.5.

${ }^{21}$ Ibid.

${ }^{22}$ Giraldus Cambrensis, (1146? -1223), archdeacon of Brecon. As stated in D.W.B.

${ }^{23}$ Glanmor Williams, The Welsh and their Religion (Cardiff: UWP, 1991), p.18.
} 
energy - that made him unsuitable in the eyes of his opponents'. There are marked parallels between him and Dean H. T. Edwards, some seven hundred years later. Whoever advised the Archbishop upon his Welsh historical commentary should have been alert to the fact that this was an area which could be subject to some ridicule and The Cambrian News's ended its detailed reportage of the day's events with a satirical poem, which clearly indicated that, after seven hundred years, nothing had changed:

'Tho' Archbishop Baldwin preached in French and I in Latin, of which languages the Welsh understood not a word, yet, wonderful and miraculous to relate, we converted hundreds of them to the Holy Crusade."-Giraldus Cambrensis, Itinerary of Wales, A.D. 1188.

Seven hundred years are past and gone

Since an English Archbishop came Wales to see, Under pretence of a Holy Crusade, To reduce St. David to Canterburie.

In Latin and French he then did preach, For never a word of Welsh knew he.

'Twas a sheer miracle, writes honest Cambrensis, We converted one Welshman to that Holy Crusade. Seven hundred years are past and gone.

And an English Archbishop again is come, Seven hundred years is a good long time, And a good many changes have happened since then, But there's never a change in the Church in Wales.

Bald Latin was there the foreigners tongue, Bald English now-never a word of Welch sublime, Not a word the Welsh can understand, To the Welch themselves in their ancient land. And there are the Bishops of the Foreign Church, Bangor, St. David's, and John Llandaff, Llandaff was "ploughed" for his Saxon Welsh, ${ }^{24}$ And Bangor's Welch is a Scottish brogue ${ }^{25}$, St. David was refused his bishopric once ${ }^{26}$, For tho' he could write it, he couldn't pronounce. There's Principal Jayne ${ }^{27}$, the head of a college,

\footnotetext{
${ }^{24}$ Bishop Richard Lewis, (1821-1905), Bishop of Llandaff from 1883 to 1905.

${ }^{25}$ Bishop James Colqhoun Campbell, (1813-1895), born in Argyllshire. Bishop of Bangor from 1859 to 1890.

${ }^{26}$ Bishop Basil Jones, (1822-1897). Bishop of St. David's from 1874 to 1897.

${ }^{27}$ Francis John Jayne, (1845-1921), bishop of Chester from 1889 to 1919. He was born in Llanelly, Brecknock, and was Principal of St. David's College from 1879 to 1886, being credited as its 'second founder'. After leaving Lampeter he served briefly as vicar of Leeds, before his elevation to the bishopric of Chester in 1888, which he held until 1919: When he was consecrated as Bishop, the sermon was preached by The Rev. Alfred George Edwards, vicar of Carmarthen, and Bishop-designate of St. Asaph and Jayne's brother in law: 'Sermon by the Bishop Designate of St. Asaph’, Rhyl Record and Advertiser, 2 March 1889, p.4.
} 
Built in the midst of Wales and the Welsh, Expressly to rear young men for the Church, Yet never a word of Welch knows he More than his Grace of Canterburie. These are the five, the miraculous five, For only by miracle can it be done, To build up a Church that's rotten and gone, The shame of our Principality. CAMBRENSIS REDIVIVUS, October 10th, 1885’ ${ }^{28}$

\section{Bringing bees back to the hive?}

When Joshua Hughes, the Bishop of St. Asaph, died in January1889, it appeared that the Prime Minister, Lord Salisbury, would struggle to identify a Welsh-speaking Bishop to whom he could offer a mitre, particularly as it was reported that: 'He has used up his one pet Welshman' ${ }^{29}$ in sending Canon Jayne to Chester' ${ }^{30}$. Reporting upon the death of Bishop Hughes, the Western Mail reminded its readers of the reason behind his elevation in 1870:

'for about 150 years the Welsh sees had been held by Englishmen, who could not enter into the national spirit of the Welsh people, and it was argued that if the bees were to be brought back to the hive one of the first steps to be taken was the appointment of Welsh bishops' ${ }^{31}$

\section{Alfred George Edwards was appointed Bishop of St. Asaph in February 1889 and the Rhyl}

Record was not alone in assuming that one of the reasons why Lord Salisbury appointed him, 'over the heads of such well-known and universally-beloved men as Canon Howell of

Wrexham', was that:

\footnotetext{
Describing the 'curious coincidence' that the Bishops of Chester and St. Asaph were married to sisters, and that both were nominated as bishops in 1889, The Times's commentary on Bishop Jayne, following his death, reported that those who had observed their careers might 'notice other similarities', in that: 'The Bishop of Chester, like his brother of St. Asaph, displayed a certain fondness for newspaper controversy', although it noted that Bishop Jayne 'applied himself with vigour, if not always with wisdom, to temperance': 'Death of Bishop Jayne. A Public house Reformer', The Times, 25 August 1921, p.11.

${ }^{28}$ The Archbishop of Canterbury at Lampeter. Extension of St. David's College', The Cambrian News, 23 October 1885, p.5.

${ }^{29}$ H. T. Edwards, 'Why are the Welsh People Alienated from The Church?', in Wales and the Welsh Church (London, 1893), ed. by David Jones: The newspaper appeared to have forgotten that Jayne did not speak Welsh. This was highlighted by Dean H. T. Edwards in 1879, in the context that although 'the recently appointed Principal of St. David's College' would 'doubtless do good service in Wales', he would have been 'more able to estimate correctly the official difficulties of a non-Welsh-speaking Bishop in Wales, if he had himself possessed a knowledge of the Welsh language, and of the inner life of the Welsh people'.

30 'The Bishop of St. Asaph', Denbighshire Free Press, 6 October 1888, p.4.

31 'Death of the Bishop of St. Asaph', The Western Mail, 22 January 1889, p.3.
} 
'For some years he has been renowned for his hatred - if not, indeed, intolerance - of Nonconformists. With tongue and pen he has attacked them. If Lord Salisbury had the least desire to conciliate Nonconformists, and to allure them back to the fold of the Mother Church, he has been ill advised as to the most likely way to bring that about'. ${ }^{32}$

A few months before he was first elected to parliament, David Lloyd George addressed a meeting of the South Wales Liberal Federation and he noted that: 'The national Church must first of all be the Church of the nation, but the established Church of Wales was emphatically not the Church of the Welsh nation', however he evoked some laughter by his reference to the fact that: 'They in South Wales had latterly exported to the north a bishop. They might have exported many more useful things', without any appreciation of the ramifications. ${ }^{33}$ When it became apparent that Bishop Joshua Hughes's period as bishop would soon end, a Welsh correspondent writing for The Times sought to suggest the characteristics of the new bishop and, presumably because of A. G. Edwards's well-known letters to that newspaper, the correspondent acknowledged that there were Welsh candidates who held 'strong polemical tendencies', but that it would have been 'unwise to select any man who has made himself prominent as a controversialist on religious matters. The waters are troubled enough as matters stand' and that the 'the times are ripe for the appointment of a peacemaker' ${ }^{34}$

The Cambrian News certainly did not anticipate the impact of his appointment or, indeed, the fact that the campaign for Welsh disestablishment was to be prolonged beyond anything the newspaper could have anticipated, when, with some hubris, it rather dismissively suggested that: 'The Church of England is greatly in need of fighting bishops, and that, we suppose, is the reason the Rev. A. G. Edwards, vicar of Carmarthen, has been made Bishop of St. Asaph’ ${ }^{35}$ It went on to claim that the interest of Nonconformist in his elevation was 'languid', because: 'The fate of the Established Church in Wales is settled, and neither the skilful manipulation of ecclesiastical statistics, nor fanciful schemes for bringing all Nonconformists into the Church of England can unsettle it'. The newspaper suggested that his appointment was surprising, but ultimately it was considered to be of no import, because it was believed that the new member of the episcopate would be the bishop of a free Church before he had served very long and would then attract no

\footnotetext{
32 'The New Bishop', Rhyl Record and Advertiser, 23 February 1889, p.2.

33 'South Wales Liberal Federation', Carnarvon and Denbigh Herald, 7 February 1890, p.5.

34 'A Crisis for the Welsh Church', The Times, 28 September 1888, p.6.

35 'The New Bishop of St. Asaph', The Cambrian News, 22 February 1889, p.4.
} 
more interest than the leaders of any denomination. It was understandable if the Cambrian News also attributed more significance to the collection of tithes by 'police and soldiery', at the time of Edwards's appointment, and believed that such actions were doing all that 'the most ardent disestablishers ever desired ${ }^{36}$, as it would have been logical for those involved in the anti-tithe agitation to regard it as 'a stepping stone to disestablishment and disendowment of the Church $^{37}$.

It has been suggested that any hope that Anglican Liberalism might prevail within the Welsh Church was undermined by the 'Tithe War' 38 and the Bishop of St. Asaph, presiding at his first diocesan annual conference in 1889, was in no mood to compromise, when he attributed the agitation to a band of agitators, who 'had taken advantage of the agricultural depression to transform the consequent rent distress and natural discontent into an agitation against the Church and the land'. ${ }^{39}$ Although he acknowledged that some farmers 'found it difficult to pay tithes', others farmers were taking advantage of the situation, where he claimed that: 'The motive power came from outside'. ${ }^{40}$ It was apparent that it was not in the Bishop's interest to acknowledge that opposition to the payment of tithes was 'only part of a much larger movement that encompassed many causes', although disestablishment was recognized as the pre-dominant issue. ${ }^{41}$ The same newspaper still tended to underestimate the Bishop’s belief that the best form of defence was offence when, in 1897, it posited that the Bishop was a 'great disestablisher', because: 'the real defenders and builders up of the Church are not manipulators of statistics, or detractors of Nonconformists, but holy livers and gentle-minded upholders of a perfect life'. ${ }^{42}$

The Western Mail identified the veracious reason for his appointment when, shortly after his enthronement, it utilised military metaphors in its veneration of the Bishop:

'The conductors of the Welsh newspapers are beginning to realise the fact that the now Bishop of St. Asaph is an antagonist who will tax all their talents and ingenuity in the impending contest between Church and Dissent. Bishop Edwards possesses the necessary qualities of a successful leader - coolness, courage, skill. He has taken a complete survey

\footnotetext{
36 Ibid.

37 J.P.D. Dunbabin, Rural Discontent in Nineteenth Century Britain (London, 1974), p.230.

${ }^{38}$ Emlyn Sherrington, Right-Wing Nationalism in Wales 1870-1935 (2015), p.4.

39 'The Welsh Tithe Agitation', The Times, 18 September 1889, p.10.

40 Ibid.

${ }^{41}$ Dunbabin, Rural Discontent in Nineteenth Century Britain, p.229.

42 'The Bishop of St. Asaph', The Cambrian News, 17 December 1897, p.5.
} 
of the field of battle, the number and discipline of the respective forces, and enters upon the conflict with well-grounded confidence'. ${ }^{43}$

The newspaper's editorial was also elated that the Bishop was 'represented as running counter to the national sentiment', and that 'he will not join the crusade against England and everything English’. With such credentials, it was not surprising that A. G. Edwards, when appointed bishop, was viewed in stark contrast to his brother, H. T. Edwards: 'Mr. Edwards has not made himself so conspicuous an advocate of purely Welsh ideas as his famous brother, the late Dean of Bangor. He is an ordinary English gentleman, with no noticeable trace of provincialism in accent, manner or mode of thought' ${ }^{44}$

The Reverend Evan Jones ${ }^{45}$ provided 'a Nonconformist View' and confirmed that 'the country would have awarded the mitre to "Llawdden"46 as a genuine Welshman, an eloquent and evangelical preacher, and a man not inexperienced in leading and managing his fellowmen'. ${ }^{47}$ In terms of Bishop Edwards, Reverend Jones, like Lloyd George, severely underestimated the eventual impact of the man, when he wrote that: 'The appointment may be looked back upon, from future ages, with interest, not so much on account of the person appointed as on account of the circumstances', being the fact that if he would probably be a bishop when disestablishment took place. Although he did acknowledge that: 'He cannot but play a great part in the drama now on the stage, and Wales will watch, not without interest, the movements of the boy-bishop', Reverend Jones could not have envisaged that this Bishop's influence would amount to much more than that of an actor who came upon a leading part in a failing production, but that the Bishop would soon occupy a role as director of this long-running drama, with not only control over a refinement of the Church defence script, but also the casting of future senior ecclesiastical parts. He would go on to secure his 'lifetime achievement award' when, after thirty-one years as a bishop, his influence was recognised by his enthronement as the first Archbishop of Wales in 1920, surrounded by the panoply of an enduring Establishment, with plaudits associated with a victor, rather than with the vanquished.

\footnotetext{
43 'The Welsh Press and the Bishop of St. Asaph', The Western Mail, 13 May1889, p.2.

44 'The New Bishop of St. Asaph', Rhyl Record and Advertiser, 23 February 1889, p.3.

${ }^{45}$ Evan Jones, (1836-1915), Calvinistic Methodist minister and journalist.

46 Dean David Howell.

47 'The See of At. Asaph. The Rev. A. G. Edwards, M.A., Bishop Designate of St. Asaph. Biographical Sketch', Carnarvon and Denbigh Herald, 22 February 1889, p.5.
} 


\section{The Rhyl Church Congress of 1891.}

As with the Archbishop of Canterbury's visit to Lampeter in 1885, the arrangements for the Rhyl Church Congress of October 1891 were intended to provide a further opportunity to promulgate the Church of England's commitment to maintain the established nature of the Church in Wales. Less than a month earlier Welsh Churchmen would have read that: 'The disestablishment campaign in Wales was inaugurated yesterday by a conference of the Welsh National Council at Pontypridd'. ${ }^{48}$ The Church Congress was therefore an opportunity to explain, in explicit terms, to English Churchmen the threat, which the Rector of Llandyrnog considered was a 'death struggle' in which 'Nonconformity is to drop the "non" and assume the "con"” and all was 'reducible to this one struggle'. ${ }^{49}$ Since its inception, in 1861, the Church Congress had been held twice before in Wales; in Swansea in $1879^{50}$ and Cardiff in 1889. It was therefore perhaps unusual that the 1891 Congress should be held in a small North Wales seaside town, until it is appreciated that it would be held within the diocese of an ambitious, vocal, active bishop, who had been elevated only two years earlier. Bishop Edwards was evidently intent to consolidate the reputation he had garnered prior to his elevation, as an avid letter-writer to The Times. He would hold a pivotal role at the Congress, as the President of the assembly, where he would be the cynosure of the whole Church of England. When he had chaired 'an influential meeting', in 1890, which addressed the preliminary arrangements, where his eagerness to reassert the case for Rhyl as the venue, despite the fact that it had already been agreed, demonstrated an atypical incident of some uncertainty, when he emphasized that Rhyl was 'Liverpool was only an hour and a half's ride away, Manchester only a couple of hours', and London could be reached in less than five hours; so, thanks to the excellent train service they had in Rhyl, this town was placed very close to great centres of population' ${ }^{51}$

\footnotetext{
48 'Welsh National Council', The Times, 11 September 1891, p.5.

${ }^{49}$ An address on the 'Church Revival in Wales', by the Rev. D. Williams, Rector of Llandyrnog, and Rural Dean of Denbigh, The Official Report of the Church Congress, held at Rhyl, October $6^{\text {th }}, 7^{\text {th }}, 8^{\text {th }}$ and $9^{\text {th }}$, 1891 (London: Bemrose \& Sons, 1891), p.61.

${ }^{50}$ In his inaugural address to the 1879 Swansea Congress, the Bishop of St. David's had defined the Church Congress: 'as a promiscuous gathering of clergy and laity, meeting annually in one after another of our most important towns in order to ventilate and to discuss matters of grave interest to the welfare of the Church of England as by law established: 'The Church Congress, The Times, 8 October 1879, p.11.

51 'The Church Congress of 1891. Influential Meeting at Rhyl', Supplement to the Rhyl Record and Advertiser|, 25 October 1890.
} 


\section{'Our chief danger is panic among Welsh and apathy among English Churchmen'.}

Although it was demonstrably a coup to attract the Congress to his diocese, it was crucial for the Bishop to have the Archbishop of Canterbury in attendance, in terms of prestige and also if the Church Congress was to serve as an adequate response to disestablishment, both within Wales but also, vitally, to sustain any interest by English Churchmen. Initially, the Archbishop had not intended to be at the Church Congress and the Bishop of St. Asaph's response was an example of his relentless determination, which would be a characteristic of his role as Church defender. In his letter to the Archbishop, dated 18 August 1891, the Bishop of St. Asaph hid behind the Bishop of London, whom he claimed had stressed that it was Bishop Edwards's 'duty to lay before your Grace one consideration which seemed to him grave’. ${ }^{2}$ It was their view that since the Cardiff Church Congress which had convened only two years earlier: 'the Welsh

Disestablishment movement has taken a distinct and formidable step forward by reason of Mr. Gladstone's declaration ${ }^{53}$ on the subject'. ${ }^{54}$

Bishop Edwards opined that with that declaration, Welsh Churchmen felt that 'the real struggle has begun' and that: 'Our chief danger is panic among Welsh and apathy among English Churchmen' and the Archbishop’s presence at the Rhyl Congress 'would put heart into our people'. He warned that his absence would imply 'that English Churchmen were not ready to identify themselves too closely with the Church in Wales', although the Bishop stressed that 'nothing could be more untrue or unfair'. In a follow-up letter to the Archbishop's official, dated, 11 September $1891^{55}$, the Bishop stated that the Archbishop’s absence would: 'seriously injure the Congress' and the Bishop again referred to Mr. Gladstone’s speech, which had 'changed the whole situation' and he repeated the concern that: 'Our main danger lies in the apathy of English Churchmen and in panic among Welsh Churchmen'. Although he acknowledged that the Congress was not in itself important, he adds that the Archbishop's absence 'may tend to

\footnotetext{
${ }^{52}$ Lambeth Palace Archives: Benson vol.94, ff.48, letter from Bishop of St. Asaph to the Archbishop of Canterbury, 18 August 1891.

53 'Church in Wales', HC Deb. 20 February 1891, vol. 350 cc1257-1267. In anticipation of adverse comment upon his objection to Welsh disestablishment in 1870, Gladstone stated that he 'had time to be born again and come of age' and that he now recognised that it was now 'the distinct expression of a strong, distinct, deliberate, and pervading national sentiment'.

${ }^{54}$ Lambeth Palace Archives: Benson vol.94, ff.48, letter from Bishop of St. Asaph to the Archbishop of Canterbury, 18 August 1891.

${ }^{55}$ Lambeth Palace Archives: Benson vol.94, 53, letter from the Bishop of St. Asaph to Mr. Baynes, 11 September 1891.
} 
increase the English apathy'. In order to increase the pressure, the Bishop described the level of enthusiasm the Archbishop's visit would evoke, with 'some hundreds of quarrymen' from North Wales 'giving up their work', in order to attend. The Vicar of Rhyl, Canon Howell Evans, who had been instituted a year earlier, was also to apply pressure upon the Archbishop, whether at the Bishop's instigation or not is moot, although it was very doubtful that he would have written without his Bishop’s agreement. ${ }^{56}$ In his letter dated 14 September 1891, the Canon described the disappointment 'throughout the whole of North Wales' if the Archbishop did not attend and that they cared little about whether or not other prelates, such as the Archbishop of York, were present. $^{57}$

On 18 September 1891, the Bishop wrote a further letter to the Archbishop, in which he endeavoured to offer 'regret' for the 'pressure', but explained that he had been obliged to advise 'leading Committeemen' of the Archbishop's intentions, because the 'pressure put upon me was so strong and persistent' 58 The Bishop then resumed his attempts to persuade the Archbishop by making reference to an editorial and article which had appeared in The Times a week earlier. ${ }^{59}$ The timing of the meeting of the meeting of the Welsh National Council was fortuitous for the Bishop’s lobbying, as the Council meeting was said to have 'inaugurated' the disestablishment campaign in Wales ${ }^{60}$, which had allowed the Bishop to allude to the fact that 'Welsh Disestablishment is to be second to if not bracketed with Home Rule on the Liberal programme at the Newcastle meeting of the National Liberal Federation', which made 'the Welsh situation grave'. ${ }^{61}$ On the same day, the Bishop wrote to Mr. Baynes again, in which he stressed that if the Archbishop attended, all he needed to do was include 'one or two strong sentences about the Church of Wales' in his sermon, or alternatively make a 'short speech at the opening. ${ }^{62}$ Whether

\footnotetext{
56 'The New Vicar of Rhyl’, Rhyl Journal, 17 May 1890, p.2.

${ }^{57}$ Lambeth Palace Archives: Benson vol.94, ff.61, letter from the Vicar of Rhyl to the Archbishop of Canterbury, 14 September 1891.

${ }^{58}$ Lambeth Palace Archives: Benson vol.94, ff.60, letter from the Bishop of St. Asaph to the Archbishop of Canterbury, 18 September 1891.

${ }^{59}$ Editorial, The Times, 11 September 1891, p.7, 'Welsh National Council', The Times, 11 September 1891 , p.5.

${ }^{60}$ Ibid.

${ }^{61}$ Lambeth Palace Archives: Benson vol.94, ff.60, letter from the Bishop of St. Asaph to the Archbishop of Canterbury, 18 September 1891.

${ }^{62}$ Lambeth Palace Archives: Benson vol.117, ff.72, letter from the Bishop of St. Asaph to Mr. Baynes, Lambeth Palace, 18 September 1891.
} 
it was a result of the Bishop’s hectoring or the developing political position, the Archbishop was to eventually succumb. ${ }^{63}$

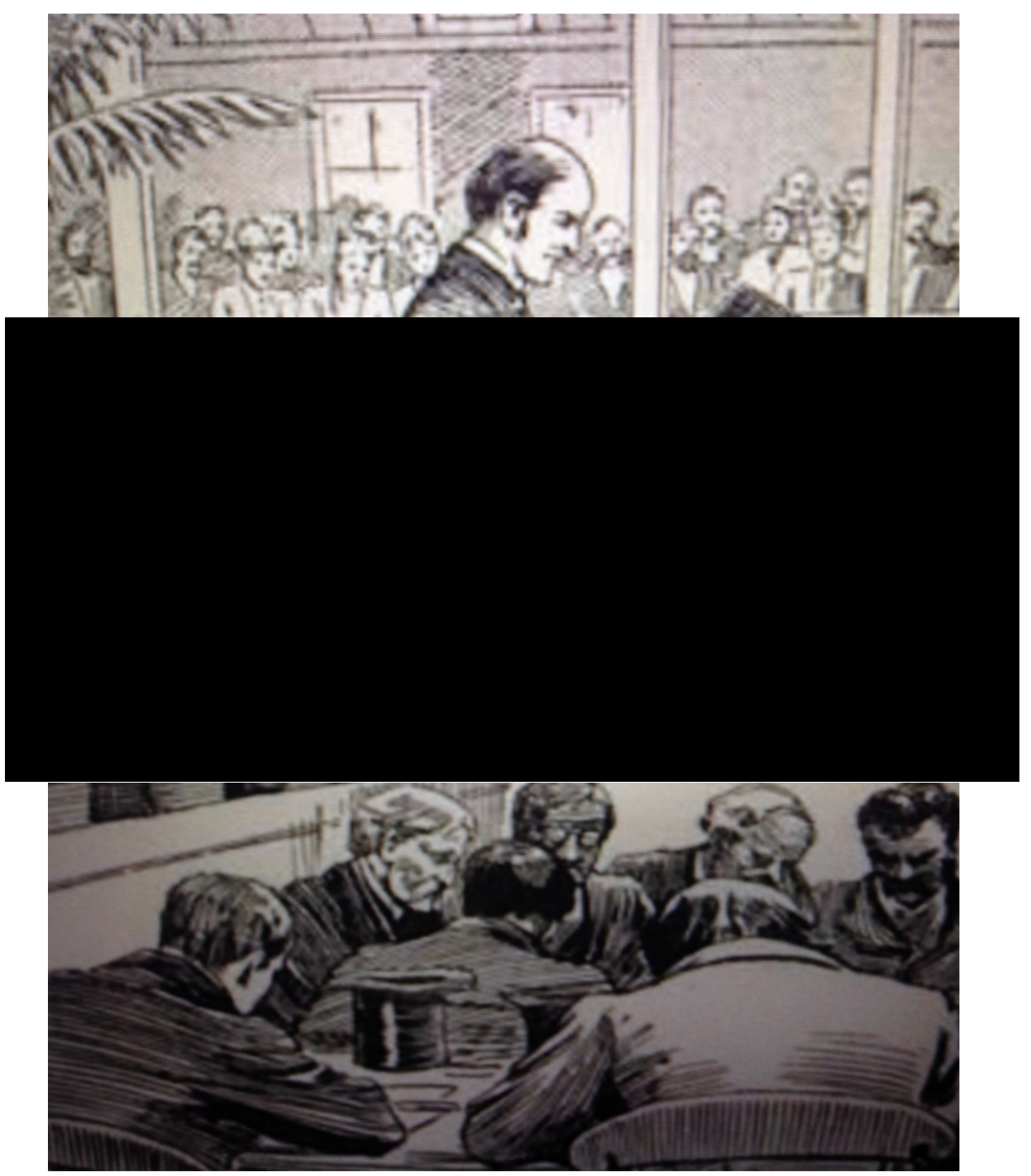

'The Church Congress at Rhyl. The Bishop of St. Asaph delivering the Opening Address', The Daily Graphic. 8 October 1891, p.4. The Archbishops of Canterbury (left) and York (right) sit behind the Bishop.

The first sermon at the Church Congress had been delivered by the Bishop of Manchester ${ }^{64}$, who dismissed any 'distinction between the Church in Wales and the Church of England' and addressed any complacency by English clerics with the warning that disendowment was a

\footnotetext{
${ }^{63}$ A.C. Benson, The Life of Edward White Benson, Sometime Archbishop of Canterbury (London, 1901), p.437, where the Archbishop's son wrote that: 'In spite of an overwhelming pressure of work, he yielded with patient consideration to the importunity of his Welsh brethren'.

${ }^{64}$ James Moorhouse was bishop of Manchester from 1886 to 1903, but he had previously served as bishop of Melbourne, from 1876 until his call to Manchester: O.D.N.B.
} 
'preposition for the piece-meal disendowment of the whole Church of England'. ${ }^{65}$ As the Rhyl Church Congress was held within his diocese, the Bishop of St. Asaph assumed the chair as president and he took advantage of his inaugural address to ensure that there were no doubts about how the Archbishop of Canterbury came to be present, as he was 'sure his Grace will forgive the importunity with which we sought his presence'. ${ }^{66}$ The fact that Bishop Edwards had been successful in lobbying for the Congress to be held within his diocese was recognised, but his success was interpreted as:

'a kind of acknowledgement of the fighting attitude he has displayed on behalf of the Church, of the fearless, if reckless character of his assertions, and of the unrelenting hostility h has manifested towards Nonconformists'. ${ }^{67}$

Ahead of the theme which the Archbishop of Canterbury would address, being the 'The Church Revival in Wales’, the Bishop took the opportunity to address the statements made by Mr. Gladstone in February $1891^{68}$, that it was the 'Church of the few' and the 'Church of the rich' and that Nonconformist were 'not contented' ${ }^{69}$ The Bishop quoted church attendance figures in his diocese, which would be challenged, and advised his audience that: 'the Principality does not lend itself either to a linguistic or geographical unity' and that 'the unity which Wales most needs is religious unity', under the auspices of the Established Church. ${ }^{70}$ The Bishop of St. Asaph would have taken satisfaction that his rebuttal of Mr. Gladstone had persuaded The Spectator that the Church was not that 'of a hopeless minority' and that 'Welsh Disestablishment has been placed in a new light'. ${ }^{71}$ However, the journal appeared to recognise that statistical offerings to support the Bishop's assertions did not address the fact that 'Wales sends to Parliament twenty-seven Disestablishment Members and only three supports of the Church’ and

\footnotetext{
65 The Official Report of the Church Congress, held at Rhyl, p.12.

${ }^{66}$ The Official Report of the Church Congress, held at Rhyl, pp.29-38. At page 29, he did go on to say that the 'importunity was merely the expression of a desire most strongly entertained by all classes in North Wales', but it would have been apparent that it was the Bishop who had orchestrated it.

67 'The Church Congress', Rhyl Record and Advertiser, 10 October 1891, p.2.

68 'Church in Wales', HC Deb. 20 February 1891, vol. 350 cc1264, where Gladstone said: 'In two vital and determining points I cannot deny that the case of the Welsh Church corresponds with that of the Church of Ireland. In the first place, it is the church of the few against the church of the many; and, in the second place, it is the church of the rich as against the church of the comparatively poor'.

${ }^{69}$ The Official Report of the Church Congress, held at Rhyl, p.30.

${ }^{70}$ The Official Report of the Church Congress, held at Rhyl, p.37.

71 'Welsh Disestablishment', The Spectator, 10 October 1891, p.21.
} 
it was drawn to the conclusion that 'it therefore lies with the Welsh Nonconformists to make out, if they can, a case for treating the Welsh church on a different footing from the English’ ${ }^{72}$

The person who would question the Bishop's attendance figures was Owen Owen, a cousin of John Owen, the Dean of St. Asaph. ${ }^{73}$ Owen Owen had attended Botwnnog grammar school with his cousin, but he had chosen a very different path and he had become a 'leader in the fight for disestablishment', although the cousins shared one interest and that was an examination of statistical information. ${ }^{74}$ Owen Owen challenged the average attendance at Welsh services, in the diocese of St. Asaph, which Bishop Edwards stated was 32,104. In Owen Owen’s opinion: ‘This figure is not far from being 4 times the actual figure' ${ }^{75}$ The diametrically opposed views of John and Owen Owen were to be given a Britain-wide prominence when letters from the two men, both dated 11 March 1892, were to appear next to each other in The Times, with John Owen, as Dean of St. Asaph, writing a scathing attack upon D. A. Thomas M.P., whereas Owen Owen was extremely critical of his cousin, whom he studiously refers to as the 'Dean of St. Asaph', in relation to statistical statements and to his attack on D. A. Thomas. ${ }^{76}$ There is no reference to their consanguinity, but it provided a graphic, public reminder of the divisive and apparently irreconcilable nature of the struggle for disestablishment.

Dean John Owen had been assigned with the task of advising the assembled Churchmen at the Rhyl Church Congress about the future prospects of Church revival in Wales, although he did not allow this brief to prohibit his own 'glance at the past and present of the Church in Wales'. ${ }^{77}$ The Dean then set about an examination of the Church’s past which, he averred, should ‘confirm

\footnotetext{
72 Ibid., p.22.

73 'The Church Revival in Wales - papers', the Very Rev. John Owen, Dean of St. Asaph, The Official Report of the Church Congress, held at Rhyl, p.52: Dean John Owen was also to speak at the 1891 Congress and his subject was the 'future prospects' of the Church Revival in Wales and he had been careful to draw in the interest of the English Churchmen present, by restating that the 'religious principles on which we take our stand are not peculiar to the Church in Wales' and that it had been thought desirable to 'test the cohesion of Churchmen by a concentrated rush on the Welsh regiment'. He confirmed that the prospect of dismemberment was opposed 'even more strenuously then we oppose disestablishment'.

74 Owen Owen, (1850-1920), first chief inspector of the Central Welsh Board for Intermediate Education in Wales, from 1897 to 1915 . He had become headmaster of a private school in Oswestry in 1878, which developed into Oswestry High School; D.W.B.

75 'The Established Church in Wales - A Census', The North Wales Express, 18 December 1891, p.6.

76 'The Church in Wales', The Times, 15 March 1892, p.13.

77 'The Church Revival in Wales - papers', the Very Rev. John Owen, Dean of St. Asaph, The Official Report of the Church Congress, held at Rhyl, pp.48-49.
} 
our trust for the future' ${ }^{78}$ Despite this attempt to buttress the Welsh Church by some historical reinvention, and omission of the true nature of the relationship between the Welsh Anglican Church and the Church in England, the Welsh Church defenders would ultimately look to English institutions, namely the Convocation of Canterbury and the House of Lords, as being the bodies that would, in the final analysis, thwart this assault upon the Anglican Church in Wales. There were many politicians and English Churchmen who, initially, encouraged them in that belief, such as the much-quoted commitment by the Archbishop of Canterbury, when he ended his speech with the words: 'I come from the steps of the chair of Augustine, your younger ally, to tell you that, by the Benediction of God, we will not quietly see you disinherited' ${ }^{79}$ His statement, that it was 'truer, historically, to speak of the "Church of Wales in England" than the “Church of England in Wales” might have been met with more scepticism before an English audience. ${ }^{80}$ However, the Archbishop's assertion was deemed as crucially important by Bishop Edwards, who wrote in his memoir: 'That note, so resolutely struck, rang throughout the whole country, and never once did the archbishop relax his efforts in the defence of the Church in Wales'. ${ }^{81}$ Dean Owen provided the Archbishop with facts and figures for his 1891 Rhyl address, and, as intimated by John Owen's daughter, it is likely that the Dean's involvement was more influential than simply imparting statistics. Eluned Owen wrote that: ‘The Archbishop’s words electrified his vast audience’ and, presciently, 'The Church had a leader indeed, and the Disestablishment of the Church in Wales was not coming yet awhile'. ${ }^{82}$ The Archbishop’s biographer, his son, also attributed a significant importance to the speech, which he claimed 'was really a turning point in the whole controversy', and from that day forward 'there was no doubt or uncertainty about the attitude of English Churchmen' and, quoting a 'very distinguished

\footnotetext{
${ }^{78}$ Ibid., p.49.

79 The Archbishop of Canterbury, The Church in Wales: Shall We Forsake Her? London, 1892, p.8.

80 The Archbishop of Canterbury, 'The Church in Wales: Shall We Forsake Her?', A Speech at the Church Congress, Rhyl, London, 1892, p.5.

${ }^{81}$ Edwards, Memoirs, p.164. It is possible to draw a slightly different, almost world-weary, approach by Archbishop Benson, when he included an entry in his diary of a sermon, which he delivered to the Church Congress, at St. John's Church, Cardiff, in September, 1889, when his point was to 'illustrate the undividedness of the Church in Wales and England in its history', but he describes it in the context of the necessity of 'trapesing' long distances, in order to 'do the people good'. It is, however, his description of those who stand and watch his archiepiscopal procession, which suggests a divide, a juncture of mutually uncomprehending worlds: 'I yearn over the troops and troops of young men - in greasy pot-hats and well-marked coats and pocketed hands, who lined the streets, more conspicuous than any other class of starers - perfectly well-behaved and rather (very rather) impressed anxious countenances - I don't think the Kingdom of God comes nearer to these. Benson, A.C., The Life of Edward White Benson, Sometime Archbishop of Canterbury, London, 1891, p.366.

${ }^{82}$ Owen, The Early Life of Bishop Owen, p.118.
} 
Liberal Churchman who was present', it 'marked an epoch in the history of the English Church' ${ }^{83}$ If so, then the Bishop of St. Asaph's strenuous efforts to persuade him to attend were justified.

The pronouncement had provided reassurance at an uncertain time and even as late as 1909, during the preparations for the Church Congress to be held at Swansea later that year, the Bishop of St. David's still considered that it was significant enough to remind the members of the General Committee of the 'historic declaration' by the late Archbishop Benson and reassured them that they still had the 'best sympathy and support of Churchmen in England at the present time' ${ }^{84}$ It is of note that the vehemence of the Archbishop's diatribe, which no doubt had substantial editorial assistance from the Bishop Edwards, was to meet with Gladstone’s disapproval, when he advised Dean John Owen, that he should: 'Tell your Bishop, that I very much regret the Archbishop came to Rhyl to speak as if it were proposed to disestablish the Apostle’s Creed'. 85

The 'normal population' of Rhyl in 1891 was reported as 'about 7,000'86 and the numbers who attended the Rhyl Congress, at 3,225, was reported as being the 'largest of the three Welsh Congresses'. ${ }^{87}$ Therefore, in terms of attendance it had been a notable event and, crucially, The Times opined that: 'The Church Congress at Rhyl had done all that its promoters can have looked for from it' and that: 'its papers and discussions have given an effective answer to the demand for Church Disestablishment in Wales', by reference to facts and figures and evidence of the Church's progress. ${ }^{88}$ The political nature of many of the pronouncements made at the Rhyl Congress were to be readily highlighted at a well-attended disestablishment meeting which was convened in Rhyl the following month, under the auspices of the Liberation Society. The newspaper report suggested a raucous affair, with a display of mordant humour, when the

\footnotetext{
${ }^{83}$ Benson, The Life of Edward White Benson, sometime Archbishop of Canterbury, p.437.

84 'Bishop of St. David's and the Church', The Pembrokeshire Herald, 29 January 1909, p.4.

85 Eluned E. Owen, The Early Life of Bishop Owen (Llandyssul: Gomerian Press, 1958), p.119.

86 'The Cemetery Question at Rhyl', Denbighshire Free Press, 7 February1891, p.3.

${ }^{87}$ Preface to The Official Report of the Church Congress, held at Rhyl, p. v: the number of members at the Swansea Congress, in 1879, was 1,825 and at the Cardiff event, in 1889, 2,348.

88 'The Church Congress at Rhyl has done all that', The Times, 10 October 1891, p. 9.
} 
meeting's chairman, Herbert Lewis ${ }^{89}$, referring to the commonly heard Church complaint that Nonconformist ministers preached politics from the pulpit, stated that:

'Now I did expect that the Church Congress when it came to Rhyl, would have set us an example in this respect. You can imagine my friends, how surprised, and shocked and pained I was to find that the first sermon preached at the Church Congress was distinctly a political sermon. ${ }^{90}$

Buttressed by the Archbishop of Canterbury’s 1891 ringing declaration of support, it was unlikely that any Welsh Churchman could have envisaged enforced separation from Canterbury, certainly not Bishop Edwards. In relation to establishing any relationship between Church and Nonconformity, Bishop Edwards demonstrated his belligerent attitude very early in his bishopric and his attempt to denigrate Nonconformity was witnessed when he was identified as creating 'false news'. In a letter to The Times in January 1891, Owen Owen disclosed that he had obliged the Bishop to admit to the fact that, in a letter to The Times in January 1888, whilst still the vicar of Carmarthen, Edwards had appeared to fabricate a statement that the Calvinistic Methodists of North Wales reported a decline in numbers, and that one of the causes was the 'removal from the list of members of those too poor to contribute to the "cause"'. Edwards had also made this claim in other places, including a pamphlet. When pressed by Owen Owen, the then Bishop had 'withdrawn' the words. However, Mr. Owen was then pressing the Bishop as to the source of his misinformation, as well as seeking to clarify that the 'slight' decrease only related to a part of Wales. $^{91}$

At least one Anglican prelate found the tone of the Congress uncongenial. The Archbishop of York, William Dalrymple Maclagan ${ }^{92}$, had only recently been elevated from the bishopric of Lichfield where he had, in 1890, welcomed 'a body of nonconformists to his palace and to the

\footnotetext{
${ }^{89}$ Sir (John) Herbert Lewis, (1858-1933), lawyer and politician. He was elected alderman and first chairman of Flintshire County Council in 1889 and he entered parliament in 1892, as a Liberal, representing Flint Boroughs. He was a close friend of David Lloyd George and he was one of the four Welsh M.P.s who participated in the 'Welsh revolt' in 1894, refusing the Liberal whip over disestablishment: O.D.N.B.

90 'Great Disestablishment Meeting at Rhyl. Church Congress Fallacies Exposed', Rhyl Record and Advertiser, 14 November 1891, p.3.

91 'The Bishop of St. Asaph and the Calvinistic Methodists', letter to the Editor, The Times, 1 January 1891, p.3.

${ }^{92}$ William Dalrymple Maclagan (1826-1910) was Archbishop of York from 1891 to 1908 and Bishop of Lichfield from 1878 to 1891.
} 
cathedral service'. ${ }^{93}$ At the Rhyl Congress he spoke relatively briefly, but tellingly, during a discussion on 'the Church in Relation to Nonconformists', where he opined that whatever the current circumstances: 'it is certainly in our duty to do all that lies in our power to minimize the evils of our unhappy divisions'. ${ }^{94}$ According to newspaper reports, he left Rhyl believing that it was the: 'most political of Church Congress' and he was critical of the opening address of Bishop Edwards, pointing out some of his inconsistencies regarding numbers and the Bishop's failure to accurately report what Gladstone had said about Nonconformists who sought disestablishment. ${ }^{95}$ Others had cause to comment on the stridency of the Congress and Osborne Morgan believed that, at the instigation of the Bishop of St. Asaph:

'the Rhyl Congress has been a false move. Many things have helped to make the Anglican Church unpopular in Wales - not the least being the tone of insolent superiority with which both English and Welsh Churchmen write and speak of Welsh Nonconformity. That this unpopularity will be successfully counteracted by garbled statistics, by rhodomontade about the 'bludgeon and the stiletto,' and by gratuitously imputing to the advocates of Disestablishment the vilest and basest of motives seems to me most unlikely'. ${ }^{96}$

The Bishop of St. Asaph had exhibited, for a young, newly enthroned prelate, extraordinary political acumen, in that he had drawn the Church Congress to a small town within his diocese and, by a perseverance which almost amounted to harassment, he had ensured that the Archbishop was in attendance. He had astutely laid down the basis on which he would lead the Church's defence for the next quarter century, and beyond. This was to be clearly evidenced by the Bishop's letter to The Times, in May 1894. when, in response to the introduction of the Welsh Disestablishment Bill, he vigorously reminded his fellow Churchmen, whom he must have assumed might not be paying sufficient attention to the matter, that the: 'Bill is not a moderate Bill. For the Church it would mean mutilation, the loss of her property, and the shattering of her organisation'. ${ }^{97}$ The Bishop went on to demonstrate his policy of exhibiting no magnanimity, when he wrote that the Bill should be 'defeated in such a decisive manner as to render its repetition impossible’ and that 'Our opponents know that it is for them "now or never”. It will be "never” if English Churchmen only do their duty “now”'.98 The Bishop's letter, in that

\footnotetext{
93 A. Ward, 'Maclagan, William Dalrymple', Oxford Dictionary of National Biography.

${ }^{94}$ The Official Report of the Church Congress Held at Rhyl, p.94.

95 'The Liberationists and the Church Congress', Carnarvon and Denbigh Herald, 6 November 1891, p.4.

96 'Mr. Osborne Morgan on the Church Congress', Wrexham and Denbighshire Advertiser, 17 October 1891, p.7.

${ }^{97}$ A. G. Asaph, letter to the Editor, 'The Welsh Disestablishment Bill', The Times, 19 May 1894, p.10.

98 Ibid.
} 
edition of The Times was followed by another missive concerning Welsh disestablishment, but from a standpoint which was diametrically opposed to the Bishop's, and the author was Owen Owen, who again challenged figures which had been published. In his letter of 19 May 1894, Owen had challenged assertions that had been made that the Welsh Anglican Church was not in the minority and, although he personally welcomed a census on religion, he was adamant that: 'The opponents of religious equality have no intention to abide by the evidence of any census that will tell against their own cause'. ${ }^{99}$ The presumably contrived juxta-positioning of the two letters provided an illustration of how familial relationships and shared backgrounds and upbringing were no guide to the stance that would be adopted on disestablishment.

\section{The Church defenders: 'More Anglican than the English'.}

Stuart Rendel wrote, in March 1893, that: 'It is lamentable that Principal Owen and Bishop Edwards should be more Anglican than the English. Both men are unhappily fighting for their personal status. ${ }^{100}$ It was of note that the announcements, in The Times, of the appointment of both A. G. Edwards as Bishop of St. Asaph and John Owen as Bishop of St. David's were to contain not only the usual reference to academic and ecclesiastical credentials but, in addition, their role as aspiring ecclesiastical politicians. The Times reported that Bishop Edwards was 'not unknown to our readers' and referred to his earlier letters to the newspaper: 'giving facts and figures about the Church in Wales'. 101 The new Bishop of St. David's was described as having taken: 'an active part in the recent movement for the defence of the Established Church in Wales'. ${ }^{102}$ As demonstrated above, an early appreciation of the campaign to be pursued by the Church defenders was to be gained from an examination of Bishop of St. Asaph's approach at the 1891 Rhyl Church Congress, with the then Dean of St. Asaph, John Owen, buttressing the position with his paper on 'Church Revival in Wales'. However, at least one newspaper attempted to distinguish between the two men, with an implicit criticism of Bishop Edwards. Dean John Owen was portrayed as ‘a more cautious man', who 'has not drawn upon his head the amount of criticism and enmity which Bishop Edwards has succeeded in doing' and then added that his defence of the Church, although 'vigorous', has 'always been kept within the limits of

\footnotetext{
${ }^{99}$ Owen Owen, 'To the Editor of The Times, 19 May 1894, p.10.

${ }^{100}$ Hamer, The Personal Papers of Lord Rendel, p.296.

101 'The New Bishop of St. Asaph', The Times, 18 February 1889, p.10.

102 'New Bishop of St. David's', The Times, 16 February 1897, p.10.
} 
fair and constant constitutional lines'. ${ }^{103}$ They had therefore 'set the stage' for their partnership over the next quarter of a century, later to be aided by their consigliere, Frank Morgan. ${ }^{104}$ These men were critical to the sustained, pugnacious campaign, where it became customary to brook no compromise. It was evident when, following the Lords' rejection of the Welsh Disestablishment Bill in February 1913, rumours of possible compromise ${ }^{105}$ were to evoke unequivocal responses from both Church defenders ${ }^{106}$ and disestablishers ${ }^{107}$ that neither side was prepared to countenance 'surrender', although it was probably apparent to the bishops that there was still a possibility that disestablishment might be thwarted or that the terms of a 'soft' disestablishment could be envisaged.

The Bishops were therefore to remain in situ whilst the efforts of the secular politicians, who supported disestablishment, were to wane, either in terms of their enthusiasm or by the fact that they were distracted by political exigencies and loyalties, career concerns or by the demands of an expectant electorate. The bishops were to successfully combine their roles as prominent Church of England clergy with a pseudo-political role, where they lectured, lobbied, advised and cajoled political leaders. A notable instance, was when Dean John Owen ${ }^{108}$ lobbied $\mathrm{Mr}$ Gladstone on 20 February, 1891, 'armed with facts and figures to show the Church's progress'. 109 The Dean's biographer, his daughter, noted that the Dean was with Mr. Gladstone for over an hour and that, when he asked the Grand Old Man: 'what he thought would be the effect of Disestablishment on the Church in Wales, his reply was: “Death, Mr. Dean, and after

\footnotetext{
103 'The Church Congress. The Invitation to Rhyl', Rhyl Record and Advertiser, 10 October 1891, p.2.

${ }^{104}$ Frank Morgan, former Fellow of Keble College, Oxford, and secretary of the Governing Body and the Representative Body of the Church in Wales, from 1920 to 1935.

${ }^{105}$ Owen, The Later Life of Bishop Owen, p.195.

106 To Thy Tents', The Cambria Daily Leader, 17 April 1913, p.4: 'It is war now - spiritual war, it is true, but war! There is to be no more laying aside of arms in this fight. It is better to lose the Bill and better to lose the Government than for us to give way one inch-more. Now we know the worst, and we must be arming against it. To thy tents, Wales! I'th bebyll o Gymru!'

107 'No Compromise', The Carmarthen Journal, 2 May 1913, p.4: 'Compromise on this question cannot possibly be entertained with a discredited party in Wales; on the contrary, every effort should be redoubled to secure the unconditional withdrawal of the Bill, or, failing that, its defeat. Churchmen must and will have no other war-cry but that of the strong man of Wales, the Bishop of St. David's, viz., "No compromise!"'

${ }^{108}$ David Walker, 'Owen, John (1854-1926', Oxford Dictionary of Welsh Biography, Oxford University Press, 2004.

${ }^{109}$ Owen, The Early Life of Bishop Owen, a Son of Lleyn, p.114.
} 
Death, Resurrection”. ${ }^{110}$ Mr. Gladstone attempted to console a downhearted Dean ${ }^{111}$ by expressing the opinion that 'he did not consider Disestablishment was imminent', and that the Church 'should have some years to prepare for it', although Mr. Gladstone could not have envisaged that the Church would have almost thirty years to do so. ${ }^{112}$

\section{'The Wheaten Bread Bishop.'}

There was evidence of the new bishop's attitude to his Welsh heritage from the beginning of his episcopacy and, reporting upon the enthronement of the Bishop of St. Asaph, the Cardiff Times reported that 'the new bishop has begun badly'. The newspaper opined that he had been appointed 'in the main because he was able to speak and preach in the Welsh language', but he had taken:

'the first opportunity of sneering at the language which obtained for him his recent promotion. He calls English the wheat-bread and Welsh the barley-bread language and suggests the inferiority of the latter in all respects'. Seeing that his knowledge of Welsh gave him the bishopric, and that episcopal fare is far removed from the barley-bread order, his lord-ship's remarks lack dignity and decency, provoking anger when they do not inspire contempt'. ${ }^{113}$

The Bishop’s reminiscences, in 1927, provided an insight into his comments upon language and food, when he described a lecture on 'Famous Welshmen' he had attended, 'when a boy', delivered by a 'brilliant lecturer, Dr. Kilsby Jones' ${ }^{\text {,14, }}$, who was quoted as ending his lecture with the words, 'Boys, if you want to succeed in the world, learn English. Remember, Welsh is a barley-bread language'. ${ }^{115}$ The South Wales Daily News also commented on the fact that several newspapers had written adversely of the ‘covert insult to Wales and things Welsh' contained within remarks made by the Bishop of St. Asaph at his enthronement in $1889 .{ }^{116}$ With reference

\footnotetext{
110 Ibid., p.115.

111 Reverend Stephen Gladstone to John Owen, 7 June 1907, N.L.W, Bishop John Owen papers, 4/7. Bishop Owen would have been heartened to receive a note from Gladstone's son. When he had been going through his father's letters, he came across an extract from a London letter written by Mr. Gladstone to his son on 20 February 1891: 'Tonight I must say a few words for Welsh Disestablishment. The Dean of St Asaph has just been here. So far as I see he is an admirable man in goodness and of high intelligence'.

112 Ibid., p.115.

113 'Welsh Gleanings', The Cardiff Times, 11 May 1889, p.1.

114 James Rhys (Kilsby) Jones, (1813-1889), Congregational minister. The entry in D.W.B. noted that he was 'regarded as one of the most notable men of his period - 'famous' in the eyes of his admirers but 'odd' in those of his critics' and that he was above 'rules, regulations, accepted modes, and customs'.

115 Edwards, Memories, p.13.

116 'What Welshmen Think. A Summary of the Welsh Press', South Wales Daily News, 8 May 1889, p.3.
} 
to the fact that, as Baner ac Amserau Cymru pointed out, the proceedings in connection with the ceremony were wholly in English, despite the fact a 'monument is about to be raised in the graveyard connected with the cathedral in memory of the immortal bishop who translated the Scriptures, into Welsh' ${ }^{117}$ T. I. Ellis, in his review of Kenneth O. Morgan’s book on disestablishment ${ }^{118}$, quoted W. J. Gruffydd's description of Bishop A. G. Edwards, alleging that he was: 'y gŵr mwyaf trychinebus a welodd Cymru erioed' (The most disastrous man that Wales has ever seen). ${ }^{119}$ Assuming that this includes an element of hyperbole, as Welsh history had already provided the Bishop with some stiff competition, it must be accepted that the Bishop has generated a significant volume of execration. Although, in terms of reputation, it is surprising that Bishop Basil Jones ${ }^{120}$ has come to be generally associated with his adverse comments about Welsh nationality and language, whereas A. G. Edwards has not garnered the same notoriety. The opprobrium which Bishop Edwards did evoke could be contrasted with the suggestion that his older brother, Dean H. T. Edwards: 'was the finest Welsh churchman of the nineteenth century'. ${ }^{121}$ It is hugely significant that in 1929, whilst A. G. Edwards was still serving as Archbishop, the late Dean Edwards was being held out as the epitome of the type of cleric who should be promoted to a Welsh bishopric, almost half a century after his death, when a correspondent was concerned about the intentions of nationalistic minded clerics:

'Many of these, I am convinced, as far as their religion is concerned, are to-day on the cross roads, and if the Church is to secure them, she will have to see to it that her bishops are true Welshmen of the type of the late Dean Edwards and possessed of the vision, churchmanship and true national spirit that dominated his - alas, too short - clerical life, to the untold good of the Church in Wales'. ${ }^{122}$

\footnotetext{
117 The Translators' Memorial was unveiled on 29 April 1892 by the Bishop of St. Asaph: 'The Bishop Morgan Memorial', Rhyl Record and Advertiser, 30 April 1892, p.1. Principal James, of Cheltenham College and a former Dean of St. Asaph, suggested, to the thousands who had gathered to witness the unveiling, that the memorial would serve as a: 'revelation to the world outside of Welsh religious unity. He knew that many people in England thought that religion in Wales consisted chiefly in controversy'. His comment that: 'These people derived their opinions from letters in the newspapers' led to some laughter, although it would be possible to imagine the Bishop of St. Asaph's response to such an obvious reference to his propensity.

${ }^{118}$ T. I. Ellis, 'The Disestablishment Campaign', Journal of the Historical Society of the Church in Wales, vol. XVII (1967), p.64.

${ }^{119}$ Professor W.J. Gruffydd's description of Bishop Edwards is quoted in Morgan, The Span of the Cross, Cardiff, 1999, p.80.

${ }^{120}$ William Basil (Tickell) Jones, (1822-1897), Bishop of St. David's from 1874 to 1897. As stated in the D.W.B., the Bishop 'had little regard for the separate nationhood of Wales'.

121 'The Life and Work of Dean Henry Thomas Edwards 1837-84', Transactions of the Caernarvonshire Historical Society, vol.40 (1979), p.135.

122 'Episcopal Appointments in Wales', by a Welsh Nationalist Priest, Welsh Outlook, vol.16 (Jan. 1929), p.15.
} 
The contention is that the appointment of Churchmen such as H. T. Edwards or David Howell ${ }^{123}$ to a Welsh bishopric would have transformed the question of how the Welsh Anglican Church approached disestablishment and indeed its relationship with Wales. Despite being identified as suitable candidates, the reputations of both Edwards and Howell were systematically traduced, to provide for a cabal of bishops to be appointed who were either staunch, uncompromising Church defenders or else proved to complicit in that policy.

\section{'Half an Englishman'.}

A. G. Edwards was quoted as explaining that: 'I am half an Englishman and half a Welshman and I have been laboring between the two all my life', which would explain his biographer's comment that: 'he rarely if ever moved Welshmen as his brother did'. ${ }^{124}$ Bishop Edwards ended the book on Landmarks in Welsh history with a quotation from Bishop Short ${ }^{125}$, which Edwards believed encapsulated a guiding ‘hope and prayer’ for Churchmen in Wales, although it was simply an exposition of the power hierarchy which was understood within Britain and the Welsh Established Church: 'May God render the Diocese a blessing to Wales, and Wales a blessing to England, and England a blessing to the world'. ${ }^{126}$ At least one newspaper identified his suitability for this role from the beginning: 'he has fought tooth and nail on behalf of the Establishment in Wales, and that without doubt is the secret of the appointment, which is thus a political job, and nothing more'. ${ }^{127}$ David Howell has been described as 'a builder of bridges: between the Welsh and English elements in his nation; between Church and Nonconformity'. ${ }^{128}$ A. G. Edwards was emphatic that in relation to the Church in Wales, there were only fortifications that required construction.

It is important to examine, in the context of the campaign for disestablishment, the differences in self-perception and self-identity between A. G. Edwards and H. T. Edwards. It would incongruous to suggest that the man who was to become the first Archbishop of Wales displayed

\footnotetext{
${ }^{123}$ Dean David Howell, (Llawdden), (1831-1903). He was curate at Neath from 1855 to 1859, secretary of the Church Pastoral Aid Society from 1857 to 1861, vicar of Pwllheli (1861), St. John’s, Cardiff (1864), Wrexham (1875) and Gresford (1891). He became archdeacon of Wrexham in 1889 and dean of St. David's in 1897. His father was a farmer and a Calvinistic Methodist elder: D.W.B.

${ }^{124}$ Lerry, Alfred George Edwards, Archbishop of Wales, p.54.

125 Thomas Vowler Short, (1790-1872), Bishop of St. Asaph from 1846 to 1870.

${ }^{126}$ Edwards, Landmarks, p.274.

127 The New Bishop of St. Asaph', Rhyl Record and Advertiser, 23 February 1889, p.3.

${ }^{128}$ Roger L. Brown, David Howell. A Pool of Spirituality (Denbigh, 1998), p.308.
} 
ambiguity about his true allegiance, but such an assertion is accentuated by comparison with the published opinions of his brother who, by reputation and by his published work, was readily identifiable as a patriot. ${ }^{129}$ It has been suggested that Bishop Edwards had: 'little regard for his Welsh upbringing and little sympathy for the Welsh movement within the Church in Wales. He seems at times to have regarded 'Welsh' and 'Nonconformist' as synonymous terms'130 and his opinion about Welsh nationalism was made apparent at the St. Asaph Diocesan Conference of 1892, when he espoused that: 'y gwirionedd iachusol o undeb ac unoliaeth Eglwysig a chenedlaethol Lloegr a Chymru'. 131

It was apparent that H. T. Edwards was not cognizant of his English 'half', despite the fact the two men had the same ‘entirely English’ mother. ${ }^{132}$ A. G. Edwards does not describe how his father and mother met, but they married when William Edwards was appointed as Curate-incharge at Llanwyddelan, Montomeryshire, in 1828, where the couple were to remain there until 1834, when he became rector of Llanymawddwy. A. G. Edwards does provide a description of Llanwyddelan as: 'a wild parish spreading over 4,000 acres', with neither school, hamlet nor village' and that 'of the 500 people in the parish few spoke English and the great majority were poor'. ${ }^{133}$ Yet there is no attempt to explore how his mother coped with her move from relatively genteel Painswick, Gloucestershire, to a remote, rural location where she was the foreigner. Llanymawddwy was described as another 'Welsh mountain parish', where the people were 'all Welsh', with 'no resident squire', so it fair to speculate that until William Edwards became Vicar of Llangollen in 1849, where there was an abundance of English settlers and tourists, Mrs. Edwards was to spend over twenty years of married life in largely monoglot Welsh-speaking areas, with no suggestion that she acquired Welsh. ${ }^{134}$ After proudly identifying his mother's antecedents, describing her as 'kin to the Woods of Brockrupp, Gloucestershire, of whom

\footnotetext{
${ }^{129}$ H. T. Edwards, 'The Church of the Cymry. A letter to the Right Hon. W.E. Gladstone M.P.', Wales and the Welsh Church, pp.94-178. This letter was persuasive in the campaign to secure the appointment of the first Welshspeaking bishop since 1702.

${ }^{130}$ Brown, David Howell. A Pool of Spirituality. A Life of David Howell (Llawdden), p.196.

131 'Cynhadledd Esgobaeth Llanelwy', Yr Haul, Hydref 1892, p.311: 'the health-giving truth of the ecclesiastical and national unity of England and Wales'.

132 Edwards, Memories, p.2, where the Archbishop wrote: 'My mother, Sarah Wood, was entirely English'. A photograph of his mother, aged 87, appears as a frontispiece to Memories, whereas his father’s photograph was located between pages 86 and 87.

133 Edwards, Memories, p.3.

134 Edwards, Memories, p.4.
} 
Richard Wood was Lord of the Manor in 1608. Some of her kindred were eminent in the Law and the Church', but he was at pains to explain that: 'Her family, his nearest in kin, were left out of his will by 'Jemmy' Wood ${ }^{135}$ the Gloucester banker'. ${ }^{136}$ A. G. Edwards had therefore established his own English gentlemanly pretensions and, perhaps a story of why his mother was to be located in a wild, Welsh parish, whereas his father's lineage ${ }^{137}$ did not offer the same unrealised ambitions of gentility. Being conscious of this bifurcated nationality could be discerned in his comment, at the Harlech Pageant, when 'three great characters in Welsh history' were portrayed during the festival, being Owain Glyndŵr, Ellis Wynn and 'Gerald the Welshman' (Geraldus Cambrensis). In the Bishop’s judgement, the 'most interesting character' was Gerald who, he pointed out, was partly Norman and partly Welsh’ ${ }^{138}$ Perhaps Archbishop Edwards interpreted his own mixed ancestry as a means by which he was well-placed to broker the Anglo-Welsh competing interests that formed such a critical component of the disestablishment campaign.

His historical empathy with Gerald may have also been enhanced by the fact that he could write of Gerald that: 'His pilgrimage with Archbishop Baldwin marks the full acceptance by the Welsh of the jurisdiction of Canterbury, and the final recognition of the unity of the two Churches' ${ }^{139}$, with a recognition that this was the true objective of the pilgrimage, rather than preach the crusade. ${ }^{140}$ In reading Bishop Edwards’s description of Giraldus Cambrensis, as: ‘A man of transparent vanity, of ubiquitous energy, and of unveiled ambitions, he studied to promote the interests of the Church with more vigour than wisdom', there would have been many who would have applied the same epithets to Alfred George Edwards. ${ }^{141}$

\footnotetext{
${ }^{135}$ Irvine Gray, 'Jemmy Wood's Journal', Transactions of the Bristol and Gloucestershire Archaeological Society, vol.90 (1971), pp.158-177. James (Jemmy) Wood, (1756-1836), owner of the Gloucester Old Bank and perhaps the wealthiest commoner of his time. It was suggested that the probate litigation, which saw most of his fortune used for legal costs, was the basis of Jarndyce v. Jarndyce in Bleak House.

${ }^{136}$ Edwards, Memories, pp.3-4.

${ }^{137}$ Edwards, Memories, p.2: 'My grandfather, born in 1760, was a devout and earnest man, much interested in and moved by the revival then within the Church. He brought up three sons to the ministry of the Church in Wales'. Edwards does not provide any detail, but his grandfather, a farmer, was a convert of Daniel Rowlands of Llangeithio.

138 'Harlech Pageant. Three Great Characters in Welsh History', The Times, 22 August 1922, p.5. It was reported that 'Dame Margaret Lloyd George played Lady Glyndŵr'.

${ }^{139}$ Edwards, Landmarks in the History of the Welsh Church, pp.89-90.

${ }^{140}$ Ibid., p.90.

${ }^{141}$ Ibid. 86.
} 
It would be difficult to ascribe to Bishop Edwards or, as will be examined, John Owen, the Bishop of St. David's, the sobriquet of 'patriotic churchmen', or to suggest that 'historically and, increasingly, in contemporary terms, the Church was just as Welsh in spirit and outlook as were the nonconformist chapels', as Lord Morgan has suggested was the case at the 'dawn of a new century’ ${ }^{142}$ Bishop Edwards made statements about nation and nationality which displayed his ambivalence and, speaking in January 1893 at Shrewsbury, he began with the expression: 'I do not wish to deride Welsh nationality, but it is not an easy matter to define it'. ${ }^{143}$ By 1895 , he did feel able to question nationality, when he purported to identify and then undermine the three arguments that were used to support the case for Welsh disestablishment; that the Church was in a 'hopeless minority', that 'the great majority of the Welsh members demanded disestablishment' and that 'Wales is a distinct and homogenous nation'. ${ }^{144}$ The Bishop appeared to relish his attack upon nationality, from his statistically-based attempt to belittle the number of Welsh speakers to his assertion that: 'there is less association between South Wales and North Wales than there is between North Wales and Lancashire or London' ${ }^{\text {,45, }}$, with a rationale that; 'A nation that cannot find a capital within its own boundaries cannot urge geographical unity in favour of its nationality'. ${ }^{146}$ It has been suggested that his 'bias towards England was most readily expressed in Edwards's antipathy towards the use and extension of the Welsh language' ${ }^{147}$ However, in terms of acknowledging loyalties, the Bishop of St. Asaph's feelings about Wales were vividly portrayed in a speech in February 1914:

'The Bishop of St. Asaph, speaking at Bangor on Friday night, said that the main argument urged for the Welsh Church Bill was that of nationality; but England and Wales were one to-day, and the Church, older than the Throne or Parliament, must only be dismembered by the will of the majority of the people of England and Wales. That very week the Welsh Church Bill was rejected by the representatives of England and Wales. Repeatedly the saving force behind the bill had been Irish, and bad Irish at that' ${ }^{148}$

It would have been informative to understand how the organisers arrived at the title of the address that the Bishop made to the Welsh National Society in Manchester. The subject was

\footnotetext{
142 Kenneth O. Morgan, Rebirth of a Nation. Wales 1880-1980 (Oxford, 1982), p.41.

${ }^{143}$ Lerry, Alfred George Edwards, Archbishop of Wales, p.49.

${ }^{144}$ A. G. Asaph, 'The Church in Wales', The Nineteenth Century, vol.38, issue:221, 9 July 1895, pp.112.

145 Ibid., p.116.

146 Ibid., p.117.

${ }^{147}$ Morgan, The Span of the Cross. Christian Religion and Society in Wales, 1914-2000, p.35.

148 'Disestablishment Sky Overcast. A Profound Change in Welsh Thought. Bishop of St. Asaph's Striking Speech', Flintshire Observer Mining Journal and General Advertiser for the Counties of Flint Denbigh, 26 February 1914, p.6.
} 
'Common-sense Patriotism', as it related to Wales and a newspaper report noted that his treatment was 'marked by his usual candour'. ${ }^{149}$ He spoke without enthusiasm about art, music, and poetry in Wales, but trusted that 'one of the fruits of improved education in Wales would be that in the records artistic achievement Wales will be represented not only among musicians, but also among painters'. It was clear that the thrust of his address was to be concerned with 'the Welsh Language and Peoples', where, after a brief positive reference, he warned that 'we cannot cabin and confine our Patriotism within the limits of the Welsh language' and 'it is time to raise a voice against the habit of calling our great English brethren aliens', where he condemned the use of expressions such as "Anglicised Welshmen”, "mongrels”, and "foreign settlers", as they did not form part of the language of 'Common sense patriotism'. Despite his own ambivalence about his Welsh background, Bishop Edwards was prone to highlighting an individual's nationality or background, if of course that person supported Welsh disestablishment and if such assertions might assist in discrediting any statement which they made.

The Bishop was clearly exercised by the activities of Stuart Rendel, whom he dismissingly described as 'a Welsh patriot, whose patriotism is entirely free from any connection with Wales either by birth, language, residence or possessions'. ${ }^{150}$ In reality, it is fair to note that Rendel 'had rather a passion for fine houses', with properties in London, Surrey and France ${ }^{151}$, although it would have been difficult to criticize the genuine adoption of Welsh causes by 'The Member for Wales', who became such a generous benefactor of Aberystwyth University and who purchased the site for the National Library of Wales. The Bishop’s opinion of Rendel would not have been assisted by Stuart Rendel's referral to Dean H. T. Edwards's 'pamphlet of fifty-seven pages', which he identified as 'one long demonstration of the almost unbroken alien character of the Church in Wales', and to which there had never been a reply. Rendel also managed to include the other Church defender in his criticism, when he added that the Dean Edwards's pronouncements ‘emanated' from A. J. Johnes’s Causes of Dissent ${ }^{152}$, and that both publications were well known to Dean John Owen and that 'he has to answer them, and not scoff at me'. 153

\footnotetext{
149 'Bishop of St. Asaph on Welsh Patriotism', The Cardiff Times, 24 February 1894, p.1.

150 The Bishop of St. Asaph, The Truth about the Church in Wales. A lecture delivered at Truro on November 7, 1889 (London, 1889), p.4.

${ }^{151}$ Hamer, The Personal Papers of Lord Rendel, p.9.

152 A. J. Johnes, On the Causes which have produced Dissent from the Established Church, London, 1832, reprinted 1870 .

${ }^{153}$ Hamer, Personal Papers of Lord Rendel, p.297.
} 


\section{Dean H. T. Edwards.}

Although A. G. Edwards was, throughout his life, to question any statistics concerning the number of Anglican worshippers, H. T. Edwards was in no doubt that 'accurate statistics would show that seven-tenths of the native Cymric population of Wales are alienated from the Church of their fore-fathers, ${ }^{154}$ and, like A. J. Johnes, a generation earlier, he attempted to explain the 'causes’ H. T. Edwards was to preach on that very topic, at a special English service at St. David’s (Welsh) Church in Liverpool, on 25 May $1879^{155}$ and in his address to the Swansea Church Congress on 9 October 1879, when he attributed: 'the decay of the Welsh Church to the anti-national policy by which prelates and clergy ignorant of the language were thrust upon the Welsh-speaking people'. ${ }^{156}$ Poignantly, H. T. Edwards's essay entitled Wales and the Welsh Church $^{157}$ was published just weeks after his death, which he wrote in the context of Llewelyn Dillwyn ${ }^{158}$ 's notice that he would 'call attention to the anomalous position of the Church in Wales'. ${ }^{159}$ In this work, Edwards recognized that there were 'alternative policies' for the removal of that anomaly, essentially positing either disestablishment and disendowment or 'a policy of reform and comprehensive revival'. ${ }^{160}$ His death removed the possibility of knowing whether Dean Edwards would have been convinced that the Church did in fact reform and revive sufficiently to counter the arguments for disestablishment. The Dean's standing was such that he could have provided a rallying-point for those Anglican clergymen who were dissatisfied and disenfranchised by the iron grip of his brother, both throughout his own diocese and eventually throughout the Church in Wales. In the biographical sketch which the Reverend David Jones wrote as a preface for his book which brought together the papers of H. T. Edwards ${ }^{161}$, he wrote that the 'great aim' of the life of the Dean 'was the reconciliation of the Welsh Church and Nation' and Jones went on to describe: 'his courage and candour in exposing what lies at the root

\footnotetext{
154 Ibid., p.95.

${ }^{155}$ H. T. Edwards, 'Why are the Welsh People alienated from the Church?', in Wales and the Welsh Church, pp.288336.

${ }^{156}$ H. T. Edwards, 'The Past and Present Position of the Church in Wales', in Wales and the Welsh Church, p.347.

${ }^{157}$ H. T. Edwards, 'Wales and the Welsh Church', in Wales and the Welsh Church, pp.179-287.

${ }^{158}$ Lewis Llewelyn Dillwyn, (1814-1892), Liberal M.P. for Swansea District from 1855 to his death. An Anglican, whose 'famous motion on the Church of Ireland (28 March 1865) influenced Gladstone's gradual move towards disestablishment and who moved annual resolutions in favour of the disestablishment of the Anglican Church in Wales' from 1883: O.D.N.B.

${ }^{159}$ Edwards, 'Wales and the Welsh Church', pp181-182.

160 Ibid., p.187.

${ }^{161}$ David Jones, Wales and the Welsh Church, p.8.
} 
of all our national dissensions, namely, the attempt to Anglicize the nation through the Church'. 162

Admiration of H. T. Edwards was to continue long after his death, with no diminution due to the circumstances of his death, at the age of forty-six, when he committed suicide on 24 May 1884, whilst staying with the oldest of the Edwards's brothers, E. W. Edwards, the vicar of Ruabon. ${ }^{163}$ The Western Mail attributed his long-standing nervous state to insomnia following an attack of typhoid fever eighteen months earlier. ${ }^{164}$ Irrespective of the manner of his death, his passing prompted an extraordinary outpouring of grief expressed though newspapers and, remarkably, to a 'munificent memorial' in the form of the construction of a new church. ${ }^{165}$ St. David's Church was built in Glanadda, Bangor, opposite the cemetery where the Dean had been interred. ${ }^{166}$ The new Church was consecrated by the Bishop of Bangor and when the then Reverend A. G. Edwards, of Carmarthen, delivered a sermon at the afternoon service, it must have occurred to many in the congregation that if he was to refer to the 'position of the Church in Wales', then his usual stance would have jarred with the many pronouncements of his late brother. Reverend Edwards did address the issue, but in an uncharacteristically irenic manner, therefore perhaps demonstrating that he was sentient of his late brother's well-known opinions:

'What, he asked, was the duty of Churchmen to-day. Let them as Churchmen in Wales do all in their power to heal the breach, to welcome every approach at conciliation, and hold out the right hand of friendship and fellowship. Short of sacrificing principle, they were in duty bound to do all that lay in their power to promote reunion'. ${ }^{167}$

Yet, only seven months earlier, the Reverend Edwards had written to a newspaper in defence of statistics used by Lord Selborne. ${ }^{168}$ As stated above, Lord Selborne was identified by Osborne Morgan as a 'foreign auxiliary' whose involvement would exacerbate relations between Nonconformist and Anglicans. Edwards appeared on that occasion to exhibit scant evidence of the ‘friendship and fellowship’ which he had commended. To make matters worse, A. G.

\footnotetext{
162 Ibid., p.8.

${ }^{163}$ Ebenezer Wood Edwards, vicar of Nantglyn, 1857, vicar of Ruabon from 1862 to 1897, Canon of St. Asaph.

164 'Suicide of the Dean of Bangor', The Western Mail, 26 May 1884, p.3.

165 'Opening of a Memorial Church to the Late Dean Edwards at Bangor', Carnarvon and Denbigh Herald, 16 June1888, p.8.

166 'The Late Dean of Bangor. The Funeral’, South Wales Daily News, 29 April 1884-05-29, p.3.

167 'The Late Dean Edwards', The North Wales Express, 15 June 1888, p.6.

168 'Lord Selborne at Lampeter', South Wales Daily News, 3 November 1887, p.3.
} 
Edwards's letter in support of Lord Selborne immediately evoked a response from one of the statistical secretaries of the general assembly of the Welsh Calvinistic Methodists, which sought to correct the figures utilised by Edwards and expressed: 'a feeling of surprise that a gentleman of his position and learning should seek to produce an impression favourable to bis cause through a partial representation of facts, and through statements which, to say the least, are not perfectly correct'. ${ }^{169}$

Upon the death of Bishop Ollivant of Llandaff in 1883, it was reported that Dean H. T. Edwards 'was looked upon as his probable successor', and it was added 'that Mr Gladstone was strongly favourable to his appointment but yielded to certain pressure which was brought upon him'. The late Bishop himself, in an article on "The Social and Religious Condition of Wales," which appeared in the Church Quarterly Review shortly before his death, spoke of Dean Edwards:

'The Dean of Bangor, by birth a native of North Wales, and by his professional engagements in earlier life well acquainted with the South, full, perhaps, to overflowing of national sentiment, a man of distinguished talent, and one who has enjoyed the advantages both of an English public school and an Oxford education." Though the Dean was not fortunate enough to obtain the appointment of Llandaff, it was the prevailing opinion that he would before long grace a See in Wales'. ${ }^{170}$

Whereas the Bishop of St. Asaph was to be notably reticent about his brother and his writings, John Owen, the Bishop of St. David's was to make a surprisingly fulsome compliment to the late Dean Edwards during his evidence to the Royal Commission, in June 1908, when he said that he was 'a high authority and he was a man of genius to whose influence personally I owe a great deal' ${ }^{171}$ It was apparent that the respective evidence by the two bishops appeared to be an issue of some contention and David Lloyd George advised his brother, in April 1907, that Bishop Edwards been 'very annoyed' at the attention given by the Commission to the Bishop of St. David's and he suggested that he had been of some assistance to Bishop Edwards in how evidence would be presented. ${ }^{172}$

\footnotetext{
169 Ibid.

170 “The Dean and the Bishopric of Llandaff', The North Wales Chronicle, 31 May 1884, p.7.

${ }^{171}$ Royal Commission on the Welsh Church, vol. IV, Minutes of Evidence, Book III, page 427, para. 46118.

172 George, My Brother and I, p.210.
} 


\section{'One of the most powerful exponents of the Progressive cause, both in religion and politics'.}

Apart from Henry Thomas and Alfred George, three of their brothers were also ordained, and when the death of Bishop Edwards’s last surviving brother, the Reverend William Joseph Edwards, occurred in August 1899, it was reported, presumably in contrast to his brother the Bishop, that he 'took no part in ecclesiastical controversies', having been rector of Llandow, to which he was appointed by his college, Jesus College, Oxford, for forty-one years. ${ }^{173}$ Reverend William Joseph Edwards was not controversial, but his son, the Reverend W. A. Edwards, was certainly a cleric who participated fully in 'controversies' and he appeared to have received significant political recognition for such involvement. In this way, W. A. Edwards does appear to have been very similar to his uncle, the Bishop, who was described by his biographer 'as an astute controversialist'. ${ }^{174}$ The late Lord Crickhowell wrote that:

'my great-great uncle, the Bishop of St Asaph, led the parliamentary fight against it, while his nephew, my grandfather, the Rev. W.A. Edwards ${ }^{175}$, while Rector of Llandow, campaigned in favour of it. A politically active social and religious reformer, he appeared on Liberal and Labour platforms during the 1906 General Election'. ${ }^{176}$

W. A. Edwards had been appointed to his late father's rectorship in Llandow, upon his father's death in 1899, but in 1908 he was offered the 'valuable living of Aberffraw' by 'The First Lord of the Treasury', being the Liberal Prime Minister, H. H. Asquith. ${ }^{177}$ The fact that the Reverend W. A. Edwards 'has come to be regarded as one of the most powerful exponents of the Progressive cause, both in religion and politics’ might have suggested that the nephew of the Bishop of St. Asaph was in receipt of a political reward. ${ }^{178}$ Reverend Edwards had 'won wide admiration and respect for his courageous utterances in favour of religious freedom and toleration' and he was a member of the National Liberal Club, and his political- services have

\footnotetext{
173 'Death of the Rector of Llandow', Evening Express, 23 August 1899, p.2.

${ }^{174}$ Lerry, Alfred George Edwards, Archbishop of Wales, p.48.

175 'The Rev. W. A. Edwards and Disestablishment', The Pembrokeshire Herald and General Advertiser, 10 July 1908, p.2: 'Then came the Rev. W. A. Edwards, rector of Aberffraw, Anglesey, formerly of Llangan, who announced that he was going to tour the constituency on behalf of Disestablishment. No one loved the dear old Church more than he, but he wished to see her free to fight with the Free Churches on the side of social reform. There were more clergy and laity in favour of Disestablishment within the Church than people were aware of, and from that he argued that no injury was meant to the Church. The Western Mail would be slinging words at him for what he had said, but they would never stop him. The only thing that would stop him would be when he gave up his breath'.

${ }^{176}$ Lord Crickhowell, 'The Conservative Party and Wales', Welsh Political Archive annual lecture, 3 November 2006.

177 'Rector of Llangan’, Evening Express, 28 February 1908, p.2.

178 'New Rector of Aberffraw', Carnarvon and Denbigh Herald, 20 March 1908, p.8.
} 
brought him into close touch with the Liberal leaders'. ${ }^{179}$ At a presentation to mark his move from Llandow, A. J. Williams ${ }^{180}$, the former M.P. for South Glamorgan, said that W. A. Edwards: 'had had the courage to stand to his opinions though those opinions were extremely unpopular amongst the body to which he belonged' and went on to posit that disestablishment would be achieved by the present government and suggested that the reverend was what that disestablished Church would need, as 'a Bishop who was in sympathy, not only with his own body, but with all parties anxious to do what was right and just'. ${ }^{181} \mathrm{~W}$. A. Edwards's 'vigorous advocacy of disestablishment' was further identified by a pamphlet which he published:

'which is regarded as a notable pronouncement by a Welsh parson on the eve of the introduction of a Welsh Disestablishment Bill. Mr. Edwards puts with much vigour and eloquence the case for Welsh Disestablishment from the point of view of the Welsh Nationalist clergyman'. ${ }^{182}$

The Reverend condemned the Established Church of England and Wales as probably: 'one of the worst administered institutions in the world to-day'. ${ }^{183}$ Ignoring any vestigial familial feelings, it is impossible to contemplate how Bishop Edwards would have reacted to the suggestion that the Liberal Party should consider the elevation of somebody who was diametrically opposed to the doctrines of Church defence. It was unlikely that a rampant disestablisher, and Nationalist, would be elevated to a Welsh see, although it would have provided for a very different dynamic among the episcopacy in Wales.

A characteristic which Reverend W. A. Edwards did appear to have in common with his uncle was ambition and, in a letter which enclosed a copy leaflet which he had just written, entitled 'The Welsh Church Question', he made the case for his personal advancement and wrote that he 'should very much like to get some official post', which would assist his 'efforts on behalf of disestablishment, temperance reform and other progressive causes', and that: 'Unless a man is a Bishop, Dean or Canon, he is at tremendous disadvantage in pursuing a cause from within the

\footnotetext{
179 Ibid.

${ }^{180}$ Arthur John Williams, (1834-1911) was a lawyer, author and Liberal Member of Parliament for South Glamorganshire from 1885-1895.

181 'Rev. W. A. Edwards Honoured. Presentation to the Late Rector of Llangan', The Glamorgan Gazette, 7 August 1908 , p.5.

182 'Rector of Aberffraw', The North Wales Weekly News, 16 April 1909, p.7.

183 Ibid.
} 
Church'. ${ }^{184}$ He was aware that the position of Dean of Lichfield was vacant and asked whether Welsh M.P.s had any influence to secure 'a position of that kind' and, to assist his plea, he added that, in that post, he could 'push forward work similar to that done by Bishop of Hereford' and that: The English People have never had any Ecclesiastic to point out to them that the present position of the Welsh Church is entirely incompatible with the sentiment of the Welsh nation'. He added a postscript that: 'the deanery of Lichfield is not a valuable one and the Crown would have this Benefice to give away if I went there'. ${ }^{185}$

\section{The Lampeter gang.}

Perhaps W. A. Edwards's desire to seek refuge at Lichfield ${ }^{186}$ can be understood in the context of what Hartwell Jones ${ }^{187}$ described as the clique which included the Church defenders, A. G. Edwards and John Owen, but also drew in the Bishop of Chester, A. G. Edwards's brother-inlaw, Francis Jayne, all of whom had association with Llandovery or Lampeter. ${ }^{188}$ In trying to understand how the manner in which Bishop Edwards was to seize and sustain his dictatorialtype control, it is important to appreciate how Reverend Hartwell Jones labelled the actions of 'The Lampeter gang', although perhaps laced with a smidgeon of frustrated personal ambition. Hartwell Jones wrote that he had knowledge of 'a knot of ambitious clerics, with their headquarters at Lampeter and Llandovery', who had, in the early 1880s formed a conspiracy to capture the highest offices in the Welsh Anglican Church, to arrogate to themselves the role of Church defenders and that 'ideology may be summed up in the words “anti-Welsh bias"'. 189 Hartwell Jones ${ }^{190}$ provided an acerbic interpretation of the Church’s leading personalities in his autobiography, which was published after his death. ${ }^{191}$ In describing the Church’s defence to

\footnotetext{
${ }^{184}$ W. A. Edwards, The Welsh Church Question, Bangor, 1909, (N.L.W., S. T. Evans Papers, 187, 1909). Reverend Edwards suggested that, with regard to his leaflet: 'Some interest may be felt as to the grounds on which a clergyman whose family has been associated with the ministry of the Welsh Church for nearly a hundred years' 185 W. A. Edwards to S. T. Evans, 25 March 1909, (N.L.W., S. T. Evans Papers, 186, 1909).

${ }^{186}$ Henry Savage was appointed Dean of Litchfield in 1909: Obituary, 'Dr. H. E. Savage. 30 Years Dean of Litchfield', The Times, 20 April 1939, p.18.

187 Jones, A Celt Looks at the World, p.69, where the Reverend describes the 'knot of ambitious clerics', who 'arrogated to themselves the title of Church Defenders'.

${ }^{188}$ Roger Lee Brown, In Pursuit of a Welsh Episcopate (Cardiff: UWP, 2005), p.37.

189 Jones, A Celt Looks at the World, Cardiff, pp.69-70.

190 The Reverend Griffith Hartwell Jones, (1859-1944); from 1888 to 1893 he was professor of Latin at the University College of South Wales and Monmouthshire, during which time he took Orders. In 1893 he was appointed to the Jesus College living of Nutfield, Surrey, which he held until his retirement in 1940, although he maintained close links with Wales.

191 Jones, A Celt Looks at the World.
} 
disestablishment, he wrote that: 'I am bound to admit that there were forces at work within the Church which undermined its influence and contributed to its overthrow - one of those forces being the hostility of the self-appointed spokesmen towards Welsh aspirations' ${ }^{192}$ The Reverend summed up their belief, ‘inconceivable outside Bedlam’, that the only means by which the Welsh Church could be saved: 'lay in pandering to England, ridiculing the Welsh language, opposing the popular aspiration after higher education and foisting monoglot English or Anglicised clergymen on Welsh-speaking parishes. And woe betide anyone who refused to come to heel'. 193

The concern about influence was evident during the selection process for the See of Bangor in 1898, with clergy prepared to publicise their concerns and the Carnarvon and Denbigh Herald reported that:

'A "Bangor dignitary," interviewed by a representative at the "Manchester Guardian" said that the clergy of the diocese were determined to do all they could to prevent the appointment of the nominee of any clique. They all knew there was danger from the intrigues of a clique in connection with the appointment, and it was, he said, the subject of common talk. The impression was abroad that the Bishops of Chester and St. Asaph aspired to control the Welsh Church, and that their influence in the highest political circles was very great. But in that diocese clergy had no sympathy with their methods'. ${ }^{194}$

Most of the clergy concerned were careful to describe themselves as 'good Conservatives and as strong against Disestablishment as the others were', but they sought to avoid the imposition of an 'administrative policy, which had created so much bad feeling and discontent as now prevailed in the diocese of St. Asaph'. They opposed 'the St. Asaph policy' because of the manner in which patronage was dispensed and the Bishop's methods of dealing with his clergy. They believed that the new bishop should be 'a man who was in thorough sympathy with the needs of the Welsh people. Bangor was the most Welsh of the four dioceses of Wales. The new Bishop ought to be efficient in the Welsh language, or, if not, ready in every way to encourage and help the Welsh work of the Church'.

\footnotetext{
192 Ibid., p.58.

193 Ibid., p.70.

194 'The See of Bangor', Carnarvon and Denbigh Herald, 30 September 1898, p.7.
} 


\section{'The Son of Lleyn'. 195}

Professor Densil Morgan believed that 'more remarkable', due to his portrayal as a 'Son of Lleyn', was the anti-Welsh bias of the Bishop of St. David's. ${ }^{196}$ It is only possible to speculate whom Owen Owen had in mind when he wrote the following, but one Church defender who clearly appeared to meet the description was his own cousin, John Owen: 'Some defenders of the Establishment in Wales profess to be ardent Nationalists, and yet in permitting their allies in England to declare that there is no such thing as a Welsh nation, they are selling their birthright for a mess of Anglican pottage'. ${ }^{197}$ With his appointment as Dean of St. Asaph in 1889, 'he now definitely and consciously embarked on the sea of agitation and controversy on which - with two brief periods of respite - he was to spend the remainder of his life'. ${ }^{198}$ By the time John Owen was elevated to the bishopric of St. David's he had, at least in the opinion of the Western Mail already established himself as a Church defender par excellence and, perhaps in a less than subtle criticism of Bishop Edwards, John Owen had 'fewer personal enemies':

'He is within an ace of being a Welsh national hero, and Welshmen from the time of Caradoc and Arthur have always been distinguished for their fondness for heroes. He has fought more battles for the Church, both in the press and on the platform, than any living Churchman, and we have no hesitation in saying that he has fewer personal enemies than, probably, any other public man in the Welsh Church or out of it'. ${ }^{199}$

The intensity, ferocity and the dynamism of his efforts to deter disestablishment were remarkable and, in addition, he was adept at redefining his arguments to meet changing circumstances. He was to be at the centre of the campaign until the 1914 legislation and, thereafter, in efforts to either repeal, or at least mitigate the effects of disestablishment. In order to gauge Owen's involvement in Church defence, from the time when legislation was first introduced, this can be best illustrated by the fact that, despite his academic duties at Lampeter, he 'was apparently up in London for the debate on the First Reading' of the 1894 Welsh Disestablishment Bill. ${ }^{200}$ His daughter wrote that: 'he helped Mr. Balfour ${ }^{201}$ with his speech for he was there officially, as it

\footnotetext{
${ }^{195}$ In her biographies of her father, Eluned Owen ascribes a sub-title of ‘A Son of Lleyn' to The Early Life of Bishop Owen, 1958, and a sub-title of 'A Son of Wales' to The Later Life of Bishop Owen, 1961.

196 Ibid., p.35.

${ }^{197}$ Owen Owen, Welsh Disestablishment. Some Phases of the Numerical Argument, Wrexham, 1895, p.11.

198 T. Huws Davies, 'The Right Rev. John Owen, Bishop of St. David’s (1854-1926), Transactions of the Honourable Society of Cymmrodorion, 1926-1927, pp.176.

199 'Bishop Owen', The Western Mail, 16 February 1897, p.4.

${ }^{200}$ Owen, The Early Life of Bishop Owen, Llandyssul, p.171.

201 Arthur Balfour, (1848-1930); from 1891 he led the Conservatives in the House of Commons, serving under his uncle, Lord Salisbury.
} 
were, as the expert on the subject in debate. His task was to watch events and see the Church defenders were supplied with ammunition'. ${ }^{202}$

Eluned Owen quotes from the Western Mail that, following this First Reading, when Owen was described as: 'One of the most interested auditors of last night's debate' and that 'he was able to discern the weak points of the adversary's armour more keenly than the ordinary politician and when in the Lobby to prime Church defenders on the best points of attack' ${ }^{203}$ The bellicosity of the descriptions did tend to highlight the levels of animus. It is perhaps surprising that even at this early stage of legislative attempts at Welsh disestablishment, John Owen had already established himself at London. Owen was a favourite of the Conservative-leaning Western Mail and he was certainly energetic in his peregrinations to speaking events, which received acclamatory reporting, such as these reports from September and December 1894:

'On Tuesday evening a crowded audience, both enthusiastic and influential, welcomed Principal Owen at the Assembly-room, Builth. Sir John Dillwyn Llewelyn presided. The case of the Church was never put more trenchantly than it was presented by Principal Owen, who spoke for over one hour'. ${ }^{204}$

'Anyone who has followed the course of the Disestablishment question and read Mr. Ellis's Carmarthen speech can hardly fail to see that Principal Owen's address is the most effective reply that could ever be made. Not a single stone in his opponent's argument is left unturned, not a sophism left unexposed, not a fallacy left un-stripped'. ${ }^{205}$

In its review of the April 1894 issue of Y Geninen, the Western Mail is again eager to ensure that its readers were aware of Owen's efforts:

'Principal Owen makes mincemeat of Mr. Asquith's speech. Much as the champion from Lampeter has written on the Church side, he has written nothing stronger or more trenchant than this article, and it is to be hoped that some Welsh Churchman will translate it for Mr. Asquith's edification'. ${ }^{206}$

When Owen attended the $35^{\text {th }}$ Church Congress, held at Norwich in 1895, his address on 'Proposed Disestablishment and Disendowment', although simply one paper in a series on 'The National Church', received special note, with a reference to the Norfolk Chronicle, which had

\footnotetext{
${ }^{202}$ Owen, The Early Life of Bishop Owen, p.172.

203 Ibid., p.172.

204 'The Welsh Church', The Western Mail, 20 September 1894, p.7.

205 'Dangling the Spoils', The Western Mail, 1 December 1894, p.4.

206 The Western Mail, 15 April 1895, p.4.
} 
grandiloquently stated that 'Principal Owen's paper will live in history'. ${ }^{207}$ Owen’s paper appears at page 408 of the 672 page Official Report of the Church Congress, but what garnered this acclaim was Owen's comment that the Church should: 'give legislative effect to the voice of the Church, adequately ascertained, in regard to the control of her own internal concerns'. 208 Whilst Owen was prescient in raising concern about the role of parliament in the Church of England's affairs, which was to later cause some in the English Church to flirt with the idea of some form of disendowment-lite disestablishment of its own, the supreme irony is that disestablishment in Wales was to provide the Anglican Church with exactly the freedom of action which Owen sought. It is also of note that the Western Mail linked Owen's carefully phrased suggestions with a desire to 'prevent the occurrence of the disgraceful conduct pursued by Mr. Lloyd George and other Welsh members during the passage of the Clergy Discipline Act'. ${ }^{209}$ Unlike Bishop Edwards, Owen was never to demonstrate any positive feelings about Lloyd George and took every opportunity to vilify him. Taking into account the ultimate constitutional chaos which would eventually ensue, it would be difficult to imagine the Bishop of St. David's in the place of the Bishop of St. Asaph, when Sir John Herbert Lewis ${ }^{210}$, described that during David Lloyd George’s marathon Budget speech of 29 April 1909, he found himself a place on the front row of the Gallery, 'by the Bishop of St. Asaph, who was unbounded in his admiration of the skill with which the Budget had been framed' ${ }^{211}$

\section{The 'undeniable' revival of the Church in Wales.}

The Bishop of St. David's was adept at his use of statistics, as the his speeches and papers demonstrated, and he utilized his attendance at the Church of England's 1908 annual Congress, held at Manchester, to showcase the 'undeniable revival of the Church in Wales after the religious depression of the Church as a whole in the eighteenth century'. ${ }^{212}$ A desire to

\footnotetext{
207 'Church and Parliament. Proposed new departure in legislation. Comments on Principal Owen’s paper at Norwich', The Western Mail, 15 October 1895, p.4.

208 The Official Report of the Church Congress, held at Norwich on 8,9,10, 11 October 1895 (London, 1895), p.411.

209 'Church and Parliament. Proposed new departure in legislation. Comments on Principal Owen's paper at Norwich', The Western Mail, 15 October 1895, p.4.

210 John Herbert Lewis, (1858-1933), lawyer and politician. Liberal member of Parliament, representing Flint boroughs from 1892 to 1906, Flintshire, 1906 to 1918 and the University of Wales from 1918 until his retirement in 1922. A close friend of both David Lloyd George and Thomas E. Ellis.

${ }^{211}$ J. Graham Jones, 'Framing the People's Budget. A New Perspective', Transactions of the Historical Society of the Cymmrodorion, (1991), p.136.

212 'The Church Congress', The Times, 9 October 1908, p.7.
} 
demonstrate that the Church was expanding in terms of places of worship and the number of worshippers was crucial to the established Church's credibility, as the proceedings at the Royal Commission had demonstrated admirably. It was also becoming important in order to impress and secure English support in efforts to resist disestablishment. The Western Mail's cartoonist, Staniforth, assisted the Bishop in his efforts to illustrate this perception by depicting the Welsh Church as magnificent Shire horse being paraded, at speed, by the Bishop, with John Bull looking on with contentment and the Nonconformist with dismay. ${ }^{213}$

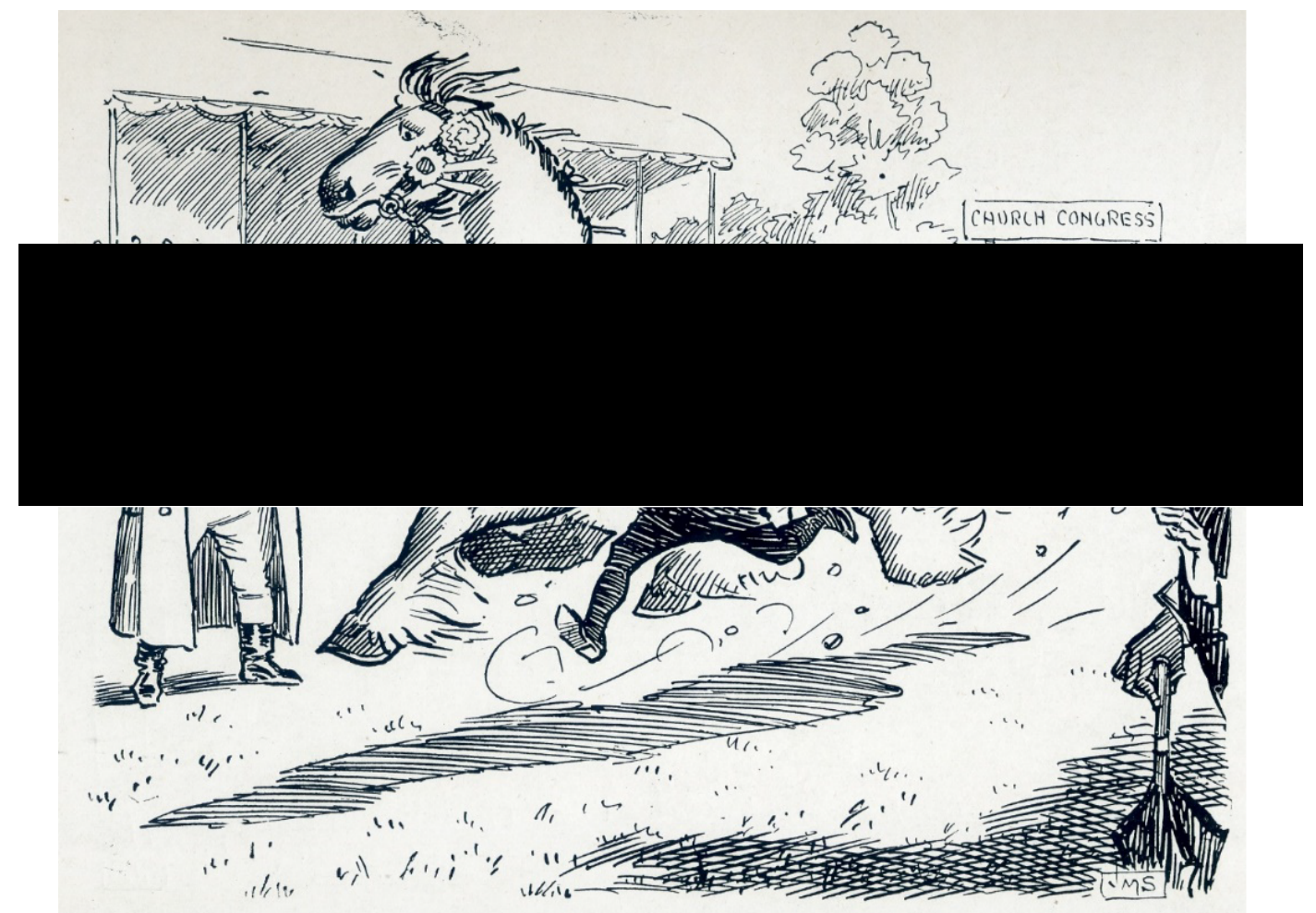

'Showing off his Paces', Western Mail, 10 October 1908.

The Liberal leaning Carmarthen Weekly pointed out the poor attendance at Bishop Owen’s session, compared with the two previous days of the Congress, which was indicative of the 'feeble interest now taken in the subject', with 'only a handful of representative English Churchmen', although the Bishop of Manchester (Edmund Knox) ${ }^{214}$ was on hand to make a statement which was indicative of Archbishop Benson’s declaration at the 1891 Rhyl Congress, when the Bishop said:

\footnotetext{
213 'Showing off his Paces', Western Mail, 10 October 1908. The strap-line reads: 'Ostler (Bishop Owen): 'What do you think of him, sir?’ John Bull: 'Splendid! He has magnificent action and great strength! Non-Com: 'Dear me! And I always thought that that horse was in decline'.

${ }^{214}$ Edmund Knox, (1847-1937), bishop of Manchester from 1903 to 1921.
} 
'that the Church in Wales and the Church in England must stand or fall together. Churchmen, Bishop Knox declared, refused to recognise any dividing line behind the English and Welsh branches of the Church and any Government which touched the question must deal, with the whole of it, or not at all'. ${ }^{215}$

It was, according to the newspaper, 'the one outstanding utterance of the conference' and it certainly pleased Bishop Owen, who must have been less than content with the relatively poor turnout as the newspaper reported that: 'the explanation offered by Welsh representatives of the small attendance was that English Churchmen do not take seriously the Government's threat to disestablish and disendow the Welsh Church', although they believed that this would change, as the government's intentions became more apparent.

The Times adopted a different interpretation of the numbers who attended and it reported that 'attendance was moderately good, but by no means sufficient to fill the great area of the hall' and, as would be anticipated, it presented the Bishop’s words in a supportive manner, with emphasis upon 'the fusion of the Welsh with the English dioceses' and that: 'The argument from Welsh nationality in favour of Welsh Disestablishment was an instance of the fallacy of ambiguity, being an argument from the historical to the political use of the word'. ${ }^{216}$ Bishop Owen had crafted his paper for an English audience, and perhaps the most startling and revealing element of his paper was his suggestion that: 'At the present moment, when Wales had almost become a uni-lingual country, thus losing its seclusion, and becoming more and more open to the influences of modern thought', whereby 'influences of modern thought' is presumably shorthand for Anglicisation. If it was necessary to illustrate the Bishop's true attitude to Wales, the Welsh language and nationality, which is often compared favourably with that of the Bishop of St. Asaph, then this aside provides sufficient cause to question the Bishop of St. David's standpoint. The Bishop of St. David's had always attempted to counter the accusation that the Welsh Anglican Church was 'alien', and he appeared to understand that if Church defence was to be palatable, in the context of newly identified Welsh nationality, then he must differentiate the Church's position and it was in this context that, in a speech delivered in Newport on 8 June 1909, he described: 'The first principle therefore on which we take our stand in opposing this

\footnotetext{
215 The Church in Wales. Discussion at the Church Congress. Paper by the Bishop of St. David's', The Carmarthen Weekly Reporter, 16 October 1908, p.2.

216 'The Church Congress', The Times, 9 October 1908, p.7.
} 
Bill [being the latest disestablishment bill] is this - Christian patriotism against secular nationalism' ${ }^{217}$ The Bishop proved adept at describing why the arguments for disestablishment should be consigned to history, as they were the same as those that had been posited for the last forty years. He also called on Church and Chapel to understand each other better, in order to meet the 'new theologies' facing them both and, after this scare-mongering, 'would the forcible separation of the Welsh from the English dioceses by Act of Parliament, against the will of Churchmen, improve the relations between Church and Chapel?'218

\section{'Christian patriotism against secular nationalism'.}

The Brecon Times, being supportive of the Conservatives and the Unionists, was content to attribute the description of 'statesmanlike' to a speech, in 1913, by the Bishop of St. David's. Although this was not unsurprising, as the manner in which the Bishop argued his case was certainly politically adept, in the manner in which he adroitly 'appealed to reasonable Nonconformists'. ${ }^{219}$ During his speeches at Pontypool and Blaenavon the Bishop referred to the impact of the proposed Welsh Church Bill on the 'future of religion in Wales', to which he stated the government had 'paid too little attention'. He quoted the question raised by a 'Welsh disestablisher', who had asked 'Where are we going?', but who had discovered that disestablishment would not bring the Welsh people to the Promised Land. In an example of how the Bishop could cleverly turn an argument on its head, he argued that the dismemberment of the Church violated the 'fundamental principle of religious liberty', although most people would be familiar with the argument that religious liberty had traditionally been a grievance associated with Nonconformists. The Bishop then, perversely, added that: 'they could never hope to attain internal religious unity in Wales by any step which would tend to weaken religious bonds of unity between Wales and England'. The 'fighting Bishop' suggested that he had indeed beaten his sword into a ploughshare, when he added that: 'He believed that at heart Nonconformist supporters of the Bill did not desire to weaken the Christian character of the State in Wales any more than Churchmen in opposing the Bill desired to retain anything which constituted any real grievance to Nonconformists’.

\footnotetext{
217 The Bishop of St. David's, The Principles of the Welsh Disestablishment Bill (Cardiff, 1909), p.8.

218 Ibid., pp.14-15.

219 'A Statesmanlike View', The Brecon County Times, 4 December 1913, p.7.
} 
The Bishop opined that: 'true religious equality was to be sought in such a constructive readjustment of the relations of the Church to the State as would be in accord with the wishes and convictions of Churchmen, and in such a constructive re-adjustment of the relations of the Nonconformist Churches to the State as would be in accord with the wishes and convictions of Nonconformists themselves’. He believed that this:

'reasonable policy of constructive reform all round, instead of the destructive policy of disestablishment, would tend towards unifying the forces of religion in the country, and thus broaden and strengthen, to meet the needs of the future, the national recognition of religion which they had inherited from the past'.

In another part of his speech, the Bishop went as far as to suggest disendowment would exacerbate 'one of the greatest social problems of Wales in the near future', which was the 'depopulation of rural Wales and the enormous increase of population in industrial Wales', and which demanded the utilization of endowed funds. In case his audiences, and the readers of the press coverage, were not persuaded by his arguments of reason, the Bishop summoned a call to patriotism and duty: 'He entirely failed to understand how it was possible for patriotic Welshmen who cared more for the cause of religion in Wales as a whole than any temporary sectarian triumph to support the secularization of Welsh religious endowments proposed in this Bill' and that: 'this generation had no moral right at all to squander these ancient religious endowments at the cost of grievous injustice to future generations in Wales'.

The Bishop of St. David further demonstrated his remarkable ability to reinterpret and restructure his representations against the Welsh Disestablishment and Disendowment Bill, when he mobilized feelings of Welsh national identity. His approach was not to view the Anglican Church as an 'alien Church', which had been a staple accusation since the 1830s, but to set the institution as a means of preserving: 'the distinctive historical characteristics of Welsh national life', which was at risk, when 'the spirit of the age set strongly in the direction of broad movements political, industrial, mental, moral, which imperilled the future of small nationalities'. The Bishop dismissed the Welsh language as a safeguard, 'since more than half the people of Wales did not know it to-day' and:

'The growing stream of immigration to Wales from outside, and the steady emigration from Wales to other countries made race an impossible safeguard of Welsh nationality under modern conditions. The habits of social life were rapidly changing, especially in 
industrial Wales, under modern conditions, and were, therefore, an unstable foundation for the future of Welsh Nationality'.

The Bishop’s contention was that religion, 'even more than language or race or habits', had been the most distinctive element of Welsh national life and that it alone could 'preserve the distinctive reality of Welsh national life in the future'. This extraordinary reinterpretation meant that the Bishop conjured up the image of a Church, which would remain as part of the Church of England, serving as the most crucial prop of 'Welsh national life' based upon religion. Indeed, he criticized those who were: 'planning to reconstruct Welsh national life on a secular basis, because they had failed to learn the secret of its organic corporate reality, should be pleased to call themselves, on that account, Welsh Nationalists'. ${ }^{220}$

This theme, of how the Church and Chapel would face the future was developed further and it was continued in his examination of the later disestablishment proposed legislation, when he attempted to express his point of view in relation 'to a true conception of Welsh national life', where he propounded the idea that 'religion is the only safeguard', thereby intimating that the Anglican Church was certainly not 'alien', nor an Anglicising factor, but was actually the nation's best defence. In an age 'which imperilled the future of small nationalities, the preservation of the distinctive historical characteristics of Welsh national life was a difficult problem' and he asked how they could prevent the loss 'which would follow the decay of the distinctive reality of Welsh national life ${ }^{221}$ Welsh Anglican patriots from the past, such as Dean H.T. Edwards, may have had some sympathy for the Bishop's attempt to view the Church as a Welsh institution, but those patriots had been ignored in the preceding decades and Welsh clergy had suffered, career-wise, for expressing such sentiments. The Bishop’s interpretation was a belated, cynical attempt to assume the cloak of the patriot, at a juncture where the Church defenders were beginning to realise that disestablishment was likely. An 'open letter to the Bishop, signed by a certain ' $X$ ', expressed great some puzzlement, and presumably incredibility, at this apparent volte-face, at the last moment, and the Bishop’s acquisition of a new persona, as Welsh nationalist:

\footnotetext{
220 'Bishop of St. David's and Welsh National Life. Religion the Only Safeguard', The Brecon County Times, 29 January 1914, p.2.

221 'Bishop of St. David’s', The Brecon County Times Neath Gazette and General Advertiser, 29 January 1914 , p. 2.
} 
'We notice in your series of speeches delivered this week in Carmarthenshire that you pose as a Welsh patriot and propound a new theory of Nationalism. Has it never occurred to you how inconsistent is your appeal for Welsh National Unity, and at the same time invite the Saxon predominant partner and the Saxon Church, whose ecclesiastical policy for centuries was the Anglicization of the Walsh nation? Why the Saxon archbishops colluded with the Saxon kings to deprive the Welsh Church of its independence as a National Church. And yet in the name of Nationality you appeal to Welsh Nonconformists to cease attacking an alien Church imposed by force by our Saxon conquerors'.222

However, in his review of the rumours circulating prior to the meeting of the Convention of the Church in Wales, in October 1917, an experienced commentator such as J. Arthur Price, could discern the seeds of a nationalist revival in the Welsh Church, as a result of disestablishment, with the view that 'the ablest minds among her clergy and laity are already turning from the dead past of Erastianism to the living future of Nationalism'. ${ }^{223}$ He was, by dint of his experience with the Welsh Church, a realist and although he anticipated a 'demand for a national Welsh Church', he feared that 'the timidity and the Anglicising prejudices of high dignitaries will prevent immediate action'. ${ }^{224}$ He questioned the actions of the Bishops of St. Asaph and St. David's and was puzzled about the creation of a Welsh Archbishopric:

'For twenty years these two prelates have been preaching and proclaiming the absolute identity of their Church in England and Wales and extolling the Canterbury connection. For either of them to adopt the role of Giraldus Cambrensis would come as a startling surprise. All the same I think that the Disestablished Church is slowly drifting to a reconciliation with Welsh Nationalism, and it is possible that even its leaders may be affected by the feeling of the hour'. ${ }^{225}$

As expounded by Frank Morgan, the possibility of a drift to Welsh nationalism was actually a factor which contributed to a desire for the Welsh Church to remain firmly within the influence of the Church of England.

\footnotetext{
222 'Open letter to the Bishop of St. David's', Y Brython, 5 February 1914, p.6.

${ }^{223}$ Price, J. Arthur, 'The awakening in the Welsh church', Welsh Outlook, vol.4, no.10 (Oct. 1917), p.361.

${ }^{224}$ Ibid, p.363.

${ }^{225}$ Ibid., p.362.
} 


\section{Chapter five: The Legacy.}

One of the architects of the constitution of the Church in Wales, Lord Justice Bankes ${ }^{1}$, believed that disestablishment held out distinct possibilities, particularly when contrasted with the Church of England, which was: 'at this moment struggling to free herself from the hindrances and disadvantages', whereas: 'Here in Wales the Church has been compulsorily set free'. ${ }^{2}$ Such a sentiment, expressed by a layman whose role was crucial to the development of the disestablished Church, would probably not be appreciated by contemporary Church commentators and, instead, there is a level of resentment or, increasingly, mystification about why the purported separation from the Church of England exists. Superficially at least, it is difficult to identify any substantive adverse outcome and: 'The Act that threatened to de-church the Welsh Church by disestablishing it not only failed to turn it into a denomination; it was not even fully effective in disestablishing it at the level of popular perception and customary practice'. ${ }^{3}$ Certainly many may struggle to recognise that such a separation had any particular manifestation, apart from the existence of an archbishop, although of course the English Anglican Church had two such prelates. Those who do not possess a historical perspective might assume that Welsh disestablishment simply reflects some post-devolution settlement and symbolizes little more than a quaint Welsh desire to maintain its own institutions, or at least ascribe 'Wales' or 'Cymru' to the title of a British body.

Reverend David Caird, the Secretary of the Liberation Society, provided a prescient interpretation of the outcome of Welsh disestablishment when he asked: 'after disestablishment what will happen? To begin with there will be little or no visible change. The churches will remain in the possession of those who now worship in them' and although the bishops would have to vacate their seats in the House of Lords, 'their position in relation to the Church in Wales

\footnotetext{
${ }^{1}$ Sir John Eldon Bankes, (1854-1946), became a judge of the High Court in 1910 and a Lord Justice of Appeal in 1915.'Politically he was a Conservative, and had unsuccessfully contested Flint Boroughs in 1906'. In collaboration with Lord Sankey he drafted the constitution of the Church in Wales. He was a leading public figure in Flintshire, his home county. The Dictionary of Welsh Biography.

${ }^{2}$ Official Report of the Proceedings of the Convention of the Church in Wales, held at Cardiff, October 2-5, 1917, p.26.

${ }^{3}$ Harris and Startup, The Church in Wales. The Sociology of a Traditional Institution, p.7.
} 
will remain unchanged'. ${ }^{4}$ Reverend Caird was to be proven correct in his prognostications and additions could be added to his list in that vestiges of establishment would remain and that Welsh cathedrals would continue to house events of national consequence. In 1989, the Reverend D. T. W. Price, then senior lecturer at St. David's University College, Lampeter, wrote of the Church in Wales that; 'legally disestablished and disendowed, but in outward appearance, in diocese and parish, largely seemingly unchanged'. ${ }^{5}$ He also added that;

'The cathedrals have preserved the distinctive character of the cathedrals of the Church in England. A visitor would find little apparent difference in atmosphere between, say, Llandaff Cathedral in Wales and Hereford Cathedral in England. Moreover, it seems to be practice on royal visits to Wales that any religious observances are held in a cathedral, when the presence of Lord Lieutenant presenting bishop to monarch recall all the pomp of Establishment' ${ }^{6}$

He could have added that many people, including worshippers, are often unaware of any substantive differences between the English and Welsh Churches. When Caird was writing in 1912, his emollient words about 'no visible change' would have simply been viewed as prodisestablishment propaganda and it did not take account of the concerns associated with disendowment, but more importantly, it failed to appreciate the alarm, at least among Welsh prelates, of dismemberment, which was viewed as a separation from the Church of England. It was the financial impact of disendowment which was usually the feature most often mooted as presenting the severest threat to the newly disestablished Church and yet, writing fifteen years after disestablishment, the leading lay Church official, Frank Morgan ${ }^{7}$, reported that: 'it is almost impossible to estimate to what extent the finances of the Church in Wales suffered by

\footnotetext{
${ }^{4}$ David Caird, Church and State in Wales. A Plain Statement of the Case for Disestablishment (London, 1912), p.126.

${ }^{5}$ William Price, 'Church and Society in Wales since Disestablishment', in Religion, State and Society in Modern Britain (Lampeter, 1989), ed. by Paul Badham, p.41.

${ }^{6}$ Ibid., p. 37.

${ }^{7}$ Frank Morgan, (1868-1935). Shortly after his death, an article noted that he 'was for nearly 30 years one of the most active laymen in the Church of Wales' and 'one of the chief artificers in building up its present constitution', H.V. “Mr. Frank Morgan”, The Times, 31 December 1935, p.6. He was the secretary of the Representative Body and the lay secretary of the Governing Body of the Church in Wales. He had his schooling at Llandovery College and he won a scholarship to Keble College, Oxford, and later became a Lecturer in History in the same college. He was invited to collect material to be put before the Royal Commission concerning the Disestablishment of the Church in Wales. When the 1914 Act of Disestablishment had been passed, he worked as the secretary of all the committees dealing with the drawing up of a constitution, and later played vital roles in both the Representative Body and the Governing Body.
} 
Disendowment' ${ }^{8}$. In 1919, Frank Morgan, the Secretary of the Governing Body and the Representative Body of the Church in Wales, had demonstrated that it would not have been in the Church's interests to be accurate about the impact of disendowment, when he wrote that:

'it was urgently important not to let Welsh Nonconformists get the idea that the Church had not suffered by Disendowment. I am absolutely clear that we want $£ 1,000,000$ new money but do not care much on what ground we put the claim' ${ }^{9}$.

The legislation introduced during the period from 1914 to 1919 introduced an attenuated form of disestablishment and the Church in Wales was re-established and re-endowed ${ }^{10}$, remaining as close as possible to the model of the Church of England. Therefore, it must be assumed that if there was, or is, any antagonism to disestablishment must be attributed to something which falls outside disestablishment per se, but is related tangentially, and that is the question of national identity, language and an association of the increase in secularistion, post-1920, with the impact of disestablishment. The disestablished Church did not, as many hoped, readily assume a new persona as a Welsh Church and in 1935, it was reported by the senior lay Church official that the Welsh Church had deliberately decided to refrain from anything that might 'widen the breach with the Church of England'. ${ }^{11}$ Trepidation of the growth of Welsh nationalism was also identified by Frank Morgan, as a reason why its new-found freedom was not pursued. It was apparent that Churchmen, both before disestablishment and after, believed that a 'fifth-column' within the Church was to be monitored and that, as Prys Morgan has suggested, many interpreted Nonconformity in a similar manner, as an oblique way for nationalists to mobilise, under the guise of benign religious activism, rather than pursue overt political enterprise, in order to achieve their ultimate goal:

'Moreover, propagandist such as Ieuan Gwynedd probably calculated that their brand of nationalism would be far more palatable to the Welsh disguised as militant Welsh Nonconformity than as naked Welsh nationalism and would be far more difficult for the

\footnotetext{
${ }^{8}$ Church \& State. Report of the Archbishops' Commission on the Relations between Church and State, volume 2 , Evidence of Witnesses (London, 1935), p.1., p.141.

${ }^{9}$ Frank Morgan to Bishop Owen, 23 September 1919, (N.L.W, Bishop John Owen papers, 12/6).

10 The way opposition to the grant of one million pounds to the Welsh Church Commissioners, by three Welsh Liberal members of Parliament, was comprehensively quashed was demonstrated by a letter to The Times ('The Welsh Church. Liberal Divisions on the New Measure', 14 August 1919, page 15), when the chairman and treasurer of the Welsh Liberal Parliamentary Party, although admitting that none of the Welsh Liberal M.P.s were 'entirely satisfied' with the 1919 Bill, were adamant that it was the only deal on the table and that, without it, it would be necessary to revisit the Welsh Church Act 1914, with the implied threat that this would have 'unforeseeable consequences', suggesting that disestablishment itself would be at risk.

${ }^{11}$ Church and State, vol. II. Evidence of Witnesses taken before the Archbishops' Commission on the Relations between Church and State, 1935, p.139: evidence taken from Mr. Frank Morgan.
} 
British or the English to resist or repress, since there was a general acceptance by that time of the religious rights of the individual'. ${ }^{12}$

As will have been already gleaned from the earlier chapters, there was some basis to this apprehension, particularly from a Unionist perspective. The essential point was that disestablishment was interpreted as an 'assault' on the Church in England and, by definition, upon the English Establishment. Whatever the case, it was difficult to equate Frank Morgan's comments with the aspirational message from Lord Justice Bankes, who envisaged that disestablishment would lead to: 'a truly national Church, a Church that will adapt itself to the needs and requirements of all classes and to the ever-changing conditions under which her work must be done'. ${ }^{13}$ On the morning that the identity of the Archbishop of Wales was announced, 'Cambrensis', wrote in The Church Times that: 'what is needed is that the Church should be at once fearlessly and wholeheartedly Nationalist'. ${ }^{14}$ He went on to suggest that:

'The future historian of the Welsh Church will probably be startled at the fact that the first Archbishop of the Welsh Church should have been Dr. Edwards of St. Asaph. If any man in the past has fought long, bravely and consistently, for the continuance of the union between the Welsh and English Churches, that man is Dr. Edwards'. ${ }^{15}$

He went on to compare, quite topically at the time, the strangeness of the new Archbishop's position to that of Sir Edward Carson ${ }^{16}$, the staunch Unionist, being elected President of an Irish Sinn Fein Republic. The writer, whilst criticizing Edwards for linking the Welsh Church to the Conservative Party, and for using 'political arguments that would carry weight with the English voter', was prepared to acknowledge that he 'lacks neither courage nor wisdom' and that, despite his failure, his fight was a brave one, and his popularity in the Welsh Church is deserved'. 'Cambrensis' had probably already concluded that this appointment was an indication that the tenor and characteristics of the Church had not changed.

\footnotetext{
${ }^{12}$ Prys Morgan, 'Pictures for the million of Wales, 1848', Transactions of the Honourable Society of Cymmrodorion, New Series, vol.1 (1995), p.79.

${ }^{13}$ Official Report of the Proceedings of the Convention of the Church in Wales, held at Cardiff, October 2-5, 1917, p.26.

14 “Cambrensis”, ‘The Chance for a Welsh Archbishop', The Church Times, 9 April 1920, p.371.

${ }^{15}$ Ibid.

${ }^{16}$ Edward Carson, Baron Carson, (1854-1935), leader of the Irish Unionist Alliance and the Ulster Unionist Party between 1910 and 1921. It has been suggested that Northern Ireland is Carson's creation. Arguably Archbishop Edwards could make a similar claim in respect of what became the disestablished Church in Wales.
} 
The foregoing chapters have attempted to understand the series of spasmodic engagements and campaigns that ebbed and flowed, eventually leading to the Welsh Church 1914, and to consider the impact upon the Welsh Anglican Church and the political life of the nation. In 1923, the Archbishop of Wales, A. G. Edwards, reported upon the Church's 'nine years of progress' in a series of two articles which he wrote for The Times. As Bishop of St. Asaph, he had frequently resorted to the letter pages of The Times and it was apparent that he attributed a particular significance to this newspaper as a method of ensuring that his interpretation of events reached the attention of the Establishment: an Establishment of which he had, as a member of the House of Lords, been a leading member, with demonstrable and extremely valuable ease of access to politicians. The first of his articles was published on the date of the enthronement of the first Bishop ${ }^{17}$ of Swansea and Brecon ${ }^{18}$ and it could have been assumed that it would provide an opportunity for the Archbishop to proclaim the Church's new freedom, but it actually led him to write critically about the election of a non-Welsh speaking bishop. He alleged, inaccurately, as a number of Welsh bishops appointed after 1870 had questionable fluency, that: 'The language qualification for a Welsh bishopric has, for the first time in fifty years, been set aside' and he warned the Church: 'nationality is a good friend but a dangerous enemy', with an admission that: 'the neglect of the Welsh language on the part of the Church contributed to the rise of Nonconformity'. ${ }^{19}$ Such trenchant comments from the 'wheaten bread' bishop would have surprised many and, if they had formed the basis of the Church's response to disestablishment, decades earlier, they might have provided a framework for conciliation. Sadly, the Archbishop's comments would need to be read in the context of a supposed personal antipathy to Bishop Bevan $^{20}$, whose 'strongest supporter' was the Bishop of St. David's. ${ }^{21}$

\footnotetext{
${ }^{17}$ Edward Latham Bevan, (1861-1934), was the fourth son of the Venerable William Latham Bevan, (1821-1908), who was Archdeacon of Brecon from 1895 to 1907. E. L. Bevan was vicar of Brecon from 1897. He succeeded his father as archdeacon of Brecon in 1907 and was appointed suffragan bishop of Swansea in 1915. (W.L. Bevan was the author of Notes on the Church in Wales, London, 1905 where he wrote on page 32 that: 'there is no trunk-road between North Wales and South Wales; hence also Wales has never had a capital - a sign that it was not a single State, nor yet a single Church'.)

18 ‘The Welsh Church. Nine Years of Progress. The Archbishop’s Review', The Times, 14 September 1923, p.11.

${ }^{19}$ Ibid.

${ }^{20}$ Owain W. Jones, Glyn Simon. His Life \& Opinions, p.55: A.G. Edwards refused to cast his vote for the ratification of E.L. Bevan, as the first Bishop of Swansea and Brecon, ostensibly on the grounds that Bevan did not speak Welsh, yet Bishop Glyn Simon 'thought that Edwards had a rather ambivalent attitude to Welsh', and that his antagonism towards Bevan was personal rather than linguistic.

${ }^{21}$ David Walker and Margaret S. Walker, 'Epilogue: A New Diocese, 1923', in Links with the Past. Swansea and Brecon Historical Essays (Llandybie: Christopher Davies, 1974), ed. by Owain W. Jones and David Walker, p.247.
} 
The second of the Archbishop's articles provides an appropriate starting point for this review of the legacy of disestablishment, as he was obliged, after attesting that; 'The bond of Establishment has gone. Few, if any, now desire to return to the old order', to provide an explanation for his 'apparent acquiescence'. After fifty years of fervent, uncompromising, unflinching public resistance, it is certain that his assertion would have perplexed many of those who had followed his utterances over those decades. He was to refer to 'a balance-sheet of loss and gain', in which he addressed disestablishment, disendowment and dismemberment. ${ }^{22}$ Remarkably, he 'dismissed' disendowment in one sentence, with a statement that the State had taken what it 'claimed as its own'.

The Archbishop identified a 'practical result' of disestablishment as being that Welsh clergy had more time to discuss their own issues, in its own National 'Convocation', and that, although the result of the exclusion from the House of Lords was 'indeterminate', the Archbishop acclaimed the 'gain' that Welsh bishops were no longer 'drawn away from their proper duties'. It was a significant admission by this peripatetic prelate, whose ubiquity, in defence of the established Church, has been described in earlier chapters. The Archbishop's recognition of these 'gains' would have appeared sufficiently noteworthy, in the context of the preceding chapters of this thesis, but he then continued with another 'gain', in that bishops were no longer appointed by the State and that the Church was 'free and independent'. ${ }^{23}$ He concluded his article with a quotation from the 'creator of the Constitution of the Church in Wales', the then Mr. Justice Sankey, who talked of finance being important, but that no Church was ever saved by money alone and that a constitution was important, but that 'no man was ever saved by the letter of the law' and that the 'Church in Wales is the Church of Christ'.

Any assumption that the Archbishop had belatedly undergone a Pauline conversion and that he had now, rather belatedly, recognised the gains flowing from disestablishment must evoke a modicum of scepticism, when contrasted with the report of a sermon he delivered in Newcastle in February 1922, when the Archbishop: 'described the disestablishment of the Church in Wales as a calamity' and that some 'of its strongest supporters recognized now that it was an impolitic

22 ‘The Welsh Church. New Bishoprics. Influence for Unity’, The Times, 15 September 1923, p.9.

23 Ibid. 
measure'. ${ }^{24}$ His lack of consistency was also again demonstrated by the Archbishop's 'address on the new province of Wales', only four months earlier, at the 1921 Church Congress held in Birmingham, where he opined that; 'Without disestablishment it was doubtful whether the Church in Wales would have had the freedom and elasticity which would have made the creation of a new province possible' and that 'the reluctance, misgivings, and even the fears entertained about the new province of Wales had proved so far quite unfounded'. He continued with the opinion that the new province had evoked a series of positive outcomes, all of which amounted to further 'gains'. ${ }^{25}$ It is possible that he wished to exhibit a certain sangfroid, avoiding any hint that his efforts since the 1880s had come to nought. It is necessary to stand back and recall his zealous opposition to such change and to reflect upon his admission in Memories, published in 1927, when he described the Welsh Church as 'cut off from the State Church in England and from its convocations with no more official share in its spiritual responsibilities than an Indian or Australian province'. ${ }^{26}$

\section{'The National Church'.}

The presence of the Archbishop of Wales at events such as the 1921 Church Congress, or his readiness to comment on matters that pertained to the Church of England, such as the controversy surrounding the new prayer book, were not solely based upon nostalgia about his standing, pre-1920. His locus standi was now predicated, as he argued in 1928, upon his position 'as a member of the oldest Church in this island' ${ }^{27}$ His argument about the status and standing of the disestablished Welsh Church provided an insight into the ambiguous position of that Church after 1920, particularly with regard to its relationship with the Church of England, as it was predicated on the extraordinary conviction that, even post-disestablishment, the Church of England maintained a position as the 'National Church of this country', which was only second to the throne in 'its uniting influence upon the loyalty and integrity of the Empire'. Archbishop Edwards emphasized that it was the British, and not the English, Empire and therefore 'to circumscribe the National Church to the English counties is a curtailed estimate of her influence

\footnotetext{
24 'Newcastle and Welsh Church', The Times, 27 February 1922, p.7.

25 'Prayer-Book Revision. Church Congress Discussion', The Times, 14 October 1921, p.15.

${ }^{26}$ Edwards, Memories, p.320.

27 'New Prayer-Book. The Church and the State. Archbishop of Wales on Establishment', The Times, 17 January 1928, p.15.
} 
and power'. ${ }^{28}$ By implication, he recognized that its 'influence and power' would continue to be exerted over Wales, which presumably made the Welsh Church a vassal Church, at least in the eyes of its senior prelate. This question of what amounted to a 'National Church' was to continue to be a matter of confusion, as it had been before 1914. It appeared to amount to the subjective, being based upon an individual's definition of nation, and such confusion was evident in The Times's reporting of the Archbishop of Canterbury's sermon at the enthronement of the first Welsh Archbishop, when the newspaper regretted the ending of the 'connection between Church and State' and exclaimed that the Welsh Church could no longer claim to be the 'National Church'. ${ }^{29}$ If any supporter of disestablishment sought belated confirmation of the muchdisputed accusation that the Welsh Anglican Church had been Anglicised and 'alien', then The Times had obliged.

In terms of the English treatment of Welsh disestablishment, after 1920, there was an inconsistent approach, which either portrayed ignorance or, more commonly, indifference. Although one of the more startling admissions, considering the adverse political and spiritual impact upon Wales that was occasioned by the quest for disestablishment, was contained in an article which appeared in The Church Times in 1922. Although it was concerned with the 'strength of the Welsh Church', it made a remarkable admission, just two years after disestablishment, when it stated that:

'In the light of accomplished facts, we can now see that for more than a hundred years before 1914 Welsh Disestablishment and Disendowment were, in the normal course of events, inevitable'. ${ }^{30}$

There was no apparent chagrin in making this statement, although the newspaper, whilst appearing to acknowledge what the statement implied, in terms of the adverse effects of the prolonged and embittered campaign, believed that: 'No one can blame Welsh Churchmen for refusing to surrender, until further resistance was impossible', whilst suggesting that the Welsh Church's 'close relations with the Tory party sealed its fate'. However, this apparently futile resistance did serve a purpose, in that it the attrition contributed significantly towards the attenuated disestablishment which was eventually delivered.

\footnotetext{
28 Ibid.

29 'The Church in Wales', The Times, 2 June 1920, p.17.

30 'The Strength of the Welsh Church', The Church Times, 21 April 1922, p.408.
} 
The thorny issue of the nature of the relationship between Church and State was a topical and pressing issue within the Church of England by 1920, and it remains so. ${ }^{31}$ However, the Archbishop of York, writing in 1950, demonstrated the incongruity of approach when he glibly ascribed 'the disestablishment and disendowment of the four Welsh dioceses' as being the result of 'adverse legislation', following 'long agitation directed against the Church' ${ }^{32}$, and then, a few pages later, whilst describing the 'Life and Liberty' campaign ${ }^{33}$ within the Church of England, the Archbishop reported that responsible Churchmen, including himself, were 'almost unanimous in deciding that if we could not obtain self-government we should ask for disestablishment' ${ }^{34}$ In his evidence to the Archbishops' Commission which sat, in 1935, to 'enquire into the present relations of Church and State', Frank Morgan, giving evidence in a personal capacity, provided an interesting insight into how the Welsh Church had developed since 1920. ${ }^{35}$ The Commission had been appointed in response to Parliament's rejection of the Prayer Book Measures of 1927 and 1928. This had led to a crisis, described, within the report, as 'a situation of peculiar difficulty', within the Church of England and, naturally, a desire to understand its relationship with the state. ${ }^{36}$ Although there was no hint of irony, in terms of the fact that many of those who had condemned Welsh disestablishment were now actively considering the possible disestablishment of the English Anglican Church, it was Frank Morgan's evidence in response to a question about the Welsh Church's 'capacity and readiness' in determining 'its rule of worship' and 'to secure conformity thereto', which provided an insight. Frank Morgan explained that although the Welsh Church was 'free to determine its rule of worship and would probably be able to obtain conformity thereto' the situation had not arisen. ${ }^{37}$ This was partly due to the fact that disestablishment had reduced differences in the Church, but also:

\footnotetext{
${ }^{31}$ HC Deb. 25 January 1999, vol.324, cc.17-8: Jeremy Corbyn (Islington North) asked for 'an assessment of the financial consequences of the disestablishment of the Church of England'. He suggested that it would be 'prudent' to do their sums now, 'so that when that democratic day dawns, it will not be such a shock for them'.

${ }^{32}$ Cyril Garbett, Archbishop of York, Church and State in England (London: Hodder \& Stoughton, 1950), p. 107.

${ }^{33}$ Temple, the Rev. W., Life and Liberty, London, 1917: a public pressure group formed in 1917 by those advocating reform and self-government for the Church of England.

${ }^{34}$ Ibid., p.112.

${ }^{35}$ Church \& State. Report of the Archbishops' Commission on the Relations between Church and State, volume 1, London, 1935, p.1.

${ }^{36}$ Ibid., p.38.

${ }^{37}$ Church \& State. Report of the Archbishops' Commission on the Relations between Church and State, volume 1, London, 1935, volume 2, Evidence of Witnesses, p.1., p.139.
} 
'because Church people in Wales are only too conscious of the danger of taking any step that would tend in any way to widen the breach between the Church of England and that in Wales. Further there is a growth of nationalism which is much stronger in the Church than it was before the War'.38

Frank Morgan described a Welsh Church which was fearful of anything which could cause it to 'divide' from the Church of England and feared that it would become 'too provincial'. Although his evidence was given in a personal capacity, his key, long-standing role, vis-à-vis the Governing Body, meant that he was aware and in accord with the Welsh Church's self-image, which appeared, fifteen years after disestablishment, to be subservient and hesitant. Mr. Morgan did allude, in his answers, to two other areas of note. Firstly, he acknowledged that section 6 of the Welsh Church (Temporalities) Act, 1919 're-established' the Welsh Church as far as marriage was concerned, thereby reintroducing one of the 'vestiges of establishment'. 39

Secondly, he, rather like the second Archbishop of Wales, Charles Green ${ }^{40}$, was suitably evasive, when asked about the results of disendowment, when he replied that 'it is almost impossible to estimate to what extent the finances of the Church in Wales suffered by Disendowment'. ${ }^{41}$ Archbishop Green also admitted, in 1935, that 'there is general satisfaction with the financial arrangements'. ${ }^{42}$ Perhaps the relative silence on the subject, or at least the muted comments, reflected a desire by Churchmen not to gloat about the eventual financial outcome, or to cause those outside the Church from enquiring too closely into the arrangements. ${ }^{43}$ The desire to be circumspect about the Church’s financial position was evident from Frank Morgan’s communication to Bishop Owen soon after disestablishment, in 1922, when he wrote that: 'I send you a copy of my figures which must be regarded as absolutely confidential. I do not want

\footnotetext{
38 Ibid.

39 Thomas Glyn Watkin, 'Vestiges of Establishment. The Ecclesiastical and Canon Law of the Church in Wales', Ecclesiastical Law Journal, (1990), pp.112-113.

${ }^{40}$ Charles Alfred Green, (1864-1944), second Archbishop of Wales, from 1934 to 1944). Upon the formation of the diocese of Monmouth, he was appointed bishop in 1921 and he translated to Bangor in 1928.

${ }^{41}$ Church \& State. Report of the Archbishops' Commission on the Relations between Church and State, volume 2 , Evidence of Witnesses (London, 1935), p.1., p.141.

${ }^{42}$ C.A.H. Green, 'Disestablishment and Disendowment in Wales', Address of the Lord Archbishop of Wales, at the Church Congress, Bournemouth, 10 October 1935, p.15.

${ }^{43}$ Lord Crickhowell, 'The Conservative Party and Wales, 1888-1997', revised and expanded text of the 20 $0^{\text {th }}$ Political Archive annual lecture, National Library of Wales, 3 November 2006. Lord Crickhowell, the great-great nephew of Bishop (later Archbishop) A. G. Edwards opined that the Bishop had 'negotiated with Lloyd George a financial settlement vastly more favourable to the Church'.
} 
them known as it would only lead to reckless spending'. ${ }^{44}$ It is reasonable to assume that such an approach would, post-1920, have given credence to an assumption, which is still believed today, that the Church’s activities had been undermined by disendowment.

The Commission did not consider 'that there is any necessary connection between Disestablishment and Disendowment', nor did it believe that 'the fear of Disendowment should be allowed to play any great part in shaping the policy of the Church'. ${ }^{45}$ However, this principled stand did not dispel a suggestion, from reading the Commission's report, that potential disendowment was a significant factor. Another witness, Reverend Dr. P. Carnegie Simpson, provided a dispassionate response to the question of whether English disestablishment and disendowment would 'be a blow to religion and an injury to the country', when he considered that 'a great deal of over-tragic language is often used about this. The case of Wales shows the exaggeration of much of it'. ${ }^{46}$

The question of how Welsh disestablishment was perceived after 1914 is crucial. Whereas the Bishop of St. Asaph, perhaps displaying his ultimate loyalty, was desperate to interpret it as an English event, within the context of the Church of England, as demonstrated by his forlorn, and ultimately inaccurate, comment that 'it is probable that March 31, 1920, will occupy a larger place in English history' ${ }^{47}$ The Bishop’s desire to maintain a close relationship with the Church of England, reflecting assurances from the Archbishop of Canterbury, but it must have become gradually apparent, after 1920, that this was essentially one-sided. ${ }^{48}$ Therefore, the Bishop's comment, made on 7 January 1920, when he was contemplating the decision to launch an appeal for one million pounds in respect of the Church in Wales, is pitiful. He thought that financial support from English sources 'would see it right, as Wales held the post against the bigger onslaught on the English Church'. ${ }^{49}$ There was no evidence that the Church of England

\footnotetext{
${ }^{44}$ Morgan to Owen, 30 March 1922, N.L.W Bishop John Owen, letters from Frank Morgan, 12/6.

${ }^{45}$ Church \& State. Report of the Archbishops' Commission on the Relations between Church and State, volume 1, p.51.

46 Ibid., p.190.

47 'The Church in Wales. Facing the Future', letter to the Editor, The Times, 31 March 1920, p.10.

${ }^{48}$ Bell, Randall Davidson, Archbishop of Canterbury, Oxford, p.988. Writing to the Bishop of St. Asaph on 24 May 1919, the Archbishop, whilst advising that the Welsh Church should pursue a separate Province, he wrote that: 'we are not going to allow the legal severance of some of the formal bonds which at present unite us to impair in the smallest degree the fellowship of the deepest kind'.

49 'Welsh Church Appeal for £1,000,000', the Times, 8 January 1920, p.11.
} 
considered that the Welsh Church had thrown itself 'in front of the disestablishment bus', for the greater good. In case potential donors were deterred by news of the one million pounds granted by the government, the Bishop stated categorically that: 'Parliament had not given one penny to the Welsh Church but provided $£ 1,000,000$ for the county councils to discharge their liabilities placed on them by the Act of 1914'.50

During the debates concerning the Welsh Church (Temporalities) Bill, the Bishop of St. Asaph referred to the Welsh Church Act of 1914 and explained that: 'A policy of total repeal could only have been ventured upon if the whole of the Church of England had rallied to the cry and had been ready to stake its whole position on the result. ${ }^{51}$ English ambivalence to Welsh disestablishment was a phenomenon which, as has been mentioned above, featured strongly in the manner which A G. Edwards went about Church defence. It was tacit in the reportage of the enthronement of the first Archbishop of Wales, on 1 June 1920, when The Times noted the 'imposing ceremony', but exhibited a certain insouciance in the manner it described the fact the incumbent of this new post was A.G. Edwards, who had been the Bishop of St. Asaph for over thirty years and had, for most of that time, been 'troubled and distracted' by the various campaigns for disestablishment. ${ }^{52}$ Although it declared that it was testimony to his leadership that he had been elected Archbishop, the fact that he had been 'distracted' intimated that he had somehow not been successful as a bishop and churchman, but simply as a politician and antagonist. A casual English reader might have surmised that he was, bizarrely, being rewarded for failure, and that it was with the archbishopric of a disestablished body which he fought, with all his strength, to foil. But although it would have been tempting to view the Archbishop's mitre and cope as some form of consolation prize, it will be argued that his efforts to defer and, ultimately, dilute the nature and terms of disestablishment and disendowment made him worthy of such a prize. The most ironic outcome was that those highly prized endowment funds, which were to be the source of such bitter acrimony, would, post-disestablishment, disappear into a

\footnotetext{
50 Ibid.

${ }^{51}$ Welsh Church (Temporalities) Bill, House of Lords, 14 August 1919, vol.36, col.917.

52 'The Church in Wales', The Times, 2 June 1920, p.17. Perhaps inadvertently, but the article also suggests the existence of a continuing hierarchical significance, when it stated that: 'The Archbishop of Canterbury presented the new Archbishop to the people of Wales'.
} 
bureaucratic and expensive rabbit hole for at least a quarter of a century, as indicated by the frustration displayed by Major Goronwy Owen ${ }^{53}$ when, in 1942, he asked the Home Secretary:

'whether he is aware that the Commissioners of Church Temporalities, established under the Welsh Church Acts for purely temporary functions, are still in possession of substantially all the funds intended for charitable purposes; and, as they have now held this fund of nearly $£ 2,000,000$ for close upon 25 years to the deprivation of charitable causes, spending nearly $£ 250,000$ on salaries and other expenses and a further $£ 40,000$ in law charges, will he take steps in the coming autumn to wind up the administration of the Commissioners'. ${ }^{54}$

In terms of what senior English Churchmen thought about the Welsh Church, on the cusp of disestablishment, and what it might mean for Wales, an address by the Archbishop of York, to the St. David's Diocesan Conference in November 1919, was illuminating. ${ }^{55}$ After expressing the sympathy which English Churchmen felt for the Church in Wales 'in the time of her trial', he reminded his audience that 'the formation of a new Province for Wales would no more separate the Church in Wales from the Province of Canterbury than it was already separated from the Province of York’ and, albeit with a reference which may have sounded unfortunate, particularly on the first anniversary of the Armistice, he appeared to accept the argument that the Established Church had not served Welsh interests in the past and that Church of England in Wales had not adapted to 'national sentiment':

'that in her new capacity as a free Church the Church in Wales would be more and more able to adapt the old Faith to the Welsh national sentiment. Taking an illustration from the strategy of Marshal Foch, he said that he had high hopes that March 31 next would be the appointed day on which the gallant Church in Wales would rise and go over the top and go straight ahead in its advance to win Wales for the Kingdom of God'. ${ }^{56}$

\footnotetext{
${ }^{53}$ Major Goronwy Owen, (1881-1963), Liberal member of Parliament for Caernarvonshire, 1923-1945. He was one of the founder members of the London Welsh Regiment. He was knighted in 1944 and, shortly before he was defeated, by a Labour party candidate in 1945, he asked the Deputy Prime Minister, Clement Attlee, whether, 'in view of the fact that the Welsh nation is a distinct nation and, in proportion to its number, has contributed as much as the three other constituent nations to the greatness and security of the United Kingdom, he will arrange that armorial emblems for Wales shall be included in the Royal Arms of the United Kingdom; that the daffodil shall be sanctioned as the floral emblem for Wales'. Mr. Attlee responded that he would have the suggestion 'considered'. 'Royal Arms (Welsh Emblems)', HC Deb. 28 February 1945, vol.408, c.1371.

${ }^{54}$ Welsh Church Commission, HC Deb 25 June 1942. Vol. 380 cc.2139-40.

55 Cosmo Gordon Lang, (1864-1945), Archbishop of York, 1908 to 1928, when he was translated to Canterbury, where he served as Archbishop until 1942.

56 'Meeting at the Albert Hall, Swansea', Y Llan, 28 November 1919, p.2.
} 
As the first Archbishop of Wales was to remain in post until 1934, so it is reasonable to assume that this view, that the Welsh Church has simply segued from one subordinate position to another, as a satellite of this 'National Church', was shared by other senior Church and lay people. As reported above, Frank Morgan, the senior lay official acknowledged that the Welsh Church had not exercised its freedoms and discretion, in part because it was still in thrall to the English Church and, partly, due to anxieties about the 'Welshness' of the disestablished Church. Thus it is difficult not to support the view that:

'It was A.G. Edwards, aided principally by Bishop John Owen of St. David's, who did more than anyone to perpetrate the idea that the episcopal Church even after disestablishment in 1920 was an alien institution and a means of further compromising the national identity of the Welsh people'. ${ }^{57}$

It is unmistakable that Frank Morgan's comments about the 'growth of nationalism' reflected the fact that the Church's official political stance still remained resolutely Unionist, and it was clear that his concern was exacerbated by a reaction to the period of 'radicalisation' in Welsh nationalist politics ${ }^{58}$. J. Arthur Price ${ }^{59}$ had written, in 1921, that the 1914 disestablishment act 'proclaimed to the world the failure of England's effort to force upon Wales an unnatural ecclesiastical unity'. ${ }^{60}$ It was apparent, in 1935 at least, that the Welsh Church was wont to cling to that 'unnatural ecclesiastical unity' and that it made a mockery of the hopes of those like 'Cambrensis', who wrote in April 1920 that: 'what is needed is that the Church should be at once fearlessly and wholeheartedly Nationalist'. ${ }^{61}$

It is necessary to understand the nature of this disestablished Welsh Church, in terms of its operation, and its perception, by both the Establishment and the Welsh public. As far as the Crown was concerned, little appeared to have changed from the halcyon days when the then

\footnotetext{
${ }^{57}$ D. Densil Morgan, 'Christianity and National Identity in Twentieth-Century Wales', Religion, State \& Society, vol.27, nos.3/4 (1999), p.330.

${ }^{58}$ D. Hywel Davies, The Welsh Nationalist Party 1925-1945. A Call to Nationhood (Cardiff: UWP, 1983), p.151.

${ }^{59} \mathrm{~J}$. Arthur Price was described by Frances Knight as: 'an intriguing figure: a nationalist who maintained a faith in that when many around him abandoned it, and a churchman who vigorously worked for disestablishment when most of his fellow Anglicans were either doubtful or hostile', in 'Welsh Nationalism and Anglo-Catholicism: The Politics and Religion of J. Arthur Price (1861-1942), Pope, R. (ed.), Religion and National Identity. Wales and Scotland, c. 1700-2000, Cardiff, 2001, p. 104.

${ }^{60} \mathrm{~J}$. Arthur Price, 'The historical case for Welsh home rule', Welsh Outlook, vol.8, no.12 (December 1921), p.274.

61 “Cambrensis”, 'The Chance for a Welsh Archbishop', The Church Times, 9 April 1920, p.371.
} 
Bishop of St. Asaph dined with Queen Victoria ${ }^{62}$ during her perambulation around North Wales, in 1889 and when he instructed the monarch on her Welsh subjects, their customs and dietary peculiarities. ${ }^{63}$ The continuation of the disestablished Welsh Church's relationship with the symbols of the 'establishment' was evident from a description of King George V's visit to officially open a sanatorium at Llangwyfan, in July 1920, when the King noted that it was his first visit to Wales since the Archbishop's enthronement and he congratulated the Churchman, when he expressed the 'hope, that under Divine guidance, the work of the Church in Wales, shall result in manifold blessings upon my people', with the Archbishop of Wales offering 'a dedicatory prayer', and no mention of any other religious representatives being involved. ${ }^{64}$ The Archbishop also conducted the service of dedication of the North Wales Heroes' Memorial Archway in Bangor, in November 1923, during a tour by the Prince of Wales ${ }^{65}$, who was to lunch with the Archbishop the following day. ${ }^{66}$ This symbolism has been vitally important in maintaining the status of the re-established Church. The Church would, to any observer, appear unaltered by disestablishment and that immutability was evident, despite the new constitution:

'In that the government of the Church, through the Governing Body of the Church in Wales, still appeared to lie in the hands of Bishops, senior clergy and titled and privileged people, many felt that things were really not any different'. The 'occasional attenders' at church still recognised a parochial system, an accessible parson, an overall reflection of the 'established Church' (in many places so close by) and the continuation of the status quo’.67

A confirmation of this perception of the Church in Wales was outlined by Lord Williams of Elvel $^{68}$, the current Archbishop of Canterbury’s stepfather, when, during a debate about the case for 'constitutional separation of the powers between Church and State throughout the United Kingdom', he said:

\footnotetext{
62 'The Queen Speaking’, South Wales Daily News, 24 August 1889, p.3. It was reported that: Her Majesty astonished her Welsh subjects to-day by speaking in Welsh', when she stated 'Diolch yn vawr iawn i chwi' (sic) upon receiving a gift of a walking stick.

${ }^{63}$ Edwards, Memories, pp.125-128. In his reminiscences, the Archbishop records that, in response to a query from the Queen, he confirmed that the Welsh were 'more quiet and contented now', but then his memoir then continued with a description of the 'grim and minatory' tithe war.

64 'King and Queen in North Wales. The War Against Consumption', The Times, 17 July 1920, p.14.

65 'The Prince in Wales. Busy Day at Bangor. Opening of Heroes’ War Memorial', The Times, 2 November 1923, p.9.

66 'The Prince’s Tour Ended. Farewell Message to Wales’, The Times, 3 November 1923, p.9.

${ }^{67}$ Winston, J., 'The Church of England and the Church in Wales. Two Radically Different Churches?', in Living Authority (Penarth, 1990), ed. by A. Willie, p.180.

${ }^{68}$ Charles Cuthbert Powell Williams, Baron Williams of Elvel, (born 1933), retired businessman and Labour peer.
} 
'Personally, I am fortunate in that I sit astride, as it were, two religious horses. I am a practising member of the Church of England, when I am in England, and of the Church in Wales, when I am in Wales. To be honest, as an ordinary man in the pew, if I may put it that way, I confess that I find very little difference between the two-the one established and the other disestablished' ${ }^{69}$

A disturbing aspect of this intervention is that it appeared to demonstrate a significant dearth of knowledge about how Welsh disestablishment came about, because, in his desire to alert his Lordships about the 'legislative implications' of any move to disestablish the Church of England, he warned: 'that it took Lloyd George seven years - admittedly, with the interruption of the First World War - to disestablish the Welsh Church, which he wished to do, so we are told, because he disliked the Welsh bishops of the day'. His Lordship’s observations, particularly as a successful biographer ${ }^{70}$, were worrying in two respects: firstly, that the 'seven years', which he incorrectly calculated, was actually the period after the Welsh Church Act became law, and that the 'legislative implications', with which he was concerned, would have been more accurately described as encompassing half a century. As written elsewhere, it is reasonable to surmise that most commentators would find such a timespan difficult to comprehend or would wish to eschew the questions that would arise from such a hiatus. Secondly, his comment about Lloyd George and the Welsh bishops demonstrated no cognizance of Lloyd George’s long-standing friendship with Bishop Edwards ${ }^{71}$ or, indeed, the convoluted causes of disestablishment, which he bizarrely appeared dismissed with an attribution to the whim of Lloyd George. ${ }^{72}$ Lord Williams’s observations demonstrate how a significant misunderstanding of Welsh disestablishment has developed and, also, importantly, how the history of disestablishment has become tainted by direct association with the manner in which many still perceive Lloyd George's personal reputation. ${ }^{73}$ At the time of the Archbishop's enthronement in 1920, Lloyd George's reputation was still in the ascendency and as reported elsewhere, the newly enthroned Archbishop of Wales

\footnotetext{
${ }^{69}$ HL Deb. 22, May 2002, vol.635, cc.769 - 816.

${ }^{70}$ Writing as Charles Williams, he had produced biographies of General De Gaulle, Chancellor Adenauer, Marshal Pétain, which won the Elizabeth Longford Prize for Historical Biography, and Harold Macmillan.

71 'Origins of Welsh Investiture. Mr. Lloyd George’s Part', The Times, 14 August 1923, p. 11: Lloyd George confirmed that: 'Our friendship began in 1904', during the 'white heat of the educational controversy' and 'Mr. Lloyd George said that the Archbishop and he had fought many battles, each doing his best for his cause; but during all these years they were personal friends and there was nothing he was prouder of than that he had won and retained the friendship of the Archbishop of Wales'.

${ }^{72}$ Edwards, Memories, p.317.

${ }^{73}$ Kenneth O. Morgan, 'Lloyd George and the Historians', Transactions of the Honourable Society of Cymmrodorion (1972), pp.65-85, in which Kenneth Morgan charts the way historians have dealt with Lloyd George, with many commentators traducing his reputation.
} 
was to refer to his belief that Lloyd George had 'saved the Empire', thereby saving Europe and indeed civilisation. ${ }^{74}$

Lord Williams was not alone in his lack of appreciation of the trauma of the bellicosity that led preceded Welsh disestablishment and in a review of the contemporary Church of England in 2012, an editorial in the Ecclesiastical Law Society, stated that;

'To some extent the path towards disestablishment is well trodden. A Parliamentary dry run took place with the passing of the Welsh Church Act 1914, which with disarming simplicity unpicked each of the indicia of establishment within the Principality'. ${ }^{75}$

The author appeared almost embarrassed by the requirement for this 'short Celtic excursus' and explained that it was solely intended to demonstrate 'the relative ease with which disestablishment can be secured if the legislature deems it politically expedient' ${ }^{76}$ If Welsh disestablishment was being examined as a template for English disestablishment, then it should have recognised the litany of attempts to achieve disestablishment in Wales and the final, desperate scramble to get across the legislature line, oozing political compromise and equivocation, utilising the fortuitous, but essential, occurrence of constitutional change in Parliament and leaving both sides with cause for dissatisfaction and lasting resentment.

Writing in 1919, the Bishop of St. Asaph struck an optimistic note with regard to the future of the Church, although his effusion might have been influenced by a post-war euphoria, immediately following the Armistice, as he anticipated that both society and the role of the Church must be transformed: 'The door of spiritual opportunity was being flung wide open to them in Wales. They had had their troubles in the past, and those troubles had been swept away. The war had been like a mighty flood it had swept away many barriers and class distinctions; it had changed the whole feeling between what they called Church and Nonconformity. ${ }^{77}$ It would appear that the 'mighty flood' might not have 'swept away' all of the 'barriers and class distinctions', as the social background of the Church's governing body was, at least until the 1930s, indicative of the traditional class system, in addition to an Anglicised pedigree:

\footnotetext{
74 'Welsh Archbishop Enthroned. A Notable Ceremony. The New Order in Wales', The Times, 2 June 1920, p.13.

${ }^{75}$ Mark Hill, 'Editorial. The Church and the State We're In’, Ecclesiastical Law Journal, 14 (2012), p.161-162.

76 Ibid., p.162.

77 ‘St. Asaph Diocesan Conference. Bishop on Future of Welsh Church’ Y Llan, 5 December 1919, p.33.
} 
'Of the 36 lay members listed for 1930-1932, there were, from St. David's diocese, for example, two peers, one baronet and two knights, and it is doubtful whether any of them were conversant with Welsh. In other words, if one may generalise, the shadow of the Church of England, with all that implied, quite naturally hung over the official persona of the Church in Wales, and that persisted up to the fifties of this century'. ${ }^{78}$

Unfortunately, even the appointment of bishops to the disestablished Church was to continue to pose problems and as one commentator, albeit one who described himself as a 'Welsh

Nationalist Priest', indicated in 1929, that nothing had apparently changed:

'With the passing of the Disestablishment and Disendowment Act, and the securing thereby of a complete measure of self-government for the Church in Wales, one had hoped that the manoeuvring and intriguing that often characterised and blurred the appointments to a Welsh Bishopric by the Prime Minister of England ceased to exist'. ${ }^{79}$

\section{A. J. Edwards, in his biography of Archbishop Green, quoted Canon D. Parry-Jones’s} observation about the Church's governing body and the fact that 'one looked in vain for the man with blue veins in his hands and face', albeit that he added that it 'was not short of blue blood', for the 1935 Governing Body had consisted of:

'at least six barons, ten baronets, five knights, eleven titled ladies, three sons of peers, two generals, one vice-admiral, one brigadier-general and sixteen colonels, not to mention majors and captains' ${ }^{80}$

The Welsh Church may have legally departed the Establishment, but the representatives of that Establishment were now firmly ensconced in the new body and therefore it was difficult to imagine how a change of outlook could realistically been anticipated. But it was not only the laymen who appeared to have represented an upper class, or at least exhibit those characteristics that were attributed to the pre-established Church. Archbishop Glyn Simon provided a graphic description of the then Bishop of Bangor, C. A. H. Green, who was to be the second Archbishop of Wales ${ }^{81}$, and who was: 'Driven in a red and silver Rolls Royce with a chauffeur in livery' when he would descend upon remote parishes, 'like some visitor from another world' ${ }^{82}$ The

\footnotetext{
78 'Beuno', 'A Leader for the Seventies? (A Comment on our 6 $6^{\text {th }}$ Archbishop)', Impact, Church in Wales Publications, vol.1, no.4 (1970), p.3.

79 'Episcopal Appointments in Wales', by a Welsh Nationalist Priest, Welsh Outlook, vol.16 (Jan. 1929), p.14.

${ }^{80}$ A. J. Edwards, Archbishop Green. His Life and Opinions (Gomer, 1986), p.87.

${ }^{81}$ Charles Alfred Howell Green, (1864-1944), was elected Bishop of Bangor in 1928 and Archbishop of Wales in 1934. He had married, in 1899, the daughter of Sir William Thomas Lewis, later Baron Merthyr, coal magnate. 82 Jones, Owain W., Glyn Simon. His Life and Opinions, pp.25-26.
} 
attribution of 'alien' to the Anglican Church in Wales had assumed a slightly different connotation.

\section{How disestablishment was described by the Church.}

Writing on the verge of disestablishment, leading Welsh lay Anglican, Frank Morgan, like the Archbishop of York in November 1919, felt that it was pertinent to utilize military metaphors when he sought to describe what Welsh Church men thought of the impending state of affairs. He acknowledged that it was not 'an easy question to answer' and, after confirming that they were facing 'the future with a quiet optimism', he adopted the bellicose analogy of an army steeled in the heat of battle, although he diplomatically emphasised that the army's eventual defeat was no reflection upon their 'trusted leaders':

'They feel that for many years they have been in the forefront of the battle against the assailers of the Church, and as they think, perhaps wrongly, against religion. They have been defeated, but are proud of having defended so hotly attacked a position so long and so stoutly and, like other comrades in arms, they have learnt to trust one another and to follow trusted leaders, and are now prepared to turn with fresh energy to the Church's real fight against the forces of religious indifference, of materialism and of anarchic selfishness'. ${ }^{83}$

It was unclear what Frank Morgan intended to portray by his reference to 'the Church's real fight', although an assumption must be drawn that the 'fight' with which it had been consumed for the last half-century was of some lesser significance, albeit that it had been a fight in which he had, personally, been actively committed, ever since the 1906 Royal Commission. A similarly combative approach was taken by the author of the text which accompanied a film strip produced by the Llandaff Diocesan Council for Religious Education, where the introduction stated that Anglicans in the early 1900s:

'went down fighting, and the church that was disestablished despite itself was, because of that fight, stronger, more united than ever before in Welsh History, with a clear sense of mission and that strength of principle which comes to those who believe that they are fighting in a righteous cause'. ${ }^{84}$

\footnotetext{
${ }^{83}$ Frank Morgan, Secretary to the Representative Body of the Church in Wales, 'The Church in Wales', Welsh Outlook (March 1920), vol.7, no.3, p.55.

${ }^{84}$ Chrystal Tilney, 'The Church in Wales. The Disestablishment Conflict', Film Strip Script, Visual Aids Committee of the Llandaff Diocesan Council for Religious Education, introduction, 1969.
} 
The fact that the script was produced, in 1969, for 'religious education', with the content demonstrating an unstinting bias, is an example of how the Welsh Anglican remembrance of disestablishment has been sustained since 1920. The film strip contains photographs of demonstrations by Church people, protesting against disestablishment, at Aberdare and at the Albert Hall, London, with accompanying posters, but with no sign of the massive demonstrations in favour. This recurring theme, of the Church's survival, in the face of adversity, is a thread which has worked its way until the present, as indicated by the former Archbishop of Wales's presidential address to the Church's governing body in $2010^{85}$, when, incongruously, in the context of the Church's troubled relationship with bilingualism, as described below, he quoted from Dafydd Iwan’s ballad, Rydym yma o hyd (we are still here). ${ }^{86}$

\section{Symbolism.}

The Church in Wales has been variously described as 're-established" ${ }^{87}$, being a body that 'retains many of the characteristics of an established church', as a disestablished Establishment, ${ }^{88}$ 'post-established', 89 or occupying an 'intermediate position between an established church and one which has never been established'. ${ }^{90}$ Prior to implementation in 1920, it was already apparent that any suggestion that the Church in Wales was to be simply disestablished was erroneous. Although described as a disestablished church, it is evident from numerous sources that this description is misleading and, according to Professor Norman Doe, 'technically' not the case. ${ }^{91}$ He cites the effect of the Welsh Church Act 1914 as creating 'the partial disestablishment of the Church of England' ${ }^{92}$ In effect, the Church's role and status would be assessed by how it was perceived and therefore symbolism was to be crucial, to buttress its claim to: 'unique legitimacy inasmuch as, like its sister-church in England, it claims

\footnotetext{
${ }^{85}$ Dr. Barry Morgan, the Archbishop of Wales, Presidential Address - Governing Body, April 2010.

${ }^{86}$ E. Wyn James, 'Painting the world green: Dafydd Iwan and the Welsh protest ballad', Folk Music Journal, vol.8, no.5 (2005), pp.594-618. The song was written in 1983 at the request of the 'pioneer Welsh nationalist Member of Parliament, Gwynfor Evans (1912-2005).

${ }^{87}$ Norman Doe, 'The Church in Wales and the State: A Juridical Perspective', Journal of Anglican Studies, vol.2, issue 1, (June 2004), p.107.

${ }^{88}$ Simon J. Taylor, 'Disestablished Establishment: High and Earthed Establishment in the Church in Wales', Journal of Contemporary Religion, vol.18, no.2 (2003), p.227.

${ }^{89}$ Harris and Startup, The Sociology of a Traditional Institution, p.11.

${ }^{90}$ Nicholas Roberts, 'The Historical Background to the Marriage (Wales) Act 2010', Ecclesiastical Law Journal, 13 (2011), p.39.

${ }^{91}$ Norman Doe, 'The Church in Wales and the State: A Juridical Perspective', Journal of Anglican Studies, vol.2, issue 1 (June 2004), p.106.

${ }^{92}$ Ibid., p.107.
} 
to be the historic Christian Church in its named territory', and 'its structure and the assumptions that underpin it are still those of an established church in a Christian society'. ${ }^{93}$

One of the most enduring and apparent symbols of the Church's continuing prominence is the stock of significant historic buildings utilized for both periodic religious services and to host national events of commemoration or celebration and, as John Davies observed: 'Indeed, as they retained possession of the parish churches and cathedrals, they continued to look like an Establishment - and to a considerable extent be treated like one'. ${ }^{94}$ This would explain why the proposal, in the 1894 Welsh Disestablishment Bill, to transfer the Welsh cathedrals to the Commissioners, caused such a commotion, with the Spectator leading the riposte. The journal suggested that the intended legislation could eventually be employed to utilize the cathedrals for secular purposes and, to the journal's horror, that they could be utilised as a venue for the Eisteddfod:

'Then the arrangement which takes away the Cathedrals from the Church in Wales, and hands them over as national monuments to Commissioners who may be compelled at any time to give them up for secular purposes, - though that, apparently, is not the immediate intention of the Government, - seems to us almost an outrage on the historic conscience of the people. Cathedrals will hardly remain historical monuments at all unless they are dedicated to the same worship for which they were built. To give them up to Eisteddfodds (sic), as we see is proposed by the socialistic party, would as surely desecrate them as to use them for the purposes of amusement or of political agitation'.95

Speaking in the House of Commons, on 1 May 1894, Mr. Asquith, as Home Secretary, sought to assuage those concerns, when he said that: "there is no intention to interfere with the use of the cathedrals, and so long as the Church body so desires they will continue to be applied to their present purpose, and to no other'. ${ }^{96}$ On 1 June 1920, one of those historic and commanding buildings, St. Asaph Cathedral, was to be the scene of an event which simultaneously demonstrated the arrival of the 'new', being the enthronement of the first Archbishop of Wales, but it also brought that ceremony safely into the fold of the existing Establishment. ${ }^{97}$ When he toasted the newly enthroned Archbishop of Wales, A.G. Edwards, on 1 June 1920, Prime

\footnotetext{
${ }^{93}$ Harris and Startup, The Church in Wales. The Sociology of a Traditional Institution, p.4 and pp.169-170.

94 John Davies, A History of Wales (London: Penguin Press, 1993), p.539.

95 'The Welsh Disestablishment Bill', The Spectator, 28 April 1894, p. 22.

96 'The Welsh Disestablishment Bill’, HC Deb. 1 May 1894, vol. 24, c.44.

${ }^{97}$ Henry Fairlie, 'Political Commentary', The Spectator, 23 September 1955. Fairlie was attributed with the invention of the term to describe 'the whole matrix of official and social relations with which power is exercised'.
} 
Minister, David Lloyd George, considered that Welsh disestablishment was: 'Now ended, not by victory but by appeasement'. ${ }^{98}$ Of course, the word 'appeasement' has now assumed negative connotations, due to its association with British foreign policy vis-à-vis Germany during the 1930s but, as described in the Archbishop’s ‘volume of reminiscences', it was here associated with concord. In the case of Welsh disestablishment, it is posited that it would depend very much upon the viewpoint of the commentator, although the overriding impression is that the form of Welsh disestablishment derived from weakness and apathy.

\section{A celebration of 'defeat'?}

One of the many paradoxes associated with Welsh disestablishment was that the commander in chief of the 'losing' side, should be promoted to be Primate of the very institution whose creation he had consistently and energetically opposed. The enthronement at St. Asaph Cathedral provided no clue of that struggle, in terms of ceremony, attendees or formalities and a six-minute silent newsreel ${ }^{99}$ appeared to depict an event which was something between an Easter parade and a Society garden party, with the fine early summer weather a bonus. Although the Archbishop was clearly of the view that the unthinkable had taken place, he appreciated that the ceremony of the enthronement of the first Archbishop of Wales proclaimed that, despite the fact that the Church was redefined by statute, it maintained a distinct place in the 'establishment'. ${ }^{100}$ The setting and the presence of the official representatives of the state ensured that nobody could mistake the fact that the event was an attempt to confirm the status of the Welsh Anglican Church was far removed from any suggestion that it had segued into another Welsh denomination. According to Archbishop Green, 'the further act of the Archbishop of Canterbury, at the invitation of the Welsh Bishops, in enthroning the first Archbishop of Wale, further signified that there was no breach of ecclesiastical usage and unity'. ${ }^{101}$ It was apparent that this was a celebration which appeared to confirm, not disavow, the status of the Welsh Anglican Church. It was a State occasion, with those representatives of the Establishment present, in order to witness and underwrite the standing of the Church. Although Lloyd George did describe it as

\footnotetext{
${ }^{98}$ Edwards, Memories, p.325.

${ }^{99}$ National Screen and Sound Archive of Wales, 'Scenes at the Enthronement of the First Archbishop of Wales, at St. Asaph, June $1^{\text {st }}, 1920$ '.

${ }^{100}$ Edwards, Landmarks in the History of the Welsh Church, p.252, where the then Bishop wrote that: 'How far has Parliament the right to rend or mutilate this Church which has come down the centuries woven without seam throughout its whole structure?'

${ }^{101}$ Green, The setting of the Constitution of the Church in Wales, London, p.210.
} 
'a Welsh festival' ${ }^{102}$, its features and ceremony appeared to seek to consolidate the Church's preeminent position and confirm that the Church might be disestablished, but it still bore the characteristics of an institution which continued to be a state church.

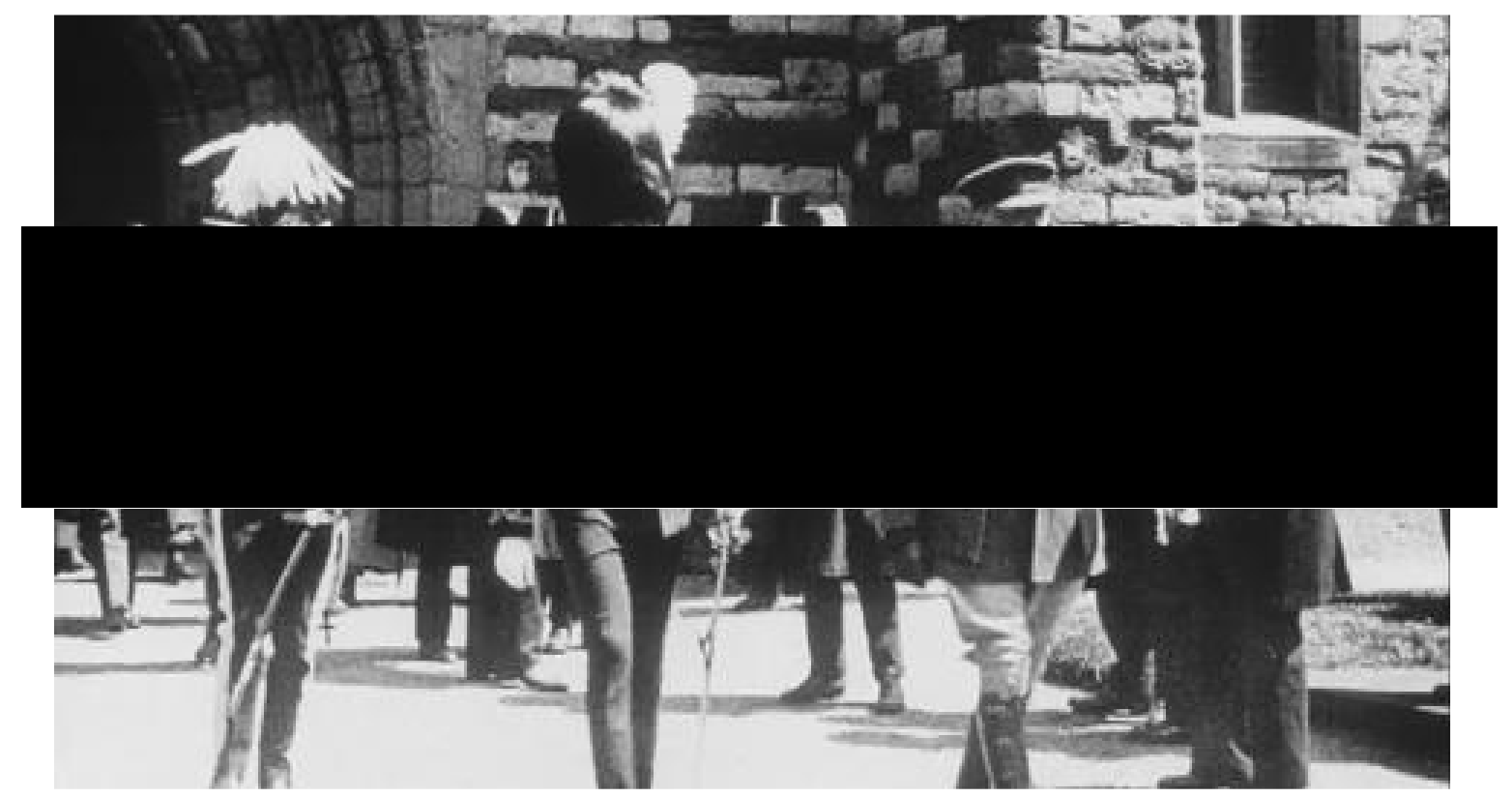

A still taken from the silent film of the Enthronement of the Archbishop of Wales in 1920, with the Prince Arthur, the Duke of Connaught and Strathearn, the third son of Queen Victoria, leaving St. Asaph Cathedral.

This was something which nobody could misconstrue and any mildly curious passer-by, standing in St. Asaph’s High Street, bedecked with Union flags, enjoying the spectacle of the passing procession of Archbishops, from Canterbury ${ }^{103}$, York and Dublin, numerous Bishops and attending clerics, all in their finest clerical garb, in the presence of Prince Arthur of Connaught $^{104}$, the Prime Minister, David Lloyd George, the Lord Lieutenant, Henry Gladstone $^{105}$, and local gentry. The presence, in his official capacity, of William Gladstone’s son, who had married Stuart Rendel's daughter, provided an unintended historical symmetry. No observer would have been alerted to the fact that anything substantive had changed. This portrayal of disestablishment as a victory, rather than as a setback, was confirmed by the

\footnotetext{
102 'Welsh Archbishop Enthroned. A Notable Ceremony', The Times, 2 June 1920, p.13.

103 Archbishop Randall Davidson, (1848-1930).

104 Prince Arthur, Duke of Connaught and Strathearn, (1850-19420, was the seventh child and third son of Queen Victoria and cousin of King George V.

${ }^{105}$ Henry Gladstone, $1^{\text {st }}$ Baron Gladstone of Hawarden, (1852-1935), was the third son of Prime Minister, W. E. Gladstone.
} 
Staniforth ${ }^{106}$ cartoon which appeared in the Western Mail on 10 April 1920, entitled 'God Speed'. It portrayed Archbishop A.G. Edwards, riding forth in apparent triumph, through a fortified castle gate, clad in armour, with lance in hand, adorned with a pennant bearing the words 'Welsh National Church', sitting on a magnificent charger.

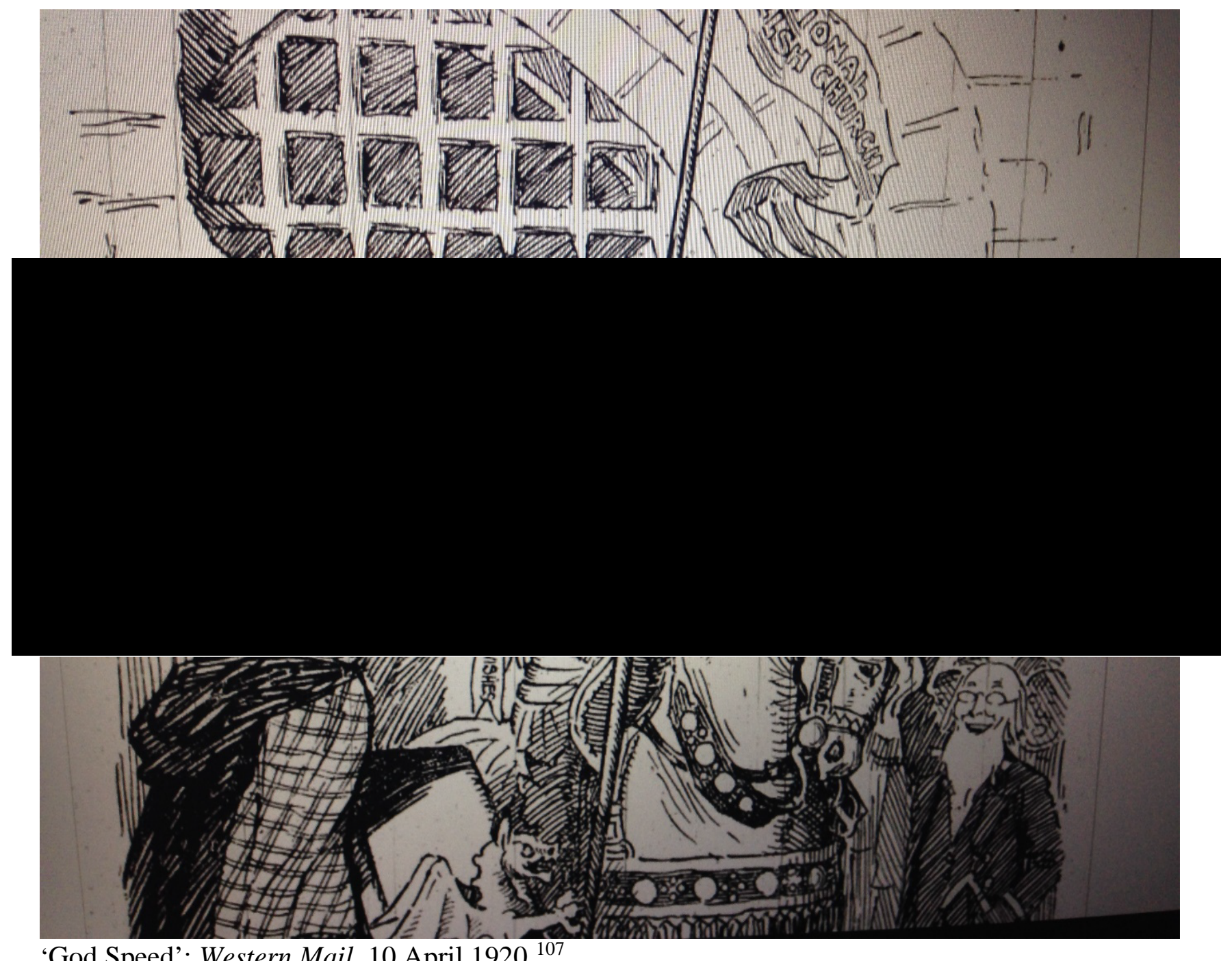

'God Speed': Western Mail, 10 April 1920. ${ }^{107}$

106 Joseph Morewood Staniforth, (1863-1921), cartoonist.

107 Staniforth based his cartoon upon God Speed, a painting by British artist Edmund Leighton, which depicts an armoured knight leaving for war, with his beloved bidding him farewell. The painting was exhibited in the Royal Academy in 1900. Staniforth recreated that same painting on two other occasions. On 25 May 1915, his cartoon is closely aligned with the original painting and the knight, with the words 'Welsh contingent' attached to his cloak, is riding to France as part of Kitchener's Army, with his love tying a ribbon to his arm, as a sign that they would be reunited. The painting was utilised on the last occasion on 18 February 1921, at the time of the Cardigan by-election, with Lloyd George's former secretary, Ernest Evans, the Coalition Liberal candidate, portrayed as the knight with his banner depicting Lloyd George’s face, and streamers noting; 'coalition' and 'Reconstruction'. He rides towards the 'tilting yard' and it was to become a bitter contest, with the Liberal Party split and William Llewelyn Williams, who had held the Carmarthen boroughs seat until it was abolished in 1918, selected to stand as the Independent Liberal candidate. 
A beaming Mam Cymru stands to one side, holding a suitable tribute, a horn with streamers bearing the words, 'best wishes' and 'love', and the bearded, formally dressed figure, which Staniforth always used to represent Nonconformity, cheering on the resplendent Bishop, with hat raised above his head and, atypically for a Staniforth cartoon, he bears a broad smile on his face. The expression on the Bishop was serious and suitably noble, but slightly scornful, although he appears to observe Mam Cymru's proffered gift, with labels entitled 'love' and 'best wishes', with some wariness. As somebody who had supported attempts to frustrate disestablishment, Staniforth was now clearly sufficiently cognizant of the Church's new status to depict it as a victory and there was nothing humble about the drawing of the new Archbishop as a triumphant paladin, with Nonconformity and Mam Cymru standing in the mud, little more than witnesses to his transformation from battling bishop to victorious Archbishop. an event which the holder of that newly created office was to proudly acclaim: 'was an event without precedent in Wales and without record of a similar ceremony in the two English Provinces' ${ }^{108}$ The cartoon's content is in marked contrast to that which Staniforth drew in 1914, and which is included later in this chapter, when the Church was represented as a stag being brought down by Nonconformist wolves, with each wolf etched with a deleterious reason for disestablishment. ${ }^{109}$

It was apparent that the Reverend Maurice Jones ${ }^{110}$ was also conscious of both the historical and symbolic significance of the events at St. Asaph Cathedral on 1 June 1920, but he was aware that this could only give rise to 'possibilities', which would require action:

'The new and Welsh orientation of the Church's aim and sympathies, fore-shadowed in the formation of the Province and the election of the Archbishop, cannot fail to exercise a profound influence upon the attitude towards it of the nation in mass, and it may possibly prove to be the primary step in a process which shall, at no great distance of time, transform the Church in Wales into the Church of Wales in the most complete sense of that term'.

A newspaper report of a meeting of the governing body of the Welsh Church, in 1920, would have intimated to the newly appointed Archbishop of Wales that symbolism could also have

\footnotetext{
${ }^{108}$ Edwards, Memories, p.321.

109 'Nearing the End of the Struggle': Western Mail, 18 May 1914.

${ }^{110}$ Maurice Jones. (1863-1957), priest. He served as chaplain to the Forces 1890 to 1916, Principal of St. David’s College, Lampeter 1923 to 1938.member of the Gorsedd of Bards, with bardic name of Meurig Prysor.
} 
unwelcome consequences when, in response to the appeal for a million pounds to place the Welsh Church on a sound financial basis, only approximately $£ 480,000$ had been received and the Archbishop had emphasized that the response from England 'had been very much less than had been hoped'. ${ }^{111}$ The then Bishop of St. Asaph had confidently anticipated that 'England would see it right, as Wales held the post against a bigger onslaught, on the English Church'. 112 But the newspaper reported that he 'did not allude to one reason which has hindered many English parishes from sending their aid'. It appeared that the admission to Communion of the Prime Minister and his wife, on the day of the Archbishop’s enthronement, and:

'the secrecy which has been observed as to the responsibility for that admissionwhether the Archbishop of Wales or the Archbishop of Canterbury was responsible has not yet been made clear - has alienated English sympathy to an extent which Welsh Churchmen have not yet realized, and has moreover made the position of loyal Welsh Churchmen most difficult at the very outset of their life in the new province. The sense of the meeting was clearly that Wales herself must be self-reliant and provide her own funds without overmuch reckoning upon the compassion of English Churchmen'. ${ }^{113}$

The Archbishop of Canterbury wrote that: 'To our surprise he (Lloyd George) and his wife appeared at the Early Service', therefore it was apparent that he had no foreknowledge, but he was relaxed about the affair 'which created a teapot storm in ecclesiastical circles of the Church Times sort'. ${ }^{114}$ The surprising element is that it would appear that this was not the first occasion and that, although unspecific about the precise date, but sometime in 1903, William George wrote that his brother 'had been spending a weekend with the Bishop of St. Asaph, and on Sunday morning he attended service and received Holy Communion at the Bishop’s hands’. ${ }^{115}$

The Bishop of St. David’s was, however, to adopt a jaundiced view of the Enthronement, describing it as a 'festival of National Sentiment' and that 'sentiment was given rather too central a place'. He recognised that it was 'natural' to invite Mr. Lloyd George to the event, as he was 'the most sentimental of Welshmen' ${ }^{116}$ Bishop Owen’s long-standing animus to the Prime

\footnotetext{
111 'Welsh Church Appeal for £1,000,000', The Times, 8 January 1920, p.11. It was reported that the Welsh Church Governing Body decided 'to make an appeal for $£ 1,000,000$, to take the place of the $£ 48,000$ annually lost to the church by the new Act'.

112 Ibid.

113 'The Church in Wales. Session of the Governing Body', The Church Times, 15 October 1920, p.345.

${ }^{114}$ Bell, Randall Davidson, Archbishop of Canterbury, volume 1, p.990.

${ }^{115}$ George, My Brother and I, p.169.

${ }^{116}$ Owen, The Later Life of Bishop Owen, pp.441-442.
} 
Minister was to drive him into being 'very much out of sorts' and in a state of nervous collapse', due to Lloyd George’s decision to take Communion. Although the Bishop advised Frank Morgan that the matter should be treated as 'altogether exceptional' and that his 'nervous collapse resulted from a fear that Lloyd George's seeking Communion would 'strain the unity of the Church'. ${ }^{117}$ His daughter's biography makes it abundantly clear that the relationship between the Bishop and his Archbishop were strained and that it was suggested that the Bishop had advised against the Prime Minister being invited to the Enthronement because he knew that 'there would be trouble of some sort'. ${ }^{118}$ It was extraordinary that the Bishop had allowed his enmity to override what surely would have been an extraordinary breach of protocol, if the country's Prime Minister had not been invited.

Whether or not Mr. and Mrs. Lloyd George taking Communion had been sufficient to deter potential English donations appeared very unlikely and probably A. G. Edwards was more accurate in his disillusioned realisation that Welsh disestablishment simply did not garner English 'public interest and attention', although he did endeavour to warn readers of The Times of the significance. ${ }^{119}$ Even that doughty defender of the Established Church, Lord Robert Cecil, had apparently moved on and, in a Francis Fukuyama/End of History-type' review of the postwar political landscape situation in Britain, which was subsequently published in The Times, he wrote that; 'None of the old crucial questions can now be so described. The Welsh Church has gone, and at present there is no question at issue about the English Church’. ${ }^{120}$ It is certain that he knew that the re-established Church was evidence that the 'Welsh Church' had not 'gone' very far, but his words probably reflect the frustration associated with the failure to defeat the campaign, combined with a genuine malaise in that post-war world. A relatively minor incident which drew attention to a 'strange lack of historical perspective' at the enthronement was the decision by the Archbishop of Canterbury to present the Archbishop of Wales with a throne, which is still in use, whose design was based upon St. Augustine’s Chair at Canterbury. ${ }^{121}$ After

\footnotetext{
117 Ibid., p.442.

118 Ibid.

119 'The Church in Wales. Facing the Future', letter to the editor, The Times, 31 March 1920.

${ }^{120}$ Lord Robert Cecil, 'Reaction and Revolution', The Times, 22 April 1922, p.18. Lord Cecil derived significant political change, following the trauma of Great War. Francis Fukuyama was to argue, in his 1989 article, that the end of the Cold War would, due to the ascendency of Western-style liberal democracy and free market capitalism, signaled: 'The End of History', being the title of article in The National Interest, no.16 (Summer 1989), pp.3-18.

121“Cambrensis”, 'The Welsh Church', The Church Times, 16 April 1920, p.395.
} 
a brief synopsis of the relevant history, 'Cambrensis' ended a letter of complaint with a statement that: 'The Welsh Church has little cause to be grateful to Canterbury'. It is of note that Archbishop Edwards himself was clearly aware of the unfortunate connotations associated with the new archiepiscopal throne because, when he described the new Church in Wales, he was careful to note that it was 'as independent as she was before Augustine came, or before the Norman Conquerors extorted from her reluctant submissions'. ${ }^{122}$ In reality, based upon the new Archbishop's perception that the Church of England was the 'National Church', it was probably quite fitting, with the Welsh Archbishop forever to be perched on a replica of the throne of an English Archbishop.

The Archbishop was to ensure that the Church continued to be to the forefront in the commemoration of the Great War and, in this, he was to establish a precedent which imitated what Norman Bonney had concluded about the Church of England: 'In some respects, the state role of the Church of England has grown substantially in the course of the last 90 years or so in connection with its core role in the annual national November remembrance service for 'The Glorious Dead' of war at the Cenotaph in Whitehall'. ${ }^{123}$ The Bishop of St. David's was the sole Welsh religious leader at a wreath-laying ceremony at the grave of the Unknown Soldier at Westminster Abbey, where a small group, including Lloyd George were present. ${ }^{124}$ The event took place the day before the annual Cenotaph Ceremony and it is of note that the Church of England had almost been denied direct involvement in that annual remembrance, as the Archbishop of Canterbury noted in his diary when describing the unveiling of the Cenotaph monument on 11 November 1920. The Archbishop reported that there had been 'keen controversy' with the Prime Minister and the Cabinet about the ceremony at the Cenotaph, with Lloyd George seeking 'wholly secular’ proceedings', ‘alleging as reason that Mohammedans and Hindus were among those to whose memory it stood'. The Archbishop did not record his response to this argument, but he simply noted that he had 'prevailed' and 'there was unanimous expression of thankfulness that we had thus marked our Christian fellowship'. ${ }^{125}$ The annual Remembrance Sunday commemoration has provided, particularly with comprehensive media

\footnotetext{
122 Edwards, Memories, p.320.

123 Norman Bonney, 'Established Religion, Parliamentary Devolution and New State Religion in the UK', Parliamentary Affairs, (2013), 66, p.428.

124 'Armistice Day. Cenotaph Ceremony To-morrow', The Times, 10 November 1924, p.19.

125 Bell, Randall Davidson. Archbishop of Canterbury, Volume II, p.1037.
} 
coverage, a platform for the Established Church of England. But perhaps, more importantly, the Welsh Anglican Church has also benefited hugely, in terms of its 're-established' role, with, for example, contingents of the armed forces present at Remembrance services held at Welsh cathedrals every year. When Wales’s own National War Memorial, in Cardiff, was unveiled by the Prince of Wales in 1928, the dedication was performed by the Archbishop of Wales, with the Bishops of Swansea and Brecon and Llandaff offering with prayers. ${ }^{126}$

The suggestion that the Anglican Church continued to maintain an officially recognised role is reinforced by the continuing role of cathedrals and churches as places to commemorate the armed services, with wall memorials and the creation of Regimental Chapels, such as the Havard Chapel at Brecon Cathedral, which became the Regimental Chapel of the South Wales Borderers in 1922, and the construction of the Royal Welsh Chapel, as an integral part Llandaff Cathedral, in 1956. It is also the custom that the laid-up regimental colours should be held and displayed by the Welsh Church and, in 2015, the last Colours of the disbanded Royal Welch Fusiliers and the Royal Regiment of Wales were laid up at St. Giles Church, Wrexham and Llandaff Cathedral respectively. All of which associate and confirm that continuing traditional link between the Welsh Anglican Church and the State, albeit that the definition of that state, particularly postdevolution, is open to differing interpretations.

Referring to the opening of the Fourth Session of the Welsh Assembly, in June 2011, by the Monarch, Norman Bonney described one of the ways in which the Church in Wales had managed to suggest its continuing pre-eminence, post-1920, despite disestablishment and an increasingly secular society:

'Interestingly, too, a blessing was given at this event by the Archbishop of the disestablished Church of Wales - the Welsh sister province of the Church of England with which it is in communion. Through various devices such as these the Church of Wales seeks to assert its continuing symbolic eminence and primacy in the devolved state sphere in Wales. The disestablishment of this minority Anglican Church of Wales in 1920 was achieved after a decade long campaign ${ }^{127}$ against considerable resistance from the Church and the House of Lords, but the church has continued successfully, through its

\footnotetext{
126 'Welsh National War Memorial', The Times, 12 June 1928, p.13.

${ }^{127}$ Bonney’s reference to a 'decade long campaign' would affirm a lack of familiarity with the background to Welsh Disestablishment, as demonstrated by Lord Williams, which is not unusual among commentators. It would be magnanimous to suggest that many historians would perhaps find the actual duration of the campaign impossible to comprehend.
} 
previous position as the established state church in Wales, through the contemporary inter-faith movement, which its leader chairs in 2011, and by involvement in the changes associated with devolution, to maintain a quasi-official standing as the senior Christian church in Wales'. ${ }^{128}$

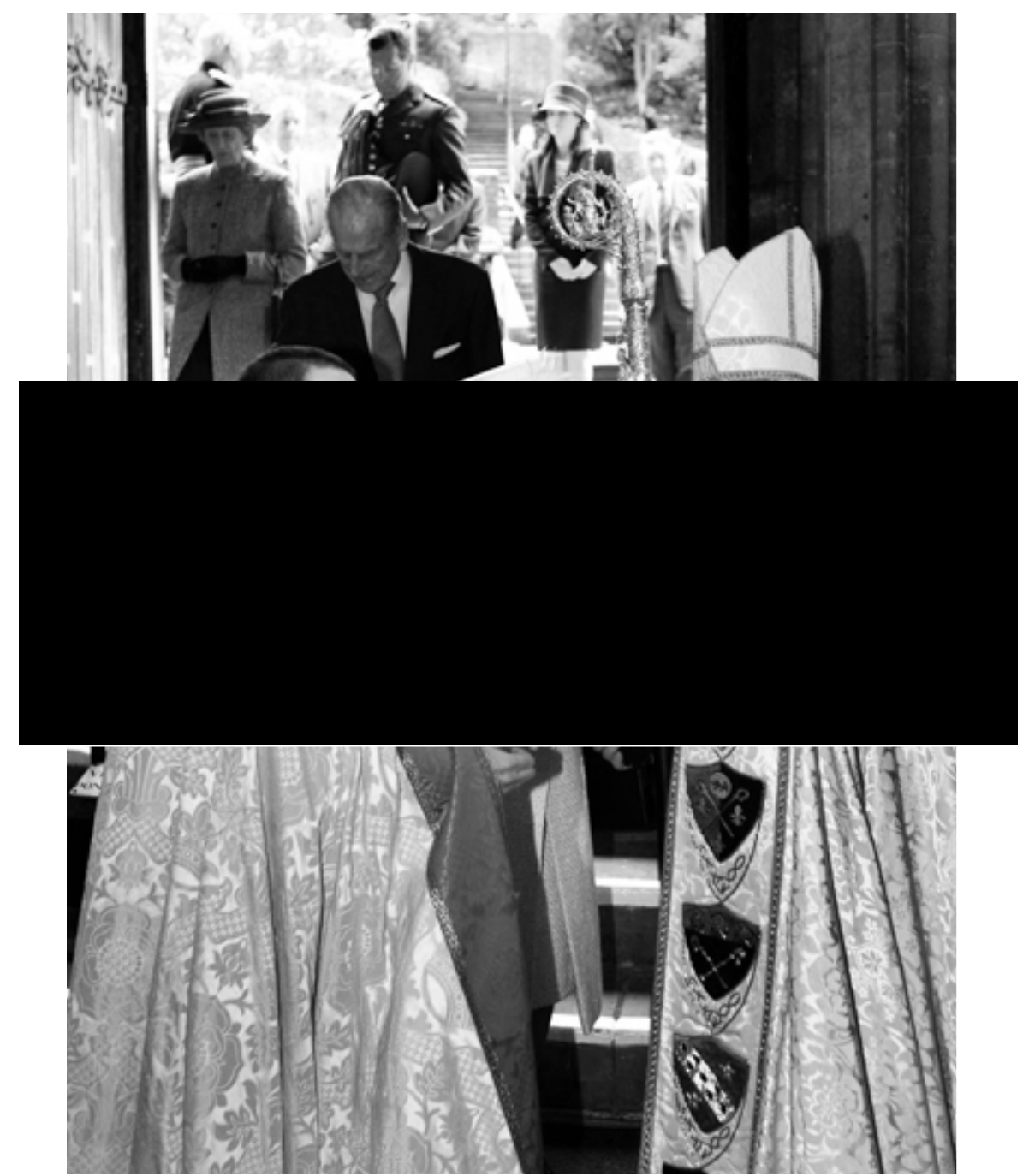

Dean John Lewis and the Archbishop of Wales greet Queen Elizabeth, as she enters Llandaff Cathedral for a Service to mark the Diamond Jubilee in April 2012.

The fact that it would have appeared apposite for the Monarch to attend a service of thanksgiving in respect of her Diamond Jubilee would continue to support Bonney’s depiction of the Church in Wales successfully maintaining a 'quasi-official' role, which appeared to confirm its role within the Establishment.

\footnotetext{
${ }^{128}$ Norman Bonney, 'Established Religion, Parliamentary Devolution and New State Religion in the UK', Parliamentary Affairs, Volume 66, Issue 2, 1 April 2013, Pages 425-442.
} 


\section{The Church in Wales.}

The name which the Church adopted was the consequence of a more prosaic process, being the proceedings of the Convention of the Church in Wales held in October $1917^{129}$, although this should not diminish the importance attached to the issue by the Churchmen gathered in Cardiff, with a discussion which ranged over the second and third days. There was general discontent with the title of 'Church in Wales' and, after 'Welsh Church' was dismissed as being 'an ethnical term', it was apparent that, apart from the Bishop of St. David’s, there was general support for the use of 'Church in Wales'. ${ }^{130}$ After a range of speeches, the amendment to change the name failed because Mr. Justice Sankey, who wanted to eventually achieve the title of 'The Church of Wales', but expressed the legal opinion that, initially, the Convention should utilise the name which appeared in the legislation. ${ }^{131}$ The Convention was left

with the understanding that the change in title would follow in due course and it was suggested to the:

'proposer and seconder and all Welsh Nationalists that we should agree to have it put on Record that this was withdrawn because of certain legal difficulties, so that at least we should go from here not defeated'. ${ }^{132}$

\section{Anniversaries.}

The various anniversaries of the date of disestablishment have always provided an opportunity for review and cogitation. A recurring theme, which can be traced back to 1920, has been that of the triumph of overcoming adversity. In 1930, the Archbishop of Wales wrote to The Times to welcome the fact that the Church Congress was about to meet in Wales, the first time for twenty years. He took the opportunity to again refer to the 'gains and losses' but was to dismiss disendowment with a pithy comment that: 'With the financial side of the question I am not now concerned', although he went on to describe:

'a certain risk, lest the Church in Wales, rightly and properly concerned with its own problems, should in some degree fail to keep in touch with the larger currents of life within the Church of England'. ${ }^{133}$

\footnotetext{
${ }^{129}$ Official Report of the Proceedings of the Convention of the Church in Wales, held at Cardiff, 2-5 October 1917.

${ }^{130}$ Ibid., p.126.

${ }^{131}$ Ibid., pp.140-147.

132 Ibid., p.147.

133 A.G. Cambr. 'The Church in Wales', letter to the editor, The Times, 15 September 1930, p.13.
} 
His concern was that the Welsh Church would become 'provincial in outlook', which would lead to a 'serious intellectual and spiritual loss', which he believed would be apparent to the 'most patriotic of Welshmen'. The Archbishop then, however, adopted a more positive stance when, after admitting the Welsh Church had 'much to learn' from the Church of England, diffidently suggested that the English Church also had something to learn from the Welsh Church's experience. ${ }^{134}$ Trying to avoid any hint of hauteur, he suggested that if the English Church was ever to face disestablishment, the Welsh experience could be of 'utmost value in offering precedents for the solution of the many problems that will arise' and, on that basis, he encouraged English Churchmen to travel to the Congress, which was held in Newport. Although The Times was to assert that the Church Congress was viewed as an 'institution which has outlived its usefulness', it reserved its criticism for the fact that, despite meeting in Wales, and bearing in the Archbishop of Wales's words, there was 'from beginning to end' no mention of the Welsh Church, with its 'special experiences and problems', which the newspaper interpreted as a lost opportunity. ${ }^{135}$

Upon the twentieth anniversary, Canon W. H. Harries posited the question, 'What the Church in Wales has been doing', and although the Canon was even-handed about the nature of the disestablishment, he begins by restating the oft-quoted statement that: 'Disestablishment smashed the machinery and robbed the safe'. ${ }^{136}$ Five years earlier, the second Archbishop of Wales, C. A. H. Green, had in October 1935, suggested that all was well, but his biographer posited: 'that although the upheaval of disestablishment was being overcome but the Church, like the nation, faced greater problems ahead without realising it', such problems as secularism and the crisis of faith. ${ }^{137}$

Around the time of the fiftieth anniversary, when launching the Church in Wales magazine, Impact, in 1969, it was admitted that it was not 'an auspicious time to embark on a new Christian periodical', as the 'channels of communication between the Church and the secular world are

\footnotetext{
134 Ibid.

135 'The Church Congress', The Times, 7 October 1930, p.15.

${ }^{136}$ Harris, Canon W.H., 'Twenty Years of Disestablishment. What the Church in Wales has been doing', Western Mail, 1 April 1920, p.7.

${ }^{137}$ Edwards, Archbishop Green. His Life and Opinions, p.88.
} 
clogged and cloudy, and they are none too clear within the Church itself'. ${ }^{138}$ The issue reprinted some of the documents associated with disestablishment, including 'an extract from one of the very many polemical speeches delivered’ by Bishop John Owen. The magazine stated that it was 'reprinting some of the polemics with which the original separation was beggared', adding that it believed that its 'proper task' was to 'assess, rather than celebrate, to look to the future rather than the past'. ${ }^{139}$ It is instructive to understand the confused manner in which disestablishment was viewed, by a senior Welsh Churchman, when, also on the fiftieth anniversary of disestablishment, in a Church in Wales publication, the Bishop of St. David’s, John Richards, ${ }^{140}$ stated that:

'I would find it hard to deny that there was justice in the demand that the Welsh Church be disestablished, but that is not the same as saying that the Bill which fulfilled that demand was both just and fair, nor is it the same as saying that the disestablishment of the Church was an act of wisdom' ${ }^{141}$

This would tend to read as vacillation and perhaps is suggestive of the fact that Anglican emotions were still extant, fifty years after the event. Whilst acknowledging that disendowment was inevitable, the Bishop conceded that 'the final settlement was far more generous to the Church than was that of the 1914 Act'. He suggested that 'it may not have been altogether just, neither was it altogether unjust' and that 'in the circumstances, I think that we have cause for thankfulness rather than for complaint'. ${ }^{142}$ Unkind observers might ascribe to this statement the type of ill-defined, woolly, thinking that has often become associated with Anglican pronouncements.

On the seventieth anniversary of disestablishment, a history of the Welsh Church in the twentieth century was commissioned ${ }^{143}$ and, in its conclusion, the author posited a series of questions, including; had the Church taken full advantage of its unsought freedom? Did it still retain too many vestiges of its old privileged state? Was it isolated in Wales? Was it marginal to Welsh

\footnotetext{
138 'Viewpoint', Impact, Church in Wales Publications, vol.1, no.1 (1969), p.1.

139 'Viewpoint', Impact, Church in Wales Publications, vol.1, no.4 (1970), front cover.

140 John Richards, (1901-1990), Bishop of St. David’s 1956-1971).

141 John St. David’s, 'Disestablished and Disendowed', Impact, Church in Wales Publications, vol.1, no.4 (1970), p.7.

142 Ibid., p.7.

143 The Rev. D.T. Price, A History of the Church in Wales (Church in Wales Publications, 1990).
} 
society? ${ }^{144}$ The fact that it was felt necessary to advance those questions, in 1990, was in itself telling, as was the fact that the Reverend Price stated that: 'some members of the Church in Wales doubtless wish that their Church was still established' and 'they long to be in a Church of which the Queen is Governor ${ }^{145}$, and they would like to see their bishops in the House of Lords'. ${ }^{146}$ It would appear that the 'vestiges of establishment' ran to more than the recognition of ecclesiastical marriage and burial. ${ }^{147}$ The Reverend Price makes a valiant attempt to respond to the questions he posed and his comments are of a similar ilk to the position, in 1955, when Bishop J. C. Jones ${ }^{148}$ of Bangor was asked whether disestablishment had been a loss or a gain, and his caveated response was that 'on the whole, up to present, it has been a gain'. ${ }^{149}$ In terms of 'integration' the Reverend Price stated that: 'It must be said that there was little integration during the first quarter of a century of the Church's independent life', although he believed that that these years were a 'period when the essential foundations were laid' 150 for the integration of the Church into Welsh life. One leading Anglican suggested that it took from 1920 to 1982 for the Church to 'truly' become the 'Church in Wales', and that the years from 1983 have been a 'difficult period', due to increased secularization and 'internal strife over issues such as the ordination of women'. ${ }^{151}$ Following the election of Glyn Simon, as Archbishop of Wales in 1968, 'Beuno’ argued that evidence of the Anglicised pre-disestablishment Church was still

\footnotetext{
144 Ibid., p.48.

145 The Monarch retains the title of 'Supreme Governor' of the Church of England, although it has been argued that the Monarch, by one interpretation of constitutional law and precedent, has royal supremacy over all British churches; Jones, P., The Governance of the Church in Wales, Cardiff, 2000, p.68. Although, today, many probably share Queen Victoria's perception, when she referred to her position as 'Head' of the Church. Gladstone wrote to Asquith with a comment that 'the Queen's studies have not yet carried her out of the delusive belief that she is still by law the "head” of the Church of England': P. Magus, Gladstone. A Biography (London: John Murray, 1954), p.410. Clearly Victoria’s ‘delusion’ had irked Gladstone, who explained the position to Rendel, on 26 November 1893, that 'Her Majesty was quite wrong in her styling herself the Head of the Church of England' and that Queen Elizabeth 1 had taken the title of Supreme Governor of the Church: Hamer, The Personal Papers of Lord Rendel, p.101.

146 Ibid., p.49.

147 Thomas Glyn Watkin, 'Vestiges of Establishment. The Ecclesiastical and Canon Law of the Church in Wales', Ecclesiastical Law Journal, (1990), pp.110-115.

148 Bishop John Charles Jones, (1904-1956), Bishop of Bangor from 1949 to 1956.

${ }^{149}$ Edward Lewis, John Bangor. The People's Bishop (London, 1962), p.196.

150 The Reverend D.T.W. Price, A History of the Church in Wales in the Twentieth Century (Church in Wales Publications, 1990), p.23.

151 The Reverend Professor D.P. Davies, 'Welsh Anglicanism', Trivium, (2008), p.111: 'first, the work of the first four archbishops (Edwards to John Morgan, 1920-1957), a period of reconstruction, that is, becoming a Church, secondly, the three most significant archbishops, in my view, who succeeded one another (Morris to G. O. Williams, 1957-1982, the first men to hold the office whose ordination to the ministry came after 1920), the time when the Church truly became the Church in Wales, finally, the last five archbishops (Childs to the present, 1983 onwards), a difficult period when the Church has faced the full force of the external challenge of secularism and internal strife over issues such as the ordination of women to the priesthood'.
} 
evident in the 1950s, in 'the shadow of the Church of England' and he suggested, perhaps somewhat hopefully, that 'possibly the last manifestation' had been the election of Edwin Morris, as Archbishop of Wales, in 1957. In his 1962 booklet, which was intended as a 'Lent look at the Prayer Book', the then Bishop of Llandaff, Glyn Simon, suggested that the Book of Common Prayer was inimical to the suggestion that it could form a 'bond of unity of the Anglican Communion spreading throughout the world', because it is 'understood as practically the same thing as "English”, He then confirmed the colonial influence of the Anglican Church, when he provided an example which linked the then named Rhodesia ${ }^{152}$ and Wales:

'At Salisbury in Rhodesia for instance the Cathedral and its arrangements might have been lifted complete from some English city. At Bangor in North Wales where all the clergy speak Welsh as they enter and leave the Church, every effort is made to render Morning and Evening Prayer exactly as they would be sung in any English Cathedral'. ${ }^{153}$

This Englishness had been perceived as beneficial by at least one commentator, albeit an ordained member of the Church in Wales, who opined that this ensured that the 'Welsh' Anglican Church has, in these 'post-Christian' times: 'suffered less than the Free Churches, probably because it is a broad Church and, secondly, because its 'establishment' outlook enables it the more easily to accommodate itself to the prevailing social, political and cultural context. Developments like greater mobility and increasing Anglicization do no real harm to the Anglican Church with its perceived English orientation and its well-established parochial network' ${ }^{154}$ Written in 1995, it appeared to supply an honest appraisal of how the disestablished Church had developed, with damning confirmation that anglicization, and a reversion to the status of an 'alien church', was viewed as a welcome outcome if it assured the future of the 'Welsh' Anglican Church.

Upon the ninetieth anniversary, in 2010, the former Archbishop of Wales, Dr. Barry Morgan ${ }^{155}$, referred to the fact that: 'It was forced upon us and one of the aims was to weaken the influence

\footnotetext{
152 At the time of his writing, Rhodesia formed part of the Federation of Rhodesia and Nyasaland, which was dissolved in 1963. A Unilateral Declaration of Independence, from the colonial rule of the United Kingdom, was issued on 11 November 1965, which led, after a brutal guerilla war, eventually led to independence in April 1980. 153 The Bishop of Llandaff, the Right Revd. W.G.H. Simon, The Landmark (London, 1962), pp.62-63.

${ }^{154}$ Davies, Against the Tide. Christianity in Wales on the Threshold of a new Millennium, p.34.

155 Barry Cennydd Morgan (born 31 January 1947), Bishop of Bangor from 1992 to 1999, Bishop of Llandaff from 1999 to his retirement in January 2017 and Archbishop of Wales from May 2003 to his retirement in 2017.
} 
of the Anglican Church in Wales'. ${ }^{156}$ This work has attempted to address the precise nature of what was 'forced' upon the Church, the nature of that 'influence' and whether, paradoxically, that influence was diminished as a result of disestablishment, as opposed to other factors, such as secularisation. There is also a possibility that disestablishment is utilised as a rallying call for the contemporary Welsh Church, as a symbolic representation of how the Church has 'overcome' the event. This could be gleaned from an interview which Dr. Morgan gave to The Times's religious affairs correspondent in 2003. The article provided an extremely favourable description of the Welsh Church's financial position, as compared with the Church of England, and posited that 'no wonder that in England there is increasing talk of disestablishment'. The article noted that Archbishop's response had been that: 'I do not think it is for me to recommend disestablishment', which implied that he would have done so, but he added that: 'It is for the Church of England to discover it', suggesting that perhaps, on the centenary of disestablishment, the Welsh Church should be expressing their gratitude for those who battled, decade after decade, to set the Church free. ${ }^{157}$

\section{'The shadow of the Church of England'.}

During the many occasions, since 1920, when the Church of England has been engaged in trying to understand what it meant to be 'established', and thereby its relationship with the state, it has rarely considered that Welsh disestablishment was able to provide a template which, in the circumstances, might appear perplexing. Although, when The Times provided a guide to Church establishment, in 1963, it queried whether disestablishment was in effect a freedom which 'unfettered' the church concerned and it suggested that the Church of Ireland 'had been seriously hampered in its freedom of development by the terms of its disestablishment in 1871, while the Church in Wales, disestablished in 1920, has not'. ${ }^{158}$ In 1984, the question was again being asked whether the Church of England, 'by ending its relationship with the state', would 'improve its relationship with the nation', mainly due to the contemporaneous tensions between the then Prime Minister, Margaret Thatcher, and bishops whom she viewed as straying into secular matters. ${ }^{159}$ The article, by The Times's religious affairs correspondent, provided an

\footnotetext{
156 The Archbishop of Wales, Presidential Address - Governing Body, April 2010, The Representative Body of the Church in Wales, 2010.

157 'Is this the bishop with the inclusive touch? Well yes and no', The Times, 23 August 2003.

158 'Guide to the Church Establishment', The Times, 6 May 1965, p.5.

159 'Hidden depths of church and state', The Times, 17 December 1984, p.12.
} 
extraordinary exposition of what could result from English disestablishment, but without any mention of the position in Wales, which again makes its conclusions fascinating. It was suggested that English disestablishment: 'would leave English society with no source of fundamental values other than the pragmatic sentiment of the majority' and that 'a secular state would have to have a secular constitution to declare what it stood for and what were the rights of its citizens'. ${ }^{160}$ The article does not attempt to address how the 'dangerous gap’ created by disestablishment had been addressed in Wales.

An earlier chapter referred to the manifestation of the 'project fear' type statements that have periodically been utilised by English Churchmen or other Establishment figures, whenever the possibility of disestablishment has arisen, predicting dire consequences and without any cognizance of Welsh disestablishment, which was staring at them from across Offa's Dyke, but which was studiously ignored. The Lord Mayor of London, Sir Leslie Boyce, was grandiloquent about the potential results of disestablishment when, in 1952, he stated that it would be 'interpreted abroad as the beginning of the break-up of that Christian civilization on which greatness of this country was based' and, rather curiously, that: 'A Church established and revered by the State and free and strong in itself was one of the safeguards against the rising tide of totalitarianism'. ${ }^{161}$ It would be tempting to dismiss such pronouncements as simply reflecting contemporary perturbations, when the City of London still bore the scars of a recent World War, with a 'Cold War' underway and with the Royal Fusiliers (City of London Regiment) about to embark for the Korean War. However, it is worth noting that, in 2002, the Archbishop of Canterbury, Dr. George Carey, also believed that 'severing the links between Church and State would lead to the collapse of civilised society', with the Church providing a 'spiritual underpinning of the State, ${ }^{162}$. On this occasion there was a recognition of the indirect sleight and a parliamentary Early Day Motion was laid on 24 April 2002, when Jon Owen Jones, the then member for Cardiff Central proposed:

'That this Houses disagrees with the statement made by the Archbishop of Canterbury, the Rt. Rev. George Carey, that "the severing of links between church and state would lead to the collapse of civilised society" and that "honesty, faithfulness, respect and love of neighbour would all be threatened if England abandoned its historic spiritual framework"; and notes that the church has been disestablished in Wales for the most part

\footnotetext{
160 'Hidden depths of church and state', The Times, 17 December 1984, p.12.

161 ““No Time for Talk of Disestablishment”. Lord Mayor’s Comments', The Times, 20 June 1952, p.3.

162 'Carey says State would fall apart without Church link’, The Times, 24 April 2002, pp.1 and 4.
} 
of a century with no evidence of a collapse in the state or an increase in dishonesty, faithlessness, disrespect or hatred of neighbours when compared with England'. ${ }^{163}$

Dr. Carey was to be followed as Archbishop by Rowan Williams who, in 2008, admitted that he recognised the case for disestablishment, because of his experience of the Church in Wales:

'I can see that it's by no means the end of the world if the Establishment disappears. The strength of it is that the last vestiges of state sanction disappeared, so when you took a vote at the Welsh Synod, it didn't have to be nodded through by parliament afterwards. There is a certain integrity to that." 164

Yet Dr. Williams went on to express unease, but for a practical reason which was concerned with modern perceptions of the place and influence of the Church in society: 'it's a very shaky time for the public presence of faith in society. I think the motives that would now drive disestablishment from the state side would be mostly to do with . . . trying to push religion into the private sphere'.

\section{The Church and State.}

Writing in 1950, Archbishop Garbett of York argued 'for some readjustment in the existing relationship between Church and State’. ${ }^{165}$ Although he was writing 30 years after Welsh disestablishment, the Archbishop is remarkably sparing in any comments about Wales and avoids any direct comparison with the position in England, although the concept of disestablishment is an integral part of his analysis. The Archbishop could have reflected upon the Welsh experience of disestablishment, as described by the Bishop of St. Asaph ${ }^{166}$ only three years earlier, in 1947, when The Spectator, albeit with some faint surprise, reported upon the Bishop’s positive observations concerning 'our twenty-seventh year of freedom'. ${ }^{167}$ The Bishop had been 'convinced that the Church throughout the Principality would be unanimous against a return to the old order'. It is crucial to try and understand the Janus-faced manner in which the Church of England adjudged disestablishment, when it appeared to maintain a steadfast resistance as far as Wales was concerned, in line with the resolutely uncompromising attitude

\footnotetext{
163 'Disestablishment of the Church’, Early Day Motion 1190, 22 April 2002.

164 'Interview: Rowan Williams', New Statesman, 18 December 2008.

165 Garbett, Church and State in England, p.5.

${ }^{166}$ William Thomas Havard M.C., (1889-1956), Bishop of St. Asaph from 1934 to 1950, when he was translated to the St. David's: D.W.B.

167 This is our twenty-seventh year of freedom," said the Bishop of St. Asaph', The Spectator, 2 May 1947, p.5.
} 
adopted by the two key Welsh defenders but was prepared to engage in a more nuanced approach, when it was considered in a purely English context.

The Archbishop accepted that: 'Disestablishment seems at first sight the quickest and surest way of gaining spiritual freedom'. ${ }^{168}$ He went on to describe the 'good' which would be drawn from disestablishment: the appointment of its own bishops and deans, the fact that the Church would be self-governing and, thirdly, that the Church would have its own spiritual courts, and, to sum up, 'Disestablishment should mean a free Church in a free State'. ${ }^{169}$ Remarkably, he admits that these would be 'valuable gains if they were certain to follow disestablishment' and yet, he made no attempt to utilize the Welsh example, in order to test these potential ‘valuable gains' or, indeed, the potential disadvantages. These disadvantages included a supposition that the 'State would not allow the Church to retain considerable property' unless 'the constitution and doctrine' of the Church were carefully defined; he anticipates some nefarious State interference, again without a view of the Welsh experience. The Archbishop appeared to attribute an extremely malign propensity to the State, although, bizarrely, he would prefer to remain beholden, when he wrote that; 'If the State itself did not draft a constitution and article for the Church, it would scrutinize them with jealous eyes if they had been prepared by the Church’ ${ }^{170}$ There is no reference to The Setting of the Constitution of the Church in Wales ${ }^{171}$, which had been published in 1937, perhaps because the author, Archbishop Green had, by the time he wrote the book:

'realised that uncovenanted blessings had accrued to the Church in Wales through disestablishment in spite of the Church's original opposition. Disestablishment enable the Church in Wales to be more closely identified with the Welsh people and the Church's position in Wales was strengthened'. ${ }^{172}$

It appeared to be untouched by the 'jealous’ scrutiny of the State. However, Archbishop Garbett did conclude that disestablishment, at that time, would present a drawback which was not associated with the legal implications or the practical outcome, but reflected how the British State, with its partial and painful decolonization, viewed itself vis-à-vis the world. The

\footnotetext{
168 Ibid., p.142.

${ }^{169}$ Ibid, p.143.

170 Ibid., p.144.

${ }^{171}$ Green, The Setting of the Constitution of the Church in Wales.

172 Edwards, Archbishop Green. His Life and Opinions, p. 92.
} 
Archbishop, in a similar vein to F. E. Smith, opined that it would discourage Christians around the world: 'at a time when millions are under the sway of ideologies which regard the Christian Church as their most dangerous foe, and when in many Moslem lands Christianity is hard pressed in the fight for survival' ${ }^{\text {173 }}$, although he did admit that 'In all probability the reasons which led to disestablishment in England would not be anti-Christian', as he recognized that many believed that Christianity would benefit generally from a separation of Church and State. ${ }^{174}$

\section{Established Church redux.}

Perceptions of what was meant by disestablishment were to change, but any examination of the causes must address the following, commonly held viewpoint:

'It can readily be believed that the intention of those who sought disestablishment may well have been to drive Anglicanism out of Wales, in the belief that Wales was and should be seen to be a radical and Nonconformist nation. Disestablishment was meant to be a punitive act'. 175

\footnotetext{
${ }^{173}$ Garbett, Church and State in England, p.146.

${ }^{174}$ Ibid., p.146.

${ }^{174}$ Ibid., p.142.

175 Thomas Glyn Watkin, 'Disestablishment, Self-determination and the Constitutional Development of the Church in Wales', in Essays in Canon Law. A Study of the Law of the Church in Wales (Cardiff, 1992), ed. by Norman Doe, p.26.
} 


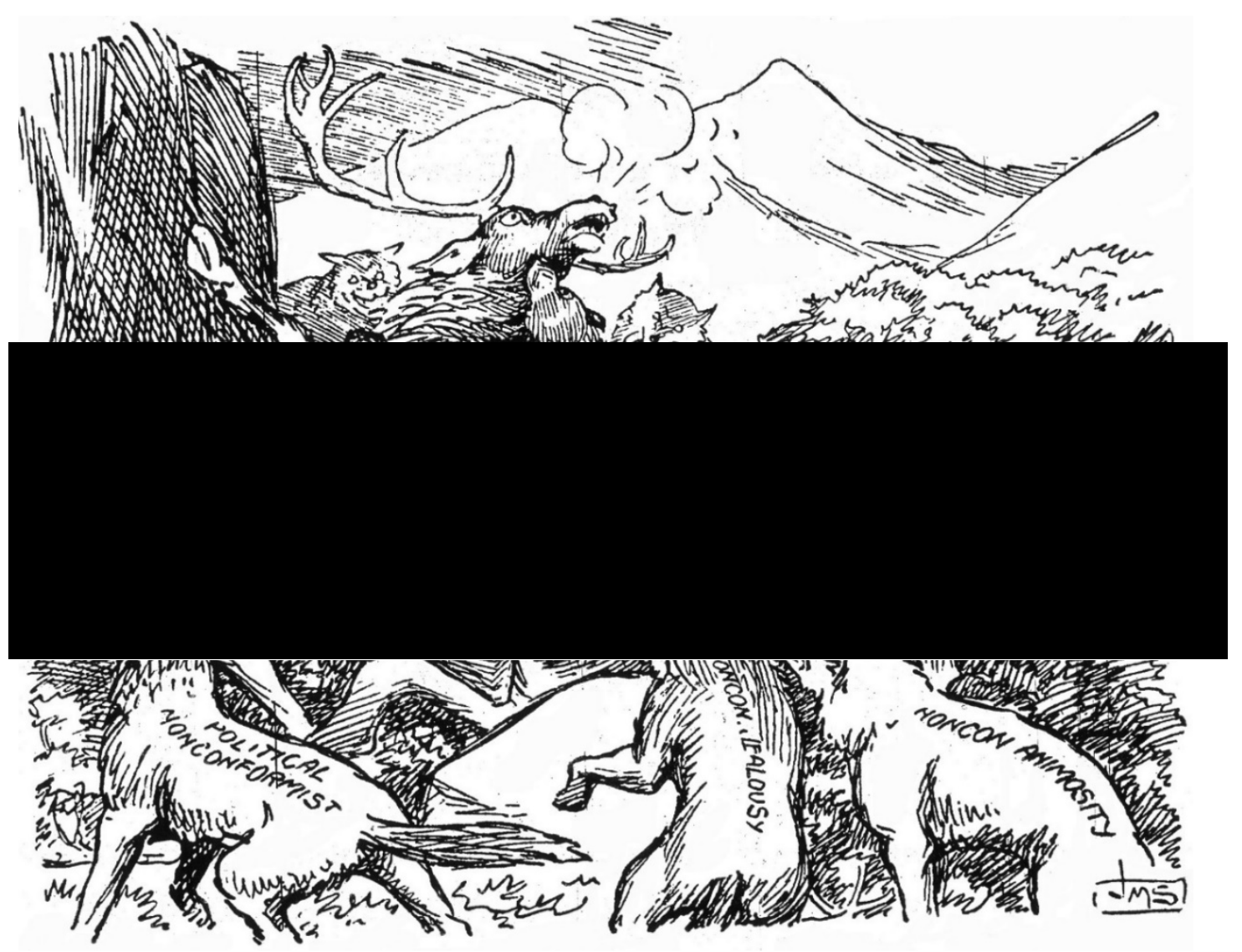

'Nearing the End of the Struggle': Western Mail, 18 May 1914.

This powerful cartoon by Staniforth would appear to encapsulate much of the narrative that had become associated with disestablishment and the veritable cornucopia of malevolent reasons that were believed to be responsible. It is possible to understand the increasingly desperate propaganda that was generated at the time but it is more challenging to understand those contemporary commentators who still cleave to this narrative. This work has attempted to demonstrate that if indeed disestablishment was intended as a 'punitive act', then it was an extraordinary defeat for the protagonists who sought disestablishment. The victors would have to be the Church defenders, whose successful efforts to delay, and then to attenuate, what was delivered by the legislation in 1914 and 1919 validated R.T. Jenkins's observation that:

'Disestablishment was postponed to so distant a date that when it came it had lost nearly all the value it may ever have happened to possess, whether in the eyes of political Dissenters or in those of cultural nationalists'. ${ }^{176}$

\footnotetext{
${ }^{176}$ Jenkins, 'The Development of Nationalism in Wales', p.173.
} 
Although most contemporary Anglican Churchmen might disagree, it is evident that by the time it took effect, in 1920, the Church in Wales had been provided with the necessary wherewithal to continue and, rather than experiencing a terminal state, it carried on without missing a heartbeat. This plus ça change approach, in describing the Church in Wales after 1920, was echoed in the Ecclesiastical Law Journal, in 1993, when the Reverend Roger Lee Brown addressed the apparent confusion about the identity of Church in Wales, seventy years after disestablishment. He wrote that there was a "wish to remain an "established" Church with a disestablished ethos. ${ }^{177}$ The fact that the Church in Wales retains the characteristics of an established church has led to it being described 'more accurately as being a 'post-established' church'. ${ }^{178}$ However, the Marriage (Wales) Act $2010^{179}$, provided a: 'textbook example of the paradox of disestablishment: a disestablished church can rarely, if ever, enjoy the same legal status as a church which has never been established, as it will always be bound by the terms of the statute by which it was disestablished'. ${ }^{180}$ The Church in Wales required an Act of Parliament to reform its marriage law, whereas paradoxically the Church of England legislated for itself by Measure. ${ }^{181}$

However, disestablishment still retains the characteristics of a 'bogey'. This is despite the fact that it provided the Welsh Church with something invaluable, being independence of decisionmaking. It is no doubt of significance that, albeit in a shambolic way, it provided one of the few occasions when the 'establishment', however delineated, failed to perpetuate the status quo although, to quote the Duke of Wellington, when describing the outcome of the Battle of Waterloo: 'it has been a damned nice thing - the nearest run thing you ever saw in your life'. The interlude of the war years furnished the Church with the respite required to re-invent the institution, thereby allowing it to be re-launched in 1920.

\footnotetext{
${ }^{177}$ Roger Lee Brown, 'What of the Church in Wales?', Ecclesiastical Law Journal, vol.3, issue12 (January 1993), p.20.

${ }^{178}$ Harris and Startup, The Church in Wales. The Sociology of a Traditional Institution, p.7.

179 The Act allowed couples to use the residency of parents or grandparents, or their parents' regular attendance in the specific Church, as a valid condition to be married in that parish.

${ }^{180}$ Nicholas Roberts, 'The Historical Background to the Marriage (Wales) Act 2010', Ecclesiastical Law Journal, 13 (2011), p.41.

${ }^{181}$ Church of England Marriage Measure 2008, No. 1.
} 
The disestablishment campaign shared characteristics with the position which dominated British politics in relation to Brexit, the proposed withdrawal of the United Kingdom from the European Union, following the referendum held in June 2016. In that the proposed constitutional change induced a high level of public antipathy and, although it is rarely acknowledged, in December 1910, as the general election was about to take place, the Bishop of St. David's called upon Churchmen 'to vote for the Unionist proposal ${ }^{182}$ for a Referendum on all matters of great gravity'. ${ }^{183}$ He anticipated that voters should decide, based upon the evidence placed before the Welsh Church Commission, whether Welsh disestablishment, and disendowment, should proceed. The Bishop would have agreed with Lord Curzon's judgement that a referendum was 'a gift of influence to democracy', in that it was viewed it as a necessary device to counter the constitutional changes to the legislature, which the 1911 Parliament Act would enact. ${ }^{184}$ It was feared that this would lead to the 'tyranny of the single chamber', with a Referendum safeguarding 'the interests of the democracy, and ensure that the will of the majority shall prevail' ${ }^{185}$ In effect, Conservatives viewed the referendum as a method of checking the legislature, acting as 'the people’s veto'. ${ }^{186}$ Such a proposal, in the case of disestablishment, would have struck at the heart of who should decide upon Welsh disestablishment, with the perennial debate about whether it was a question which should be decided solely by the Welsh electorate or whether this attempt to disestablish four dioceses of the Church of England was a matter for English consideration as well.

Arguably, the contemporary dilemma of a 'hard' or 'soft' Brexit also bears comparison with Welsh disestablishment, as it is apparent the Church experienced a 'soft' transformation from its established status. Even its dismemberment from the Convocation of Canterbury was to prove to be an unexpected boon, as it provided the Welsh Church with an independence of action and organisation which the Church of England could only begrudgingly covet from across the border.

\footnotetext{
182 'Mr. Balfour on Unionist Policy', The Times, 30 November 1910, p.11: Balfour had addressed an audience at the Albert Hall, on 29 November 1910, at which the question of referenda was raised.

183 'The General Election and the Church of England', letter to The Times, 3 December 1910, p.14.

184 'Come to Stay', Evening Express, 2 December 1910, p.2. Lord Curzon felt certain that it would 'be adopted as part of the Constitutional machinery. In this contest the peers were defending the sovereignty of the people and giving to democracy the greatest political influence they had yet enjoyed'.

185 'The Referendum Issue', The Spectator, 3 December 1910, p.5.

${ }^{186}$ M. Qvortrup, ‘A. V. Dicey: the referendum as the people's veto’, History of Political Thought, vol. 20, no.3 (March 1999), pp. 531-546.
} 
As described elsewhere in this study, the Church of England rarely thought it worthwhile to seriously consider the example of the disestablished Welsh Church during the frequent enquiries into its own establishment. Soon after Welsh disestablishment and demonstrating the very independence that the Church defenders had striven to avoid, the newly disestablished Church's governing body decided, in September 1921, to create the new diocese of Monmouth. ${ }^{187}$ This was followed, in 1923, by the formation of a new bishopric of Swansea and Brecon, albeit that there had been a proposal to create three diocese, Brecon, St. David's and Swansea. ${ }^{188}$ The newly disestablished church was compromised from the outset' ${ }^{189}$, due to the influence of the new Archbishop and his former 'adjutant', the Bishop of St. David’s, who maintained as much of the 'establishment ethos and privilege as was possible'. 190

\section{An appraisal of the disestablished Church.}

There is evidence that the disestablished Welsh Church appears, through good intent, to escape the scrutiny which, as a Welsh institution, it requires. This contention was confirmed by Lord Morgan's ${ }^{191}$ depiction of the Church, during a House of Lords debate in 2002, when he went to some lengths to describe the 'success' of disestablishment. ${ }^{192}$ He spoke of a Church that had been 'transformed. It has grown; it has been a dynamic Church; whereas the Welsh nonconformist chapels have gone into decline. It has been far more responsive to social and cultural change'. Lord Morgan gave, as an example, the poetry of R. S Thomas, with its 'social and cultural criticism', which he suggested was 'inconceivable in the suffocating atmosphere of the Church prior to disestablishment'. This failed to acknowledge that the writings of such Churchmen as Dean H. T. Edwards and Canon David Jones were testament to the fact that 'social and cultural criticism' was evident. ${ }^{193}$ Although there is only room to touch briefly on the subject, Lord Morgan's other contention, that the disestablished Church 'has done much to

\footnotetext{
${ }^{187}$ Walker, 'Disestablishment and Independence', in A History of the Church in Wales, p.171.

${ }^{188}$ Price, A History of the Church in Wales in the Twentieth Century, p.20.

189 J. Morgan-Guy, 'The Church in Wales', in The Religious History of Wales. Religious Life and Practice in Wales from the seventeenth century to the present day (Cardiff, 2014), ed. by R. Allen, David Ceri Jones, with Trystan O. Hughes, (eds.), p.20.

190 Ibid.

${ }^{191}$ Kenneth O. Morgan, Baron Morgan, (born 1934), historian and Labour peer since 2000.

${ }^{192}$ HL Debate, 22 May 2002, vol.635, cc.769-816.

${ }^{193}$ Canon David Jones, The Welsh Church and Welsh Nationality, p.114: where he wrote that Welsh 'was saved from actual extinction in Welsh centres, not by well-paid incumbents, but by Welsh speaking curates, who kept alive the fire on her altars for a miserable pittance, while the alien and alienised pluralists who hired them, were accumulating or dissipating fortunes in luxury and lethargy'.
} 
promote the Welsh language' should be examined. The Church's attitude to the Welsh language was an important feature of the campaign for Welsh disestablishment, but it appears that the Church’s uncertain relationship with the language continued, post-disestablishment, and a somewhat begrudging, tactless and condescending comment, in a report of the proceedings of the Church’s governing body in 2007, merits examination. It revealed that: 'Although not under any statutory obligation to do so, from the time of Disestablishment, the Church had recognised the equality of Welsh and English'. ${ }^{194}$ The author's observation, without any apparent awareness of the Church's past, fraught relationship with the Welsh language, appeared to suggest that the Church should have been congratulated for its magnanimity. It is difficult to reconcile his statement with an address which the Archbishop of Wales made to the same body, eighty-five years earlier, when he attached a somewhat greater priority: 'the subject of language, which he described as the most sensitive, most difficult, and yet most imperative in its urgency for the future of the Church in Wales' ${ }^{195}$ It was apparent, a quarter of a century later, in 1949, there was continuing official admission of the Church’s apparent inability to address the issue:

'We cannot deny that in Welsh-speaking Wales the Church is widely held to be isolated from Welsh life and that her alleged lack of interest in the preservation of Welsh culture and tradition is being interpreted as a sign of total lack of care for the well-being of the people'. ${ }^{196}$

Shortly afterwards, tensions within the Welsh Church were to become particularly evident, with the election of non-Welsh speakers to be Archbishop of Wales ${ }^{197}$ and Bishop of Swansea and Brecon $^{198}$, within weeks of each other. The Times reported that the appointment of an Englishman, who does not speak Welsh, 'provided ammunition for those Welshmen who claimed that the national spirit is being crushed by an anglicized squirearchy', wording which was emblematic of reportage from the previous century. ${ }^{199}$ The new Archbishop was quoted as saying that he did: 'not accept that there is a tendency among Welshmen to think of the Church

\footnotetext{
194 Archdeacon P. Morris of Margam, 'Governing Body of the Church in Wales, April to September 2007', Ecclesiastical Law Journal, vol.10, no.1 (January 2008), p.109.

195 'The Church in Wales. Problems for Governing Body’, The Times, 28 September 1922, p.12.

196 Report of the Nation and Prayer Book Commission, (1949), p.42.

197 Alfred Edwin Morris, (1894-1971), bishop of Monmouth from 1945 to 1967 and Archbishop of Wales from 1957 to 1967.

198 John James Absalom 'Jack’ Thomas, (1908-1995), bishop of Swansea and Brecon from 1958 to 1976.

199 'Archbishop of Wales without the language’, The Times, 18 November 1958, p.6.
} 
in Wales as an alien body, an instrument of the establishment in all but name'. ${ }^{200}$ Then, without any apparent discernment, he explained that there was no:

'sinister significance in the shortage of Welsh speakers among the clergy, nor in the fact that the proceedings of the governing body are conducted in English. This was no more than a reflection of the trend in the Principality as a whole'.

Sixty years ago, the controversy concerning archiepiscopal and episcopal elections led to an entertaining exchange of letters in the Western Mail, which caused the author, 'a prominent layman of the Church in Wales' writing under the pen name of 'Theomemphus', to draft a 'pungent and penetrating pamphlet', entitled Bilingual Bishops and All That. ${ }^{201}$ The identity of the author, Aneirin Talfan Davies ${ }^{202}$, soon became known, and the pamphlet made it clear that had it not been for the supportive statements by the Bishops of Llandaff and Bangor:

'the people inside, and more importantly those outside the Church, would have been led to believe that the Welsh language, and all that is bound up with it was held of no account in our Church, and thus give to outsiders an added reason for their mistaken belief that the Church in Wales is in reality nothing more than the Church of England in Wales, more concerned with maintaining anglicizing influences, than in ministering to the welfare of Wales and its people and maintain those things which make us what we are - a nation'. ${ }^{203}$

In his 1976 history of the Welsh Church, Canon Walker acknowledged: 'In the last analysis, integration in Wales is integration into both Welsh-speaking and English-speaking communities, and in the third quarter of the twentieth century that complex issue remains the most delicate and the most critical question for the Church in Wales to solve'. ${ }^{204}$ The fact that this statement brought his history to a close might have tempted readers to believe that this was a subject upon which the Welsh Church would now attribute a level of priority, although some might have reflected upon the words of Dean H. T. Edwards, written almost one hundred years earlier when, in considering the future of the Welsh Anglican Church, he wrote that:

'Let the Church have a native ministry that can regain that Welsh heart, and she will be strong and rich; and when another Congress is held in Swansea by our children at the end

\footnotetext{
200 Ibid.

201 'Theomemphus’, Bilingual Bishops and All That (Llandybie, 1958).

${ }^{202}$ Aneirin Talfan Davies, (1909-1980), bard (Aneirin ap Talfan), broadcaster and literary critic.

203 'Theomemphus', Bilingual Bishops and All That, p.1.

${ }^{204}$ Walker, D., 'Disestablishment and Independence', in A History of the Church in Wales, p.187.
} 
of thirty years, some of us may then be living to hear them call her, not the Church in Wales, but the Church of Wales'.205

Canon Walker's contention, in 1976, that: 'There is a strong case to argue that Welsh is now essential within the Welsh Church' ${ }^{206}$, should be contrasted with Cynog Dafis's foreword to a 2011 report, in which he wrote that: 'Our analysis and recommendations arise from a deep conviction that a far-reaching change is necessary in order to give the Welsh language its rightful place in the future life of the Church in Wales'. ${ }^{207}$ A clear indicator that the Church authorities did not ascribe any genuine import to the recognition of 'the equality of Welsh and English' could be drawn from the fact that although: 'It was decreed that the Constitution of the Church in Wales should be published in both Welsh and English, yet it was until 1972 that volume I of the Constitution was published in Welsh, and the Welsh version of volume II did not appear until 1980 - sixty years after disestablishment'. ${ }^{208}$ Although it has been suggested that there were some administrative reasons which may have led to the delay in translation, it is difficult to seriously ascribe such an excuse to a delay amounting to decades.

Writing in 1893, David Jones excoriated the Church’s past leaders, with a statement that: 'The Anglicising policy of past generations, which has prevailed too largely in the promotion of the higher dignitaries of the Church has tended to discourage the due cultivation of the Welsh language and to crush out the national sentiment from the heart of the ministry' ${ }^{209}$ In case revisionist historians might suggest that such nineteenth-century pronouncements were unduly fervid and bear no relevance in contemporary times, it should be compared with an article in The Church Times, in 2012, when the Bishop of Bangor, Andrew John, was reported as warning: 'Our communities are becoming more Welsh, but there is a real danger that the Church in Wales is becoming more English because of the leadership in our churches' ${ }^{210}$ In 2008, D. P. Davies intimated that: 'Episcopal elections in the disestablished Church give lie to the charge that the

\footnotetext{
205 Dean H.T. Edwards, 'The Past and Present Position of the Church in Wales'. An address delivered at the Church Congress, Swansea, October 9, 1879, in Wales and the Welsh Church, p.346.

${ }^{206}$ David Walker, 'Disestablishment and Independence', in A history of the Church in Wales, p.186.

${ }^{207}$ Pob un yn ei iaith ei hun/Each in our own language, Report of the Welsh Language Vocations Group to the Standing Committee of the Church in Wales, December 2011, p.1.

${ }^{208}$ Enid Pearce Roberts, 'The Welsh Church, Canon Law and the Welsh Language', in Essays in Canon Law. A Study of the Law of the Church (Cardiff, 1992), ed. by N. Doe, p.155.

209 Jones, The Welsh Church and Welsh Nationality, p.vii.

210 'Church seeks Welsh-speakers to fill language gap', The Church Times, 27 April 2012, p.6.
} 
Church in Wales is an alien, anti-Welsh language body', and, stated that two-thirds of those elected bishops have been Welsh-speakers. ${ }^{211}$ The current position with episcopal appointments in the Church in Wales, close to the centenary of Welsh disestablishment, would suggest that the Reverend Professor D. P. Davies would be required to look elsewhere to 'give lie to the charge'.

But perhaps one of the most telling aspects is how the Church in Wales will understand the centenary of disestablishment, with Reverend J. Hywel Davies suggesting that: 'Much of the debate in the Governing Body of the Church in Wales on a recent working-party report is coloured by what happened in 1847. It has taken that long for the Church in Wales (disestablished in 1920), structurally, to face up to its relationship with the Welsh language'. He commented that when 'good practice is well established and known, and when both languages are treated with respect, there is no problem. It takes effort and time, but if the Church in Wales is to celebrate its centenary in 2020 as a truly national institution, serving all the people of Wales, it can no longer afford to be in hock to the values of $1847^{\prime} \cdot{ }^{212}$

\section{Conclusion.}

A range of factors have led to significant misunderstandings about both the campaign that sought Welsh disestablishment and what resulted. Reference has been made to those commentators who, often from an Anglo-centric perspective, have, by reason of brevity or from a paucity of knowledge, not provided an accurate depiction. Other commentators have perhaps attempted to assuage the potential sensitivities of a re-established Church that, in a time of secularisation, is understood to warrant support. However, other factors have tended to distort our understanding. Professor R.J.W. Evans suggested that by 1900: 'the symbiosis of Nonconformism and ethnic identity had begun to run its course in Wales', ${ }^{213}$ and there followed the dual 'crisis' of faith and of the nation, as analysed by Professor Tudur Jones. ${ }^{214}$ Such religious and societal influences have caused disestablishment to appear less relevant and any analysis of the period immediately prior to 1914 is liable to be influenced by the enormity of events of 1914 to 1918. David Reynolds has written of the 'long shadow' cast by the Great War over the twentieth century, but

\footnotetext{
${ }^{211}$ Davies, the Reverend Professor D.P., ‘Welsh Anglicanism', Trivium (2008), p.118.

212 The Reverend J. Hywel Davies, The Church Times, 2 May 2012.

${ }^{213}$ R.J.W. Evans, 'Nonconformity and Nation: The Welsh Case', The Welsh History Review, vol.25, no.2 (December 2010), p.237.

${ }^{214}$ R. Tudur Jones, Faith and the Crisis of a Nation. Wales 1890-1914 (Cardiff: UWP, 2004), ed. by Robert Pope.
} 
it is apparent that events prior to the advent of war have also been adumbrated, so that the true enormity of what took place, constitutionally, within Britain, is, retrospectivity viewed as being of minor significance. ${ }^{215}$

As mentioned in the Introduction to this thesis, a critical characteristic of the Welsh disestablishment campaign was its longevity, and this represented a crucial feature. Despite a revisionist interpretation whose cynosure suggests that the support for disestablishment was ebbing by 1914, it was evident that it retained a hold, despite setbacks, disappointments and failure by those Welsh Liberal politicians who often achieved and sustained their political careers based upon its public espousal. The passage of time did attenuate the relevance of disestablishment, but a more complete summation should also acknowledge that it was the form of 'soft' disestablishment and quasi-disendowment delivered which impoverished the consequence of a fifty-year campaign. This reality contrasting starkly with G.I.T. Machin’s observation that 'the passage of Welsh disestablishment had been a clear victory for radical Nonconformity'. ${ }^{216}$ The reasons which lay behind the longevity of the campaign are often overlooked, partly because commentators have, as shown in this thesis on several occasions, stumbled over the issue, conflating dates and events, and thereby distorting the campaign itself. But, in addition, there was an uncomfortable, fundamental issue of how the half century of campaigning demonstrated that Welsh democratic will was unable to influence matters and, as J. Arthur Price concluded:

'There can be no doubt that if Wales had possessed an independent Legislature of her own, competent to deal with the subject, Disestablishment would have been effected in 1868. The fact that England, which had no practical knowledge of Welsh feeling on the subject, could not be moved to do justice in the matter, caused the question to be postponed until 1914 and the result that much political was wasted and much bad feeling was stirred up. This fact every Welsh Liberal must admit'. ${ }^{217}$

However it would be misleading to ignore the fact that Welsh Liberal politicians failed to exploit their position within Westminster and although, when he was writing in 1918, Llewelyn Williams was, in part, motivated by a certain antipathy which had developed concerning his

\footnotetext{
${ }^{215}$ David Reynolds, The Long Shadow. The Great War and the Twentieth Century, London, 2013.

${ }^{216}$ Machin, Politics and the Churches in Great Britain 1869 to 1921, p.313.

217 J. Arthur Price, 'Welsh nationalism and Mr. Lloyd George’s speech', Welsh Outlook, vol.5, no.9 (September 1918), p.274.
} 
former Liberal Party comrades, his opprobrium would, based on any objective examination of events, appear justified. After listing people such as Lord Rendel, T. E. Ellis, Sir George Osborne Morgan, David Lloyd George, D. A. Thomas and Alfred Thomas, whom he described as 'most courageous and independent of men', he then presented a disconsolate, but seemingly accurate riposte to anybody who attempted to understand why the journey to Welsh disestablishment had been turbulent, prolonged and, in the end, relatively nugatory:

'Such men could and should have won for Wales all that she wanted: or, at all events, should have forced a friendly Government to agree to their reasonable demands. The secret of their failure for fail they did was that they could not work together. Each was a man of strong and dominant personality. None had the excess of experience, success and age which would entitle him to the leadership. And so, Wales, after ploughing the sands for a quarter of a century, found that when at last the rare and refreshing fruits of Disendowment fell to her lot in 1920, they were but Dead Sea apples that turned to ashes in her mouth'.218

${ }^{218}$ W. Llewelyn Williams, 'Political Life', in D. A. Thomas, Viscount Rhondda, by his Daughter [Viscountess Rhondda] and Others (London, 1921), ed. by Margaret Haig Mackworth, p.63. 


\section{Bibliography}

\section{Archives:}

U.K. Parliamentary Archives.

- The Lloyd George Papers

National Library of Wales.

- Bishop John Owen Papers

- Lord Rendel Papers

- Viscount Sankey (Welsh Disestablishment) Papers

Church of England Archives, Lambeth Palace.

- Benson Papers

Glamorgan Archives.

- Lord Pontypridd (Sir Alfred Thomas) Papers

Swansea University, Richard Burton Centre.

- Reverend Griffith Thomas collection

\section{Reports:}

- First report from the Select Committee of the House of Lords on matters affecting the Church in Wales: together the proceedings of the Committee, minutes of evidence and appendices, HMSO, printed 7 August 1914.

- The Official Report of the Church Congress, held at Rhyl, October $6^{\text {th }}, 7^{\text {th }}, 8^{\text {th }}$ and $9^{\text {th }}$, 1891, edited by the Rev. C. Dunkley, London, 1891.

- Official Report of the Proceedings of the Convention of the Church in Wales, held at Cardiff, October 2-5, 1917.

- The Archbishops' Committee on Church and State, SPCK, London, 1917.

- Church and State. Report of the Archbishops' Commission on the Relations between Church and State, London, 1935.

- Report of the Archbishops' Commission, Church and State, London, 1970.

- $\quad$ The Official Handbook of the Church in Wales, 1930, Cardiff, 1930. 
- Illustrated Guide to the Church Congress and Church Congress Exhibition held in Newport, Mon. from 4 - 10 October 1930.

- The Case for the Retention by the Church in Wales of the Ancient Churchyards of Wales, which 699 Local Authorities have declined to accept, Church in Wales, Representative Body, 1944.

- The Archbishop's Commission on the Boundaries and Structure of the Church in Wales. Final Report, July 1978.

- Pob un yn ei iaith ei hun (Actau 2:8), the report of the Welsh Language Vocations Group to the Standing Committee of the Church in Wales, December 2011.

- Separating Church and State: The Case for Disestablishment, National Secular Society, December 2007.

\section{Pamphlets:}

- Benson, E.W., Archbishop of Canterbury, The Church in Wales: Shall We Forsake Her? London, 1892.

- Bevan, The Ven. W.L., Notes on the Church in Wales, London, 1905.

- Bradley, J. Fovarque, The Case Against Welsh Disendowment, London, 1911.

- Bradley, J. Fovargue, Nonconformists and the Welsh Church Bill, London, 1912.

- Caird, David, Church and State in Wales. The Case for Disestablishment, London, 1912.

- Central Campaign Committee, The Disestablishment and Disendowment of the Church of England in Wales, London, 1912.

- Davies, David and Thomas, Griffith, The Debate on The Disestablishment and disendowment of the Church in Wales, Swansea, 1911.

- Downing, S.E., The Church in Wales. Disestablishment and Disendowment.An Explanatory Analysis of The Welsh Church Act 1914, London, 1915.

- Edwards, A.G., The Truth about the Church in Wales, London, 1889.

- Edwards. A.G., A Handbook on Welsh Church Defence, London, 1895.

- Evans, Howard, The Case for Disestablishment in Wales, London, 1907.

- Gibbon, J.M., Weighed in the Balance. The Case for Welsh Disestablishment, London, 1910.

- Howell, David, The Welsh Church. A Sermon preached in St. Margaret's Church, Westminster, London, 1890.

- Jones, Griffith, New Work on The Welsh Church Bill Controversy. Facts not generally known by English and Welsh people, London, 1913.

- Lewis, Sir Henry, Is Establishment Just? Conwy, 1914.

- Jones, Evan, A vindication of the educational and moral condition of Wales, in reply to William Williams, Esq. Late M.P. for Coventry, Llandovery, 1848. 
- Ormsby Gore, The Hon. W.G.A., Welsh Disestablishment and Disendowment, London, 1912.

- Owen, Owen, Welsh Disestablishment. Some Phases of the Numerical Argument, Wrexham, 1895.

- St. David's, The Bishop of, The Principles of the Welsh Disestablishment Bill. Two speeches delivered at Newport and Cardiff, on June $8^{\text {th }}$ and $9^{\text {th }}$, 1909, Cardiff, 1909.

- Williams, Jane (Ysgafell), Artegall; or Remarks on the Reports of the Commissioners of Inquiry into the State of Education in Wales, London, 1848.

- Williams, Rev. Robert, The Attack on the Church in Wales. "Evidence and Facts Collected and Sifted" against Disestablishment and Disendowment, London, 1911.

- Williams, William, A Letter to the Right Honourable Lord John Russell, first Lord of the Treasury, on the Report of the Commissioners Appointed to Inquire into the State of Education in Wales, London, 1848.

- Wilson, P.W., Welsh Disestablishment, London, 1912.

\section{Newspapers:}

A wide range of Welsh and English newspapers have been accessed, including:

The Aberdare Leader

The Aberdare Times

Abergavenny Mail

The Aberystwyth Observer

The Brecon County Times

The Bristol Times and Mirror

The Cambrian Daily Leader

The Cambrian

The Cambrian News

The Cardiff and Merthyr Guardian

The Cardiff Times

The Carmarthen Journal

The Carmarthen Weekly Reporter

Carnarvon and Denbigh Herald

County Observer

Cymro a'r Celt Lundain

Evening Express

Llandudno Advertiser

The London Welshman

The Merthyr Express

Monmouthshire Guardian

Monmouthshire Merlin

Montgomery County Times

The Montgomeryshire Express 
The North Wales Chronicle

The North Wales Express

The Pembroke County Guardian

The Pembrokeshire Herald

Pontypridd Chronicle

The Rhondda Leader

The Rhyl Record and Advertiser

Rhyl Journal

South Wales Daily News

South Wales Daily Post

The Weekly Mail

The Welsh Coast Pioneer

The Welshman

The Western Mail

Wrexham and Denbigh Advertiser

The Times

The Guardian

The Spectator

\section{Cartoons:}

Unless a particular newspaper is named, cartoons were taken from:

Cartoons, by “J. M. S.”, Subscription Copy, Western Mail, Cardiff, 1908: featuring J. M. Staniforth’s cartoons from 27 August 1900 to 23 July 1908.

Cartooning the Road to War, which forms part of the 'Cartooning the First World War' project, supported by the Heritage Lottery Fund and based at University College Cork, where it is led by Professor Chris Williams, Head of the College of Arts, Celtic Studies and Social Sciences.

\section{Secondary sources:}

Books

- Adamson, David L., Class, Ideology and the Nation, Cardiff, 1991.

- Asquith, H. H., the Earl of Oxford and Asquith, Memories and Reflections, volumes 1 and 2, London, 1928.

- Avis, P., Church, State and Establishment, London, 2001. 
- Barker, Michael, Gladstone and Radicalism. The Reconstruction of Liberal Policy in Britain, 1885-94', Harvester Press, 1975.

- Barlow, Robin, Wales and World War One, Gomer, 2014.

- Bebbington, D.W., The Nonconformist Conscience, London, 1982.

- Bell, G.K.A., Randall Davidson, Archbishop of Canterbury. Volumes I and II, Oxford, 1935.

- Bell, P.M.H., Disestablishment in Ireland and Wales, London, 1969.

- Benson, A.C., The Life of Edward White Benson, sometime Archbishop of Canterbury, London, 1901.

- Briggs, Asa, Victorian People. A Reassessment of Persons and Themes 1851-67, London, 1954.

- Briggs, Asa (ed.), Chartist Studies, London, 1959.

- Brose, Olive J., Church and Parliament. The Reshaping of the Church of England 18281860, London, 1959.

- Brown, Roger Lee, Lord Powis and the Extension of the Episcopate', Cardiff, 1989.

- Brown, Roger L., Reviving the Clergy. Renewing the Laity. Archbishop Benson's Mission in Wales, Welshpool, 1994.

- Brown, Roger L., David Howell. A Pool of Spirituality, Denbigh, 1998.

- Brown, Roger Lee, Reclaiming the Wilderness. Some Aspects of the Parochial Life and Achievements of the Diocese of Llandaff during the Nineteenth Century, Welshpool, 2001.

- Brown, Roger Lee, Welsh Patriotism and Justice to Wales. The Association of Welsh Clergy in the West Riding of Yorkshire, Welshpool, 2001.

- Brown, Roger L., Parochial Lives, Llanwrst, 2002.

- Brown, Roger Lee (ed.), The Letters of Edward Copleston, Bishop of Llandaff, 18281849, Cardiff, 2003.

- Brown, Roger Lee, In Pursuit of a Welsh Episcopate. Appointments to the Welsh Sees, 1840-1905, Cardiff, 2005.

- Brown, Roger L., Ten Clerical Lives. Essays relating to the Victorian Church in Wales, Welshpool, 2005.

- Brown, Roger L., John Griffith. The Unmitred Bishop?', Welshpool, 2007.

- Bruce, Alex, Cathedral 'Open and Free': Dean Bennett of Chester, Liverpool, 2000.

- Bruce, Henry Austin, Letters of the Rt. Hon. Henry Austin Bruce, G.C.B., Lord Aberdare of Duffryn, vol.II, Oxford, 1902.

- Campbell, John, F.E. Smith, First Earl of Birkenhead, London, 1991.

- Cannadine, David, Victorious Century. The United Kingdom 1800-1906, London, 2017.

- Chadwick, Owen, The Victorian Church, London, 1966.

- Chadwick, Owen, Hensley Henson, A study in the friction between Church and State, Norwich, 1983.

- Chappell, Edgar L., Wake Up, Wales! A Survey of Welsh Home Rule Activities, London, 1943. 
- Charles-Edwards, T. M. and Evans, R. J. W. Evans (eds.), Wales and the Wider World. Welsh History in an International Context, Donington, 2010.

- Clark, G. Kitson, Churchmen and the Condition of England 1832-1885. A study in the development of social ideas and practice from the Old Regime to the Modern State, London, 1973.

- Clwyd Record Office, The Tithe War, Hawarden, 1978.

- Copleston, W. J., Memoir of Edward Copleston D.D., Bishop of Llandaff. With Selections from his Diary and Correspondence, London, 1851.

- Coupland, Reginald, Welsh and Scottish Nationalism. A Study, London, 1954.

- Cragoe, Matthew, An Anglican Aristocracy. The Moral Economy of the Landed Estate in Carmarthenshire, 1832-1895, Oxford, 1996.

- Cragoe, Matthew, Culture, Politics and National Identity in Wales 1832-1886, Oxford, 2004.

- Cragoe, M. and Williams, C. (eds.), Wales and War. Society, Politics and Religion in the Nineteenth and Twentieth Centuries, Cardiff, 2007.

- Cranmer, F., Lucas, J. and Morris B., Church and State. A Mapping Exercise, U.C.L., London, 2006.

- Crosby, Travis L., The Unknown Lloyd George. A Statesman in Conflict, London, 2014.

- Dangerfield, George, The Strange Death of Liberal England, New York, 1935.

- Davies, Charlotte Aull, Welsh Nationalism in the Twentieth Century. The Ethnic Option and the Modern State, New York, 1989.

- Davies, D. Hywel, The Welsh Nationalist Party, 1925-1945, Cardiff, 1983.

- Davies, E.T., The Layman's Guide to the Church in Wales, Penarth, 1958.

- Davies, E. T., Religion in the Industrial Revolution in South Wales, Cardiff, 1965.

- Davies, E. T., Religion and Society in the Nineteenth Century, Llandybïe, 1981. Davies, James, The Chartist Movement in Monmouthshire, Newport, 1981.

- Davies, John, Cardiff and the Marquesses of Bute, Cardiff, 1981.

- Davies, John, A History of Wales, London, 1993.

- Davies, Noel A., A History of Ecumenism in Wales, 1956-1990, Cardiff, 2008.

- Davies R. R., Griffiths R. A., Jones, I. G. and Morgan, K. O. (eds.), Welsh Society and Nationhood, Cardiff, 1984.

- Davies, R.R., The Age of Conquest, Wales 1063-1415, Oxford, 1987.

- Davies, Russell, Hope and Heartbreak. A Social History of Wales and the Welsh, 17761871, Cardiff, 2005.

- Davies, Russell, People, Places \& Passions. Pain and Pleasure: A Social History of Wales and the Welsh 1870-1945, Cardiff, 2015.

- Doe, Norman, The Law of the Church in Wales, Cardiff, 2002.

- Dymond, G. and Deadman, H., The Salisbury Doctrine, House of Lords Library Note, 30 June 2006.

- $\quad$ Eaton, Jack, Judge John Bryn Roberts, Cardiff, 1989.

- Edwards, A.G., The Archbishop of Wales, Memories, London, 1927. 
- Edwards, A. J., Archbishop Green. His Life and Opinions, Llandysul, 1986.

- Edwards, H.T., Jones, David, Wales and the Welsh Church, London, 1888.

- Edwards, Hywel Teifi, The Eisteddfod, Cardiff, 1990.

- Edwards, Hywel Teifi, The National Pageant of Wales, Llandysul, 2009.

- Egremont, M., Balfour. A Life of Arthur James Balfour, London, 1980.

- Ellis, John S., Investiture. Royal Ceremony and National Identity in Wales, 1911-1969, Cardiff, 2008.

- Evans, Leslie Wynne, Education in Industrial Wales 1700-1900, Cardiff, 1971.

- Evans, Neil and Pryce, Huw (eds.), Writing a Small Nation's Past: Wales in Comparative Perspective, 1850-1950, Farnham, 2013.

- Evans, Rhys, Gwynfor Evans. Portrait of a Patriot, Talybont, 2008.

- Evans, Thomas, The Background of Modern Welsh Politics 1789-1846, Cardiff, 1936.

- Freeden, Michael, The New Liberalism. An Ideology of Social Reform, Oxford, 1978.

- Gaffney, Angela, Aftermath. Remembering the Great War in Wales, Cardiff, 1998.

- Garbett, Cyril, the Archbishop of York, Church and State in England, London, 1950.

- Gash, Norman, Reaction and Reconstruction in English Politics 1832-1852, Oxford, 1965.

- Gilbert, Bentley Brinkerhoff, David Lloyd George, a political life. The Architect of Change, 1863-1912, London, 1987.

- Green, C.A.H., The Setting of the Constitution of the Church in Wales, London, 1937.

- Griffiths, Robert, S.O. Davies - A Socialist Faith, Gomer Press, 1983.

- Guedalla, P., The Queen and Mr. Gladstone, 1880-19898, London, 1933.

- Hamer, D.A., Liberal Politics in the Age of Gladstone and Rosebery, Oxford, 1972.

- Hamer, D.A., The Politics of Electoral Pressure. A Study in the History of Victorian Reform Agitations, Sussex, 1977.

- Hamer F.E. (ed.), The Personal Papers of Lord Rendel. London, 1931.

- Hanham, H.J., Scottish Nationalism, London, 1969.

- Hardie, Frank, The Political Influence of Queen Victoria,1861-1901, London, 1963.

- Harris, Chris and Startup, Richard, The Church in Wales. The Sociology of a traditional Institution, Cardiff, 1999.

- Hastings, A., A History of English Christianity, 1920-1985, London, 1986.

- Hawkins, Angus, Victorian Political Culture, Oxford, 2015.

- Hechter, Michael, Internal Colonialism, the Celtic Fringe in British National Development, 1536-1966, London, 1975.

- Heffer, Simon, High Minds. The Victorians and the Birth of Modern Britain, London, 2014.

- Hetherington, J.W., The Life and Letters of Sir Henry Jones, Professor of Moral Philosophy in the University of Glasgow, London, 1924.

- House of Commons, The Parliament Acts, Briefing Paper, no. 00675, 25 February 2016.

- Houghton, Walter E., The Victorian Frame of Mind 1830-1870, New Haven and London, 1957. 
- Hutton, A.W. and Cohen, H.J., The Speeches of the Right Hon. W.E. Gladstone, London, 1902.

- Humphreys, Emyr, The Taliesin Tradition. A Quest for Welsh Identity, London, 1983.

- Iremonger, F.A., William Temple, Archbishop of Canterbury. His Life and Letters, London, 1948.

- Ives, Keith A., Voice of Nonconformity: William Robertson Nicoll and the British Weekly, The Lutterworth Press, 2010.

- James, David W., St. David's and Dewisland, A Social History, Cardiff, 1981.

- James, Robert Rhodes, Rosebery. A Biography of Archibald Philip, Fifth Earl of Rosebery, London, 1963.

- Jenkins, Roy, Mr. Balfour's Poodle, London, 1954.

- Jenkins, Roy, Asquith, London, 1964.

- Johnes, A. J., an Essay on the Causes which have produced Dissent from the Established Church in the Principality of Wales, Llanidloes, 1870.

- Johnes, A. J., A Letter to Lord John Russell, on the operation of the Established Church Bill, with reference to the interests of the Principality of Wales, London and Chester, 1836.

- Jones, Aled, Press, Politics and Society, Cardiff, 1993.

- Jones, David, The Welsh Church and Welsh Nationality, London, 1893.

- Jones, David Ceri, Schlenther, Boyd Stanley, White, Eryn Mant, The Elect Methodists. Calvinistic Methodism in England and Wales, 1735-1811, Cardiff, 2012.

- Jones, David J. V., Before Rebecca, Popular Protests in Wales, 1793-1835, Harmondsworth, 1973.

- Jones, David J. V., The Last Rising. The Newport Insurrection of 1839, Oxford, 1985.

- Jones, David J. V., Rebecca's Children. A Study of Rural Society, Crime and Protest, Oxford, 1989.

- Jones, David J. V., Crime in Nineteenth-Century Wales, Cardiff, 1992.

- Jones, Dot, The Coming of the Railways and Language Change in North Wales 18501900, Aberystwyth, 1995.

- Jones, The Rev. G. Hartwell, A Celt Looks at the World, Cardiff, 1946.

- Jones, Ieuan Gwynedd and Williams, David (eds.), The Religious Census of 1851. A Calendar of the Returns Relating to Wales, Vol.1, South Wales, Cardiff, 1976.

- Jones, Ieuan Gwynedd, Explorations and Explanations. Essays in the Social History of Victorian Wales, Llandysul, 1983.

- Jones, Ieuan Gwynedd, Mid-Victorian Wales. The Observers and the Observed, Cardiff, 1992.

- Jones, J. Hughes, Wales Drops the Pilots, London, 1940.

- Jones, Philip. The Governance of the Church in Wales. Cardiff, 2000.

- Jones, R. Merfyn, The North Wales Quarrymen 1874-1922, Cardiff, 1982.

- Jones, R. Tudur, Faith and the Crisis of a Nation, Wales 1890-1914, ed. Robert Pope, Cardiff, 2004. 
- Khleif, Bud B., Language, Ethnicity and Education in Wales, The Hague, 1980.

- Lerry, G. G., Alfred George Edwards, Archbishop of Wales, Oswestry, 1940.

- Lewis, Edward, John Bangor. The People’s Bishop, London, 1962.

- Loades, Judith (ed.), The Life and Times of David Lloyd George, Bangor, 1991.

- McCormick, D., The Mask of Merlin, London, 1963.

- McKenna, Stephen, Reginald McKenna, 1863-1943, London, 1948.

- McLean, I. and Johnes, M., Aberfan, Government and Disasters, Welsh Academic Press, 2000.

- Machin, G. I. T., Politics and the Church in Great Britain, 1832-68, Oxford, 1977.

- Machin, G. I. T., Politics and the Church in Great Britain, 1869-1921, Oxford, 1987.

- Mackintosh, William H., Disestablishment and Liberation, The Movement for the Separation of the Angican Church from State Control, London, 1972.

- Magnus, Philip, Gladstone. A Biography, London, 1954.

- Marsh, P.T., The Victorian Church in Decline. Archbishop Tait and the Church of England, 1868-1882, London, 1969.

- Mason, Rhiannon, Museums, Nations and Identities, Wales and its National Museums, Cardiff, 2007.

- Masterman, Neville, The Forerunner: Dilemmas of Tom Ellis, 1859-99, Llandybie, 1972.

- Mather, F.C., Public Order in the Age of the Chartists, Manchester, 1959.

- Morgan, D. Densil, Wales and the World. Historical perspectives on religion and Welsh identity, Cardiff, 2008.

- Morgan, D. Densil, The Span of the Cross. Christian Religion and Society in Wales 19142000, Cardiff, 2011.

- Morgan, D. Densil, Theologia Cambrensis. Protestant Religion and Theology in Wales, Volume 1:1588-1760, Cardiff, 2018.

- Morgan, Sir George Osborne, The Church of England and the People of Wales, Liberal Publication Department, 1895.

- Morgan, Rev. J. Vyrnwy, Welsh Religious Leaders in the Victorian Era, London, 1905.

- Morgan, Rev. J. Vyrnwy, Welsh Political and Educational Leaders in the Victorian Era, London, 1908.

- Morgan, Rev. J. Vyrnwy, The Church in Wales in the Light of History. A Historical and Philosophical Study, London, 1918.

- Morgan, John, Four Biographical Sketches: Bishop Ollivant, Bishop Thirlwall, Rev. Griffith Jones, Vicar of Llanddowror and Sir Thomas Phillips Q.C. with a Chapter on 'The Church in Wales', London, 1892.

- Morgan, Kenneth O., Freedom or Sacrilege, Penarth, 1965.

- Morgan, Kenneth O., Keir Hardie, radical and socialist, London, 1975.

- Morgan, Kenneth, Consensus and Disunity, The Lloyd George Coalition Government 1918-1922, Oxford, 1979.

- Morgan, Kenneth O., Wales in British Politics 1868-1922, Cardiff, 1991. 
- Morgan, Kenneth O., Revolution to Devolution. Reflections on Welsh Democracy, Cardiff, 2014.

- Morgan, Prys, The Eighteenth Century Renaissance, Llandybïe, 1981.

- Morgan, W. J. (ed.), The Welsh Dilemma. Some Essays on Nationalism in Wales, Llandybie, 1973.

- Morris, R.M. (ed.), Church and State. Some reflections on Church Establishment in England, London, 2008.

- Mumford, Alan, David Lloyd George, A Biography in Cartoons, Matador, 2014.

- Murray, Bruce K., The People's Budget 1909/1910: Lloyd George and Liberal Politics, Oxford, 1980.

- Neuberger, Julia, Lloyd George's Disestablishment Legacy: Reaching for Egalitarianism, The Annual Lloyd George Memorial Lecture 1999, Cyngor Gwynedd, 2000.

- Newsome, David, The Victorian World Picture, London, 1998.

- O’Leary, Paul, Immigration and Integration. The Irish in Wales, 1798-1922, Cardiff, 2000.

- O'Leary, Paul, Claiming the Streets, Processions and Urban Culture in South Wales, c.1830-1880, Cardiff, 2012.

- Owen, Frank, Tempestuous Journey. Lloyd George. His Life and Times, London, 1954.

- Park, Trevor, Nol Episcopari. A life of Charles John Vaughan, 1816-1897, St. Bega, 2014.

- Parry, Cyril, The Radical Tradition in Welsh Politics, a study of Liberal and Labour politics in Gwynedd 1900-1920, Hull, 1970.

- Parry, Jonathan, The Rise and fall of Liberal Government in Victorian Britain, Yale, 1993.

- Peart-Binns, J.S., Alfred Edwin Morris, Archbishop of Wales, Gomer, 1990.

- Philip, Alan Butt, The Welsh Question. Nationalism in Welsh Politics 1945-1970, Cardiff, 1975.

- Phillips, Gregory D., The Diehards. Aristocratic Society and Politics in Edwardian England, London, 1979.

- Phillimore, Sir Robert, The Ecclesiastical Law of the Church of England, Second Edition by Sir Walter Phillimore, London, 1895.

- Phillips, Thomas, Wales: The Language, Social Condition, Moral Character and Religious Opinions of the People, considered in their relation to Education, London, 1849.

- Pope, Robert, Building Jerusalem. Nonconformity, Labour and the Social Question in Wales, 1906-39', Cardiff, 1998.

- Pope, Robert (ed.), Religion and National Identity. Wales and Scotland c.1700-2000, Cardiff, 2001.

- Pope, Robert, Seeking God's Kingdom, Cardiff, 2015.

- Prest, John, Lord John Russell, London, 1972. 
- Price, D. T. W., A History of St. David's University College, Lampeter, Volume 1: to 1898, Cardiff, 1977.

- Price, D. T. W., Bishop Burgess and Lampeter College, Cardiff, 1987.

- Price, D.T.W., A History of Saint David's University College, Lampeter, volume 1, Cardiff, 1977.

- Price, D.T.W., A History of Saint David's University College, Lampeter, volume 2, Cardiff, 1990.

- Price, Emyr, Lloyd George a'r Eisteddfod Genedlaethol, Caernarfon, 2005.

- Pryce, Huw, J. E. Lloyd and the Creation of Welsh History, Cardiff, 2011.

- Rees, J. Lambert, Timothy Rees of Mirfield and Llandaff, London, 1945.

- Rees, J. Tudor, Disestablishment Points. Objections Answered, London, 1912.

- Renowden, Raymond, A Genial, Kind Divine. Watkin Herbert Williams, 1845-1944, Denbigh, 1998.

- Reynolds, David, The Long Shadow. The Great War and the Twentieth Century, London, 2013.

- Rhys, John and Jones, David Brynmor, The Welsh People, London, 1923.

- Richard, Henry, Letters and Essays on Wales, London, 1884.

- Roberts, Gwyneth Tyson, The Language of the Blue Books, Wales and Colonial Prejudice. Cardiff, 1998.

- Robbins, Keith, England, Ireland, Scotland and Wales. The Christian Church 1900-2000, Oxford, 2008.

- Rowland, Peter, Lloyd George, London, 1975.

- Sandry, Alan, Plaid Cymru. An Ideological Analysis, Cardiff, 2011.

- Shannon, R.T., Gladstone and the Bulgarian Agitation 1876, London, 1963.

- Shannon, Richard. Mr Gladstone and Swansea 1887: Inaugural Lecture Delivered at the College on 18 November 1980. Swansea: University College of Swansea, 1982.

- Shannon, Richard, Gladstone: Heroic Minister 1865-1898, London, 1999.

- Simon, Glyn the Right Rev., the Bishop of Llandaff, The Landmark, London, 1962.

- Spender, J. A., Life, Journalism and Politics, vol.1, London, 1927.

- Stansky, Peter, Ambitions and Strategies, Oxford, 1964.

- Steele, David, Lord Salisbury. A Political Biography, Abingdon, 1999.

- Stephens, Meic (ed.), The New Companion to the Literature of Wales, Cardiff, 1998.

- Symonds, Jellinger C., A Letter to the Lord President of the Committee of Council on the Report on Education in Wales, Llandovery and London, 1848.

- Temple, The Rev. W., Life and Liberty, London, 1918.

- Theomemphus (Aneirin Talfan Davies), Bilingual Bishops and All That, Llandybie, 1958.

- Thomas, J.E., Social Disorder in Britain, 1750-1850. The Power of the Gentry, Radicalism and Religion in Wales, London, 2012.

- Thomas, M. Wynn, In the Shadow of the Pulpit, Cardiff, 2010.

- Thomas, M. Wynn, The Nations of Wales, Cardiff, 2016. 
- Tilney, Chrystral, The Church in Wales, The Disestablishment Conflict; Film Strip Script', Llandaff, 1969.

- Turner, J., The Labour Church. Religion and Politics 1890-1914, London, 2018.

- Wade-Evans, A.W., Papers for Thinking Welshmen, London, 1909.

- Walker, David (ed.), A History of the Church in Wales, Cowbridge, 1977.

- Wallace, Ryland, 'Organise! Organise! Organise!' A Study of Reform Agitations in Wales, 1840-1886, Cardiff, 1991.

- Watkin, Thomas Glyn, The Legal History of Wales, Cardiff, 2012.

- Williams, David, The Rebecca Riots: A Study in Agrarian Discontent, Cardiff, 1955.

- Williams, David, A History of Modern Wales, London, 1969.

- Williams, Glanmor, Religion, Language and Nationality in Wales, Cardiff, 1979.

- Williams, Gwyn A., The Merthyr Rising, Cardiff, 1978.

- Williams, Gwyn A., The Welsh in their History, London, 1982.

- Williams, Gwyn A., When was Wales? London, 1991.

- Williams, J. Gwynn, The University Movement in Wales, Cardiff 1993.

- Wilkinson, Richard, Lloyd George. Statesman or Scoundrel, London, 2018.

- Wilson, John R., Memoralizing History; Public Sculpture in Industrial South Wales, Aberystwyth, 1996.

- Wright, Martin. Wales and Socialism. Political Culture and National Identity Before the Great War, Cardiff, 2016.

- Zimmern, Alfred E., My Impressions of Wales, London, 1921.

- Legatum Institute, The Future of the Union (Roads to Freedom), London, 2014.

Chapters in books:

- Aubel, Felix, 'The Conservatives in Wales, 1880-1935', in Martin Francis and Ina Zweiniger-Bargielowska (eds.), The Conservatives and British Society, 1880-1990, Cardiff, 1996.

- Ballinger, Chris, 'The Parliament Act 1949', in David Feldman (ed.), Law in Politics, Politics in Law, Oregon, 2013.

- Bebbington, D. W., 'Gladstone and the Nonconformists: A Religious Affinity in Politics', in Derek Barker (ed.), Church Society and Politics, Oxford, 1975.

- Bebbington D. W., 'Religion and National Feeling in Nineteenth-Century Wales and Scotland', in Stuart Mews (ed.), Religion and National Identity, Oxford, 1982.

- Benbough-Jackson, Mike, 'Celebrating a Saint on His Home Ground: St. David's Day in St. David's Diocese during the Nineteenth Century', in W. Gibson and J. Morgan-Guy (eds.), Religion and Society in the Diocese of St. David's 1485-2011, Farnham, 2015.

- Boyce, D.G.,' 'The Marginal Britons”: The Irish', in Colls, R. and Dodd, P., (eds.), Englishness. Politics and Culture 1880-1920, London, 1986. 
- Brown, Roger Lee, 'Pastoral Problems and Legal Solutions', in Essays in Canon Law. A Study of the Law of the Church in Wales, Cardiff, 1992.

- Brown, Roger L., 'In Pursuit of a Welsh Episcopate', in Robert Pope (ed.), Religion and National Identity Wales and Scotland 1730 - 2000, Cardiff, 2001.

- Cosgrove, Richard A., 'A Useable Past: History and Politics of National Identity in Late Victorian England', in Nancy LoPatin-Lummis (ed.), Public Life and Public Lives. Politics and Religion in Modern British History, Oxford, 2008.

- Cunningham, David, 'The Conservative Party and Patriotism', in Colls, Robert and Dodd, Philip (eds.), Englishness; Politics and Culture 1880-1920, London, 1986.

- Davies, John, 'Victoria and Victorian Wales', in Jenkins, Geraint H. and Smith, J. Beverley (eds.), Politics and Society in Wales, 1840-1922, Cardiff 1988.

- Day, Graham and Suggett, Richard, 'Conceptions of Wales and Welshness: Aspects of Nationalism in Nineteenth-century Wales', in Gareth Rees, Janet Bujra, Paul Littlewood, Howard Newby and Teresa L. Rees (eds.), in Political Action and Social Identity. Class, Locality and Ideology, London, 1985.

- Dunbabin, J.P.D., 'The Welsh 'Tithe War', in J.P.D. Dunbabin, Rural Discontent in Nineteenth-Century Britain, London, 1974.

- Dunbabin, J.P.D., 'Ideas and Arguments - the Tithe War', in J.P.D. Dunbabin, Rural Discontent in Nineteenth-Century Britain, London, 1974.

- Edwards, Andrew and Griffith, Wil, 'Welsh national identity and governance, 1918-45', in Duncan Tanner, Chris Williams, Wil Griffith and Andrew Edwards (eds.), Debating nationhood and governance in Britain, 1885-1945, Manchester, 2006.

- Edwards, A., 'God and Caesar', in Willie, A.R., (ed.), Living Authority. Essays in Memory of Archbishop Derrick Childs, Penarth, 1990.

- Escott, Margaret, 'Monmouth Borough', in Fisher, D. R. (ed.), The History of Parliament: The House of Commons 1820-1832, London, 2009.

- Escott, Margaret, 'Hall, Benjamin (1802-1867), of Abercarn and Llanofer Court, Mon.', in Fisher, D. R. (ed.), The History of Parliament: The House of Commons 1820-1832, London, 2009.

- Evans, Eric, 'Englishness and Britishness: National identities, c.1790-c.1870', in Grant, A. and Stringer, Keith J., (eds.), Uniting the Kingdom, The making of British History, London, 1995.

- Evans, Neil, 'A Nation in a Nutshell': The Swansea Disestablishment Demonstration of 1912 and the Political culture of Edwardian Wales', in R.R. Davies and Geraint Jenkins (eds.), From Medieval to Modern Wales. Historical essays in Honour of Kenneth $O$. Morgan and Ralph A. Griffiths, Cardiff, 2004.

- Evans, Neil, 'The Changing Context of Welsh Historiography, 1890-2000', in Brocklehurst, H. and Phillips, R., (eds.), History, Nationhood and the Question of Britain, London, 2004.

- Evans, R.J.W, 'National Historiography, 1850-1950: The European Context', in 
- Green, C.A.H., The Archbishop of Wales, 'Disestablishment and Disendowment in Wales', in The Official Handbook of the Church in Wales, Cardiff, 1936.

- Griffith, Wil, 'Devolutionist tendencies in Wales, 1885-1914', in Duncan Tanner, Chris Williams, Wil Griffith and Andrew Edwards (eds.), Debating nationhood and governance in Britain, 1885-1945, Manchester, 2006.

- Hopkin, Deian, 'Labour's Roots in Wales, 1880-1900', in Duncan Tanner, Chris Williams and Deian Hopkin (eds.), The Labour Party in Wales, 1900-2000, Cardiff, 2000.

- Howell, David, 'A 'Less Obtrusive and Exacting' Nationality: Welsh Ethnic Mobilisation in Rural Communities, 1850-1920', in David Howell (ed.), Roots of Rural Ethnic Mobilisation. Comparative Studies on Governments and Non-Dominating groups in Europe, 1850-1940, Vol. VII, Dartmouth, 1993.

- Jenkins, Geraint H., 'Wales, the Welsh and the Welsh Language', in G. H. Jenkins (ed.), The Welsh Language and its Social Domains, 1801-1911, Cardiff, 2000.

- Jones, D. Gwenallt, 'National Movements in Wales in the Nineteenth Century', in D. Myrddin Lloyd (ed.), The Historical Basis of Welsh Nationalism, Cardiff, 1950.

- Jones, Ieuan Gwynedd, 'The Liberation Society and Welsh Politics, 1844-68', Explorations and Explanations. Essays in the Social History of Victorian Wales, Llandysul, 1981, pp.217-235.

- Jones, Ieuan Gwynedd, 'Ecclesiastical economy: aspects of church building in Victorian Wales’, in Welsh Society and Nationhood. Historical Essays Presented to Glanmor Williams, Cardiff, 1984.

- Jones, Ieuan Gwynedd, 'Franchise Reform and Glamorgan Politics 1869-1921', in Prys Morgan (ed.). Glamorgan County History, Vol.VI, Cardiff, 1988.

- Jones, Ieuan Gwynedd, 'Religion and Society in the First Half of the Nineteenth Century', in Mid-Victorian Wales. The Observers and the Observed, Cardiff, 1992, pp.123.

- Jones, Ieuan Gwynedd, '1848 and 1868: “Brad y Llyfrau Gleision” and Welsh Politics', in Mid-Victorian Wales. The Observers and the Observed, Cardiff, 1992, pp.103-165.

- Jones, R. Tudur, 'Glamorgan Christianity in 1905-6: A Statistical survey’, in Prys Morgan (ed.). Glamorgan County History, Vol.VI, Cardiff, 1988.

- Jones, Robert Tudur, 'Religion, Nationality and State in Wales, 1840-1890', in D. A. Kerr (ed.), Religion, State and Ethnic Groups, Aldershot, 1992.

- Knight, Frances, 'Welsh Nationalism and Anglo-Catholicism: The Politics and Religion of J. Arthur Price (1861-1942), in Robert Pope (ed.), Religion and National Identity, c. 1700-2000, Cardiff, 2001.

- Lewis, Anthony T., 'The Case for Constitutional Renewal in the Church of Wales', in Norman Doe (ed.), Essays in Canon Law. A Study of the Law of the Church in Wales, Cardiff, 1992. 
- Machin, Ian, 'Disestablishment and democracy, c.1840-1930', in Eugenio F. Biagini (ed.), Citizenship and community. Liberals, radicals and collective identities in the British Isles, 1865-1931, Cambridge, 1996.

- McClelland, V. Alan, 'Gladstone and Manning: a Question of Authority’, in Peter J. Jagger, (ed.), Gladstone, Politics and Religion, London, 1985.

- Mitchell, Leslie, 'Britain's Reaction to the Revolutions', in R.J.W. Evans and Haertmut Pogge Von Strandmann (eds.), The Revolutions in Europe, 1848-1849, Oxford, 2000.

- Morgan-Guy, John, 'The Church in Wales', in Richard C. Allen and David Ceri Jones with Trystan O. Hughes (eds.), The Religious History of Wales. Religious Life and Practice in Wales from the Seventeenth Century to the Present Day, Welsh Academic Press, Cardiff, 2014.

- Morgan. D. Densil, “The essence of Welshness”?: some aspects of Christian faith and national identity in Wales c.1900-2000’, in Robert Pope (ed.), Religion and National Identity Wales and Scotland 1730 - 2000, Cardiff, 2001.

- Morgan, Kenneth O., 'Tom Ellis versus Lloyd George: The Fractured Consciousness of Fin-de-siecle Wales’, in Modern Wales: Politics, Places and People, Cardiff, 1995.

- Morgan, Prys, 'The Clouds of Witnesses. The Welsh Historical Tradition', in R. Brinley Jones (ed.), Anatomy of Wales, Cowbridge, 1972.

- Morgan, Prys, 'From Long Knives to Blue Books', in Welsh Society and Nationhood. Historical Essays Presented to Glanmor Williams, Cardiff, 1984.

- Morgan, Prys, 'Keeping the Legends Alive', in Tony Curtis (ed.), Wales: The Imagined Nation. Studies in Cultural and National Identity, Cardiff, 1986.

- Morgan, Prys, 'From a Death to a View: The Hunt for the Welsh Past in the Romantic Period', in Hobsbawn, Eric and Ranger, Terence (eds.), The Invention of Tradition, Cambridge, 1992.

- Morgan, Prys, 'Early Victorian Wales and its crisis of identity', in L. Brockliss and D. Eastwood (eds.), A Union of Multiple Identities. The British Isles c. 1750-c.1850, Manchester, 1997.

- Morgan, Prys, 'A Nation of Nonconformists: Thomas Rees (1815-85) and Nonconformist History', in Neil Evans and Huw Pryce (eds.), Writing a Small Nation's Past. Wales in Comparative Perspective, 1850-1950, Farnham, 2013.

- Morgan, Prys, 'Welsh National Consciousness - The Historical Background', in W. J. Morgan, (ed.), The Welsh Dilemma, Some Essays on Nationalism in Wales, Llandybie, 1973.

- Morgan, Prys, 'The Gwerin of Wales: Myth and Reality', in I. Hume and W.T.R. Pryce, (eds.), The Welsh and their Country, Llandysul, 1986.

- Morgan-Guy, J., 'The Church in Wales', in Allen, R., Jones, David Ceri, with Hughes, Trystan O., (eds.), The Religious History of Wales. Religious Life and Practice in Wales from the seventeenth century to the present day, Cardiff, 2014.

- Norton, Philip, 'Parliament Act 1911 in its Historical Context', in David Feldman (ed.), Law in Politics, Politics in Law, Oregon, 2013. 
- O’Day, Alan, 'Irish Home Rule and Liberalism', in Alan O’Day (ed.), The Edwardian Age: Conflict and Stability, 1900-1914, London, 1979.

- Okey, Robin, 'Wales and Eastern Europe: Small Nations in Comparison', in CharlesEdwards, T. M. and Evans, R. J. W. Evans, (eds.), Wales and the Wider World. Welsh History in an International Context, Donington, 2010, pp.184-217.

- O’Leary, Paul, 'Religion, Nationality and Politics: Disestablishment in Ireland and Wales, 1868-1914', in John R. Guy and W.G. Neely (eds.), Contrasts and Comparisons: Studies in Irish and Welsh Church History, Welshpool, 1999.

- O'Leary, Paul, 'Accommodation and Resistance: A Comparison of Cultural Identities in Ireland and Wales, c.1880-1914', in S.J. Connolly (ed.), Kingdom United? Great Britain and Ireland since 1500. Integration and Diversity, Dublin, 1999.

- O'Leary, Paul; 'The Languages of Patriotism in Wales 1840-1880', in G. H. Jenkins (ed.), The Welsh Language and its Social Domains 1801-1911, Cardiff, 2000.

- O'Leary, Paul, 'A Tolerant Nation? Anti-Catholicism in Nineteenth-Century Wales', in R.R. Davies and Geraint H. Jenkins (eds.), From Medieval to Modern Wales. Historical Essays in Honour of Kenneth O. Morgan and Ralph A. Griffiths, Cardiff, 2004.

- Okey, Robin, 'Education and Nationhood in Wales, 1850-1940', in Janusz Tomiak (ed.), Schooling, Educational Policy and Ethnic Identity, New York, 1991.

- Peart-Binns, John S., Herbert Hensley Henson. A Biography. Lutterworth, 2013.

- Pope, Robert, 'Christ and Ceasar? Welsh Nonconformists and the State, 1914-1918', in Matthew Cragoe and Chris Williams (eds.), Wales and War. Society, Politics and Religion in the Nineteenth and Twentieth Centuries, Cardiff, 2007.

- Price, William, 'Church and Society in Wales since Disestablishment', in Paul Badham, (ed.), Religion, State and Society in Modern Britain, Lampeter,1989.

- Pryce, Huw, 'Modern Nationality and the Medieval Past: The Wales of John Edward Lloyd', in R.R. Davies and Geraint Jenkins (eds.), From Medieval to Modern Wales. Historical essays in Honour of Kenneth O. Morgan and Ralph A. Griffiths, Cardiff, 2004.

- Purvey-Tyrer, Neil, 'Lloyd-George, The Bishop of St. Asaph and the Disestablishment Controversy', in Judith Loades (ed.), The Life and Times of David Lloyd-George, Bangor, 1991.

- Robbins, Keith, 'Religion and Identity in Modern British History', in Stuart Mews (ed.), Religion and National Identity, Oxford 1982.

- Robbins, Keith, 'Church Establishment, Disestablishment and Democracy in the United Kingdom of Great Britain and Ireland, 1870-1920', in Keith Robbins (ed.), Political and Legal Perspectives, Leuven University Press, 2010.

- Roberts, Enid Pearce, 'The Welsh Church, Canon Law and the Welsh Language', in Norman Doe (ed.), Essays in Canon Law. A Study of the Law of the Church in Wales, Cardiff, 1992.

- Roberts, Glyn, 'Carmarthenshire: Political Affairs from 1536 to 1900', in Aspects of Welsh History. Selected Papers of the late Glyn Roberts, Cardiff, 1969. 
- Roberts, Gwyneth Tyson, '”Under the Hatches.” English Parliamentary Commissioners' Views of the People and Language of Mid-nineteenth-century Wales', in Bill Schwarz (ed.), The Expansion in England. Race, ethnicity and cultural history, London, 1996.

- Sherrington, Emlyn, 'Welsh Nationalism, the French Revolution and Influence of the French Right 1880-1930', in David Smith (ed.), A People and a Proletariat. Essays in the History of Wales 1780-1980, London, 1980.

- Stead, Peter, 'Labour Party and the Claims of Wales', in Osmond John (ed.), The National Question Again. Welsh Political Identity in the 1980s', Gomer Press, 1985.

- Thomas, the Honourable Mr. Justice, 'Legal Wales: Its Modern Origins and its Role after Devolution. National Identity, the Welsh Language and Parochialism', in Thomas Glyn Watkin (ed.), Legal Wales: Its Past, its Future, Cardiff, 2001.

- Thompson, David M., 'The politics of the enabling act (1919)', in Derek Baker (ed.), Studies in Church History, vol.12, Church Society and Politics, Oxford, 1975.

- Walker, David and Walker, Margaret S., 'Epilogue: A New Diocese, 1923', in Owain W. Jones and David Walker (eds.), Links with the Past. Swansea and Brecon Historical Essays, Llandybie, 1974.

- Ward, P., 'Nationalism and National Identity in British Politics, c.1880s to 1914', in Brocklehurst, H. and Phillips, R., (eds.), History, Nationhood and the Question of Britain, London, 2004.

- Watkin, Thomas Glyn, 'Authority within the Church in Wales', in Willie, A.R., (ed.), Living Authority. Essays in Memory of Archbishop Derrick Childs, Penarth, 1990.

- Watkin, Thomas Glyn, 'Disestablishment and Self-Determination and the Constitutional Development of the Church in Wales', in Norman Doe (ed.), Essays in Canon Law, Cardiff, 1992.

- Weston, Corinne Comstock, 'Salisbury and the Lords, 1868-1895', in Jones, Clyve and Lewis, David, (eds.), Peers, Politics and Power: The House of Lords, 1603-1911, Hambledon, 1986.

- White, Erin, 'From Ejectment to Toleration in Wales, 1662-89', in Alan P. F. Sell (ed.), The Great Ejectment of 1662, Eugene, Oregon, 2012.

- Williams, Chris, 'Sir Thomas Phillips and the Problem of 'Class-Antagonism', in Reform and Reformers in Nineteenth Century Britain, Michael J. Turner (ed.), Sunderland, 2004.

- Williams, Chris, 'Popular Movements, 1780-1850', in Chris Williams and Sian Rhiannon Williams (eds.), The Gwent County History, Vol.4, Industrial Monmouthshire, 17801914, Cardiff, 2011.

- Williams, Chris, 'Cartooning the rise of Labour, 1900-21', in Chris Williams and Andrew Edwards (eds.), The Art of the Possible. Politics and Governance, 1885-1997: Essays in Memory of Duncan Tanner, Manchester, 2015.

- Williams, Glyn, 'The Ideological Basis of Nationalism in Nineteenth Century Wales: The Discourse of Michael D. Jones', in Glyn Williams (ed.), Crisis of Economy and Ideology: Essays on Welsh Society, 1840-1980, Bangor, 1983. 
- Williams, Gwyn A., 'Ambiguous Hero: Hugh Owen and Liberal Wales', in The Welsh in their History, London, 1982, pp.151-170.

- Williams, Harri, 'St. David's and Disestablishment: Reassessing the Role of Bishop John Owen', in , W. Gibson and J. Morgan-Guy (eds.), Religion and Society in the Diocese of St. David's 1485-2011, Farnham, 2015.

- Williams, Llewelyn, 'Political Life', in Viscountess Rhondda, Mackworth, Margaret Haig, (ed.), D. A. Thomas, Viscount Rhondda, by his Daughter [Viscountess Rhondda] and Others, London, 1921.

- Winston, Jeremy, 'The Church of England and the Church in Wales. Two Radically Different Churches?', in Willie, A.R., (ed.), Living Authority. Essays in Memory of Archbishop Derrick Childs, Penarth, 1990.

- Yates, Nigel, .Wind, Rain and the Holy Spirit: Welsh Evangelism in a Pan-Celtic Context 1750-1850', in Nigel Yates (ed.), Bishop Burgess and his World. Culture, Religion and Society in Britain, Europe and North America in the Eighteenth and Nineteenth Centuries, Cardiff, 2007.

- Yates, Nigel, 'A Reforming Episcopate', in Welsh Church from Reformation to Disestablishment 1603-1920, Cardiff, 2007.

Articles:

- Anson, William R., 'The Parliament Act and the British Constitution', 12 Columbia Law Review (1912), pp.673-684.

- Ballinger, Chris, 'Hedging and Ditching: The Parliament Act 1911', Parliamentary History, vol.30, issue 1 (February 2011), pp.19-32.

- Bebbington, D. W., 'The Free Church M.P.s of the 1906 Parliament', Parliamentary History, vol.24, issue 1 (February 2005), pp.136-150.

- Berrington, Hugh, 'Partisanship and dissidence in the nineteenth centuty House of Commons', Parliamentary Affairs, vol.21, issue 1 (June 1968), pp.338-374.

- Benbough-Jackson, Mike, 'Five-Foot-Five Nation: Size, Wales and the Great War', Welsh History Review, vol.28, no.4 (December 2017), pp.618-645.

- Blakeley, Derek W., 'The Archbishop of Canterbury, the Episcopal Bench, and the Passage of the 1911 Parliament Act', Parliamentary History, vol.27, issue1 (February 2008), pp.141-154.

- Bonney, Norman, 'Established Religion, Parliamentary Devolution and New State Religion in the UK', Parliamentary Affairs, vol.66, issue 2 (April 2013), pp.425-442.

- Brinkley, Richard, 'Connop Thirlwell, Bishop of St. David's', Ceredigion, vol.8, no.1 (1972), pp.131-151.

- Brock, Michael, 'The Strange Death of Liberal England', Albion: A Quarterly Journal Concerned with British Studies, vol.17, no.4 (Winter, 1985), pp.409-423. 
- Brown, Roger Lee, 'What of the Church in Wales?', Ecclesiastical Law Journal, vol.3, issue 12 (January 1993), pp.20-29.

- Brown, Roger L., 'Traitors and compromisers', Journal of Welsh religious history. Vol.3 (1995), pp.35-53.

- Brown, Roger Lee, ‘The Disestablishment of the Church in Wales?', Ecclesiastical Law Journal, vol. 5, issue 25 (July 1999), pp.252-264.

- Brown, Roger L., 'The 1870 Appointment to the Diocese of St. Asaph. A Note', Journal of Welsh religious history. Vol.5 (2005), pp.97-100.

- Brown, Roger L., 'The Newtown Clerical Association 1876-1877', The Montgomeryshire Collections, vol.104 (2016), pp.77-83.

- Carr, W., 'A Developing Establishment', Theology, 102 (1999), pp.2-10.

- Chambers, Paul, 'Out of Taste, Out of Time: The Future of Nonconformist Religion in Wales in the Twenty-First Century', Contemporary Wales, vol.21, no.1 (September 2008), PP.86-100.

- Charmley, Gerard, 'J. Vyrnwy Morgan (1861-1925): Wales in Another Light', Welsh History Review, vol.24, no.2 (December 2008), pp.120-143.

- Charmley, Gerald, 'Alfred Thomas and Wales in Parliament, 1885-1910', Transactions of the Honourable Society of Cymmrodorion', vol.16 (2010), pp.39-60.

- Chase, Malcolm, 'Rethinking Welsh Chartism', Llafur, Journal of Welsh Labour History, vol.10, no.3 (2010), pp.39-54.

- Clarke, P.F., 'The Electoral Position of the Liberal and Labour Parties, 1910-1914', The English Historical Review, vol.90, no.357 (October 1975), pp.828-836.

- Conybeare, W. J., 'The Church in the Mountains', Edinburgh Review, 97 (1853), pp. 342-80, reprinted in Conybeare, W. J. (1855), Essays Ecclesiastical and Social. Reprinted, with Additions, from the Edinburgh Review (London), pp.1-56.

- Cosgrove, Richard A., 'Reflections on the Whig Interpretation of History', Journal of Early Modern History, vol.4, issue 2 (2000), pp.147-167.

- Crickhowell, Lord, 'The Conservative Party in Wales 1888-1998', 20 ${ }^{\text {th }}$ Welsh Political Archive Annual Lecture, National Library of Wales, 2006.

- Cragoe, Matthew, 'YY Gohebydd', and the General Election of 1868 in Wales', Transactions of the Honourable Society of Cymmrodorion', vol.4 (1998), pp.48-64.

- Cragoe, Matthew, 'A Question of Culture: The Welsh Church and the Bishopric of St. Asaph, 1780-1820', Welsh History Review, vol.18, no.2 (December 1996), pp.228-254.

- Cragoe, Matthew, 'George Osborne Morgan, Henry Richard, and the Politics of Religion in Wales, 1868/74', Parliamentary History, 19 (2000), pp.118-130.

- Cragoe, Matthew, 'Welsh Electioneering and the Purpose of Parliament: "From Radicalism to Nationalism” Reconsidered', Parliamentary History, 17 (1998), pp.113130.

- Davies, B. L., 'The Right to a Bilingual Education in Nineteenth Century Wales', Transactions of the Honourable Society of the Cymmrodorion (1988), pp.133-151. 
- Davies, D.P., 'Welsh Anglicanism: A Renewed Church for a Reviving Nation', Trivium, Vol.38 (2008), pp.105-121.

- Davies, R. R., ‘Colonial Wales’, Past \& Present, no.65 (November 1974), pp.3-23.

- Davies, T.Huw., 'The Right Rev. John Owen, Bishop of St. David’s, (1854-1926), Transactions of the Honourable Society of Cymmrodorion', (1928), pp.170-182.

- Davies, T. Huw, 'The Rt. Hon. Sir Ellis J. Ellis Griffith, (1860-1927), Transactions of the Honourable Society of Cymmrodorion', (1928), pp.183-190.

- Devine, T.M., 'The Break-Up of Britain? Scotland and the End of Empire: The Prothero Lecture', Transactions of the Royal Historical Society, sixth series, vol.16 (2006), pp.163-180.

- Dodd, A. H., 'Nationalism in Wales', Transactions of the Honourable Society of Cymmrodorion, (1970, Part 1), pp.33-49.

- Doe, Norman, 'The Notion of a National Church: A Juridical Framework', Law \& Justice. Christian Law Review, 149 (2002), pp.77-91.

- Doe, Norman, 'The Church in Wales and the State: A Juridical Perspective', Journal of Anglican Studies, vol.2, issue 1 (June 2004), pp.99-124.

- Drewry, G. and Brock, J., 'Prelates in Parliament', Parliamentary Affairs, Volume 24, Issue 3 (Summer 1971), pp.222-250.

- Dutton, D. J., 'The Unionist Party and Social Policy 1906-1914', The Historical Journal, vol.24, no.4 (1981), pp.871-884.

- Edwards, E.W., 'Cardiff becomes a city', Morgannwg, Vol.9 (1965), pp.80-87.

- Ellens, J.P., 'Lord John Russell and the Church Rate Conflict: The Struggle for a Broad Church, 1834-1868', Journal of British Studies, vol.26, no.2 (April 1987), pp.232-257.

- Ellis, John S, “"The Methods of Barbarism” and the "Rights of Small Nations”: War Propaganda and British Pluralism', Albion, vol.30, no.1 (Spring 1998), pp.49-75.

- Ellis, John S., 'Reconciling the Celt: British National Identity, Empire, and the 1911 Investiture of the Prince of Wales', Journal of British Studies, vol.37, no.4 (October 1998), pp.391-418.

- Erasmus, T.P., 'The Flint Boroughs By-Election of January 1913’, Flintshire Historical Society Journal, vol.31 (1983-1984), pp.193-196.

- Evans, Adam, 'An Interlude of Agreement? A Reassessment of the Conference on Devolution's 'Consensus' on Powers', Contemporary British History, vol.29, no.4, (December 2015), pp.421-440.

- Evans, Adam, 'Wales as nation or region? The Conference on Devolution's Judiciary Sub-Committee, 1919-20', Welsh History Review, vol.28, no.1 (June 2016), pp.146-173.

- Evans, Gareth W., 'The Aberdare Report and education in Wales, 1881', Welsh History Review, vol.11, no.2 (Dec.1982), pp.150-172.

- Evans-Jones, Peris, ‘Evan Pan Jones-Land Reformer’, Welsh History Review, vol.4, no.2 (December 1968), pp.143-159. 
- Evans, Neil, 'Finding a new story: The search for a usable past in Wales, 1869-1930', Transactions of the Honourable Society of the Cymmrodorion, 2003, New Series, vol. 10 (2004), pp.144-162.

- Evans, R. J. W., 'Nonconformity and Nation', Welsh History Review, vol.25, no.2 (December 2010), pp.231-238.

- Fowler, Carwyn, 'Nationalism and the Labour Party in Wales', Llafur, vol.8, no.4 (2003), pp. 97-105.

- Frank, Cathrine O., 'Trial Separations: Divorce, Disestablishment, and Home Rule in "Phineas Redux"”, College Literature, vol.35, no.3, Law and Literature (Summer, 2008), pp.30-56.

- Fraser, Maxwell, 'Sir Benjamin and Lady Hall in the 1840s', National Library of Wales Journal, vol.14, no.2 (Winter 1965), pp.194-213.

- Fraser, Maxwell, 'Lady Llanover and Her Circle', Transactions of the Honorable Society, of Cymmrodorion (1968), pp.170-196.

- Freeman, Peter, 'The Response of Welsh Nonconformity to the Oxford Movement', Welsh History Review, vol.20, no.3 (June 2001), pp.435-465.

- Gaffney, Angela, 'A National Valhalla for Wales', Transactions of the Honourable Society of Cymmrodorion', vol.5 (1999), pp.131-144.

- George, William B., 'Welsh Disestablishment and Welsh Nationalism', Historical Society of the Church in Wales, 25 (1970), pp.77-91.

- Gibson, William, 'Gladstone and the Llandaff vacancy of 1882-3', Transactions of the Honourable Society, of Cymmrodorion (1987), pp.105-111.

- Gibson, William, ““A Great Excitement” Gladstone and Church Patronage 1860-1894’, Anglican and Episcopal History, vol.68, no.3 (September 1999), pp.372-396.

- Gibson, W.T., 'Fresh light on Bishop Connop Thirlwall of St. David’s (1840-1875), Transactions of the Honourable Society, of Cymmrodorion (1992), pp.141-158.

- Griffith, Wil, 'Saving the Soul of the Nation: Essentialist Nationalism and Interwar Rural Wales', Rural Wales, (2010), 21, 2, pp.177-194.

- Harling, Philip, 'Rethinking “Old Corruption”', Past and Present, No.147 (May 1995), pp.127-158.

- Harlow, A., Cranmer, F. and Doe, N., 'Bishops in the House of Lords: a critical analysis', Public Law, (autumn, 2008), pp.490-509.

- Harris, C. and Startup, R., 'The Church in Wales: A Neglected Welsh Institution', Contemporary Wales. Vol. 7 (1995), pp.97-116.

- Herrick, Francis H., 'The Origins of the National Liberal Federation', Journal of Modern History, vol.17, no.2 (June 1945), pp.116-129.

- Heyck, T.W., 'Home Rule, Radicalism, and the Liberal Party, 1886-1895', Journal of British Studies, vol.13, no.2 (May 1974), pp.66-91.

- Horwill, Herbert W., 'The Referendum in Great Britain', Political Science Quarterly, vol. 26, No. 3 (September 1911), pp. 415-431. 
- Howell, David W., 'The Land Question in nineteenth-century Wales, Ireland and Scotland: a comparative study', Agricultural History Review, vol.61, no.1 (June 2013), pp.83-110).

- Hughes, Michael, 'Archbishop Davidson, the "Edwardian Crisis," and the Defense of the National Church', Journal of Church and State, vol.57, no.2, pp.217-242.

- Hughes, Herbert, ‘Thomas Price (Carnhuanawc), Cwm-du, 1787-1848', Brycheiniog, vol.34 (2002), pp.133-152.

- Inglis, K.S., 'Patterns of Religious Worship in 1851', Journal of Ecclesiastical History, II, i (April 1960), pp.74-86.

- Jalland, Patricia and Stubbs, John, 'The Irish Question after the outbreak of war in 1914: some unfinished party business’, English Historical Review, vol.96, no.381 (Oct. 1981), pp.777-807.

- Jenkins, Geraint H., “Taphy-land historians' and the Union of England and Wales 15362007', Journal of Irish and Scottish Studies, vol.1, issue 2 (2008), pp.1-27.

- Jenkins, Gwyn, 'The Welsh Outlook', National Library of Wales journal, Vol.24, no.,4 (Winter 1986), pp.463-492.

- Jenkins, Philip, 'The Plight of Pygmy Nations; Wales in Early Modern Europe', North American Journal of Welsh Studies, Vol.2, 1(Winter 2002), pp.???

- Jenkins, R. T., 'The development of Nationalism in Wales', Sociological Review, vol.27, issue 2 (April 1935), pp.169-182.

- Johnes, Martin, 'For Class and Nation: Dominant Trends in the Historiography of Twentieth-Century Wales’, History Compass, 8/11 (2010), pp.1257-1274.

- Johnes, Martin, 'History and the Making and Remaking of Wales', History, vol.100, issue 343 (2015), pp.667-684.

- Jones, Aled and Jones, Bill, 'The Welsh world and the British Empire, c.1851-1939: An exploration’, The Journal of Imperial and Commonwealth History, vol.31, no.2 (2003), pp.57-81.

- Jones, David J.V., 'Chartism in Welsh Communities', Welsh History Review, vol.6, no.3 (1972-3), pp.243-61.

- Jones, David J.V., 'Rebecca, Crime and Policing: A Turning Point in Nineteenth-Century Attitudes', Transactions of the Honourable Society of Cymmrodorion (1990), pp.99-115.

- Jones, E.D., 'Welsh Church Commission Records', National Library of Wales journal, II, (1941-2), pp.82-83.

- Jones, Francis, 'A Victorian Bishop of Llandaff', National Library of Wales Journal, vol.19, no.1 (Summer 1975), pp.14-56.

- Jones, Huw, 'The Church in Wales: A Church for the Welsh Nation', Law \& Justice, 149 (2002), pp.134-144.

- Jones, Ieuan Gwynedd, 'Church Building in Flintshire in the Mid-Nineteenth Century', Flintshire Historical Society journal, vol. 29 (1979/1980), pp.89-112.

- Jones, J. Graham, 'E.T. John and Welsh Home Rule, 1910-14’, Welsh History Review, vol.13, no.4 (December 1987), pp.453-467. 
- Jones, J. Graham, 'Early campaigns to secure a Secretary of State for Wales, 1890-1939', Transactions of the Honourable Society of Cymmrodorion', (1988), pp.153-175.

- Jones, J. Graham, 'Socialism, devolution and a Secretary of State for Wales, 1940-64', Transactions of the Honourable Society of Cymmrodorion', (1989), pp.135-159.

- Jones, J. Graham, 'Lloyd George, Edward VII and a 'Minister for Wales', Bulletin of the Board of Celtic Studies, vol.37 (1990).

- Jones, J. Graham, 'Framing 'The People’s Budget': a New Perspective', Transactions of the Honourable Society of Cymmrodorion', (1991), pp.285-298.

- Jones, J. Graham, 'Lloyd George, Cymru Fydd and the Newport meeting of January 1896', National Library of Wales Journal, vol.29, no.4 (Winter 1996), pp.435-453.

- Jones, J. Graham, 'Michael Davitt, David Lloyd George and T.E. Ellis: The Welsh Experience', Welsh History Review, vol.18, no.3 (June 1997), pp.450-482.

- Jones, J. Graham, 'Lloyd George, W. Llewelyn Williams M.P. and the 1916 Conscription Bill', National Library of Wales Journal, vol.31, no.2 (Winter 1999), pp.173-187.

- Jones, J. Graham, 'Arthur J. Williams M.P. (1830-1911’, Morgannwg, vol.44 (2000), pp.105-128.

- Jones, J. Graham, 'Dean Charles Vaughan, A. J. Williams and the Disestablishment Debate of November 1885', Journal of Welsh religious history, vol.8 (2000), pp.43-61.

- Jones, J. Graham, 'The Journalist as Politician: W. Llewelyn Williams M.P. (1867-1922', Carmarthenshire Antiquary, vol.36 (2001).

- Jones, J. Graham, 'S. O. Davies and the Government of Wales Bill, 1955', Llafur, vol.8, no.7 (2002), pp.67-77.

- Jones, J. Graham, 'QQuietly I hope to push om Welsh questions substantially': Thomas Edward Ellis as Second Whip', Journal of the Merioneth Historical and Record Society, Vol.14, pt.3 (2004), pp.230-239.

- Jones, J. Graham, 'A Proved and Loyal Friendship: The Diary of W. Llewelyn Williams M.P., National Library of Wales journal, vol.34, no.3 (2008), pp.322-374.

- Jones, Keith B., 'The religious climate of the Chartist insurrection at Newport, Monmouthshire, $4^{\text {th }}$ November 1839', Journal of Welsh religious history, vol.5 (1997), pp.57-71.

- Jones, Marian Henry, 'Judge A.J. Johnes, 1808-1871 Patriot and Reformer’, Montgomeryshire Collections, vol.58, part 1 (1963), pp.3-20.

- Jones, Marian Henry, 'Wales and Hungary', Transactions of the Honorable Society, of Cymmrodorion (1968, part 1), pp.7-27.

- Jones, Mark Ellis, “An Invidious Attempt to Accelerate the Extinction of Our Language': The Abolition of the Court of Great Sessions and the Welsh Language', Welsh History Review, vol.19 (December 1998), no.2, pp.643-678.

- Jones, Mark Ellis, “Wales for the Welsh’: The Welsh County Court Judgeships, c. 18681900’, Welsh History Review, vol.19 (December 1999), no.4, pp.226-264.

- Jones, Peter Meurig, 'The Welsh Church Acts Fund of Denbighshire County Council', Denbighshire Historical Society Transactions, vol.49 (2000), pp.72-94. 
- Jones, R. Merfyn, 'Beyond Identity? The Reconstruction of the Welsh', Journal of British Studies, vol.31, no.4 (October 1992), pp.330-357.

- Jones, R. Tudur, 'The Origins of the Nonconformist Disestablishment Campaign 18301840', Journal of the Historical Society of the Church in Wales, vol. XX (1970), pp.3976.

- Kollar, Rene, 'The Anglo-Catholic Campaign against the Revision of the Book of Common Prayer: The Hickleton Conference of 1911', Studia Liturgica, vol.23 (1993), pp.194-206.

- Lambert, W.R., 'The Welsh Sunday closing act 1881', Welsh History Review, vol.6, no.2 (December 1972), pp.161-189.

- Lambert, W.R., 'Some working class attitudes towards religion in nineteenth-century Wales’, Llafur, vol.2, no.1 (Spring 1976), pp.4-17.

- Lerry, George, 'A.G. Cambrensis', Journal of the Historical Society of the Church in Wales, vol.1, no.2 (1947), pp.72-80.

- Lloyd-Jones, Naomi, 'Liberalism, Scottish Nationalism and the Home Rule Crisis, c. 1886-93’, English Historical Review, vol.129, no.539 (2014), pp.862-887.

- Lloyd-Jones, Naomi, 'Liberal Unionism and political representation in Wales, c.18861893’, Historical Research, vol.88, no.241 (August 2015), pp.482-507.

- McCready, H.W., 'Home Rule and the Liberal Party, 1899-1906', Irish Historical Studies, vo.13, no.52 (Sept. 1963), pp.316-348.

- McGill, Barry, 'Francis Schnadhorst and Liberal Party Organization". Journal of Modern History, vol.34, no.1 (1962), pp.19-39.

- McGill, Barry, 'Asquith’s Predicament’, Journal of Modern History, vol.39, no.3 (September 1967), PP.283-303.

- Machin, G.I.T., 'A Welsh church rate fracas, Aberystwyth, 1832-33', Welsh History Review, vol.6, no.4 (December 1973), pp.462-468.

- Machin, G.I.T., 'Gladstone and Nonconformity in the 1860s: The Formation of an Alliance', The Historical Journal, vol. xvii, no.2 (1974), pp.347-364.

- Machin, G.I.T, 'The Last Victorian Anti-Ritualist Campaign, 1895-1906', Victorian Studies, vol.24, no.3 (Spring, 1982), PP.277-302.

- Machin, G.I.T., 'Parliament, the Church of England, and the Prayer Book Crisis, 1927-8', Parliamentary History, vol.19, issue1 (Feb.2000), pp.131-147.

- Manton, Kevin, 'Edwardian Conservatism and the Constitution: The Thought of Lord Hugh Cecil’, Parliamentary History, Vol.34, part 3 (2015), pp.365-382.

- Masterman, C.F.G., 'Liberalism and Labour', The Nineteenth Century and After, (November 1906), pp.706-718.

- Matthews, G., 'For Freedom and Justice': The Responses of Chapels in the Swansea area to the First World War', Welsh History Review, vol.28, no.4 (December 2017), pp.676710.

- Meadowcroft J. and Taylor, M. W., 'Liberalism and the Referendum in British Political Thought 1890-1914’, Twentieth Century British History, vol.1, Issue (1990), pp. 35-57. 
- Medhurst, Ken, 'The Church of England: A Progress Report', Parliamentary Affairs, vol.52, issue 2 (April 1999), pp.275-290.

- Morgan, D. Densil, 'Christianity and National Identity in Twentieth-Century Wales', Religion, State \& Society, Vol.27, Nos.3/4, 1999, pp.327-342.

- Morgan, D.H.J., 'The social and educational background of Anglican bishopscontinuities and changes', British Journal of Sociology, vol.20, no.3 (September 1969), pp.295-310.

- Morgan, Kenneth O., 'Democratic politics in Glamorgan, 1884-1914', Morgannwg, vol.4 (1960), pp.5-27.

- Morgan, Kenneth O., 'Gladstone and Wales’, Welsh History Review, vol.1, no.1 (1960), pp.65-82.

- Morgan, Kenneth O., 'Liberals, Nationalists and Mr. Gladstone', Transactions of the Honourable Society of Cymmrodorion (1960), pp.36-52.

- Morgan, Kenneth O., "The Liberal Unionists in Wales", National Library of Wales Journal, vol. 16, no.2 (Winter 1969), p.163-171.

- Morgan, Kenneth O., 'Welsh Nationalism: The Historical Background', Journal of Contemporary History, vol.6, no.1 (1971), pp.153-171.

- Morgan, Kenneth O., 'The new Liberalism and the challenge of Labour', Welsh History Review, vol.6, no.3 (June 1973), pp. 288-312.

- Morgan, Kenneth O., 'The Member for Wales', Transactions of the Honourable Society of Cymmrodorion’, (1984), pp.149-171.

- Morgan, Kenneth O., 'Leaders and led in the Labour Movement', Llafur, vol.6, no.3 (1994), pp.109-119.

- Morgan, Kenneth O., 'Lloyd George and Germany', The Historical Journal, vol.39, no.3 (Sep. 1996), pp.755-766.

- Morgan, Kenneth O., 'Wales in British Politics', Llafur, vol.9, no.1 (2004), pp.19-26.

- Morgan, Kenneth O., 'The Relevance of Henry Richard', Welsh History Review, vol.25, no.3 (June 2011), pp.401-423.

- Morgan, Kenneth o., '7 December 1916: Asquith, Lloyd George and the Crisis of Liberalism', The History of Parliament Annual Lecture, 2016, Parliamentary History, vol.36, pt.3 (2017), pp.361-371.

- Morgan, Prys, 'Pictures for the millions of Wales, 1848', Transactions of the Honourable Society of Cymmrodorion', New Series, vol.1 (1995), pp 65-80.

- Morgan, Trevor, 'The Blue Books and Monmouthshire', Gwent Local History: The Journal of Gwent Local History Council, no.77 (Spring 1991), pp.19-26.

- Morgan, Walter T., 'County Elections in Monmouthshire, 1705-1847', National Library of Wales Journal, vol.10, no. 2 (Winter 1957), pp.167-184.

- Morgan-Guy, John, 'William Van Mildert and the Logic of Disestablishment', paper delivered at the Day Conference of the Welsh Religious History Society, 1994.

- Morris, Bob., 'The Future of 'High' Establishment”, Ecclesiastical Law Journal, vol.13, issue 3 (Sep. 2011), pp.260-273. 
- Nelmes,Grahame V., 'Stuart Rendel and Welsh Liberal political organization in the latenineteenth century’, Welsh History Review, vol.9, no.4 (December 1979), pp.468-485.

- Norton, P., 'Resisting the Inevitable? The Parliament Act 1911', Parliamentary History, vol.31, pt.3 (2012), pp.444-459.

- Ogilvie, M.H., 'What is a Church by Law Established?', 28, Osgoode Hall Law Journal (1990), pp.179-236.

- O’Leary, Paul, 'When was Anti-Catholicism? The Case of Nineteenth- and TwentiethCentury Wales’, Journal of Ecclesiastical History, vol.56, no.2 (April 2005), pp.308-325.

- Owen-Jones, Sheila M., 'Religious Influence and Educational Progress', Welsh History Review, vol.13, no.1 (June 1986), pp.72-86.

- Packer, Ian, 'Lloyd George and Land Reform: The Welsh Context', Transactions of the Honourable Society of Cymmrodorion',Vol.15 (2009), pp.127-145.

- Pearson, Michael J., 'The records of the Welsh Church Commission held in the National Library of Wales', Journal of Welsh religious history, vol.3 (1995), pp.66-75.

- Peart-Binns, John S., 'Arglwydd Archesgob Cymru. Alfred Edwin Morris Election and aftermath’, Journal of Welsh Ecclesiastical History, vol.2 (1985), pp.55-86.

- Peterson, Scot and MacLean, Iain, 'Of Wheat, The Church in Wales and the West Lothian Question’, Welsh History Review, vol.23, no.3 (June 2007), pp.151-174.

- Pickering, W.S.F., 'The 1851 Religious Census-A Useless Experiment?', The British Journal of Sociology, vol.18 (1967), pp.382-407.

- Pope, Robert, 'Welsh Methodists and the Establishment in the Nineteenth Century', Welsh Journal of Religious History, 6 (2011), pp.31-48.

- Powell, David, 'The New Liberalism and the Rise of Labour, 1886-1906', The Historical Journal, vol.29, no.2 (1986), pp.369-393.

- Price, J. Arthur, 'The awakening in the Welsh church', Welsh Outlook, vol.4, no.10 (October 1917), pp.361-364.

- Price, J. Arthur, 'Welsh nationalism and Mr. Lloyd George’s speech', Welsh Outlook, vol.5, no.9 (September 1918), pp.273-275.

- Price, J. Arthur, 'The historical case for Welsh home rule', Welsh Outlook, vol.8, no.12 (December 1921), pp.272-274.

- Pryce, Huw, 'British or Welsh? National Identity in Twelfth-Century Wales', The English Historical Review, Vol.116, No.468 (September 2001), pp.775-801.

- Pryce, Huw, 'Identity, and the Medieval Revival in Victorian Wales', Proceedings of the Harvard Celtic Colloquium, vol.31 (2011), pp.1-40.

- Pryce, Huw, 'Medieval Welsh History in the Victorian Age', Cambrian Medieval Celtic Studies, 71 (Summer 2016), pp.1-28.

- Qvortrup, M., 'A. V. Dicey: the referendum as the people's veto', History of Political Thought, vol. 20, no.3 (March 1999), pp. 531-546.

- Ramm, Agatha, 'Gladstone’s Religion’, The Historical Journal, 28, 2 (19850, pp.327340. 
- Rendel, Stuart, 'Welsh Disestablishment', The Contemporary review, 1866-1900: Dec. 1886, pp.777-787.

- Richards, Gwynfryn, 'James Henry Cotton, Dean of Bangor 1838-1868, National Library of Wales Journal, vol.19, no.2 (Winter 1975), pp.147-180.

- Richards, Noel J., 'The Education Bill of 1906 and the Decline of Political Nonconformity', Journal of Ecclesiastical History, vol.23, no.1(January 1972), pp.49-63.

- Richter, Donald, 'The Welsh Police, The Home Office and the Welsh Tithe War of 188691', Welsh History Review, vol.12, no.1 (June 1984), pp.50-75.

- Ridley, Jane, 'The Unionist Opposition and the House of Lords 1906-1910', Parliamentary History, vol.11, part 2 (1992), pp.235-253.

- Ripsman, N.M. and Levy, J.S., 'Wishful Thinking or Buying Time? The Logic of British Appeasement in the 1930s', International Security, Vol. 33, No. 2 (Fall, 2008), pp. 148-181.

- Robbins, Keith, 'Episcopacy in Wales’, Journal of Welsh Religious History, vol.4 (1996), pp. 63-78.

- Robbins, Keith G., 'Wales and the British Question', Transactions of the Honourable Society of Cymmrodorion', New Series, vol.9 (2003), pp. 152-161.

- Robbins, Keith, 'Political Anglicanism: Church and State in the Twentieth Century', Trivium, Vol.38 (2008), pp.89-104.

- Roberts, Harri, 'Embodying Identity: Class, Nation and Corporeality in the 1847 Blue Books Report', North American Journal of Welsh Studies, vol.3, no.1 (Winter 2003), pp.1-21.

- Roberts, M. J. D., 'Pressure-Group Politics and the Church of England: The Church Defence Institution', Journal of Ecclesiastical History, vol.35, no.4 (October 1984), pp. 560-582.

- Roberts, M. J. D., 'Private Patronage and the Church of England, 1800-1900', , Journal of Ecclesiastical History, vol.32, no.2, April 1981, pp.199-223.

- Roberts, Nicholas, 'The Historical Background to the Marriage (Wales) Act 2010', Ecclesiastical Law Journal, (2011), pp.39-56.

- Roberts, R.O., 'The Life and Work of Dean Henry Thomas Edwards 1837-84', Transactions of the Caernarvonshire Historical Society, vol.40 (1979), pp.135-160.

- Rubenstein, W. D., 'The End of the “Old Corruption” in Britain 1780-1860', Past and Present, no.101 (November 1983), pp.55-86.

- Sandiford, Keith A. P., 'W. E. Gladstone and Liberal-Nationalist Movements', Albion, vol.13, no.1 (Spring, 1981), pp.27-42.

- Say, The Rt. Rev. David, 'Towards 2000: Church and State Relations', Ecclesiastical Law Journal, (1990), pp.152-158.

- Simon, Alan, 'Church Disestablishment as a Factor in the General Election of 1885'. The Historical Journal, vol.18, no.4 (December 1975), pp.791-820.

- Simon, The Most Reverend Glyn, 'Being Welsh Today', Transactions of the Honourable Society of Cymmrodorion', New Series, (1970), pp.50-57. 
- Smith, Barry, 'Bishop Edwards of St. Asaph and disestablishment', Denbighshire Historical Society, vol. 59 (2011), pp.192-206.

- Spafford, George, Brown, Roger L., Nicholls, Ben, 'Working Party on 'Disestablishment Report', Ecclesiastical Law Journal, vol.6, issue 30 (Jan. 2002), pp.264-269.

- Stead, Peter, 'Working-class leadership in South Wales, 1900-1920', Welsh History Review, vol.6, no.3 (June 1973), pp.329-353.

- Stevens, Catrin, 'The ‘Burial Question': Controversy and Conflict c. 1860-1890', Welsh History Review, vol.21, no.2 (December 2002), pp. 328-356.

- Taylor, Simon J., 'Disestablished Establishment: High and Earthed Establishment in the Church in Wales', Journal of Contemporary Religion, vol.18, no.2 (2003), pp.227-240.

- Taylor, S. and Huzzey, R., 'From Estate under Pressure to Spiritual Pressure Group: The Bishops and Parliament', Parliamentary History, vol.37, issue 51 (July 2018), pp.89-101.

- Thackeray, David, 'Rethinking the Edwardian Crisis of Conservatism', The Historical Journal, vol.54, no.1 (March 2011), pp.191-213.

- Thomas, Geraint, 'The Conservative Party and Welsh Politics in the Inter-War Years', English Historical Review, vol.128, no.533 (2103), pp.877-913.

- Wager, David, 'The Politics of Wales in Relation to the Movement for Parliamentary Reform 1780-1832', Welsh History Review, vol.7, no.4 (1975), pp.427-449.

- Watkin, T.G., 'Vestiges of establishment - the ecclesiastical and canon law of the Church in Wales', Ecclesiastical Law Journal, 1990, 2 97), pp.110-115.

- Webster, J.R., 'The Welsh intermediate education act of 1889', Welsh History Review, vol.4, no.3 (June 1969), pp.273-291.

- Weston, Corinne Comstock, ‘The Liberal Leadership and The Lords’ Veto, 1907-1910', The Historical Journal, vol.xi, no.3 (1968), pp.508-537.

- Weston, Corinne Comstock and Kelvin, Patricia, 'The 'Judas Group’ and the Parliament Bill of 1914', English Historical Review, vol.99, no.392 (Jul. 1984), pp,551-563.

- Wiggins, Deborah, 'The Burial Act of 1880, The Liberation Society and George Osborne Morgan, Parliamentary History, vol.15, pt.2 (1996), pp.173-189.

- Williams, C.R., 'The Welsh Religious Revival, 1904-5', The British Journal of Sociology, vol.3, no.3 (September 1952), pp.242-259.

- Williams Chris, 'History, Heritage and Commemoration: Newport, 1839-1989', Llafur: Journal of Welsh Labour History, vol.6, no.1, (1992), pp.5-16.

- Williams, Chris, 'Wales's “Unionist Nationalist”: Sir Thomas Phillips, (1801-67), Llafur: Journal of Welsh Labour History, vol.8, no.4, (2003), pp.7-17.

- Williams, Emyr W., 'Liberalism in Wales and the Politics of Welsh Home Rule 18861910', Bulletin of the Board of Celtic Studies, vol.33 (1970), pp.191-207.

- Williams, H.G., 'Longueville Jones and Welsh Education', Welsh History Review, vol.15, no.3 (June 1991), pp.416-442.

- Williams, H.G., 'Nation State versus National Identity: State and Inspectorate in MidVictorian Wales', History of Education Society, vol. 40. no.2 (Summer 2000), pp.145168. 
- Williams, H. G., 'The Forster Education Act and Welsh Politics, 1870-1874', Welsh History Review, vol.14, no.2 (December 1988), pp.242-268.

- Williams, H.G., 'Arthur Acland, Tom Ellis and Welsh Education: A Study in the Politics of Idealism', Welsh History Review, vol.17, no.3 (June 1995), pp.387-410.

- Williams, R.J. and Greenaway, J.R., 'The Referendum in British Politics: A Dissenting View’, Parliamentary Affairs, Volume 28, Issue 1975mar, March 1975, pp. 250-260.

- Williams, Tom, 'The Rebirth of Conservatism in North-East Wales: the Denbigh Boroughs in the General Elections of 1910', Transactions of the Denbighshire Historical Society, vol.54 (2005/2006), pp.104-118.

- Williams, W. Llewelyn, 'Disendowment: The present position', Welsh Outlook, vol.4, no.10 (October 1917), pp.358-360.

- Wills, Wilton D., 'The Rev. John Griffith and the Revival of the Established Church in Nineteenth Century Glamorgan', Morgannwg, vol. 13 (1969), pp.75-102.

- Wills, Wilton D., 'The Established Church in the Diocese of Llandaff, 1850-70, Welsh History Review, vol.4, no.3 (June 1969), pp.235-271.

- Wills, Wilton D., 'The Clergy in Society in Mid-Victorian South Wales', Journal of The Historical Society of the Church in Wales, vol.23, no.28 (1973), pp.27-43.

- Wykes, David L., 'Introduction: Parliament and Dissent from the Restoration to the Twentieth Century', Parliamentary History, 2005, pp.1-26.

- Yates, W. N., 'The Welsh Church and Celtic Nationalism', Journal of Welsh Ecclesiastical History, vol.1, (1984), pp.1-10.

- Zimmerman, John D., 'A Chapter in English Church Reform: The Enabling Act of 1919', Historical Magazine of the Protestant Episcopal Church, vol.46, no.2 (June 1977), pp.215-225. 
